\title{
Políticas de habitação e Desenvolvimento Urbano em Municípios Saudáveis: o Caso de Bertioga
}

\section{FRANCISCO DE ASSIS COMARÚ}

Tese apresentada na área de concentração de Serviços de Saúde Pública da Faculdade de Saúde Pública da Universidade de São Paulo para Obtenção do Grau de Doutor.

Área de concentração: Serviços de Saúde Pública Orientadora: Profa. Dra. Marcia faria WESTPHAL

Co-Orientadora: Profa. Dra. ERmínia Terezinha Menon Maricato

São Paulo 2004

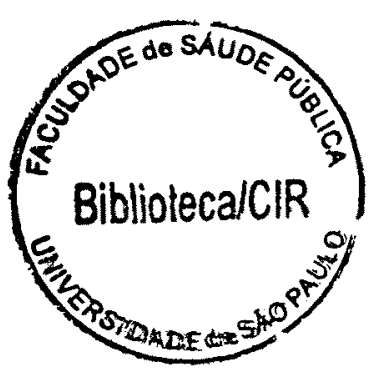




\section{$44630 \mid 2004$ doc}

Autorizo, exclusivamente para fins acadêmicos e científicos, a reprodução total ou parcial desta tese, por processos fotocopiadores. Ao usá-lo cite a(s) fonte(s).

São Paulo, 29 de janeiro de 2004. 
Aos meus, mais próximos,

Semente, raiz da minha história e inspiração do futuro.

Meu pai Francisco, minha mãe Marlucia, Anselmo, Rosana e o pequeno Arthur; Tio João Comarú, minha avó Julia e minha companheira Letizia. 
De infinitos encontros

se constróem, -

que também em desencontros,

se desfazem, -

as referencias culturais

do tempo e do ser.

Em saudável transparência

de ternura

explode o abraço da matéria inteligente

no encantado coração comunitário.

Cria! Arruma! e nascem

textos, forma, cor e luz.

Montanha e mar definem

teus caminhos, -

e o vento sopra vida, vida!

São encontros infinitos

que constroem

as cidades saudáveis

e saudosas:

Bem-te-quero Bertioga, litoral!

João B. Comarú 


\section{APRESENTAÇÃO E AGRADECIMENTOS}

Este trabalho é fruto direto de quatro anos de atividades de pesquisa e extensão universitária realizada por intermédio da Faculdade de Saúde Pública da Universidade de São Paulo em diversas cidades, onde a equipe do Cepedoc - Centro de Estudos Pesquisa e Documentação em Cidades Saudáveis desenvolveu Projetos Municípios Saudáveis, entre 2000 e 2003.

O trabalho representa também, indiretamente, o acúmulo de muitas outras atividades que tenho tido a oportunidade de participar, em pouco mais de dez anos, desde que me formei em engenharia civil. Minha trajetória tem se caracterizado pela dedicação aos processos participativos, em projetos, políticas e programas de habitação, políticas urbanas e ambientais. A opção de atuar na universidade - desde o mestrado na Poli da USP - buscando articular extensão/ensino/pesquisa me pareceu uma possibilidade interessante de lutar para transformar a realidade que nos cerca (e a nós mesmos), sem cair em "basismos" e, ao mesmo tempo, não descolar jamais, da nossa realidade brasileira, tão concreta.

Foi absolutamente fundamental, nesse curto e intenso pedaço de história de pessoas e processos, a experiência nas ONG's, seja assessorando os movimentos de moradia, favelas, cortiços, seja nos mutirões autogeridos de São Paulo por meio da AD - Assessoria em Habitação aos Movimentos Populares, quanto lutando pela assistência, justiça e por educação popular e políticas públicas adequadas para realidade dos cortiços e excluídos no centro de São Paulo no Centro Gaspar Garcia de Direitos Humanos.

Foi e tem sido fundamental também participar como membro do LabHab Laboratório de Habitação e Assentamentos Humanos da USP onde encontrei uma referencia teórica de esquerda consistente relativo ao habitat $e$ cidades. Uma prática militante dentro da USP. A passagem de cinco anos como professor numa escola de arquitetura e urbanismo em Taubaté foi outra experiência transformadora e marcante para todos os que ousaram construir lá, o novo - uma utopia inacabada no ensino de arquitetura e urbanismo.

Por fim, o Cepedoc na FSPUSP, onde pude conhecer e exercitar em outros campos de conhecimento, como a saúde pública, a educação ambiental e 
educação popular, onde pude refletir, estudar e atuar com uma equipe rica e radicalmente interdisciplinar de uma forma realmente privilegiada.

Assim, da habitação, pelas políticas urbanas até a saúde pública ampliei horizontes altos, realizei muitas trocas, sobretudo aprendi muito com diversos profissionais de formação sofisticada, e de forma muito especial, com lideranças e com as pessoas simples e comuns do povo, do dia a dia, das cidades.

Agora é inadiável o tempo de agradecer a todos os que direta ou indiretamente contribuíram e participaram na execução desta tese e na minha formação profissional e acadêmica. Divido os eventuais méritos deste trabalho com vocês, assumindo a responsabilidade pelos equívocos ou omissões. E me desculpo pelos que, eu possa ter deixado de citar aqui.

A Profa. Dra. Márcia Faria Westphal pela orientação constante, pelo apoio e ajuda durante toda elaboração, particularmente, pelo acompanhamento especialmente atencioso nos meses finais de redação do trabalho. A Profa. Dra. Ermínia Maricato pela co-orientação, por tanto aprendizado, pelo estímulo no ingresso ao Doutorado na FSPUSP, pelo apoio e pelas lutas e sonhos vividos e compartilhados. Aos integrantes da banca de qualificação: Prof.(s). Dr.(s). Marcia Westphal, Ermínia Maricato e Marco Akerman pelas sugestões e recomendações valiosas. Aos amigos do Cepedoc da FSPUSP, por compartilharem comigo novas práticas e conhecimentos, na harmonia $\mathrm{e}$ nos conflitos: Rosilda, Endyra, Lavinia, Samuel, Isadora, Bárbara, Ana Letícia, Mariana, Marco, Paulo, Claudia, Marcelo, Lucia. Agradeço muito especialmente à Ana Caricari e ao Victor Arai, pelas trocas intensas, pelo aprendizado, pela amizade sincera, e pela paciência que tiveram comigo. (Victor, tuas transcrições de fitas foram cruciais). Ao Prof. Dr. José Barata, amigo de longa e (quase) conterrâneo, por muito ter me incentivado a ingressar no Doutorado da FSPUSP e pelo apoio de sempre. Aos professores e funcionários da Faculdade de Saúde Pública: Fernando Lefreve, Cleide, Ana, Mila, Cidinha do Departamento de Práticas, a Angela, Márcia, Renilda e Cidinha da Secretaria de Pós Graduação e à Daniela, Ivani e Samuel pela transcrição das fitas. Aos amigos do LabHab da FAUUSP pelo apoio: Malu Refinetti, João Sette, Giselle, André, Paulo Emilio, Fernanda, Laura Bueno, Moretti, Caio Boucinhas, pelo que aprendemos no Jd. Angela e no dia a dia. 
A Lara pela ajuda importante no trabalho com os gráficos, mapas, formatações e a Rosella Vitale pela ajuda na tradução, Marta, Mary e Matteo pelo apoio. Aos técnicos e membros da prefeitura de Bertioga pela ajuda em diversos momentos: Tupy, Aluisio, Gisela, Daniela, Gervasio, Rogério, Lucilia, Percival, Osvaldo, Sergio, Manolo, Vanessa, Macleide, Nelo, Adriana. À Comunidade Indígena da Aldeia do Rio Silveiras de Bertioga, particularmente ao Cacique Adolfo. Ao Mario Barreiros da Emplasa, ao Paulo, Miriam e Ortiz da Fundação Seade, ao Paulo, Zundt e Kuiú da Agencia Metropolitana da Baixada Santista - Agem. Ao Laboratório de Aerofoto do Departamento de Geografia da FFLCH da USP. Ao Centro Gaspar Garcia de Direitos Humanos e integrantes, pelas lições do centro de São Paulo: René, Linnis, Michael, Maria, Soraia, Luciana, Fabiana, João, Davide, Lucia, Teresa, Adriana (e também ao Luiz, Regina, Vera e Gilberto). Aos moradores de Bertioga, particularmente os que participaram das atividades do Projeto Bertioga Município Saudável, Comissão Intersetorial e Grupo do Plano Diretor, entre os quais, pelo menos: Quirino, Nivinha, Daniel, Rosa, Suely, Shimidt, Kátia, Sr. Martins, Galego, Tomi, Zé Carlos, Marcelo, Cláudio, Mauricio, Rita, Romana, Aluisio, Paulo, entre tantos muitos outros, que foram meus professores. À Beta e Roberto Pompéia pela coordenação da oficina de habitação durante o Curso em Bertioga. Aos amigos das Assessorias Técnicas, onde, muito do que há em mim, começou - das favelas aos cortiços e movimentos - particularmente Joel, Celso e Julio e também aos amigos da Taubaté pelas aventuras, ousadias e trabalhos que realizamos (os que são, sabem). Ao Alê Nogueira pela nossa irmandade boa e velha. Ao Sydnei e Tomás pelo apoio e pelo trabalho em Santos. Também ao Pedro Carlos, Nanci (e outros amigos de outras paragens) pelo reforço físico e espiritual. A Letizia pela ajuda e compreensão em tantos momentos e também pela tradução, formatação e montagem. Ao meu pai pela ajuda importante na revisão ortográfica e minha mãe pelo apoio fundamental de mãe com visão profissional. Finalmente, agradeço à Capes/Ministério da Educação pela concessão de uma bolsa de estudos durante à execução da pesquisa. Agradeço também a OPAS - Organização Pan-Americana de Saúde/Brasil e Ministério da Saúde que, ao apoiarem o Projeto em Bertioga, contribuíram também, mesmo que indiretamente, para a viabilização desta pesquisa. 


\section{LISTA DE SIGLAS E ABREVIATURAS}

ACIPEB - Associação Comercial, Industrial e Pesqueira de Bertioga

AGEM - Agencia Metropolitana da Baixada Santista

APP - Área de Preservação Permanente

BNH - Banco Nacional da Habitação

CEF - Caixa Econômica Federal

CEPAM - Centro de Estudos e Pesquisas Municipais - Fundação Prefeito Faria Lima

CEPEDOC - Centro de Estudos Pesquisa e Documentação sobre Cidades/Municípios Saudáveis da Faculdade de Saúde Pública da Universidade de São Paulo

CESP - Companhia Energética de São Paulo

DEPRN - Departamento Estadual de Proteção dos Recursos Naturais da Secretaria de Estado do Meio Ambiente

DER - Departamento de Estradas de Rodagem

DOA - Diretoria de Operações Ambientais da Prefeitura do Município de Bertioga

ECAUSP - Escola de Comunicações e Artes da Universidade de São Paulo

EMPLASA - Empresa Paulista de Planejamento Metropolitano

FAPESP - Fundação de Amparo à Pesquisa do Estado de São Paulo

FAUUSP - Faculdade de Arquitetura e Urbanismo da Universidade de São Paulo

FEHIDRO - Fundo Estadual para os Recursos Hídricos da Secretaria de Estado do

FGTS - Fundo de Garantia por Tempo de Serviço

FSPUSP - Faculdade de Saúde Pública da Universidade de São Paulo

HIS - Habitação de Interesse Social

IAP's - Institutos de Aposentadoria e Pensão

IBGE - Instituto Brasileiro de Geografia e Estatística

IPT - Instituto de Pesquisas Tecnológicas do Estado de São Paulo

IPTU - Imposto Predial, Territorial e Urbano 
IRA - Infecções Respiratórias Agudas

LABHAB - Laboratório de Habitação e Assentamentos Humanos da Faculdade de Arquitetura e Urbanismo da Universidade de São Paulo

OMS - Organização Mundial da Saúde

ONG - Organização Não Governamental

ONU - Organização das Nações Unidas

OP - Orçamento Participativo

OPAS - Organização Pan-Americana de Saúde

PAHO - Pan American Health Organization

PBMS - Projeto Bertioga Município Saudável

PD - Plano Diretor

PMB - Prefeitura do Município de Bertioga

PMDI - Plano Metropolitano de Desenvolvimento Integrado da Baixada Santista

PMSP - Prefeitura do Município de São Paulo

PNAD - Pesquisa Nacional de Amostra Domiciliar do Instituto Brasileiro de Geografia e Estatistica

RMBS - Região Metropolitana da Baixada Santista

RPPN - Reserva Permanente de Proteção Natural

SABESP - Companhia de Saneamento Básico do Estado de São Paulo

SEDU - Secretaria de Estado do Desenvolvimento Urbano da Presidência da Republica

SFH - Sistema Financeiro da Habitação

SESC - Serviço Social do Comércio

UN - HABITAT - Programa das Nações Unidas para os Assentamentos Humanos

USP - Universidade de São Paulo

ZEIS - Zona Especial de Interesse Social

WHO - World Health Organization 


\section{Listas de Figuras, TABelas, Gráficos e ImagenS}

\section{FIGURAS}

Figura 1 -Região metropolitana da baixada Santista Divisão Político-

Administrativa: 2002

Figura 2 -Região Metropolitana da Baixada Santista (RMBS) Drenagem Principal

Figura 3 -Região Metropolitana da Baixada Santista Unidades de Conservação Ambiental

Figura 4 - Região metropolitana da baixada Santista Densidade demográfica, segundo os municípios : 2000 (Hab/ha)

pág.99

\section{FOTOGRAFIAS}

Fotografia 1 Vista sobre o CANAL DE BERTIOGA No tRECHO DE ENCONTRO COM O MAR

pág.81

Fotografia 2 - VISTA do CANAL DE BERTIOGA COM O FORTE AO FUNDO pág.86

FOTOGRAFIA 3 - FAVELA LEVANTADA PELOS MORADORES PARTICIPANTES DO PBMS

pág.122

Fotografia 4 - MORADIAS PRECÁRIAS LEVANTADAS EM BERTIOGA

pág. 122

Fotografia 5 - FAVELA NA PERIFERIA DE BERTIOGA, ONDE HÁ PRESSÃo POR NOVAS OCUPACÕES ILEGAIS

pág.124

FOTOGRAFIA 6 - FAVELA DO INDAIÁ, ONDE É MAIOR O NÚMERO DE MORADORES PERMANENTES

FotOgRAFIA 7 - LOTEAMENTO RIVIERA DE SÃo LOURENÇO, CONSIDERADO POR MUITOS UM MODELO, E QUE POSSUI BAIXA DENSIDADE URBANA

pág.141

FotOGRAFIA 8 - VISTA DO CONJUNTO HABITACIONAL COOPERATIVA BURIQUIOCA, UMA DAS PRIMEIRAS E UNICAS INICIATIVAS DE PRODUCAO DE MORADIA PARA OS MORADORES DO SEGMENTO MEDIO BAIXO.

Fotografia 9 - HABITAÇ̃̃o INDÍgENA NA ALDEIA DO RIO SILVEIRAS DA ETNIA GuARANi (EXECução da CDHU) pág.145

Fotografia 10 - CONJUNTO HABITACIONAL DE 240 UNIDADES, PRODUZIDO COM RECURSOS DA CEF, POR MEIO DO PROGRAMA DE ARRENDAMENTO RECIDENCIAL NO JD. VISTA LINDA pág.146

Fotografia 11 - VALA A CEU ABERTO EM RUA SEM SISTEMA DE, SEM PAVIMENTACAO E SEM SISTEMA DE ESGOTOS SANITARIOS NO JD. VISTA LINDA, BERTIOGA pág.154

FOTOGRAFIA 12 - TRAFEgO DE VEICULOS NA RODOVIA RIO-SANTOS, EM TRECHO DO MUNICIPIO ONDE NÃO HÁ ACESSO INTRA-URBANO. FOTO REALIZADA EM DIA DA SEMANA, JULHO DE 2003

FotografiA 13 - PARTICIPANTES DA PRIMEIRA OFICINA DO PROJETO BERTIOGA Município SAUdÁVEL, NO SESC BERTIOGa (2000) pág.186

FotografIA 14 - GRUPO DE DISCUSSAO DURANTE SEMINARIO MUICIPAL NO SESC BERTIOGA

Fotografia 15 - VISTA dO SEMINARIO MUNICIPAL NO AUDITORIO DO SESC

BERTIOGA pág. 201

Fotografia 16 - PARTICIPANTES DE OFICINA DO FUTURO EM ESCOLA MUNICIPAL DE BERTIOGA 
FOTOGRAFIA 17 - MURO DAS DIFICULDADES E DOS SONHOS EM OFICINA DO FUTURO pág.209

FOTOGRAFIA 18 - VISTA DA FAVELA DO INDAIAZINHO. PROBLEMAS HABITACIONAIS, AMBIENTAIS E SANITARIOS pág.211

Fotografia 19 - Oficina EM Boracéia COM OS PARTICIPANTES DA ALDEIA DO RIO SILVEIRAS. pág.221

FotogRAFIA 20 - EXEMPLOS DE BIOMAPAS PRODUZIDOS PELOS MORADORES DE BERTIOGA pág.265

FOTOGRAFIA 21 - UM DOS FACILITADORES DA FSPUSP TRABALHA EM OFICINA DO PLANo Diretor (2002) pág.265

\section{AEROFOTOGRAFIAS}

AEROFOTO 1 - Municipio de Bertioga -2002-;

AEROFOTO 2 - Favela Vicente de carvalho II;

AEROFOTO 3 - Loteamento Riviera de São Lourenço, favela Indaiá e favela Indaiazinho;

AEROFOTO 4- Favela Indaiá e favela Indaiazinho;

AEROFOTO 5 - Praia de Itaguaré;

AEROFOTO 6 - Loteamento moradia da praia e favela Boracéia ;

AEROFOTO 7 - Favela Boracéia

\section{TABELAS}

Tabela 1 - Concentração de renda no Brasil pág. 3

Tabela 2 - Taxa geométrica de crescimento populacional (1991/2000)

pág.94

Tabela 3 - RMBS: Evolução da População Residente, segundo os municípios - 1970 / 1980 / 1991 / $1996 / 2000$ pág.94 Tabela 4 - População residente permanente (2002) pág.95

Tabela 5 - Evolução de alguns dados demográficos entre 1993 e 2000 pág.96

Tabela 6 - Evolução da taxa de mortalidade infantil por municípios (RMBS): 1993/2002 (óbitos menores de 1 ano por mil nascidos vivos) pág.97 Tabela 7 - RMBS: População Fixa residente e projeção da população flutuante $1995-1996-2000$ pág. 100 Tabela 8 - Rendimento dos responsáveis pelos domicilios (\% de faixas) 2000 pág.107

Tabela 9 -Taxas de analfabetismo da população de 15 anos ou mais (\%) 2000 pág.108

Tabela 10 -Taxas do Ensino Fundamental (Total em \%) pág.109

Tabela 11 -Taxas do Ensino Médio (Total em \%) pág.109

Tabela 12 -RMBS : Domicílios Particulares Permanentes por condição de ocupação, segundo Municípios - 1991/2000 (em percentagem) pág.114 Tabela 13 - Município de Bertioga- Forma de Ocupação dos Domicílios pág.115

Tabela 14 -Domicilios Ocupados e de uso ocasional em alguns loteamentos e favelas de Bertioga 
Tabela 15 -Assentamentos Irregulares no Município de Bertioga pág.119

Tabela 16 -Identificação dos Núcleos de Favelas

pág. 120

Tabela 17-Dados de levantamentos de campo realizado pela equipe do

PBMS -2003

pág. 121

Tabela 18-Densidade segundo legislação de Belo Horizonte-MG pág.138

Tabela 19-Densidade em favela pesquisadas (LabHab)

pág. 138

Tabela 20-Densidade em conjuntos Habitacionais ou Loteamentos

populares

pág.139

Tabela 21-Bertioga: Algumas favelas e loteamentos: população, área e densidade (aproximadas)

pág.140

Tabela 22-Bertioga: Densidade de alguns loteamentos com concentração de residências secundárias

pág. 121

Tabela 23-Bertioga: Preços de terrenos pesquisados ( $R \$ / \mathrm{m}^{2}$ ) pág.142

Tabela 24-Saneamento ambiental -Nível de atendimento (\%) -2002

pág.147

Tabela 25-RMBS: Domicilios particulares permanentes por condição de abastecimento de água, segundos os Municípios -1999/2000 (em percentagem)

Tabela 26-Domicílios particulares permanentes por escoadouro da instalação sanitária , segundo os Municípios :1991

pág.149

Tabela 27-RMBS: Domicílios particulares permanentes por existência de banheiros ou sanitários e tipo de esgotamento sanitário, segundo os municipios -2000 (em percentagem)

pág.149

Tabela 28-RMBS: Domicílios particulares permanentes por destino do lixo, segundo os municípios -2000 pág.151

Tabela 29-RMBS: Evolução do fluxo anual de veículos no sistema Anchieta. Imigrantes, segundo rodovias e pedágios- 1995/2000 pág.157

Tabela 30-Causas de mortes por grandes capítulos, segundo os municípios 2000

pág.164

Tabela 31-Taxa de mortalidade por homicídios e acidentes de transportes Bertioga 1996/2000

pág.167

Tabela 32-Morbidade hospitalar - Município de Bertioga -2002 .

Distribuição percentual das internações por grupos de causa e faixa etária (por local de residência)

pág.172

Tabela 33-Problemas de Bertioga citados pelos entrevistados no mapeamento de lideranças.

pág.194

Tabela 34-Aspectos positivos citados pelos entrevistados no mapeamento de lideranças

pág.195

Tabela 35-Sonhos para Bertioga, mencionados pelos entrevistados no mapeamento de lideranças

pág.197

Tabela 36- Numero de avaliações recebidas no curso de formação de agentes multiplicadores para assentamentos humanos saudáveis pág.247 


\section{MAPAS}

Mapa 1 - Complexo Metropolitano expandido -CME- Macro Metrópole Paulista

Mapa 2 - Densidade Habitacional (HAB/HÁ)

\section{GRÁFICOS}

Gráfico 1 - RMBS - Evolução da população permanente, segundo municípios pág. 88

Gráfico 2 - RMBS - Quadro de distribuição e a classificação semanal das praias monitoradas, segundo os municípios - 1999 pág.93

Gráfico 3 - Taxa de Mortalidade Infantil Município de Bertioga e RMBS $1993 / 2002$ pág.98

Gráfico 4 - Distribuição do numero de segundo setores de atividade

pág.102

Gráfico 5 - RMBS: Distribuição do numero de empregos por setor econômico - 2000 pág.103

Gráfico 6 - RMBS: Evolução do Numero de Consumidores de energia elétrica por municípios

Gráfico 7 - Distribuição por faixa etária (favela do Indaiá) pág.131 Gráfico 8 - Situação ocupacional (favela do Indaiá) pág.132

Gráfico 9 - Tempo de residencia em anos (favela do Indaiá) pág.132

Gráfico 10 - Material de construção (favela do Indaiá) pág.133

Gráfico 11 - Número de cômodos (favela do Indaiá) pág.133 Gráfico 12 - Número de banheiros (favela do Indaiá) pág.134 Gráfico 13 - Ligação de água (favela do Indaiá) pág.135 Gráfico 14 - Situação de esgoto sanitário (favela do Indaiá) pág. 135 Gráfico 15 - Renda dos chefes de família (favela do Indaiá) pág.136 Gráfico 16 - Principais causas de óbito -homens /1999 pág.165 Gráfico 17 - Principais causas de óbito -mulheres /1999 pág.166 Gráfico 18 - Taxa de mortalidade por homicídios segundo as capitais (por 100.000 habitantes /1998) 


\section{Í N D I CE}

\section{RESUMO}

SUMMARY

1. INTRODUCÃO 1

1.1 Justificativa: contexto sanitário, urbano e cenário de estudo 6

$\begin{array}{ll}1.2 \text { Objetivos } & 17\end{array}$

2. SANITARISMO E AS PRIMEIRAS INTERVENCÕES URBANAS E HABITACIONAIS

3. PROMOCÃO dA SAÚdE E MUNICÍPIOS SAUdÁVEIS

3.1 Promoção da Saúde

3.2 Estratégias para Promoção da Saúde: matriz e conceitos 38

3.2.1 Cidades/Municípios Saudáveis: matriz e conceitos 38

3.2.2 Empoderamento 51

3.2.3 Políticas Públicas Saudáveis 58

3.2.4 Advocacia em Promoção da Saúde 61

4. CONCEPÇÃO DO ESTUDO e METODOLOGIA 64

5. BERTIOGA: DIAGNÓSTICO SÓCIO-ESPACIAL E CONDIÇÕES OBJETIVAS DE VIDA

5.1 Características físico-ambientais $\quad 74$

5.2 Aspectos históricos de ocupação e demografia 83

5.2.1 A busca por residências secundárias a partir das décadas de 1950 e $1960 \quad 88$

5.2.2 Movimento emancipatório $\quad 89$

5.2.3 Intensificação do processo de urbanização nos anos $1980 \quad 90$

5.2.4 O crescimento populacional na década de 1990: população residente 93

5.2.5 Crescimento populacional vegetativo e migratório 96

5.2.6 População flutuante $\quad 98$

5.2.7 Características da população residente: ocupação e procedência 
5.2.8 Resultados do crescimento populacional intenso e da especulação imobiliária: agressão ao meio ambiente

$\begin{array}{ll}\text { 5.3 Moradia dos que habitam e trabalham } & 114\end{array}$

5.3.1 Favelas e assentamentos precários $\quad 117$

5.3.2 Áreas de risco 117

5.3.3 Assentamentos precários $\quad 119$

5.3.4 Dados sobre a favela do Indaiá 131

5.3.5 Densidade e oferta de terra urbana 137

5.3.6 Algumas ações locais para a produção ou melhorias em habitação 144

5.4 Saneamento ambiental $\quad 147$

5.5 Sistema viário, transportes e mobilidade 153

5.6 Aspectos da legislação urbanística municipal atual 158

5.7 Aspectos e dados epidemiológicos 163

5.8 Dados aerofogramétricos e cartográficos 173

6 O PROJETO BERTIOGA MUNICÍPIO SAUdÁVEL E A PERCEPÇÃo DOS MORADORES SOBRE OS PROBLEMAS URBANOS 183

6.1 Antecedentes e primeiras atividades 185

6.2 A Oficina: Iniciando o Projeto Bertioga Município Saudável 190

6.3 Pesquisa exploratória: levantamento preliminar do tecido social do Município de Bertioga

192

6.3.1 Percepção dos participantes da pesquisa exploratória

6.4 Oficinas Regionais de Sensibilização, Oficinas do Futuro, Seminário Municipal e formação da Comissão Intersetorial 198

6.4.1 Percepção dos participantes das Oficinas do Futuro 201

\section{EMPODERAMENTO dA POPULAÇÃO E ADVOCACIA PELAS} POLÍtICAS URBANAS SAUdÁVEIS

7.1 Percepções dos participantes nas primeiras atividades do Projeto

7.1.1 O discurso e o empoderamento

7.2 Nova estratégia para capacitação local: Curso de Formação de Agentes Multiplicadores para Assentamentos Humanos Saudáveis

7.2.1 Percepções dos participantes 246

7.3 Evidências de empoderamento e o processo de revisão do Plano Diretor Municipal 
7.3.1 Resultados das Oficinas do Plano Diretor

7.3.2 Discussão dos resultados e propostas

7.3.3 A advocacia por políticas públicas saudáveis e evidências do empoderamento: Audiências públicas do Plano Diretor

8 DISCUSSÃO: CONDIÇÕES OBJETIVAS DE VIDA, PESQUISA AÇÃO PARTICIPANTES E REFERENCIAL TEÓRICO

9 CONCLUSÕES E RECOMENDAÇÕES

9.1 Conclusões 298

9.2 Recomendações 300

\section{REFERÊNCIAS BIBLIOGRÁFICAS}

ANEXOS

ANEXO I - Quadro com os participantes do projeto na cidade

ANEXO II -Tabelas contendo os parâmetros e coeficientes da atual legislação municipal.

ANEXO III - Exemplo de material referente às iniciativas promovidas pelos Grupos no final do Curso de Formação de Agentes Multiplicadores para Assentamentos Humanos Saudáveis

ANEXO IV - Exemplo de Convite para Seminário do Curso de Formação de Agentes Multiplicadores para Assentamentos Humanos Saudáveis

ANEXO V - Exemplo de ficha de Avaliação de atividade de formação no Projeto Bertioga Município Saudável 


\section{RESUMO}

Este trabalho tem por objetivo a análise e discussão de políticas de habitação e desenvolvimento urbano no município de Bertioga, São Paulo, à luz das proposições do Ideário Municípios Saudáveis, conceito e estratégia recomendados pela OMS - Organização Mundial da Saúde. Para situar o problema no contexto da saúde pública, realizou-se um breve resgate das relações históricas entre as práticas de saúde pública as intervenções urbanas e habitacionais que ocorreram ao longo do tempo, nas cidades do Brasil. A pesquisa foi concebida a partir do marco conceitual da Promoção da Saúde e seus princípios básicos de ação - participação social, equidade, intersetorialidade e sustentabilidade - contemplados na estratégia de Municipios Saudáveis. A metodologia escolhida dentro das opções de investigação qualitativa foi a pesquisa ação participante. Foram utilizados dados secundários quantitativos para descrever e analisar as condições objetivas de vida da população e dados qualitativos da pesquisa ação participante realizada ao longo de três anos de trabalho no município de Bertioga. A apresentação dos resultados foi subdividida em três partes: na primeira, são apresentados os dados do diagnóstico sócio-espacial e na segunda são relatadas as percepções dos participantes do Projeto sobre as condições objetivas de vida em Bertioga. $\mathrm{Na}$ terceira parte são analisados, o processo de "empoderamento" da população, que ocorreu ao longo da pesquisa ação participante, e suas conseqüências para a advocacia em relação às políticas urbanas. Constatou-se que o território de Bertioga é extenso, rico em vegetação, especialmente matas, rios e corpos d'água. Sofreu intensa ocupação, principalmente a partir da década de 1980, constituindo-se num dos municípios que mais aumentou sua população nos últimos dez anos no Estado de São Paulo, em função principalmente da migração. Os atrativos naturais da cidade motivaram intensa especulação imobiliária, ampliação da indústria da construção civil voltada para produção de residências secundárias, ampliação do setor dos serviços, e o aprofundamento do problema habitacional e urbano, com um número crescente de pessoas vivendo em favelas e assentamentos precários, agravados pela 
inexistência de uma política de habitação e desenvolvimento urbano nos últimos anos. Foram identificados, ainda, problemas de saneamento ambiental, transportes e mobilidade urbana que têm interferido na manutenção ou aumento de mortalidade infantil, de mortalidade por causas externas e por doenças respiratórias. A análise da percep̧̧ão dos moradores sobre os problemas do município, identificados durante os anos de pesquisa, permitiu verificar também, que os problemas relacionados às políticas urbanas foram elencados entre os mais graves, portanto prioritários em diversos momentos do processo. A pesquisa demonstra a necessidade premente de elaboração e implementação de uma política habitacional, articulada às demais políticas urbanas, visando melhorar as condições de vida e saúde da população. Demonstram-se também, evidências da ocorrência de um processo de conscientização da população sobre as causas dos problemas urbanos, que têm interferido na saúde e condições de vida na cidade. Ao mesmo tempo há evidências do empoderamento de setores da população, que vem fortalecendo a organização popular na advocacia por políticas urbanas saudáveis.

Descritores: municípios saudáveis, promoção da saúde, políticas de habitação e desenvolvimento urbano, políticas urbanas, participação social, empoderamento, litoral paulista - Brasil. 


\section{SUMMARY}

The aim of this work is to analyse and discuss housing and urban development policies in the Bertioga Municipality, São Paulo, through the Healthy Cities notions, concept and strategy proposed by WHO - World Health Organisation. The research is based on the logical frame of the Health Promotion - and its fundaments of action - social participation, equity, intersectorial action and sustainability - according to the Healthy Cities strategy. It starts with a summary of the historical relationships among hygienist movement and the urban and housing interventions in the Brazilian cities to set the research work in the framework of the Healthy Public Policy. Considered the quality nvestigations options, the chosen methodology can be defined as research participation action. It was used quantitative secondary data - describing and analyzing the objective life conditions of population, and qualitative data resulting by the research participant action undertaken in the Bertioga Municipality during a three years' work. The outcome presentation is organised in three parts: the first part contains the diagnostic of spatial data, while the second part contain the perceptions of the participants of the Project about the conditions of life in Bertioga. The third part contains the analysis of the empowerment of the population and the consequences for advocacy related to urban policies. It was verified that the territory of Bertioga is vast and rich in vegetation, characterised by forest, rivers and natural water. Since 1980 an intense occupation has occurred, causing the larger population growth related to the São Paulo State administration cities in the last ten years, mainly caused by immigration dynamic. The natural attractive elements caused the intensive real estate speculation, the building site industry development due to the holiday houses demand, the service expanding and the housing and urban problems deepening the population living in slums and in precarious settlements increase together with the lack of housing and urban policies during the last years. Other problems have been identified: "environmental sanitation problems", transport and urban mobility, all of them, conditioning the infant mortality maintenance or growth, the mortality causing by external reasons and respiratory diseases. The 
analysis of the resident's perceptions about the municipality questions, identified during the years of research, highlights the problems related with urban policies as priorities in different moments of the process. The research proves the urgent need for housing policy elaboration and implementation, related with the others urban policies, aiming at upgrading life and healthy conditions of the population. The work also demonstrates that an awareness process is beginning among population regarding the causes of urban problems, related to health and life condition in the city and that the empowerment of population sectors is taking place, all this supporting the request of popular organisation for healthy urban policies.

Descriptors: healthy cities, health promotion, housing and urban development policies, social participation, empowerment, State of Sao Paulo's coast - Brazil. 


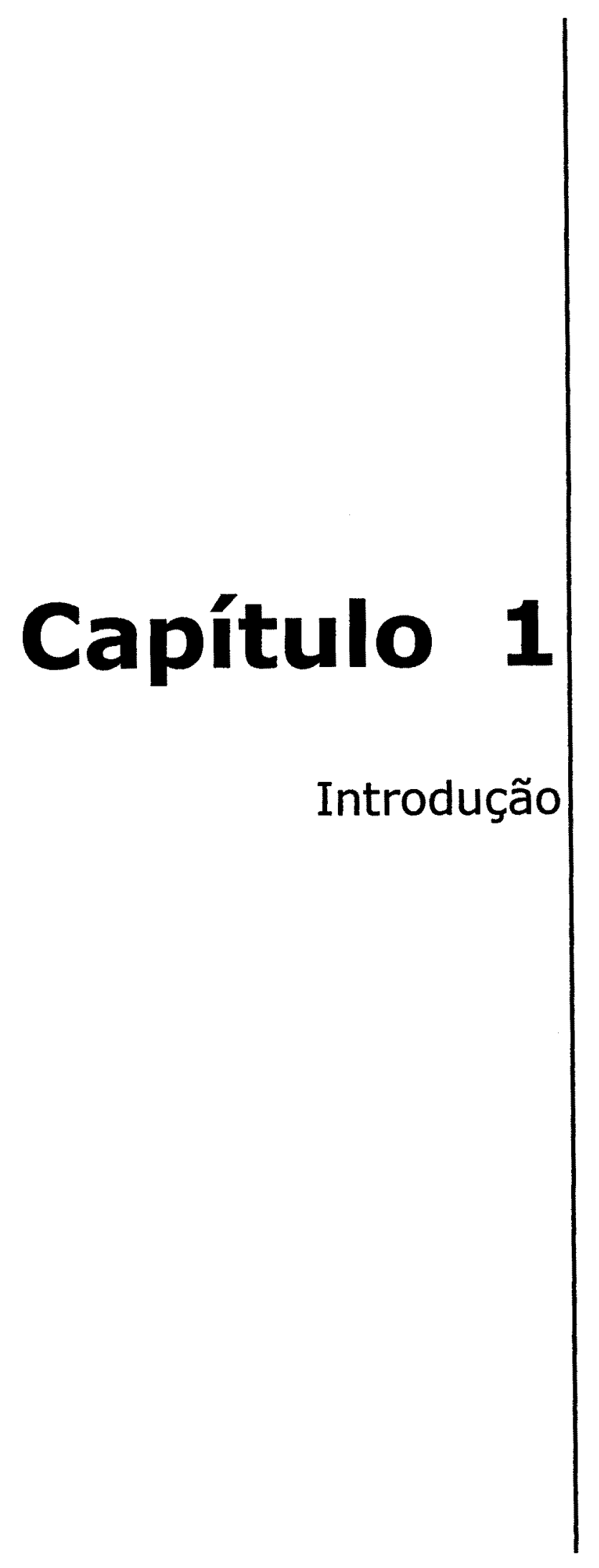


De acordo com a Organização das Nações Unidas o planeta atingiu em outubro de 1999 a marca de 6 bilhões de habitantes (Pnud, 1999). Dados da mesma fonte indicam que em 2025 dois terços da população mundial viverá nas cidades e o aumento dessa urbanização se concentrará nos países do chamado terceiro mundo.

Em 1996, a Agenda Habitat elaborada por representantes dos inúmeros países participantes da Conferência das Nações Unidas para os Assentamentos Humanos em Istambul, relata que pelo menos 1 bilhão de pessoas residiam em moradias inadequadas que não atendiam aos requisitos mínimos de habitabilidade, vivendo em inaceitáveis condições de pobreza, a maioria nos paises em desenvolvimento, representando $22 \%$ da população total. Cerca de 100 milhões de pessoas não têm onde morar, vivendo nas ruas. (Agenda Habitat, 1996).

Dados mais recentes divulgados no "Habitat's new Global Report on Human Settlements - The Challenge of Slums" confirmam que o número de pessoas habitando as favelas vem aumentando constantemente, chegando a cerca de 1 bilhão de pessoas vivendo nestas condições em todo o mundo, cerca de $32 \%$ da população urbana total do planeta (UN - Habitat, 2003). Segundo o relatório, "as favelas representam o pior da pobreza urbana e das desigualdades". Este problema afeta mais diretamente os países em desenvolvimento, que possuem $43 \%$ de sua população vivendo em favelas em grande contraste com os paises mais ricos onde esse percentual é de $6 \%$.

Na América Latina e Caribe, vivem em favelas cerca de $32 \%$ da população total. O relatório prevê que se não forem realizados esforços e ações conjuntas entre governos de todos os niveis, sociedade civil e comunidade internacional, a chamada "urbanização da pobreza" e a crise se intensificarão nos próximos 30 anos, sobretudo nos países mais pobres e a população habitando as favelas tende atingir cerca de 2 bilhões de pessoas (UN Habitat, 2003).

O Brasil, por sua vez, foi marcado neste século por uma quantidade grande de transformações, entre as quais, 0 intenso processo de urbanização, a exemplo de outras nações em desenvolvimento. Em 
poucas décadas o Brasil passou de um país predominantemente rural, para um país com mais de $75 \%$ da população morando em áreas urbanas. Em 1940 a taxa de urbanização era de 26,35\% e em 1980 alcançou 68,86\% (IBGE, 1991). "Entre 1940 e 1980, dá-se verdadeira inversão quanto ao lugar de residência da população brasileira". (Santos, 1994). Nesses quarenta anos triplica a população total do país, ao passo que a população urbana se multiplica por sete vezes. Em 2000 a população urbana ultrapassou $80 \%$ da população total (IBGE, 2000).

Outro grande desafio para o país consiste em superar a imensa desigualdade social, expressa principalmente pela má distribuição das riquezas entre a população. O Relatório de Desenvolvimento do Banco Mundial de 1999/2000 apresenta o Brasil como um dos países com a maior desigualdade na distribuição de renda no mundo. Enquanto os $10 \%$ mais ricos do país concentram $47,9 \%$ da renda total, os $10 \%$ mais pobres detém $0,8 \%$ da renda nacional total no ano de 1995 (World Bank, 1999).

Nas décadas de 1980 e 1990 a concentração de renda se aprofundou, como mostra a o quadro abaixo: (Maricato, 2001)

Segundo Ermínia Maricato (2001) "essa desigualdade não surge simplesmente da estruturação produtiva e do recuo das políticas sociais, mas trata-se de um aprofundamento da desigualdade numa sociedade histórica e tradicionalmente desigual".

Tabela 1 - CONCENTRAÇÃO DE RENDA NO BRASIL

\begin{tabular}{l|l|l}
\hline & 1981 & 1995 \\
\hline $50 \%$ mais pobres & $14,5 \%$ da renda & $13,3 \%$ da renda \\
\hline $10 \%$ mais ricos & $44,9 \%$ da renda & $47,1 \%$ da renda \\
\hline $1 \%$ mais ricos & $13,4 \%$ da renda & $14,4 \%$ da renda \\
\hline
\end{tabular}

fonte: Maricato, 2001

É neste contexto, que o presente trabalho de pesquisa pretende analisar e discutir a pertinência de elaboração das políticas de habitação e desenvolvimento urbano nos Projetos Municípios Saudáveis, tendo como referência uma pesquisa ação participante desenvolvida no município de 
Bertioga - SP. Para tanto, toma-se como ponto de partida uma breve sistematização das inter-relações entre intervenções habitacionais $e$ urbanas e de saúde pública no período do sanitarismo na virada do século XIX para o século XX, no Brasil.

Ao estudar as relações entre política habitacional e promoção da saúde, na perspectiva da nova saúde pública (Ashton, 1991; Santos e Westphal 1999) procura-se considerar neste estudo aspectos relevantes da evolução de práticas urbanísticas, de planejamento urbano e as práticas sanitárias.

O trabalho centra investigações no estudo de um caso no litoral paulista. Trata-se de um Projeto de Pesquisa e Extensão Universitária desenvolvido no Município de Bertioga.

O objetivo do trabalho é analisar a pertinência das políticas de habitação e desenvolvimento urbano nos Projetos Municípios Saudáveis, tendo como foco de aprofundamento, o trabalho de pesquisa e extensão universitária, realizado em Bertioga.

O trabalho pretende mostrar a centralidade ocupada pelo tema da habitação, bem como das demais questões que envolvem as políticas urbanas - saneamento ambiental, transportes e mobilidade urbana, planejamento e gestão urbana - no contexto de um município no litoral paulista.

Esta posição de centralidade da questão habitacional e urbana entre os problemas do município é evidenciada a partir da análise e sistematização dos dados quantitativos de fontes secundárias, levantadas em diversos órgãos públicos e privados. Outras evidências disso, podem ser constatadas, por meio da análise da percepção da população e atores locais sobre os problemas sentidos no dia a dia, e sua opção por priorizar ações no campo das políticas urbanas (Capítulo 6).

O trabalho demonstra que, tanto do ponto de vista da análise das condições objetivas de vida quanto da percepção dos moradores de Bertioga, as políticas urbanas e habitacionais são fundamentais para que 
- município possa tornar-se saudável. Este fato torna-se relevante na medida em que os Projetos Municípios Saudáveis, apesar de preceituarem a importância da participação dos diversos setores na produção social da saúde, geralmente nascem e desenvolvem-se sob o protagonismo e articulação mais central do setor saúde (Mendes, 2000).

Como bem coloca Mendes (2000) baseada em seu estudo sobre as Cidades Saudáveis no Brasil, há uma resistência por parte dos outros setores em envolver-se num projeto com a marca "Cidade Saudável". Esta resistência parece se iniciar no interior do próprio governo: "construir no interior de um governo local, a marca Cidade Saudável, não é uma questão fácil de ser equacionada, já que, muitas vezes, o adjetivo saudável é tido como estando relacionado apenas à saúde, e gera dificuldades com outras secretarias de governo. Alguns depoimentos relatam a concorrência entre as diferentes áreas do governo e sugerem que esses projetos dão maior poder ao setor da saúde". (Mendes, 2000).

Para superar essas dificuldades o trabalho da autora sugere a busca por pactos horizontais entre os setores e a articulação com outras forças políticas e com outras instâncias de controle social.

Assim, esta pesquisa revela o quão importante é o envolvimento dos outros setores, particularmente habitação, desenvolvimento e políticas urbanas. Outro elemento importante revelado pelo estudo, consiste nas evidências de que o Projeto Bertioga Município Saudável, pautado por metodologias participativas, contribuiu para o empoderamento (ou "empowerment") dos moradores na luta e advocacia pela implementação de políticas públicas urbanas saudáveis (Carta de Adelaide, 1988; Wallerstein, 1992; Labonte, 1994; Dallari, 1996).

Estas evidências são obtidas a partir da sistematização e análise do discurso e da percepção dos moradores e atores locais no decorrer de diferentes atividades do projeto na cidade, que culmina com a participação nas Audiências Públicas para a Revisão do Plano Diretor Municipal. 
Obviamente, que o empoderamento de integrantes da sociedade civil na luta por influenciar políticas públicas urbanas não constitui um evento original ou privilégio do caso de Bertioga. Pelo contrário, em inúmeros municípios esses movimentos sociais urbanos participativos decisivos, deram-se com resultados importantes para a modernização $e$ aperfeiçoamento do aparato legal e urbanístico, como por exemplo, Santo André-SP e Angra dos Reis-RJ (Guimarães, 1997).

O que nos chama a atenção no entanto, é o fato da luta pró-políticas urbanas ter-se dado na perspectiva de um Projeto Município Saudável, sob a inspiração conceitual da Promoção da Saúde e da produção social da saúde (Czeresnia, 2003).

O trabalho pretende centrar investigações na perspectiva de discutir também outros aspectos norteadores, conseqüentes das questões centrais mencionadas. Como ocorreu o desenvolvimento urbano em Bertioga? Qual o resultado do mesmo? Como a população e os atores locais percebem os problemas urbanos? Um Projeto Município Saudável pode contribuir para ampliar a luta social por políticas urbanas saudáveis?

Assim, diante da relação conhecida entre saúde e moradia já demonstrada em outros trabalhos (Taschner, 1982), procuraremos estudar a relação entre políticas de habitação e desenvolvimento urbano e a promoção da saúde e a pertinência dessas políticas urbanas em Projetos Municípios Saudáveis, por meio da sistematização de elementos teóricos e da análise de dados coletados sobre Bertioga, no litoral do Estado de São Paulo.

\subsection{Justificativa: contexto urbano, de saúde e o cenário de estudo}

Ao chegarmos ao final do século XX, talvez possamos afirmar que assistimos, nos últimos cem anos, à mais significativa transformação nas condições de saúde da população humana da história (Waldman 2000). "Além de avanços em conhecimentos a respeito das causas e efeitos das doenças, houve progresso no campo do saneamento, em condições de nutrição da 
população, na segurança, no trabalho, foram desenvolvidas vacinas e drogas eficazes. Um exemplo dessa trajetória é o fato de povos pouco desenvolvidos viverem atualmente, em média, mais do que as populações prósperas à algumas décadas atrás" (Word Development Report, 1993; Beaglehole, Bonita, 1997 apud Waldman 2000).

No entanto, esse processo não conseguiu diminuir as grandes diferenças entre ricos e pobres e também não tem conseguido evitar, em boa parte do chamado Terceiro Mundo, elevadas taxas de doenças evitáveis e de mortes prematuras.

A análise dos dados que configuram a chamada transição epidemiológica mostra que "convive-se hoje com taxas muito elevadas de mortalidade por novos fatores como violência, acidentes de trânsito, AIDS, doenças cardiovasculares, de um lado, e de hantavírus, febre de lassa, dengue, cólera, coqueluche, febre amarela de outro. Vemos lado a lado velhos e novos problemas de saúde pública" (CDC, 1994 apud Waldman 2000).

O desafio da promoção da saúde, em conseqüência do próprio conceito, promoção da qualidade de vida na acepção mais ampla e positiva da expressão, passa pela revisão crítica, readequação e reestruturação de diversas práticas sociais, econômicas, políticas e comportamentais na contemporaneidade.

Diversos autores têm concluido que o substrato para melhoria das condições de vida e, em especial, dos indicadores de saúde, fundamenta-se na capacidade dos Estados de oferecerem, a todos os cidadãos, acesso às condições básicas de sobrevivência - alimentação, habitação e água - assim como educação, informação, liberdade, e oportunidades de ascensão social.

Alguns autores afirmam que esses fatores, a longo prazo, são mais relevantes na evolução favorável dos padrões de saúde das populações do que as intervenções tecnológicas e o desempenho dos serviços sanitários (Murray, Chen, 1993 apud Waldman 2000).

Constata-se assim, que a melhoria das condições de vida e a promoção da saúde da população, em muitos casos, depende mais diretamente dos investimentos e políticas públicas de setores outros como saneamento, 
habitação, desenvolvimento urbano, transporte, meio ambiente, educação, democratização de informações, geração de emprego e renda, do que de investimentos prioritários na área médica e do setor da saúde propriamente dito. É óbvio que sempre há que se considerar de que tipo de investimentos e políticas se tratam.

Nesta perspectiva, o movimento por cidades/municípios saudáveis, é uma das estratégias recomendadas pela OMS - Organização Mundial da Saúde que objetiva fomentar ou promover a articulação dos setores público, privado, entidades civis, voluntários, e as comunidades, para que possam, por intermédio de parcerias, focar no desenvolvimento da saúde urbana. Visa também colocar a saúde na agenda dos tomadores de decisão nas cidades, anelando construir uma forte organização pela saúde pública no nível local. Em última instância os projetos cidades/municípios saudáveis visam promover o bem estar físico, mental, social e ambiental das pessoas que vivem e trabalham em áreas urbanas (Werna, 1995).

Nesta concepção, a moradia, especialmente, políticas e programas habitacionais e urbanos apropriados, podem ser estratégicos para a promoção da saúde, a elevação da qualidade de vida nas cidades e eficiência nos investimentos públicos, especialmente nos países em desenvolvimento, onde grande parte da população mora em condições subnormais do ponto de vista sanitário, jurídico, de segurança, urbanístico e/ou construtivo.

Já é conhecido, tanto no meio técnico como no meio popular, o fato de que condições inadequadas de habitação causam problemas e agravos à saúde, que vão desde doenças transmissíveis, muito associadas à carência de saneamento básico, até as doenças respiratórias, associadas à umidade de ar dos ambientes, insuficiência de ventilação, insolação, poluição atmosférica. "Em pesquisa realizada junto aos moradores de diferentes tipos de habitação na Periferia de São Paulo, Jacobi (1995) evidencia dois aspectos importantes: o primeiro diz respeito ao fato de que a população identifica com clareza as deficiências existentes na moradia e relaciona tais problemas ao aparecimento de agravos respiratórios" (Chiesa, 1999).

As correntes de ar frio, os buracos na construção, o chão frio, as infiltrações de água e a falta de ventilação foram apontados como as principais causas 
de bronquites, resfriados, gripes e pneumonias (Jacobi, 1990 apud Chiesa, 1999).

No Brasil, constata-se o crescimento considerável no número de unidades faveladas entre os anos 1980 e 1991: se em 1980 o IBGE computou 480.595 unidades faveladas, $1,89 \%$ dos domicílios brasileiros, em 1991 o percentual subia para $3,28 \%$, com mais de 1,14 milhão de moradias em favelas. Ao mesmo tempo, sabe-se que as condições de vida e habitação em regiões de favela são altamente desfavoráveis à saúde da população ${ }^{1}$ (Taschner 1996).

\section{Moradia e Crise Urbana}

O problema habitacional brasileiro tem origem na própria gênese do processo de urbanização e de formação das cidades brasileiras. Neste sentido, inúmeros autores mostram como as condições de moradia eram precárias a partir da segunda metade do século XIX, com os cortiços paulistanos e com os cortiços e as favelas cariocas (Bonduki, 1998, Lemos, 1998, Piccini, 1996; Chalhoub, 1996; Kowarick e Ant, 1994; Morse, 1970).

Maricato (2001) contextualiza de forma bastante consistente a situação de "crise urbana" em que chegaram as cidades brasileiras. A autora questiona o pleno processo de modernização da nossa sociedade, ressaltando o processo de "recriação do atraso" na urbanização ocorrida principalmente durante o século XX.

Há uma quantidade relativamente grande de elementos que concorreram para a emergência desta situação de crise, entre os quais o intenso processo de urbanização pelo qual passamos nos últimos cem anos, que gerou a necessidade de um "gigantesco movimento de construção de cidade" incluindo-se aí moradia, saneamento ambiental, transportes, infra-estrutura (Maricato, 2001).

Maricato mostra, utilizando referência de outros autores estudiosos da economia e da história do Brasil, fatos relacionados ao caos urbano ou à

\footnotetext{
${ }^{1}$ Estas proporções estão subestimadas, pois o IBGE considera núcleo de favela apenas aqueles que se compõe de 50 ou mais unidades de domicilios.
} 
"tragédia urbana" e à produção do ambiente urbano construído: a privatização da terra a partir de 1850 e a emergência do trabalho "livre" a partir de 1988, a questão fundiária (concentração das propriedades de terra, a desorganização das informações e registros cartoriais), a desigualdade social expressa pela má distribuição das riquezas (Maricato, 2001), o modelo de desenvolvimento econômico vigente historicamente - incluindo-se aí o grau predatório do processo de industrialização ocorrido a partir dos anos 1950 - "fordismo periférico" (Furtado, 1995 apud Maricato, 2001), e o grau de dependência externa da economia (Prado Jr. apud Maricato, 2001).

Segundo o Fórum Nacional da Reforma Urbana - FNRU, um movimento importante que congrega há décadas inúmeras entidades e ativistas na luta pela democratização das cidades, o processo de urbanização no Brasil, "acelerado e caótico atendeu aos interesses do desenvolvimento e da produção capitalistas, em um modelo de acumulação desigual, que excluiu sistematicamente a maioria da população do acesso a bens, serviços $e$ direitos. Assim, as cidades brasileiras se constituem em importantes mecanismos (ou espaços) de reprodução de àcumulação do capital, transformando-se em mecanismo de espoliação urbana onde a violência e a precariedade estão intrinsecamente ligadas (...)" (FNRU, 2003).

O Fórum adverte também que a "carência habitacional está no centro do problema urbano", na medida da exclusão de grande parte da população do mercado imobiliário formal. Cresce assim, o déficit e as "formas de inserção marginal na cidade". Desta forma, quem está fora do mercado só tem acesso à moradia à margem da cidade (FNRU, 2003).

O Projeto Moradia elaborado pelo Instituto Cidadania (2002) apresenta-nos dados da Fundação João Pinheiro, frutos de análises com base no censo de 1991 e na PNAD - Pesquisa Nacional de Amostra por Domicilio de 1995, que apontam para um déficit habitacional quantitativo na área urbana no Brasil, da ordem de 4 milhões de unidades. Nas áreas rurais o déficit é de 1,6 milhões, totalizando em 5,6 milhões a demanda por novas moradias.

A Fundação João Pinheiro define como necessidades habitacionais as moradias "com infra-estrutura carente ou inadequada, com custo excessivo para a renda familiar ou excessivamente adensadas". Representam assim, 
unidades que necessitam de intervenções para melhorar a qualidade da moradia ou o acesso aos serviços e infra-estrutura urbana. Não demandam a necessidade de reposição por uma moradia nova (Instituto Cidadania, 2002).

O déficit qualitativo, desde os anos 1940 "cresceu vertiginosamente como conseqüência do padrão desordenado de desenvolvimento urbano". Essa carência habitacional traduzida em déficit qualitativo está estimada em cerca de 5,6 milhões de unidades em termos de necessidades de infra-estrutura urbana e 1,3 milhões de unidades em termos de adensamento excessivo (Instituto Cidadania, 2000).

O Projeto Moradia aborda também a problemática da previsão das demandas futuras de habitação, fruto do crescimento demográfico. As projeções revelam a necessidade, de 1996 até 2015, do financiamento com o subsídio para a produção de 3,9 milhões de novas unidades e 2,7 milhões de unidades a serem melhoradas (Instituto Cidadania, 2002).

Outra conclusão importante, fruto das pesquisas nas últimas décadas de ativistas e acadêmicos do campo urbano e habitacional, é que os mecanismos de mercado são absolutamente insuficientes para combater o déficit, em função da sua distribuição em função da renda. De acordo com o Instituto Cidadania (2002) $63,32 \%$ do déficit urbano está concentrado nas famílias com renda mensal de até 3 salários mínimos. Considerando a faixa de renda de até 12 salários mínimos, a concentração do déficit se eleva para $92,46 \%$. Ou seja, são os mais pobres e os miseráveis que mais precisam de financiamento e das políticas públicas subsidiadas. (Instituto Cidadania, 2002; Maricato, 2001, FNRU, 2003).

Cerca de $78 \%$ do déficit rural está concentrado nas famílias com renda até dois salários mínimos (Instituto Cidadania, 2002). Estes dados mostram que o subsídio é indispensável para equacionar o problema da maior parte dos necessitados.

Além disso, há que se considerar o processo de deterioração e obsolescência do parque habitacional produzido nos últimos cinqüenta anos (incluindo a significativa produção de má qualidade do Banco Nacional de Habitação - 
$\mathrm{BNH}^{2}$ ). Essas edificações obsoletas necessitarão ser repostas ou melhoradas, conforme o que já ocorre em diversos países com maior tradição de provisão habitacional pública para a classe trabalhadora.

Com relação à qualidade dos serviços de infra-estrutura urbana, estima-se que $28 \%$ do total de domicílios no Brasil são inadequados, ou seja carecem de pelo menos um dos serviços básicos essenciais. O serviço mais deficitário nos domicílios brasileiros é o esgotamento sanitário ( $79,3 \%$ de déficit), seguido da ausência de rede geral de abastecimento de água $(15,3 \%$ de déficit). "A concentração de domicilios inadequados se dá na faixa de até três salários mínimos, representando $58 \%$ dos carentes no pais" (FNRU, 2003).

O número de assentamentos de favelas no Brasil tem aumentado. Estima-se pelos dados do Censo do IBGE de 2000 que entre 1991 e 2000 o número de favelas teria aumentado $22 \%$ em todo o Brasil, atingindo um total de 3.905 núcleos (Maricato, 2001).

Uma dificuldade central no setor urbano habitacional é a obtenção de dados confiáveis. Esta tendência revela, de alguma forma, a pouca importância que ainda é dada ao problema e tem como conseqüência um menor ou um conhecimento menos aprofundado do mesmo.

Seja por falhas metodológicas, seja por uma dificuldade de reconhecer os títulos da terra sobre a qual as favelas se instalam, "O IBGE apresenta dados bastante subdimensionados" (Maricato, 2001).

Estima-se que a proporção de população moradora de favelas em algumas cidades brasileiras seja da ordem de: Rio de Janeiro (20\%), São Paulo (22\%), Belo Horizonte (20\%), Salvador (30\%), Recife (46\%) (Maricato, 2001).

Além das favelas, há que se considerar que o quadro da ilegalidade na ocupação do solo engloba também os loteamentos ilegais, sem falar nos cortiços que são outra forma ilegal de moradia. Considerando todas estas modalidades, diversas metrópoles brasileiras atingem mais de $50 \%$ de sua

\footnotetext{
2 Segundo Maricato (2001) o BHN - Banco Nacional da Habitação produziu cerca de 4 milhões de unidades habitacionais entre 1964 e 1986, em uma escala jamais vista no Brasil.
} 
população morando de forma ilegal. Segundo Maricato (2001) o processo de urbanização se apresenta como uma máquina de produzir favelas e de agressão ao meio ambiente.

Todo este quadro foi agravado pela desorganização e desarticulação institucional pública e estatal, dos órgãos responsáveis pelas áreas de habitação e pelo desenvolvimento urbano no Brasil.

De acordo com o FNRU (2003) "sempre predominou uma desorganização da área habitacional, com a atuação de diferentes esferas de governo, cada qual adotando regras de financiamento diferentes, dispersando recursos em intervenções sobrepostas, adotando subsídios sem critérios claros (...) Faltou aos ministérios que trataram até agora da questão habitacional apoio institucional às atividades de suporte à implantação de políticas públicas (...)".

Apesar da existência, operação e produção do BNH - Banco Nacional da Habitação de 1964 a 1986 (período em o país contou com um Sistema Nacional de Habitação), nunca houve no país uma política integradora, articulada e descentralizada que viabilizasse a definição clara das atribuições de cada esfera de governo e dos agentes públicos e privados envolvidos.

A tudo isso se soma a desorientação do crescimento urbano, norteado por interesses econômicos e imobiliários que, contando com incentivos legais e governamentais, produziram em inúmeras cidades, novas centralidades (enquanto localizações imobiliárias), por meio de novas avenidas, empreendimentos tipo "ilhas de primeiro mundo", enquanto o Estado por sua vez, participou do desperdício e má aplicação do dinheiro público das prefeituras, Estados e União por falta de uma política habitacional e urbana no país (Instituto Cidadania, 2002).

Nos dias atuais, todo este quadro se desenvolve em um cenário novo, no qual a moradia é reconhecida como um direito humano e uma condição básica de cidadania. De acordo com o Instituto Cidadania (2002) "o acesso à moradia digna é condição básica de cidadania, devendo portanto, receber o mesmo tratamento que a educação e a saúde, ou seja, deve ser uma 
prioridade nacional e ter garantidos recursos e mecanismos institucionais para a sua concretização".

Neste sentido, a moradia digna é a aquela localizada em terra urbanizada (provida de infra-estrutura), com acesso a todos os serviços públicos essenciais por parte da população, como saneamento ambiental (abastecimento de água, esgotos sanitários, coleta e tratamento de resíduos sólidos, drenagem), energia elétrica, iluminação pública, pavimentação, bem como equipamentos de educação, saúde, cultura, esporte e lazer, que deve estar abrangida por programas e alternativas geradoras de trabalho e renda (Instituto Cidadania, 2002).

Moradia é um direito humano, reconhecido pelo Tratado dos Direitos Sociais e Econômicos da Organização das Nações Unidas (ONU), ratificado pelo Brasil em 1992, e como tal, deve ser reconhecido e efetivado através de políticas públicas específicas. $O$ seu não cumprimento significa uma violação aos direitos humanos. A consagração constitucional do direto à moradia digna é fato recente no Congresso Nacional, e sua aplicação implicaria o desembolso obrigatório de recursos públicos no encaminhamento de soluções (Brasil, Estatuto da Cidade, 2001; Instituto Cidadania, 2002).

Outra novidade recente, refere-se à criação do Ministério das Cidades pelo Governo Federal em 2003, que representa sem dúvida, um avanço histórico muito importante, na medida em que integra os setores afetos à política urbana (habitação, transportes e mobilidade urbana, saneamento ambiental e programas urbanos) e propõe-se a desenvolver uma política nacional de desenvolvimento urbano. Segundo Martins (2003) o significado do Ministério das Cidades "é da maior importância para a politica urbana brasileira, pois eleva as cidades a novo patamar, já apontado com a aprovação do Estatuto da Cidade (Lei 10.257/2001), que atribui às cidades brasileiras um novo estatuto".

Neste sentido como lembrado pela autora (Martins, 2003), o Estatuto da Cidade também representa um avanço muito importante, aprovado após muitos anos de luta e 12 anos de tramitação no Congresso Nacional; reconhece a função social da cidade e da propriedade imobiliária, a 
importância da gestão democrática das cidades e 0 direito à cidade sustentável (FNRU, 2003).

\section{Cenário de Estudo: Município de Bertioga}

Diante das evidentes relações entre saúde pública e políticas habitacionais e urbanas e no contexto da Nova Saúde Pública e do Movimento Municípios Saudáveis, o presente trabalho procura analisar e discutir a pertinência da adoção de políticas de habitação e desenvolvimento urbano em Projetos Municípios Saudáveis. Além disso, espera-se explicitar algumas contribuições que a abordagem dos Projetos Municípios Saudáveis podem trazer para o enfrentamento da problemática urbana. Discute-se também, o papel das políticas habitacionais e urbanas na estratégia de promoção da saúde.

O cenário de todas as análises é o município de Bertioga, localizado na Região Metropolitana da Baixada Santista (RMBS). A sua escolha para a realização desta pesquisa se justifica em função de diversas características. Primeiramente por tratar-se de cidade litorânea, num país com uma imensa costa de mais de 8 mil quilômetros, e parcela considerável da população distribuída por esta faixa do território.

Em segundo lugar, é relevante a presença de remanescentes consideráveis de Mata Atlântica e conseqüentemente, legislação de preservação ambiental. Além disso, a região sofre o efeito de um fenômeno migratório intenso, sem apresentar infra-estrutura adequada para fazer frente aos problemas decorrentes.

Outro aspecto importante diz respeito às atividades econômicas principais na região, que giram em torno dos serviços e comércio voltados para o atendimento da população turística e do setor da construção civil e mercado imobiliário, prioritariamente voltado para a produção de residências secundárias.

O municipio de Bertioga caracteriza-se também por fazer parte das cidades recém emancipadas do país e sua posição geográfica o distingue enquanto 
município periférico da RMBS, da Macro-Metrópole Paulista $^{3}$ e, ao mesmo tempo, transição da Região Santista com o litoral norte do Estado de São Paulo.

No âmbito institucional e acadêmico, a pesquisa foi viabilizada, graças à assinatura de um acordo de cooperação entre a Faculdade de Saúde Pública da Universidade de São Paulo (FSPUSP) e a Prefeitura do Município de Bertioga (PMB) no ano de 2000. Este acordo institucional envolvendo a FSPUSP contou com alguns outros apoios e financiamentos institucionais que viabilizaram a realização da pesquisa ação participante no município.

Após esta introdução, que contém a justificativa e os objetivos do trabalho; no capítulo 2 são apresentados notas e fatos históricos sobre as políticas de saúde e as primeiras intervenções urbanas e habitacionais do final do século XIX e início do século XX no Brasil (enfatizando o caso de São Paulo), focalizando o ideário orientador e integrador das duas áreas de ação social.

No capítulo 3 procura-se realizar uma sistematização dos conceitos e pressupostos da área da Promoção da Saúde relacionando-os às políticas urbanas no sentido de produzir saúde socialmente. Neste contexto apresenta-se a matriz conceitual do ideário Municipios Saudáveis, proposto pela OMS - Organização Mundial da Saúde.

O capítulo 4 contém a concepção do estudo e a metodologia utilizada na condução geral da pesquisa. Cabe notar que optamos por realizar comentários de alguns aspectos metodológicos mais específicos também nos capítulos 6,7 e 8 que descrevem atividades desenvolvidas no município.

O trabalho procura apresentar no capítulo 5 um diagnóstico sócio-espacial e uma discussão sobre as condições objetivas de vida no município em estudo. Estas análises têm por base, dados secundários e quantitativos levantados em diversos órgãos públicos e privados.

${ }^{3}$ O Termo Macro Metrópole Paulista vem sendo utilizado como referência às três regiões metropolitanas muito próximas no Estado de São Paulo: Região Metropolitana de São Paulo, Região Metropolitana de Campinas e Região Metropolitana da Baixada Santista. 
No capítulo 6 é realizada uma sistematização e discussão da percepção dos moradores e participantes do Projeto Bertioga Município Saudável (PBMS) sobre os problemas que mais afetam as condições de vida e de saúde.

No desenvolvimento do capítulo 7 procura-se mostrar e discutir as evidências da ocorrência de um processo de empoderamento de setores da população, durante a pesquisa ação participante, e suas conseqüências na advocacia por políticas urbanas saudáveis.

No capítulo 8 realiza-se uma discussão final, tendo como base o material sistematizado e analisado nos capítulos anteriores. As conclusões são apresentadas no capitulo 9 do trabalho.

\subsection{Objetivos}

A pesquisa tem como objetivo geral analisar a pertinência das políticas de habitação e desenvolvimento urbano em Projetos Municípios Saudáveis, tendo como foco central de estudo o municipio de Bertioga.

Os objetivos específicos do trabalho são:

a) caracterizar o município de Bertioga nos seus aspectos sociais, demográficos, econômicos, urbanísticos, habitacionais e ambientais, incluindo saneamento básico;

b) analisar a percepção da população e atores locais, participantes do Projeto Bertioga Município Saudável, sobre as potencialidades do município e os problemas que mais afetam as condições de vida, particularmente os problemas urbanos (moradia, saneamento ambiental, transportes e mobilidade);

c) identificar as evidências da ocorrência de um processo de empoderamento dos participantes do Projeto Bertioga Municipio Saudável ao longo do desenvolvimento da pesquisa ação participante e suas conseqüências para a advocacia por políticas urbanas saudáveis; 
Politicas de habitação e desenvolvimento urbano em municípios saudáveis: o caso de Bertioga Capitulo 1- Introdução

d) sugerir diretrizes para as políticas de habitação e desenvolvimento urbano em Projetos Municípios Saudáveis, mais especialmente voltados, para a realidade do litoral paulista. 


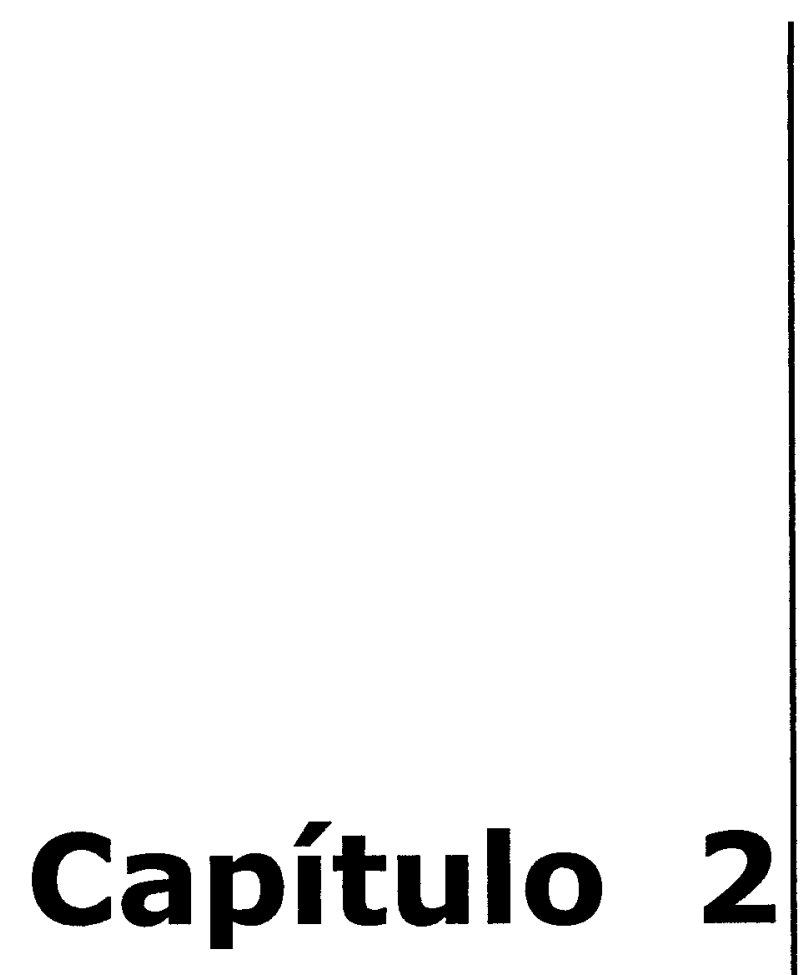

Sanitarismo e as primeiras intervenções urbanas e habitacionais 
Buscando identificar relações na história política e econômica do Brasil, por meio das referências bibliográficas que informam sobre as origens da saúde pública e das políticas urbanas e habitacionais, verificamos interconexões entre estes dois setores.

Neste sentido, alguns trabalhos constituem pontos de partida para análises complementares. Particularmente os trabalhos de Bonduki (1998), Hochman (1998) e Andrade (1992) norteiam as análises que serão expostas a seguir. Os estudos de Bonduki apresentam-nos as origens da habitação social no Brasil, e contém o registro crítico das primeiras intervenções públicas em habitação nas cidades brasileiras.

Hochman (1998) analisa quando, como e em que condições a saúde se tornou pública (e Estatal) no Brasil. Andrade (1990 e 1991) em seus estudos sobre o trabalho do engenheiro Saturnino de Brito, apresenta-nos um panorama crítico das idéias e das práticas dos sanitaristas que influenciaram paradigmaticamente o desenho, a construção e o desenvolvimento de inúmeras cidades modernas brasileiras.

Pode-se dizer que as primeiras medidas de saneamento urbano que acenavam para as origens das ações públicas em saúde no Brasil, iniciaram-se após a vinda da família real para o país em 1808, quando ocorreram medidas para controle de doenças pestilênicas. Muitas das primeiras intervenções públicas urbanas e habitacionais no país tiveram uma relevante preocupação sanitária e higienista na segunda metade do século XIX, quando a população de algumas cidades brasileiras crescia vertiginosamente e grande parcela dos habitantes não encontrava formas saudáveis de moradia.

As políticas de saúde se caracterizavam por se articularem com os interesses econômicos e políticos das classes dominantes nacionais, representados então, principalmente, pelos produtores de café. Fatos históricos importantes como a abolição da escravatura e o início do processo de industrialização no final do século XIX, concorreram para a intensificação dos contingentes populacionais que migraram para as cidades, ainda não aparelhadas para abrigá-los adequadamente. 
Em São Paulo, por exemplo, os cortiços tornavam-se a única alternativa (ou falta de) para a população pobre e migrante que necessitava alojar-se na cidade. Conforme nos relata Lemos (1998) sobre os primeiros cortiços paulistanos "com a abastança trazida pelo café, São Paulo iniciou o seu incontrolável processo de construção caracterizado pela novidade da alvenaria de tijolos, pela presença da mão de obra estrangeira, pelos materiais importados (...) tudo isso graças às facilidades do transporte propiciado pela estrada de ferro construida pelos ingleses e graças também às infindáveis ondas migratórias responsáveis pelo aumento populacional" (Lemos 1998).

O crescimento populacional nas cidades acarretou problemas de saúde pública causados pela ausência de infra-estrutura urbana, saneamento, moradia. A problemática das epidemias e moléstias ocorriam também em outras cidades importantes como Santos, Rio de Janeiro e Vitória que se caracterizavam pela existência dos portos.

São Paulo, por exemplo, "ao receber milhares de novos moradores passou a exigir transportes rápidos pois as distâncias passaram a ser medidas em quilômetros, os chafarizes deixaram de dar conta do consumo, aumentou o risco contaminação da água e o esgoto sem destino certo tornou-se o principal inimigo da saúde pública. Os problemas que mais preocupavam as autoridades eram os que agravavam as condições higiênicas das habitações, dado que no final do século foram inúmeros os surtos epidêmicos que atingiram as cidades brasileiras. Esta questão passou a receber tratamento prioritário do Estado e pode-se dizer que a ação estatal sobre a habitação popular se origina e permanece na Primeira República voltada para quase que apenas esse problema". (Bonduki, 1998). Essas ações caracterizavam-se essencialmente pela idéia de limpeza da cidade, e de controle policial das condições consideradas insalubres ou promíscuas.

Diante deste quadro de crescimento e de profundas transformações sociais e em toda a estrutura urbana das grandes cidades, ocorre, na virada do século uma reformulação de conceitos e ações de saúde pública. Com apoio do poder central, iniciou-se no Brasil uma nova fase mais intervencionista, num contexto marcado por inúmeros outros 
eventos e transformações estruturais, que vão das fisicas às morais e do discurso, influenciados pelas recentes descobertas, debates e ações em curso na Europa e América do Norte.

As pautas da moralidade sanitária foram instauradas no Brasil no século $X I X$. O discurso médico-higiênico acompanhou 0 processo de transformação política e econômica desse século, que assinala a constituição de uma economia urbano-comercial e a projeção de uma elite dominante com "ideais burgueses", que procura viabilizar, no país, a existência de uma ordem social "européia" e capitalista. A higiene elegeu como alvos principais de controle o ambiente da cidade colonial e a educação sanitária das elites. (...) Os preceitos e regras higiênicas relativos à habitação popular visaram enquadrar o espaço urbano $e$ estabelecer a necessária vigilância sobre a moralidade de seus ocupantes. (...) Junto às tarefas de polícia sanitária da febre amarela, peste, variola e tuberculose, entre outras enfermidades, a higiene cumpriu, dessa forma a tarefa de normatização da arquitetura do espaço urbano e o controle higiênico das camadas baixas da população. (Costa, 1987)

No campo da ação pública em saúde, Almeida et al (1997) mostra que desde o final do século XIX até a metade dos anos 1960, "praticou-se como modelo hegemônico de saúde o sanitarismo campanhista, de inspiração militar, que visava o combate das doenças através de estruturas verticalizadas e estilo repressivo de intervenção e execução de suas atividades sobre a comunidade $e$ as cidades". Estes foram implantados com muito sucesso por eminentes sanitaristas, como Oswaldo Cruz (que combateu a febre amarela no Rio de Janeiro em 1903 e esteve à frente da Diretoria Geral de Saúde Pública criada em 1904) Rodrigues Alves (saneamento do Rio de Janeiro em 1902), Carlos Chagas, Emílio Ribas e Saturnino de Brito (saneamento da cidade e porto de Santos em 1906), entre outros. Em 1897 foram criados o Instituto Manguinhos, Adolfo Lutz e Butantã, para a pesquisa, produção de vacina e controle de doenças (Almeida et. al. 1997). 
Foi um período de evolução acelerada do conhecimento científico, em que surgiram novas normas e organização sanitária que, de certo modo, contribuíram para a implementação de uma legislação sanitária, de uma estrutura burocrática, ampliação de diversos interesses e ações de nível estatal, em sintonia com os interesses das elites dominantes.

É no período da Primeira República que no dizer de Hochman, a "saúde se torna pública e estatal" no Brasil. $O$ autor mostra que no início e ao longo da Primeira República, "os problemas de saúde foram de maneira crescente identificados como um dos principais elos de interdependência da sociedade brasileira e que se construiu uma consciência, entre as elites, sobre os efeitos negativos gerados pelas condições sanitárias do pais e sobre a precariedade de saúde de sua população" (Hochman 1998). A possibilidade do contágio tornara indissociáveis pobres e ricos, sãos e doentes, palácios e cortiços, regiões diversas de um mesmo país e do planeta. Ninguém em nenhum lugar poderia escapar da ameaça da doença, e por isso mesmo ninguém poderia ser indiferente à sorte, má sorte de outros indivíduos, estejam onde estiverem (...) afinal o que aproximaria um americano próspero de um pobre camponês russo? 0 micróbio causador de doenças (Hochman 1998).

Além disso, argumenta-se que as precárias condições de saúde e a ameaça de epidemias à parcelas significativas da população, tanto de áreas rurais, quanto de áreas urbanas de São Paulo e de cidades portuárias como Santos, Rio de Janeiro, Vitória, teriam efeitos muito negativos aos interesses econômicos e comerciais do país. A questão sanitária tornou-se prioritária (...) o receio do caos e da desordem, a ameaça que os surtos epidêmicos representavam para a organização econômica, o pânico que um mal desconhecido trazia à população, o prejuízo que a morte de imigrantes recém chegados causava às finanças públicas e enfim, o medo da classe dirigente vir a ser atingida pelas doenças, foram as razões que levaram o Estado a intervir no espaço urbano (Bonduki, 1998).

Esta situação provocou um tipo de intervenção pública na moradia das classes populares, que constava, na maior parte das vezes, na demolição 
de casas, cortiços, estalagens e expulsão dos moradores. Há diversos relatos desses acontecimentos em São Paulo e no Rio de Janeiro (Bonduki, 1998; Costa, 1987; Lemos, 1998).

Os processos de industrialização, urbanização e crescimento populacional tinham constituído uma sociedade na qual um dos elos principais seria a doença, em especial quando se apresentava à sociedade sob a forma de epidemia. (Hochman, 1998).

Esta conjuntura foi adequada para adotar no Brasil "práticas urbanísticas assentadas em teorias e propostas então em plena voga na Europa, no início do século". Andrade (1992) relata aspectos conceituais e técnicos que orientavam a atuação de um dos mais importantes engenheiros sanitaristas da virada do século, Saturnino de Brito, "que realizou projetos e obras para cerca de quarenta cidades brasileiras, entre os anos de 1896 - quando elaborou o projeto de saneamento e de melhoramentos do "Novo Arrabalde", na cidade de Vitória, capital do Espirito Santo - e 1929 - ano de seu falecimento em pleno exercício profissional na cidade de Pelotas, no Rio Grande do Sul".

"Conceber a cidade como um corpo são e belo, portanto funcional, só foi possivel porque Saturnino de Brito apoiava seus princípios de intervenção e sua leitura da cidade em uma visão organicista, que se fundamentava na teoria dos meios, em oposição à teoria microbiana" (Andrade, 1992).

Como sanitarista e engenheiro, via na atuação sobre o meio insalubre, através das obras de saneamento, "a alternativa não apenas ao cordão sanitário e às quarentenas, como também às ações da polícia sanitária e, sobretudo, a alternativa às campanhas de vacinação da população, que impunham aos corpos dos cidadãos constrangimento que levava Brito a insurgir-se de modo veemente" (Andrade, 1992).

Seus projetos e obras de saneamento, dos quais se destacam os canais de drenagem como "elementos estruturadores do espaço urbano, não apenas propiciavam condições de salubridade ao meio físico, eliminando as causas das epidemias, mas ao mesmo tempo, colocavam a 
necessidade de previsão do crescimento das cidades - daí a exigência dos "planos gerais" (preconiza o planejamento como modo de assegurar uma dinâmica de desenvolvimento harmônico do crescimento das cidades) apoiados em precisos levantamentos topográficos - $e$ constituiam uma nova paisagem urbana, marcada pela presença de equipamentos sanitários e pela configuração de uma cidade ordenada $e$ limpa, instaurando novos espaços públicos em uma nova cenografia urbana" (Andrade, 1992).

É interessante destacar que os planos urbanos de combate às pestes e epidemias, elaborados e implementados pelos sanitaristas naqueles tempos foram pioneiros no Brasil e tornaram-se referência para as atividades dos futuros planejadores e gestores arquitetos, urbanistas, engenheiros, sociólogos, geógrafos, economistas, nas contemporâneas atividades do planejamento e gestão urbana.

Percebe-se que o urbanismo sanitarista perdurou como modelo (por vezes prático, por vezes teórico) importante de intervenção, ordenação de ações de saneamento do espaço urbano em cidades brasileiras por longo período. O discurso higiênico e sanitarista justificavam, em nome da saúde, ou melhor do combate às doenças, à desordem, à imoralidade e promiscuidade, as intervenções nas cidades. Estas se davam por meio de obras urbanas, drenagem e demolição e queima de moradias consideradas insalubres - causando, de um lado a expulsão e desalojamento e agravamento do problema habitacional e das condições de vida desses habitantes, e de outro, as melhorias sanitárias por meio das obras de saneamento e o embelezamento das áreas mais nobres $\mathrm{e}$ importantes das cidades. Os que desfrutavam mais diretamente das melhorias $e$ investimentos eram os setores dominantes e as elites.

As descobertas científicas relativas ao início da era bacteriológica e, em seguida, a era terapêutica, influenciaram consideravelmente as ações sanitárias para o combate às doenças enquanto combate aos micróbios, através das vacinas e da medicina curativa e provocaram com o tempo, o afastamento (teórico e prático) do setor sanitário das preocupações relativas a intervenções e projetos urbanos e habitacionais. 
Este processo deu-se gradativamente, em função das possibilidades de deslocamento de recursos para assistência e atendimento à saúde. Até a década de 1920 aqueles que necessitavam de assistência médica eram obrigados a comprar serviços dos profissionais liberais. "Aos despossuídos restava principalmente o auxílio das Santas Casas de Misericórdia, destinado ao tratamento e amparo aos indigentes e pobres. o processo de industrialização que pôs fim ao modelo econômico agroexportador induziu ao aparecimento da assistência médica da Previdência Social" (Almeida et al 1997).

Nas cidades, todavia, o que se constatava era uma enorme carência de infraestrutura urbana, saneamento e moradia adequada. Em São Paulo, desde o surgimento do problema habitacional no final do século XIX até a década de 1930, surgiram várias modalidades de moradia para alojar os setores sociais de baixa e média renda, todas construídas pela iniciativa privada, principalmente por pequenos empreendedores. Entre elas, as mais difundidas foram o cortiço-corredor, o cortiço-casa de cômodos, os vários tipos de vilas e correr de casas geminadas. Essas habitações eram quase todas de aluguel (Bonduki, 1998).

A partir do Estado Novo de Getúlio Vargas, sob a doutrina do seguro e com orientação de economia dos gastos, teve início a implantação dos Institutos de Aposentadoria e Pensões (IAP's), estruturados por categorias profissionais e não mais por empresas. (Almeida et al 1997).

O clima político, econômico e cultural durante a ditadura de Getúlio Vargas (1930-1945) colocou na pauta a questão da habitação social com uma força jamais vista anteriormente. "Tem início também neste período, a produção estatal de habitação, principalmente através dos Institutos de Aposentadoria e Pensões da Fundação da Casa Popular, primeiros órgãos federais do setor da habitação social". (Bonduki, 1998).

A evolução do processo na área da habitação social passa pela instituição da lei do inquilinato em 1942, que provocou início de uma forte depressão no mercado habitacional e na produção massiva com fins locatários, iniciando-se novo ciclo de incentivo e expansão do auto-empreendimento da casa própria a 
partir dos anos 1940. "Com o início da disseminação do transporte urbano a pneus, desvinculado dos trilhos, surgiu o processo de crescimento mais intenso das periferias das grandes cidades brasileiras - e os problemas se tornaram, possivelmente, mais complexos" (Bonduki, 1998).

Este período se caracteriza também pela opção governamental de promover uma ampliação dos serviços de atendimento médico, e do aparato público estatal e mesmo habitacional, motivados, entre outros, pelo interesse de aliviar tensões oriundas do movimento operário, cada vez mais forte no país.

Durante o segundo governo Vargas e o de Juscelino Kubitschek, o setor saúde experimentava um impacto considerável também em função da ação dos IAP's, principalmente com a ampliação da estrutura, particularmente a hospitalar. A grande maioria dos hospitais públicos brasileiros foram construidos neste período. Concomitantemente, cada vez mais adotava-se o modelo de saúde (norte) americano, incorporando-se indiscriminadamente tecnologia em uma visão de saúde hospitalocêntrica $e$, naturalmente de alto custo, favorecendo o fortalecimento da indústria de medicamentos $e$ equipamentos hospitalares (Almeida et al 1997).

Um pouco depois, durante a ditadura militar, "após 1964, foram dadas algumas das condições para a intervenção mais profunda que o Estado brasileiro jamais havia feito na provisão da habitação e que viria a transformála totalmente: O BNH - Banco Nacional da Habitação e SFH - Sistema Financeiro da Habitação, criados em 1964" (Maricato, 1997).

A proposta do SFH estava baseada no principio da autosustentação e tinha duas principais fontes de recursos, uma voluntária, a partir das Cadernetas de Poupança/SBPE (Sistema Brasileiro de Poupança e Empréstimo) e outra compulsória o FGTS (Fundo de Garantia por Tempo de Serviço). A gestão central do sistema estava a cargo do BNH. Em toda a sua existência o sistema SFH/BNH financiou 4,8 milhões de moradias (estimativa), ou praticamente $25 \%$ do incremento de moradias construídas no Brasil de 1964 a 1986, ano em que o BNH foi extinto (Maricato, 1997).

Reduziu-se sua capacidade de investimento, elevou-se a inadimplência e ampliaram-se as críticas ao $\mathrm{BNH}$, tendo como um dos pontos de maior 
contestação, a excessiva centralização da política habitacional (Bonduki,1992). Quando o BNH foi extinto, não sucedeu qualquer proposta mais elaborada de reorganização da Política Habitacional, pulverizando-se sua burocracia e transferindo-se seus Fundos para a Caixa Econômica Federal, que não dispunha de instrumentos para planejar e formular políticas públicas de habitação alternativas.

Neste período, já não se identificam relações no âmbito prático ou do discurso, entre as políticas e programas públicos urbanos e habitacionais e a saúde pública. Ao contrário, os setores mantinham-se em isolamento progressivo.

No final dos anos 1980 e década de 1990 acentuou-se a tendência de descentralização da execução, e mesmo da formulação dos programas e projetos habitacionais, a partir de uma diretriz mais geral de desencargo da União em relação às políticas sociais (Ministério do Bem Estar Social, 1993). Assim, o Governo Federal, através dos programas Habitar Brasil e Morar - Município (criados pela antiga Secretaria Nacional de Habitação do Ministério do Bem Estar Social), estimulou os municípios a criarem Fundos e Conselhos Municipais de Habitação, tornando-os condições indispensáveis para participar daquele Programa, além da necessidade de investirem recursos próprios, como contrapartida financeira.

A criação dos Fundos Municipais de Habitação gerou um instrumento que permitiu aos municípios estruturarem uma intervenção mais concreta $e$ contínua na área da moradia, apesar de contarem obviamente com limitações visíveis de recursos financeiros e capacitação técnica frente às demandas por habitação. Admite-se a hipótese de que "depois do período de centralização e homogeneização da forma de intervenção na habitação social que foi representado pelo ciclo BNH/COHABs, ocorre, na esfera municipal, uma fase de atomização de experiências, com grande heterogeneidade em todos os aspectos da política habitacional" (Arretche,1993).

No setor urbano-habitacional essa atomização de experiências a partir dos anos 1980, se expressou por meio de políticas e programas inovadores do ponto de vista da concepção urbanística, de projeto, de financiamento, da gestão, da participação das demandas, etc. Pode-se citar como exemplos os 
programas de urbanização de favelas da prefeitura de São Paulo, da Prefeitura de Santo André, do Rio de Janeiro (Programa - Favela Bairro), o Funaps Comunitário da Prefeitura de São Paulo de 1989-1992, experiências já sistematizadas e analisadas por diversos trabalhos e autores (Bonduki et. al.1993; Ronconi 1995; Bonduki, 1996; Maricato 1997; Maricato, 1997; Felipe 1997; Comarú, 1998, LabHab, 1999, Bueno, 2000; Denaldi, 2003).

No campo da saúde, por outro lado, assistiu-se a partir de 1974 com o fim do período do milagre econômico - que garantia base de apoio social ao regime - lenta e progressivamente o processo de abertura política, em que se questionava a política social do governo e a repercussão dos efeitos do modelo econômico e de saúde adotados. "Na década de 1970, - país apresentava um modelo hegemônico de saúde: médicoassistencial-privatista. Mas é também neste periodo que surge os alicerces político-ideológicos para o surgimento do movimento da Reforma Sanitária" (Almeida et al 1997).

De fato, o modelo hospitalocêntrico, tecnológico de alto custo, terapêuticocurativista também esgotava-se. Diversos grupos representativos do setor sanitário, insatisfeitos com as condições de trabalho, a insuficiência do sistema e com os casos de desvios e corrupção, motivaram o fortalecimento do movimento sanitário no Brasil.

Como resultado das lutas do movimento sanitário brasileiro antes e durante a transição democrática, institucionalizou-se uma nova política de saúde, o Sistema Único de Saúde (SUS), universal, integrador, descentralizado e referenciado na participação popular.

A nova Constituição de 1988 e a Lei Orgânica de Saúde de 1990 (incluindo as leis 8080 e 8142 de 1990) que regulamenta o SUS, fundamentam suas bases integradoras, democratizantes, com uma proposta racionalizadora do sistema de saúde no pais. Este aparato jurídico representa a conquista do reconhecimento legal do direito à saúde, considerada em sua ampla determinação - social, política, econômica, cultural e ambiental. Este momento representou a redefinição formal do papel político da saúde, 
considerada a partir de então, como um direito do cidadão e um dever do Estado, que deveria promovê-la, por meio de políticas econômicas e sociais.

Para se ter uma idéia do desafio e da importância representados pelo SUS, basta dizer que a sua implementação constitui a maior Reforma de Estado em curso no Brasil (na virada do século XX e século XXI), considerando os aspectos ligados à gestão, descentralização (municipalização do sistema) e universalização do atendimento.

Em diversos outros países, sobretudo no Canadá, o modelo flexneriano, curativista, tecnológico e individual, centrado nas doenças, também começava a ser questionado, abrindo espaço para novas propostas e para o alvorecer de uma nova saúde pública, de caráter coletivo, universal, preventivista, mas principalmente promotora de saúde (Westphal e Santos, 2000).

Assim, na década de 1990 dentro do contexto do SUS, os pressupostos e propostas de Promoção da Saúde gestadas fora do Brasil, começam a ser discutidas e aplicadas à realidade brasileira, com as devidas adaptações.

Como este trabalho pretende articular pressupostos teóricos e abstrações que norteiam políticas, vamos a seguir, desenvolver aspectos do ideário de Promoção da Saúde e do Movimento por Cidades / Municípios Saudáveis. 


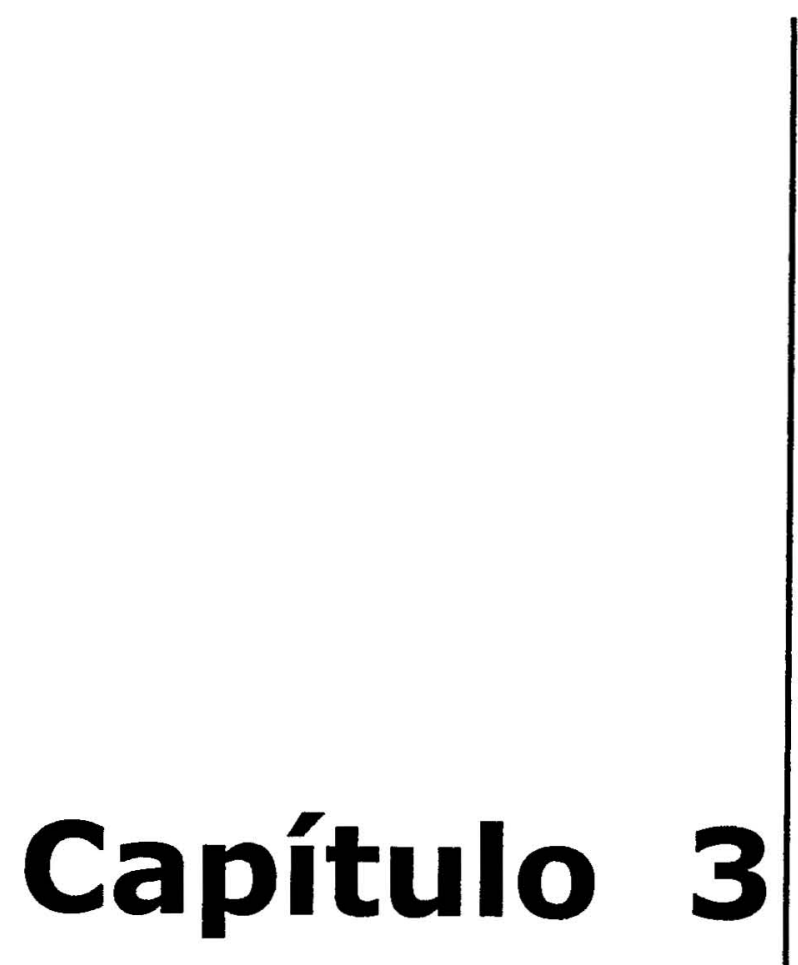

Promoção da saúde e municípios saudáveis 


\subsection{Promoção da Saúde}

"O importante não é o rótulo - cidade saudável, cidade protetora, cidade educadora, o importante é a forma de agir e de pensar".

(Leonard Dulh, na FSPUSP, em encontro com equipe do Cepedoc,.2003)

Esta frase do Professor Dulh, na ocasião em que esteve reunido em São Paulo, com pesquisadores a ativistas do movimento Cidades Saudáveis, expressa de maneira convincente, a essência de um Projeto Cidade Saudável, enquanto uma Agenda estratégica da Nova Saúde Pública, cuja contribuição maior é a introdução explícita de um novo paradigma, na prática social, política, econômica e pedagógica dos profissionais que atuam nas cidades.

A maneira de agir e pensar mencionada por Dulh deve (ou deveria) integrar setores governamentais e a sociedade civil, pela melhoria da qualidade de vida da população, superando as eventuais disputas entre eles, no sentido de priorizar suas agendas (saúde, educação, assistência e promoção social, meio ambiente, habitação, políticas urbanas, etc.) e interesses.

No mundo ocidental as referências conhecidas sobre os principais pressupostos do movimento Municipios Saudáveis podem ser relacionadas com as antigas preocupações do Movimento Sanitário europeu do século XIX, cujo conteúdo ambientalista reconhecia os governos locais e associações comunitárias como importantes agentes no equacionamento dos problemas de saúde (Westphal et al, 2000 apud Ashton 1992).

Engels (1974) em seu estudo sobre a Situação da Classe Trabalhadora na Inglaterra abordou o sofrimento dos operários por causa das doenças infecciosas como a tuberculose, além do alcoolismo e outras relacionadas com determinantes ambientais e sociais. Aqueles estudos articulam a interconecção entre enfermidades e classes sociais. (Engels, 1974).

O seu trabalho se insere num contexto de crescimento das cidades da Europa, da revolução industrial, de aumento da consciência operária da exploração capitalista e das relações entre saúde, as condições de vida, de trabalho e de habitação. Foi também um momento histórico de ampliação 
das demandas em vista de um Estado de bem-estar da classe trabalhadora (Andrade e Barreto, 2002).

Autores contemporâneos consideram que estas políticas podem ser precursoras das atuais políticas públicas saudáveis e do movimento por cidades saudáveis. (Ashton, 1993; Restrepo, 2001).

Outros sanitaristas pioneiros, a partir de meados no Século XIX na Europa foram Edwin Chadwick e Rudolf Virchow. O primeiro, Chadwick, com sua contribuição sobre a "Lei dos pobres", pode ser considerado "um visionário precursor do movimento de Cidades Saudáveis", por sua grande contribuição teórica na publicação "Report on the Sanitary Condition of Labouring Class" e por sua militância política, contribuindo para a melhoria das condições de vida sanitária nas cidades da Inglaterra em sua época (Andrade e Barreto, 2002).

O segundo foi "o médico-sanitarista e político alemão Virchow, que recebeu uma missão do governo da Prússia de estudar a epidemia de tifo na Silesia em 1847. Naquela ocasião recomendou que a população vitimada necessitava, entre outras intervenções médicas, de completa e ilimitada democracia, educação, liberdade e prosperidade." (Andrade e Barreto 2002 apud Restrepo 2001).

A partir daquele período foi observado o início do conflito entre dois diferentes paradigmas no campo da saúde, - "promoção/prevenção" versus "cura" no processo saúde/doença. E também uma dicotomia: o da medicina social voltada para a esfera coletiva (sócio-ambiental) e o da medicina biológica voltada para a cura das doenças, de cunho pasteuriano (Andrade e Barreto, 2002).

A partir da "era bacteriológica", com a descoberta dos gérmens, iniciada em princípios do século $X X$, este movimento foi reforçado. Até aquele momento não existiam ainda fármacos de eficiência comprovada mas, com a descoberta da penicilina e das sulfamidas nos anos 1930, deu-se início a chamada "era terapêutica" que contribuiu para a perpetuação da dicotomia. 
Desde então, as políticas públicas de saúde, nos países desenvolvidos e em desenvolvimento, tem sido hegemonicamente orientadas nesta perspectiva, concentrando as ações de saúde em grandes hospitais com superespecialistas (Westphal et al, 2000 apud Ashton 1992).

Durante décadas, este modelo hegemônico foi dominante e as tentativas de revertê-lo não tiveram êxito. Nos anos 1970 iniciaram-se novas tentativas de reverter o modelo. A maioria dos países vivenciou uma crise no setor saúde, decorrente dos altos custos da medicina curativa e da tecnologia de ponta, confirmados por levantamentos e pesquisas que mostravam que os gastos de saúde (setor saúde) não refletiam em melhoria de qualidade de vida da população.

No plano externo, a partir de 1978 surge a proposta internacional de priorização da atenção e dos cuidados primários de saúde, na Conferência Mundial de Saúde de Alma-Ata, promovida pela OMS Organização Mundial da Saúde. No nosso país, essa proposta coincidia com a necessidade de expandir a atenção médica, a partir de um modelo de baixo custo para as populações excluídas, especialmente as que viviam nas periferias das cidades e nas zonas rurais (Almeida, et. al 1997).

Esta concepção avançada e abrangente de estratégia e conceito em saúde teve suas origens renovadas a partir do Informe Lalonde. Neste informe o Ministro da Saúde do Canadá rebelou-se contra a abordagem medicalizada e de alto custo de saúde e propôs um novo conceito, de "campo de saúde", que deveria orientar a reformulação do setor naquele país.

Lalonde questionou a utilização tecnológica surgida no campo da medicina, desvinculada de outras determinações relacionadas à saúde enquanto estratégia de saúde pública. $O$ relatório que leva seu nome $e$ publicado pelo governo do Canadá, foi (...) uma declaração teórica compreensiva no âmbito da saúde pública. Pela primeira vez foi oficialmente questionado o impacto real para a saúde dos gastos excessivos com a organização dos cuidados médicos (Ferraz, 1999). 
A formulação do conceito de "campo da saúde" propôs a inclusão de quatro amplos componentes: biologia humana, meio ambiente, estilo de vida e organização da atenção à saúde, componentes estes identificados nas causas e fatores básicos de morbidade e mortalidade. Mais tarde reconheceu-se, ainda no Canadá, a importância do "entorno" (meio ambiente) de modo que foi considerado por especialistas como o mais importante dos quatro elementos do "campo da saúde" (Gentile, 1999).

O que Lalonde propôs em um contexto de pais próspero do Século $X X$ nos remete, respeitados os contextos histórico e social, às recomendações de Chadwick de que seria econômico tomar medidas preventivas na Inglaterra no século $\mathrm{XIX}$, quando produziu o primeiro relatório da Comissão de Saúde das Cidades, apontando para as péssimas condições a que estava submetida a população: alta densidade demográfica, pobreza, crime, insalubridade e alta mortalidade. 0 sanitarista relacionava pobreza às doenças, reconhecendo ser a doença, um fator de aumento do número de pobres.

É interessante notar que os questionamentos do modelo hegemônico do sistema de saúde em vigor parecem dar-se em função de dois argumentos mais centrais: os custos crescentes de sua manutenção e ampliação e a própria eficiência da assistência curativista. É o que expressa Czeresnia et al (2003) em recente estudo teórico sobre o ressurgimento da promoção da saúde: "uma das origens importantes desse ressurgimento foi o questionamento da eficiência da assistência médica curativista de alta tecnologia (...) da necessidade de controlar os custos crescentes do modelo biomédico, abriu-se espaço para criticar o estreitamento progressivo que este modelo produziu na racionalidade sanitária e no resgate do pensamento médico social que, em meados do século XIX, enfatizava relações mais amplas entre saúde e sociedade" (Czeresnia et al., 2003).

Atualmente no setor da saúde pública, alguns autores defendem 0 desenvolvimento econômico e social como forma de promover a saúde e, ao mesmo tempo, a promoção da saúde como um investimento para o desenvolvimento econômico e social (Ziglio, 2000). 
Amplia-se o número de autores que admitem "a conceituação circular de que, por exemplo, saúde produz desenvolvimento social tanto quanto desenvolvimento social produz saúde" (Pinheiro, 2003).

Assim, considerando "a existência das iniqüidades sociais em saúde, existe também uma relação sinérgica entre situação de saúde e nível de desenvolvimento, mediada pela melhoria das condições básicas de vida das populações, mas também, nem todo crescimento econômico beneficia por igual a saúde de todos os habitantes" (Pinheiro, 2003 apud Castellanos, 2000). E esta ponderação parece relevante em nossos dias.

No Brasil, a partir dos anos 1970, na medida em que o país preparava-se para o processo de redemocratização, acompanhado dos acontecimentos internacionais, fortaleceu-se o movimento sanitário nacional, de modo que em 1986, como resultado de uma vitalidade científica própria, foi proposta uma mudança radical nas políticas de saúde. A VIII Conferência Nacional de Saúde - marco importante no avanço das políticas de saúde pública - constituiu numa proposta inovadora tão importante, que culminou com a introdução histórica do ideário reformista, na Constituição de 1988 (Almeida et. al 1997 e Czeresnia et at., 2003).

Naquele mesmo ano de 1986, no plano internacional organizava-se a I Conferência Internacional de Promoção da Saúde em Otawa (Canadá), considerada marco fundador do movimento da promoção da saúde no mundo (Czeresnia et al., 2003). A Carta de Otawa preconizou que as condições e "os requisitos para a saúde são: a paz, a educação, a moradia, a alimentação, a renda, um ecossistema estável, justiça social e equidade" (Carta de Otawa, 1986). O texto acentua também que "qualquer melhoria da saúde há de ter como base necessariamente, estes pré-requisitos" (Carta de Otawa, 1986).

A Carta de Otawa redigida durante a I Conferência Mundial de Promoção da Saúde em 1986 define que esta "consiste em proporcionar aos povos os meios necessários para melhorar sua saúde e para exercer um maior controle sobre a mesma" (Carta de Otawa, 1986). 
A mesma Carta - uma das referências centrais entre os documentos já produzidos de promoção da saúde - preconiza que "para alcançar um estado de bem estar físico, mental e social, um grupo deve ser capaz de identificar e realizar suas aspirações, satisfazer suas necessidades $e$ mudar ou adaptar-se ao meio ambiente. A saúde, então, não vem como um objetivo, mas como uma fonte de riqueza da vida cotidiana. Trata-se de um conceito positivo que acentua os recursos sociais e pessoais, assim como as aptidões fisicas. Portanto, dado que o conceito de saúde como bem estar, transcende a idéia de formas de vida sadias, a promoção da saúde não concerne exclusivamente ao setor sanitário" (Carta de Otawa, 1986).

Vai tornando-se mais claro o fortalecimento de novas perspectivas para as políticas públicas e o setor sanitário, assentadas em múltiplas estratégias para a promoção da saúde, em última instância da qualidade de vida: a promoção do conceito, a promoção dos meios, a atuação como mediador em abordagem interdisciplinar a intersetorial, a criação de ambientes favoráveis à saúde, o reforço da ação comunitária com participação e controle social (Carta de Otawa, 1986). Diversos grupos de sanitaristas militantes traduzem esta mensagem como "empoderamento" ou "empowerment", que significa 0 ato de tomar 0 poder por quem carece dele para definir o seu destino, atuando como sujeito na sociedade (Suarez 2002).

Além disso, a Carta propôs o desenvolvimento das aptidões pessoais (políticas, sociais, culturais, intelectuais e profissionais), a reorganização dos serviços sanitários, a criação de redes de apoio à saúde e a ação internacional.

Várias outras conferências foram realizadas posteriormente, procurando reforçar os pressupostos da Promoção da Saúde através de Cartas, Declarações e Recomendações (Cartas de Sundswal e Adelaide). A IV Conferência Internacional de Promoção da Saúde de Jacarta, na Indonésia e a do México trouxeram também novidades. Reforçaram a saúde como produção social, necessitando do comprometimento de todos os setores de governo e da sociedade civil. Reforçaram também a 
necessidade de parceria e alianças a serem conseguidas através de negociações entre os diferentes setores de governo e da sociedade civil.

Em função destas discussões e diretrizes, nos anos 1990 ocorre a emergência de um leque de alternativas de políticas municipais, programas, projetos e processos de produção inovadores sob diversos pontos de vista. Inicia-se um movimento de reforço às intenções da Reforma Sanitária e do SUS, na perspectiva da revisão do entendimento de saúde, como um produto social, ou como resultante das condições de vida e trabalho. Difunde-se o conceito segundo o qual "a saúde (ou a doença) é produzida socialmente" (Westphal, et al, 2000).

Nesta década de 1990, técnicos canadenses e a Organização Pan-Americana de Saúde começam a difundir a estratégia de Cidades / Municípios Saudáveis no Brasil.

\subsection{Estratégias para Promoção da Saúde}

\subsubsection{Cidades Saudáveis: matriz e conceitos}

A origem da proposta de Cidades/Municipios Saudáveis ${ }^{1}$ deu-se na década de 1980 em meio aos diversos processos e mudanças comentados no item anterior. Seu conceito apresentou-se como um projeto estruturante de promoção da saúde. Duhl e Hancock, em 1984 na América do Norte, formularam idéias precisas sobre o papel dos municípios em promoção da saúde nos termos das políticas públicas favoráveis à saúde, que eles passaram a chamar cidades saudáveis

\footnotetext{
${ }^{1}$ No Brasil alguns autores e profissionais adotam a expressão Cidades Saudáveis, enquanto outros preferem utilizar Municípios Saudáveis. Os defensores da expressão Cidade Saudável alegam que, internacionalmente considera-se que o foco de atuação dos Projetos deve ser a população urbana, assim Cidade Saudável seria mais preciso - argumento com o qual concordamos. Entretanto a equipe da FSPUSP encontrou em alguns municípios pequenos do interior do Estado de São Paulo a necessidade profunda de abordar com a população urbana o tema da integração com a população rural de Assentamentos da Reforma Agrária (e a discussão da integração e interdependência Urbano-Rural). Em Bertioga, apesar da abordagem mais urbana do trabalho, desde os primeiros contatos, adotou-se o nome Projeto Bertioga Municipio Saudável. Assim utilizaremos aqui mais freqüentemente a expressão utilizada pelos atores que se envolveram neste projeto, nosso estudo de caso: Bertioga Municipio Saudável.
} 
Assim, segundo Hancock e Duhl, uma cidade saudável "é aquela que está continuamente criando e modificando seu ambiente físico e social e expandindo seus recursos para as pessoas se capacitarem a apoiar uma às outras, para que todos desempenhem a contento as funções da vida $e$ desenvolvam ao máximo seu potencial" (Ferraz, 1999).

Gradativamente diversas cidades na Europa e América do Norte aderem ao movimento denominado "Cidades Saudáveis" como uma nova proposta de ação em saúde que (..) em nivel internacional vem sendo empregada para expressar uma filosofia de ação, baseada em uma concepção ampla de saúde que incorpora, além dos aspectos biológicos que interferem no processo saúde-doença, os determinantes sociais, econômicos e ambientais, ou melhor que ampliam o conceito de saúde, para além da consideração simples de saúde como "ausência de doença" (Westphal 1997).

Pesquisadores brasileiros e de outros países da América Latina, mais recentemente, têm procurado revisar a conceituação de cidades/municípios saudáveis, a partir da experiência vivenciada no continente. Neste sentido Mendes (1996) considera que cidade saudável é "aquela em que todos os atores sociais em situação de governo, organizações não governamentais, famílias e indivíduos orientam suas ações no sentido de transformar a cidade em um espaço de produção social da saúde, construindo uma rede de solidariedade".

O desafio no Brasil é que mesmo com as declarações nacionais e internacionais e das leis que regulamentam o SUS - Sistema Único de Saúde, seja por motivos históricos, culturais, corporativos ou econômicos "a saúde continua a ser considerada, em cada municipio, como uma atividade que se refere exclusivamente à doença e, portanto, inserida ainda nos paradigmas flexneriano, mecanicista e curativista" (Westphal 1997).

Nota-se todavia, que em nosso país, diversos municípios engajaram-se no Movimento por Municípios Saudáveis. Embora o movimento e as adesões sejam recentes, observa-se também a importância da 
adequação da proposta à realidade do país. Neste sentido, torna-se relevante o desenvolvimento de programas que permitam a sistematização de metodologias de implementação dos projetos, levando em conta as nossas necessidades e condições; além do desenvolvimento de métodos, critérios $e$ indicadores que permitam promover 0 monitoramento e a avaliação dessas práticas ${ }^{2}$ (Akerman et al., 2002).

A Organização Pan-Americana de Saúde (OPAS), bem como diversos autores contemporâneos preconizam que a Estratégia Municípios Saudáveis deve articular-se pelo menos em quatro pressupostos de ação básicos: participação social ou democratização, equidade, intersetorialidade e sustentabilidade de políticas públicas saudáveis.

Outros pesquisadores, sanitaristas e militantes defendem a inclusão de outros pressupostos, princípios ou estratégias de ação na cidade que podem incluir: o aperfeiçoamento da relação poder público/sociedade civil, o estabelecimento de parcerias, a ação educativa e pedagógica, incluindo-se aí também a advocacia em saúde. (Mendes, 2000; Dallari, 1996).

Reconhecemos, entretanto, que tanto no nivel mais teórico, quanto no nivel prático os pressupostos ou princípios de ação não são estanques, mantendo relações entre si. Por exemplo, a prática dos processos participativos em uma determinada realidade pode induzir ou pressionar a situação de uma determinada localidade por ações mais integradas e intersetoriais.

\section{Participação social}

Segundo Mendes (2000) na literatura internacional das agências ligadas às Nações Unidas, as justificativas para a inclusão dos países em desenvolvimento no movimento por Municípios Saudáveis vêm sendo

\footnotetext{
${ }^{2}$ Pesquisadores do Cepedoc - Centro de Estudos Pesquisa e Documentação sobre Cidades Saudáveis da Faculdade de Saúde Publica da USP, tem participado de pesquisas acadêmicas sobre a avaliação de experiências de cidades saudáveis no Brasil e outros paises da América
} 
relacionadas, fundamentalmente a três fatores: a situação de crise da política social e o papel do Estado frente a ela; a importância da descentralização das ações e do fortalecimento do poder local, e o significado da participação no delineamento de políticas públicas (OPS, 1992; PAHO, 1997; PAHO, 1999; OPAS 2002).

A participação de amplos setores sociais é referida como base de sustentação do município saudável, constituindo-se como um elemento central que permeia todos os conceitos que dão suporte à proposta (Mendes, 2000).

Os programas e projetos implementados na perspectiva da Promoção da Saúde têm sido enfáticos quanto à necessidade de serem adotadas abordagens participativas que envolvam, desde a etapa de planejamento até a execução.

A Carta de Otawa (1986) preconiza que a promoção da saúde começa na participação efetiva e concreta da comunidade na eleição de prioridades, na tomada de decisões e na elaboração e desenvolvimento de estratégias para alcançar melhor nivel de saúde.

O termo participação possui inúmeras conceituações na medida em que for considerado um meio ou fim. Assim, em decorrência de processos de participação, podem ocorrer mudanças nas relações de poder (Arai 2002 apud Demo 1988) e, em função disto, muitas vezes, a abertura ou aumento do diálogo entre Estado e instituições da sociedade civil.

Entre as diversas conceituações já elaboradas e discutidas, adotamos para este trabalho o entendimento de participação social como o conjunto de "múltiplas ações para poder influenciar a formulação, execução, fiscalização e avaliação de políticas públicas" (Valla 1993).

Logo, a implementação da idéia de políticas públicas saudáveis segue a premissa da participação social, que deve envolver entidades não governamentais, sindicatos, associações de moradores e de bairros, 
membros de comunidades, cidadãos comuns. Como políticas públicas não são exclusivas do aparelho estatal, devem ser elaboradas e pactuadas em fóruns participativos, sujeitas às negociações e às lutas políticas em diversas arenas e cenários, representando uma redistribuição de direitos, responsabilidade e poder entre Estado e sociedade civil (Westphal et al. 2000 apud Carvalho 1998, Labonte, 1992).

O fortalecimento da capacidade da população de tomar decisões, quanto aos aspectos que interferem e determinam a condição de vida, trabalho e de saúde está contido no conceito de "empowerment", implícito, em nossa interpretação, nos princípios em que se apóia a Promoção da Saúde na Carta de Otawa.

A Carta preceitua que a promoção da saúde consiste num processo de capacitação da população para identificar seus problemas de saúde e suas causas, a fim de que defina os meios necessários para melhorar sua saúde e exercer um maior controle sobre a mesma. Tem-se como objetivo central que os indivíduos e os setores sociais, aumentem o controle sobre os determinantes do processo saúde/doença, ou seja, fortaleçam-se na luta para a melhoria das suas condições de vida.

Segundo Westphal et al (2000) o conceito do "empowerment" ou empoderamento implica, também no acesso e controle dos recursos necessários para a tomada de decisões que impliquem em ações individuais ou coletivas. $O$ empoderamento individual refere-se às características psicológicas de auto-estima, confiança em si mesmo, auto-controle, conhecimento, habilidades para alcançar uma meta individual. $O$ empoderamento comunitário, o qual a Promoção da Saúde realmente objetiva, refere-se às caracteristicas de organização social, alianças entre grupos de pressão que podem influenciar os niveis de decisão econômica e política de tal maneira que alcancem as metas de interesses do grupo ou da comunidade (Tones 1994; Toward 1990; Bernstein et al. 1994). 
A participação é importante também, na medida em que permite reconhecer que as ações relacionadas às políticas públicas não são só realizadas pelos profissionais técnicos. Assim, reforça-se como uma estratégia de construção de capacidade da comunidade para analisar e priorizar suas necessidades, formular e negociar suas propostas. Tratase assim, de construir laços de solidariedade na comunidade, reconhecer a informalidade e flexibilidade dos grupos sociais e fomentar 0 intercâmbio de saberes. - popular $x$ popular; popular $x$ técnico; técnico $x$ técnico.

Pedro Demo, fundamentado na sociologia do conflito, reforçou a idéia de que o poder de participar, inclusive a autonomia decisória, não é uma dádiva, mas sempre fruto de uma conquista e, portanto, um processo dinâmico e permanente na vida dos grupos sociais (Arai, 2002 apud Demo 1988).

Dalmo Dallari (2001) por sua vez, defende que a participação constitui-se em "um direito e, ao mesmo tempo, um dever, pois se, de um lado é necessário que todos estabeleçam regras de convivência para que se possa ter segurança, de modo a desenvolver-se e viver em paz, por outro lado, a participação é um dever, pois os seres humanos dependem uns dos outros".

Também nas diretrizes do Projeto Moradia para o Brasil a participação é considerada fundamental. Para seus autores, o enfrentamento do problema da moradia, no Brasil, exige uma ampla participação de toda a sociedade brasileira: "governos, setor privado, legislativo, judiciário, movimentos sociais, organizações não governamentais, universidades, agentes técnicos $e$ entidades de classe" (Instituto Cidadania, 2002).

\section{Equidade}

A equidade tem sido considerada como um dos pressupostos mais importantes no seio da Proposta de Municípios Saudáveis, no nosso país, em função da profunda desigualdade e injustiça social que nos marca historicamente. 
É possivelmente também, uma das metas mais dificeis de se atingir, considerando o sistema capitalista e as condicionantes externas e internas que impuseram e impõem o atual modelo de desenvolvimento ao país. O impacto deste modelo nas cidades brasileiras foi e tem sido abordado por diversos autores (Maricato, 2000; Ferreira, 2003).

Segundo Sposati (2000) o conceito de equidade é concebido como reconhecimento e efetivação, com igualdade, dos direitos da população, sem restringir o acesso a eles, nem estigmatizar as diferenças que conformam os diversos segmentos que a compõem.

Almeida (2000) considera duas importantes dimensões a serem consideradas na abordagem de equidade em saúde: as desigualdades nas condições de vida e saúde e as desigualdades no acesso aos serviços de saúde. No caso, ambas têm dimensões dentro do setor saúde e fora dele, geralmente cumulativas (Almeida, 2000).

Pinheiro (2003) no seu trabalho sobre equidade em saúde $e$ as Conferências Nacionais de Saúde sugere que a ocorrência de acumulatividade de desigualdades alimenta um circulo vicioso, no qual a pessoa não tem acesso à educação, alimentação, trabalho, moradia e conseqüentemente saúde, chegando ao extremo da exclusão social. Todavia, se concordarmos com a tendência do acúmulo de desigualdades, podemos supor que a superação das mesmas, em uma perspectiva de Promoção da Saúde se dará por meio de políticas públicas que integrem estas distintas dimensões, para criar então, um círculo virtuoso que tanto pode ter início em um setor, como em outro, mas que deve integrar todos.

Neste sentido Maricato (1996) em Metrópole na Periferia do Capitalismo já havia introduzido no Brasil a expressão: "a exclusão é um todo" inspirada da "Charte Européenne pour le Droit à Habiter et la Lutte contre I'Éxclusion". Nela, a autora, com foco na análise da exclusão social sob o ponto de vista do habitat, chama a atenção de que a exclusão ambiental é parte do processo de exclusão como um todo em 
seus aspectos diversos: sociais, culturais, econômicos, políticos e ambientais. (Maricato, 1996).

Assim, embora do ponto de vista do objetivo final da política, a equidade se expresse em termos de igualdade para o alcance de níveis mais eqüitativos, o processo distributivo deve ser necessariamente desigual, na medida em que requer uma discriminação positiva para redução das desigualdades consideradas socialmente injustas (Almeida 2000).

Whitehead (1990) em sua obra sobre a equidade em saúde conceitua que "equidade em saúde implica que idealmente todo mundo deveria ter a justa oportunidade de atingir seu completo potencial de saúde, e mais pragmaticamente, que ninguém deveria estar em desvantagem para atingir este potencial, se isto pode ser evitado. Equidade desta maneira concerne em criar iguais oportunidades para saúde, reduzindo os diferenciais de saúde aos mais baixos possiveis".

Esta formulação sintoniza-se com a dos grupos que defendem que adotar - princípio da equidade no processo de tomada de decisão governamental, resulta em concentrar energias, recursos e políticas junto aos mais excluidos.

Pinheiro (2003), em sua pesquisa sobre a análise da equidade nas Conferências Nacionais de Saúde pós Constituição Federal de 1988, conclui que apesar de uma certa evolução e valorização da "equidade" ao longo dos relatórios oficiais de encontros e conferências, nota-se uma grande valorização dos aspectos formais e sugere que esta pode "ser uma das causas da abordagem superficial da equidade em saúde", nas definições das diretrizes para políticas de saúde.

O autor comenta também que a equidade é tratada nesses documentos sem focalizar grupos sociais ou necessitados em saúde. "embora, predomine uma postura ativa em relação à produção social da saúde, esta postura é neutralizada, uma vez que predomina a postura meramente discursiva e da equidade em saúde apenas como um fim". Desta maneira entende que "a postura geral é de resistência à incorporação da equidade em saúde como 
um instrumento para a elaboração das diretrizes de políticas públicas" (Pinheiro, 2003).

\section{Intersetorialidade}

A complexidade dos problemas de saúde e da qualidade de vida e a multiplicidade de condições interferentes, a ampla determinação do processo saúde/doença indicam a necessidade de ações intersetoriais, integradoras. Trata-se da busca de uma unidade do fazer, em uma sintese, de modo que a intersetorialidade não anula a ação setorial; ao contrário reconhece os domínios temáticos, comunicando-os para a construção de uma síntese (Westphal et al. 2000).

A intersetorialidade para Junqueira e Inojosa (1997) é entendida com "a articulação de saberes e experiências no planejamento, a realização e a avaliação de ações, com o objetivo de alcançar resultados integrados em situações complexas, visando um efeito sinérgico no desenvolvimento social". Essa abordagem supõe uma nova forma de gerir a cidade "buscando superar a fragmentação das políticas, considerando o cidadão na sua totalidade" em suas necessidades e potencialidades. "Isso passa pelas relações homem/natureza, homem/homem que determinam a construção social da cidade" (Junqueira 1997).

Nossa observação empírica, principalmente no Estado de São Paulo tem mostrado que, de uma maneira geral, a questão da interdisciplinaridade, tem encontrado uma maior receptividade e aceitação nos últimos anos por um número cada vez maior de professores, pesquisadores e profissionais. Entretanto na implementação prática da intersetorialidade é que estão certamente, os maiores desafios e entraves. Principalmente no seio das instituições públicas e estatais, têm se verificado uma dificuldade histórica de maior diálogo entre diferentes setores, secretarias e níveis de governo que, em tese, deveriam realizar trabalho conjunto. Ao contrário, em muitas situações observamos, e com freqüência, a competição entre secretários, técnicos e políticos situados em uma mesma prefeitura, por exemplo. 
Este é um dos desafios que a equipe do Cepedoc $^{3}$ - Centro de Estudos, Pesquisa e Documentação sobre Cidades Saudáveis da Faculdade de Saúde Pública da Universidade de São Paulo tem encontrado na implementação do Projeto de Ampliação de Municípios Saudáveis no Estado de São Paulo ${ }^{4}$ principalmente nas cidades de porte médio.

Um estudo avaliativo sobre os Projetos Municípios Saudáveis europeus conclui que "embora a ação intersetorial se coloque como uma exigência, a retórica parece ter sido mais desenvolvida que a prática". De acordo com Goumans (1997) "a intersetorialidade pode ocorrer em diferentes níveis e esferas. A retórica da colaboração defende que os atores são iguais, isto é, tem igual poder de colaborar entre si. No entanto, mais freqüentemente, os atores têm graus variados de poder, devido às iniqüidades estruturais subjacentes, tais como: acesso ao dinheiro, conhecimento ou poder" (poder político por exemplo).

Experiência relatada por Erio Ziglio do Escritório Regional Europeu da OMS Organização Mundial da Saúde, durante o Curso de Verão de 2001 na Faculdade de Saúde Pública da USP sobre investimentos em saúde, descreve que em algumas cidades da Inglaterra, após as crises de re-estruturação produtiva, ocorreram em inúmeros novos problemas de desemprego e saúde pública. O governo local iniciou a implementação de um procedimento que previa que um mesmo funcionário de nível técnico receberia $50 \%$ de seu salário de uma secretaria municipal e 50\% de outra secretaria. Este mecanismo induzia o funcionário a ter que responder a duas chefias diferentes e a ter interesse em aproximar os dois setores e promover maior esforço para o trabalho conjunto e intersetorial.

\footnotetext{
${ }^{3}$ O Cepedoc é um Centro ligado à Universidade de São Paulo, que tem por missão promover estudos, pesquisa, documentação e assessoria em projetos de Promoção da Saúde e Municipios Saudáveis. Uma das suas características refere-se à interdisciplinaridade da equipe e à forma de atuação, pautada nos principios da participação, intersetorialidade, equidade e sustentabilidade.

4 Projeto com financiamento do Ministério da Saúde e apoio da Opas - Organização PanAmericana de Saúde que objetiva a implementação de Cidades Saudáveis em cinco municipios no Estado de São Paulo: Itaoca, Ribeira, Lins, Motuca e Bertioga. Objetiva também implementar um embrião da Rede Paulista de Municípios Saudáveis.
} 
No Brasil, algumas iniciativas importantes têm sido implementadas por municípios e se inscrevem na tentativa de introduzir novas formas de gestão e controle social. É o caso, entre outros, do Programa Integrado de Inclusão Social desenvolvido no município de Santo André - SP (Denaldi, 2003), do Orçamento Participativo em Porto Alegre e do Congresso da Cidade da Prefeitura do Municipio de Belém, no Pará, que se inserem nas Agendas Sociais semelhantes à de Municípios Saudáveis (Belém, 2001).

Entretanto, o avanço mais recente e significativo do ponto de vista institucional no país, refere-se à criação do Ministério das Cidades na composição do novo Governo Federal eleito para o período de 2003/2006. Este fato representa uma conquista histórica relevante sob vários pontos de vista da política urbana no Brasil, especialmente no que se refere às possibilidades de atuação intersetorial, na medida em que constam em seu organograma - dentro de um mesmo Ministério - os setores da habitação, do saneamento ambiental, dos transportes e mobilidade urbana, além da abordagem dos programas urbanos (Ministério das Cidades, 2003).

Todavia, "barreiras burocráticas e corporativas" ainda dificultam o pleno desenvolvimento das práticas intersetoriais, que ficam restritas a poucos municípios, ou setores específicos, constituindo-se em experiências frágeis e por isso temporárias, isto é, passíveis de serem interrompidas (Westphal et al 2000).

A experiência "in locu" do Cepedoc em alguns municipios mostra que em cidades pequenas estas barreiras tendem a ser menores, e a proximidade é maior entre os setores e secretarias. Nas cidades médias e grandes, ao que tudo indica, localizam-se os maiores desafios (Cepedoc, 2003).

\section{Sustentabilidade}

A idéia de sustentabilidade vem sendo aplicada de forma mais ou menos diferenciada, conforme a área e a complexidade em questão. Possui uma relação estreita com o uso da expressão "desenvolvimento sustentável", muito utilizada no seio do movimento e das preocupações ambientalistas. 
Algumas fontes indicam que o "conceito de sustentabilidade originou-se nas ciências agrárias e baseia-se na capacidade de um sistema agrário de manter a sua produtividade, diante das intempéries, alterações da qualidade do solo e do meio ambiente, e outros". Esse termo, ao ser transposto à projetos de preservação ou recuperação de ecossistemas naturais, tem a ver com a sua capacidade de resistir à tensões e sua capacidade de recuperação diante das diversas alterações (Herrero, 1997).

A expressão "desenvolvimento sustentável" traz a perspectiva da sustentabilidade num processo de desenvolvimento que incorpora o conceito de sustentabilidade ambiental.

No entanto, o termo sustentabilidade vem sendo recentemente utilizado por outros setores como o econômico, o político e o social. Ao incorporar a dimensão social, na perspectiva de uma intervenção humana na natureza, passa-se de um conceito de sustentabilidade ecológica para um conceito de sustentabilidade ambiental. Considera-se que um enfoque mais atual de sustentabilidade agrega outros critérios de trabalho o que, segundo a Cepal - Comissão Econômica para a América Latina, torná-lo-ia mais complexo, tais como a intervenção da população nas políticas e nas instituições (Westphal 2000 et al. apud Herrero 1997).

Arai (2000) considera a idéia de sustentabilidade em projetos Municípios Saudáveis como a continuidade, a capacidade de adaptação e recuperação de uma política pública gestada em conjunto com a sociedade civil, diante de mudanças administrativas conjunturais.

No caso dos Municípios Saudáveis, a noção de sustentabilidade tem um foco na necessidade de continuidade de um processo, quer seja um projeto, um programa ou uma política, principalmente quando elaborado com legitimidade em um processo articulado com participação social. Outro aspecto importante também da sustentabilidade, mais ligado às discussões ambientais diz respeito às formas de desenvolvimento que garantam a sobrevivência das gerações atuais e das futuras.

Assim, considera-se importante a sustentabilidade entendida também, enquanto referência norteadora do ponto de vista da continuidade desejável 
dos processos que contribuem para promover a saúde e fortalecer a população, além obviamente, do compromisso e responsabilidade com as gerações presentes e futuras.

Sob esse enfoque, a abordagem de Municipios Saudáveis incorpora a discussão sobre as formas de garantir a irreversibilidade dos processos que promovem saúde. A prática da participação social teria neste caso, um papel essencial. Nesta linha, diversos autores sugerem que a formação de lideranças efetivas pode garantir a permanência de um projeto no município, mesmo após as mudanças de governo municipal (Malik, 1997).

Demo (2000), com este foco, atribui ênfase no controle democrático como possibilidade da sustentabilidade do desenvolvimento, sobretudo da competência política da população para imprimir qualidade aos projetos.

A questão seria então de trabalhar de forma a contribuir para produzir a chamada "competência política da população" (Demo, 2000). Além disso, a atuação de diferentes setores da sociedade civil teria um papel importante para a sustentabilidade sob a forma de compromissos, parcerias, patrocínios, apoios, considerando que o enraizamento das políticas em um espaço público deve transcender a esfera estatal.

Estudo de Spink, Clemente e Keppke realizado em 1998, citado por Farah (1999) revela que $88 \%$ dos programas municipais inscritos em um programa de premiação de iniciativas inovadoras em 1996, denominado "Gestão Pública e Cidadania" da Fundação Getulio Vargas, sobreviveram à mudança de governo municipal ocorrida em 1997 . Desses, $78 \%$ envolviam parcerias com agências governamentais, com entidades civis ou do setor privado e dos que foram interrompidos, $65 \%$ não possuiam formas significativas de parcerias (Westphal et al 2000).

Esses dados ajudam a mostrar o que empiricamente vem se observando, ou seja, que projetos que contam com o apoio e o engajamento, além do governo local, de organismos não governamentais, de universidades, empresas, outros niveis de governo, entidades internacionais, e que contam com diferentes fontes de financiamento, apresentam uma capacidade maior para sobreviver nos momentos de crises ou mudanças políticas conjunturais, 
do que aqueles inseridos em um contexto de apoio e financiamento mais restritos. Estas reflexões podem servir de subsídio para a discussão da sustentabilidade ou continuidade em Municípios Saudáveis.

Na dimensão das políticas urbanas, a recente Lei 10.257 de 10 de julho de 2001, - Estatuto da Cidade, estabelece a garantia do direito à cidades sustentáveis como uma das diretrizes da política urbana:

"a garantia do direito a cidades sustentáveis, entendido como o direito à terra urbana, à moradia, ao saneamento ambiental, à infra-estrutura urbana, ao transporte e aos serviços públicos, ao trabalho e ao lazer, para as presentes e futuras gerações" (Estatuto da Cidade, 20 $, 1,2001$ ).

Esta passagem esclarece por fím que o direito garantido por lei a cidades sustentáveis, está diretamente articulado à garantia do direito à terra urbana, moradia, saneamento ambiental, infra-estrutura, transportes e serviços públicos, trabalho e lazer.

Outro aspecto importante ressaltado por Santos et al (2002) refere-se à noção ampliada de sustentabilidade mais adotada ultimamente, que concilia abordagem dos problemas sociais e abordagem dos problemas ambientais, reforçada pela Agenda 21 brasileira por inúmeras iniciativas de formulação de Agendas 21 Locais.

\subsubsection{Empoderamento}

A palavra "empoderamento" vem sendo utilizada no Brasil para designar o significado de "empowerment" do inglês, cuja tradução para "fortalecimento" é insuficiente para expressar o conteúdo mais apropriado que o conceito encerra. No idioma espanhol, portanto, nos outros países da América Latina é utilizada a expressão "empoderamiento" que se avizinha mais da palavra inglesa. Ao longo deste trabalho utilizaremos a expressão "empoderamento" como tradução do inglês "empowerment" ou do espanhol "empoderamiento".

Wallerstein (1992) da Universidade do Novo México, em seu trabalho "Powerlessness, empowerment, and health: implications for health 
promotion programs" discute a origem do conceito e o significado da aplicação de empoderamento de maneira consistente na área da Promoção da Saúde. A autora articula também na discussão, o conceito de impotência, argumentando que o termo empoderamento apareceu no passado, muitas vezes associado, como um contraponto ao conceito de impotência.

Wallerstein (1992) toma como referências diversos trabalhos científicos relativos à epidemiologia social, psicologia do empoderamento (psychology empowerment), psicologia social, pesquisas sobre estresse, psicologia comunitária e competência comunitária, além de citar o ideário Municípios Saudáveis. A autora propõe também um modelo de educação para o empoderamento e adota como referência para isso, os conceitos desenvolvidos pelo educador brasileiro Paulo Freire (1970).

Ao argumentar sobre empoderamento na perspectiva da epidemiologia social a autora enfatiza a conhecida relação entre pobreza e níveis mais elevados de doenças e mortes. "Desde 0 século $X X$ diversos estudos têm documentado consistentemente que as pessoas que vivem em situação de pobreza apresentam taxas mais altas de mortalidade e de morbidade que os grupos de um alto nivel sócio-econômico" (Wallerstein, 1992).

Segundo a autora, desde os anos 1950 o fenômeno da impotência tem sido examinado pelas ciências sociais e políticas e de forma alternativa referida à alienação, culpabilização da vítima, opressão intencionada, agressões ou danos ocultos (Wallerstein, 1992).

Neste sentido, a impotência é considerada como um fator de risco para as doenças. A autora procura responder à questão central que se situa na abordagem do empoderamento em saúde pública: "é possivel considerar 0 empoderamento como uma estratégia de promoção da saúde, capaz de reduzir o risco de enfermidades, fruto da impotência?" (Wallerstein, 1992).

Segundo Wallerstein (1992) o empoderamento tem surgido mais recentemente como um conceito afirmativo. Assim, para a autora, em sentido amplo o empoderamento: "é uma construção multidimensional, que engloba as pessoas que assumem o controle e a capacidade sobre suas vidas no contexto de seu meio social e político". 
Esta conceituação se aproxima de alguns elementos da proposta de promoção da saúde preceituado na Carta de Otawa que se refere também à importância do controle sobre a saúde: "A promoção da saúde consiste em proporcionar aos povos os meios necessários para melhorar a sua saúde $e$ exercer um maior controle sobre a mesma" (Carta de Otawa, 1986).

Wallerstein (1992) propõe que o "controle sobre o destino ou a falta do mesmo se apresenta como um fator de risco e como uma estratégia para os programas de promoção da saúde. A falta de controle sobre o destino fomenta o surgimento de enfermidades, principalmente para os que vivem em situações marginais e com falta de recursos, falta de apoios ou habilidades para exercer controle sobre suas vidas".

Desta forma, a autora conclui que o empoderamento aparece diretamente como uma estratégia dirigida para a falta de controle sobre o destino. Assim, argumenta "apesar dos fatores de risco sociais e físicos, as pessoas (pelo processo de empoderamento) adquirem a convicção de que podem controlar os seus mundos, adquirem o sentido de comunidade e o desenvolvimento de habilidades para trabalhar conjuntamente na aquisição de recursos e em uma transformação real das condições sócio-politicas" (Wallerstein, 1992).

$\dot{E}$ bastante interessante 0 relato que a autora faz de algumas pesquisas realizadas em paises do norte com idosos hospitalizados. Os grupos de pacientes que tiveram acesso a informações sobre seu estado de saúde, sobre a sua doença, e sobre os procedimentos que deveriam ocorrer no tratamento apresentaram melhoras mais significativas quando comparados com outros grupos de pacientes na mesma situação que não tiveram acesso a informações sobre o próprio estado de saúde e doença (Wallerstein, 1992). Aí, os aspectos relacionados ao conhecimento e controle da própria situação e ao controle do destino, parecem relacionar-se com o processo de melhoria e cura.

A pesquisadora mostra que em inúmeras pesquisas sobre individuos e sobre grupos se evidencia o fato de que quando as pessoas assumem um maior controle sobre as suas vidas e sobre os seus destinos, ocorre um processo de empoderamento, que contribui para a promoção da saúde. Assim, o conceito 
de controle sobre o destino aparece como aspecto central do empoderamento.

Por fim, Wallerstein (1990) utiliza como referência de aplicação para o empoderamento na promoção da saúde, a proposta de Paulo Freire (1970), na perspectiva de promover o educando enquanto sujeito do próprio aprendizado - e não um recipiente vazio a ser preenchido pelo conhecimento do professor.

Nesta linha, propõe-se uma abordagem baseada no exercício do diálogo e o no "ouvir" que se desenvolve em quatro passos: a) escutar as experiências de vida das pessoas (suas visões sobre os problemas); b) desenvolver o diálogo, de modo que todos possam participar como iguais e juntos busquem interpretar os problemas da comunidade, com pensamento crítico sobre os problemas procurando analisar a raiz das causas dos problemas, em contexto sócio-econômico, político, histórico e cultural; c) a abordagem do diálogo educacional que requer a colocação dos problemas $e$ questionamentos de modo a incorporar a experiência pessoal na análise das forças sociais e no entendimento do papel das pessoas no contexto destas forças; d) as ações nos programas de educação para o empoderamento que devem ser definidas pelos próprios participantes.

Esta linha de abordagem no trabalho participativo se afina muito com 0 arcabouço desenvolvido e sistematizado por Paulo Freire (1996) para quem: "ensinar não é transferir conhecimento, mas criar as possibilidades para a sua produção ou a sua construção." Freire (1996) vai mais longe, afirmando também a importância de que "o educando mantenha vivo em si o gosto pela rebeldia que, aguçando a sua curiosidade e estimulando a sua capacidade de arriscar-se, de aventurar-se, de certa forma o imuniza contra o poder apassivador do bancarismo ${ }^{5 n}$.

Com relação ao fortalecimento da população, a Declaração da Conferência Internacional de Saúde de Bogotá (Carta de Bogotá, 1992), no contexto da América Latina reconhece e afirma a necessidade do compromisso em "(...)

\footnotetext{
${ }^{5}$ Referencia que o autor faz ao ensino tipo "bancário" como pré-formatado, vertical e adestrador, que deforma a necessária criatividade do educando.
} 
fortalecer a capacidade da população na tomada de decisões que afetem a sua vida (...)".

Oakley e Clayton (2003) no trabalho Monitoramento e avaliação do empoderamento, discutem o conceito de empoderamento e apresentam dados de avaliação e monitoramento, fruto de uma sistematização realizada por integrantes de organizações não governamentais (ONG's) internacionais que apóiam o trabalho de outras ONG's que trabalham diretamente com comunidades na perspectiva do desenvolvimento e do empoderamento. No trabalho discute-se o empoderamento a partir de estudos de caso em diversos países em desenvolvimento como o Sudão, Honduras, Etiópia, Bangladesh, Tanzânia, Nicarágua e Egito.

Os autores consideram que o conceito de "poder" desde a última década está no centro das explicações $e$ análises sobre as "iniqüidades" e os "desequilíbrios", bem como sobre a "marginalização e a opressão", como bases para a explicação da pobreza de milhões de pessoas.

A abordagem das origens do conceito de empoderamento, na perspectiva do desenvolvimento, é importante como ponto de partida para análises mais amplas e contemporâneas. Segundo os autores "desde a década de 1970 encontram-se trabalhos analíticos que influenciaram no surgimento do poder como conceito central que define todos os processo de desenvolvimento" (Oakley e Clayton, 2003).

O trabalho reconhece também que Paulo Freire (1970) desenvolveu de maneira convincente o argumento que somente o "poder real" poderia romper com o que chamou de "cultura do silêncio" que caracteriza a população pobre e a marginalidade dos carentes de poder.

Os autores consideram que o "poder" é a base da riqueza enquanto o "desempoderamento" ou a "impotência" (como se refere Wallerstein) a base da pobreza (Oakley e Clayton, 2003).

Outro aspecto relevante, também considerado nesta análise refere-se ao fato de que o poder está relacionado ao conhecimento, que consiste em uma fonte de poder e em uma forma de adquiri-lo. Assim argumentam : "todo o 
trabalho de desenvolvimento está relacionado ao controle do conhecimento" (...). "Se os "subprivilegiados" pudessem controlar as fontes de conhecimento, as estruturas das relações de poder existentes se alterariam radicalmente. $O$ conhecimento pode oferecer legitimidade e autoridade, e sua construção e disseminação são ferramentas poderosas. $O$ conhecimento ajuda a interpretar e dar forma ao contexto em que se vive. Mas sem ele carece-se de poder" (Ocampo, 1996 apud Oakley e Clayton, 2003).

Como objetivo do desenvolvimento, o empoderamento tem sido instrumentalizado, por meio de metodologias práticas e projetos, e em relação ao seu efeito e impacto, começam a ser traduzidas as referências em medidas observáveis. Nesta perspectiva, o empoderamento pode se manifestar em três grandes áreas, segundo Oakley e Clayton (2003):

a) o poder como maior confianca na capacidade pessoal para levar adiante alqumas formas de ação;

b) o poder como aumento das relações efetivas que as pessoas desprovidas de poder podem estabelecer com outras organizações;

c) o poder como resultado da ampliacão do acesso aos recursos econômicos, tais como crédito e insumos.

Com relação às medidas, sinais e evidências do empoderamento podem ser citadas as seguintes propostas de Wallerstein (1992): o ato de participar na discussão sobre as mudanças na coletividade que provoca reflexões sobre valores pessoais e mudança dos mesmos e reforça a potencialidade de enfrentar situações dificeis e conflituosas; o aumento da autoconfiança pessoal e da capacidade de interferir nas políticas; o desenvolvimento de habilidades de auto-ajuda e ajuda-mútua e de convencimento de transformações na comunidade que desenvolve a capacidade de mobilizar empatia e outras respostas emocionais para mudanças nos processos; o desenvolvimento de consciência crítica acerca das raízes (causas) dos problemas que amplia expectativas sobre os resultados; além do aumento da capacidade para o exercitar uma maior controle sobre o destino e ampliar o senso de coerência acerca do próprio lugar no mundo. 
Além disso, a autora enfatiza que a capacidade de mobilizar pessoas dentro dos grupos, fortalece as redes sociais entre os individuos e melhora a competência da organização da comunidade para colaborar na resolução dos problemas de saúde. Por fim, deve-se considerar também a melhoria das condições de saúde do meio e as habilidades da comunidade para conseguir recursos para melhorar a sua saúde.

Com relação às formas de verificação, Oakley e Clayton (2003) propõem como exemplos de indicadores para o processo de empoderamento de grupo, entre os diversos utilizados: a coesão interna dos grupos e o sentido de solidariedade, a habilidade para discutir e analisar criticamente, formação e a ocorrência de estruturas internas e elementos de autogestão, o desenvolvimento de atividades coletivas pelos grupos e a habilidade de relacionar-se com os outros.

Como se pode notar, a concepção de empoderamento, tanto nos projetos de desenvolvimento, quanto na promoção da saúde, tem sido crescentemente discutida e considerada dada à premência de sua utilização, especialmente em países e sociedades como as nossas, onde a desigualdade e a injustiça social colocam-se como desafios históricos seculares.

No Brasil, por conta de sua formação e histórica cultura política, social e econômica, discutida e analisada por diversos autores e intelectuais brasileiros, como Holanda (1971), Furtado (1972), Fernandes (1975), Freyre (1997), Oliveira (1972), Schwarz (1973), Prado Jr. (1990) entre outros, torna-se absolutamente pertinente efetivar discussão, o entendimento e a prática do conceito de empoderamento, particularmente junto aos setores excluídos do sistema econômico e social estabelecido. 


\subsubsection{Políticas Públicas Saudáveis}

Neste sentido a Carta de Otawa (1986) aborda aspectos iniciais, porém importantes relacionados às políticas públicas saudáveis. A primeira questão colocada refere-se à responsabilização dos que elaboram os programas políticos em todos os níveis e todos os setores, de forma que tomem consciência das conseqüências que suas decisões podem ter para a saúde.

Interessante notar que esse aspecto da responsabilidade dos governantes, formuladores e implementadores de políticas, aparece novamente na Declaração de Adelaide, com mais propriedade, uma vez que a Conferência em que ela se apóia, teve como tema: Políticas Públicas Saudáveis.

Assim, o documento fruto da primeira conferência pós-Carta de Otawa ressalta também que os diversos setores do governo devem se responsabilizar pelas conseqüências à saúde de suas decisões políticas - e ressalta "eles devem prestar tanta atenção à saúde quanto à economia" (Conferência de Adelaide, 1988).

A Declaração da Conferência de Adelaide (1988) reserva um item específico para tratar da importância da responsabilização em saúde. Sob este prisma coloca de maneira central a responsabilização de todos os niveis de governo. "O comprometimento com as políticas públicas saudáveis significa que os governos devem medir e relatar o impacto de suas políticas sobre a saúde, em uma linguagem que todos os grupos na sociedade compreendam prontamente".

Estes diversos documentos ressaltam o quanto a ação comunitária é central para o incentivo às políticas públicas saudáveis. Além disso, a Conferência de Adelaide defende a importância da avaliação do impacto das políticas. Neste sentido argumenta sobre a necessidade de "criação e desenvolvimento de sistemas de informação em saúde" que apóiem este processo. "Isso encorajará a tomada de decisões mais informada acerca de futura alocação de recursos para a implementação de políticas públicas saudáveis" (Conferência de Adelaide, 1988). 
Já aos grupos sociais, profissionais e ao pessoal de saúde corresponde, especialmente "a responsabilidade de atuar como mediadores entre interesses antagônicos em favor da saúde". (Carta de Otawa, 1986)

Outro aspecto central de uma política pública saudável constitui a preocupação com ações que tenham como foco a atuação coordenada dos setores e a equidade. Esta ênfase é defendida de forma veemente na Carta de Otawa e reforçada na Declaração de Adelaide.

Para tanto, a Carta de Otawa (1986) ressalta "a política de Promoção da Saúde tem que combinar enfoques diversos, se bem que complementares, nos quais figuram a legislação, medidas fiscais, o sistema tributário e as mudanças governamentais. É a ação coordenada o que leva a prática uma política sanitária, monetária e social, que permita uma maior equidade".

Em Adelaide as recomendações explicitam a importância de priorizar os grupos desprivilegiados e vulneráveis, bem como criar ambientes de suporte, que apóiem a Promoção da Saúde, na medida em que conscientemente busquem a promoção da saúde no cotidiano dos espaços em que militam (por exemplo: escolas, indústrias, entre outros)

Assim, a Carta defende que "as desigualdades em saúde tem suas raízes nas iniqüidades na sociedade. Logo para diminuir o distanciamento em saúde entre as pessoas social e educacionalmente em desvantagem $e$ as pessoas em situação de maior vantagem, requer-se uma política que melhore 0 acesso a bens e serviços que melhorem a saúde e que criem ambientes de suporte" (Conferência de Adelaide, 1988).

De acordo com a declaração adotada na Segunda Conferência Internacional sobre Promoção da Saúde (Conferência de Adelaide, 1988) políticas públicas saudáveis "são caracterizadas por uma preocupação explícita com relação a saúde e equidade em todas as áreas de políticas e por uma responsabilização com relação ao seu impacto sobre a saúde".

A Conferência de Jacarta realizada em 1997 sobre a "Promoção da Saúde pelo Século XXI adentro" reafirma a necessidade da responsabilidade social para com a saúde, tanto dos tomadores de decisão, do setor público quanto 
do setor privado e ressalta a inclusão da "avaliação do impacto sobre a saúde focalizado na equidade como parte integral da elaboração de políticas" (Declaração de Jacarta, 1997).

A declaração atesta que "o alvo principal das políticas públicas saudáveis é a criação de ambientes que permitam às pessoas levar vidas saudáveis. Tais políticas tornam as escolhas em saúde possíveis ou mais fáceis para os cidadãos. Elas fazem com que os ambientes sociais e fisicos melhorem a saúde" (Conferência de Adelaide, 1988).

Com relação aos ambientes favoráveis à promoção da saúde a Carta de Otawa (1986) menciona que "é essencial que se realize uma avaliação sistemática do impacto que as mudanças do meio ambiente produzem na saúde, particularmente nos setores da tecnologia, trabalho, energia, produção e urbanismo".

Se a Carta de Otawa chama a atenção para a importância da criação de ambientes saudáveis, na Declaração de Adelaide defende-se a criação de ambientes de apoio à Promoção da Saúde, como uma questão chave e prioritária para as políticas públicas saudáveis. (Carta de Adelaide, 1988).

A Carta de Bogotá (1992) reconhecendo as iniqüidades em saúde existentes na região da América Latina defende a importância de "incentivar políticas públicas que garantam a equidade".

Em Adelaide, por sua vez, reafirmou-se a importância da justiça social, equidade como pré-requisitos para a saúde e a advocacia e a mediação como processos para a sua consecução (Carta de Adelaide, 1988).

Em suma, diversos conceitos, princípios, pressupostos, pré-requisitos e processos são elencados como elementos-chave na promoção da saúde. Do ponto de vista das políticas de habitação e desenvolvimento urbano em Projetos Municípios Saudáveis, os que mais se destacam a nosso ver, considerando a experiência desenvolvida em Bertioga são, além da participação social, intersetorialidade, equidade, sustentabilidade, a criação de ambientes de apoio e infra-estrutura favoráveis à saúde, a advocacia por 
políticas públicas saudáveis, a mediação de conflitos, o desenvolvimento de habilidades pessoais e competência comunitária e o empoderamento.

\subsubsection{Advocacia em Promoção da Saúde}

Outro conceito importante que vem sendo crescentemente utilizado no universo da Promoção da Saúde é a advocacia. Diversos autores desenvolvem argumentos relevantes sobre a importância da advocacia na perspectiva da saúde e das políticas públicas saudáveis.

Segundo Westphal e Arroyo et. al. (2000) advogar, enquanto tradução do termo "advocacy" necessita de uma reconsideração semântica para uma apreensão mais precisa do conteúdo. Assim, advogar significa "defender, argumentar a favor de alguém ou alguma coisa, sustentar um causa contra algum interesse externo, defender uma idéia". Por sua vez, representar "significa desempenhar atividades ou negociações visando atingir alguma coisa para alguém, exercer o poder de realizar algo para o interesse de alguém, de grupos, comunidades ou da sociedade como um todo" (Westphal, Arroyo, et. al. 2000).

Os mesmos autores consideram também que, em uma revisão da estratégia de advocacia no contexto da promoção da saúde, "o conceito possui as duas conotações: advogar e representar. Enquanto estratégia, a advocacia é orientada no campo do empoderamento (construção individual e coletiva do poder) e no campo da disputa ideológica e política, pelo desenvolvimento da saúde". (Westphal e Arroyo, 2000).

Suely Dallari (1996) considera que a "advocacia concretizou-se como um processo que utiliza um conjunto de estratégias políticas visando promover direitos não respeitados, através de meio legais e éticos, a favor de grupos sociais desfavorecidos ou oprimidos".

A autora complementa seu argumento enfatizando a advocacia em saúde como uma estratégia que "desenvolve ações que procuram influenciar autoridades e particulares, sensibilizando-os para carências e necessidades 
sanitárias". Isto se articula com o entendimento de advogar, enquanto reivindicação pelo direito à saúde (Dallari, 1996).

Assim, a advocacia no campo da saúde pública é reconhecida como uma estratégica legítima e necessária que se efetua num campo político, ideológico e prático a favor da saúde e que pode (e deve) ser desenvolvida pelos setores desfavorecidos, por profissionais do setor sanitário e de outros setores, extrapolando, portanto, um papel mais restrito de que tal tarefa caberia somente aos bacharéis em direito.

Ressalte-se nesta discussão a diferenciação entre educação em saúde e advocacia em saúde. Neste particular Dallari adverte que o educador prepara para a cidadania, enquanto o advogado promove ou defende o exercício da cidadania. "Em outras palavras, a educação em saúde é condição absolutamente necessária para que a advocacia em saúde se manifeste. Essa relação de dependência que a advocacia em saúde guarda com a educação é que, curiosamente, torna possível ao cidadão se emancipar: à medida em que reconhece seus problemas e pleiteia solução para eles, vai se tornando seu próprio advogado" (Dallari, 1996).

A literatura sobre o tema informa em diversas referências que a advocacia em saúde é essencial para a defesa diante da distribuição desigual dos recursos, de riqueza material, de poder político, muitas vezes já garantido por algumas leis, no entanto, não efetivados na sociedade.

É o que afirma Wise (2001), para quem a advocacia em saúde "é essencialmente, um processo político que tem como finalidade influenciar decisões políticas sobre a distribuição dos recursos da sociedade".

Nesta perspectiva, também Knitzer (1976) citado por Dallari (1996) enfatiza que a advocacia em saúde se baseia em alguns pressupostos, entre os quais: "que a advocacia em saúde é inerentemente política, por assumir que há inadequação na distribuição de autoridade, recursos e acesso à informação e que a advocacia em saúde está dirigida às falhas institucionais que produzem ou agravem problemas individuais" (dentro do nosso 
entendimento e realidade, deve-se pensar principalmente em danos à coletividade) ${ }^{6}$.

Neste particular, Wise (2001) deixa clara a sua concepção de que a advocacia está mais próxima de combater problemas de saúde onde se verifica que a ausência (ou carência) de poder está relacionada aos problemas de saúde. Assim, a advocacia deve articular-se na aproximação dos segmentos que sofrem com a falta de poder, na perspectiva de motivar uma ampla ação social e política envolvendo-os de modo a ir além das mudanças nos comportamentos sanitários pessoais, priorizando o âmbito do coletivo.

Por fim, Wise (2001) ao citar Labonte (1999) enfatiza a responsabilidade dos que advogam em saúde com as metas da saúde pública tornar-se uma ferramenta do empoderamento das comunidades.

No seu trabalho, Wise (2001) explicita "a importância do engajamento no processo político para efetivar mudanças nas políticas e no meio ambiente, de forma a facilitar às populações o acesso a escolhas saudáveis".

A autora considera também que (infelizmente) ainda tem havido pouco sucesso no uso da advocacia para a redução das desigualdades em saúde, no entanto este consiste, certamente no seu maior desafio, que a nosso ver, significa no país a redistribuição das riquezas, conhecimentos e poder.

${ }^{6}$ Nota de Dallari, S. (1996). 


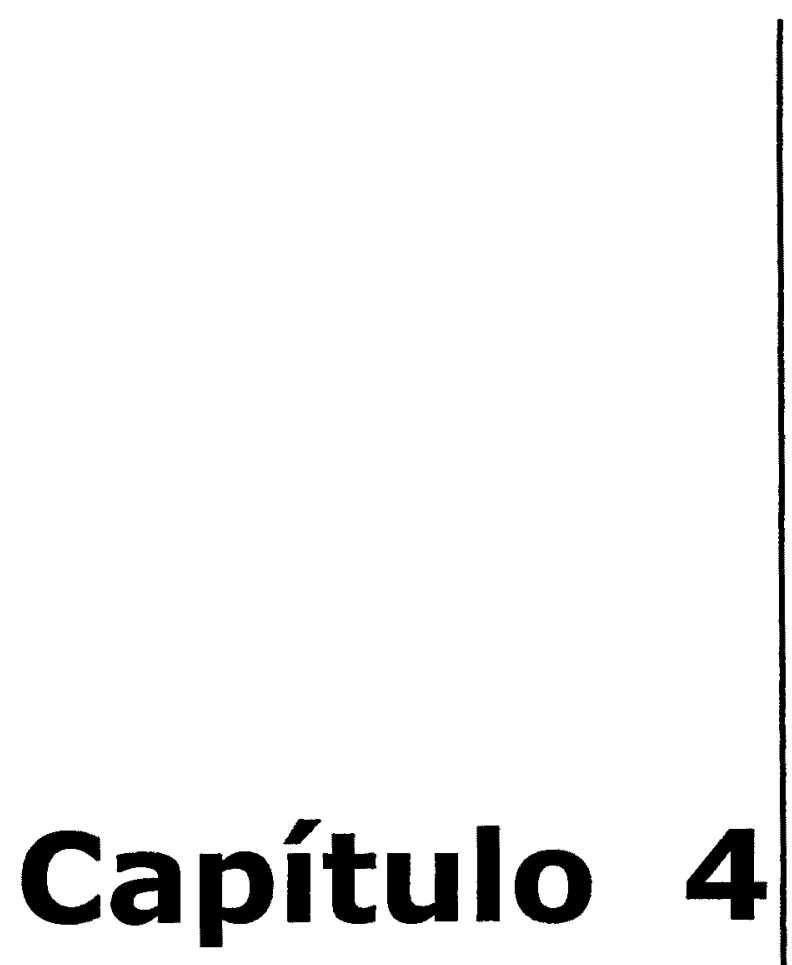

Concepção do estudo e metodologia 
Na primeira parte do trabalho, procurou-se elaborar uma matriz conceitual e teórica que embasa a pesquisa empírica. A mesma se baseia em fatos históricos em saúde pública, políticas e intervenções urbanas e habitacionais, os movimentos do sanitarismo e o higienismo, as relações entre habitação e saúde em geral e entre políticas urbanas e promoção da saúde em particular.

Definiu-se o problema da pesquisa, discutindo a questão do espaço urbano e o histórico de ocupação desordenada e segregação social de uma região litorânea de proteção ambiental.

O estudo das políticas urbanas e sua referência ao movimento de Municípios Saudáveis como estratégia de promoção da saúde/produção social da saúde/doença foi realizado no município de Bertioga, SP, selecionado em função do acordo de cooperação técnica efetivado entre a prefeitura de Bertioga com a Faculdade de Saúde Pública da Universidade de São Paulo (Westphal et al, 2000).

Atualmente o eixo temático de Promoção da Saúde do Departamento de Prática de Saúde Pública da USP e o CEPEDOC - Centro de Estudos, Pesquisa e Documentação em Cidades Saudáveis desenvolve um projeto no município. A presente pesquisa representa uma fase deste Projeto Município Saudável que se propõe, experimentalmente, a implementar as proposições teóricas da Nova Saúde Pública (Santos e Westphal, 1999). Sua função, além de fornecer subsidios para a continuidade do projeto, é mostrar a pertinência das políticas de habitação e desenvolvimento urbano em Municípios Saudáveis e estabelecer diretrizes para políticas urbanas saudáveis em uma realidade litorânea, considerando como elemento relevante, a participação da população na advocacia pela saúde.

Para buscar compreender as questões habitacionais e urbanas e sua relação com o processo saúde/doença partiu-se do pressuposto que a investigação no campo da saúde e no campo das políticas urbanas, devem ser consideradas e abordadas como pesquisa de natureza social, visto que estas são práticas sociais. Como tais, só podem ser entendidas no contexto social do município, nos seus sistemas de significação que embasam seus simbolismos, suas instituições, suas finalidades. 
Assim é coerente que se utilize, de diferentes técnicas de pesquisa social quantitativa e qualitativa, conforme a etapa e o objeto específico do estudo, na condução geral da pesquisa a fim de entender os mecanismos estruturais municipais e regionais que estariam determinando a configuração urbana, as condições de vida e saúde da população.

Entendemos aqui que o uso de apenas um tipo de técnica não seria capaz de dar conta dos inúmeros aspectos inerentes ao objeto de pesquisa em questão. Muitos pesquisadores ainda rejeitam esta fusão, uma vez que aceitam e praticam o dualismo entre cultura científica e humanidades. Conforme Carvalho (2003), no mundo ocidental estas duas visões, cartesiana e fenomenológica, na origem, não se intercomunicam malgrado os esforços de múltiplas áreas do conhecimento de religar saberes. Snow, já em 1959, ponderava que, enquanto esses dois sentidos do mundo estivessem separados, nenhuma sociedade seria capaz de pensar com sabedoria.

Ao optar pela pesquisa ação participante como referência metodológica geral adotada, e diante da discussão da relação "sujeito-objeto", consideramos, aqui, superada a doutrina positivista que desconsiderou o sujeito cognoscente, privilegiando o fato como autônomo e verdadeiro a ser conhecido (Haguete, 1987). Neste particular, tanto o pensamento oriental (quase sempre ignorado pela ciência ocidental) quanto a física moderna e a quântica descortinam novos paradigmas para os pesquisadores que buscam renovadas formas de se relacionar com o conhecimento e a sua produção, inclusive nas ciências sociais, humanas e de saúde.

Neste sentido cabe citar um trecho de C. Jung no prefácio de "I Ching, o livro das Mutações" na ocasião da tradução do idioma chinês para o idioma alemão em 1972. " (...) é indispensável deixar de lado certos preconceitos da mente ocidental. É curioso que um povo tão dotado e inteligente como o chinês nunca tenha desenvolvido o que chamamos de ciência. Nossa ciência (ocidental) é baseada no princípio da causalidade, o qual é considerada uma verdade axiomática. Mas uma grande mudança está ocorrendo em nosso ponto de vista. O que a crítica da razão pura de Kant não conseguiu, está sendo realizado pela fisica moderna. Os axiomas da causalidade estão sendo abalados em seus fundamentos: sabemos agora que o que denominam leis 
naturais são meramente verdades estatísticas que supõe, necessariamente exceções. Ainda não nos apercebemos que necessitamos do laboratório com suas decisivas limitações para demonstrar a validade invariável das leis naturais. Se deixarmos a natureza agir, veremos um quadro muito diferente: o acaso vai interferir total ou parcialmente em todo o processo, tanto assim que, em circunstâncias naturais, uma seqüência de fatos que esteja em absoluta concordância com leis especificas constitui quase uma exceção" (Jung, 1972).

Concordando com estes autores, e no contexto de pesquisa social resolvemos discutir a questão da cidade e do planejamento urbano em moldes, também menos fragmentados e hiper-especializados, reunindo em um só raciocínio sujeito, objeto e contexto, racionalidade e subjetividade.

Para isso, foram realizadas análises documentais, análises de dados de fontes secundárias e caracterização e análise urbana e habitacional.

Partiu-se da análise dos dados do Censo de 2000 do IBGE que permitiram uma caracterização social, demográfica da população local e das estruturas econômicas, urbanísticas e ambientais.

Dados complementares foram obtidos por meio de consulta e análise de dados e documentos (relatórios, pesquisas, levantamentos, cartas, mapas, plantas, fotos aéreas, cartografia) em entidades públicas e privadas locais, regionais e nacionais como Prefeitura do Município de Bertioga, Agencia Metropolitana da Baixada Santista - Agem, Fundação Seade, Emplasa, Empresa Paulista de Planejamento Metropolitano, IBGE - Instituto Brasileiro de Geografia e Estatística, Secretaria de Estado do Meio Ambiente, Secretaria de Estado da Saúde, Sabesp - Companhia de Saneamento Básico do Estado de São Paulo, Cetesb - Companhia Estadual de Tecnologia Ambiental, Instituto Florestal, INPE - Instituto Nacional de Pesquisas Espaciais, CDHU - Companhia de Desenvolvimento Habitacional e Urbano do Estado de São Paulo, Ministério da Saúde, Ministério do Trabalho, Ministério das Cidades.

Para a análise habitacional e urbanística e para a elaboração das diretrizes de políticas de habitação e desenvolvimento urbano foram utilizados, métodos e dados da pesquisa Parâmetros para urbanização de favelas, 
realizada pelo LABHAB (1999) Laboratório de Habitação e Assentamentos Humanos da Faculdade de Arquitetura e Urbanismo da USP, que contou com financiamento da FINEP/CEF - Financiadora de Estudos e Projetos/Caixa Econômica Federal, em pesquisa científica e tecnológica. $O$ estabelecimento desses parâmetros foi baseado em avaliações de dados de pesquisas de urbanização de favelas em 5 (cinco) municípios brasileiros: São Paulo, Diadema, Rio de Janeiro, Goiânia e Fortaleza (LabHab, 1999).

Utilizamos também como referência, os métodos e dados dos Relatórios produzidos pelo LabHab da FAUUSP para a formulação e implementação do Programa Bairro Legal da Sehab da Prefeitura do Município de São Paulo'. (LabHab, 2003).

Para compreender melhor a complexidade do fenômeno em estudo, seus paradoxos e contradições, realizamos os cruzamentos de dados de diversas fontes, no sentido de se identificar as relações entre as condições de moradia, dos assentamentos humanos e do desenvolvimento urbano e dos indicadores de saúde e condições de vida. Procura-se levantar alguns dados que gerem hipóteses sobre quais e como as condições e transformações no meio habitado influem na saúde $e$ na doença, no decorrer do desenvolvimento do projeto Bertioga Município Saudável.

Foram utilizados métodos da pesquisa ação participante, a análise qualitativa de conteúdo do discurso de atores locais apreendidos durante a realização de oficinas, seminários, reuniões e encontros no âmbito do PBMS (Haguette, 1987; Thiollent, 2000).

Os dados obtidos durante a pesquisa ação participante que ocorreu em Bertioga durante os anos de 2000 a 2003 permitem identificar e analisar a percepção dos participantes sobre os problemas relativos às políticas urbanas. Possibilitaram também, obter dados sobre o empoderamento da

\footnotetext{
1 O Programa Bairro Legal é um programa da Sehab - PMSP que objetiva formular e implementar Planos de Ação Habitacional e Urbano em Distritos periféricos e com indicadores elevados de violência - objetiva assim viabilizar a contribuição do setor habiracional-urbano na minimização dos múltiplos fatores que contribuem para o fenômeno da violência. O LabHab teve como missão desenvolver a metodologia de elaboração e implementação dos Planos Habitacionais e Urbanos. Na primeira etapa foram incluidos os Distritos do Jardim Ângela, Cidade Tiradentes e Brasilandia. Alem da PMSP, o projeto conta com financiamento do Citties Alliance - Bird.
} 
população, que viabilizou a sua participação no processo de revisão do Plano Diretor e sua defesa pública.

A metodologia geral da condução da pesquisa no município, por ocasião da ação do trabalho de extensão universitária e assessoria técnica para a implementação do Projeto Bertioga Município Saudável é a pesquisa ação participante. Este método já vem sendo e empregado em outras pesquisas correlatas realizadas já realizadas por professores e pesquisadores da FSPUSP (como Westphal, Adorno, Zione e Lefèvre) e do Cepedoc (Arai, 2002).

O método consiste, como informa Haguete (1987) citando Gianotten e De With (1985) "em um processo de investigação, educação e ação onde há a participação da comunidade juntamente com um compromisso intelectual apontando para a transformação social (...), com o elemento de organização político-econômico, instância mediadora, que promove a passagem do saber popular para o saber orgânico".

Considera-se este método de investigação como o mais apropriado para apreender uma visão processual das percepções dos participantes do projeto de pesquisa e extensão.

Para Thillent (2000) a pesquisa ação participante é um tipo de pesquisa social com base empírica que é concebida e realizada em estreita associação com uma ação ou com a resolução de um problema coletivo e no qual os pesquisadores e os participantes representativos da situação ou do problema estão envolvidos de modo cooperativo ou participativo (Thiollent, 2000).

Os defensores da pesquisa-ação argumentam que a prática da sua utilização leva a considerar que não é possivel realizar pesquisa sem ação, nem ação sem pesquisa (Haguete, 1987). De forma análoga Paulo Freire (1996) em "Pedagogia da Autonomia" enfatiza, com relação ao processo de ensino e pesquisa: "não há ensino sem pesquisa, nem pesquisa sem ensino". E complementa "pesquiso para constatar, constatando, intervenho, intervindo educo e me educo".

Nota-se que estas considerações conceituais utilizadas pelos autores citados, com respeito ao processo de produção do conhecimento e da ação na 
sociedade, guardam semelhanças entre si e foram utilizadas como pressupostos neste trabalho.

A descrição detalhada das fases da pesquisa ação será encontrada nos capítulos referentes aos resultados, vinculando 0 processo social desenvolvido à análise e discussão dos dados.

Para validar os dados e a estabilidade do grupo sujeito da pesquisa, apresentamos no Anexo 1, o Quadro com a relação dos participantes das principais atividades do PBMS - Projeto Bertioga Município Saudável, assinalando as etapas que cada um participou. Note-se que há um grupo (diversos individuos) que participou de quase todas as etapas do Projeto. Este grupo foi gradativamente se empoderando e transferindo o resultado do trabalho conjunto a outros integrantes que se incorporavam no processo ao longo do tempo. Ocorreu também uma transferência de conhecimentos produzidos e um apoio difuso dos outros participantes que foram se sucedendo nas etapas do processo (Anexo 1).

Foi utilizado, como recurso de análise final a técnica da triangulação, para validação dos dados trabalhados nas diferentes metodologias, identificação de congruências, complementaridades e contradições. A metodologia da triangulação é considerada fundamental para verificar a propriedade das interpretações fundadas em dados qualitativos, e permite observar a realidade a partir de distintos ângulos, possibilitando uma discussão interativa e intersubjetiva dos dados. A utilização de multimeios, própria da proposta de triangulação, garante a validade dos dados, ou seja, na operacionalização de um determinado método, permite que seus problemas e limitações sejam compensados pelo uso de outros métodos (Mendes, 2000).

Para compreender melhor a complexidade do fenômeno em estudo, seus paradoxos e contradições, utilizamos e realizamos os cruzamentos destes dados objetivos com os dados de diversas outras fontes, no sentido de se identificar as relações entre as condições de moradia, dos assentamentos humanos e do desenvolvimento urbano e dos indicadores de saúde e condições de vida. Procurou-se ainda, ao relacionar os dados, levantar 
algumas hipóteses sobre como as condições e transformações no ambiente construído têm influído na saúde e na doença da população.

\section{Forma de análise dos resultados}

São realizados um conjunto de análises, a partir da caracterização social, habitacional, urbanística e ambiental, que informam sobre as condições de habitabilidade e vida no município, considerando qualidade urbana e ambiental, infra-estrutura - abastecimento de água, esgotos sanitários, sistema de drenagem, energia elétrica, coleta de resíduos sólidos.

Utilizamos aqui o princípio da avaliação iluminativa (Parlett e Hamilton, 1992), que define que a interpretação e análise qualitativa permite iluminar os resultados quantitativos. Com relação aos dados qualitativos serão utilizados a análise documental em fontes de órgãos públicos, escritórios técnicos, organizações não governamentais, entre outras.

A análise de conteúdo, a ser utilizada no entendimento das falas dos participantes das atividades do PBMS, é a expressão mais comumente utilizada para representar 0 tratamento dos dados de uma pesquisa qualitativa. No entanto o termo significa mais que um procedimento técnico, e faz parte de uma histórica busca teórica e prática no campo das investigações sociais (Minayo, 1992).

A análise de conteúdo pode ser definida como um conjunto de técnicas de análise de comunicação visando obter, por procedimentos sistemáticos e objetivos de descrição do conteúdo das mensagens, indicadores que permitam a inferência de conhecimentos relativos às condições de produção/percepção dessas mensagens (Bardin 1979 apud Minayo 1992).

Como forma de obtenção de informações relevantes para a pesquisa, são utilizados métodos de análise de conteúdo das falas de diferentes depoentes, colhidos durante as atividades do PBMS. (Minayo, 1992).

Procurou-se realizar uma análise lógica final dos dados levantados e discutidos, a fim de efetuar um confronto comparativo crítico-analítico entre o marco teórico-conceitual desenvolvido na primeira parte do trabalho; e o material empírico coletado, tratado e analisado nas fases seguintes da 
pesquisa. Entende-se que este constitui-se em um esforço de busca de conclusões a partir dos elementos derivados dos processos das análises e sínteses, em uma perspectiva dialética (Haguete, 1987).

A seguir é realizada a caracterização do cenário de estudo escolhido, para depois, confrontá-la com as percepções da população residente no município de Bertioga. 


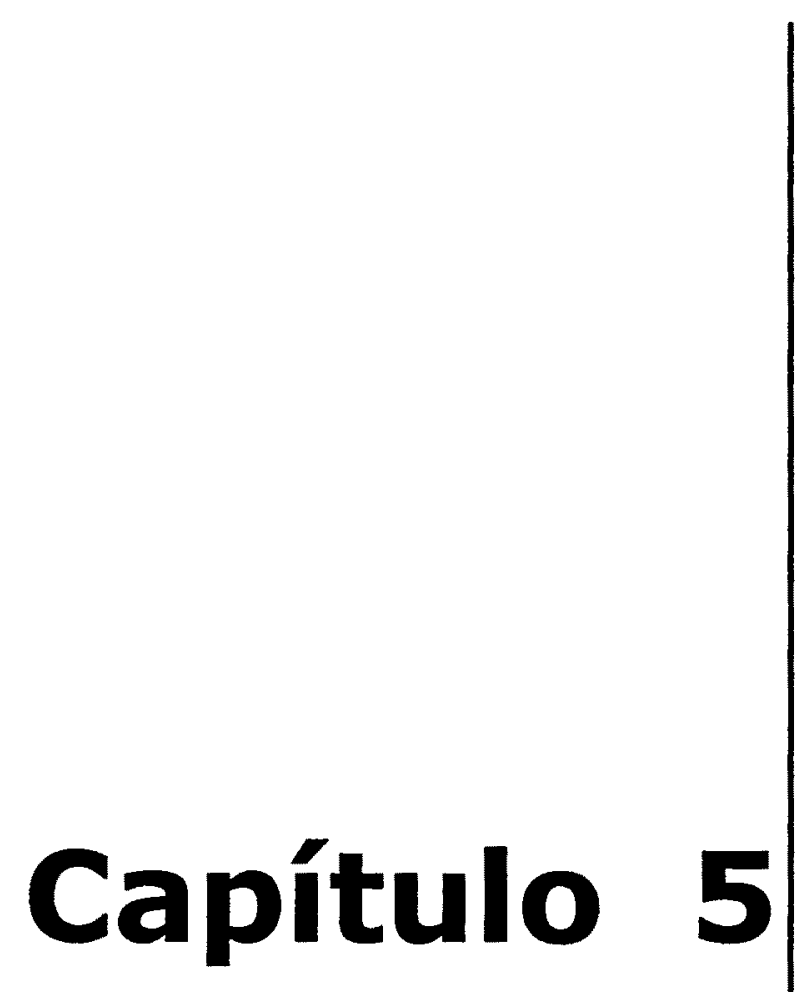

Bertioga: diagnóstico sócio-espacial e condições objetivas de vida 
Neste capítulo apresentar-se o cenário de estudo - Município de Bertioga. Como mencionado, optou-se, do ponto de vista metodológico, por combinar análises de dados quantitativos e de dados qualitativos. Nesta perspectiva, são apresentados, de forma sucinta, os dados secundários levantados junto a diversos órgãos e instituições públicas e privadas, que viabilizaram a construção de um perfil ou uma matriz sócio-espacial, constituída de elementos centrais das condições objetivas de vida da população residente no município. Como se verá adiante, procuramos mostrar ao longo do capítulo, que a questão da habitação e do desenvolvimento urbano, bem como das demais áreas que compõem o complexo das políticas urbanas, constituem problemas centrais no âmbito regional e municipal. Os dados sugerem, do ponto de vista de uma análise técnica, a necessidade de prioridade emergencial no campo das políticas públicas e governamentais destes setores, visando a melhoria das condições de saúde e da qualidade de vida da população - finalidade maior da Estratégia Município Saudável.

Com este diagnóstico sócio-espacial de Bertioga pretendemos demonstrar que para o município tornar-se saudável é fundamental a elaboração e implementação de uma política de habitação e desenvolvimento urbano integrada à implementação das outras políticas urbanas, de saneamento ambiental, transportes públicos e mobilidade urbana, entre outras.

\subsection{Características físico-ambientais}

Bertioga enquanto municipio emancipado em 1991, pertence à Região Metropolitana da Baixada Santista (Figura 2). Entre os nove municípios que constituem essa importante metrópole paulista, Bertioga possui a $2^{\mathrm{a}}$. maior área territorial com cerca de $482 \mathrm{Km} 2$. O maior da região é o município de Itanhaém com $581 \mathrm{~km} 2$. De qualquer forma, Bertioga possui cerca de 20,3\% da extensão territorial da Baixada Santista.

Como pode-se notar por meio da observação do Mapa 1, a região santista insere-se na Macro-Metrópole Paulista que contempla a Região Metropolitana de São Paulo, a Região Metropolitana de Campinas e a Região Metropolitana da Baixada Santista (Mapa 1). 
A cidade conta também com longos trechos de praias. São cerca de $36 \mathrm{Km}$ de praias oceânicas e amplas. O clima da região é fortemente influenciado pelos sistemas tropical e polar atlântico e por fatores geográficos locais: relevo, altitude e proximidade do mar. Na planície costeira a temperatura média anual é superior a $24^{\circ} \mathrm{C}$ e as chuvas anuais são muito freqüentes e variam entre 2000 a $3500 \mathrm{~mm}$. Na área serrana a temperatura média anual oscila entre $20^{\circ}$ e $24^{\circ} \mathrm{C}$ e a média das mínimas fica entre $8^{\circ} \mathrm{C}$ e $10^{\circ} \mathrm{C}$. As chuvas são mais intensas na encosta, ultrapassando os $4000 \mathrm{~mm}$ anuais como se verifica no médio vale do Itapanhaú em Bertioga. (Agem, 2003; Emplasa, 2003). 


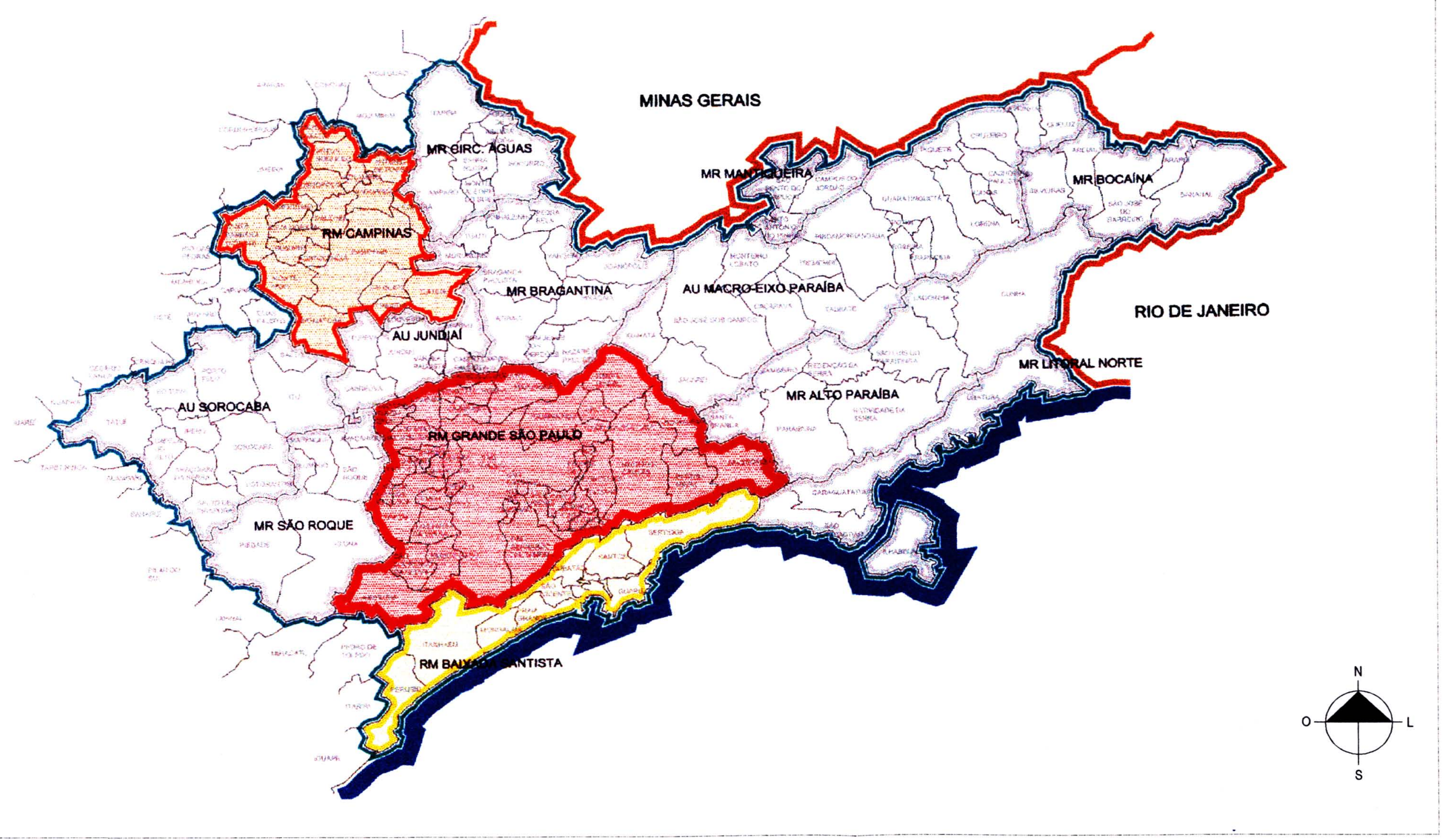

\section{LEGENDA}

AU - Aglomeração Urbana

MR - Microrregião

RM - Região Metropolitana
MAPA 1

COMPLEXO METROPOLITANO EXPANDIDO - CME

fonte: Agem - Agência Metropolitana da Baixada Santista Emplasa - Empresa Paulista de Planejamento Metropolitano SA 


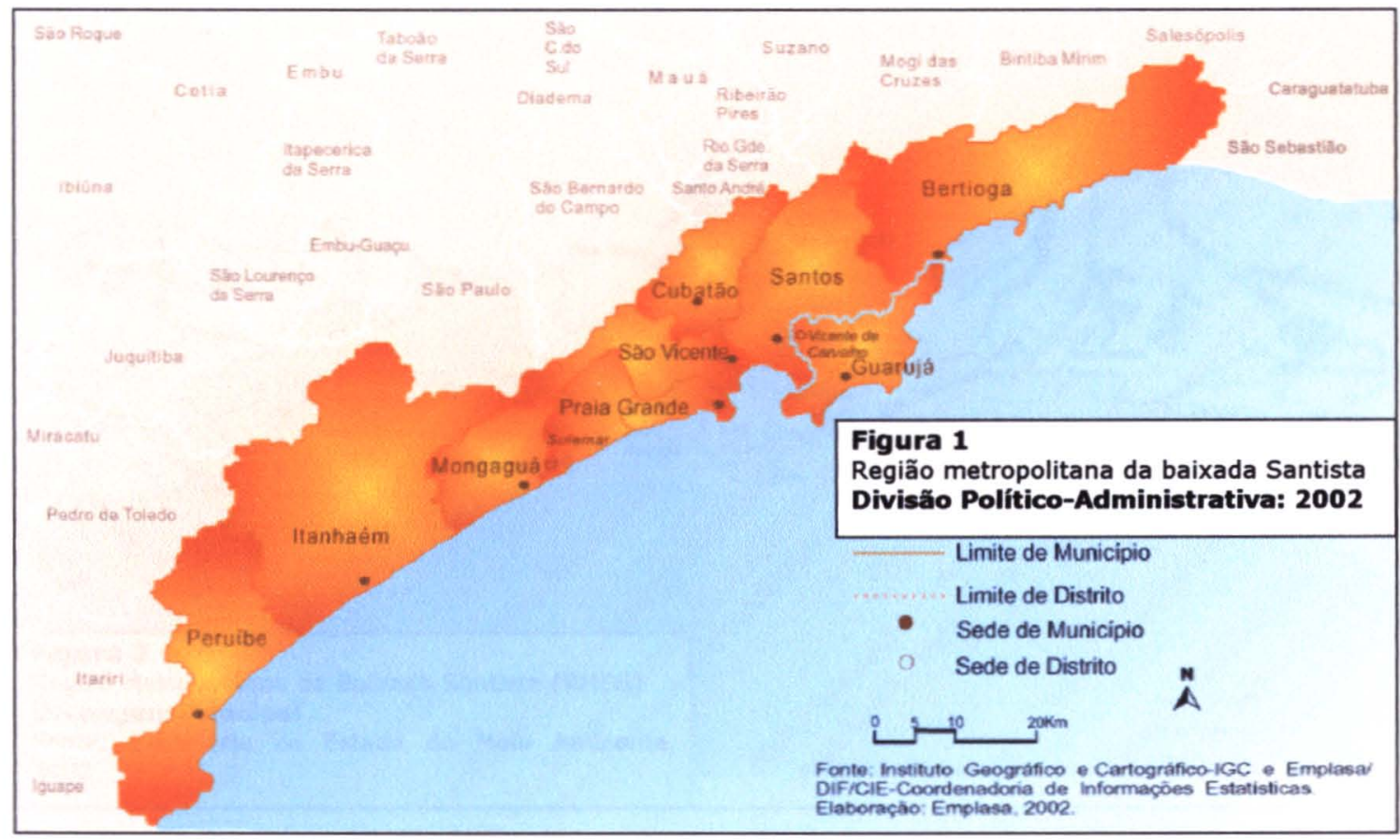

O sistema estuarino de Santos, compreende a Baía de Santos e todo um complexo emaranhado de rios (Piaçabuçu, Paranhos, Cascalho, Mariana, Cubatão, Perequê, Moji, da Onça, Quilombo, Jurubatuba, Diana, Santo Amaro, etc.) o canal de Bertioga, o dos Barreiros, de Piaçaguera, o Mar Pequeno (São Vicente), os largos da Pompeba, do Caneú e o de Santa Rita. Localizam-se no mesmo, as cidades de São Vicente, Santos, Cubatão, além do Porto de Santos e do Parque Industrial petroquímico-siderúrgico de Cubatão.

"Esta área, principalmente relativa aos municípios de São Vicente, Santos, Cubatão e Guarujá tem sido considerada como crítica em poluição hídrica, do ar e do solo, apresentando séria destruição de manguezais e inclusive agravos à saúde humana" (Tommasi, 1982). Ao lado deste sistema considerado poluído localiza-se um sistema dotado de qualidade remota, no caso a qualidade própria (limpa) das águas ainda preservadas de uma forma aparente, pois estudos quase inexistentes desta qualidade deveriam ser intensificados (Figura 2). 


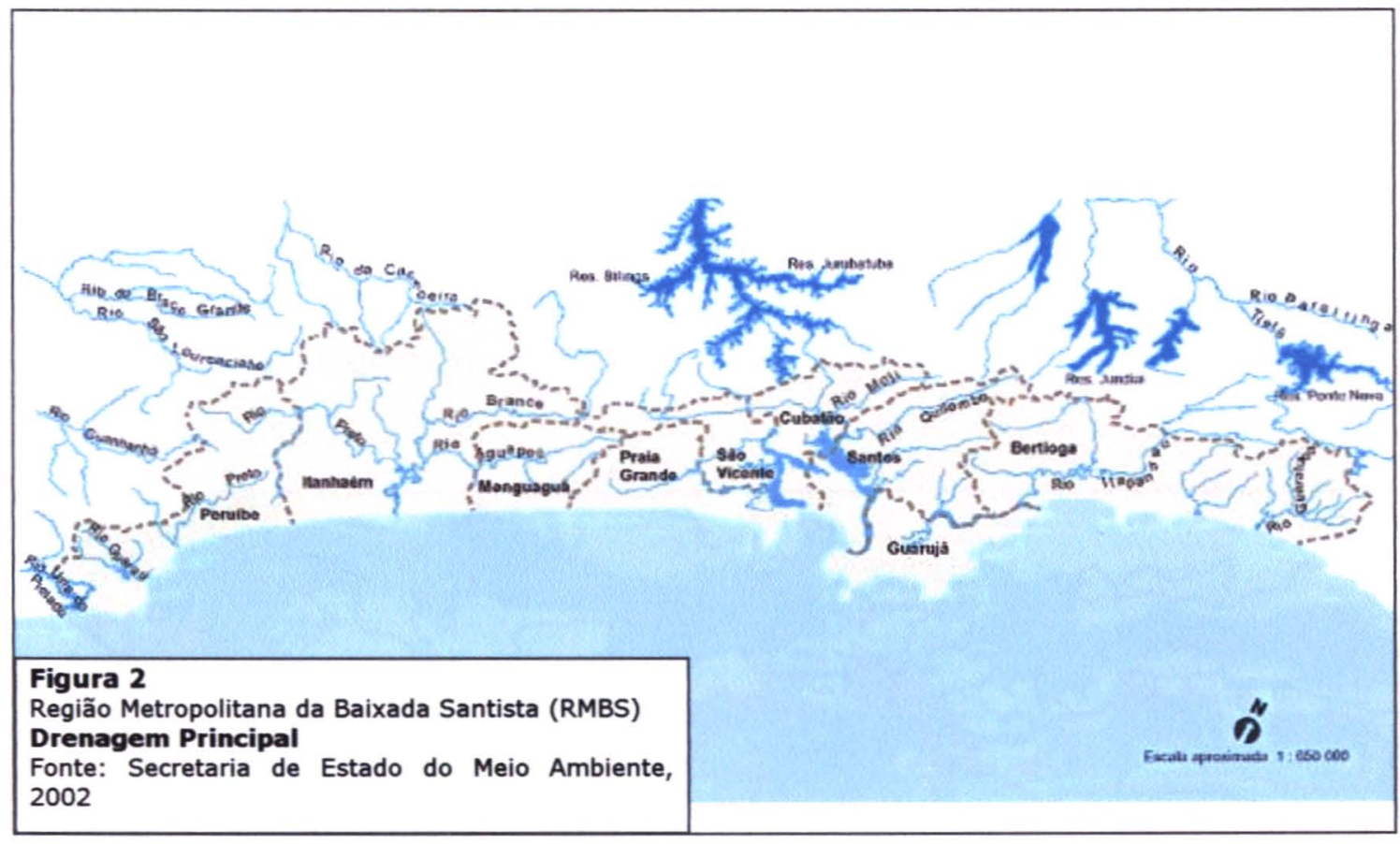

Diversos pesquisadores da Universidade de São Paulo (particularmente do Instituto Oceanográfico e do Instituto de Geociências), no âmbito da elaboração do Projeto Temático de Pesquisa do Projeto Bertioga Município Saudável em 2000, consideraram: "(...) há a necessidade de estudos para avaliação da qualidade das águas da região de Bertioga abrangendo desde a Ilha do Guará até a Ponta do Una, passando pelos corpos de água que banham as praias da Enseada, Praia de São Lourenço, Praia do Guaratuba até a Praia de Boracéia acrescidos de estudos no sistema hídrico fluvial formado por: Rio Itapanhaú, Canal de Bertioga, Rio Itaguaré e Rio Boracéia, que poderiam fornecer parâmetros para a avaliação real da qualidade do sistema, fornecendo subsídios para assegurar a manutenção da estabilidade do ecossistema hídrico." (Saraiva 2000 apud Westphal, 2000).

Os corpos d'água da região, particularmente de Bertioga representam um patrimônio inquestionável. Como mencionado, são inúmeras bacias hidrográficas com diversas quedas, cachoeiras, rios e estuários. No município, têm destaque as bacias do Rio Itapanhaú, do Rio Itaguaré e do Rio Guaratuba, que formam cachoeiras e quedas d'água na encosta da Serra do Mar e barras nas desembocaduras com o mar. Apesar da intensidade da 
ocupação nos últimos anos, e da conseqüente supressão de parte significativa de áreas verdes, existe ainda, uma vasta porção preservada e presente de mangue e de mata de restinga (Figura 3 ).

Do ponto de vista de proteção do ambiente natural, a região conta com apoio de diversas leis nos âmbitos federal, estadual e municipal, sendo que, provavelmente a mais conhecida de todas é a que institui o Parque Estadual da Serra do Mar (Figura 3).

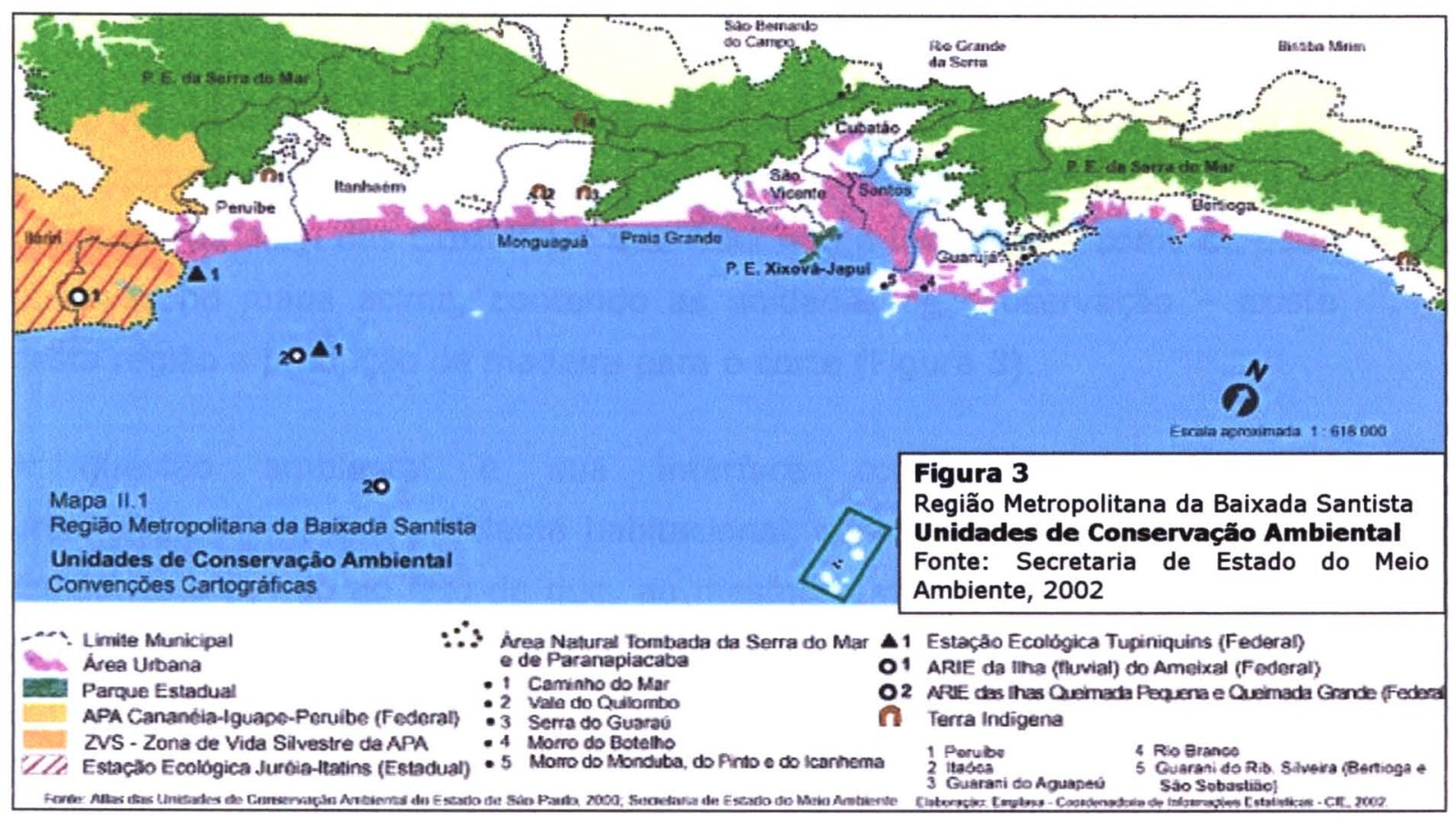

A Zona Costeira do Estado de São Paulo apresenta grande diversidade de ambientes naturais representados por extensos maciços e fragmentos preservados da Mata Atlântica e seus ecossistemas associados, entre eles: vegetação de restinga, extensos maguezais, praias, costões rochosos e ilhas aflorando. A Mata Atlântica e sua área de abrangência no litoral paulista foram reconhecidos como reserva da Biosfera pela UNESCO em 1992. (São Paulo, 2002).

A região da Mata Atlântica de Bertioga, além de constituir parte da Reserva da Biosfera e de ser protegida como Unidade de Conservação Ambiental do Parque Estadual da Serra do Mar é também protegida como Área Natural 
Tombada (Serras do Mar e de Paranapiacaba) e possui um trecho de Terra Indigena, a Reserva Guarani do Rio Silveiras. Além disso há uma área situada na planicie que é Tombada pelo Condephaat (Conselho do Departamento do Patrimônio Histórico do Estado de São Paulo).

Outras leis relevantes do ponto de vista ambiental são: o Código Florestal (Federal) e resoluções Conama - Conselho Nacional do Meio Ambiente, a Lei Municipal que cria e regulamenta o Condema - Conselho Municipal do Meio Ambiente criado em 9 de dezembro de 1994, as suas respectivas resoluções, o Código Ambiental Municipal.

O Parque Estadual da Serra do Mar abrange cerca de $46 \%$ do território do município de Bertioga. Há inclusive um trecho no alto da serra, próximo ao município de Mogi das Cruzes em que a lei não é incidente - como se pode observar no mapa acima, contendo as unidades de conservação - existe nesta região a produção de madeira para o corte (Figura 3 ).

A questão ambiental e sua interface com 0 desenvolvimento urbano/imobiliário e o problema habitacional, constituem sérios conflitos na região. Isto devido ao fato de que, ao mesmo tempo em que se reconhece um patrimônio ambiental de interesse público e difuso, o mesmo patrimônio agrega valor turístico, de uso e de mercado para toda a região. Isto exige uma série de cuidados e demandas por instrumentos jurídicos, planos, planejamento e gestão participativa. Neste sentido, o patrimônio ambiental é visto por muitos, como se descreverá melhor ao longo do trabalho, como uma fonte de benesses e riqueza, e por outros, como um entrave ao desenvolvimento mais livre do setor da construção civil e do mercado imobiliário voltado para a produção de segundas residências.

Além disso, há um conflito com a ocupação que a população de baixa renda, sem alternativas de adquirir a moradia via mercado imobiliário formal, e sem atendimento de moradia de interesse social por meio da produção pública financiada e subsidiada, procura para solucionar o seu problema por meio de expedientes como a autoconstrução improvisada e ilegal em áreas de risco e/ou ambientalmente sensiveis. 
Decorre daí que a especulação imobiliária, a presença de grileiros, a incapacidade de atendimento habitacional para a população de baixa renda, os assentamentos irregulares constituem desafios enormes para a cidade.

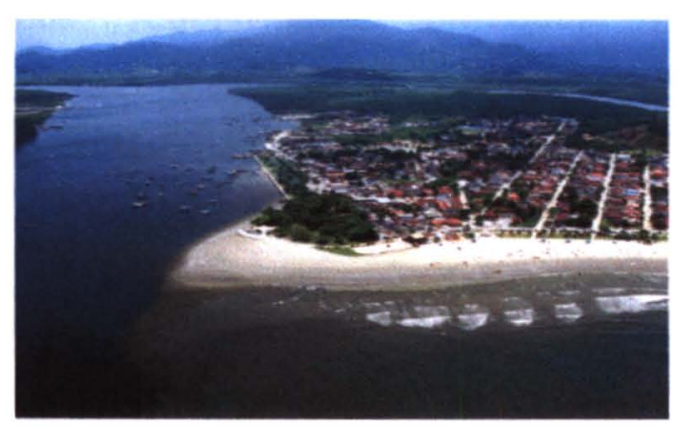

\section{FOTOGRAFIA 1}

Vista sobre o Canal de Bertioga no trecho DE ENCONTRO COM O MAR

Fonte: Prefeitura do Município de Bertioga, 2002

Um dos temas mais debatidos localmente refere-se à importância do desenvolvimento urbano imobiliário como forma estratégica de desenvolvimento econômico por meio das obras que geram emprego no setor da construção civil principalmente - posição defendida, por exemplo, por integrantes de algumas Associações de Moradores de Loteamentos e Condomínios, membros da Associação de Engenheiros, Arquitetos e Agrônomos de Bertioga e alguns técnicos da prefeitura.

Diversos moradores e técnicos da prefeitura alegam que o desenvolvimento de Bertioga tem sido estancado por causa do excessivo rigor das leis e lentidão dos trâmites de aprovação de novos empreendimentos, que necessitam conseqüentemente de executar a supressão de vegetação. Essa problemática diz respeito particularmente ao licenciamento ambiental exigido pelo Governo do Estado de São Paulo por meio do DEPRN - Departamento Estadual de Proteção dos Recursos Naturais da Secretaria de Estado do Meio Ambiente.

A prefeitura alega que o rigor dos órgãos estaduais tem impedido a solução de problemas básicos de infra-estrutura da cidade. Daí existe um conflito complicado, pois diversos moradores acusam a prefeitura de aprovar projetos - incluindo as providências relativas à supressão de vegetação - e 
quando o serviço está sendo realizado, membros da Policia Florestal ou outros de órgãos de fiscalização ambiental estadual autuam com flagrante. Há diversos casos em que os responsáveis pelas obras aprovadas pela prefeitura, foram encaminhados à delegacia para o registro de ocorrência das irregularidades cometidas. Há um conflito e uma discordância entre Prefeitura e Governo do Estado relativamente à interpretação e aplicação das leis ambientais. Para agravar o quadro, há os casos de denúncias de corrupção de fiscais e agentes representantes dos órgãos públicos. Os mais afetados são os moradores, os proprietários, os turistas e por fim o meio natural.

Durante Seminário do I Curso de Formação de Agentes Multiplicadores para Assentamentos Humanos Saudáveis, um técnico do segundo escalão da Secretaria de Meio Ambiente da prefeitura, quando questionado por um morador sobre manutenção do sistema viário, responde:

"(...) tudo isso está vinculado as duas palavras mágicas de Bertioga que fala "licenciamento ambiental". Estas duas palavras, na realidade envolvem todo contexto do desenvolvimento de Bertioga. Nenhuma obra, nenhuma atividade pode hoje ser dado efeito em Bertioga se ela não for ambientalmente licenciada. Então essa é a palavra, e se nós não tivermos licenciamento ambiental, Bertioga não desenvolve, se nós deixarmos licenciamento ambiental por entidades, por entes mesmo federativos, mas estranhos ao nosso municipio, nós corremos o risco de ter processos como temos, processos há mais de um ano, dois anos colocados em órgãos estaduais sem termos respostas de sim ou de não. Então essa questão da não implantação do sistema viário era exatamente isso porque nós não tínhamos autonomia para licenciar a abertura ou manutenção de uma rua, mesmo bairros antigos como Boracéia ou Balneário Mogiano, que já haviam sofrido a supressão de vegetação (...), eu falo supressão porque cada vez que eu ouço falar de desmatamento eu me arrepio. Agente não autoriza o desmatamento. Desmatamento é a forma irregular de se ocupar o solo, o que a gente autoriza é a supressão da vegetação que é uma atividade assistida e dentro da lei, apenas dentro da lei. Então nós tínhamos ruas que eram abertas, ruas que depois a vegetação, naturalmente havia a 
regeneração, o estágio secional que a gente fala e não podia ser implementado, a pessoa não podia ter acesso a seu lote porque não era permitido a Prefeitura abrir ou manter esta rua. Hoje nós estamos através da Secretaria do Meio Ambiente da prefeitura licenciando essas operações. Corremos o risco de ser questionados, mas nós temos a lei que está nos amparando, não é. Então essa administração (municipal) tem como compromisso o desenvolvimento de Bertioga e não vai deixar que as ruas deixem de ser abertas ou mantidas porque um órgão estadual não dava a licença. Hoje nós mesmos assumimos a responsabilidade de garantir essa, a continuidade desse serviço (...)".(representante da Secretaria Municipal de Meio Ambiente durante seminário do I Curso de Formação de Agentes Multiplicadores em outubro de 2001).

\subsection{Aspectos históricos de ocupação e demografia}

A ocupação de Bertioga, foi marcada por inúmeros fatos e eventos, e que poderia ser, teoricamente, sistematizada em diferentes períodos. Este trabalho, no entanto, concentrará esforços de análise do processo de ocupação e desenvolvimento no período pós-emancipação ao município de Santos, ou seja pós 1991, sem entretanto omitir alguns aspectos relacionados com a sua origem.

O município, assim como inúmeras regiões do litoral contém vestígios de ocupação pré-histórica. Há pelo menos três sambaquis publicamente identificados e considerados sítios de interesse arqueológico.

Apesar disto, constitui-se em uma das áreas do litoral paulista pouco ou nada conhecidas do ponto de vista arqueológico, embora a faixa costeira do Estado de São Paulo já se encontre contemplada por estudos de pesquisadores do Museu de Arqueologia e Etnologia da Universidade de São Paulo, do qual fazem parte os municipios de Cubatão, Santos, Peruíbe, Mongaguá, Ubatuba e Baixada Cananéia-Iguape (Uchôa, 2000).

Fontes de pesquisadores em arqueologia indicam que a faixa costeira do Brasil de Norte a Sul foi povoada não mais que há 10.000 anos; logo, num 
período pré-histórico, por grupos pescadores-coletores de moluscos, o conhecido "homem do Sambaqui". (Uchôa, 2000)

"A cronologia conhecida até o momento para o litoral do Estado de São Paulo não vai além de 5.000 anos para o seu povoamento; embora tenhamos que considerar o reduzido número de sítios datados para todo o litoral brasileiro, mas ainda assim podemos considerar através de uma cronologia relativa de 5.000 anos aproximadamente, para Bertioga" (Uchôa, 2000).

O nome Bertioga, segundo diversas fontes e historiadores é uma variação ou evolução de "buriquioca" que significa morada dos macacos bugios. (Ribeiro 2002; Lichti 2002)

Historicamente, Bertioga teve sua origem em meados do séc. XVI, alguns anos após o "descobrimento do Brasil" (ou a posse do Brasil pelos portugueses em 1500), ocasião em que Martin Afonso de Souza aqui chegou. Desde então, passou a contar com a construção de fortes para defesa de seus setores estratégicos, sendo o acesso ao seu canal, um deles. Contou também com a construção do Forte São Tiago e a paliçada Simão da Veiga, localizada na extremidade setentrional da Ilha de Santo Amaro que juntamente com o Forte defendiam a entrada do Canal de Bertioga. (Uchoa, 2000)

No período imediato à chegada dos europeus, os fatos mais registrados da história da cidade relacionam-se quase sempre à construção do Forte São João, como pode-se ver neste pequeno trecho:

"(...) a sua origem (Bertioga) está ligada à construção do Forte de São Tiago, ordenada por Martim Afonso de Souza em 1532. (...) Diversos ataques indígenas sofreu ao longo do tempo até que, em 1710, após sofrer novos reparos,ganhou uma capela e muda o nome para São João em 1765. Assumiu sua forma atual em 1817, com a intervenção do oficial José Felizardo. O forte centralizou o desenvolvimento de um povoado de pescadores e depois do balneário da Bertioga. Administrativamente, Bertioga foi distrito do município de Santos, com sede no povoado de Bertioga, a partir de 30 de novembro de 1944. Adquiriu autonomia política em 30 de dezembro de 1991" (Seade, 2003). 
Ou nesta interessante e não menos detalhada passagem:

"Em 1531, Martim Afonso de Souza aportou no lugar chamado Bertioga e foi para São Vicente, onde encontraria entre os índios, o aventureiro João Ramalho. No ano seguinte Martim Afonso constatou que os Tamoios e Tupinambás vinham de Iperoig a Maebique com suas velozes ubás de guerra, entravam no canal de Bertioga, que separa a ilha de Santo Amaro do continente, e iam atacar São Vicente. Martim Afonso traçou sua estratégia. Mandou João Ramalho chefiando um grupo de homens armados para Bertioga. Ali já existia algum sinal de civilização e o grupo deveria verificar possibilidades de construírem defesas (...). João Ramalho encontra Diogo de Braga, um dos primeiros colonizadores de Bertioga. Esse português sua mulher índia e cinco filhos mamelucos ajudam Ramalho a construir uma paliçada. Mas tempos depois os índios atacaram e arrasaram a paliçada. Foi uma carnificina, só sobraram oito. Em 1547, no mesmo local, os irmãos Braga, os sobreviventes e novos colonos levantaram o forte São Tiago, hoje conhecido como Forte São João ou Forte de Bertioga. (...) fica na boca do canal do mesmo nome. Dali os colonizadores podiam vigiar o alto-mar e o canal. Mas a bugrada aguerrida conseguia burlar a vigilância e passava pelo canal nas sombras da noite, rente à ilha de Santo Amaro. E atacava sempre São Vicente. Brás Cubas, obedecendo ordem do Rei, começou a contruir em 1550 o Forte São Felipe na Ilha de Santo Amaro, defronte do Forte de Bertioga. Assim inimigo algum passaria sem ser percebido. Nenhum português queria ficar no forte que ainda não oferecia segurança. Um alemão aventureiro de nome Hans Staden aceitou ficar no forte. Por nomeação do Governador Geral Tomé de Sousa, foi seu primeiro condestável. Nos anos de 1557 e 1560 as fortalezas de São Tiago (São João) e São Felipe (São Luis) foram ampliadas e reconstruídas" (Jornal Folha de São Paulo de 03/03/1967 apud Lichti 2002).

Após a vinda e instalação dos portugueses, diversas atividades econômicas extrativistas, agrícolas e pesqueiras tiveram lugar de destaque em muitos trechos do litoral. "Nos sítios que se espalhavam pelas várzeas e encostas ricas da baixada santista havia plantações de arroz, cacau, algodão, cana de açúcar, feijão e outros produtos, criação avícola e criação de gado 
constituíram economia apreciável, superior a qualquer outra da costa brasileira até algumas décadas atrás" (Rosa e Fierz, 1999).

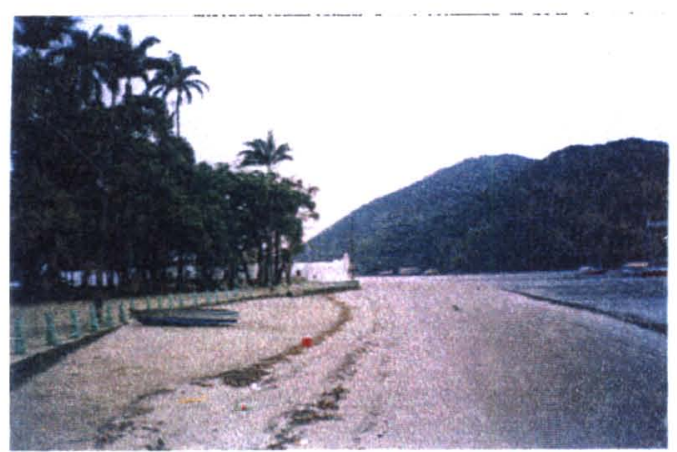

Fotografia 2 - Vista do Canal de Bertioga COM O FORTE AO FUNDO

Quase não seria necessário afirmar que ao longo do tempo os índios originais dessa região, donos ou usufrutuários genuínos da terra foram expulsos ou dizimados pelos brancos, em muitas batalhas e lutas não registradas pelos historiadores. Restam, no entanto, como verdadeiro patrimônio humano e cultural, algumas aldeias da etnia Guarani ao longo do litoral e em pontos do sudeste do Estado. Entre elas a Aldeia do Rio Silveiras, na divisa de Bertioga com São Sebastião - cujo povo tradicional - constitui exemplo vivo de resistência, beleza e uma provocação concreta para as possibilidades de vida e de comunidades mais saudáveis.

Nos séculos XVII e XVIII além de produtora de grande quantidade de aguardente, Bertioga foi fornecedora de azeite de baleia que viabilizava a iluminação pública para diversas localidades, entre as quais Santos, São Vicente e São Paulo e em algumas ocasiões São Sebastião e Rio de Janeiro. "Com a substituição do combustível para a iluminação e, antes mesmo disso, com a crescente dificuldade para a captura de cetáceos, Bertioga adormece esquecida no tempo (...) a fábrica deixa de produzir regularmente a partir de 1830". (Bertioga, 1998).

Assim, um lento processo de aumento populacional da cidade, que indicaria os primeiros sinais da sua futura urbanização iniciou-se apenas nos anos 
1940 com a implantação da primeira Colônia de Férias do SESC - Serviço Social do Comércio, mais precisamente em 1948. Sobre esses primórdios de atividades mais afetas ao fenômeno do núcleo urbano, registramos o relato de um morador e diretor da Acipeb - Associação Comercial, Industrial e Pesqueira de Bertioga - durante seminário no Curso de Difusão Cultural ${ }^{1}$ realizado no município: "(...) então nós temos uma história marcante, nós temos até que a primeira padaria foi inaugurada na década de trinta, ela funcionava numa casa há 4 quilômetros do centro, e o João de Andrade, um morador antigo foi o primeiro fornecedor de pão na cidade, foi 10 anos fornecendo pão pra toda Bertioga, depois na década de 40 aí já começou mesmo o primeiro comércio em si, e foi também uma padaria, uma vendinha. E hoje nos temos até o Sabino, a mercearia do Sabino que também vem dessa época bem antiga (...)" (membro da Diretoria da Associação Comercial em outubro/2001 em seminário durante o Curso de Formação).

Vale ressaltar também que a abertura da Rodovia Anchieta, em 1947, permitiu uma comunicação e acesso entre planalto e litoral sem precedentes. Com o tempo os velhos palacetes de Santos e São Vicente foram sendo removidos cedendo "lugar aos prédios na orla, dando uma nova feição ao espaço urbano com a orla toda verticalizada" (São Paulo, 2002). 0 adensamento populacional promovido por este processo ligado ao lazer $\mathrm{e}$ turismo atingiu também São Vicente, Praia Grande, Guarujá e outros municipios da região que passam "a adquirir uma configuração nitidamente urbana". (São Paulo, 2002).

\footnotetext{
${ }^{1}$ No segundo semestre de 2001 foi realizado o primeiro Curso de Difusão Cultural organizado pelos integrantes do Projeto Bertioga Município Saudável, em nome da Faculdade de Saúde Publica da USP gratuitamente para a formação de cerca de 50 lideranças locais, moradores, trabalhadores e membros de entidades da sociedade civil com cerca de 80 horas/aula. Contou com o apoio e patrocínio de 7 (sete) empresas e entidades locais além da OPAS - Organização Pan-Americana de Saúde e da Faculdade de Saúde Publica da USP.
} 


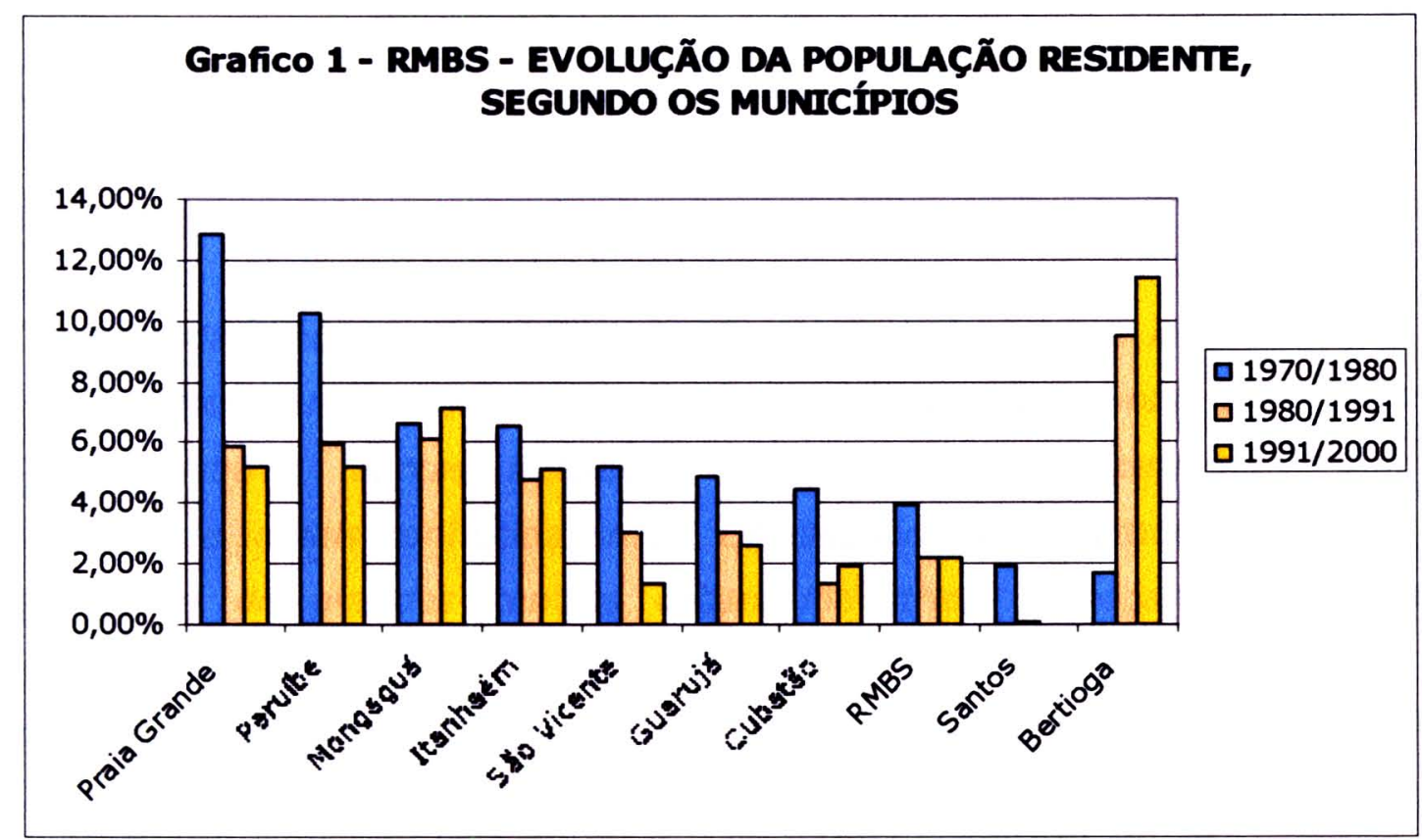

Fonte: Emplasa, 2002

Se em Bertioga a intensidade da ocupação urbana ocorreu somente nas duas últimas décadas (anos 1980 e 1990), o processo de povoamento urbano de outras cidades do litoral paulista, não constitui fenômeno tão recente. Diversos municípios do litoral sul do Estado experimentaram um intenso crescimento a partir dos anos 1960 e 1970, como pode-se verificar no Gráfico 1 acima, que apresenta as taxas médias de crescimento populacional das diferentes cidades da Região da Baixada Santista. Por meio do Gráfico nota-se que Bertioga atravessa nos anos 1990, por um crescimento populacional comparável ao de Praia Grande e Peruíbe nos anos 1970 (Gráfico 1).

\subsubsection{A busca por residências secundárias a partir das décadas de 1950 e 1960}

O estímulo ao processo de industrialização e do desenvolvimento de um modelo urbano-industrial, voltado para as necessidades produtivas do capital e para o consumo das camadas privilegiadas, bem como o aumento na taxa de motorização por transporte a pneus - viabilizado pelo vigor da indústria 
automobilística constituíram fatores que contribuíram para o incremento das viagens entre capital e litoral, além de promover a reconfiguração das médias e grandes cidades brasileiras da época, particularmente no que diz respeito ao espraiamento das periferias.

"A partir das décadas de 1950 e 1960, a grande arrancada industrial que 0 Brasil experimenta, incluindo a nascente industria automobilistica, trouxe consigo outras marcas indeléveis de destruição da paisagem, numa intensidade jamais conhecida antes. Os cidadãos dos segmentos médios $e$ superiores de grandes centros urbano-industriais começaram a buscar residências secundárias, constituindo-se em mercado consumidor de casas e apartamentos no litoral e no interior (...). Isso provocou intensa especulação imobiliária (...) sem padrões mínimos para com a paisagem e com a arquitetura" (Yázigi, 1998 apud Siqueira, 2002). O referido autor enfatiza ainda que o Estado brasileiro em suas várias instâncias, teve papel importante no estímulo à urbanização ligada ao lazer, que se acentua a partir de 1970.

\subsubsection{Movimento emancipatório}

O fato novo do crescimento intenso que viria a ocorrer em Bertioga nos anos 1980, somar-se-ia à outros fatores, como a descentralização no Estado Brasileiro e o movimento emancipatório de inúmeros municipios, criando as condições necessárias para que, também na Baixada Santista, mais uma cidade se tornasse autônoma do ponto de vista administrativo. Nas atividades iniciais do Projeto Bertioga Município Saudável, pudemos verificar que diversos moradores faziam referência ao momento de maior união das entidades, associações de bairro e lideranças locais jamais visto - o movimento emancipatório de Bertioga.

"A luta pela emancipação de Bertioga, já antiga, teve inicio em 1958, quando pouco mais de uma centena de eleitores foram às urnas e disseram NÃO à autonomia. Desta vez porém a situação é completamente diferente. Ao andar pelas ruas podem-se vislumbrar faixas, adesivo e camisetas, todas 
com mensagens alusivas ao SIM no dia 19 de maio de 1991. Os emancipacionistas esclareceram as dúvidas a respeito da capacidade de Bertioga se autogerir. O Presidente da Frente Distrital Paulista de Emancipação, Pérsio Dias Pinto, citou estudos realizados pelo - CEPAM (Centro de Estudos e Pesquisas Municipais - Fundação Prefeito Faria Lima) que atestam a possibilidade de o distrito conseguir a autonomia: Bertioga arrecadava mais que municipios como Ilha Bela, Iguape e Caraguatatuba e, após a separação, as receitas poderiam crescer em torno de $50 \%$ devido à transferência de tributos federais e estaduais a que teria direito como municipio autônomo. Com população fixa de 20 mil habitantes, que na temporada de verão subia para 200 mil, Bertioga estava entre os 250 municípios mais populosos do Estado de São Paulo (...) a população de Bertioga estava ressentida com a então prefeita do Município-Mãe (...) que em 1989, conseguiu, através de mandato de segurança, impedir a realização de um plebiscito. O temor foi afastado definitivamente quando no dia 09 de maio o Supremo Tribunal Federal negou o pedido de liminar requerido pelo então procurador (...) No dia 19 de maio de 1991, finalmente, um domingo ensolarado que ficaria na história de Bertioga, a população compareceu às urnas e conquistou o direito de transformar Bertioga em Município. A maioria esmagadora disse SIM à tese emancipacionista. Das 3.925 pessoas que votaram 3.698 foram favoráveis à independência e apenas 179 disseram não, 21 votaram em branco e 27 anularam a cédula (...)" (Lichti 2002).

Após a emancipação, a tendência de crescimento populacional e de ocupação urbana (desordenada) do território se acentuou como mostraremos a seguir.

\subsubsection{Intensificação do processo de urbanização nos anos 1980}

Assim, Bertioga, seja pelo relativo isolamento do ponto de vista do acesso rodoviário e ferroviário, seja por ter sido ao longo da segunda metade do século XX, distrito de Santos, experimentou só muito recentemente - nos anos 1980 - o processo de urbanização mais intenso. 
A inauguração das Rodovias Mogi-Bertioga em 1982 e Rio-Santos em 1985 permitiram uma comunicação muito mais rápida e fácil com a capital do Estado. Os investimentos no setor imobiliário de casas de segunda residência viabilizados principalmente por meio dos loteamentos dotados de sistemas de segurança ou fechados e condomínios que vendem "vista para o mar, natureza e segurança" tiveram um papel determinante em impulsionar 0 crescimento dos setores econômicos ligados ao comércio e serviços.

Um exemplo paradigmático deste tipo de empreendimento é o Riviera de São Lourenço. Trata-se de um loteamento, ou como os empreendedores dizem um "modelo de urbanização" de uma área de 9 milhões de metros quadrados cujas obras se iniciaram em 1979. "Atualmente a Riviera apresenta cerca de $50 \%$ de sua área ocupada. "São mais de 2.000 casas construídas e habitadas, 330 casas em construção, 120 edificios entre 6 e 10 pavimentos habitados e em construção, um segmento do Riviera Shopping em funcionamento com 50 lojas, escolas, consultórios médico e dentário, saneamento básico com rede de coleta e Estação de Tratamento de Esgotos, adução, tratamento e abastecimento próprio de água e coleta seletiva de residuos sólidos. $O$ plano urbanístico foi organizado em três zonas residencial, turística e mista - projetadas para abrigar no final de sua implantação uma população de 65 mil pessoas." (Lichti 2002).

Alguns autores realizam análises críticas do fenômeno do desenvolvimento e exploração atual do turismo em diversas cidades no Brasil e em outros países. Segundo esses estudos há uma tendência mais ou menos geral por padronizar localidades completamente projetadas para receber determinados tipos de turistas e veranistas (de rendas média e alta). Assim, nota-se uma repetição de paisagens de lugares turísticos (sempre com coqueiros, palmeiras e alguns tipos de paisagismo comumente utilizados) e dos tipos de serviços (como lojas, shoppings e restaurantes) encontrados. Isto acaba permitindo que o turista encontre no local de férias, praticamente tudo o que encontra em São Paulo, por exemplo (quase nada contribuindo para acrescentar novos elementos ao seu repertório pessoal e cultural). Ao mesmo tempo os moradores originais ou migrantes já integrados com nessas cidades não identificam relações desses locais com a cidade "normal" e com 
a sua cultura. Neste sentido poderia se dizer que alguns loteamentos, condomínios, hotéis ou "resorts" estão mais perto de São Paulo do que do núcleo urbano da cidade a que pertencem. No nosso caso, há moradores de Bertioga participantes do Projeto Bertioga Município Saudável que concordam que a Riviera de São Lourenço está mais próxima de São Paulo do que do centro de Bertioga. Isto em função da característica que Riviera tem de "quintal" de São Paulo e também pelo fato de diversos turistas proprietário de casas de apartamentos no loteamento, realizarem o trajeto São Paulo-Riviera de helicóptero.

De maneira geral, tanto para os turistas de classes sociais mais elevadas, quanto para os das classes mais populares, pode-se verificar que o cenário natural e as praias cumprem papel muito importante como fator de atração de milhares de habitantes da região metropolitana de São Paulo e interior do Estado, ávidos por desfrutar momentos de lazer, entretenimento e contemplação que as belezas locais podem propiciar.

Deste modo, proximidade à capital, facilidade e rapidez de acesso, belezas naturais - incluindo extraordinária diversidade biológica, praias limpas, livres da poluição que atinge boa parte do litoral sul - e mercado imobiliário ávido aos rendimentos com empreendimentos de casas de segunda residência, foram os ingredientes suficientes para que Bertioga fosse um dos municípios com maior crescimento populacional do Estado de São Paulo nos anos 1990.

Nota-se pelo Gráfico 2, a seguir, produzido com dados da Cetesb Companhia de Tecnologia e Saneamento Ambiental com a classificação semanal de qualidade das praias em 1999, que Bertioga encontrava-se ainda recentemente, ao menos por esse quesito, em condições favoráveis de receber os turistas que buscam o litoral (Gráfico 2). 


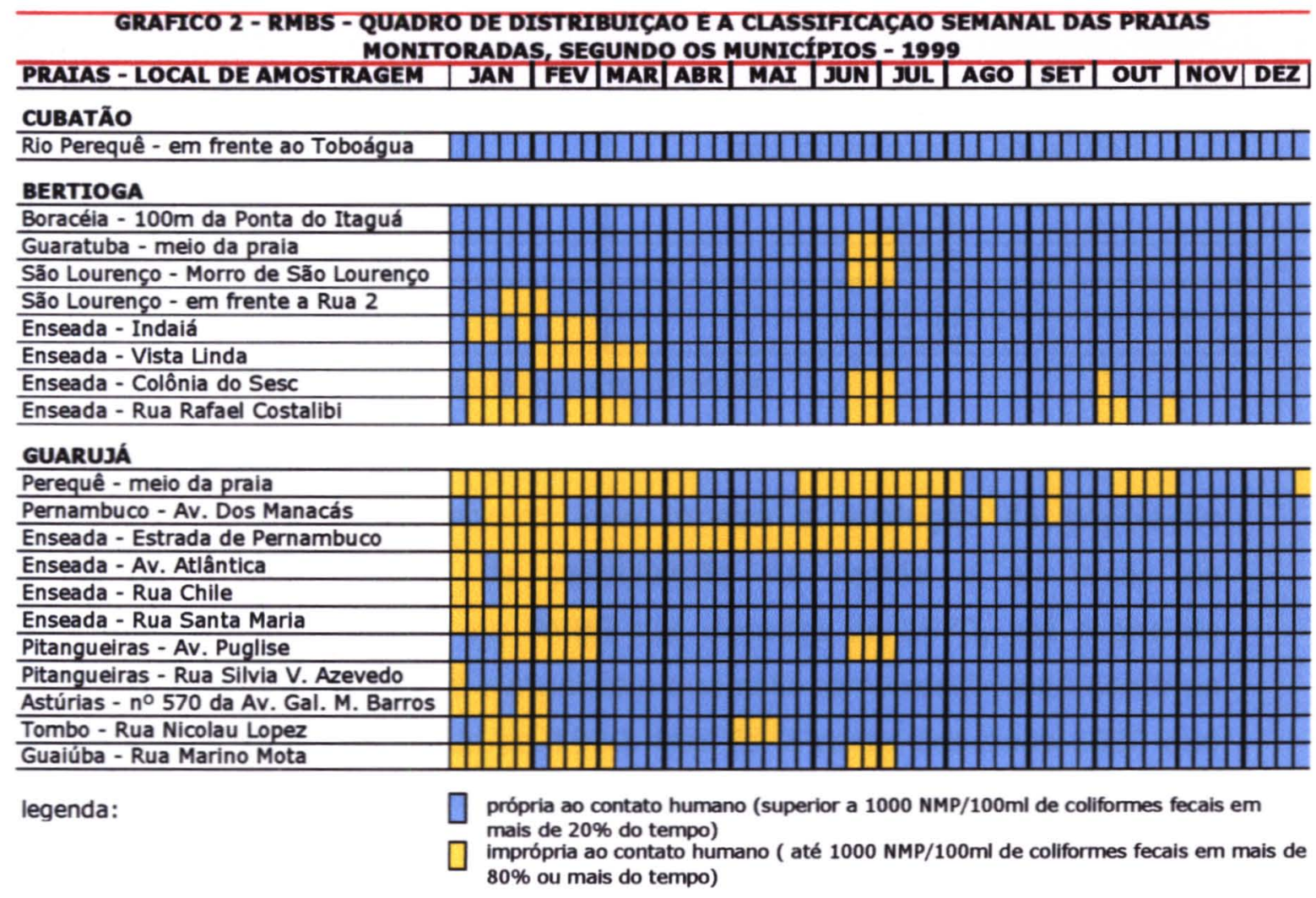

fonte: Emplasa, 2002

(1) os pontos de amostragem situados junto às ruas e avenidas relacionadas estão sempre em frente aos referidos logradouros

\subsubsection{O Crescimento populacional na década de 1990: população residente}

De acordo com os dados do Censo do IBGE - Instituto Brasileiro de Geografia e Estatística de 1991 e de 2000, Bertioga cresceu com taxa média anual de $11,36 \%$. São Sebastião que tem passado por um crescimento intenso também, atingiu taxas de $6,26 \%$ ao ano no mesmo período. Guarujá, que tem crescimento mais estabilizado, obteve taxa de $2,65 \%$. A média da Região Metropolitana da Baixada Santista ${ }^{2}$ foi de $2,17 \%$ e do Estado de São Paulo 1,82\% (Tabela 2).

\footnotetext{
${ }^{2}$ Compõem atualmente a Região Metropolitana da Baixada Santista nove municípios: Santos, São Vicente, Cubatão, Praia Grande, Mongaguá, Itanhaém, Peruíbe, Guarujá e Bertioga.
} 
Tabela 2 - Taxa Geométrica de Crescimento Populacional (1991/2000)

\begin{tabular}{l|c}
\hline \multicolumn{1}{c|}{ localidade } & taxa crescimento anual (\%) \\
\hline Bertioga & 11,36 \\
\hline São Sebastião & 6,26 \\
\hline Guarujá & 2,65 \\
\hline Região da Baixada Santista & 2,17 \\
\hline Estado de São Paulo & 1,82 \\
\hline
\end{tabular}

Fonte: Fundação SEADE (Site www.seade.sp.gov.br, 07/06/03)

Observando a Tabela 3, abaixo, que mostra a evolução da população residente, a porcentagem de participação na região e as taxas de crescimento dos municípios da RMBS nas décadas de 1970, até o ano de 2000, nota-se que Bertioga é o município que está com crescimento contínuo de população desde a década de 1970. Mas foi a partir dos anos 1980 que iniciou uma fase de crescimento mais intenso, próximo a $10 \%$ ao ano.

Já os municípios de Praia Grande e Peruíbe tiveram crescimento intenso nos anos 1970 e Mongaguá, assim como Bertioga apresenta uma tendência constante de crescimento ao longo das três últimas décadas.

\begin{tabular}{|c|c|c|c|c|c|c|c|c|c|c|c|c|c|c|}
\hline \multirow{2}{*}{ municípios } & \multicolumn{2}{|c|}{1970} & \multicolumn{2}{|c|}{1980} & \multicolumn{2}{|c|}{1991} & \multicolumn{2}{|c|}{1996} & \multicolumn{2}{|c|}{2000} & \multicolumn{4}{|c|}{ TGCA (\%) } \\
\hline & $n^{0}$ abs. & $\%$ & $n^{0}$ abs. & $\%$ & $\mathrm{n}^{\circ}$ abs. & $\%$ & $n^{0}$ abs. & $\%$ & $\mathrm{n}^{0}$ abs. & $\%$ & $1970 / 80$ & $1980 / 91$ & $1991 / 96$ & $1996 / 00$ \\
\hline Bertioga & 3.573 & 0,5 & 4233 & 0,4 & 11473 & 0,9 & 17002 & 1,3 & 30039 & 2 & 2 & 9,49 & 8,33 & 15 \\
\hline Cubatão & 50.906 & 7,8 & 78630 & 8,2 & 91136 & 7,5 & 97257 & 7,4 & 108309 & 7,3 & 4 & 1,35 & 1,33 & 3 \\
\hline Guarujá & 94.021 & 14,4 & 151127 & 15,7 & 210207 & 17,2 & 226365 & 17,3 & 264812 & 17,9 & 5 & 3,05 & 1,52 & 4 \\
\hline Itanhaém & 14.515 & 2,2 & 27464 & 2,9 & 46074 & 3,8 & 58017 & 4,4 & 71995 & 4,9 & 7 & 4,82 & 4,8 & 6 \\
\hline Mongaguá & 5.214 & 0,8 & 9927 & 1 & 19026 & 1,6 & 27065 & 2,1 & 35098 & 2,4 & 7 & 6,09 & 7,43 & 7 \\
\hline Peruíbe & 6.966 & 1,1 & 18407 & 1,9 & 32773 & 2,7 & 41398 & 3,2 & 51451 & 3,5 & 10 & 5,98 & 4,87 & 6 \\
\hline Praia Grande & 19.704 & 3 & 66011 & 6,9 & 123492 & 10,1 & 150388 & 11,5 & 191811 & 13,1 & 13 & 5,88 & 4,09 & 6 \\
\hline Santos & 342.057 & 52,3 & 412448 & 42,5 & 417450 & 34,2 & 412243 & 31,5 & 417983 & 28,3 & 2 & 0,11 & $-0,25$ & 0 \\
\hline São Vicente & 116.485 & 17,8 & 193002 & 20,1 & 268618 & 22 & 279528 & 21,4 & 303551 & 20,6 & 5 & 3,05 & 0,81 & 2 \\
\hline Total & 653.441 & 100 & 961.249 & 100 & 1220249 & 100 & 1.309 .263 & 100 & 1476820 & 100 & 4 & 2,19 & 1,44 & 3 \\
\hline
\end{tabular}

fonte: Emplasa, 2000

Nota-se também que Bertioga, a partir dos anos 1980 vem aumentando a sua participação proporcional na população da Região. Em 1980 participava com 0,4\% da população da região e em 2000 participava com 2,0\% da população da mesma região. Este fenômeno verifica-se também para Guarujá, Itanhaém, Mongaguá, Peruíbe e Praia Grande (Tabela 3). 
O município de Santos, no entanto, vem perdendo em participação. Em 1970 detinha 53,2\% da população da região e em 2000 possuía 28,3\% do total regional. Note-se que ocorreu um crescimento maior nos municípios mais periféricos da RMBS (Tabela 3).

Segundo os dados do PNAD - Pesquisa Nacional de Amostragem Domiciliar realizada pelo IBGE em 1996, no período de 1996 à 2000 a população da cidade de Bertioga cresceu com taxas de cerca de $16 \%$ ao ano, o segundo maior crescimento populacional no período no Estado de São Paulo. 0 primeiro foi Ilha Comprida, outra cidade litorânea paulista.

\begin{tabular}{l|rr|r}
\hline \multicolumn{4}{c}{ Tabela 4 - População Residente permanente - 2002} \\
\hline localidade & população & $\begin{array}{c}\text { Porcentagem em } \\
\text { Relação ao Estado } \\
\text { de_SP (\%) }\end{array}$ & taxa de urbanização (\%) \\
\hline Bertioga & 34.969 & $0,09 \%$ & $97,13 \%$ \\
\hline São Sebastião & 63.525 & $0,17 \%$ & $98,99 \%$ \\
\hline Guarujá & 276.648 & $0,73 \%$ & $99,97 \%$ \\
\hline Região da Baixada Santista & 1.531 .461 & $4,02 \%$ & $99,59 \%$ \\
\hline Estado de São Paulo & 38.123 .695 & $100,00 \%$ & $93,41 \%$ \\
\hline
\end{tabular}

Fonte: Fundação SEADE (Site www.seade.sp.gov.br, 07/06/03)

O Censo realizado em 2000 mostrou uma população fixa de 30.619 habitantes. Estima-se para 2002, cerca de 34.969 habitantes (Seade, 2003), ou seja, 2,28\% da população da Região Metropolitana da Baixada Santista e cerca de $0,1 \%$ da população total do Estado de São Paulo. São Sebastião conta com 63.525 habitantes e Guarujá com 276.648 habitantes em 2002. Conforme mostra a Tabela 4, como toda a região litorânea, Bertioga, no século XXI já pode ser considerada uma cidade urbanizada, com cerca de 97,13 \% da população vivendo na área urbana (Tabela 4). 


\subsubsection{Crescimento populacional vegetativo e migratório}

Observando a Tabela 5 nota-se que o aumento da população em Bertioga teve contribuição tanto do número de nascimentos, quanto do número de migrantes, mas proporcionalmente o crescimento se deveu muito mais à migração que ao crescimento vegetativo. Entre 1993 e 2000 a taxa de natalidade oscilou positivamente entre 21,9 a 23,4 por mil nascidos vivos.

Embora o número de migrantes seja grande, ele não tem aumentado neste período oscilando pouco em torno de 2.000 pessoas ao ano, uma média de 167 pessoas que chegam no município por mês (Tabela 5).

Pelo fato de o número de migrantes manter-se relativamente estável e a população total aumentar, a taxa de migração tem diminuído potencialmente ano após ano, perfazendo cerca de 66 por mil habitantes em 2000 (Tabela 5).

TABELA 5 - Bertioga: Evolução de alguns dados demográficos entre 1993 E 2000

\begin{tabular}{c|c|c|c|c|c|c|c|c}
\hline & população & nascimento & mortes & $\begin{array}{c}\text { número de } \\
\text { migrantes }\end{array}$ & $\begin{array}{c}\text { taxa de } \\
\text { crescimento }\end{array}$ & $\begin{array}{c}\text { taxa de } \\
\text { natalidade }\end{array}$ & $\begin{array}{c}\text { taxa de } \\
\text { mortalidade }\end{array}$ & $\begin{array}{c}\text { taxa de } \\
\text { migração }\end{array}$ \\
\hline 1993 & 15,137 & 330 & 102 & & & 21,8 & 6,7 & \\
\hline 1994 & 17,193 & 365 & 102 & 2,072 & 135,8 & 21,2 & 5,9 & 121 \\
\hline 1995 & 19,26 & 379 & 129 & 2,066 & 120,2 & 19,7 & 6,7 & 107 \\
\hline 1996 & 21,351 & 489 & 177 & 2,006 & 108,6 & 22,9 & 8,3 & 94 \\
\hline 1997 & 23,565 & 631 & 135 & 1,948 & 103,7 & 26,8 & 5,7 & 83 \\
\hline 1998 & 25,882 & 675 & 158 & 2,028 & 98,3 & 26,1 & 6,1 & 78 \\
\hline 1999 & 28,248 & 749 & 154 & 1,987 & 91,4 & 26,5 & 5,5 & 70 \\
\hline 2000 & 30,619 & 715 & 170 & 2,025 & 83,9 & 23,4 & 5,6 & 66 \\
\hline
\end{tabular}

fonte: Fundação Seade. Sistema de Estatísticas Vitais

Obs. As taxas estão expressas em valores por mil habitantes

Nota-se que a taxa de mortalidade vem decrescendo também, apresentando média para o período 1993-2000 de 6,3 por mil habitantes (Tabela 5).

\section{mortalidade infantil}

A mortalidade infantil é um dos indicadores que tem evoluído positivamente no Brasil nas últimas décadas, fruto de melhorias sociais, dos serviços sanitários e de infra-estrutura ocorridas ao longo de todo o século XX. 
Entretanto nas cidades onde a cobertura por saneamento básico é deficiente, perduram taxas elevadas.

Tabela 6 - Evolução da taxa de mortalidade infantil por municípios (RMBS): 1993/ 2002 (6́bitos menores de 1 ano por mil nascidos vivos)

\begin{tabular}{l|c|c|c|c|c|c|c|c|c|c}
\hline \multicolumn{1}{c|}{ municípios } & 1993 & 1994 & 1995 & 1996 & 1997 & 1998 & 1999 & 2000 & $\mathbf{2 0 0 1}$ & 2002 \\
\hline Bertioga & $\mathbf{3 9 , 3 9}$ & $\mathbf{3 2 , 8 8}$ & $\mathbf{3 4 , 3 0}$ & $\mathbf{3 8 , 8 5}$ & $\mathbf{4 1 , 2 0}$ & $\mathbf{2 6 , 6 7}$ & $\mathbf{1 4 , 6 9}$ & $\mathbf{1 3 , 9 9}$ & $\mathbf{1 6 , 1 1}$ & $\mathbf{2 3 , 1 7}$ \\
\hline Cubatão & 27,67 & 24,30 & 26,67 & 21,32 & 19,84 & 22,43 & 18,75 & 22,54 & 17,40 & 23,21 \\
\hline Guarujá & 31,71 & 30,77 & 35,94 & 31,06 & 26,21 & 20,93 & 18,27 & 21,88 & 17,41 & 22,58 \\
\hline Itanhaém & 37,48 & 37,29 & 37,58 & 29,30 & 29,77 & 30,54 & 28,33 & 21,92 & 23,05 & 21,72 \\
\hline Mongaguá & 58,68 & 42,99 & 75,47 & 20,41 & 35,52 & 27,21 & 29,01 & 33,68 & 26,91 & 26,98 \\
\hline Peruíbe & 25,03 & 41,27 & 38,79 & 29,79 & 26,98 & 23,94 & 20,56 & 26,59 & $\mathbf{2 4 , 4 3}$ & 15,37 \\
\hline Praia Grande & 39,06 & 33,52 & 41,04 & 36,91 & 27,67 & 26,14 & 24,97 & 25,06 & 25,49 & 22,78 \\
\hline Santos & 27,17 & 26,13 & 26,14 & 25,53 & 21,52 & 17,06 & 18,89 & 15,14 & 16,92 & 17,98 \\
\hline São Vicente & 30,28 & 27,94 & 33,75 & 26,76 & 30,20 & 22,39 & 19,30 & 26,64 & 26,22 & 23,48 \\
\hline RMBS & 31,28 & 29,63 & 33,69 & 28,43 & 26,24 & 22,05 & 20,32 & 21,64 & 21,05 & 21,61 \\
\hline
\end{tabular}

Fonte: Fundação Seade (www.seade.sp.gov.br, Ago / 2003)

Bertioga figurava entre 1993 e 1997 com taxas entre 30 e 42 mortes por mil nascidos vivos, um dos indicadores mais elevados da região. Nota-se que entre 1997 e 2000 houve uma queda significativa deste indicador. Em 2001 e 2002 ele voltou a crescer novamente, oscilando neste último ano, um pouco acima da média da RMBS que é 21,61 mortes por mil nascidos vivos. (Tabela 6 e Gráfico 3).

Estes dados da mortalidade infantil muito possivelmente estão relacionaodos às precárias condições de saneamento básico em diversos bairros (particularmente as favelas) de Bertioga, como se verá adiante neste capítulo.

Os dados da Fundação Seade indicam também que de 1993 a 1995 e de 1998 a 2002 o município de Mongaguá é o que tem apresentado os indicadores mais comprometidos da região, sendo que no primeiro período, as taxas foram as mais elevadas e corresponderam a 58,68 (1993), 42,99 (1994) e 75,47 (1995) por mil habitantes. Em 2002, Mongaguá apresentava 26,98 mortos por mil nascidos vivos. Nos anos de 1996 e 1997 Bertioga apresentou também os piores indicadores da região, 38,85 e 41,20 mortes por mil nascidos vivos, respectivamente, superando Mongaguá (Tabela 6). 
Observando o Gráfico 3, pode-se notar mais claramente o comportamento do indicador de mortalidade infantil de Bertioga comparado ao indicador médio da RMBS. Nota-se que o município vem obtendo valores acima da média da região, com exceção dos anos 1999, 2000 e 2001 (Gráfico 3).

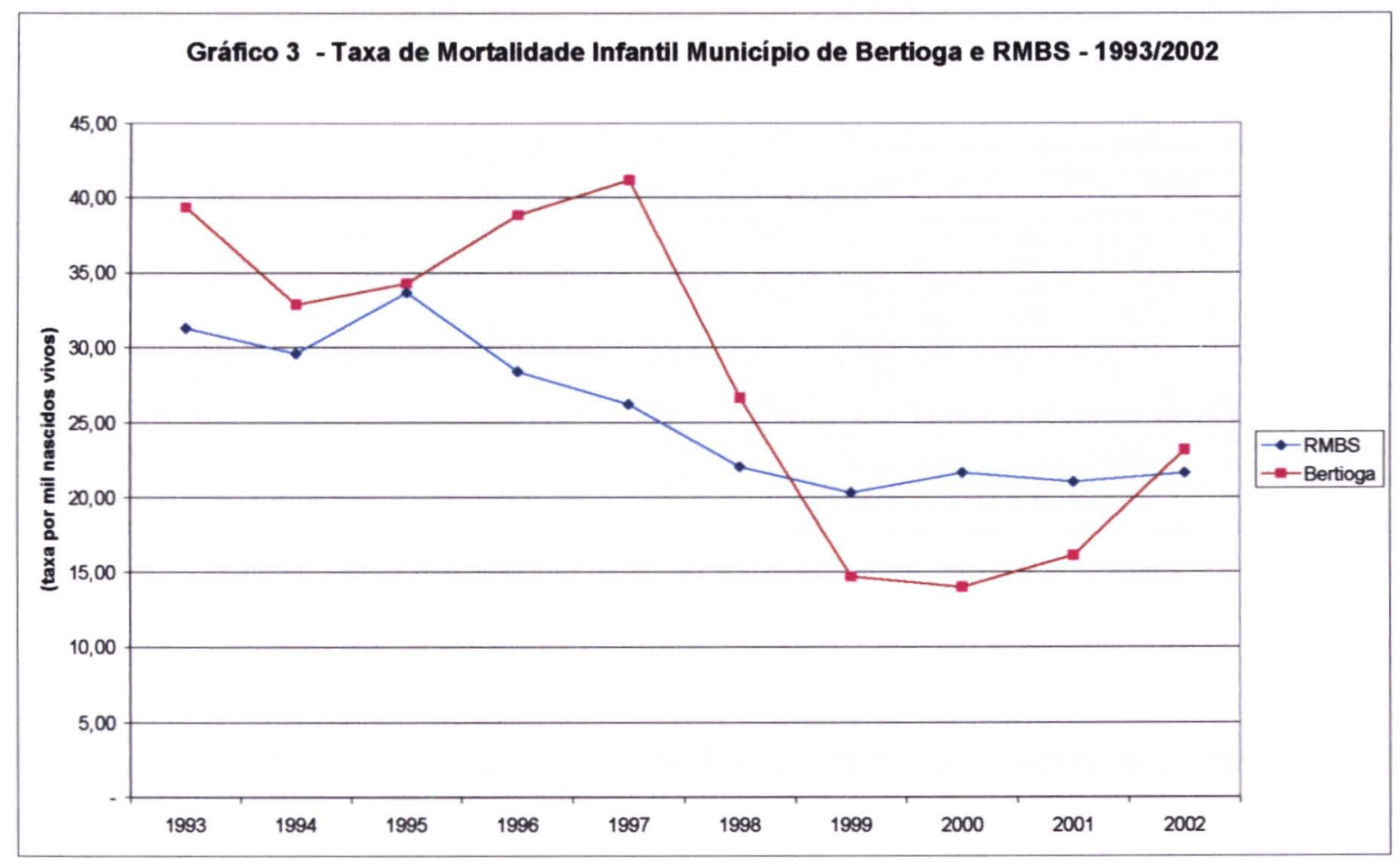

Fonte: Fundação Seade, 2003

\subsubsection{População flutuante}

Em função da dimensão territorial, da considerável parcela de áreas protegidas do ponto de vista ambiental e do, ainda relativamente limitado número de habitantes, Bertioga é pouco povoado. 0 município tem densidade demográfica média de 62 hab/Km2, enquanto que Região Metropolitana da Baixada Santista apresenta densidade média de 622 hab/Km2, dez vezes maior. Estes dados podem ser conferidos pela observação da Figura 4. No entanto há grandes desigualdades de densidade intra-urbana como se verá adiante no item sobre a moradia. 


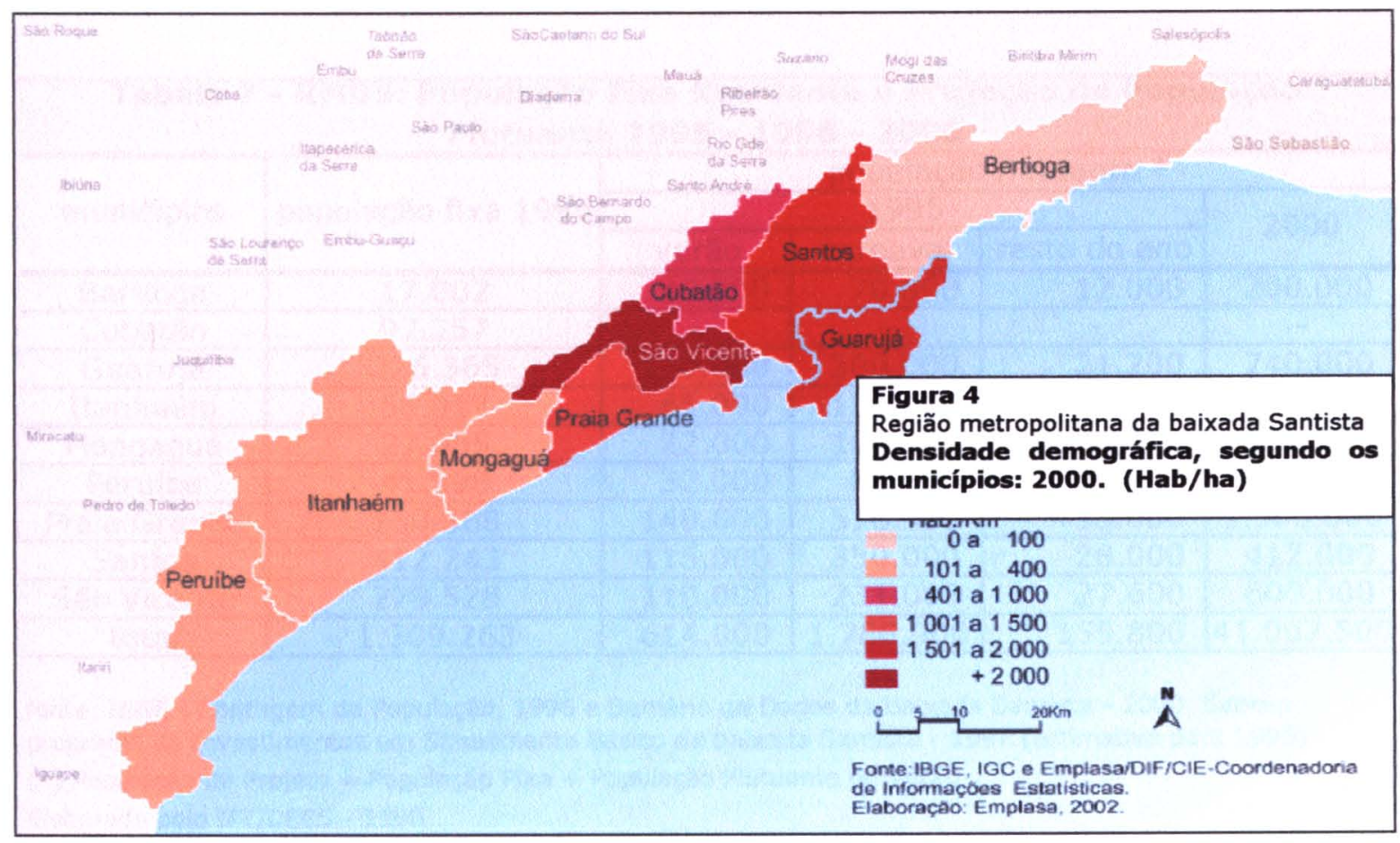

Do ponto de vista da atividade turística é importante considerar o aumento populacional nos períodos de alta temporada. Vale lembrar que a população flutuante equivale à de uma cidade média do Estado de São Paulo. A prefeitura municipal, com base na coleta de resíduos sólidos, estima que a população flutuante chega a atingir de 200.000 até 300.000 pessoas no auge da ocupação nos períodos de alta temporada de turismo - férias de verão e particularmente os feriados de Ano Novo e Carnaval. (Bertioga, 2002)

O Plano Integrado de Desenvolvimento Metropolitano da Baixada Santista utiliza os dados da Tabela 7 , relativo às populações fixa e flutuante para os municípios da baixada, com base em dados da contagem de população do IBGE e do Programa de Investimentos em Saneamento Básico da Região da Baixada Santista (São Paulo, 2000). 


\begin{tabular}{|c|c|c|c|c|c|}
\hline \multicolumn{6}{|c|}{$\begin{array}{c}\text { Tabela } 7 \text { - RMBS: População Fixa Residente e Projeção da População } \\
\text { Flutuante } 1995-1996-2000\end{array}$} \\
\hline \multirow{3}{*}{ municípios } & \multirow{3}{*}{ população fixa 1996} & \multicolumn{4}{|c|}{ população flutuante * } \\
\hline & & \multicolumn{3}{|c|}{1995} & \multirow{2}{*}{2000} \\
\hline & & verão & carnaval & resto do ano & \\
\hline Bertioga & 17.002 & 40.000 & 70.000 & 12.000 & 200.000 \\
\hline Cubatão & 97.257 & - & - & - & - \\
\hline Guarujá & 226.365 & 110.000 & 300.000 & 21.200 & 740.000 \\
\hline Itanhaém & 58.017 & 45.000 & 130.000 & 12.000 & 220.000 \\
\hline Mongaguá & 27.065 & 22.000 & 101.000 & 2.000 & 135.500 \\
\hline Peruíbe & 1.398 & 32.000 & 88.000 & 8.000 & 300.000 \\
\hline Praia Grande & 0.388 & 140.000 & 516.900 & 35.000 & 1.500 .000 \\
\hline Santos & 2.243 & 5.0 & 350.000 & 28.000 & 412.000 \\
\hline São Vicente & 279.528 & 110.000 & 231.000 & 27.600 & 600.000 \\
\hline total & 1.309 .263 & 614.000 & 1.786 .900 & 155.800 & 41.007 .500 \\
\hline
\end{tabular}

fonte: IBGE - Contagem da População, 1996 e Sumário de Dados da Baixada Santista - 2000 Sabesp programa de Investimentos em Saneamento Básico da baixada Santista - 1997 (estimativa para 1995)

(*) População de Projeto = Populaçãp Fixa + População Flutuante de Verão

Elaborado pelo IPT/DEES - 1998

Pode-se notar que o fenômeno da população flutuante afeta todos os municípios da região com exceção de Cubatão que tem característica de Pólo Industrial e não possui praias oceânicas (Tabela 7).

Note-se também que o município de Bertioga recebeu no Carnaval de 1995 um número de turistas de aproximadamente 4 vezes maior que a sua população permanente (do ano de 1996), a maior proporção da região. Os outros municípios que receberam mais que três vezes a sua população permanente foram Mongaguá (cerca de 3,7 vezes) e Praia Grande (3,4 vezes).

Em 2000 a população flutuante prevista para Bertioga era de 200.000 pessoas segundo os cálculos do IPT - Instituto de Pesquisas Tecnológicas do Estado de São Paulo. Neste ano a população fixa era constituída de cerca de 31.000 pessoas. (São Paulo, 2000 e IBGE, 2000).

No Plano Metropolitano da RMBS admite-se o problema, relacionando-o com o fenômeno da migração, particularmente das populações mais pobres: "(...) é de se salientar que a população flutuante funcione como indutora de atividades de serviços nesses municípios e contribui para o aumento de 
empregos, mesmo temporários, configurando-se como chamariz às populações com menor poder aquisitivo e desempregadas a se tornarem residentes, mantendo o saldo migratório positivo (...)" (São Paulo, 2000).

E segue justificando a ocorrência de doenças relacionadas à falta de tratamento de esgotos sanitários: "(...) o número de turistas que se dirigem para a Baixada Santista é motivo permanente de preocupação em vista da falta, na Região, de infra-estrutura adequada para garantir seu atendimento. A falta de tratamento de esgoto, apesar dos investimentos feitos pelo Governo do Estado em Saneamento, faz aumentar a ocorrência em época de temporada, por exemplo, das doenças ligadas à pele, e outras mais graves como a hepatite A. (...)" (São Paulo, 2000).

Parte relevante da população flutuante é constituida dos chamados turistas de 1 (um) dia. São aqueles que por razões principalmente econômicas, passam o dia na cidade, desfrutando da praia e retornam à noite para o local de origem - constituem a atividade excursionista. A abordagem da questão do crescimento populacional acelerado e do "problema" do excesso de turistas de 1 dia e das características dos mesmos - nível sócio-econômico baixo - ocupam grande parte das preocupações daqueles moradores atuais que não estão excluídos socialmente, e que compõem uma certa elite econômica local, formada por pequenos comerciantes, funcionários públicos, artesãos, prestadores de serviços, profissionais liberais.

Um membro da Secretaria do Meio Ambiente em alusão a este fenômeno em um seminário do Curso de Formação de Agentes Multiplicadores para Assentamentos Humanos Saudáveis, se expressou: "então (o ditado) diz 0 seguinte: praia curta, turista rico, praia longa, turista pobre. Isso é um ditado espanhol, em Basco para ser mais preciso, e tem aumentado a minha preocupação (...) tem razão não é que se tem razão (...) não adianta você querer receber o supra-sumo da nata paulistana em nossas praias, porque em nossas praias as características são outras (...)". (representante da Secretaria Municipal de Meio Ambiente em Seminário do Curso de Formação de Agentes Multiplicadores em outubro de 2001). 


\subsubsection{Características da população residente: ocupação e procedência}

Apesar da ocupação inicial de Bertioga ter sido iniciada na década de 1950, através da busca de residências secundárias pela população dos segmentos médios e superiores, os moradores permanentes são em sua maioria migrantes e pobres.

Com relação às atividades econômicas exercidas, é interessante notar que a RMBS - Região Metropolitana da Baixada Santista e o município de Santos possuem uma grande proporção de empregos no setor dos serviços, quando comparado com a média no Estado de São Paulo e a média no Brasil. Enquanto no Brasil e no Estado de São Paulo há a proporção de cerca de $42 \%$ de empregos no setor dos serviços, na RMBS esse valor corresponde a $60,6 \%$ e no município de Santos $71,3 \%$ (Gráfico 4).

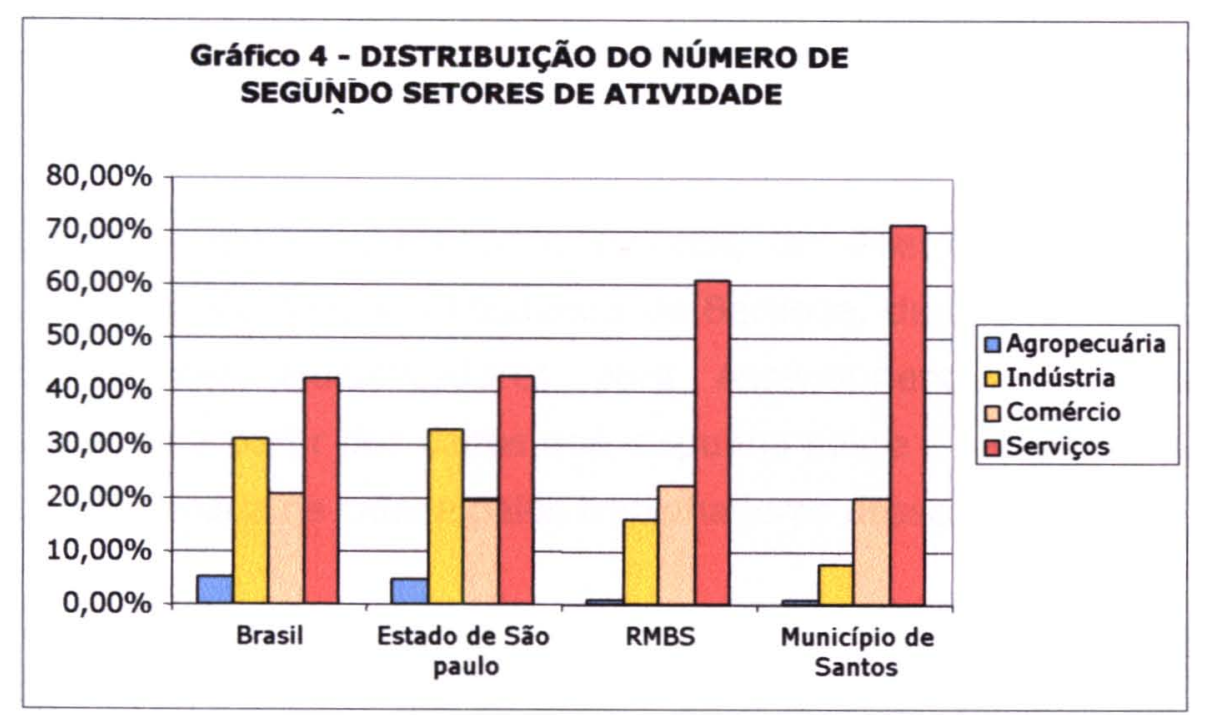

Fonte: : Ministério do Trabalho, 2000 e Emplasa, 2002;

Observando o Gráfico 5 abaixo, com dados do Ministério do Trabalho de 2000, nota-se que o município de Bertioga segue a mesma tendência de Santos e da Baixada, com $67,0 \%$ do número de empregos no setor dos serviços, $28,9 \%$ dos empregos no setor do comércio - também significativo, 
$3,9 \%$ no setor da indústria e apenas $0,1 \%$ dos empregos em atividades agropecuárias. Nota-se que historicamente houve uma forte tendência por desenvolver esses setores (Gráfico 5).

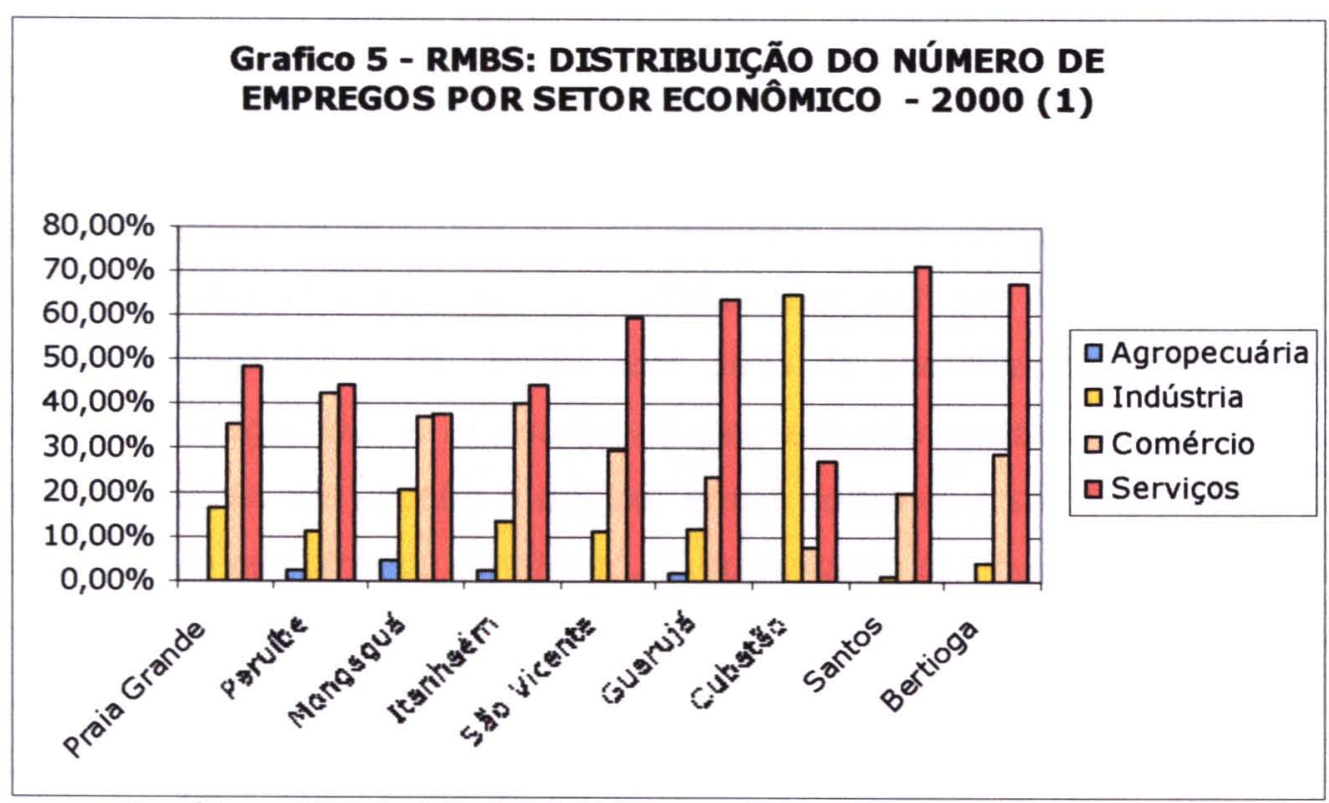

Fonte: Ministério do Trabalho, 2000; Elaborado por: Emplasa, 2002;

(1) Exceto Administração Pública, Defesa e Seguridade Social

Sobre o setor de comércio e serviços, um diretor da Acipep - Associação Industrial, Comercial e Pesqueira de Bertioga, durante I Curso de Formação de Agentes Multiplicadores para Assentamentos Humanos Saudáveis discorreu a partir dos dados que dispunha sobre a baixa remuneração média proporcionada na cidade pelos trabalhadores desses setores:

"(...) E aí que, como parâmetro, para vocês verem o seguinte. Numa relação de novembro de 2000 contávamos com 426 empresas cadastradas na prefeitura, então 426 empresas registradas com alvará, e aí nós levantamos (...) com um dado que tinham algumas empresas que já trabalhavam mais de 3 a 4 anos e que não tinham alvará ainda não é. Então agora com a nova administração (da Acipeb) com outros funcionários e projetos e estamos legalizando essa questão. Desses 426 comércios da cidade 30\% mais ou menos são de maior porte, são limitadas maioria, consideradas micro empresa. Então, nós deparamos com comércio, embora bem estruturados nas avenidas principais, mas no geral, o município um é pouco fraco. Não 
temos grandes empresas, as empresas maiores que nós temos são a Riviera São Lourenço, se é que pode ser incluída nisso, o SESC, temos também a Riviera Administradora, e os supermercados. Hoje, pelos dados que nós temos, o SESC tem 296 funcionários todos registrados e na faixa salarial de $R \$ 700,00$, mais ou menos quatro salários mínimos por ai né. Mas a maioria das nossas empresas têm mais ou menos $10 \%$ de funcionários sem registro que é um dado complicado na questão social... mas até em decorrência dessa dificuldade em que se apresentam, elas também acompanham as mesmas dificuldades que o municipio tem por ser muito novo ainda. 0 comércio também sofre, então tem $10 \%$ de trabalhadores sem o registro, $20 \%$ de estagiários. E aí estagiário por ele não contar o tempo de casa e aposentadoria, ele recebe o básico, então sobra que só $53 \%$ dessas pessoas é que estão registrados direitinho. $E$ outro dado também complicado é que a média de salário desse pessoal vai de um salário e meio a dois salários (mínimos) ... uma mascarada nesses dados na questão do SESC que vai para três e meio ... mas em termos gerais é dois salários, no máximo. Pouco não é... Agora em termos de contribuição (tributária) para município o comércio contribui bastante. Eu não tenho a porcentagem, mas sabemos que contribui(...)". (morador e diretor da Acipeb em seminário do I Curso de Formação de Agentes Multiplicadores em outubro de 2001).

Relativamente ao incentivo de desenvolvimento de outros setores, em uma discussão de uma proposta elaborada pelos integrantes do PBMS - Projeto Bertioga Município Saudável um participante defendeu o seguinte "(...) do outro lado da rodovia poderia ser bom atividades que fossem viáveis economicamente e sustentáveis, que seria uma opção para gerar empregos alternativos ao veranismo. São projetos que temos que pensar e elaborar como extração de palmito, criação de peixes, madeira para móveis, orquídeas, são alternativas ao modelo atual (...)".

Como comentado, segundo os dados do Ministério do Trabalho, o município de Bertioga é o segundo, com a maior proporção dos empregos no setor dos serviços da RMBS; só perdendo para Santos. Vale notar que o setor da Indústria da Construção Civil aparece com uma proporção bastante reduzida (setor industrial) nos dados oficiais. De acordo com as declarações locais isso 
se deve, principalmente em função da grande informalidade existente nas relações de trabalho entre empregado e empregador característicos do setor da construção civil como já mostrado por Vargas (1987). (Ver Gráfico 5).

Analisando os dados secundários dos órgãos públicos como IBGE, Fundação Seade, Emplasa, Agencia Metropolitana da Baixada Santista (AGEM) e da própria prefeitura e considerando o relato de diversos moradores de Bertioga, percebe-se que grande parte dos novos moradores atraídos pelas possiveis perspectivas de vida no litoral paulista provêm de outras regiões do Estado de São Paulo, da Bahia, Minas Gerais, Paraná, Pernambuco.

De acordo dados do IBGE (2001), considerando o Censo de 1991, a contagem populacional de 1996 e a malha municipal digital do Brasil de 1997; em 1996 havia 5.092 pessoas que não residiam em Bertioga em 01.09.1991 maiores de 4 anos.

Destes migrantes cerca de $52,2 \%$ provinham do próprio Estado de São Paulo, $14,8 \%$ provinham da Bahia, $6,1 \%$ do Paraná, 5,9\% de Minas Gerais, $3,4 \%$ de Pernambuco, $2,8 \%$ do Ceará e $2,1 \%$ de Sergipe. 0 restante proveio dos outros Estados do Brasil (IBGE, 2001).

Parte relevante dos homens foram atraídos ou trazidos por construtoras ou pequenas obras. Depois do primeiro emprego na cidade, ou da primeira obra, a dificuldade de re-inserção no mercado de trabalho é maior, uma vez que as construtoras preferem trazer novos operários a cada nova obra, por motivos e conveniências econômicas. Muitos sobrevivem também dos bicos ou trabalhos mais ou menos temporários, esporádicos como jardineiros, zeladores, caseiros. Muitas mulheres trabalham como faxineiras, domésticas, como funcionárias ou fazendo bico em bares, pousadas, restaurantes ou hotéis nos períodos de alta temporada.

Com relação à migração um participante de uma oficina do Projeto Bertioga Município Saudável externou suas preocupações: "(...) esse grupo, pra fazer na prática o município saudável, com a velocidade da migração, temos que ser rápidos, ter uma base pra fazer um trabalho, pra contrapor os que estão chegando. Ao término (deste projeto) vai se chegar a uma proposta pra 
cidade. As pessoas que chegam podem tirar a idéia das pessoas (que já estão na cidade). $A$ união nossa tem que ser rápida pra impedir a ação de poderosos que chegam depois e impõem seus projetos".(morador participante do I Curso de Formação de Agentes Multiplicadores em novembro de 2001).

De uma forma genérica, observa-se que existem dois tipos de migrantes: os que são donos de estabelecimentos comerciais, profissionais liberais, funcionários públicos e aposentados, provenientes principalmente da grande São Paulo, de segmentos médios, em busca de uma cidade com melhor qualidade de vida; e os migrantes assalariados ou desempregados, atraídos para o trabalho no setor da construção civil principalmente, e no setor de serviços como ajudantes ou tarefeiros.

\section{Rendimentos}

O crescimento acelerado da população de renda mais baixa atraída pelas possibilidades de emprego e melhores condições de vida, a dependência econômica ao setor dos serviços e comércio, muito sujeitos à sazonalidade e - modelo de desenvolvimento urbano pautado pela opção por empreendimentos de loteamentos para casas de segunda residência, culminaram com um perfil de renda dos habitantes permanentes, que denuncia a desigualdade sócio-econômica e a concentração de renda e de acesso à terra urbanizada, características comuns em maior ou menor grau na maior parte dos municípios médios, grandes ou em crescimento acelerado do Brasil, e particularmente o litoral.

Com relação às dificuldades de estabelecer-se na cidade, outro participante do Curso de Formação de Agentes Multiplicadores para Assentamentos Humanos Saudáveis, hoje funcionário público, ao descrever sua trajetória em Bertioga comenta "(...) estou a doze anos aqui, tive uma banca de jornal, uma adega, uma série de coisas e é muito difícil (...)". 
Relativamente à renda dos responsáveis por domicílios, a Tabela 8 mostra que no município de Bertioga, cerca de 49,77\% dos responsáveis por domicílios têm rendimento de 0 a 3 salários mínimos ou seja são dependentes da ajuda do Estado por meio das políticas públicas para suprir suas necessidades básicas (Tabela 8 ).

Os dados mostram que cerca de $72,20 \%$ dos responsáveis por domicílios ganham de 0 a 5 salários mínimos e apenas 8,68\% dos chefes de família tem rendimentos superiores a 10 salários mínimos. Para se ter uma idéia do impacto disso no problema habitacional, segundo Maricato (2001) "o financiamento habitacional no Brasil não atinge a população que ganha menos de 12 salários". Além disso, estudos na cidade de São Paulo recomendam a ampliação do mercado residencial formal como meio de combater o déficit, uma vez que para acessá-lo é necessário ter renda superior a 12 salários mínimos (Castro e Silva, 1997; Castro 1999; Maricato, 2001).

Tabela 8 - Rendimento dos Responsáveis pelos Domicílios (\% de fabxas) - 2000

\begin{tabular}{l|c|c|c|c|c}
\hline \multicolumn{1}{c|}{ localidade } & Bertioga & São Sebastião & Guarujá & RMB Santista & Estado de SP \\
\hline Sem rendimento & $\mathbf{8 , 5 3}$ & 9,37 & 9,13 & 9,38 & 8,94 \\
\hline Até 1/2 salário mínimo & $\mathbf{0 , 5 1}$ & 0,44 & 0,6 & 0,36 & 0,37 \\
\hline Entre mais de 1/2 a 1 salário mínimo & $\mathbf{6 , 3 8}$ & $\mathbf{8 , 3 7}$ & 9,75 & 7,23 & 9,31 \\
\hline Entre mais de 1 a 2 salários mínimos & $\mathbf{1 7 , 6 6}$ & 16,83 & 16,29 & 12,76 & 14,76 \\
\hline Entre mais de 2 a 3 salários mínimos & $\mathbf{1 6 , 6 8}$ & 16,67 & 15,18 & 12,46 & 13,58 \\
\hline Entre mais de 3 a 5 salários mínimos & $\mathbf{2 2 , 4 4}$ & 20,32 & 21,85 & 20,04 & 18,96 \\
\hline Entre mais de 5 a 10 salários mínimos & $\mathbf{1 9 , 1 2}$ & 17,62 & 19,45 & 23,16 & 19,77 \\
\hline Mais de 10 salários mínimos & $\mathbf{8 , 6 8}$ & 10,38 & 7,75 & 14,61 & 14,31 \\
\hline Total & $\mathbf{1 0 0 , 0 0}$ & 100,00 & 100,00 & 100,00 & 100,00 \\
\hline Rendimento Médio (R\$) & $\mathbf{7 9 1 , 1 4}$ & $\mathbf{8 5 2 , 3 5}$ & $\mathbf{7 8 9 , 3 9}$ & $\mathbf{1 0 5 8 , 4 3}$ & $\mathbf{1 0 7 6 , 2 1}$ \\
\hline
\end{tabular}

Fonte: Fundação SEADE (Site www.seade.sp.gov.br, 07/06/03)

Daí, pode-se compreender que, do ponto de vista da renda, parte muito significativa dos habitantes da cidade de Bertioga, de fato não têm condições de acessar o mercado formal residencial - isso ajuda a explicar a grande proporção dos habitantes em assentamentos informais - favelas, loteamentos irregulares, clandestinos, moradias coletivas, como se verá nos próximos itens. 


\section{Analfabetismo, evasão, aprovação e reprovação escolar}

A Tabela 9 mostra que, também com relação aos indicadores de analfabetismo, o município apresenta-se abaixo da média do Estado de São Paulo. Juntamente com Guarujá e São Sebastião, Bertioga tem um dos piores indicadores relativos ao baixo grau de instrução da região, com 8,26\% de analfabetos entre seus moradores. São Sebastião conta com 8,84\% e Guarujá conta com $8,45 \%$ de analfabetos. Enquanto isso a Região da Baixada Santista conta com 6,27\% na média e o Estado de São Paulo tem média de 6,64\% de analfabetismo (Tabela 9).

\begin{tabular}{l|c}
\hline \multicolumn{1}{|c|}{ Tabela 9 - Taxas de Analfabetismo da População de 15 anos ou mais (\%) - 2000 } \\
\hline Bertioga & taxa (\%) \\
\hline São Sebastião & 8,26 \\
\hline Guarujá & 8,84 \\
\hline Região da Baixada Santista & 8,45 \\
\hline Estado de São Paulo & 6,27 \\
\hline
\end{tabular}

Fonte: Fundação SEADE (Site www.seade.sp.gov.br, 07/06/03)

Com relação às taxas de evasão, reprovação e aprovação ${ }^{3}$ escolar dos moradores de Bertioga, nota-se que a cidade apresenta também indicadores negativos, se comparada com outras cidades litorâneas ou com as médias da RMBS e do Estado de São Paulo.

A tabela 10 mostra que Bertioga possuía tanto em 1991 (4,92\%) quanto em 2000 (5,35\%) taxas de evasão escolar do ensino fundamental mais elevadas que Guarujá (3,57\% e 3,07\%), São Sebastião (3,26\% e 2,03\%) RMBS $(3,52 \%$ e $3,63 \%)$ e que a média do Estado (3,29\% e 3,43\%).

\footnotetext{
${ }^{3}$ Definições: Taxa de Evasão - Porcentagem de alunos que abandonaram a escola antes da avaliação final ou que não preencheram os requisitos mínimos em frequência previstos em legislação, em relação ao total de alunos matriculados no fim do ano letivo.

Taxa de aprovação - Porcentagem de alunos que preencheram em avaliação final, os requisitos mínimos em aproveitamento e freqüência, previstos em legislação, em relação ao total de alunos matriculados no fim do ano letivo.

Taxa de Reprovação - Porcentagem de alunos que não preencheram em avaliação final, os requisitos mínimos em aproveitamento, previstos em legislação, em relação ao total de alunos matriculados no fim do ano letivo. (Fonte: F. Seade).
} 
O município de Bertioga só se apresenta melhor neste indicador, quando comparado com Mongaguá. Note-se também que, de 1999 a 2000 houve um aumento considerável deste indicador para Bertioga. As taxas de reprovação mostram a mesma tendência de aumento entre 1999 e 2000 e um destaque para Bertioga e Guarujá, com taxas acima da média da região e bem acima da média do Estado (Tabela 10). A mesma tendência é verificada para as taxas de aprovação, em que Bertioga também apresenta números inferiores às médias da região e do Estado.

Tabela 10 - Taxas do Ensino Fundamental (Total em \%)

\begin{tabular}{l|c|c|c|c|c|c}
\hline \multirow{2}{*}{ localidades } & \multicolumn{2}{|c|}{ taxa de evasão } & \multicolumn{2}{c|}{ taxa de reprovação } & \multicolumn{2}{c}{ taxa de aprovação } \\
\cline { 2 - 7 } & 1999 & 2000 & 1999 & 2000 & 1999 & 2000 \\
\hline Bertioga & 4,92 & 5,35 & 4,18 & 7,9 & 90,9 & 86,75 \\
\hline Guarujá & 3,57 & 3,07 & 8,54 & 10,13 & 87,89 & 86,8 \\
\hline Mongaguá & 7,22 & 6,63 & 5,12 & 6,79 & 87,66 & 86,58 \\
\hline São Sebastião & 3,26 & 2,03 & 5,07 & 6,59 & 91,68 & 91,38 \\
\hline RMBS & 3,52 & 3,63 & 5,69 & 7,3 & 90,79 & 89,08 \\
\hline Estado de SP & 3,29 & 3,43 & 3,68 & 4,61 & 93,04 & 91,96 \\
\hline
\end{tabular}

Fonte: SEADE e CIE (Secretaria da Educação/Centro de Informações Educacionais)

Da observação da Tabela 11, nota-se que os estudantes do ensino médio em de Bertioga também possuem mais dificuldades para concluir o período de estudo. O município possuía em 1999 taxa de 12,65\% de evasão escolar e $17,06 \%$ de evasão em 2000.

Tabela 11 - Taxas do Ensino Médio (Total em \%)

\begin{tabular}{l|c|c|c|c|c|c}
\hline \multirow{2}{*}{ localidades } & \multicolumn{2}{|c|}{ taxa de evasão } & \multicolumn{2}{c|}{ taxa de reprovação } & \multicolumn{2}{c}{ taxa de aprovação } \\
\cline { 2 - 7 } & 1999 & 2000 & 1999 & 2000 & 1999 & 2000 \\
\hline Bertioga & 12,65 & 17,06 & 3,16 & 6,37 & 84,18 & 76,57 \\
\hline Guarujá & 12,39 & 10,4 & 5,6 & 10,68 & 82,01 & 78,92 \\
\hline Mongaguá & 16,67 & 13,72 & 5,76 & 4,08 & 77,57 & 82,2 \\
\hline São Sebastião & 13,37 & 17,39 & 3,09 & 8,49 & 83,54 & 74,12 \\
\hline RMBS & 9,57 & 9,88 & 5,74 & 8,7 & 84,69 & 81,43 \\
\hline Estado de SP & 9,25 & 10,44 & 5,42 & 6,72 & 85,33 & 82,84 \\
\hline
\end{tabular}

Fonte: SEADE e CIE (Secretaria da Educação/Centro de Informações Educacionais) 
Na RMBS estes indicadores correspondem a 9,57\% e 9,88\% e no Estado de São Paulo 9,25\% e 10,44\% respectivamente (Tabela 11). Note a diferença significativa de valores.

Com relação às taxas de reprovação, Bertioga apresenta indicadores sensivelmente melhores que a região e que o Estado. Porém a taxa de aprovação no ensino médio apresenta-se inferior, quanto se faz a mesma comparação (Tabela 11).

\subsubsection{Resultados do crescimento populacional intenso e da especulação imobiliária: agressão ao meio ambiente}

O crescimento populacional refletiu, obviamente, num aumento de demanda por infra-estrutura urbana e serviços públicos. A título de exemplo, tendo por base os dados da Cesp - Companhia Energética de São Paulo, nota-se que houve um considerável crescimento do número de consumidores de energia elétrica em Bertioga entre 1995 e 1998, o equivalente a 9,76\% de taxa geométrica de crescimento anual. Este aumento guarda, de certa maneira, uma relação com o crescimento da população permanente (consumidores residenciais) e com crescimento do consumo, principalmente por novos estabelecimentos de serviços e comércio (Gráfico 6).

O Gráfico 6 mostra também a capacidade, em termos de agilidade de atendimento, no caso de crescimento de demanda do setor elétrico. Esta rapidez de expansão da rede de serviços e infra-estrutura urbana não se verifica para o caso da cobertura de coleta e tratamento de esgotos sanitários, por exemplo, como se verá adiante.

É importante considerar também, em relação ao número de consumidores de energia elétrica, que Santos, que possui população e economia em crescimento mais estável, obteve taxas de apenas 0,19\% entre 1990 e 1995 e taxa de $1,55 \%$ entre 1995 e 1998. O segundo maior crescimento foi registrado pelo municipio de Mongaguá no período de 1995 a 1998 com taxas de $7,07 \%$ de novos consumidores em média ao ano. 


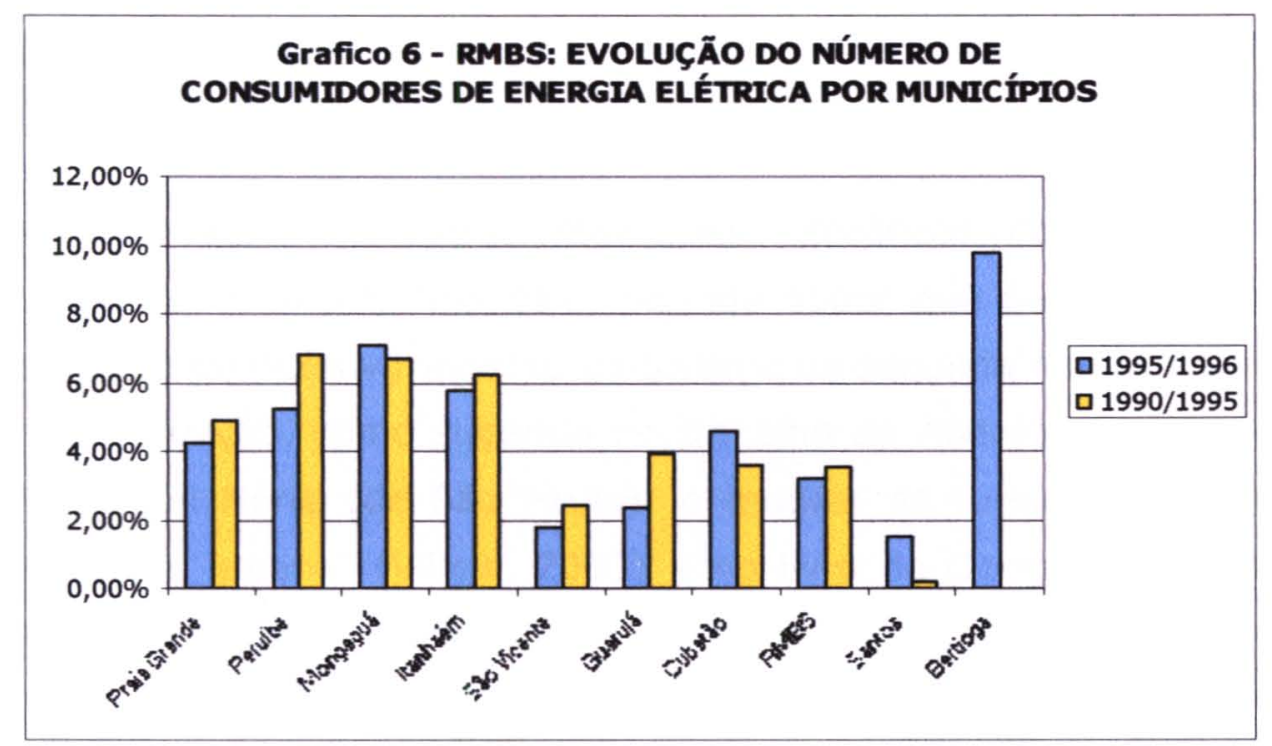

Fonte: Cesp (Companhia Energética de São Paulo) e Emplasa, 2002; Adaptada pelo autor.

Os impactos do crescimento populacional e da atividade imobiliária são inúmeros, de modo que tanto os atores locais, como entidades governamentais têm demonstrado preocupação.

Documentos de órgãos como a Secretaria de Estado do Meio Ambiente também têm mostrado preocupação com a situação do litoral. No documento sobre "Informações Básicas para o Planejamento Ambiental" discorre (...) cerca de 5,5\% da população do Estado vive na Zona Costeira, perfazendo 2.057.000 habitantes (IBGE, 2001). Alguns Municípios tem apresentado elevadas taxas de crescimento, muito acima da média estadual que está em torno de 2,2\% ao ano, como Ilha Comprida (17,7\%), Bertioga $(16,1 \%)$ e Ilha Bela (12,2\%). São Sebastião, Mongaguá, Praia Grande e Cananéia estão crescendo com taxas superiores a $6 \%$ ao ano (...) os municípios litorâneos são em sua maioria, muito dependentes de impostos territoriais urbanos 0 que faz da atividade imobiliária e da construção civil o maior vetor de crescimento e da pressão sobre os ecossistemas costeiros, seja pelo desmatamento na fase de implantação de loteamentos, ou pela poluição hídrica resultante da ocupação geralmente desordenada. Os principais recursos explorados são areias fluviais e materiais para aterro (caixas de empréstimo) ambos para a construção civil. Algumas pedreiras são utilizadas para brita e pedras ornamentais. São inúmeras as áreas de lavras em 
atividade ou desativadas que detém planos de recuperação, muitas delas representam grandes passivos ambientais (São Paulo, 2002).

A observação de outros municípios litorâneos do Estado, como São Sebastião, Guarujá, Ilha Bela, permite supor que há uma relação entre o processo de desenvolvimento do turismo de segunda residência e o processo de favelização, como sugerido no trabalho de Andréa Villela - "Favelização no Litoral Norte (de São Paulo): o modelo de turismo e seu impacto na estrutura urbana" (Villela, 2003) e no livro de Gonçalo Guimarães (1997) sobre a trajetória para a construção de um plano diretor democrático e inclusivo em Angra dos Reis no litoral sul do Estado do Rio de Janeiro. Nossas observações empíricas e pesquisas na região litorânea nos levam a crer que em Bertioga esta tendência se confirma.

O problema da sujeição da economia à sazonalidade ou às temporadas é sentido também como um dos problemas graves por diversos atores locais. Um outro morador e também membro da Acipep durante a Oficina de Habitação do referido Curso salientou: "(...) principalmente hoje qual o maior problema das cidades do litoral e de Bertioga (..).o desemprego (...) $\mathrm{Na}$ alta temporada todo mundo arruma algum bico no comercio por ai. Na baixa temporada fica todo mundo correndo atrás de emprego, então a cidade precisa trabalhar nesta direção (...)".

Entretanto, este modelo de desenvolvimento econômico, que mantêm relações estreitas com o modelo de desenvolvimento urbano e imobiliário centrado no incentivo aos empreendimentos para o turismo de segundas residências, começou em 2002 a ser questionado por setores locais, por ocasião das discussões sobre a revisão do Plano Diretor da cidade 4 .

Observa-se que há uma influência importante das leis que disciplinam o uso e a ocupação do solo no processo de desenvolvimento urbano, e na atividade imobiliária. As leis ambientais Federais e Estaduais impõem limites claros ao processo de urbanização. Entretanto a falta de uma política habitacional

\footnotetext{
4 No segundo semestre de 2002 foi realizado um conjunto de 5 (cinco) oficinas e 1 (um) seminário municipal, alem de diversas reuniðes com membros da sociedade civil organizada e população visando à capacitação para a participação no processo de revisão do Plano Diretor da cidade.
} 
consistente e o aumento populacional leva a uma forte pressão por ocupações irregulares e ilegais da população de baixa renda, que tem sido reprimida com força pela prefeitura.

Por outro lado, as leis municipais do Plano Diretor, e Lei de Uso e Ocupação do Solo historicamente não se adequaram às necessidades da população de baixa renda, no sentido de mecanismos e parâmetros mais flexiveis e menos exigentes. As ZEIS - Zonas Especiais de Interesse Social foram implementadas em 2001, entretanto houve uma dificuldade grande de articulação entre a lei e a gestão e a implantação de moradia social (que é também histórica no Brasil, como nos mostra Villaça, 1999 e Maricato, 2001).

Ao contrário, as leis municipais privilegiaram e concederam proteção aos empreendimentos de loteamentos - voltados para implantação de residências secundárias. Isto pode ser verificado por meio da análise das leis (Bertioga, 1998). Algumas zonas estipulam que os parâmetros e índices urbanísticos serão definidos conforme a análise do memorial descritivo do empreendimento - inclui-se aí o Loteamento Riviera de São Lourenço.

Um dado que ajuda a mostrar o descompasso entre lei e gestão, refere-se ao anúncio em diversos meios de comunicação local em que a Câmara Municipal "comemorava" juntamente com os 11 anos de emancipação da cidade, a marca de 500 leis aprovadas. (Jornal Costa Norte, 2002). 


\subsection{Moradia dos que habitam e trabalham}

\section{Domicílios em números e formas de ocupação}

De acordo com dados do IBGE o município de Bertioga possuía em 2000 cerca de 8.479 domicílios particulares permanentes e um número médio de 3,48 moradores por domicílio, bem próximo à média da RMBS que é de 3,45.

Da RMBS, Bertioga é o município que possui a menor proporção de domicílios próprios, como condição de ocupação. Em 2000 possuía cerca de $51,8 \%$ de domicílios com esta condição de ocupação, 15,4\% de domicílios alugados e a maior proporção da RMBS de domicílios cedidos, com 22,3\% em proporção ao total de domicílios (Tabela 12).

Tabela 12 - RMBS: Domicílios Particulares Premanentes por Condição de Ocupação, Segundo Municípios - 1991/2000 (em porcentagem)

\begin{tabular}{|c|c|c|c|c|c|c|c|c|c|c|}
\hline \multirow{2}{*}{ municípios } & \multicolumn{5}{|c|}{1991} & \multicolumn{5}{|c|}{2000} \\
\hline & próprios & alugados & cedidos & outra & total & próprios & alugados & cedidos & outra & total \\
\hline$\overline{\text { Bertioga }}$ & - & - & - & - & - & 51,8 & 15,4 & 22,3 & 10,5 & 100 \\
\hline Cubatão & 67 & 24,4 & 8,4 & 0,2 & 100 & 77,4 & 14,3 & 5,7 & 2,6 & 100 \\
\hline Guarujá & 68,6 & 16 & 14,5 & 0,9 & 100 & 72,6 & 12,4 & 11,8 & 3,2 & 100 \\
\hline Itanhaém & 59,6 & 14,2 & 25,6 & 0,6 & 100 & 71,3 & 11,4 & 16 & 1,3 & 100 \\
\hline Mongaguá & 63,4 & 14,7 & 19,7 & 2,2 & 100 & 69,5 & 12,4 & 13,8 & 4,3 & 100 \\
\hline \begin{tabular}{l|l} 
Peruíbe & \\
\end{tabular} & 60,2 & 13,3 & 25,1 & 1,4 & 100 & 69,9 & 12,7 & 15,8 & 1,6 & 100 \\
\hline Praia Grant & de 62,3 & 22,7 & 14,2 & 0,8 & 100 & 71 & 16,8 & 10,6 & 1,6 & 100 \\
\hline Santos (1) & 60,6 & 33,1 & 6 & 0,3 & 100 & 67,6 & 26,9 & 4,6 & 0,9 & 100 \\
\hline São Vicenț & 66 & 27 & 6,8 & 0,2 & 100 & 73,8 & 19,9 & 5,6 & 0,7 & 100 \\
\hline \begin{tabular}{l|l} 
RMBS & \\
\end{tabular} & 63,6 & 25,9 & 10 & 0,5 & 100 & 71 & 19,1 & 8,1 & 1,8 & 100 \\
\hline
\end{tabular}

fonte: Emplasa, 2002

(1) inclui, em 1991, as informações referentes ao Município de Bertioga, à época distrito do Municipio de Santos

Apesar de não constarem dados de Bertioga de 1991 (ano da emancipação), por meio da Tabela 12 pode-se verificar que de 1991 para 2000 tem havido uma tendência, em todos os municípios da RMBS, de aumento da proporção de domicílios próprios, diminuição da proporção de domicílios alugados e diminuição da proporção de domicílios cedidos.

Ainda, de acordo com os dados do IBGE, no Censo de 2000 foram identificados cerca de 26.054 domicílios particulares no município, sendo a grande maioria na área urbana e apenas 966 na área rural. Também na área urbana, contam-se 8.478 domicílios ocupados permanentemente e cerca de 15.691 particulares não ocupados, de uso ocasional, ou seja de uso 
predominantemente como segundas residências. Se considerarmos os domicílios não ocupados vagos e os não ocupados fechados temos 17.326 unidades (Tabela 13).

Daí verifica-se que cerca de $66,3 \%$ ou $2 / 3$ dos domicílios particulares urbanos são fechados, tem uso ocasional ou são vagos e apenas $1 / 3$, ou seja $33,4 \%$ dos domicílios particulares urbanos são ocupados permanentemente. Este sem dúvida é resultado de um modelo de desenvolvimento econômicourbano e imobiliário que priorizou muito os empreendimentos de loteamentos e condomínios, predominantemente com casas de segunda residência com fins de turismo e veranismo (Tabela 13).

Se em 2000 Bertioga possuía 30.619 habitantes e 26.149 domicílios, temos aí uma relação (média) de 1,17 de pessoas/domicílio. Entretanto em função das condições de desigualdade de acesso à terra urbanizada e à moradia adequada convive-se com esta situação em que 2/3 dos domicílios são de uso ocasional - utilizados na sua maioria como segundas residências e parcela significativa da população ocupa áreas ilegais e moradias irregulares do ponto de vista urbanístico e inadequadas do ponto de vista de salubridade e habitabilidade (Tabela 13).

\begin{tabular}{l|r|r}
\hline \multicolumn{2}{c}{ Tabela 13 - Municipio de Bertioga - Forma de Ocupação dos Domicilios } \\
\hline \multicolumn{1}{c}{ tipologia dos domicílios } & quantidade & porcentagem \\
\hline Particulares não ocupados - vagos, & 1.497 & $5,7 \%$ \\
\hline Particulares não ocupados - uso ocasional & 15.691 & $60,0 \%$ \\
\hline Particulares não ocupados - fechados & 138 & $0,5 \%$ \\
\hline Sub Total - Particulares não ocupados & 17.326 & $66,3 \%$ \\
\hline Particulares ocupados & 8.728 & $33,4 \%$ \\
\hline Total de Domicílios Particulares & 26.054 & $99,6 \%$ \\
\hline Domicílios coletivos & 95 & $0,4 \%$ \\
\hline Total de Domicílios & 26.149 & $100,0 \%$ \\
\hline
\end{tabular}

Fonte: Censo do IBGE de 2000

Apenas como referência, a questão do número de imóveis vagos ociosos representa proporções muito relevantes em todo o Brasil. Segundo o IBGE havia 2.962.815 imóveis urbanos vagos em todo o país em 1991 (cerca de $9,3 \%$ do total de domicílios). Em São Paulo, estima-se que havia 252.893 domicílios que poderiam hipoteticamente abrigar mais de 1 milhão de pessoas (Instituto Cidadania, 2002). 
Como subsídio aos participantes das Oficinas de Capacitação para participação na revisão do Plano Diretor Municipal foi desenvolvida uma atividade do Projeto Bertioga Município Saudável em 2002, em que foi calculado, a partir do Censo de 2000, o número de domicílios permanentemente ocupados e de uso ocasional por setores censitários.

Os dados da Tabela 14 demonstram que existem bairros ou loteamentos inteiros que são quase que exclusivamente utilizados por casas de segunda residência. Existem obviamente outros habitados principalmente por moradores, entre eles os residentes em favelas (Tabela 14).

Tabela 14 - Domicilios Ocupados e de uso ocasional em alguns loteamentos e favelas de Bertioga

\begin{tabular}{|c|c|c|c|c|c|}
\hline bairro & $\begin{array}{c}\text { numero } \\
\text { domicilios } \\
\text { ocupados }\end{array}$ & $\%$ & $\begin{array}{l}\text { número domicílios } \\
\text { de uso ocasional }\end{array}$ & $\%$ & $\begin{array}{l}\text { total de } \\
\text { domicilios }\end{array}$ \\
\hline Jardim Vista Alegre & 70 & $16,1 \%$ & 366 & $83,9 \%$ & 436 \\
\hline Vila Clois & 85 & $17,1 \%$ & 412 & $82,9 \%$ & 497 \\
\hline Hanga Hoa, Jardim Indaiá - Lot. Fechado & 188 & $22,7 \%$ & 640 & $77,3 \%$ & 828 \\
\hline Vila Tupi & 157 & $28,4 \%$ & 395 & $71,6 \%$ & 552 \\
\hline Jardim Vista linda & 343 & $28,7 \%$ & 854 & $71,3 \%$ & 1197 \\
\hline Jd Albatroz I e Vila Agaó & 446 & $36,4 \%$ & 779 & $63,6 \%$ & 1225 \\
\hline Chácara Vista linda & 217 & $37,4 \%$ & 363 & $62,6 \%$ & 580 \\
\hline Caiubura & 234 & $40,1 \%$ & 349 & $59,9 \%$ & 583 \\
\hline Jd Lido & 213 & $41,0 \%$ & 307 & $59,0 \%$ & 520 \\
\hline Jd Rafael, Sesc e Jd das Canções & 272 & $40,8 \%$ & 394 & $59,2 \%$ & 666 \\
\hline Vila Itapanhaú & 187 & $45,8 \%$ & 221 & $54,2 \%$ & 408 \\
\hline Centro & 188 & $41,9 \%$ & 261 & $58,1 \%$ & 449 \\
\hline Jd Rio da Praia & 478 & $47,8 \%$ & 521 & $52,2 \%$ & 999 \\
\hline Centerville & 193 & $50,5 \%$ & 189 & $49,5 \%$ & 382 \\
\hline B. Santista, Clipper, Vila Tamoios. & 229 & $52,6 \%$ & 206 & $47,4 \%$ & 435 \\
\hline Parque Estoril, Jardim Paulista & 741 & $68,0 \%$ & 348 & $32,0 \%$ & 1089 \\
\hline Jd AlbatrozII & 323 & $70,1 \%$ & 138 & $29,9 \%$ & 461 \\
\hline Núcleo Jd Veleiros - Assent. precário & 41 & $75,9 \%$ & 13 & $24,1 \%$ & 54 \\
\hline Núcleo Jd Ana Paula lot. clandestino & 146 & $78,1 \%$ & 41 & $21,9 \%$ & 187 \\
\hline Núcleo Itha I* - favela & 139 & $86,3 \%$ & 22 & $13,7 \%$ & 161 \\
\hline Núcleo Jd Vista Linda* & 183 & $91,0 \%$ & 18 & $9,0 \%$ & 201 \\
\hline Núcleo Vicente de Carvalho II - favela & 330 & $91,2 \%$ & 32 & $8,8 \%$ & 362 \\
\hline Jd Maitinga & 330 & $91,2 \%$ & 32 & $8,8 \%$ & 362 \\
\hline Núcleo Ilha II* - favela & 150 & $95,5 \%$ & 7 & $4,5 \%$ & 157 \\
\hline
\end{tabular}

fonte: Censo IBGE 2000, dados preliminares por setores censitários.

Da observação da Tabela 14, nota-se que também que diversos loteamentos como Jardim Vista Alegre, Indaiá, Jardim Vista Linda, Vila Clois, Hanga Hoa possuem cerca de $70 \%$ a $80 \%$ de domicílios de uso ocasional, figurando assim como predominantemente com uso de turismo e veranismo. Outros loteamentos ou favelas como Núcleo Ilha 2, Núcleo Jardim Vista Linda, 
possuem de $90 \%$ a $95 \%$ de domicílios de ocupação permanente. Supomos assim que estes últimos tendem a concentrar a população de mais baixa renda.

\subsubsection{Favelas, assentamentos precários e áreas de risco}

Alguns técnicos da Secretaria de Habitação, Planejamento e Desenvolvimento Urbano da PMB afirmam que os dados, levantamentos e estimativas da própria prefeitura sobre o número de favelas e o número de pessoas habitando as favelas tem uma confiabilidade baixa. Um dos motivos segundo os próprios técnicos é que a prefeitura só procura realizar levantamento e cadastramento de famílias nas áreas em que tem uma proposta concreta de projeto, melhoria ou intervenção, logo não há informações disponíveis para boa parte dos assentamentos.

De qualquer forma existem alguns dados que, feitas essas ressalvas, foram utilizados como elementos diagnósticos. 0 documento da Prefeitura do Município de Bertiga entitulado "Diagnóstico sobre a Capacidade Institucional do município no Setor Urbano/Habitacional para atendimento das populações de baixa renda", de fevereiro de 2001, elaborado com a participação do CEPAM e da PMB para a SEDU - Secretaria de Estado do Desenvolvimento Urbano da Presidência da Republica, aponta para a existência de 4.400 pessoas morando em favelas, 100 morando em cortiços, 3.500 em loteamentos irregulares e $3.336 \mathrm{em}$ loteamentos clandestinos, perfazendo um total de 11.336 moradores de habitações subnormais ou irregulares do ponto de vista das leis ambientais, de uso e ocupação do solo, leis de parcelamento ou código de edificações.

\subsection{2 Áreas de risco}

De acordo com relatório do Governo do Estado "Elaboração de Estudos Técnicos, Levantamento e Diagnóstico para o "Programa de Identificação e Monitoramento de Áreas Críticas, de Inundações, Erosões e Deslizamentos" realizado pela Agência Metropolitana da Baixada Santista - Agem (São Paulo, 2002) sobre o impacto de processos erosivos e situações de risco na 
RMBS, em Bertioga existem 20 áreas críticas, sendo 18 do ponto de vista de alagamentos e inundações e duas do ponto de vista geotécnico.

Entre essas 18 áreas ou pontos de inundação/alagamentos destacam-se as margens do Rio Itapanhaú, o mais importante curso d'água da cidade. Na região de manguezal nas bordas do mesmo rio, localiza-se a favela Vicente de Carvalho II, parcialmente em terreno particular, a segunda maior favela de Bertioga com 410 domicílios, de acordo com dados disponíveis da prefeitura (Bertioga 2002).

Pelo fato do desenvolvimento urbano do município ter ocupado, por enquanto, a região da planície costeira do território - que é relativamente ampla, foram identificadas apenas 2 (duas) situações de risco de erosões ou deslizamentos.

O mesmo estudo conclui que as causas para o problema na cidade referemse principalmente à inexistência ou inadequação dos sistemas de macro e micro-drenagens. Os estudos concluem que nos casos em que existe a micro-drenagem e ocorre inundação e/ou alagamentos, notou-se que os sistemas (tubos, bocas de lobo, canais abertos) encontravam-se obstruídos ou assoreados, o que mostra que além da necessidade de projetos e obras de micro-drenagem, há a necessidade de melhor operação e manutenção dos sistemas por parte do poder público, principalmente considerando as características locais já citadas sobre o clima chuvoso e o solo com lençol freático aflorante (São Paulo, 2001)

A AGEM com recursos do Fehidro - Fundo Estadual para os Recursos Hídricos elaborou propostas (cujas obras não foram viabilizadas até o momento) para as diversas áreas problemáticas. Foram feitas duas propostas de "mitigação com limpeza e desobstrução de canais, dez com melhorias de microdrenagem, seis na macro-drenagem. Para os problemas de geotecnia são propostos uma estrutura de contenção, uma recomposição de solo e replantio de vegetação". (São Paulo, 2002). 


\subsubsection{Assentamentos precários}

Apesar da confiabilidade relativa dos dados, se considerarmos os levantamentos que a prefeitura procura realizar, a população moradora de assentamentos precários tem aumentado constantemente, seguindo a tendência verificada em diversos municípios da região, conforme pode se verificar na Tabela 15.

Tabela 15 - Assentamentos Irregulares no Município de Bertioga - 2001

\begin{tabular}{l|c|r|r}
\hline assentamentos irregulares & quantidade & $\begin{array}{r}\mathrm{n}^{0} \text { de } \\
\text { domicílios }\end{array}$ & população \\
\hline Favelas & 15 & 1.475 & 4.400 \\
\hline Cortiços & 1 & 25 & 100 \\
\hline Loteamentos irregulares & 3 & 1.700 & 3.500 \\
\hline Loteamentos clandestinos & 2 & 834 & 3.336 \\
\hline Total & 17 & 4.034 & 11.336 \\
\hline
\end{tabular}

Fonte: Prefeitura Municipal de Bertioga: Seção de Habitação, 2001.

Um documento mais recente da PMB, o "Diagnóstico para Assentamentos Subnormais do Município de Bertioga", elaborado por empresa contratada, tendo em vista o Programa Habitar Brasil/Bid do Governo Federal em fevereiro de 2002 mostra que na cidade existem 22 assentamentos considerados subnormais (Bertioga, 2002):

15 (quinze) núcleos favelados com 2063 domicílios

2 (dois) cortiços com 50 domicilios

3 (três) loteamentos irregulares com 1.700 domicílios

2 (dois) loteamentos clandestinos com 1.340 domicílios

O documento informa também que "em todos os casos predomina ocupação de média densidade em terrenos planos, atingindo em alguns casos áreas alagadiças" (Bertioga, 2002).

Os levantamentos e estimativas realizadas pela prefeitura em documentos da Secretaria de Habitação de 1999 e de 2002 mostram uma tendência de aumento nos moradores dos assentamentos irregulares, particularmente das 
favelas. O número de domicílios em favelas apresentado varia de 1.474 para 2.063 no período.

O documento apresenta o quadro com informações sobre as 15 favelas que reapresentamos abaixo (Tabela 16). Nele consta que a favela mais antiga, Jardim Veleiros, que fica no Centro, foi ocupada em 1977 e possui 80 domicílios. A mais recente é o Jardim Albatroz II ocupada em 1998 com 30 domicílios. As maiores são a Favela do Indaiá com 430 domicílios, ocupada a partir de 1982, a favela Vicente de Carvalho II com 410 domicílios, ocupada a partir de 1992 e o Mangue Seco com 250 domicílios, ocupada a partir de 1987.

O diagnóstico apresenta cerca de 2.063 domicílios nestas 15 favelas citadas (Bertioga, 2002). Se considerarmos o valor de médio de 3,48 pessoas por domicílio (IBGE, 2003), totalizam-se cerca de 7.180 pessoas habitando nestas 15 favelas no município. Este valor nos leva a crer que o número de

\begin{tabular}{c|l|c|c}
\hline \multicolumn{4}{c}{ Tabela 16 - Identificação dos Núcleos de Favelas } \\
\hline item & \multicolumn{1}{|c}{ nome da favela } & ano de ocupação & domicilios \\
\hline 1 & Jd. Veleiros & 1977 & 80 \\
\hline 2 & Center Ville & 1987 & 150 \\
\hline 3 & Parque Estoril & 1995 & 20 \\
\hline 4 & jd. Vicente de Carvalho II & 1992 & 410 \\
\hline 5 & Jd. Albatroz & 1998 & 30 \\
\hline 6 & Ilha I & 1971 & 80 \\
\hline 7 & Ilha II & 1982 & 120 \\
\hline 8 & Mangue Seco & 1987 & 250 \\
\hline 9 & Jd. Ana paula & 1995 & 200 \\
\hline 10 & Indaiazinho & 1992 & 54 \\
\hline 11 & Indaiá & 1982 & 430 \\
\hline 12 & Boracéia & 1991 & 137 \\
\hline 13 & Chácara Vista Linda & 1996 & 70 \\
\hline 14 & Vila Itapanhaú & 1989 & 12 \\
\hline 15 & Jd. Das Canções & 1997 & 20 \\
\hline \multicolumn{2}{|c|}{ Total } & - & 2.063 \\
\hline
\end{tabular}

fonte: Prefeitura do Município de Bertioga - 2002

moradores em favelas aumentou consideravelmente de 1999 para 2002.

Entretanto cabe destacar que, de acordo com integrantes da Secretaria de Habitação, Planejamento e Desenvolvimento Urbano da PMB há favelas novas que não constam nestes documentos oficiais. 
Além disso, a partir da análise das fotos aéreas de 2002 e considerando informações da Gerência da Sabesp - Companhia de Saneamento Básico do Estado de São Paulo - Bertioga, foi possível identificar outras áreas de favelas na cidade (Foto Aérea - Município de Bertioga).

Neste sentido, um levantamento realizado pelos integrantes do grupo de Estudos para Revisão do Plano Diretor do PBMS em dezembro de 2003, mostra a existência de pelo menos 25 áreas de favelas e assentamentos precários conforme pode-se observar na Foto Aérea - Município de Bertioga, e na Tabela 17 abaixo.

Tabela 17 - Dados de Levantamento de Campo realizado pela Equipe do PBMS - 2003

\begin{tabular}{|c|c|c|c|c|c|c|c|c|}
\hline \multicolumn{3}{|c|}{$\begin{array}{l}\text { FAVELAS E ASSENTAMENTOS } \\
\text { PRECÁRIOS (F) }\end{array}$} & \multicolumn{3}{|c|}{$\begin{array}{c}\text { GLEBAS / TERRENOS OCIOSOS NA } \\
\text { ÁREA URBANA (G) }\end{array}$} & \multicolumn{3}{|c|}{$\begin{array}{c}\text { LOTEAMENTOS / CONDOMINIOS NAO } \\
\text { INTEGRADOS NA MALHA URBANA } \\
\text { (L) }\end{array}$} \\
\hline & área $(\mathrm{ha})^{1}$ & $\%$ da área urbana ${ }^{2}$ & & área (ha) ${ }^{1}$ & $\%$ da área urbana ${ }^{2}$ & & área $(h a)^{1}$ & $\%$ da área urbana ${ }^{2}$ \\
\hline$F 1$ & 0,14 & $0,00 \%$ & $\overline{G 1}$ & 9,26 & $0,09 \%$ & $\mathrm{L1}$ & 9,39 & $0,09 \%$ \\
\hline$F 2$ & 0,90 & $0,01 \%$ & G2 & 0,68 & $0,01 \%$ & L2 & 35,29 & $0,33 \%$ \\
\hline F3 & 1,12 & $0,01 \%$ & G3 & 0,86 & $0,01 \%$ & L3 & 34,22 & $0,32 \%$ \\
\hline $\mathrm{F} 4$ & 0,35 & $0,00 \%$ & G4 & 13,17 & $0,12 \%$ & L4 & 2,85 & $0,03 \%$ \\
\hline F5 & 2,84 & $0,03 \%$ & G5 & 81,56 & $0,76 \%$ & L5 & 7,13 & $0,07 \%$ \\
\hline F6 & 3,56 & $0,03 \%$ & G6 & 5,57 & $0,05 \%$ & L6 & 812,40 & $7,61 \%$ \\
\hline $\mathrm{F} 7$ & 35,60 & $0,33 \%$ & G7 & 44,16 & $0,41 \%$ & $L 7$ & 528,05 & $4,95 \%$ \\
\hline$F 8$ & 0,86 & $0,01 \%$ & G8 & 26,34 & $0,25 \%$ & L8 & 278,47 & $2,61 \%$ \\
\hline F9 & 0,59 & $0,01 \%$ & G9 & 2,21 & $0,02 \%$ & & & $0,00 \%$ \\
\hline F10 & 2,88 & $0,03 \%$ & G10 & 197,40 & $1,85 \%$ & & & $0,00 \%$ \\
\hline F11 & 7,60 & $0,07 \%$ & G11 & 9,77 & $0,09 \%$ & & & $0,00 \%$ \\
\hline F12 & 1,13 & $0,01 \%$ & G12 & 52,97 & $0,50 \%$ & & & $0,00 \%$ \\
\hline F13 & 14,06 & $0,13 \%$ & G13 & 101,24 & $0,95 \%$ & & & $0,00 \%$ \\
\hline F14 & 11,50 & $0,11 \%$ & G14 & 11,70 & $0,11 \%$ & & & $0,00 \%$ \\
\hline F15 & 1,35 & $0,01 \%$ & G15 & 19,65 & $0,18 \%$ & & & $0,00 \%$ \\
\hline F16 & 0,77 & $0,01 \%$ & G16 & 104,07 & $0,98 \%$ & & & $0,00 \%$ \\
\hline F17 & 3,43 & $0,03 \%$ & G17 & 50,02 & $0,47 \%$ & & & $0,00 \%$ \\
\hline F18 & 0,50 & $0,00 \%$ & G18 & 26,43 & $0,25 \%$ & & & $0,00 \%$ \\
\hline F19 & 2,70 & $0,03 \%$ & G19 & 14,61 & $0,14 \%$ & & & $0,00 \%$ \\
\hline $\mathrm{F} 20$ & 0,21 & $0,00 \%$ & G20 & 5,99 & $0,06 \%$ & & & $0,00 \%$ \\
\hline $\mathrm{F} 21$ & 0,13 & $0,00 \%$ & G21 & 339,18 & $3,18 \%$ & & & $0,00 \%$ \\
\hline$F 22$ & & $0,00 \%$ & G22 & 157,48 & $1,48 \%$ & & & $0,00 \%$ \\
\hline F23 & 0,11 & $0,00 \%$ & & & $0,00 \%$ & & & $0,00 \%$ \\
\hline F24 & & $0,00 \%$ & & & $0,00 \%$ & & & $0,00 \%$ \\
\hline $\begin{array}{ll}\mathrm{F} 25 \\
\end{array}$ & 1,59 & $0,01 \%$ & & & $0,00 \%$ & & & $0,00 \%$ \\
\hline TOTAL & 93,93 & $0,88 \%$ & TOTAL & 777,68 & $7,29 \%$ & TOTAL & 1707,80 & $16,00 \%$ \\
\hline
\end{tabular}

1: Áreas aproximadas

2: Área urbana $\sim 107 \mathrm{Km} 2$

3: Área total do Município $=420 \mathrm{Km} 2$

Fonte: Levantamentos de Campo dos participantes do PBMS

Nesta ocasião do levantamento, um grupo de moradores assessorado pela equipe da FSPUSP, procurou identificar também as glebas de ociosas dentro da malha urbana (provável reserva para empreendimentos imobiliários futuros), tendo em vista a discussão em curso da revisão da Lei do Plano Diretor municipal. 
Foram identificados também loteamentos/condomínios fechados ou que apresentam dificuldade de integração com o restante da cidade, por ocasionarem bloqueio ou interrupção do sistema viário, entrada e saída única para veículos, portarias com seguranças privados, sistemas de câmaras e/ou cancelas.

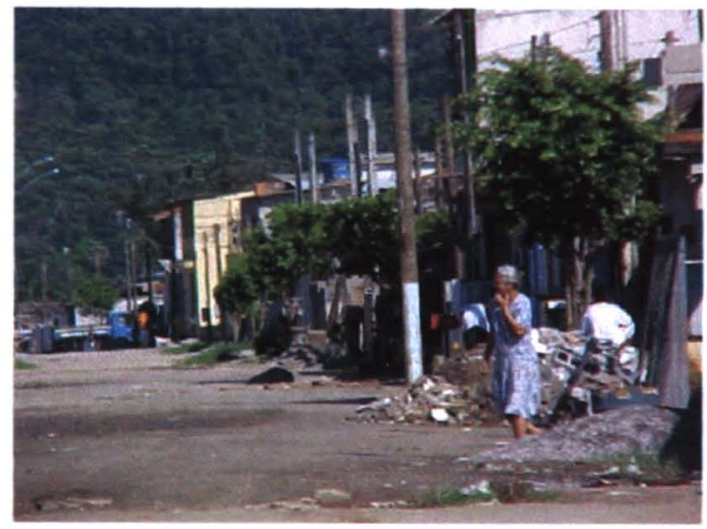

Fotografia 3 - Favela levantada pelos MORADORES PARTICIPANTES DO PBMS

Observando-se a Foto Aérea do Município de Bertioga, no final deste capitulo, pode-se notar que boa parte das favelas e glebas ainda disponíveis situam-se na primeira metade da extensão do município (do Centro até o Indaiá). A maior parte das terras que já foram destinadas como loteamentos/condomínios fechados (ou não integrados à malha urbana) localiza-se na $2^{\text {a }}$. metade do território do município (da Praia de São Lourenço até a Boracéia).

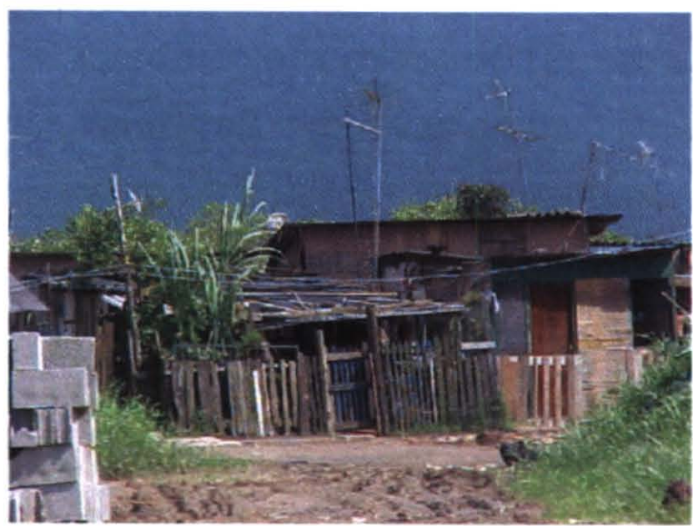

Fotografia 4 - Moradias precárias levantadas em Bertioga

A maioria das favelas de Bertioga ainda não foi urbanizada. Entretanto, segundo os técnicos da prefeitura, entre as 15 favelas citadas naquele levantamento da PMB, existem algumas, em que tiveram início, além do 
processo de melhorias com infra-estrutura e regularização fundiária, ações de assistência técnica para pequenas reformas nas unidades. Entre elas estão: Indaiá, Mangue Seco, Boracéia e Ilha II.

A análise dos dados da Tabela 17 acima permite verificar a intensidade da desigualdade no acesso a terra urbana na cidade. Considerando que a área urbana do município corresponde a $107 \mathrm{Km} 2$ (a Área total do município é de $420 \mathrm{Km} 2)$, verificamos que a soma das áreas de todas a favelas $\mathrm{e}$ assentamentos precários levantados pela equipe do PBMS (onde reside parte significativa da população) equivale a $0,88 \%$ da superfície da área urbana. Enquanto isso a soma das áreas já utilizadas pelos loteamentos $\mathrm{e}$ condomínios fechados e/ou com dificuldade de integração na malha urbana equivalem a $16 \%$ da mesma superfície urbana (Tabela 17 ).

A soma das áreas de glebas ainda vazias ou ociosas dentro da área urbana (entre a Rodovia Rio-Santos e a Praia) corresponde a $7,29 \%$ da superficie urbana. Cabe lembrar que essas glebas são propriedades privadas, e de acordo com o relato de políticos e moradores locais, boa parte deve ser destinada também para mais e novos empreendimento de turismo e veranismo (Tabela 17). O restante das áreas urbanas, correspondem a loteamentos na área central, loteamentos comuns e abertos distribuídos pelo território da cidade, áreas totalmente protegidas (de mangue por exemplo), etc.

De acordo com o relato de técnicos e gestores da prefeitura são inúmeras e constantes as tentativas de invasão e ocupação de novas áreas bem como as ações de repressão e desalojamento das famílias em moradias ilegais. Assim, em função desta dinâmica de pressão constante pela ocupação (invasão) de novas áreas, há que considerar que têm surgido novos núcleos, mesmo que relativamente escondidos e pequenos além do adensamento dos já existentes. Os técnicos admitem isso verbalmente, embora não documentem o quadro. O levantamento realizado pelo PBMS em dezembro de 2003 identificou diversos desses núcleos nascentes.

Veja-se relato de um membro da Secretaria do Meio Ambiente e Obras em Seminário do Curso de Formação promovido pela FSPUSP: 
"Que é uma preocupação de toda a população quanto à questão de controle de invasões, e se encontram mais de $50 \%$ nas áreas de preservação ambiental. Infelizmente a gente tem que conter e existe uma legislação (...) é um trabalho difícil pra quem executar, é um trabalho difícil pra quem está sujeito também.. tem .. que fazer isso daí, e é o nosso dia-dia infelizmente. É o nosso dia-dia. As nossas ações, nós temos uma guarda patrimonial que faz toda a fiscalização, nós temos não só os fiscais de obras, como fiscais de meio ambiente, como a própria guarda ambiental que faz esse patrulhamento e está conseguindo conter aquele ímpeto um pouco maior. $O$ problema é quando (a invasão) é direcionada (organizada) como aconteceu em alguns lugares, de serem 14 edificações e num final de semana de tijolo, e a gente chega lá na segunda-feira, ou no próprio domingo ir lá (...) e demolir, isso é complicado (...) então esse é um problema que é temporário nosso, é um problema sociocultural todo. (...) A legislação esta ai pra ser cumprida. Nós já tivemos lá no Jd.(...) a gente pegou machados, e tivemos que fazer algumas detenções, e isso é o ponto cardíaco (...) mas é o nosso trabalho, que tem que estar sendo envolvida toda a legislação, envolvida a própria policia civil, a policia civil ambiental (...)" (Membro da Secretaria de Meio Ambiente e Obras da PMB em seminário do Curso de Formação de Agentes Multiplicadores, em outubro de 2001).

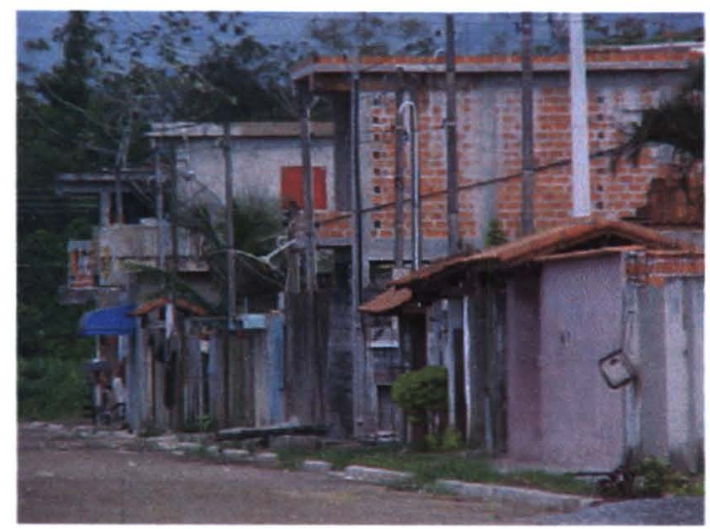

Fotografia 5 - FAVELA NA PERIFERIA DE BERTIOGA, ONDE HÁ PRESSÃO POR NOVAS OCUPAÇÕES ILEGAIS

Como se pode ver, a dinâmica de tentativa de novas invasões e as investidas para contenção e desalojamento são inúmeras e constantes - faz parte do cotidiano. Estas ações contam com o apoio de muitos munícipes que 
consideram a favela uma manifestação da desordem e a relacionam com as drogas como se verá no capítulo 6 .

A esta dinâmica de atuação policial e repressora, feita em nome da ordem e da lei (ambiental), por uma cidade mais limpa, segura e higiênica, poder-seia traçar um paralelo com as ações sanitaristas e higienistas do final do século $X I X$ e início do século $X X$, descritas no capítulo 2 do trabalho. As maiores vítimas deste histórico controle continuam sendo os mais pobres, os excluídos, os migrantes (ou imigrantes).

Voltando à Bertioga, como o território é fragmentado, alternando trechos loteados com trechos de mata de restinga, a identificação e controle de desmatamentos ou atividades ilegais (de todos os tipos) torna-se mais difícil. Recentemente a Diretoria de Operações Ambientais da Secretaria de Meio Ambiente e Obras da PMB adquiriu um pequeno avião tipo "ultra leve", que faz vôos semanais (às vezes diários) levantando, fotografando e flagrando diversos tipos de ocorrências ilegais como: incêndios, queima de lixo, lançamentos de dejetos nos rios, abertura de loteamentos ilegais por grileiros, desmatamentos em condomínios e loteamentos fechados sem licenciamento ambiental e também invasões da população de baixa renda.

Com relação aos loteamentos irregulares e clandestinos constata-se que recentemente a prefeitura iniciou um trabalho de regularização fundiária em alguns loteamentos na cidade - entretanto os processos ainda estão em andamento.

Os técnicos da prefeitura, consideram loteamento irregular aquele que contou com um projeto para sua aprovação, mas na sua implantação, o loteador/empreendedor não atendeu às exigências de suprir o mesmo com a infra-estrutura. Já o loteamento clandestino é considerado aquele que iniciou um processo de aprovação na prefeitura, porém sua implantação não respeitou o próprio projeto.

Também, com relação aos loteamentos irregulares e clandestinos, os técnicos da prefeitura alegam que não possuem dados precisos. Entretanto sabe-se que constituem uma gama diversa de tipologias na cidade. Há os habitados por moradores de baixa renda e os habitados por moradores de renda média. Boa parte desses loteamentos possui processos de aprovação e 
foram projetados no tempo em que Bertioga pertencia ao município de Santos, de modo que os registros de Cartório ainda permanecem vinculados àquele município, gerando mais dificuldades para 0 processo de regularização fundiária pretendido pelo poder público municipal.

Alguns moradores mais antigos chegaram a relatar oralmente como terrenos da cidade foram "esquentados" por operações de grilagem no passado, envolvendo atuais proprietários e pessoas públicas importantes do municipio

As favelas, por sua vez, não possuem, obviamente, nenhum projeto de aprovação na sua implementação e estão à margem de todas as leis urbanísticas, de edificação e código de obras e de meio ambiente - são assentamentos totalmente "espontâneos".

Desta forma, a população mais excluida e mais pobre está concentrada nas favelas, em alguns cortiços e em parte dos loteamentos clandestinos e irregulares. Já existem também alguns moradores de rua nas proximidades do centro e da balsa que faz a travessia para o Guarujá.

De acordo com o Diagnóstico Situacional do Município de Bertioga elaborado por técnicos do setor de Vigilância Sanitária da Secretaria da Saúde e Bem Estar da PMB e por pesquisadores da FSPUSP (Ribeiro et. al., 2002), o déficit habitacional quantitativo do município naquele ano era de 4.000 unidades.

Segundo informações verbais dos técnicos da Secretaria de Habitação, Planejamento e Desenvolvimento Urbano (SHPDU) da PMB, cálculos recentes (2003) realizados no município estimam que o déficit quantitativo atual é da ordem de 5.000 unidades habitacionais.

Os técnicos do setor de promoção social da SHPDU da PMB consideram, a partir de levantamentos pontuais, atendimentos à população e da observação "in locu", o valor médio de 4 pessoas por domicílio, um pouco acima da média indicada pelo IBGE para a cidade como um todo de 3,48 .

Segundo relatos de moradores, técnicos e políticos de Bertioga, o processo de surgimento dos primeiros núcleos de favelas, coincidiu com a instalação dos grandes empreendimentos imobiliários - loteamentos e condomínios voltados, principalmente para o público veranista, a partir do final da década de 1970 e em 1980. 
Sobre isso, um morador e participante do Projeto Bertioga Município Saudável comenta, durante a apresentação de seu trabalho em uma oficina, acerca "do que não gosta na cidade":

"não gosto do problema habitacional, dos aluguéis, 56\% da população vive no subúrbio na beira dos rios, e ao mesmo tempo, a maioria das casas (no restante da cidade) está tudo vazia". (morador de Bertioga e participante da Oficina de Habitação promovida durante o I Curso de Formação de Agentes Multiplicadores, novembro de 2001).

Outro morador relaciona, na sua fala, os diversos problemas: das favelas com a questão dos domicílios de segunda residência desocupados, com os da migração e os da violência:

"vendo os problemas, desmatamentos da vegetação nativa (...) ao lado de um monte de condomínios que ficam vazios, assim é fácil, assaltos depredações, drogas (...) as pessoas vêm no feriado, vêem um monte de casas e de construção e pensam que tem bastante emprego, ai tentam morar aqui. Aí (depois) vêm as invasões, ligação a céu aberto (de esgotos), problemas nas praias, etc". (morador de Bertioga e participante da Oficina de Habitação promovida durante o I Curso de Formação de Agentes Multiplicadores, novembro de 2001).

De fato, diversos moradores, técnicos e políticos que testemunharam, relatam que as favelas do Indaiá e de Boracéia (hoje entre as maiores da cidade) se iniciaram com os ex-operários das obras dos Loteamentos Riviera de São Lourenço e Morada da Praia na praia de São Lourenço e de Boracéia respectivamente.

A outra favela importante, a Vicente de Carvalho II, segundo os atores locais, surgiu por iniciativa (nada saudável) de vereadores da cidade que promoviam ou incentivavam - com pagamento de passagens, e até "kit barraco" (composto por uma cesta básica para construir um barraco de madeira) - a vinda de migrantes de outros estados do Brasil em troca de vantagens pessoais (votos) nos periodos de pleitos eleitorais, nos anos 1990. Esta prática apesar de não constar registrada nos documentos pesquisados é confirmada verbalmente por várias fontes locais, e certamente contribuiu para o aumento da migração e para o aumento da população nas favelas. 
Um registro oficial sobre este processo inicial de surgimento e crescimento dos assentamentos subnormais, encontra-se na versão do primeiro e atual (até $1^{\circ}$. semestre de 2003) Plano Diretor de Desenvolvimento Sustentado do Município de Bertioga, elaborado em 1998:

"(...) assiste-se nesta década de 90 ao surgimento nefasto de processos de favelamento, não obstante as tentativas heróicas de contenção, que são, como não poderia deixar de ser, fruto apenas do defasamento sociológico de uma legislação de parcelamento anacrônica e inadequada ao momento difícil em que mergulhou a população mais carente, que se vê obrigada à migrar de suas regiões de origem, não mais em busca de melhor condição de vida, porém, o que é pior, da própria sobrevivência (...)". (Bertioga, 1998).

Dados fornecidos verbalmente pelos responsáveis pelo trabalho social da Secretaria de Habitação da PMB indicam que existem pelo menos três favelas situadas parcialmente em áreas de risco de inundação/alagamento: Ilha I com um total de 80 domicilios, Mangue Seco com total de 250 domicílios e Vicente de Carvalho II com total de 410 domicílios, perfazendo um total de 740 domicílios. Se considerarmos uma média de 4 pessoas por domicílio obtém-se cerca de 2.960 pessoas nestas três favelas.

Todavia, como estas favelas estão parcialmente em áreas de risco, possuem unidades em setores mais próximos à margem de rios e corpos d'água, logo sujeitos ao risco, e unidades em setores que estão fora de risco. Os técnicos da prefeitura afirmam que estão em curso projetos e ações para viabilizar a remoção e provisão de moradia para essas familias. (Bertioga, 2002).

\section{dinâmica das ocupações ilegais/invasões urbanas}

Apesar das ações iniciais em curso pela PMB cuja descrição realizaremos no próximo item, consideramos que a ausência de uma política habitacional integrada com as outras políticas urbanas de saneamento, transportes e mobilidade (praticamente inexistentes) consistente nas duas últimas décadas, aliada ao crescimento demográfico intenso, com participação considerável da população de baixa renda, tem provocado o aumento de densidade dos assentamentos irregulares já ocupados, como as favelas, por 
exemplo, e ocasionado, conseqüentemente, a pressão por ocupação de novas áreas.

Estas ocupações ilegais (invasões), como já mencionado, têm sido fortemente reprimidas pela prefeitura, como se pode ver no discurso de um profissional do segundo escalão da Secretaria de Meio Ambiente e Obras da PMB, durante Seminário do I Curso de Formação de Agentes Multiplicadores para Assentamentos Humanos Saudáveis, promovido no âmbito do Projeto Bertioga Municipio Saudável.

"Invasão, bom, invasão nós temos uma diretoria específica que cuida desse caso que é o DOA, é uma diretoria da Secretaria do Meio Ambiente, Diretoria de Operações Ambientais que tem feito monitoramento sistemático. Hoje mesmo quando eu estava saindo para vir para cá, o diretor estava chegando com uma ferramenta, uma cavadeira ou coisa parecida de um barraco que eles tinham ido derrubar. Então é um serviço que eu não gostaria de ter, eu digo o seguinte que toda a parte charmosa da Secretaria do Meio Ambiente cabe à minha diretoria, a parte difícil cabe ao DOA que é realmente demolir um barraco, desalojar alguém e tem família é meio complicado e não é nada charmoso, eu pelo menos acho assim, mas infelizmente não se pode conviver com a ocupação irregular, como eu disse na primeira fala, ninguém é faturado porque quer, mas a administração não pode permitir que manguezais, e APP - Área de Preservação Permanente sejam tomadas de assalto. Por necessidade a gente sabe, mas nós temos que preservar porque são áreas de preservação permanente. O Carlos Sérgio falou, alguém, 0 Quirino, se eu não me engano, falou em loteamentos populares e o Carlos Sérgio tocou no assunto, realmente é muito dificil que se aprovem novos loteamentos, mas estão sendo feitos estudos junto a nova Secretaria que vai ser criada que é a Secretaria da Habitação (SHPDU), onde programas da CDHU e programas como PAR (Programa de Arrendamento Residencial) da Caixa Econômica Federal, que estão sendo implementados, para, não loteamentos populares. Mas condomínios populares. Então são condomínios abaixo de quinze mil metros e porque abaixo de quinze mil metros? Porque se nós tivermos que chegar acima de quinze mil metros nós entramos na legislação do Graprohab. No Graprohab tem assento, entre outras entidades, o DEPRN (Departamento Estadual de Proteção dos Recursos Naturais). Então 
nós teremos sérias dificuldades em aprovar qualquer tipo de intervenção que for de domínio do DEPRN. Então nós operamos abaixo de quinze mil metros para que esta legislação fique em nivel municipal. Nós sabemos a dificuldade que nós temos em licenciar 373,23 m2 que foi a área que foi embargada na sexta-feira. Então nós sabemos também da dificuldade que nós vamos ter em liberar quatorze mil, novecentos e noventa, treze mil, mas esse é um compromisso que a Administração tem, nós temos um déficit habitacional considerável e a Administração tem esse propósito. 0 nosso prefeito, até pela própria formação acadêmica tem essa sensibilidade, do social. Então olha com muito carinho para que essa questão do déficit habitacional de baixa renda seja também implementado, a sua solução".

Como se pode notar, do ponto de vista da população de baixa renda que migra para a cidade, além dos conflitos e dificuldades advindas da sobrevivência na condição de exclusão social em termos de renda, emprego, escolaridade, condições de saúde, há o conflito permanente proveniente da ação dos agentes e fiscais locais (DOA, guarda ambiental municipal e guarda civil) que cumprem um papel, como expressado "nada charmoso".

Em entrevista ao Jornal da Baixada (de circulação regional) de 22 a 28 de setembro de 2001, um dos diretores da Secretaria de Meio Ambiente confirma: "(...) mensalmente são desmanchadas seis casas populares (barracos ou casas autoconstruídas ilegalmente) ${ }^{1}$ e nas últimas semanas a prefeitura vem enfrentando o problema das ocupações irregulares nos bairros Jardim Ana Paula, Jardim Vista Linda e Balneário Mogiano em Boracéia (...) Bertioga tem uma população fixa de aproximadamente 31.000 habitantes e talvez o número de habitantes que estejam em casas populares seja de aproximadamente 15.000. Por isso, não queremos que a cidade se deteriore. Precisamos de apoio da população (no caso, para fiscalizar e denunciar as invasões utilizando o disque-denúncia recém implementado naquele período) (...)" (Jornal da Baixada, 2001).

Os entraves para implementar uma política habitacional compromissada com o acesso e o direito à terra urbanizada e o direito à moradia são inúmeros como se poder notar, entre os quais: insuficiência de recursos, o preço elevado da terra afetado pelas condições de um mercado voltado para

\footnotetext{
${ }^{1}$ Grifo nosso.
} 
atender os turistas, a inexistência de um banco ou estoque de terras públicas municipais para habitação social, existência de um mercado muito reduzido incapaz de atender demandas locais de renda, por exemplo entre 3 e 6 salários mínimos. Por fim, outro entrave costuma ser a percepção de muitos atores locais (moradores, técnicos e políticos), muitas vezes equivocada e/ou marcada por recortes ideológicos superficiais ou preconceituosos acerca da população migrante e pobre, dos moradores das favelas, acerca inclusive, do meio ambiente e da sua preservação.

\subsubsection{Dados sobre a favela do Indaiá}

O diagnóstico para assentamentos subnormais do Município de Bertioga elaborado como requisito para o Programa Habitar Brasil/Bid (Bertioga, 2002), mostra alguns dados sobre a favela do Indaiá (ver Foto Aérea Município de Bertioga - pág 175; Aerofoto 3 - pg 176 e Aerofoto 4 - pg 177). Segundo o relato de diversos moradores e técnicos da cidade, a favela do Indaiá surgiu durante e após as obras para a construção do Riviera de São Lourenço. Em 2002 era a maior favela da cidade com cerca de 430 domicílios. Segunda a prefeitura, sua ocupação ocorreu a partir do ano de 1982. Neste assentamento precário e irregular $43 \%$ dos moradores encontram-se na faixa etária de 22 a 45 anos, sendo que $11 \%$ são crianças que possuem de 0 a 6 anos, $18 \%$ na faixa de 7 a 14 anos, $12 \%$ na faixa de 15 a 17 anos e $10 \%$ possuem de 18 a 21 anos de idade. Mais da metade dos seus moradores são crianças e jovens até 21 anos. (Gráfico 7).

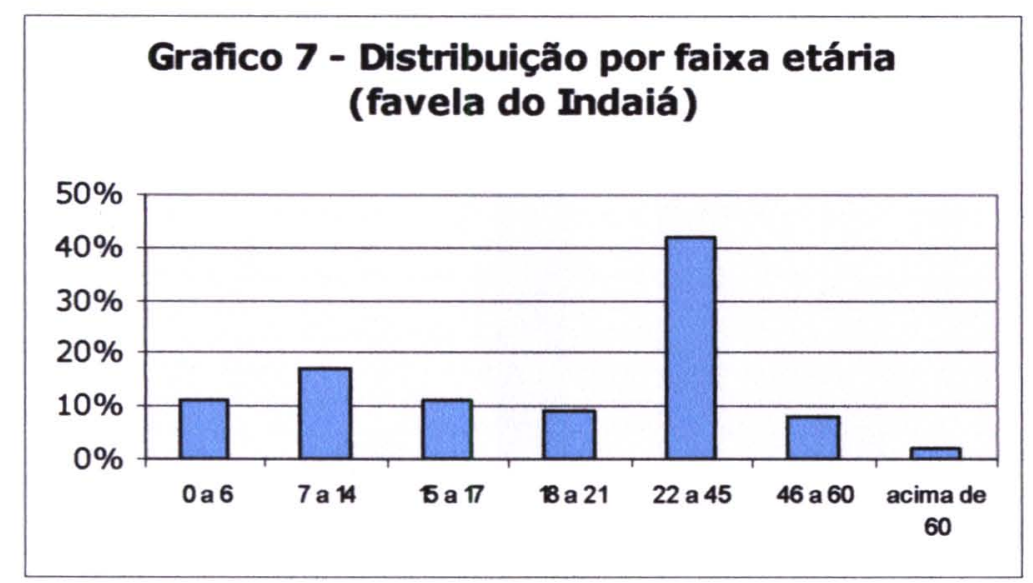

Fonte: Prefeitura do Município de Bertioga, 2002 
Do ponto de vista da ocupação econômica, dos que se encontram na idade economicamente ativa, mais da metade exercem algum tipo de atividade produtiva. Os que declararam ser empregados correspondem a $35 \%$, autônomos $22 \%$ e os que vivem de "bicos" $32 \%$. Ainda, cerca de $5 \%$ realizam trabalhos domésticos, $2 \%$ declararam ser aposentados, $2 \%$ desempregados e $1 \%$ declarou ser pensionista (Gráfico 8).

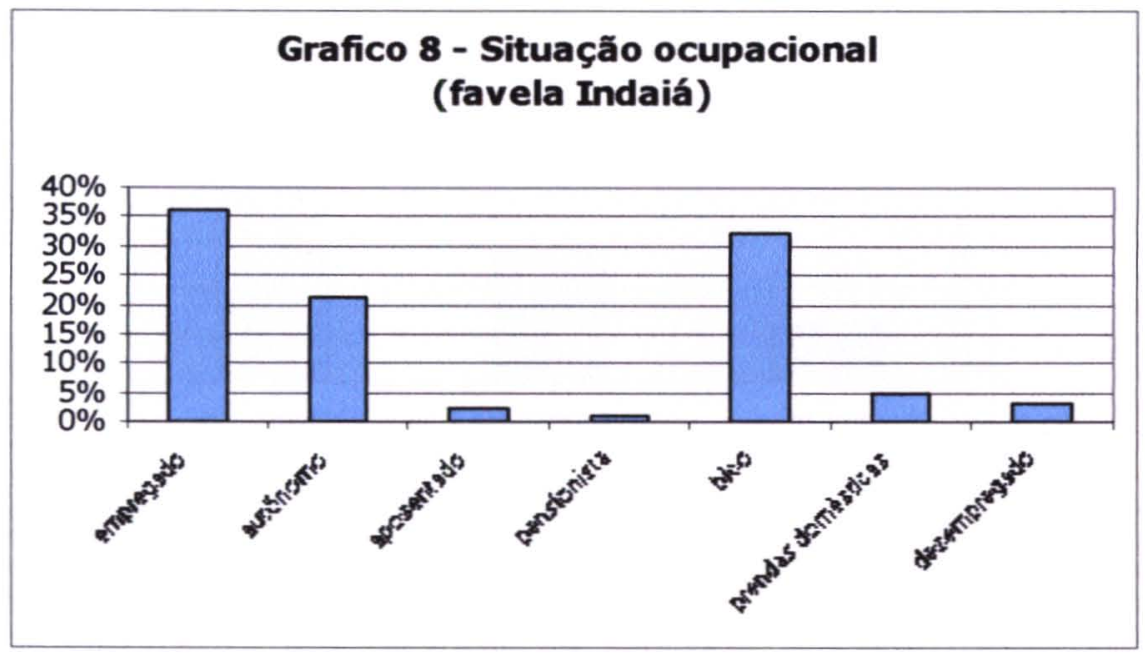

Fonte: Prefeitura do Município de Bertioga, 2002

Considerando a dinâmica populacional regional, pode-se notar que os seus moradores estão relativamente estáveis ou consolidados no local de moradia. Cerca de $98 \%$ reside na favela há mais de 4 anos, sendo que $88 \%$ residem de 4 a 10 anos. Cerca de $47 \%$ reside de 4 a 5 anos, $41 \%$ de 6 a 10 anos e $10 \%$ residem de 11 a 15 anos. Apenas $1 \%$ declarou residir há mais de 15 anos na área (Gráfico 9).

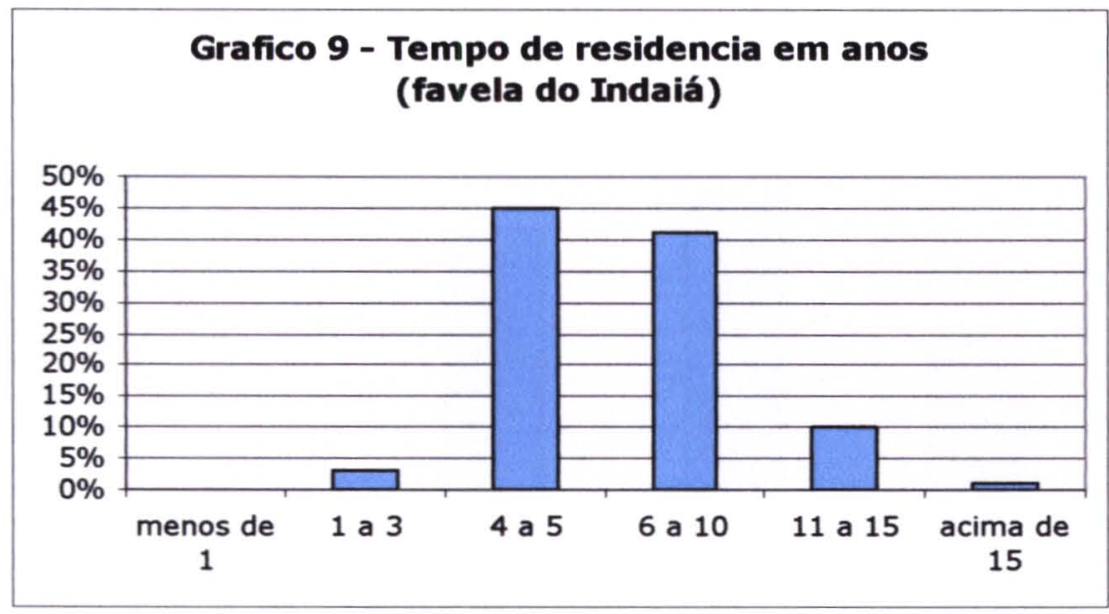

Fonte: Prefeitura do Município de Bertioga, 2002 
Nesta favela, em $92 \%$ dos casos o uso do domicílio é exclusivamente residencial, entretanto $7 \%$ têm uso misto com comércio e $1 \%$ misto com serviços. Com relação ao material de construção nota-se que $62 \%$ são de alvenaria, $27 \%$ de madeira e $11 \%$ possuem materiais mistos (Gráfico 10 ).

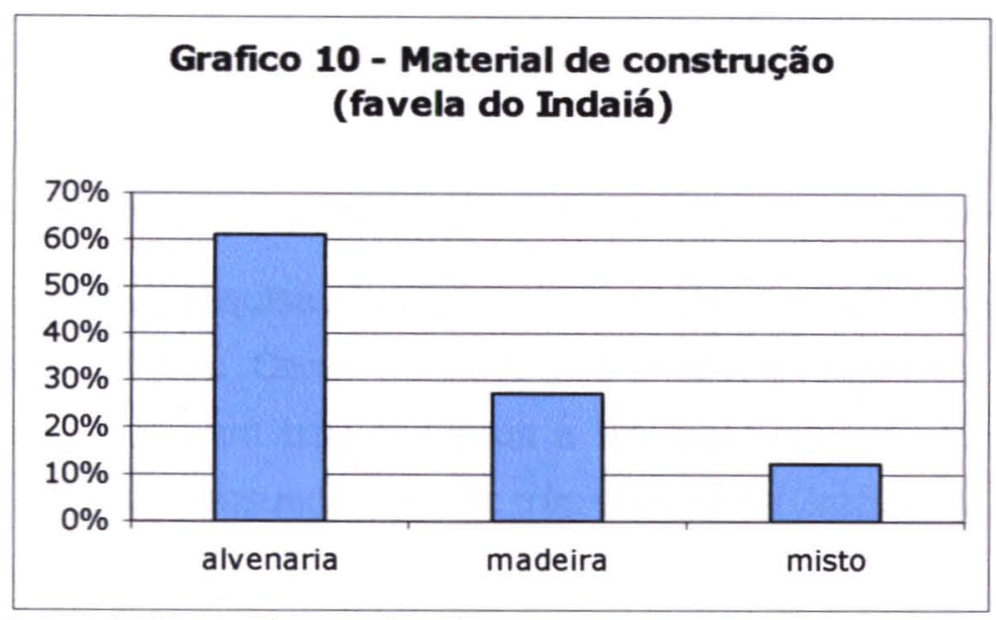

Fonte: Prefeitura do Município de Bertioga, 2002

Chamam a atenção, a baixa proporção de unidades com uso exclusivamente de alvenaria como material de vedação, e a alta proporção de unidades de madeira ou materiais mistos (38\%) comparativamente à São Paulo e outras cidades como Diadema, que possuem favelas mais antigas e mais consolidadas (Gráfico 10). Além do tempo de desenvolvimento do núcleo de favela outra possivel explicação para isso é o custo mais alto dos materiais de construção nas cidades do litoral, comparativamente a São Paulo, seja devido ao custo do frete, seja, devido ao contexto de mercado de casas de materiais mais voltado para as obras turísticas, portanto mais inflacionado.

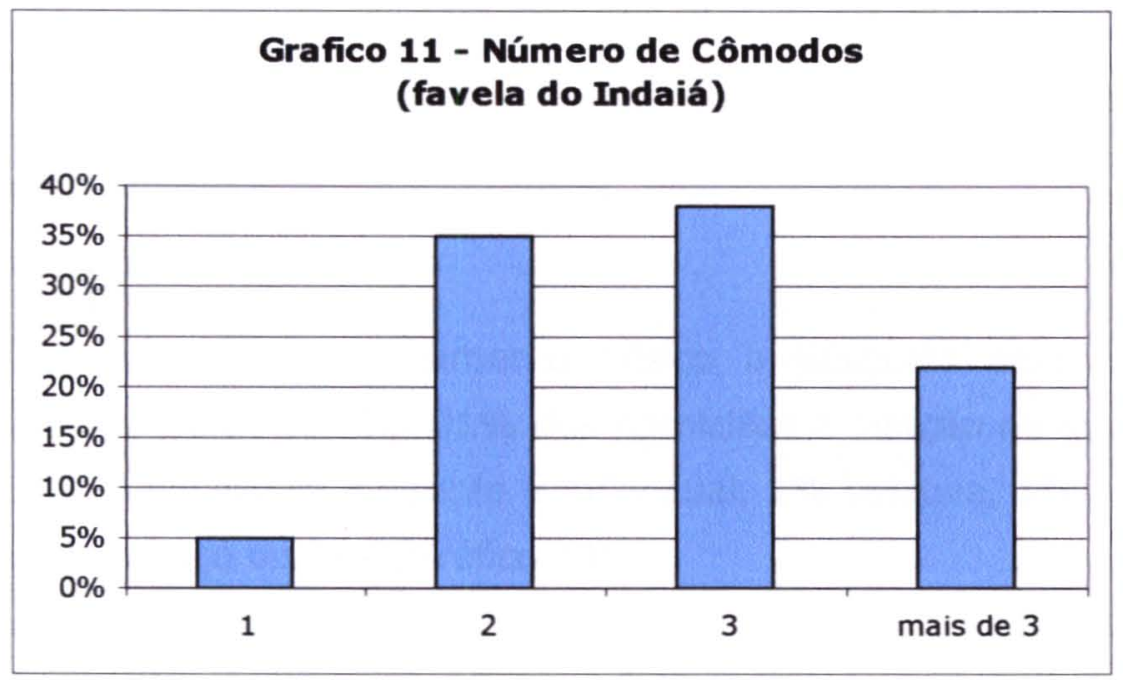

Fonte: Prefeitura do Município de Bertioga, 2002 
De acordo com relato dos técnicos da PMB a população das favelas mais consolidadas vem realizando melhorias e alterando o material de construção. Esta é uma tendência já observada e documentada. Conforme afirma Taschner (1997) sobre a evolução das favelas em São Paulo: "é espantosa a mudança do perfil do tipo predominante de construção: se em 1973 e em 1980 1,3\% e 2,4\% das casas eram de alvenaria, em 1987 50,5\% dos domicílios favelados tem paredes externas em tijolo ou bloco de concreto $e$ em 1991 praticamente 75\% das casas são de material durável"

Do total pesquisado no Indaiá, $98 \%$ dos domicílios são próprios e apenas $2 \%$ são cedidos. Cerca de $35 \%$ das unidades possuem apenas dois cômodos, $39 \%$ possuem três cômodos e $5 \%$ possuem um cômodo. Apenas $22 \%$ das moradias possuem mais de três cômodos (Gráfico 11).

Todas as unidades possuem banheiros, sendo que cerca de $98 \%$ possuem banheiro individual interno e apenas $2 \%$ possuem banheiro individual externo (Gráfico 12). Não há banheiros de uso coletivo (Bertioga, 2002).

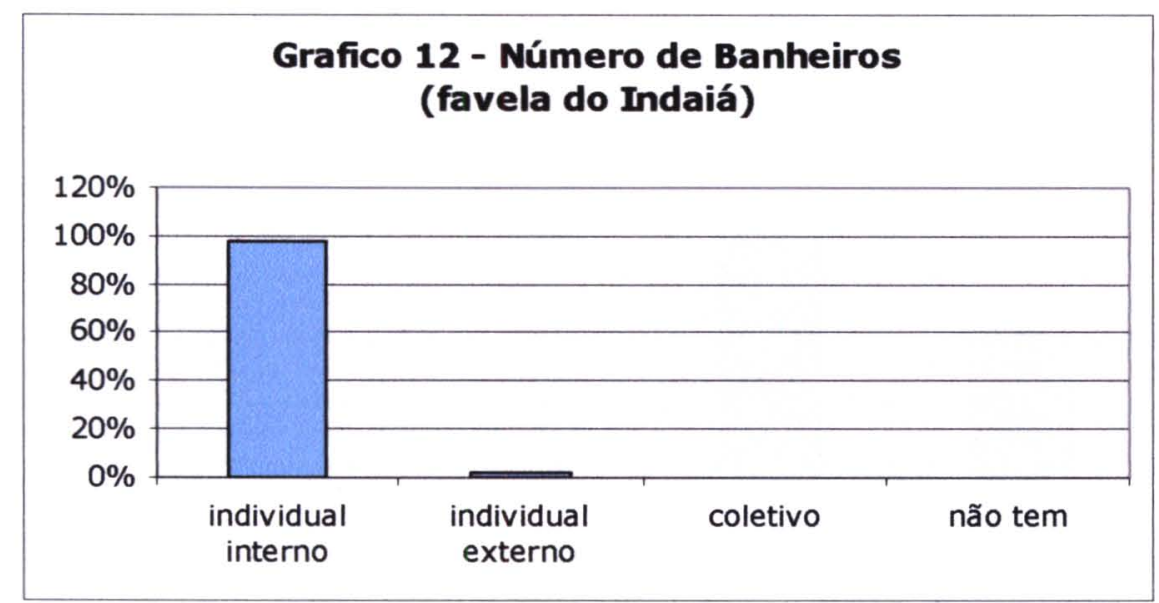

Fonte: Prefeitura do Município de Bertioga, 2002

Com relação ao saneamento básico a pesquisa apresenta dados mais comprometedores. Em $91 \%$ dos domicílios a ligação da água é clandestina. Em $7 \%$ dos casos a ligação é individual, 1\% coletiva, 1\% emprestada e 1\% utilizam poço ou bica (Gráfico 13). 


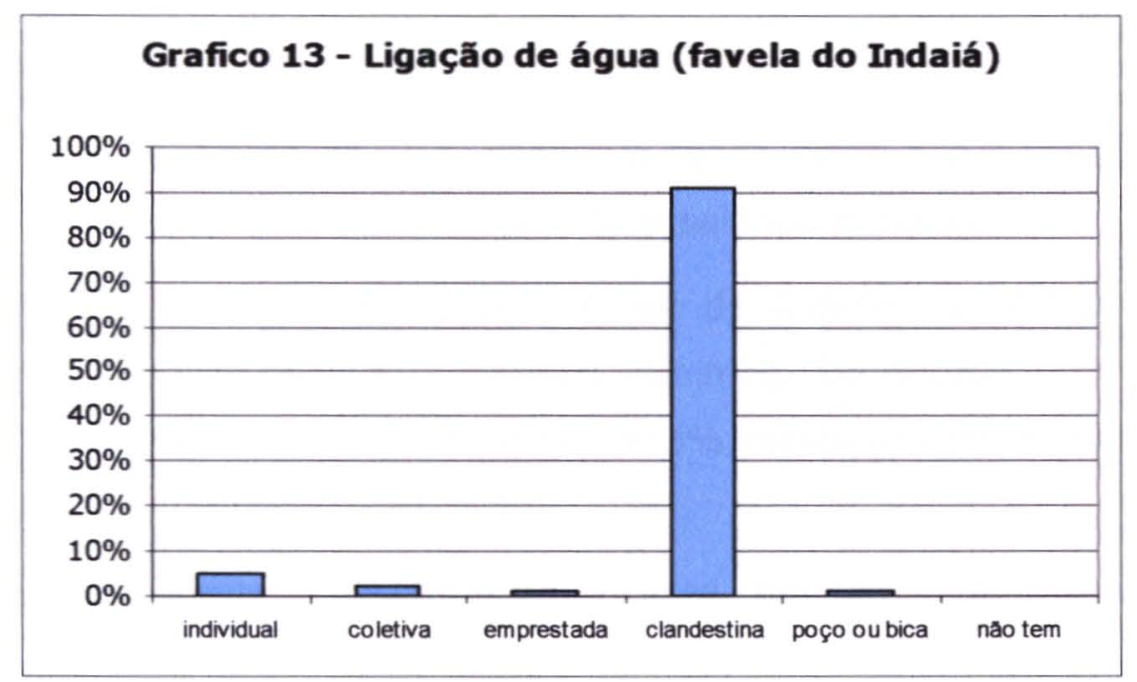

Fonte: Prefeitura do Município de Bertioga, 2002

O esgotamento sanitário é solucionado por meio de fossa em $56 \%$ dos domicílios e o mesmo é lançado a céu aberto por outros $41 \%$ dos domicílios. Apenas $3 \%$ estão conectados à rede pública de esgotamento sanitário. Todas as unidades contam com coleta pública de resíduos sólidos (Gráfico 14).

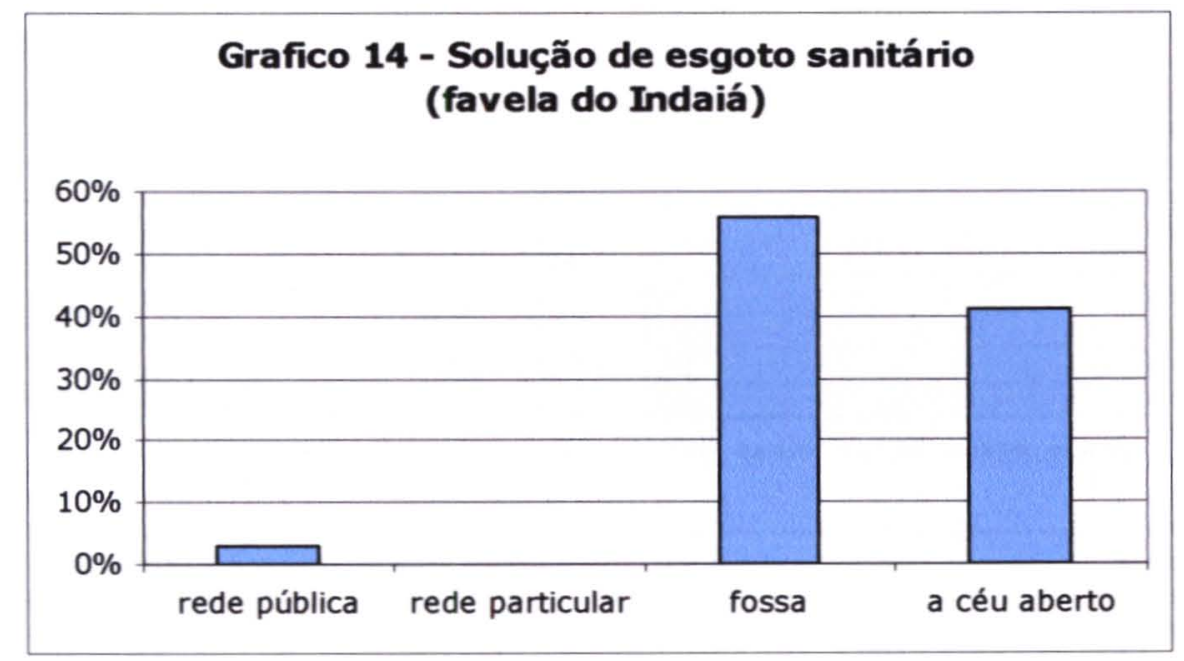

Fonte: Prefeitura do Município de Bertioga, 2002

A ligação de energia elétrica é individual em $60 \%$ dos casos, coletiva em $12 \%$ dos casos, emprestada em $17 \%$ e clandestina em $11 \%$ (Bertioga, 2002). 
Com relação à renda dos chefes de família nota-se que cerca de $6 \%$ não possuem renda, enquanto que $10 \%$ possuem rendimentos até 0,99 salários mínimos. Cerca de $16 \%$ possuem renda entre 1 e 1,99 salários mínimos e $46 \%$ possuem renda entre 2 e 2,99 salários mínimos.

Nota-se que a maioria dos chefes de família, ou $78 \%$ do total recebem rendimentos de 0 a 3 salários mínimos. De acordo com esses dados, na favela no Indaiá apenas cerca de $3 \%$ recebem rendimentos superiores à 4 salários mínimos (Gráfico 15).

É importante considerar que esta favela ainda não foi plenamente urbanizada. Após as intervenções de urbanização com provisão adequada de infra-estrutura e serviços essenciais, desadensamento e construção de unidades novas para famílias removidas os parâmetros tendem a melhorar sensivelmente.

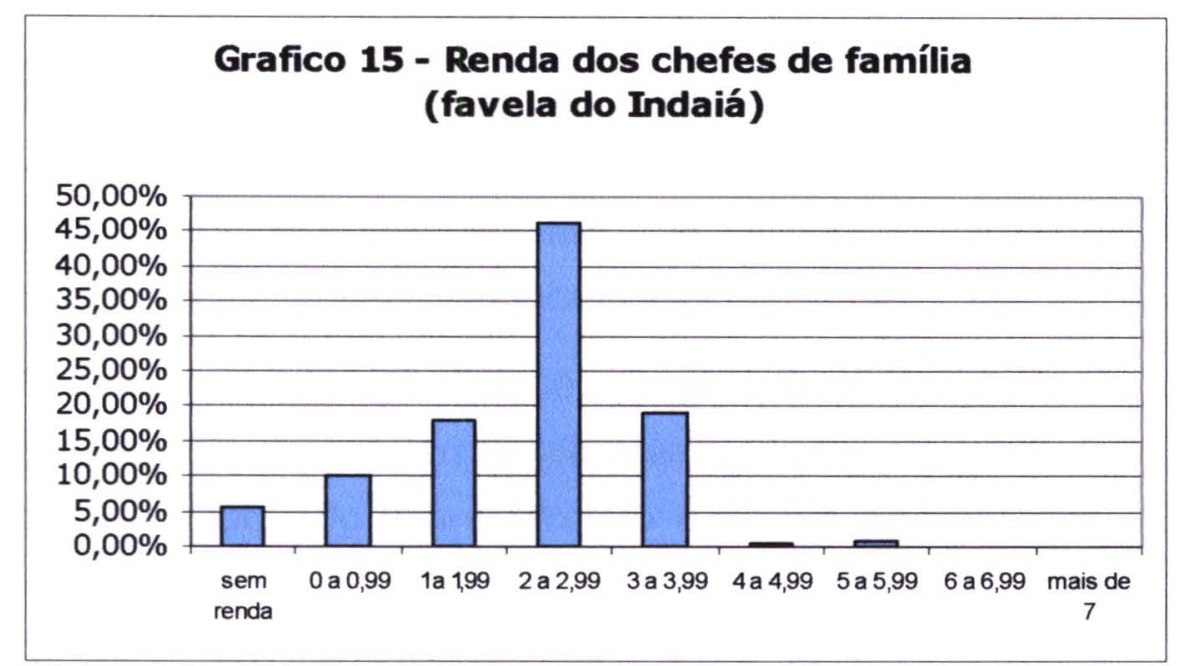

Fonte: Prefeitura do Município de Bertioga, 2002

Como mencionado, a maior parte das favelas da cidade não foi urbanizada. A prefeitura aguarda a aprovação de financiamentos para poder urbanizar algumas e tem procurado realizar melhorias (utilizando recursos próprios ou casados de programa de outros órgãos como a CEF), com infra-estrutura urbana em algumas favelas da cidade. Os técnicos da Secretaria de Habitação, Planejamento e Desenvolvimento Urbano (SHPDU) afirmam também que têm realizado assessoria técnica e jurídica para os moradores 
das favelas onde se desenvolvem as melhorias de infra-estrutura e urbanização.

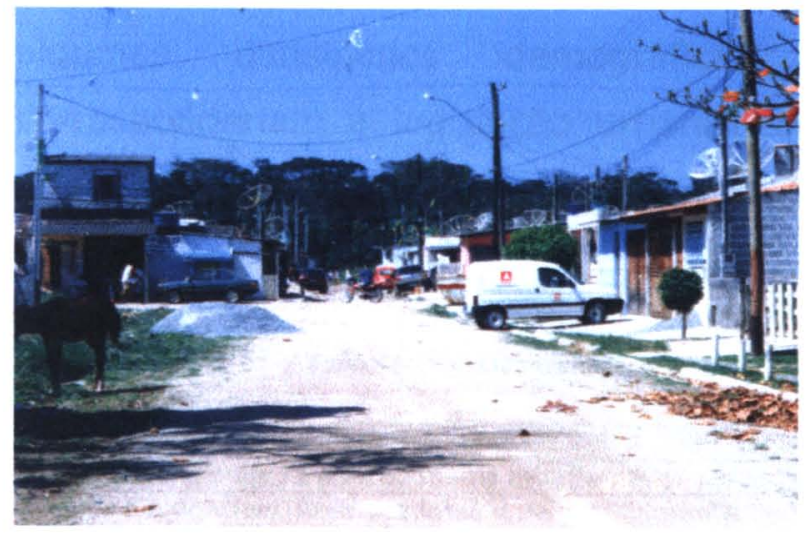

Fotografia 6 - FaVela do INDAIÁ, ONDE É MAIOR O NÚMERO DE MORADORES PERMANENTES

\subsubsection{Densidade e oferta de terra urbana}

Durante o levantamento e análise de diferentes índices, parâmetros urbanísticos e características urbanas de Bertioga, chamou-nos a atenção pela desigualdade que expressa - as diversas situações de densidade bruta encontradas em diferentes localidades da cidade.

A densidade demográfica ou populacional relaciona a quantidade de moradores a uma determinada área ou bairro. Laura Bueno (2000) em sua tese de doutorado sobre "Projeto e Favela: metodologia para projetos de urbanização" considera que "a análise desse indicador torna possível comparar condições de habitabilidade de favelas com outros locais da cidade". De acordo com a autora, a densidade populacional tem sido utilizada como parâmetro urbanístico na literatura técnica, em planos diretores, assim como no cálculo da previsão de infra-estrutura urbana (Bueno, 2000).

Acioly (1998) em seu estudo sobre densidade urbana diferencia densidade (populacional ou demográfica) bruta de densidade líquida. A densidade bruta expressa o número de pessoas residindo numa determinada área urbana dividida pelo total da área em hectares, incluindo escolas, espaços públicos, logradouros, áreas verdes e outros equipamentos públicos. Já a densidade 
líquida, expressa a mesma relação entre pessoas residindo numa determinada zona urbana, porém dividindo pela área estritamente utilizada para fins residenciais.

Bueno (2000) com base em Crespo (1997) na Tabela 18, discute sobre algumas densidades demográficas de zonas urbanísticas que corresponderiam à legislação urbanística de Belo Horizonte (Crespo 1997 apud Bueno 2000).

Tabela 18 - Densidade segundo legislação de Belo Horizonte - MG

\begin{tabular}{l|c}
\hline caracteristicas dos setores & dens. bruta (hab/ha) \\
\hline Setores residenciais unifamiliar: lotes de 400 a 1000 m2 & $50-120$ \\
\hline Setore residenciais de padrão médio multifamiliar: casas geminadas: lotes de 360 a 600 m2 & $130-300$ \\
\hline Prédios residenciais. Área dos lotes igual ou superior a 360 m2 & $400-800$ \\
\hline Prédios residenciais e comerciais. Área central da cidade. Ocupação prox à saturação & $600-1500$ \\
\hline
\end{tabular}

Fonte: Adaptada de Crespo (1997)

A pesquisa realizada pelo LabHab - Laboratório de Habitação e Assentamentos Humanos da Faculdade de Arquitetura e Urbanismo da Universidade de São Paulo sobre "Parâmetros para urbanização de favelas" (LabHab 1999), sistematizadas e discutidas também por Bueno (2000), mostra que em diversas favelas urbanizadas pesquisadas em cinco municípios brasileiros - São Paulo, Diadema, Goiânia, Rio de Janeiro e Fortaleza, as densidades variam conforme a Tabela 19 abaixo.

\begin{tabular}{c|c|c}
\hline \multicolumn{2}{c}{ Tabela 19 - Densidades em favelas pesquisadas (LabHab) } \\
\hline \multirow{2}{*}{ cidade } & favela & $\begin{array}{c}\text { densidade bruta } \\
\text { (hab/ha) }\end{array}$ \\
\hline São Paulo & Santa Lúcia II & 506 \\
\hline \multirow{2}{*}{ Diadema } & Jd. Esmeralda & 881 \\
\cline { 2 - 3 } & Barão de Uruguaiana & 814 \\
\cline { 2 - 3 } Fortaleza & Vila Olinda & 388 \\
\hline \multirow{2}{*}{ Goiânia } & Castelo Encantado & 89 \\
\cline { 2 - 3 } & Jd. Conquista & 150 \\
\hline \multirow{2}{*}{ Rio de Janeiro } & Jadeira dos Funcionários/Pq. & 1.193 ou 881(1) \\
\hline
\end{tabular}

fonte: LABHAB (1996)

(1) contando equipamentos

A título de exemplo, na referida pesquisa realizada nas favelas já urbanizadas constatou-se que em São Paulo a favela Santa Lúcia apresenta 
densidade de 506 hab/ha enquanto a favela Jd. Esmeralda apresenta a densidade de $881 \mathrm{hab} / \mathrm{ha}$ (Tabela 19).

Tabela 20 - Densidade em Conjuntos Habitacionais ou Loteamentos Populares

\begin{tabular}{c|c}
\hline tipologia & densidade bruta (hab/ha) \\
\hline $\begin{array}{c}\text { Parque Bancários / Jd. Sinhá - } \\
\text { Loteamento irregular - São Paulo } \\
\text { (Ceneviva, 1994) }\end{array}$ & 325,73 \\
\hline $\begin{array}{c}\text { Conjunto Cohab Ribeirão Preto (Falcoski, } \\
\text { 1997) }\end{array}$ & 96 \\
\hline $\begin{array}{c}\text { Conjunto José Bonifácio - Cohab São } \\
\text { Paulo (Castro, 1986) }\end{array}$ & 450 \\
\hline $\begin{array}{c}\text { Conjunto Rincão - HABI - São Paulo } \\
\text { (Falcoski, 1997) }\end{array}$ & 956 \\
\hline
\end{tabular}

fonte: Bueno (2000)

A densidade mais alta corresponde à favela Ladeira dos Funcionários no Rio de Janeiro com $1.193 \mathrm{hab} / \mathrm{ha}$ e a mais baixa a favela Jd. Conquista com 89 hab/ha (Tabela 19).

A tabela 20 mostra como conjuntos habitacionais ou loteamentos populares na cidade São Paulo podem apresentar diferentes densidades. Por exemplo: Parque dos Bancários (Ceneviva, 1994 apud Bueno 2000) que é um loteamento irregular com 325 hab/ha, Conjunto José Bonifácio que é um conjunto da Cohab-SP ${ }^{2}$ com 450 hab/ha (Castro 1986 apud Bueno 2000), Conjunto Rincão de Habi/Sehab ${ }^{3}$ com 956 hab/há (Tabela 20).

O Conjunto habitacional Celso Garcia em São Paulo que é um empreendimento de densidade alta na região central de São Paulo produzido pelo Programa Funaps ${ }^{4}$ Vertical da Sehab/PMSP em sistema de mutirão autogerido (ou co-gerido) apresenta densidade de 1.800 hab/ha (Comarú, 1998).

2 Cohab: Companhia Metropolitana de Habitação ligada à Secretaria de Habitação e Desenvolvimento Urbano da Prefeitura do Município de São Paulo.

3 Habi: Superintendência de Habitação Popular da Secretaria de Habitação e Desenvolvimento Urbano da Prefeitura do Município de São Paulo.

${ }_{4}$ Fundo Municipal de Atendimento à População Moradora de Habitação Subnormal. A Construção foi viabilizada pelo processo de Mutirão e Autogestão. 
Embora se possa constatar um crescimento dos núcleos de favelas no município estudado, a maioria dos bairros e loteamentos - em aproximadamente $84 \%$ do território - apresentam densidade bruta da população permanente muito baixa, de 0 a 10 hab/ha, como se pode verificar no mapa sobre densidades do município (Mapa 2, no final deste capítulo).

As razões para isso podem ser diversas. Em primeiro lugar, o território está ocupado principalmente por casas de veraneio, que utilizam espacialmente grandes porções de terra do território da cidade com pouca quantidade de moradores permanentes. (Cepedoc, 2002). Segundo, em função da existência de inúmeros vazios urbanos - fragmentação - lotes vagos, terrenos e glebas ociosas dentro da malha urbanizada. Outro motivo é a tipologia de casas, na maioria térreas em lotes e ruas de dimensões que ocasionam densidades mais baixas. Isto se deve também à legislação urbanística municipal atual - Plano Diretor e Lei de Uso e Ocupação do Solo - que adota parâmetros, como recuos frontais, laterais, de fundo, coeficientes de aproveitamento e taxas de ocupação que não contribuem para otimizar o uso da infra-estrutura urbana, influenciando no sentido de baixas densidades urbanas ${ }^{5}$.

A análise da densidade populacional bruta em diferentes regiões do município permite constatar uma profunda iniqüidade de condições no acesso à terra urbana e à moradia.

Tabela 21 - Bertioga: Algumas favelas e loteamentos: população, área e densidade (aproximadas)

\begin{tabular}{l|c|c|c|c}
\hline \multicolumn{1}{c|}{ favelas } & população (1) & área (m2) (2) & $\begin{array}{c}\text { área } \\
\text { (ha) }\end{array}$ & $\begin{array}{c}\text { densidade } \\
\text { (hab/ha) }\end{array}$ \\
\hline Jd Veleiros & 177 & 2300 & 0,23 & 769,6 \\
\hline Vicente de Carvalho II & 1371 & 40000 & 4,00 & 342,8 \\
\hline Ilha II & 597 & 10000 & 1,00 & 597,0 \\
\hline Indaiá & 1519 & 8500 & 0,85 & 1787,1 \\
\hline Indaiazinho & 218 & 1200 & 0,12 & 1816,7 \\
\hline Boracéia & 516 & 5000 & 0,50 & 1032,0 \\
\hline
\end{tabular}

(1) Dados Censo IBGE 2000

(2) área aproximada

\footnotetext{
${ }^{5}$ Ver no Anexo II, as Tabelas contendo os parâmetros e coeficientes da atual legislação de uso e ocupação do solo municipal.
} 
Enquanto grandes porções da cidade são ocupadas por loteamentos ou condomínios que atendem prioritariamente os veranistas (e alguns moradores permanentes locais) e que apresentam baixa densidade populacional bruta (menos de 10 hab./ha); os assentamentos precários, especialmente as favelas que acolhem boa parte da população permanente ocupam porções ínfimas de terra e apresentam altíssima densidade (algumas acima de 1500 hab/ha) conforme mostram as Tabelas 21 e 22.

Tabela 22 - Bertioga: Densidade de alguns loteamentos com concentração de residencias secundárias

\begin{tabular}{l|c|c|c|c}
\hline loteamento / condomínio & população (1) & área (m2) (2) & $\begin{array}{c}\text { área } \\
\text { (ha) }\end{array}$ & $\begin{array}{c}\text { densidade } \\
\text { (hab/ha) }\end{array}$ \\
\hline Riviera de São Lourenço & 1678 & 2121000 & 212,10 & 7,9 \\
\hline Costa do Sol & 1368 & 1950000 & 195,00 & 7,0 \\
\hline Total & 3046 & 4071000 & 407,10 & - \\
\hline
\end{tabular}

(1) Dados Censo IBGE 2000

(2) área aproximada

A população permanente que habita os loteamentos regulares encontra-se principalmente no Centro e em Indaiá - que possuem densidades que variam de 10 a 100 hab/ha. Por outro lado os assentamentos subnormais representam pequenas porções do território, algumas em áreas de risco de inundação, como já mencionado. Já os loteamentos prioritariamente utilizados por segundas residências têm densidade baixíssima. O Riviera de São Lourenço e o Costa do Sol, por exemplo, possuem de 7 a 8 hab/ha (Tabela 22).

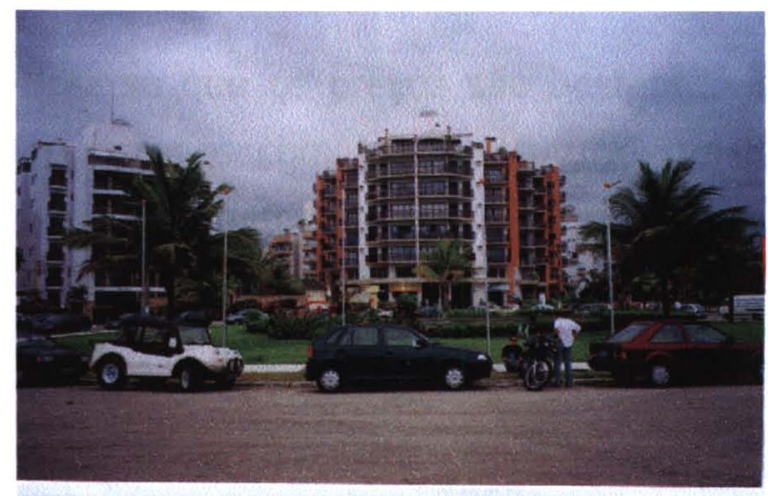

Fotografia 7 - LOTEAMENTO RIVIERA DE SÃo LOURENÇO, CONSIDERADO POR MUITOS UM MODELO, E QUE POSSUI BAIXA DENSIDADE URBANA 
A proporção da ocupação do território pelos dois tipos de moradias significativos de Bertioga, bem como as respectivas taxas de densidade demográfica mostram, de alguma forma, a intencionalidade dos investimentos realizados na produção do espaço construído - uma cidade ao avesso, prioritariamente produzida para os que nela não moram.

Uma das questões centrais que impede o acesso à terra urbanizada e à moradia adequada e legal para a população de baixa renda é o preço dos imóveis urbanos. Pesquisa realizada pela equipe do CEPEDOC (2002) durante as oficinas para a revisão do Plano Diretor junto a imobiliárias locais, mostraram a variação dos preços em função da existência ou não de infraestrutura, da proximidade à praia e do padrão de renda do bairro ou loteamento - predominantemente para moradores de Bertioga ou predominantemente para turistas. (Tabela 23).

Tabela 23 - Bertioga: Preços de terrrenos pesquisados (R\$/m2)

\begin{tabular}{l|c|c}
\hline \multicolumn{1}{|c|}{ bairro / loteamento } & infra-estrutura disponível & preço por m2 \\
\hline Jardim Itapanhaú - proximo ao centro & Completa (água, luz, asfalto, esgoto) & $\mathrm{R} \$ 100,00$ \\
\hline Jardim Albatroz & Sem rua aberta & $\mathrm{R} \$ 50,00$ \\
\hline $\begin{array}{l}\text { Jardim Vicente de Carvalho II - } \\
\text { loteamento frente à favela }\end{array}$ & Asfalto e luz & $\mathrm{R} \$ 40,00$ \\
\hline São Rafael & Asfalto e luz & $\mathrm{R} \$ 40,00$ \\
\hline $\begin{array}{l}\text { Chácaras Vista Linda (baixa densidade) } \\
\text { distante da praia }\end{array}$ & Sem infra-estrutura & $\mathrm{R} \$ 15,00$ \\
\hline Jardim Vista Linda & Sem infra-estrutura & $\mathrm{R} \$ 50,00$ \\
\hline Jardim São Lourenço & - & $\mathrm{R} \$ 50,00$ \\
\hline Guaratuba - distante da praia & completa (água, luz, asfalto, esgoto) & $\mathrm{R} \$ 50,00$ \\
\hline Guaratuba - próximo à praia & completa (água, luz, asfalto, esgoto) & $\mathrm{R} \$ 100,00$ a \\
\hline Balneário Mogiano - distante da praia & sem infra-estrutura & $\mathrm{R} \$ 200,00$ \\
\hline Balneário Mogiano - próximo à praia & sem infra-estrutura & $\mathrm{R} \$ 100,00$ \\
\hline
\end{tabular}

Fonte: Cepedoc - FSPUSP. Projeto Bertioga Município Saudável, 2002

Nota-se que os preços são bastante elevados, principalmente para acessar os terrenos com infra-estrutura. Um corretor quando perguntado por nós onde poderíamos encontrar uma oferta mais adequada para população mais pobre respondeu, algo realista e sincero:

"(...) e rapaz, aqui ninguém faz coisa para pobre não (...)" (corretor de imobiliária respondendo sobre a existência de imóveis populares no município, novembro, 2002). 
De acordo com os corretores de imobiliárias consultados, no mercado local, praticamente não existe oferta real de terrenos, especialmente aqueles dotados de infra-estrutura. A oferta é muito pequena e a procura tende a ser maior. Apesar disso, os corretores reclamam constantemente que o mercado está estagnado, em função das exigências para o licenciamento ambiental de novos loteamentos e novas construções, por parte do DEPRN (motivo de conflito de interpretação e de ações entre Governo do Estado e a prefeitura como mostrado).

Assim, em função das dificuldades dos trâmites de aprovação de loteamentos, de obras, e (nos casos que cabem) obter o licenciamento ambiental para promover a supressão da vegetação, dentro da lei, os terrenos que possuem vegetação em estado secundário ou de regeneração, tem uma liquidez mais baixa - há muita pressão por aprovação de novos loteamentos, porém a maior parte das construções, tem ocorrido nos loteamentos existentes já aprovados nas décadas anteriores. O quadro, segundo os corretores (que se queixam) é de pouca comercialização.

Ao mesmo tempo outras fontes anunciam que cresce 0 número de condomínios em Bertioga. Segundo o Jornal Costa Norte (2002) em edição comemorativa do aniversário de 11 anos de emancipação de Bertioga: "(...) em apenas um ano foram registrados mais de 100 casas e prédios de apartamentos como pertencentes a condomínio (...)". Ainda, segundo o jornal, o Sicon - Sindicato dos Condomínios Prediais do Litoral Paulista afirma que "(...) o município que conta com mais de 300 condomínios é o que registra a maior procura de investidores na construção civil. Em todo o litoral, de Ubatuba a Peruíbe estão cadastrados 12 mil condomínios (...)".

Outro aspecto importante a ser notado é que, segundo informações dos atores locais, diversos proprietários de terrenos e glebas grandes são investidores individuais ou empresas de porte médio ou grande que os adquirem como investimento.

Este tipo de investimento em glebas, dentro da região urbanizada, sem que a propriedade cumpra uma função social, pode e deve ser combatido por uma política urbana municipal, que agora pode contar com os novos instrumentos urbanísticos do Estatuto da Cidade. (Brasil, 2001). 
Neste sentido, alguns autores já estudaram e descreveram sobre a importância de combater a extração de mais valia que os proprietários de terra urbana obtém, beneficiando-se injustamente dos investimentos públicos realizados ao longo do tempo. (Smolka, 2001; Silva, 1998)

\subsubsection{Algumas ações locais para produção ou melhorias em habitação}

Ao contrário da produção para o turismo, a história da produção de moradia para os setores populares e trabalhadores assalariados em Bertioga é muito recente e quase inexistente. Entretanto algumas poucas iniciativas, acreditamos, merecem ser mencionadas.

Uma das primeiras iniciativas, pós-emancipação, registradas por nós, ocorreu em 1998, quando um grupo de funcionários ligados ao Sindicato dos Servidores Municipais de Bertioga, iniciou uma articulação para a constituição de uma cooperativa (Cooperativa Buriquioca). Esta visou a produção de moradias para os funcionários públicos - muitos recémconcursados - que, apesar de trabalhar em Bertioga, residiam em Santos ou Guarujá, por falta de alternativas habitacionais na cidade.

Após cerca de 1,5 ano de negociações e seleção da demanda, tiveram início as obras de um conjunto habitacional de 128 unidades, financiado pela CEF Caixa Econômica Federal com recursos do FGTS - Fundo de Garantia por Tempo de Serviço. Puderam participar os funcionários que comprovassem pertencer à faixa salarial de $R \$ 1.300,00$ a $R \$ 1.600,00$, além do cumprimento da exigência de possuir o nome limpo na praça.

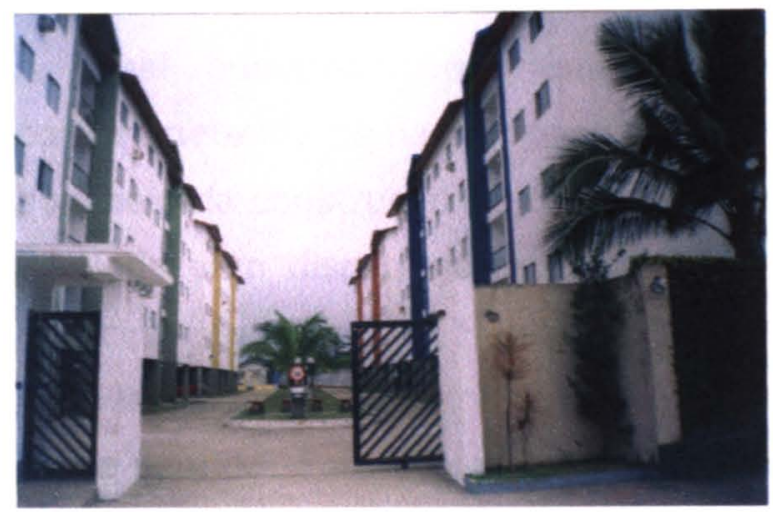

Fotografia 8 - VISTA dO CONJUNTO Habitacional CoOperativa BuRIQUioca, uma das Primeiras E ÚNICAS INICIATIVAS dE Produção de Moradia para os Moradores DO SEGMENTO MÉDIO BAIXO. 
Segundo o relato de um dos idealizadores e organizadores do grupo, por parte do sindicato, o custo unitário do apartamento ficou por volta de $\mathrm{R} \$$ 30.000,00 em valores da época. Segundo a mesma fonte, na ocasião, houve cerca de 700 funcionários interessados em participar do empreendimento, entretanto naquelas condições somente se viabilizaram 130.

Após vários anos de reivindicação e discussão, outro projeto foi iniciado em janeiro de 2002. Trata-se do conjunto de unidades para 59 famílias indígenas da Aldeia Guarani do Rio Silveiras (que fica na divisa de Bertioga com São Sebastião). O empreendimento foi viabilizado pela CDHU Companhia de Desenvolvimento Habitacional e Urbano do Estado de São Paulo, e contou com a intermediação da Prefeitura de São Sebastião.

O projeto teve o mérito de procurar se adequar, tanto em termos de desenho, como de tecnologia e materiais de construção, à linguagem e cultura do povo tradicional indígena. Durante a execução deste trabalho as obras estavam em fase de finalização.

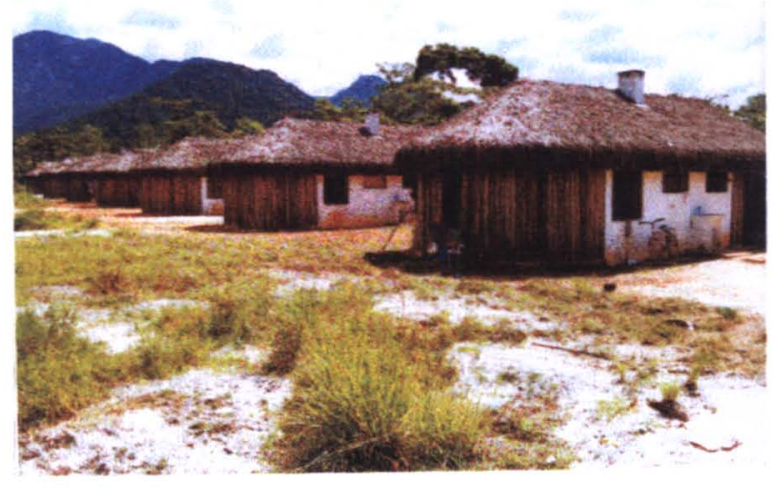

Fotografia 9 - HABITAÇÃo INDIGENA NA Aldeia do Rio Silveiras da EtNia Guarani (EXECUÇÃO DA CDHU)

A atual administração municipal de Bertioga (2001/2004) elegeu-se comprometendo-se na campanha eleitoral, combater o problema da moradia por meio da construção de conjuntos populares. A prefeitura do município de Bertioga vem discutindo desde a administração anterior a possibilidade de participar do Programa Habitar / Brasil / BID, por intermédio da CEF - Caixa Econômica Federal. Entretanto até julho de 2003 não havia uma realização neste sentido. Este projeto previu a intervenção em três favelas da cidade: Boracéia, Indaiá e Indaiazinho. 
Outra tentativa desta administração foi realizada junto ao Programa de Arrendamento Residencial/Modalidade Construção - PAR com financiamento da CEF. Por meio deste programa foram construídas e entregues 240 unidades de apartamentos em edifícios de 5 pavimentos no bairro de Vista Linda - próximo à Rodovia Rio-Santos para o lado da Serra do Mar

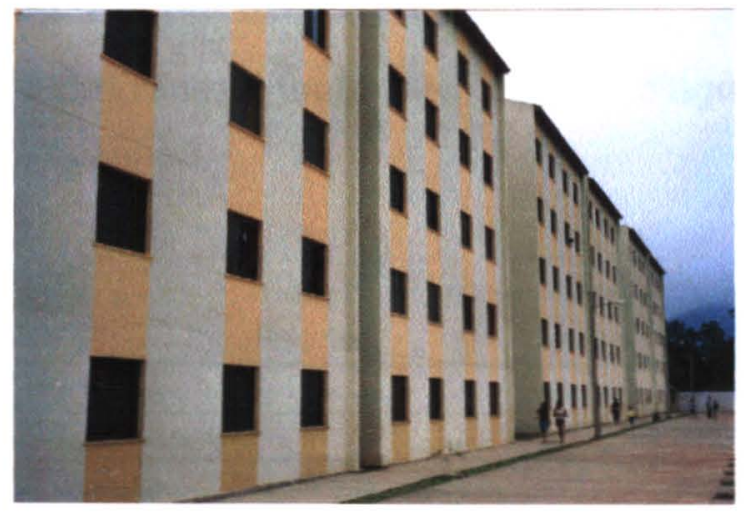

Fotografia 10 - Conjunto Habitacional de 240 UNIDADES, PRODUZIDO COM RECURSOS DA CEF, POR MEIO do PROgRama de ARRENDAMENTO RESIDENCIAL NO JD. VISTA LINDA

Algumas outras iniciativas pontuais têm sido praticadas pela prefeitura como um programa de regularização fundiária (que foi iniciado, em alguns casos, antes da efetiva urbanização e da provisão de infra-estrutura) em favelas e loteamentos irregulares e clandestinos. Mais recentemente ocorrem algumas ações de melhorias e provisão de infra-estrutura em algumas favelas: Indaiá, Mangue Seco, Boracéia e Ilha II.

Foi elaborado também um projeto de uma vila residencial para integrantes da Policia Militar do Estado de São Paulo, que já trabalham na cidade, porém residem em Guarujá ou Santos e têm interesse em residir em Bertioga. Neste caso, uma negociação casada indica também, por meio do PAR da CEF, a produção de 32 unidades para reassentar famílias em situação de risco na favela do Mangue Seco e a produção de 126 unidades novas para policiais militares do Estado de São Paulo. 


\subsection{Saneamento Ambiental}

Os indicadores de saneamento da cidade revelam a sua face mais dramática de periferia da Macro-Metrópole Paulista (Mapa1) e ao mesmo tempo periferia da metrópole santista, em tempos de plena explosão demográfica e sob os interesses econômicos e imobiliários locais e regionais (Tabela 24).

O abastecimento de água do município é operado pela Sabesp - Companhia de Saneamento Básico do Estado de São Paulo. O tipo de captação é subterrânea, junto aos corpos d'água da região, particularmente, o Rio Itapanhaú.

Tabela 24 - Saneamento ambiental - Nível de atendimento (\%) - 2000

\begin{tabular}{l|cc|c}
\hline \multicolumn{1}{c|}{ localidade } & abastecimento de água & esgoto sanitário & coleta de lixo \\
\hline Bertioga & 92,1 & 19,49 & 97,67 \\
\hline São Sebastião & 71,75 & 36,48 & 98,51 \\
\hline Guarujá & 92,86 & 72,07 & 98,46 \\
\hline Região da Baixada Santista & 95,93 & 67,00 & 98,74 \\
\hline Estado de São Paulo & 97,38 & 85,72 & 98,90 \\
\hline
\end{tabular}

Fonte: Fundação SEADE (Site www.seade.sp.gov.br, 07/06/03)

Além do sistema da Sabesp o município conta também com sistemas de abastecimento privados em diversos loteamentos e condomínios. Entre eles estão a Sociedade Amigos "Morada da Praia" em Boracéia, a "Codesp" na Usina de Itatinga, a "Consurb" Empresa de Engenharia e a Sociedade Amigos de Guaratuba em Guaratuba, a Sociedade Amigos da Riviera na Riviera de São Lourenço, o Condomínio Hanga Hoa na Vista Linda, a Sociedade Amigos de Caiubura nas Chácaras Caiubura, o SESC - Serviço Social do Comércio no Jardim Rio da Praia e a Sociedade Amigos Jaguareguava no Sitio São João (Ribeiro, 2002).

Do ponto de vista da saúde, é conhecido o fato da poluição das águas de superfície ter como efeito direto sobre a saúde, a aquisição de doenças intestinais e de pele (...), em virtude do consumo e de banhos em águas poluídas. "As doenças intestinais são causadas pela presença de patogênicos na água potável e no ambiente doméstico, o que traz como conseqüência taxas elevadas de mortalidade infantil" (Geo Brasil 2002). 
Conforme se pode observar na Tabela 25 a seguir, em 1991 Bertioga possuía o pior indicador de condição de abastecimento de água da RMBS, com cerca de $72 \%$ dos domicílios atendidos na rede geral por este serviço essencial. Cerca de 23,5\% dos domicílios utilizavam-se de poço ou nascente e 4,6\% utilizavam alguma outra forma de abastecimento. Em 2000 a proporção dos domicílios conectados à rede geral passou para 92\%, com $4 \%$ utilizando-se de poço ou nascente e $4 \%$ de outro meio de abastecimento. De qualquer forma, neste ano o indicador encontrava-se abaixo da media da RMBS de $95,7 \%$ dos domicílios conectados na rede geral (Tabela 25).

\begin{tabular}{|c|c|c|c|c|c|c|c|c|}
\hline \multirow{2}{*}{ municípios } & \multicolumn{4}{|c|}{1991} & \multicolumn{4}{|c|}{2000} \\
\hline & rede gera & poco ou nascente & outra forma (1) & total & rede geral & poço ou nascente & outra forma (2) & total \\
\hline Bertioga & 72 & 23,5 & 4,5 & 100 & 92 & \begin{tabular}{|r|}
4 \\
\end{tabular} & 4 & 100 \\
\hline Cubatão & 90,7 & 8,2 & 1,1 & 100 & 84,6 & 0,9 & 14,5 & 100 \\
\hline Guarujá & 94,8 & 2,6 & 2,6 & 100 & 92,8 & 2,4 & 4,8 & 100 \\
\hline Itanhaém & 78,9 & 18,5 & 2,6 & 100 & 84,6 & 13,4 & 2 & 100 \\
\hline Mongaguá & 92,1 & 5,2 & 2,7 & 100 & 93,4 & 5 & 1,6 & 100 \\
\hline \begin{tabular}{|l|l|} 
Peruíbe & \\
\end{tabular} & 77,9 & 19,6 & 2,5 & 100 & 87 & 11,2 & 1,8 & 100 \\
\hline Praia Grande & 96,7 & 0,6 & 2,7 & 100 & 98,2 & 0,2 & 1,6 & 100 \\
\hline Santos (1) & 99,3 & 0,5 & 0,2 & 100 & 99,5 & 0,2 & 0,3 & 100 \\
\hline São Vicente & 97,1 & 1,8 & 1,1 & 100 & 99,4 & 0,3 & 0,3 & 100 \\
\hline RMBS & 95,6 & 3,1 & 1,3 & 100 & 95,7 & 1,8 & 2,5 & 100 \\
\hline
\end{tabular}

fonte: Emplasa, 2002

(1) domićlios abastecidos com água das chuvas, por carro pipa , fonte pública, pogo, bica, etc., fora da propriedade

(2) domicilios abastecidos com água das chuvas, de reservatório (ou caixa), por carro pipa ou nascente localizados fora do território ou da propriedade

Como se pode notar pelos dados apresentados sobre a favela do Indaiá, e também de acordo com o relato de técnicos da Sabesp de Bertioga e da PMB, as condições de abastecimento de água em alguns assentamentos da cidade são muito precárias. Houve casos em que foi instalado uma bica de água onde grupos de moradores se serviam com baldes e outros recipientes em suas necessidades básicas.

Alguns técnicos da prefeitura e Sabesp alegam preocupação com a intensidade do crescimento populacional e a dificuldade de atender a demanda, principalmente em algumas favelas em áreas particulares.

Todavia, deve-se atentar que é na situação do esgotamento sanitário que reside um dos maiores desafios para as políticas públicas governamentais, tendo em vista suas implicações sobre as condições de vida da população e sobre o meio ambiente. (GEO Brasil 2002). 
Em 1991 (Tabela 26) a situação dos esgotos sanitários em Bertioga era muito precária. Assim como em Mongaguá, em Bertioga não haviam domicílios conectados à rede geral, $53 \%$ dos domicílios possuíam fossa séptica (incluindo ligações à rede pluvial), $27,1 \%$ fossa rudimentar, $11,5 \%$ utilizavam-se de vala como escoadouro da instalação sanitária, 3,3\% utilizavam outras formas de escoadouro (incluindo-se aí rios, lagos e corpos d’água locais).

Tabela 26 - Domicílios particulares permanentes por escoadouro da instalação sanitária, segundo os municípios: 1991

\begin{tabular}{l|c|c|c|c|c|c|c|c}
\hline \multirow{2}{*}{ municipios } & \multicolumn{7}{c}{ escoadouro de intalação sanitária } \\
\cline { 2 - 10 } & rede & fossa séptica & fossa & vala & outro (2) & não & não tem & total \\
\hline Bertioga & - & 53,7 & 27,1 & 11,5 & 3,3 & 0,9 & 3,6 & 100 \\
\hline Cubatão & 18,6 & 64,5 & 0,6 & 2,9 & 9,5 & 0,1 & 3,9 & 100 \\
\hline Guarujá́ & 74,9 & 9,9 & 1,4 & 10,9 & 1,3 & 0,1 & 1,5 & 100 \\
\hline Itanhaém & 4,7 & 69,8 & 7,6 & 11,1 & 1,6 & 2,4 & 2,9 & 100 \\
\hline Mongaguá & - & 64,5 & 13,1 & 11 & 1,5 & 4,9 & 4,9 & 100 \\
\hline Peruíbe & 3,6 & 65,3 & 17,2 & 6,4 & 0,3 & 0,7 & 6,4 & 100 \\
\hline Praia Grande & 25 & 31,5 & 1,4 & 40,3 & 0,2 & 0,2 & 1,3 & 100 \\
\hline Santos & 88,9 & 5 & 1,1 & 2,6 & 1,8 & 0 & 0,5 & 100 \\
\hline São Vicente & 37,6 & 31,8 & 5,2 & 18,7 & 3,9 & 0,1 & 2,7 & 100 \\
\hline \multicolumn{1}{c}{ RMBS } & 56,9 & 23,7 & 3,1 & 11,8 & 2,5 & 0,3 & 1,8 & 100 \\
\hline
\end{tabular}

fonte: Emplasa, 2002

(1) inclúi ligações à rede pluvial

(2) rios, lagos, etc. usados diretamente como escoadouros

Os dados do Censo Demográfico de 2000 do IBGE, mostram que no serviço de coleta de esgotos sanitários de Bertioga a situação é também a mais grave da região. Também neste indicador, a cidade apresenta a condição de maior carência na RMBS, só perdendo para Peruíbe. No ano de 2000, apenas $18,9 \%$ dos domicílios particulares permanentes que possuíam banheiro estavam interligados à rede geral de esgotos ou à rede pluvial (Tabela 27).

\begin{tabular}{|c|c|c|c|c|c|c|c|c|}
\hline \multirow{2}{*}{ municípios } & \multicolumn{6}{|c|}{ sim - tipo de escoadouro sanitário } & \multirow{2}{*}{ não } & \multirow{2}{*}{ total } \\
\hline & rede geral ou pluvial & fossa séptica & fossa rudimentar & vala & outros (1) & total & & \\
\hline Bertioga & 18,9 & 64 & $\mathbf{8 , 5}$ & 4,5 & 1,7 & 97,6 & 2,4 & 100 \\
\hline Cubatão & 44,1 & 20 & 1,6 & 20,1 & 13,1 & 98,8 & 1,2 & 100 \\
\hline Guarujá & 72 & 7 & 1,4 & 11,9 & 6,7 & 99,1 & 0,9 & 100 \\
\hline Itanhaém & 14,8 & 65,9 & 7,8 & 8,4 & 2 & 98,9 & 1,1 & 100 \\
\hline Mongaguá & 18,7 & 60,3 & 9,4 & 6,8 & 3,1 & 98,3 & 1,7 & 100 \\
\hline \begin{tabular}{l|l} 
Peruíbe \\
\end{tabular} & 9 & 68,9 & 17,3 & 1,8 & 1,6 & 98,7 & 1,3 & 100 \\
\hline Praia Grande & 57,6 & 25,1 & 3,1 & 12,7 & 1,2 & 99,7 & 0,3 & 100 \\
\hline Santos (1) & 94 & 0,8 & 0,3 & 1,6 & 3,1 & 99,8 & 0,2 & 100 \\
\hline São Vicente & 66,7 & 17,6 & 3 & 7 & 5,4 & 99,7 & 0,3 & 100 \\
\hline RMBS & 66,7 & 17,7 & 2,8 & 7,7 & 4,5 & 99,4 & 0,6 & 100 \\
\hline
\end{tabular}

fonte: Emplasa, 2002

(1) rios, lagos, etc, usados diretamente como escoadouros 
A grande maioria, correspondente a $64 \%$ do total, utilizava como solução de escoadouro do esgoto sanitário a fossa séptica - que na maior parte da cidade apresenta problemas para um funcionamento adequado devido às características do tipo de solo e ao afloramento do lençol freático. Além disso, a fossa séptica não é apropriada para situações de densidades urbanas mais elevadas. Cerca de $8,5 \%$ dos domicílios particulares permanentes, utilizava fossas rudimentares e $4,5 \%$ a vala como solução de lançamento. Foi detectado ainda que $1,7 \%$ utiliza os corpos d'água como local de descarga direta dos esgotos (Tabela 27).

Observa-se pela Tabela 27, que o município de Santos é o que possui, de acordo com dados do IBGE, o melhor indicador de domicílios conectados à rede geral com $94 \%$ de atendimento por essa solução, seguido do município do Guarujá, São Vicente e Praia Grande com 72,0\%, 66,7\% e 57,6\% respectivamente. Note-se que esses são os municípios mais centrais - ou menos periféricos da RMBS - estão também entre os mais populosos e tiveram seus ciclos de crescimento demográfico mais acentuados há mais tempo (Tabela 27).

Com relação ao tratamento dos esgotos, sabe-se que no Estado de São Paulo, 57\% dos municípios realizam algum tipo de tratamento para remoção da carga orgânica gerada pelos esgotos domésticos e $42 \%$ não fazem nenhum tipo de tratamento (São Paulo, 2002).

Em termos de tratamento dos esgotos sanitários, segundo a Sabesp e a Secretaria de Estado do Meio Ambiente, em Bertioga há uma redução de $21 \%$ a $40 \%$ da carga orgânica, enquanto a média da RMBS é de $56 \%$ de redução de carga orgânica. A população atendida pela coleta e tratamento de esgotos equivalia apenas a 8.411 habitantes em 2000, aproximadamente $27,2 \%$ da população naquele ano (São Paulo, 2002).

No municipio existe também um sistema privado de coleta e tratamento de esgotos sanitários exclusivo da Riviera de São Lourenço. Segundo Ribeiro et al (2002) a Riviera de São Lourenço possui uma rede de $46,5 \mathrm{Km}$ de esgoto para o atendimento de mais de $\mathbf{2 . 8 0 0}$ domicílios e Estação de Tratamento de Esgotos com 4 lagoas ( 1 anaeróbica para $20.700 \mathrm{~m} 3$ e 3 facultativas para $61.263 \mathrm{~m} 3$ de capacidade). 
A capacidade atual de tratamento da Estação corresponde à 32.000 pessoas. O sistema conta também com 12 Estações Elevatórias que bombeiam o material para as 9 torres de carga. Após o tratamento há uma redução de cerca de $80 \%$ na carga orgânica do esgoto (Ribeiro et al, 2002).

Com relação ao destino dos resíduos sólidos na RMBS, nota-se que o município de Bertioga, neste indicador está mais próximo à média da região. Segundo os dados do Censo de 2000 a cidade conta com 97,5\% do lixo coletado nos domicílios particulares permanentes. Cerca de 1,9\% do lixo é queimado, $0,2 \%$ enterrado, $0,3 \%$ jogado no rio, mar, terrenos ou rua (Tabela 28).

\begin{tabular}{|c|c|c|c|c|c|c|c|c|c|c|c|c|}
\hline \multirow{2}{*}{ municípios } & \multicolumn{2}{|c|}{ coletado } & \multicolumn{2}{|c|}{ queimado } & \multicolumn{2}{|c|}{ enterrado } & \multicolumn{2}{|c|}{ jogado (1) } & \multicolumn{2}{|c|}{ outro } & \multicolumn{2}{|c|}{ total } \\
\hline & $n^{\circ}$ abs. & $\%$ & $n^{0}$ abs. & $\%$ & $n^{0}$ abs. & $\%$ & $n^{\circ} a b s$. & $\%$ & $n^{\circ}$ abs. & $\%$ & $n^{\circ}$ abs. & $\%$ \\
\hline Bertioga & 8.269 & 97,5 & 157 & 1,9 & 15 & 0,2 & 26 & 0,3 & 12 & 0,1 & 8.479 & 100 \\
\hline Cubatão & 29.491 & 96,3 & 94 & 0,3 & 2 & 0 & 393 & 1,3 & 14 & 0 & 29.994 & 100 \\
\hline Guarujá & 71.009 & 96,4 & 271 & 0,4 & 13 & 0 & 790 & 1,1 & 53 & 0,1 & 72.136 & 100 \\
\hline Itanhaém & 19.070 & 93 & 969 & 4,7 & 141 & 0,7 & 274 & 1,3 & 59 & 0,3 & 20.513 & 100 \\
\hline Mongaguá & 9.276 & 94,4 & 402 & 4,1 & 37 & 0,4 & 95 & 1 & 18 & 0,2 & 9.828 & 100 \\
\hline Peruíbe & 13.664 & 95 & 541 & 3,8 & 76 & 0,5 & 80 & 0,6 & 15 & 0,1 & 14.376 & 100 \\
\hline Praia Grande & 54.519 & 99,1 & 251 & 0,5 & 8 & 0 & 153 & 0,3 & 99 & 0,2 & 55.030 & 100 \\
\hline Santos (1) & 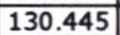 & 99,5 & 81 & 0,1 & 8 & 0 & 361 & 0,3 & 163 & 0,1 & 131.058 & 100 \\
\hline São Vicente & \begin{tabular}{|l|}
83.092 \\
\end{tabular} & 99,5 & 63 & 0,1 & 15 & 0 & 262 & 0,3 & 65 & 0,1 & 83.497 & 100 \\
\hline RMBS & 418.835 & 98,6 & 2.829 & 0,7 & 313 & 0,1 & 2.437 & 0,6 & 495 & 0,1 & 424.909 & 100 \\
\hline
\end{tabular}

fonte: Emplasa, 2002

(1) jogado em terreno baldio ou logradouro, rio, lago ou mar

É importante salientar que o lixo, desde os primeiros encontros com os atores locais no desenvolvimento do PBMS é sentido como um problema grave pelos moradores. Conforme nos mostra Arai (2002), os moradores referem-se à falta de limpeza como algo que deprecia a cidade:

"O mal cheiro do canal e peixes mortos, um cheiro horrível, no forte tem muito lixo na temporada" (Morador da Riviera de São Lourenço durante Oficina do Futuro em outubro, 2001)

"Aqui em Boracéia é o fim é o último bairro - um lixo" (morador de Boracéia na Oficina do Futuro em outubro de 2001)

Ao final do Curso de Agentes Multiplicadores para Assentamentos Humanos Saudáveis em $2001^{1}$ a maioria dos trabalhos finais dos participantes (que constavam de iniciativas e intervenções práticas na cidade) abordou o tema

\footnotetext{
${ }^{1}$ Promovido no âmbito do Projeto Bertioga Município Saudável.
} 
dos resíduos sólidos, como a mostrar para o poder público a necessidade de interferir neste problema. Entretanto as iniciativas realizadas não mobilizaram a prefeitura no sentido de incorporar as estratégias utilizadas e demonstradas pela população como forma adequada de atuar no monitoramento e limpeza de áreas sensíveis (como o Canal de Bertioga, praias e trilhas ecológicas).

Segundo informações dos técnicos da Secretaria Municipal do Meio Ambiente, atualmente (2003) o serviço de coleta de resíduos sólidos é terceirizado a uma empresa privada. A empresa contratada coleta o lixo e realiza uma triagem/separação de materiais orgânicos e inorgânicos na área onde funcionava o Lixão da cidade até 2002. O material orgânico é levado pela empresa para um Aterro Sanitário de Itaquaquecetuba-SP. O material inorgânico, após separado é encaminhado para reaproveitamento ou reciclagem.

Apesar de nunca ter existido um Censo ou levantamento da população de rua, por meio do nosso trabalho e da observação empírica no município, nos últimos quatro anos, foi possivel perceber que tem ocorrido um aumento sensivel da população mais pobre e excluída, notadamente das pessoas em situação de rua. Tem ocorrido também, o trabalho dos catadores de materiais reaproveitáveis como papel branco, papelão, vidro, plástico, latas de alumínio e outros metais.

De acordo com membros de escalão superior da Secretaria Municipal de Meio Ambiente e Obras, a prefeitura não realiza programa de coleta seletiva com participação da população na cidade (nem programa de Educação Ambiental) e não tem aproveitado, na coleta pública, o trabalho dos catadores, na perspectiva de agentes ambientais ou agentes de reciclagem, como ocorre em diversos municípios do Brasil - como Belo Horizonte, Porto Alegre, São Paulo - de maneira integrada à programas de geração de emprego, renda e inclusão social, por meio da organização dos trabalhadores em cooperativas ou associações com capacitação técnica (FNRU, 2003).

No âmbito privado, o Loteamento Riviera de São Lourenço desenvolve um programa de gestão integrada de resíduos sólidos, que inclui coleta separada, triagem, reaproveitamento e reciclagem. Segundo Lichti (2002) "em janeiro de 2001 o programa ultrapassou a marca de 1.000 toneladas de 
lixo reciclado, coletado, triado e vendido. Os números de 2002 ultrapassam a marca de 1.500 toneladas".

Segundo Ribeiro (2002) no mesmo período, em janeiro de 2001 foi coletado cerca de 2.940 toneladas de resíduos domiciliares e 3,02 toneladas de resíduos hospitalares em Bertioga, pelo sistema público municipal.

\subsection{Sistema viário, transportes e mobilidade}

Apesar das referências existentes no texto do Plano Diretor de Desenvolvimento Sustentado de 1998 (Bertioga, 1998), na prática, observase que o município de Bertioga não possui um sistema hierarquizado de vias públicas para a circulação dos veículos.

O sistema viário existente é resultado dos loteamentos e parcelamentos que foram sendo implantados na cidade de forma dispersa e sem obedecer uma lógica e um desenho racional integrador, no sentido da otimização dos investimentos e custos da infra-estrutura urbana.

Dado que o desenvolvimento da cidade sujeitou-se, historicamente, ao interesse dos empreendedores de loteamentos (fechados) e condomínios, dotados de muros, sistemas de segurança, vigilantes particulares, cancelas e portões de entrada, o sistema viário que deveria desenvolver-se paralelamente à Rodovia Rio-Santos, foi interrompido e os automóveis que compõem o tráfego local e que percorreriam deslocamentos interbairros têm que utilizar a Rodovia, aumentando muito o risco de acidentes e ocasionando conflitos de usos e de veículos com efeitos sérios de aumento do risco de acidentes, principalmente nos períodos de temporada.

Esta interrupção do sistema viário é observada, principalmente no caso dos Loteamentos Riviera de São Lourenço e nos loteamentos da praia de Guaratuba (Guaratuba e Costa do Sol).

A implantação de loteamentos espraiados (muitos isolados) horizontalmente pelo território do município ocasionou uma descontinuidade da malha viária e a ocorrência de inúmeros trechos e glebas como vazios urbanos, ainda dotados de mata de restinga. Esse processo foi determinante para o 
desenvolvimento de uma cidade fragmentada do ponto de vista dos assentamentos habitacionais e do sistema viário.

Apesar da legislação detalhista do Plano Diretor Municipal, esta configuração urbanística é típica de casos em que não houve uma articulação adequada entre o planejamento e gestão urbana capaz de coibir a especulação imobiliária. Este fenômeno da desconexão entre planos e gestão, aliás, já é bem reconhecido e debatido entre alguns urbanistas e planejadores (Villaça, 1999, Maricato, 2001).

Essas características e o resultado disso podem ser conferidos, em parte, pela análise das Fotografias Aéreas do município do ano de 2002: uma cidade pouco servida e muito custosa do ponto de vista da infra-estrutura urbana, notadamente os sistemas de saneamento básico, drenagem, viário, pavimentação, transporte e circulação (Agem, 2003).

Não existe um levantamento ou dados disponíveis que indiquem a quantidade exata, mas observa-se que é grande o numero de deslocamentos a pé e principalmente de bicicleta. Apesar disso, os calçamentos para pedestres são inexistentes na grande maioria dos bairros.

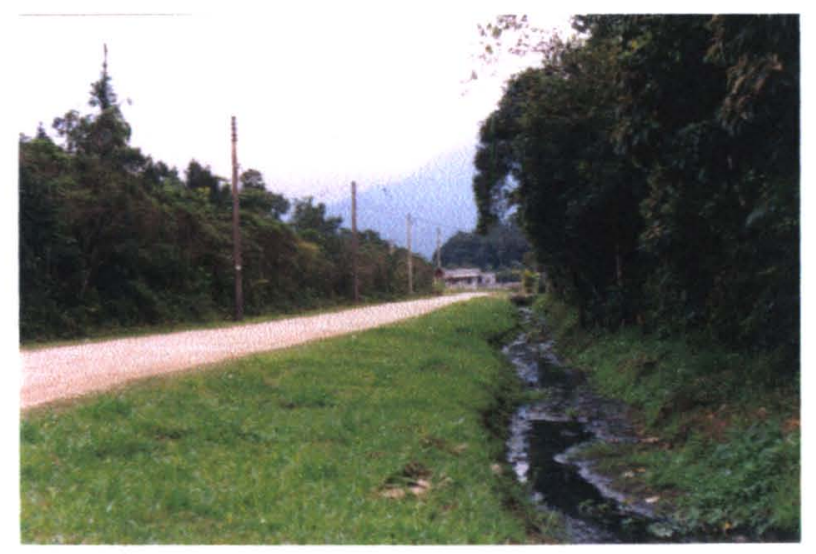

Fotografia 11 - Vala a cÉu aberto em RUA SEM SISTEMA DE DRENAGEM, SEM PAVIMENTAÇÃO E SEM SISTEMA DE ESGOTOS SANITARIOS No Jd. Vista LINDA, BERTIOGA.

Cabe registrar que existe somente uma ciclovia de cerca de $900 \mathrm{~m}$ paralela à Rio-Santos próxima à entrada da cidade, executada no final da gestão $1997 / 2000$ da prefeitura. 
Como muitas ruas não possuem o sistema de micro-drenagem solucionado e a grande maioria não são pavimentados (exceção a algumas ruas do centro e alguns loteamentos predominantemente de segunda residência), os pedestres, as bicicletas e os veículos motorizados disputam as ruas de terra batida existentes nos meses de seca. Como já citado anteriormente neste trabalho, a taxa de pluviosidade é muito alta em boa parte do ano, especialmente no verão. Assim, sucedem inúmeros alagamentos $e$ inundações das vias dificultando a circulação por qualquer meio de transporte.

A taxa de motorização é uma das mais baixas da RMBS, conforme dados do IBGE e do Detran - Departamento Estadual de Trânsito (Emplasa, 2003)², provavelmente, em função dos limites da situação de renda da maioria dos habitantes. Entretanto, o município, devido à condição de Estância Balneária e pólo receptor de grande número de veículos nos períodos de temporada, precisa desenvolver e implementar um plano de transporte e circulação, integrado aos sistemas viários existentes, locais e intermunicipais, considerando principalmente as rodovias, e o sistema de vias locais dos loteamentos. Estes deveriam contemplar a micro e a macro drenagem, pavimentação de vias para automóveis e pedestres e um sistema de ciclovias para atender a população trabalhadora que se desloca cotidianamente a fim de evitar o conflito com os veículos, prevenindo mortes e ferimentos.

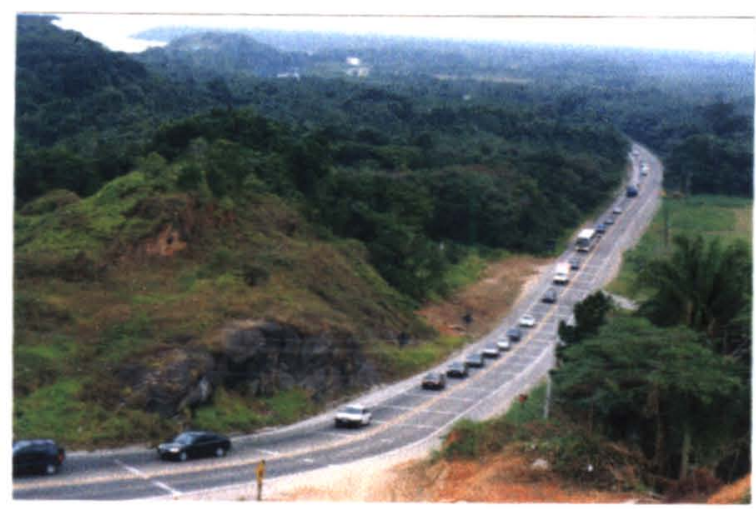

Fotografia 12 - TrÁfEgo de VefCulos NA RODOVIA RIO-SANTOS, EM TRECHO DO MUNICIPIO ONDE NÃO HA ACESSO INTRA-URBANO. FOTO REALIZADA EM DIA DE SEMANA, JULHO DE 2003

\footnotetext{
${ }^{2}$ Sitio www. emplasa.sp.gov.br
} 
Com relação aos serviços de transporte coletivo que servem à cidade, Bertioga conta com frota de ônibus de empresa particular que possui linhas para a ligação entre os bairros extremos da cidade. Entretanto, os moradores reclamam que para acessar algum bairro intermediário, têm muitas vezes, que percorrer um trajeto muito maior e efetuar o pagamento de duas tarifas.

Não há terminal de ônibus intermunicipal na cidade. Os ônibus que servem aos turistas que se deslocam para o município estacionam em frente aos guichês das empresas que se localizam na Av. Anchieta, no centro, próximo à balsa que faz a travessia para o Guarujá, ou seja, numa região totalmente inadequada tanto para os moradores, quanto para os turistas e veranistas.

Outro aspecto importante de considerar refere-se à ação cada vez mais intensa de dificultar ou criar barreiras para que ônibus, peruas e vans acessem o município de Bertioga nos fins de semana e feriados. São tentativas de frear o acesso da população de baixa renda ao município que se constitui como excursionista ou turista de um dia.

Segundo um dos coordenadores da AGEM, esta ação é uma tendência geral nos governos municipais e uma prática que ocorre em praticamente todos os municípios da RMBS. Assim, medidas como proibição de estacionar próximo à praia ou em qualquer trecho da cidade, bem como bloqueio de acesso nas estradas - contando com apoio da Polícia Rodoviária - já foram realizados. Estes procedimentos, apesar de procurarem ser justificados pelos gestores locais como forma de disciplinar o uso e acesso à cidade, podem ferir um dos direitos e garantias fundamentais previstos na Constituição Federal do país, que define a liberdade de locomoção, entrada e permanência no território nacional em tempos de paz (Brasil, 2001).

Estes conflitos e dificuldades tendem a se agravar se considerarmos o aumento populacional da cidade, a tendência de aumento de turistas e excursionistas e o aumento do número de veículos em função da inauguração da recente nova pista da Rodovia dos Imigrantes do Sistema Anchieta-Imigrantes, que interliga a capital à Baixada Santista.

A Tabela 29, com dados da Dersa e da Ecovias, permite ter uma idéia da evolução do número de veículos nas rodovias da Região da Baixada Santista 
entre os anos de 1995 a 2000. Nota-se por essas informações que no Sistema Anchieta-Imigrantes verificou-se, por meio dos pedágios, um incremento relativo da ordem de $8,5 \%$ (Imigrantes) a $10 \%$ (Anchieta) no período e 12,3\% na Rodovia Padre Manuel da Nóbrega que contempla os veículos que vão para o litoral norte (Tabela 29 ).

De acordo com o Plano Diretor de Turismo da Baixada Santista, desenvolvido pela Agem (São Paulo, 2002) "com a segunda pista da Rodovia dos Imigrantes $o$ fluxo entre planalto e litoral deverá aumentar significativamente, pois a capacidade do sistema aumentará em $40 \%$ facilitando as atividades comerciais e principalmente o turismo."

\begin{tabular}{|c|c|c|c|c|}
\hline \multirow[b]{2}{*}{ ano } & Anchieta & Imigrantes & Cônego Domênico Rangoni & Padre Manuel da Nóbrega \\
\hline & $\begin{array}{c}\text { Pedágio Riacho } \\
\text { Grande }\end{array}$ & \begin{tabular}{|c|} 
Pedágio \\
Piratininga \\
\end{tabular} & Pedágio Santos pista oeste & $\begin{array}{c}\text { Pedágio São Vicente pita } \\
\text { leste }\end{array}$ \\
\hline 1995 & 5.238 .021 & 7.384 .566 & 3.329 .660 & 2.744 .714 \\
\hline 1996 & 5.780 .879 & 7.762 .110 & 3.474 .221 & 3.837 .288 \\
\hline 1997 & 6.422 .863 & 8.071 .534 & 3.642 .274 & 3.947 .279 \\
\hline 1998 & 6.335 .295 & 8.043 .421 & 3.660 .715 & 3.589 .872 \\
\hline 1999 & 6.331 .058 & 8.321 .520 & 3.722 .953 & 3.544 .585 \\
\hline 2000 & 5.761 .972 & 8.014 .111 & 3.431 .200 & 3.083 .358 \\
\hline $\begin{array}{c}\text { incremento relativo (\%) } \\
1995-2000\end{array}$ & 10 & 8,5 & 3 & 12,3 \\
\hline
\end{tabular}

fonte: Emplasa, 2002

(1) Considera o total de veículos que utilizam as rodovias Anchieta e Imigrantes com destino ao litoral paulista

(2) Considera apenas o total de veículos que utilizam a Rodovia Cônego Domênico Rangoni com destino a São Paulo

(3) Considera apenas o total de veículos que utilizam a RodoviaPadre Manuel da Nóbregacom destino a São Paulo

Nota: O Sistema Anchieta- Imigrantes compreende: Via Anchieta - SP 150, Rodovia dos Imigrantes - SP 160, Via Interligação/Baixada - SP 59, Rodovia Cônego Domênico rangoni - SP 140, Rodovia padre Manuel da Nóbrega - SP 170 e Rodovia Caminho do Mar - SP 148

No entanto a Agência Metropolitana da Baixada Santista (AGEM), no seu Plano Metropolitano de Desenvolvimento Integrado (PMDI) elaborado no ano de 2002, afirma que o fluxo de veículos entre planalto e litoral aumentou $21 \%$ na Rodovia Anchieta e $13 \%$ na Rodovia dos Imigrantes no período 1995/1999. Segundo a Agência: "(...) os dados revelam ainda que os acidentes vem aumentando em proporções ainda maiores sobretudo na Imigrantes, onde o número de feridos cresceu 145\% entre 1995 e 1999. Já na Rodovia Anchieta verificou-se uma redução significativa de $22 \%$ no número de vitimas fatais (...)". O texto alega também que em 1999 cerca de $62 \%$ dos acidentes registrados na Rodovia Anchieta e $48 \%$ dos registrados 
na Rodovia dos Imigrantes "ocorreram no Planalto, trecho de maior risco na viagem ao litoral" (São Paulo, 2002).

Considerando que as condições e a facilidade de acesso foram um dos fatores centrais que permitiram e incentivaram o crescimento populacional, a visitação e urbanização de Bertioga, pode-se prever um novo aumento do fluxo para o litoral e, conseqüentemente, do impacto no sistema de transportes local nos próximos anos, com a operação da segunda pista recém-inaugurada em 2002 (São Paulo, 2002).

\subsection{Aspectos da legislação urbanística municipal atual}

A legislação urbana municipal de Bertioga (Lei 315-98 do Plano Diretor, Lei 31798 de Uso e Ocupação do Solo, 316-98 que institui o Código de Edificações, e leis complementares) está em pleno processo de revisão em função de determinação da Lei do Plano Diretor de 1998 e do Estatuto da Cidade (Bertioga, 1998).

Este trabalho não tem como objetivo central realizar uma análise aprofundada da legislação urbanística do município. Entretanto, entendemos necessário contextualizar sobre alguns instrumentos urbanísticos condicionantes e relacionados à realidade sócio-espacial, na perspectiva de contribuir para formulações alternativas, a partir de toda a discussão realizada, fruto da atividade da pesquisa.

Assim, com relação ao conjunto de leis urbanísticas municipais, alguns comentários cabem ser feitos, como esclarecimento e discussão de suas características principais.

Os mapas que servem de referência espacial para a aplicação das leis territoriais urbanas têm como base o vôo aerofotogramétrico de 1994. O desenho do sistema viário contido nos mapas não se refere à cidade existente, mas sim aos loteamentos aprovados ou em processo de aprovação na prefeitura (muitos deles do tempo da Prefeitura de Santos, portanto antes de 1991). Portanto existem informações, como loteamentos e arruamentos, constantes no mapa, mas que não foram implantados, logo não existem na realidade. Por outro lado, encontram-se loteamentos também, incluindo 
arruamentos e assentamentos, que existem na cidade e que não constam no mapa.

Além disso, os mapas oficiais utilizados pela PMB não contemplam todo o território municipal, mas apenas a faixa costeira referente ao perímetro urbano, que corresponde a uma menor porção do território. Soma-se a isto o grande número de zonas (e de cores e hachuras diferentes no desenho). Todos esses detalhes, dificultam em muito a compreensão da lei e do território da cidade por parte dos técnicos, e praticamente impossibilitam a leitura por um cidadão comum ou pessoa leiga sem formação técnica em geografia, cartografia ou urbanismo (arquiteto, engenheiro ou geógrafo).

O conjunto de leis urbanísticas municipais em vigor até a presente data foi aprovado pela Câmara Municipal em 1998, tendo sido elaborado com participação ativa da Associação de Engenheiros, Arquitetos e Agrônomos de Bertioga. O Plano possui uma primeira parte mais genérica das diretrizes, a maior parte pertinentes e bem intencionadas.

A lei de uso e ocupação do solo é bastante detalhada. Na sua versão aprovada estabelece 10 (dez) grandes Zonas disciplinadoras do espaço urbano: Zona de Suporte Urbano - ZSU, Zona de Suporte Ambiental - ZSA, Zona de Proteção Ambiental - ZPA, Zona de Parque Temático - ZPT, Zona de Suporte Náutico - ZSN, Zona de Usos Especiais - ZUE, Zona de Interesse Histórico e Cultural - ZHC, Zona de Baixa Densidade - ZBD, Zona Turística ZTR, Zona Residencial - ZR. Em 2001 foram aprovadas as Zonas Especiais de Interesse Social - ZEIS.

Estas zonas se subdividem em outras inúmeras, em um nível de grande detalhamento. Por exemplo, a Zona Residencial de subdivide em outras 5 (cinco zonas) ZR1, ZR2, ZR3, ZR4 e ZR5, de forma que destas, as ZR3, ZR4, ZR5 constituem-se "Zona residencial de uso conforme Memorial Descritivo especifico do empreendimento" (Bertioga, 1998).

O mesmo procedimento de subdivisão das zonas se verifica para Zona Turística (4 zonas), Zona Comercial ( 4 zonas), Zona Industrial (4 zonas), Zona Mista ( 2 zonas), constituindo um grande número de subzonas, cada uma delas com o seu respectivo conjunto de parâmetros específicos a serem obedecidos (taxa de ocupação; coeficiente de aproveitamento; recuo frontal, 
recuo lateral e recuo de fundos muitas vezes em função da altura da edificação; área mínima de terreno; dimensão mínima de testada do lote; número de pavimentos da edificação).

Uma parcela considerável de Zonas prevê lotes grandes com parâmetros que induzem a baixas densidades, principalmente próximas a áreas mais sensíveis do ponto de vista do meio natural. Nestas Zonas é comum a adoção de áreas mínimas de $1.000 \mathrm{m2}, 2.000 \mathrm{m2}, 3.000 \mathrm{m2}, 5.000 \mathrm{~m} 2$ até $10.000 \mathrm{~m} 2$ por lotes, constituindo-se verdadeiras chácaras ou sítios (Bertioga, 1998).

A concepção geral do zoneamento está baseada na idéia do estabelecimento de um gradualismo tipo "degradê" em que, a partir da região da praia até a mata de restinga e a região de preservação permanente (em direção a Serra do Mar), o uso e as ocupações sejam disciplinados por parâmetros urbanísticos que permitem ocupações e usos mais intensivos (mais próximo à praia) e ocupação e uso de baixa densidade e mais baixo impacto (mais próximo às áreas preservadas).

Na versão original da lei a única Zona que permitiria a implementação de Habitação de Interesse Social (HIS) é a Zona de Suporte Urbano que corresponde a uma faixa de 100 à 200 metros, paralela à rodovia RioSantos. Nesta Zona são permitidas também a instalação de comércios, galpões e atividades produtivas voltadas para 0 atendimento dos usuários da Rodovia.

Com relação a possibilidade de implantação de HIS, a lei se referencia da seguinte forma: "(...) está prevista também a edificação de unidades de habitação de padrão popular e econômico, com densidades maiores, especial cuidado deve ser dado ao sistema viário, dotando-o de ruas largas, com calçadas mínimas de três metros, dotando-as de arborização farta e intensiva, além de cuidados para garantir plenamente o fluxo de deficientes físicos, idosos, gestantes, de bicicletas e dos veículos em geral, com o resultado final de maior insolação, frescor e ventilação em todo o conjunto (...)" (Bertioga, 1998). 
A lei de uso e ocupação do solo municipal institui a área mínima de lote para fins de habitação popular de $125 \mathrm{~m} 2$ e no mínimo 5,00 $\mathrm{m}$ de testada do lote. (Bertioga, 1998).

No ano de 2001 foi aprovada a Lei de Zonas Especiais de Interesse Social (ZEIS) que previa alguns parâmetros urbanísticos mais flexíveis para Habitação de Interesse Social - HIS. Notou-se entretanto, uma dificuldade grande em viabilizar tanto a implantação de conjuntos populares, quanto à urbanização de favelas e assentamentos precários nas áreas definidas pela lei, principalmente por falta de uma política habitacional e urbana na cidade.

Nota-se que, historicamente, não houve uma preocupação por parte da legislação urbanística em privilegiar e induzir a produção de HIS ou ao menos facilitar a auto-promoção da moradia pela população de mais baixa renda. Um exemplo da visão elitista da lei, refere-se à que não era permitido a construção de edificação tipo "edícula" (fundo do lote), se não houvesse já sido edificada uma construção principal no miolo ou na frente do lote.

Ao mesmo tempo a lei prevê inúmeras zonas para os fins mais diversos ligados ao turismo e ao veranismo, como Parques Temáticos, empreendimentos de loteamentos de grande e médio porte para os segmentos médio e alto, condomínios, chácaras, sítios, serviços, comércio, indústria (apesar de pouco desenvolvida), atividades náuticas e usos recreativos, além dos institucionais, e de interesse histórico e cultural.

A lei prevê também a hierarquização das vias de forma a detalhar como e onde cada tipo de via deve ser implantada: "Vias Regionais; Sistema Viário Principal (Eixo Principal de Conexão; Vias Marginais; Via de Distribuição Principal; Via de Penetração Principal.); Sistema Viário Secundário (Via Secundária 1; Via Secundária 2; Via de Uso Local; Via de Pedestres; Ciclovia) e Viela Sanitária". Prevê-se também passarelas sobre a Rodovia Rio-Santos para reduzir o risco de acidentes e proteger os pedestres e os motoristas (Bertioga, 1998).

Com mais de $\mathbf{4 0}$ quilômetros de praias, a única passarela existente em toda a extensão do município foi viabilizada pela Associação de Moradores do Loteamento Morada da Praia em Boracéia. 
Na prática, a maior parte das vias não é pavimentada, não possui sistema de micro-drenagem e algumas vias importantes foram interrompidas por muros dos condomínios e loteamentos, prejudicando muito a suposta racionalidade, harmonia e equilíbrio previstos na lei (ver Aerofoto 3).

A lei municipal prevê também os sistemas de drenagem, o saneamento ambiental (incluindo abastecimento de água, esgotos sanitários, coleta e destinação final de resíduos sólidos), a arborização, o paisagismo, o sistema de placas e sinalização com diferentes nuances e detalhes descritivos e normativos.

Em Bertioga, aparentemente repete-se o fenômeno do descolamento entre legislação urbanística e gestão da cidade e da realidade urbana. 0 município convive com uma lei detalhista, tecnicista que prega a harmonia de um lado e com uma realidade urbana excludente, repleta de irregularidades, ilegalidades e conflitos do outro.

Este fato não é exclusivo de Bertioga, mas ao contrário, tem sido constatado por alguns autores em muitos municípios brasileiros. (Villaça, 1999, Maricato, 2001, Fix, 2001). Flavio Villaça em um estudo sobre os Planos Diretores das cidades brasileiras mostra o quanto eles, apesar das boas intenções, são inócuos (Maricato, 1997).

Maricato confirma que o conteúdo dos planos diretores no Brasil é descolado da realidade (1997) "(...) a exposições de motivos (nos planos diretores) constituem, em geral prolongados textos recheados de princípios sobre 0 equilíbrio e a harmonia no uso e ocupação do solo, os quais são negados pelas gestões urbanas efetivamente praticadas. A realidade urbana empírica é o maior testemunho (...)".

Além disso a autora, baseada em inúmeros casos conhecidos afirma: "a lei se aplica nas áreas que tem interesse para o mercado imobiliário privado" (Maricato, 1997). Este fenômeno foi demonstrado também por Fix (2001) sobre estudo na cidade de São Paulo no caso das Operações Urbanas e remoções de favelas na Av. Faria Lima e Córrego das Águas Espraiadas.

Esta é a realidade sócio-espacial de Bertioga em seus problemas e potencialidades, evidenciados por meio da análise de dados secundários obtidos em pesquisas oficiais e de profissionais das universidades. 
A partir de agora tentaremos relacionar estas condições de vida a condições de saúde, através, ainda, dos indicadores relativos de doença e mortes.

\subsection{Aspectos e dados epidemiológicos}

Os dados epidemiológicos de Bertioga se expressam como conseqüência das condições de vida, de moradia e trabalho da população. Como já discutido na parte teórica deste estudo, as condições de moradia, saneamento ambiental, transportes e mobilidade e acesso a terra urbanizada tendem a exercer influência considerável no processo saúde/doença.

\section{causas de mortalidade}

Observando as causas agrupadas de morte do ano de 2000 nos municípios que compõem a Região da Baixada Santista, observamos que entre as de maior proporção figuram as doenças do aparelho circulatório, de modo que Guarujá e Bertioga possuem as maiores porcentagens de incidência com $30,7 \%$ e $28,2 \%$ dos casos respectivamente.

Esta tendência se confirma na média da RMBS com $24 \%$ das causas de mortes. Chama-nos a atenção que na Praia Grande, em primeiro lugar, figuram as causas externas de mortalidade com $22,2 \%$ seguidas das doenças do aparelho circulatório com 21,0\% dos casos (Tabela 30). Neste município as causas externas superam todas as demais, considerando homens, mulheres e todas as faixas etárias.

Cabe salientar que as doenças do aparelho circulatório - principalmente as doenças isquêmicas do coração e cérebro-vasculares - constituem no Brasil o primeiro grupo de causas de morte, mesmo nas regiões mais pobres (como o Norte e Nordeste), onde ainda é relativamente grande a mortalidade por doenças transmissiveis (DATASUS, 2002). 
Tabela 30 - Causas de Morte por Grandes Capítulos, segundo os municipios: 2000 (em percentagem)

\begin{tabular}{|c|c|c|c|c|c|c|c|c|c|c|}
\hline causas de morte & Bertioga & Cubatão & Guarujá & Itanhaém & Mongaguá & Peruibe & Prala Grande & Santos & São Vcente & RMBS \\
\hline $\begin{array}{l}\text { algumas afeccões originadas no } \\
\text { período perinatal }\end{array}$ & 2,9 & 5 & 4,2 & 3,4 & 7,2 & 4,7 & 4,3 & 1,4 & 4,7 & 3,4 \\
\hline $\begin{array}{l}\text { doenças do aparelho } \\
\text { respiratório }\end{array}$ & 8,2 & 9,6 & 9,7 & 7,1 & 104 & 8,6 & 7,3 & 11,2 & 8,3 & 9,5 \\
\hline $\begin{array}{l}\text { malformaçōes congênitas, } \\
\text { deformidades e anomalias }\end{array}$ & 0,6 & 1,3 & 1,2 & 1,6 & 0,4 & 1,2 & 0,9 & 0,6 & 0,8 & 0,9 \\
\hline $\begin{array}{l}\text { algumas doenças infecciosas } \\
\text { e parasitárias }\end{array}$ & 5,9 & 6,6 & 6,1 & 3,9 & 2,9 & 4 & 3,3 & 5,4 & 6,3 & 5,3 \\
\hline $\begin{array}{l}\text { causas externas de } \\
\text { morbidade e mortalidade }\end{array}$ & 19,4 & 19,9 & 20,5 & 13,8 & 19,1 & 13,5 & 22,2 & 8,8 & 15,1 & 15,1 \\
\hline neoplasias (tumores) & 9,4 & 12 & 11,8 & 10,1 & 7,6 & 7,9 & 10,6 & 17,4 & 11,1 & 13,1 \\
\hline $\begin{array}{l}\text { doenças do aparelho } \\
\text { circulatório }\end{array}$ & 28,2 & 19,9 & 30,7 & 24,9 & 24,1 & 23 & 21 & 27 & 19,7 & 24,6 \\
\hline $\begin{array}{l}\text { doenças endócrinas, } \\
\text { nutricionais e metabóllicas }\end{array}$ & 4,7 & 3,6 & 4,9 & 6,3 & 6,1 & 4 & 3,9 & 4,9 & 4,8 & 4,7 \\
\hline doenças do aparelho digestivo & 4,7 & 4,3 & 4,6 & 4,7 & 4 & 72 & 4,8 & 5 & 5,2 & 4,9 \\
\hline $\begin{array}{l}\text { doenças do sistema nervoso e } \\
\text { óraz̃os dos sentidos }\end{array}$ & 1,8 & 1 & 0,9 & 1 & 1,1 & 1,6 & 1 & 1,5 & 0,9 & 1,2 \\
\hline $\begin{array}{l}\text { sintomas, sinais e achados } \\
\text { anormais de exames }\end{array}$ & 11,8 & 14,6 & 2,9 & 20,1 & 14 & 20,7 & 18,1 & 13,7 & 20,1 & 14,5 \\
\hline $\begin{array}{l}\text { doenças do aparelho } \\
\text { qeniturinário }\end{array}$ & 0,6 & 1,1 & 1,2 & 1,2 & 1,1 & 2,1 & 1,8 & 1,6 & 1,6 & 1,5 \\
\hline $\begin{array}{l}\text { doenças do sangue e órgãos } \\
\text { hematopoéticos }\end{array}$ & 0,6 & 0,3 & 0,2 & 1,6 & 0,7 & 0,7 & 0,1 & 0,4 & 0,4 & 0,4 \\
\hline $\begin{array}{l}\text { transtornos mentals e } \\
\text { comportamentals }\end{array}$ & 0,6 & 0,1 & 0,1 & - & 0,7 & 0,5 & 0,3 & 0,5 & 0,2 & 0,3 \\
\hline $\begin{array}{l}\text { omplicaçóes da gravidez, parto } \\
\text { e puerpério }\end{array}$ & - & 0,1 & 0,1 & 0,2 & - & 0,5 & 0,1 & 0,1 & 0,2 & 0,1 \\
\hline $\begin{array}{l}\text { doenças da pele e do tecldo } \\
\text { subcutâneo }\end{array}$ & - & 0,1 & 0,5 & - & 0,4 & - & 0,1 & 0,2 & 0,2 & 0,2 \\
\hline $\begin{array}{l}\text { doenças do sistema } \\
\text { osteomuscular e do tecido co. }\end{array}$ & 0,6 & 0,4 & 0,4 & 0,2 & 0,4 & - & 0,1 & 0,3 & 0,2 & 0,3 \\
\hline total & 100 & 100 & 100 & 100 & 100 & 100 & 100 & 100 & 100 & 100 \\
\hline
\end{tabular}

fonte: Emplasa, 2002

Este convívio de doenças crônicas não transmissíveis juntamente com doenças transmissiveis evidencia um quadro de transição epidemiológica, uma condição perversa e desafiadora do ponto de vista da organização dos serviços de saúde.

A segunda causa em boa parte dos municípios são as causas externas de mortalidade. É o caso de Bertioga, onde elas constituem 19,4\% dos casos, de Cubatão (19,9\%), de Guarujá (20,5\%), de Mongaguá (19,1\%), conforme a Tabela 30.

Em terceiro lugar figura a categoria dos chamados sintomas, sinais $e$ achados anormais de exames com cerca de $11,8 \%$ dos casos registrados. Em seguida, figurando em quarto lugar, estão as doenças do aparelho respiratório com $8,2 \%$ dos casos no município. Em quinto lugar aparecem as doenças infecciosas e parasitárias com 5,9\% dos casos, conforme os dados da Fundação Seade, na Tabela 30, elaborada pela Emplasa. 
No nosso país, muitas dessas enfermidades são decorrentes das más condições ambientais, falta de saneamento básico, ocupação desordenada do solo e invasão dos sistemas naturais para atividades produtivas (Brasil, Ministério do Meio Ambiente, 2002).

Note-se que de entre as 5 (cinco) principais causas de mortalidade no município estudado, pelo menos 3 (três) estão direta ou indiretamente relacionadas com as condições urbano-habitacionais, incluindo aí saneamento, transportes e mobilidade, ou em outras palavras relacionam-se com as políticas urbanas, quer sejam causas externas de mortalidade, doenças do aparelho respiratório e doenças infecciosas e parasitárias.

É de se notar que os dados da RMBS, enquanto expressão da média do litoral paulista mostra as causas de mortalidade (e suas proporções) na seguinte ordem: "doenças do aparelho circulatório" (24,6\%), "causas externas de morbidade e mortalidade" (15,1\%), "sintomas, sinais e achados anormais de exames" (14,5\%), "neoplasias" (13,1\%), "doenças do aparelho respiratório" (9,5\%) e "doenças infecciosas e parasitárias" (5,3\%).

Observando-se os gráficos 16 e 17 elaborados pela Fundação Seade, que mostram as mortes por sexo em Bertioga de 1999, vemos que para os homens figuram em primeiro lugar as causas externas com cerca de $31 \%$ do total, seguido das doenças do aparelho circulatório com $20 \%$, o grupo das mal definidas $(11 \%)$, neoplasias $(9 \%)$ e as doenças do aparelho respiratório (8\%) (Fundação Seade, 2003).

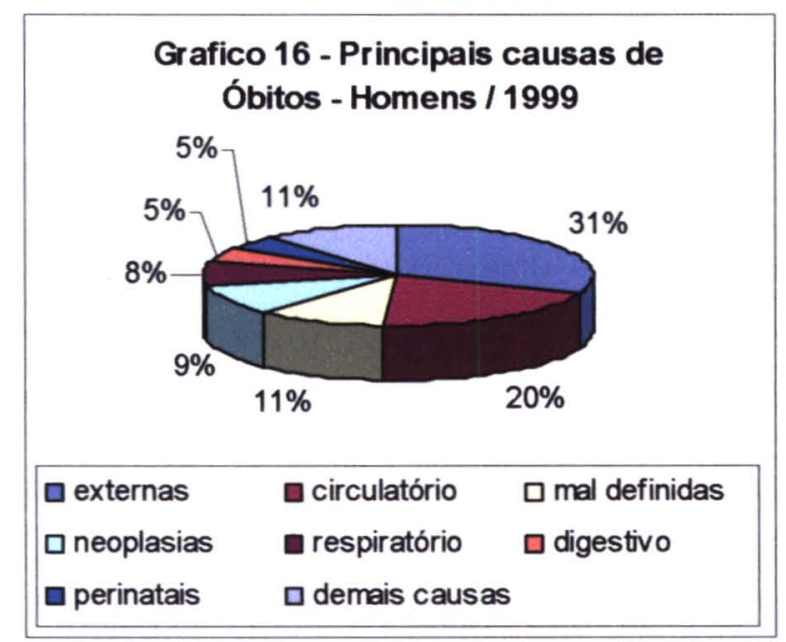

Fonte: Fundação Seade, 2000 
Diferentemente, para as mulheres, em primeiro lugar constam as doenças do aparelho circulatório com $34 \%$ dos casos, as doenças do aparelho respiratório e as neoplasias, ambas com $12 \%$ dos casos. Note-se que a tendência das mortes por causas externas atingirem mais o público masculino se confirma também para o município de Bertioga.

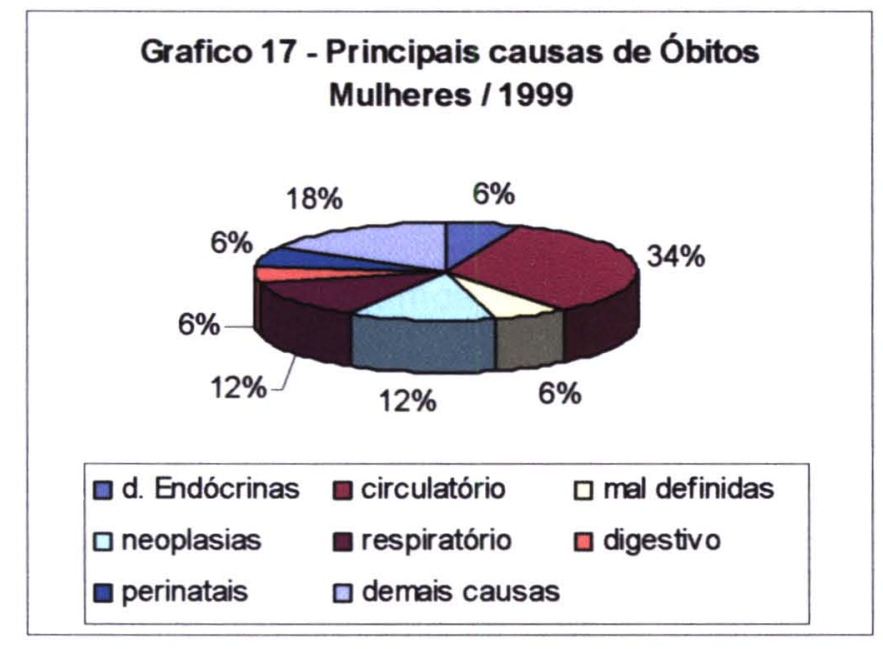

Fonte: Fundação Seade, 2000

\section{causas externas de mortalidade}

Cabe salientar que o grupo das causas externo de mortalidade constituído de homicídios, suicídios, mortes no trânsito, no trabalho e afogamentos (esta última no caso das cidades litorâneas), têm aumentado progressivamente em diversas cidades no nosso país nos últimos anos.

A Tabela 31 abaixo, com dados da Fundação Seade, mostra o número de casos e as taxas para homicídios e acidentes de transporte no município de Bertioga no período de 1996/2000.

Devido ao fato de o número absoluto de casos ser pequeno, em função do próprio tamanho do município, do ponto de vista estatístico as variações ano a ano precisam ser analisadas com maior cuidado.

No período de 1996 a 2000 há uma taxa média de 47 homicídios por cem mil habitantes, enquanto que a taxa média de mortes por acidentes de transportes foi de 37 casos por cem mil habitantes (Tabela 31). 


Tabela 31 - Taxa de mortalidade por homicídios e acidentes de transportes
Bertioga - 1996/2000
(por 100.000 habitantes)

fonte: Fundação Seade. Sistema de Estatísticas Vitais

Os dados dos últimos Censos demonstram que, particularmente, os homicídios têm aumentado em todas as regiões do Brasil, sobretudo nos grandes centros urbanos (IBGE, 2003). Neste sentido tem sido motivo crescente de preocupação a emergência e o impacto da questão da violência urbana nos mais diferentes setores, expressando no meio técnico e acadêmico a percepção de que se a violência é multicausal ou multifatorial, cada setor deve buscar compreender em que aspectos podem contribuir para amenizá-la ou para fortalecer e atuar a favor da comunidade, aumentando a presença do Estado, dos serviços e das políticas públicas, principalmente nas periferias metropolitanas (LabHab, 2003).

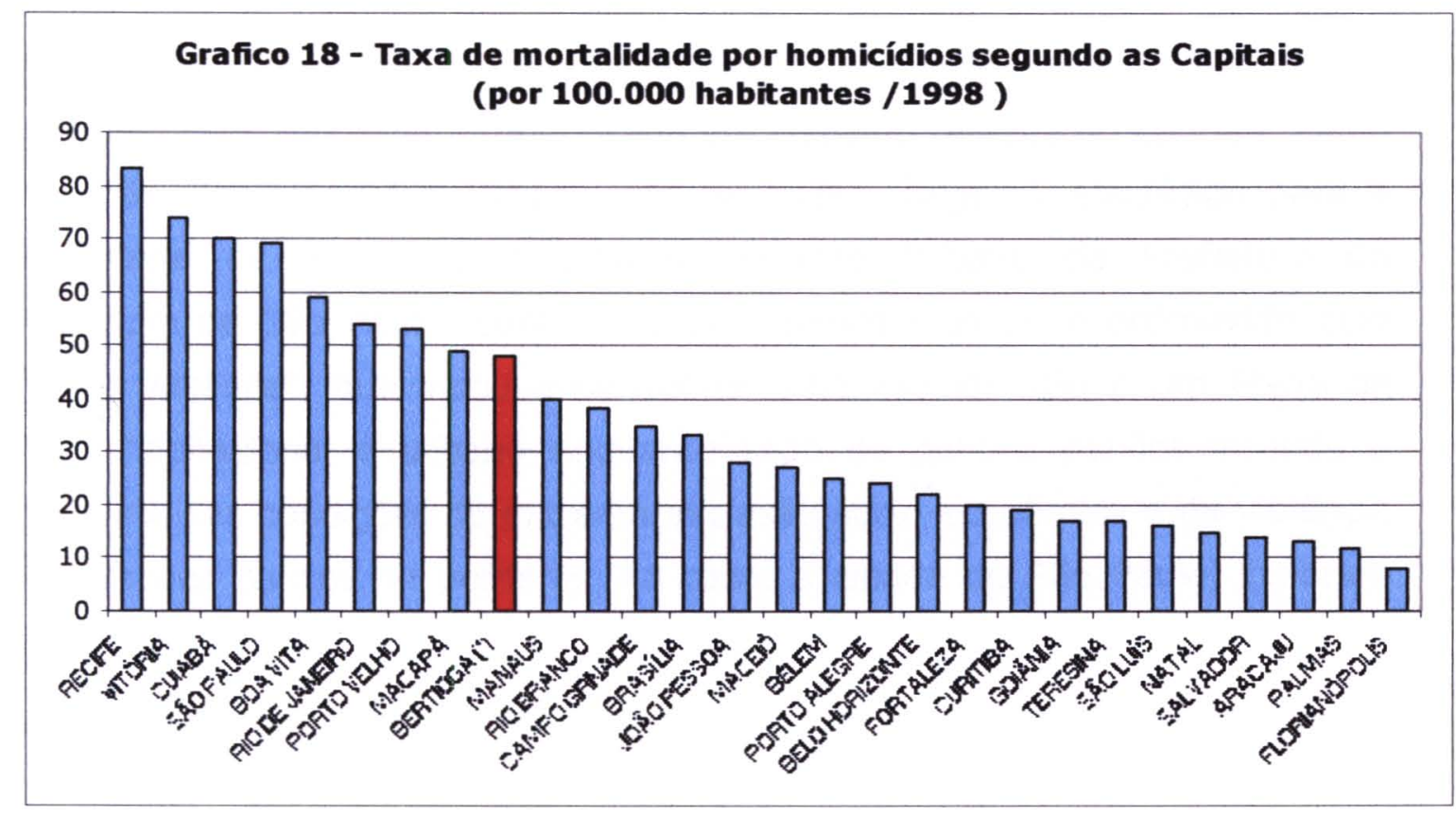

Fonte: Fundação Seade (2000) 
Assim, o tema tem tido recentemente, lugar de destaque também na agenda dos setores afetos às políticas urbanas. Como enfatiza o documento preparatório para a Conferência Nacional das Cidades de 2003 do FNRU Fórum Nacional da Reforma Urbana: "(...) nas metrópoles assiste-se o efeito desorganizador da criminalidade violenta, com o vínculo estreito que se estabeleceu entre tráfico, uso de armas e comércio varejista de drogas ilícitas (...)". (Fórum Nacional da Reforma Urbana, 2003)

Vale destacar também a magnitude do problema das mortes de trânsito e transportes, um outro aspecto da violência urbana no país. No caso de Bertioga e da baixada estes conflitos tendem a se agravar com o aumento intenso dos fluxos nos períodos de temporada. Isto se relaciona com a infraestrutura de transportes, o sistema viário e com a política hegemônica de mobilidade centrada no uso indiscriminado dos automóveis (Fórum Nacional da Reforma Urbana, 2003).

Como pode-se verificar no Gráfico 18 acima com dados da Fundação Seade, Bertioga, apesar de ser município novo e pequeno, possuía em 1998 taxa de mortalidade por homicidios próxima, na média, à diversas cidades médias e grandes do país, como Manaus, Macapá, Brasília, Rio de Janeiro (Fundação Seade).

A causa de morte por homicídios, tem sido utilizada como um dos indicadores de violência em estudos e planos articulados com a habitação e desenvolvimento urbano, na perspectiva de subsidiar as políticas públicas urbanas. Esta abordagem foi utilizada em trabalho recente do LabHab "Plano de Ação Habitacional e Urbano para o Jardim Ângela", elaborado para a Secretaria de Habitação e Desenvolvimento Urbano da Prefeitura do Município de São Paulo, contratado pelo Banco Mundial e promovido pelo "Cities Alliance", que visou desenvolver uma metodologia e um Plano de Ação habitacional e urbano enquanto ação de política pública visando a melhoria das condições de extrema exclusão sócio-econômica e de violência vividas nos bairros de periferia (no caso, a cidade de São Paulo) (LabHab 2003).

Tratou-se de um trabalho que buscou inovar no campo do planejamento e da gestão habitacional e urbana, na perspectiva de uma contribuição visando minimizar as causas da violência e fortalecer as comunidades e os serviços 
públicos, em aspectos habitacionais e urbanísticos (congestionamento e densidade habitacional e urbana, acessibilidade, sistema viário e iluminação publica, por exemplo), além do empoderamento e participação da população no planejamento e gestão locais.

morbidade hospitalar: doenças respiratórias, infecciosas e parasitárias

Dados do Ministério da Saúde sobre a morbidade hospitalar no município também mostram a incidência de taxas elevadas de doenças e grupos de doenças relacionadas com a precariedade das condições de moradia, conflitos de tráfego e transportes, carência de infra-estrutura urbana, particularmente saneamento e drenagem.

Conforme se verifica na Tabela 32 adiante, em Bertioga, a maior causa de internação hospitalar para crianças de 0 a 9 anos refere-se a doenças do aparelho respiratório com $40,7 \%$ dos atendimentos para a faixa etária de 0 a 1 ano, 38,7\% das internações para a faixa de 1 a 4 anos e $30,5 \%$ para a faixa de 5 a 9 anos (Tabela 32).

Ainda, com relação às doenças do aparelho respiratório, nota-se que constituem a segunda maior causa de internação para a faixa de 65 anos ou mais, perdendo apenas para as doenças do aparelho circulatório.

Sabe-se que as doenças respiratórias na infância têm constituído a cada dia motivo de preocupação constante na área da saúde pública. Segundo dados da OMS - Organização Mundial da Saúde, cerca de 13 milhões de crianças menores de cinco anos morrem anualmente no mundo por doenças do aparelho respiratório, sendo que $95 \%$ das mortes ocorrem em países em desenvolvimento (OPAS, 1993 apud Chiesa 1999). Também de acordo com a OMS (1998) as doenças respiratórias agudas e crônicas possuem associação a exposições ambientais da ordem de $50 \%$ a $60 \%$.

Chiesa (1999), em sua pesquisa sobre equidade e controle de agravos respiratórios na infância, afirma que algumas investigações evidenciam que o aumento da incidência dos agravos respiratórios em âmbito mundial encontra-se relacionado a fatores ambientais. Para isso contribuem o processo de urbanização crescente que altera a qualidade do ar em 
decorrência da deterioração do meio ambiente (casos das metrópoles como São Paulo), assim como o processo de sociabilização precoce das crianças que, principalmente em decorrência do trabalho materno, permanece desde tenra idade em ambientes coletivos por prolongados períodos.

Apesar da inexistência de levantamentos de campo específicos neste sentido, esta última referência da autora poderia nos levar à hipótese de que as condições de moradia da população de baixa renda, sobretudo as que habitam as favelas, considerando as características, por exemplo, da favela do Indaiá (em que há considerável proporção de materiais de construção inadequados - $38 \%$ de madeira ou misto, alta densidade urbana, número pequeno de cômodos), associadas às condições desfavoráveis da região, como alta pluviosidade, lençol freático aflorante (combinado com a deficiência no sistema de drenagem urbana) e alta umidade relativa do ar, contribuiriam para tornar ainda mais grave e/ou aumentar a incidência na população das doenças do aparelho respiratório.

Victora (1998) citado por Chiesa (1999) destaca fatores ambientais relacionados à IRA - Infeç̧ões Respiratórias Agudas, como "a exposição à fumaça, a aglomeração de pessoas em espaços fechados e a exposição ao frio decorrentes de moradias insatisfatórias". Com relação a este último aspecto, sabe-se que o "aumento ou diminuição abrupta da temperatura do corpo modifica a perda relativa de calor e tem um efeito desfavorável no estado geral do indivíduo. Assim, a moradia deve minimizar os efeitos das mudanças de temperatura externa, contribuindo para isso, o material de construção, o acabamento, o tipo de forração, assim como o tipo de piso para garantir vedação adequada" (Westphal, 1982).

Os fatores mais importantes relacionados às IRA foram "exposição das crianças à grande concentração de pessoas nos dormitórios e à umidade excessiva no interior dos domicilios, assim como as mudanças bruscas de temperatura. Estudos permitiram verificar que uma variação semanal média de $1^{\circ} \mathrm{C}$ esteve associada a um aumento de $6 \%$ na incidência das doenças respiratórias (...)" (Cardoso 1997 apud Chiesa 1999).

De acordo com estudiosos do assunto, outro fator de risco para as IRA diz respeito à concentração de pessoas por dormitório. Segundo Westphal (1982), a "American Public Health Association" recomenda que a 
concentração de pessoas por dormitório não ultrapasse a relação de 1,5 por cômodo.

Segundo o IBGE o número médio de moradores por domicílio em Bertioga é 3,48 pessoas. Entretanto diversos fatores nos levam a crer que este número é subestimado para as famílias moradoras das favelas. Em função da intensa fiscalização e combate à construção de novas unidades há uma tendência à superlotação dos domicílios já constituídos, por agregados e familiares.

Com relação ao fenômeno da superlotação habitacional há referências dos próprios atores locais em Bertioga. Um ex-Secretário do Meio Ambiente da prefeitura citou em uma Oficina de Habitação do Curso de Formação:

"(...) Posso dizer uma coisa, sabe o que é ... o numero de construções pra essas favelas .. de barracos era quase (...) famílias inteiras,(...) com mais de 17 pessoas morando dentro (...)" (ex-Secretário do Meio Ambiente durante Oficina de Habitação do Curso de Formação de Agentes Multiplicadores, novembro, 2001).

Assim se considerarmos cerca de 3,48 pessoas por domicílio, a título de ilustração, para a favela do Indaiá, que possui $40 \%$ dos domicílios com 1 ou 2 cômodos, verificamos que, no mínimo, estas famílias convivem com uma relação pessoas/cômodo acima do recomendado segundo parâmetros internacionais (Westphal, 1982).

Voltando aos dados do Ministério da Saúde para Bertioga, contata-se que a segunda maior causa de internações hospitalares para as faixas de 1 a 4 anos, de 4 a 9 anos e 10 a 14 anos constituiu-se de doenças infecciosas $e$ parasitárias - muitas delas relacionadas pelos técnicos locais e pela própria população com a carência de saneamento básico e drenagem - com $26,9 \%$, $22,0 \%$ e $18,2 \%$ dos atendimentos de internação no serviço de saúde local, respectivamente.

No Brasil, estima-se que as doenças decorrentes da falta de saneamento são responsáveis por cerca de $65 \%$ do total de internações nos hospitais públicos e conveniados do país. Este trabalho tem como objetivo analisar dados sobre habitação e desenvolvimento urbano que orientem a definição dos investimentos em saúde. No entanto julgamos útil apresentar um panorama ampliado que auxilie na análise. 
Neste sentido, registra-se que alguns estudos estimam que cada $R \$ 4,00$ investidos em saneamento significam uma economia de $R \$ 10,00$ em internações hospitalares (GEO Brasil, 2002).

Segundo a mesma fonte, outros estudos apontam as doenças veiculadas pela água como responsáveis por $65 \%$ das internações pediátricas na rede pública, e por $80 \%$ das consultas pediátricas nessa mesma rede (Geo Brasil 2002).

Tabela 32 - Morbidade hospitalar - Municipio de Bertioga - 2002

Distribuiçâo percentual das internações por grupos de causas e faixa etária (por local de residencia)

\begin{tabular}{|c|c|c|c|c|c|c|c|c|c|}
\hline grupo de causas & menor 1 & 1 a 4 & 5 a 9 & 10 a 14 & 15 a 19 & 20 a 49 & 50 a 64 & $\begin{array}{l}65 \mathrm{e} \\
\text { mais }\end{array}$ & $\begin{array}{l}\text { total (todas } \\
\text { as idades) }\end{array}$ \\
\hline Algumas doenças infecciocas e parecit́brias & 16 & 26,9 & 22 & 18,2 & $\mathbf{3 , 4}$ & 7,7 & 14,5 & 9,9 & 10,2 \\
\hline Neoplasias (tumores) & - & 0,8 & 3,4 & 2,3 & 1 & 2,3 & 4,4 & 3,1 & 2,2 \\
\hline Doenças de sangue órgăos hemat e transt imunitár & - & 0,8 & 1,7 & - & - & 0,7 & 1,3 & - & 0,6 \\
\hline Doenças endócrinas nutricionais e metabólicas & - & - & 1,7 & - & 1 & 0,9 & 3,8 & 4,6 & 1,3 \\
\hline Transtornos mentais e compotamentais & - & - & - & - & - & 0,6 & 1,3 & - & 0,4 \\
\hline Doenças do sistema nervoso & - & 2,5 & 1,7 & 2,3 & - & 0,7 & 0,6 & 3,8 & 1 \\
\hline Doenças do olho e anexos & - & - & - & - & - & 0,1 & 0,6 & - & 0,1 \\
\hline Doenças do ouvido e da apófise mastóide & - & 0,8 & - & - & - & 0,1 & - & - & 0,1 \\
\hline Doenças do aparelho circulatório & 1,2 & - & - & - & 0,5 & 3,4 & 17,6 & 34,4 & 6 \\
\hline Doenças do aparolho respiratório & $\mathbf{4 0 , 7}$ & 38,7 & $\mathbf{3 0 , 5}$ & 9,1 & - & 3,4 & 6,3 & 20,6 & 9,4 \\
\hline Doencas do aparelho digestivo & 6,2 & 10,1 & 13,6 & 13,6 & 4,3 & 8,4 & 17 & 12,2 & 9,3 \\
\hline Doenças de pele e do tecidobubcutâneo & - & 3,4 & 5,1 & 4,5 & 0,5 & 2 & 1,9 & 0,8 & 1,9 \\
\hline Doenças sist osteomuscular e tec conjuntivo & - & 0,8 & 6,8 & 2,3 & 1 & 1,5 & 1,3 & 0,8 & 1,5 \\
\hline Doenças do aparelho geniturinário & - & 0,8 & 1,7 & - & 1 & 4,2 & 13,2 & 3,1 & 3,9 \\
\hline Gravidez, parto e purpório & - & - & - & 22,7 & $\mathbf{8 3 , 7}$ & $\mathbf{5 4 , 2}$ & - & - & 40,7 \\
\hline Algumas afec originadas no período perinatal & 25,9 & 1,7 & - & - & - & - & - & - & 1,2 \\
\hline Malf cong deformidade e anomalias cromossômicas & 8,6 & 3,4 & 1,7 & - & 0,5 & 0,3 & - & - & 0,9 \\
\hline Sist sinais e achad anorm ex dín e laborat & - & - & 3,4 & 2,3 & - & 0,7 & - & 3,1 & 0,8 \\
\hline Lesobes enven e alg out conseq causas extermas & - & 5,9 & 1,7 & 15,9 & 2,9 & 6,2 & 10,7 & 3,1 & 5,8 \\
\hline Causas externas de morbidade e mortalidade & 1,2 & 3,4 & 5,1 & 6,8 & 0,5 & 2,6 & 5,7 & 0,8 & 2,6 \\
\hline Contatos com serviços de saúde & - & - & - & - & - & 0,2 & - & - & 0,1 \\
\hline CID 10a Revisão não disponivel ou não preenchido & - & - & - & - & - & - & - & - & - \\
\hline Total & 100 & 100 & 100 & 100 & 100 & 100 & 100 & 100 & 100 \\
\hline
\end{tabular}

fonte: Ministério da Saúde (SIH SUS): www.datassus.gov.br (02.08.02)

No caso de Bertioga, chama-nos também a atenção a proporção de internações de adolescentes e jovens na faixa de 15 a 19 anos por causa de gravidez, parto e puerpério, com cerca de $83,7 \%$ dos atendimentos nessa faixa etária (Tabela 29). Cabe salientar, todavia, de nossa parte, que não consideramos gravidez uma doença, apesar de exigir atendimento e atenção dos serviços de saúde materno-infantil.

Do total das internações, consideradas todas as idades, destaca-se em primeiro lugar gravidez, parto e puerpério com total de $40,7 \%$ das 
internações, seguidas das doenças infecciosas e parasitárias com 10,2\% dos casos e das doenças do aparelho respiratório com $9,4 \%$ dos atendimentos.

Vale ressaltar a alta incidência das internações por doenças e grupos de doenças que tradicionalmente incidem mais nas populações e comunidades de baixo nivel sócio-econômico (Seade, 2003) com carências de serviços básicos de atenção à saúde e também com relação às condições de moradia, infra-estrutura, saneamento, transporte e desenvolvimento urbano: as infecciosas e parasitárias, do aparelho respiratório e as causas externas (particularmente homicidios e acidentes de tráfego).

\subsection{Dados Aerofogramétricos e Cartográficos}

A seguir são apresentadas as Aerofografias (Ortofotos) da região urbana do município de Bertioga, realizadas a partir de vôo aerofogramétrico de 2002, que permite visualizar espacialmente diversas características e aspectos levantados neste capítulo e discutidos ao longo do trabalho.

Entre essas características, destaca-se na Foto Aérea 1 do Município de Bertioga, além de um panorama geral da cidade, a identificação das favelas, dos assentamentos precários, das glebas ociosas dentro da área urbana e dos loteamentos/condomínios não integrados à malha urbana - levantados pelos moradores participantes do PBMS com assessoria dos pesquisadores da FSPUSP em dezembro de 2003. Nesta Foto Aérea pode-se notar também a fragmentação urbana que se desenvolveu no município bem como seu traçado e geografia predominantemente lineares e dependentes do sistema viário regional (Rodovia Rio-Santos).

As principais favelas da cidade podem ser visualizadas em detalhe na Aerofoto 2 (Favela Vicente de Carvalho II), Aerofoto 4 (Favelas do Indaiá e Indaiazinho), Aerofoto 6 (Favela de Boracéia), Aerofoto 7 (Favela de Boracéia).

A área de preservação ambiental (dentro do distrito urbano), da Praia de Itaguaré, pode ser visualizada na Aerofoto 5. A praia de Itaguaré corresponde a uma das últimas praias do litoral paulista, que contém vegetação nativa. Esta área pertence a um proprietário de terras que, 
segundo os próprios vereadores, tem interesse em viabilizar um grande empreendimento voltado para a atividade turística.

Durante as discussões de Revisão do Plano Diretor em 2003, membros do PBMS, ao apresentarem uma proposta de preservação desta área do Itaguaré, foram advertidos por um vereador importante da cidade, sobre a inviabilidade de preservar uma área privada que tem alto valor de mercado, e cujo proprietário intenciona investir.

Alguns dos membros do PBMS ficaram espantados com a naturalidade com que o vereador argumentava na discussão sobre a Revisão do Plano Diretor, defendendo que 0 interesse de um grande proprietário não poderia ser contrariado por uma lei pública (que defendesse um interesse coletivo ou difuso).

O desvio para o bairro do Indaiá, e a interrupção da Av. Anchieta, em função do fechamento promovido pelo Loteamento Riviera de São Lourenço pode ser visualizado por meio da Aerofoto 3.

Note-se também, que a Aerofoto 3 mostra espacialmente todo o Loteamento Riviera de São Lourenço, que deu origem à favela do Indaiá e a Aerofoto 6 mostra espacialmente todo o Loteamento Morada da Praia que deu origem à favela de Boracéia ${ }^{3}$.

Observe-se também o Mapa 2 que contém os dados espacializados das diferentes faixas de densidades urbanas encontradas, a partir dos dados dos setores censitários do IBGE de 2000, executado no âmbito das Oficinas do Plano Diretor do PBMS (Mapa 2).

Todos estes dados são percebidos pela população residente de Bertioga, com diferenças mediadas pelos interesses ou vivências individuais e de grupos de moradores.

A seguir serão apresentados os dados da pesquisa ação participante realizada em Bertioga nestes últimos quatro anos, que privilegiam a voz dos sujeitos e moradores que participaram do Projeto Bertioga Município Saudável.

\footnotetext{
${ }^{3}$ As Ortofotos do Municipio de Bertioga foram adquiridas pelo autor na Agência Metropolitana da Baixada Santista - AGEM em 2003.
} 
$\ln ^{2}$

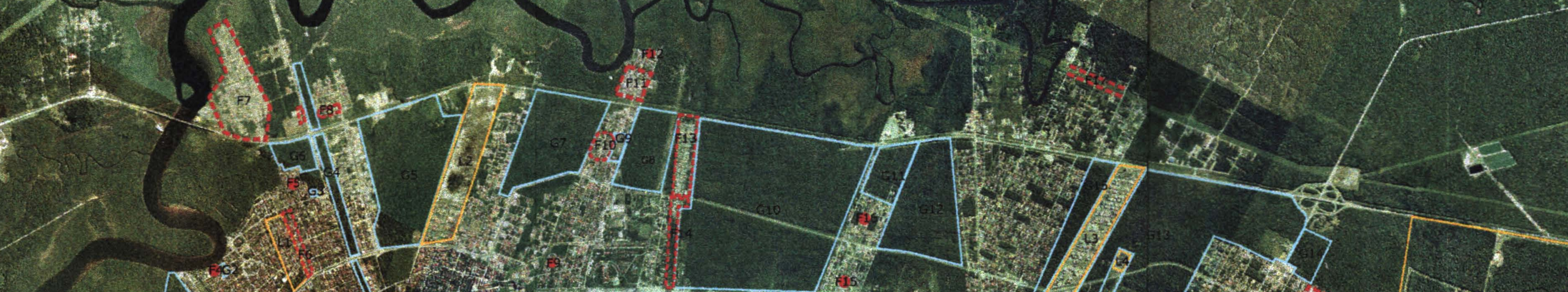

PRAA DA ENSEADA

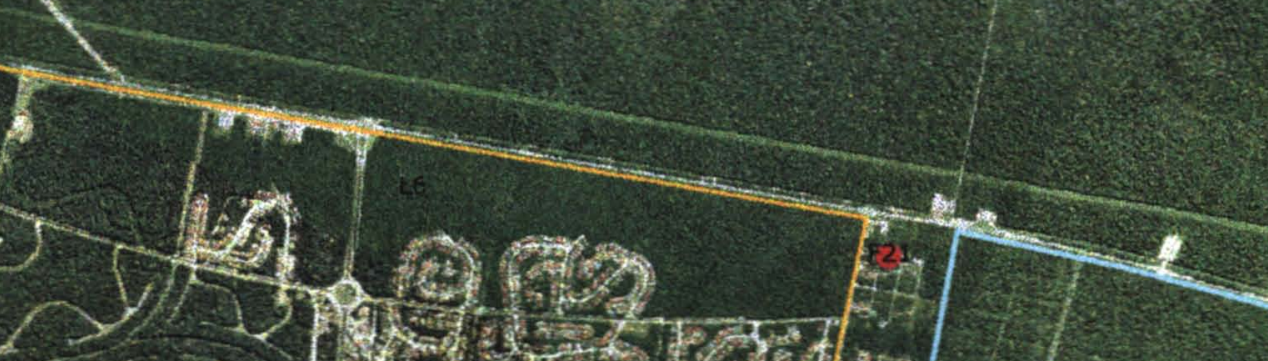

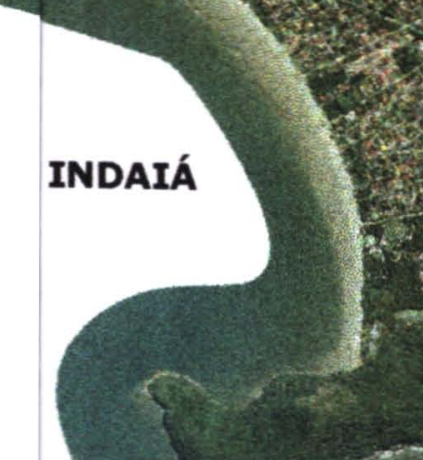

(1)

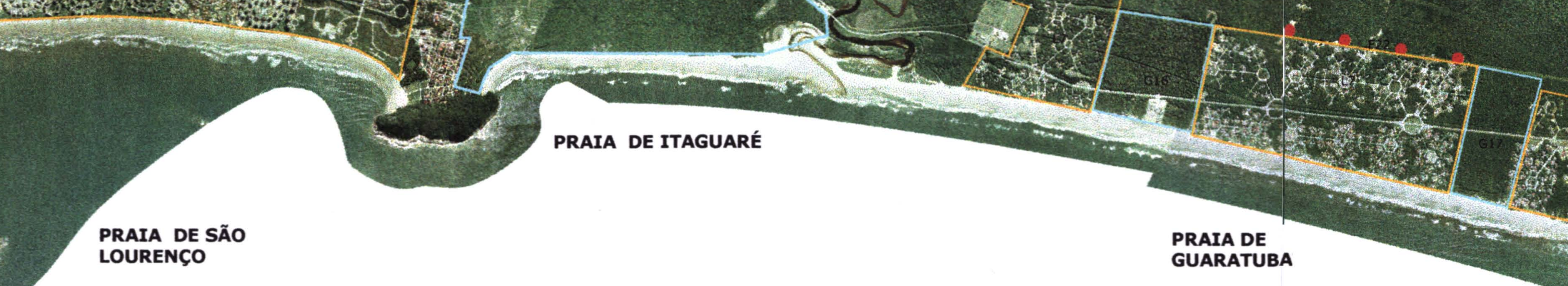

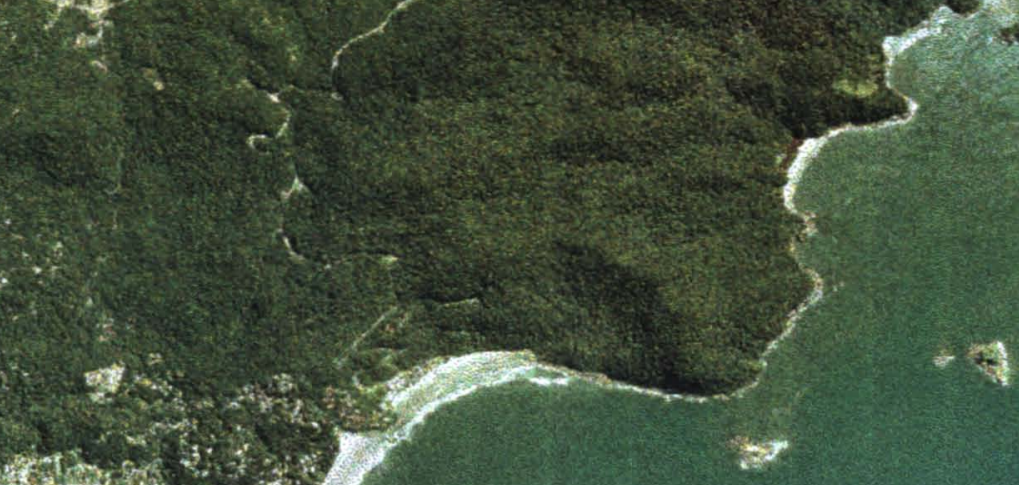




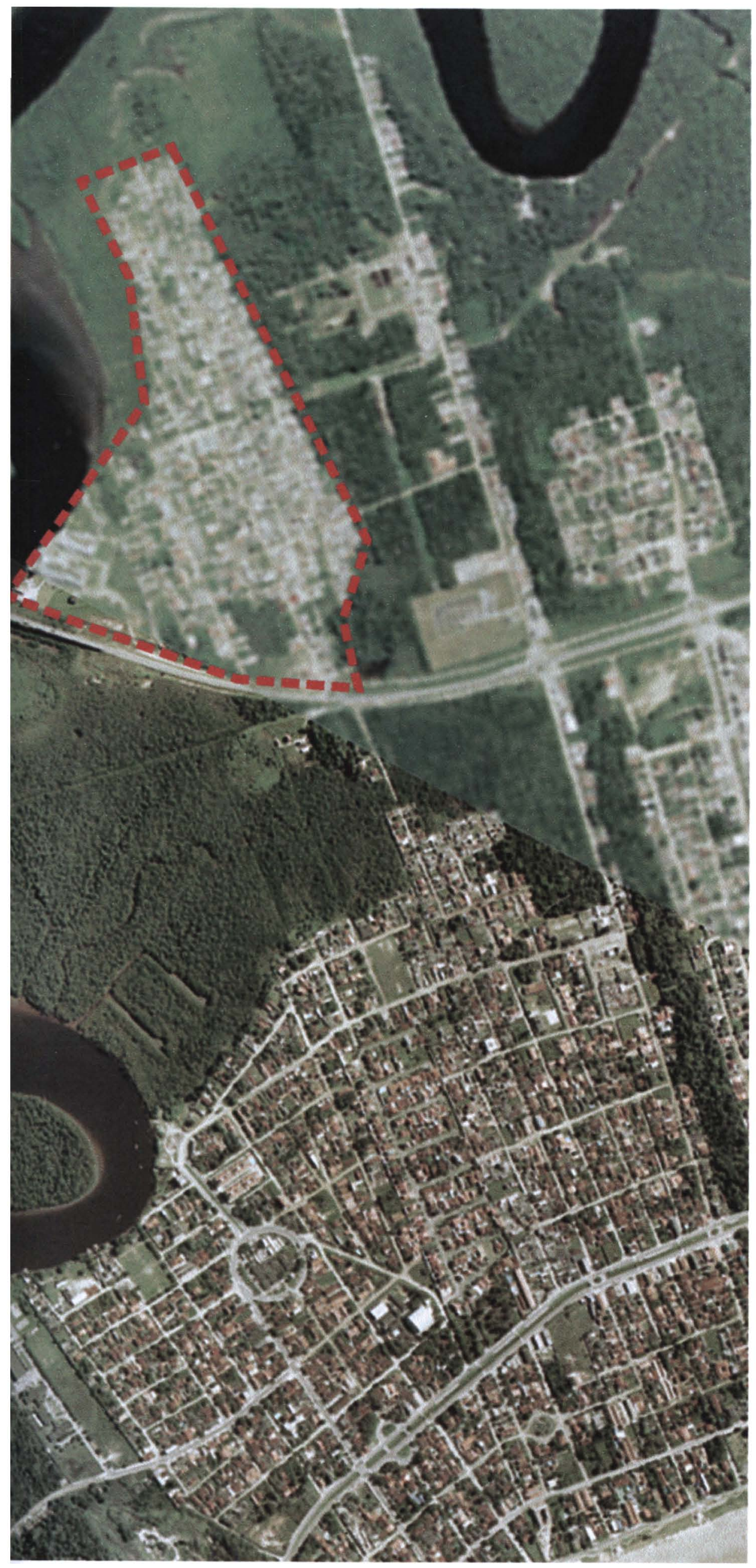

AEROFOTO 2

FAVELA VICENTE DE CARVALHO II

Legenda:

- Favela V. De

Carvalho II

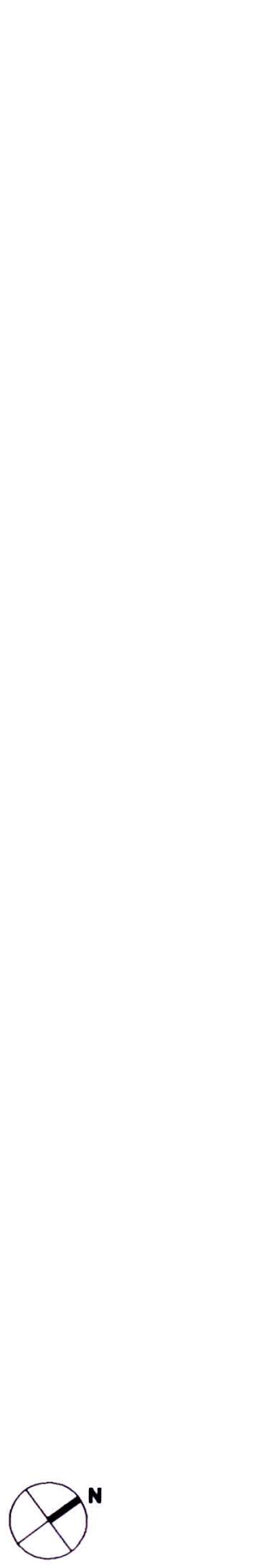

S/ ESCALA

Fonte: AGEM - 2002 


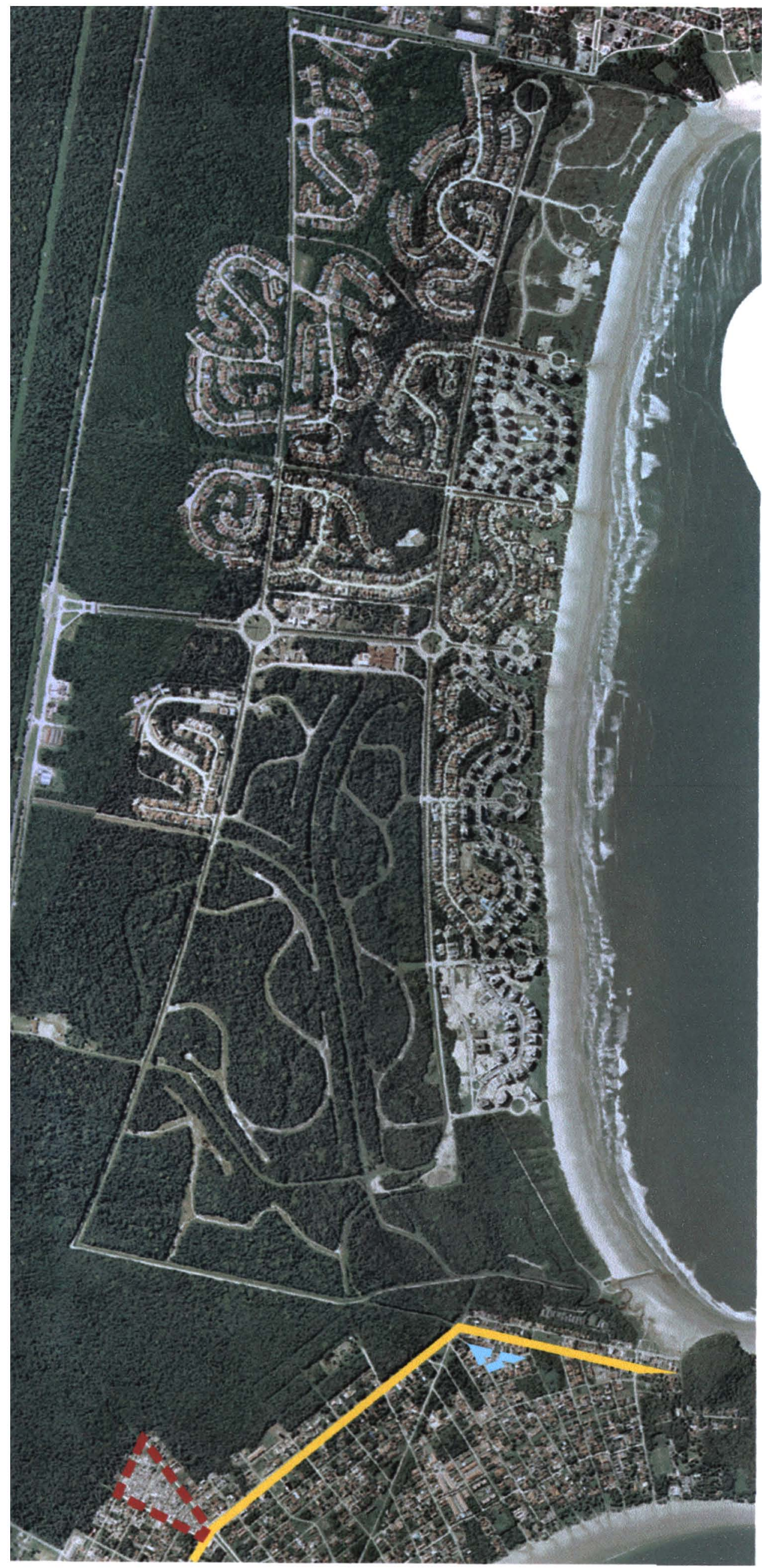

AEROFOTO 3

LOTEAMENTO

RIVIERA DE SÃO

LOURENÇO,

FAVELA INDAIÁ E

FAVELA

INDAIAZINHO

Legenda:

$\square$ Av. Anchieta

Favela Indaiá

Favela

Indaiazinho

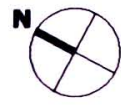

S/ ESCALA

Fonte: AGEM - 2002 


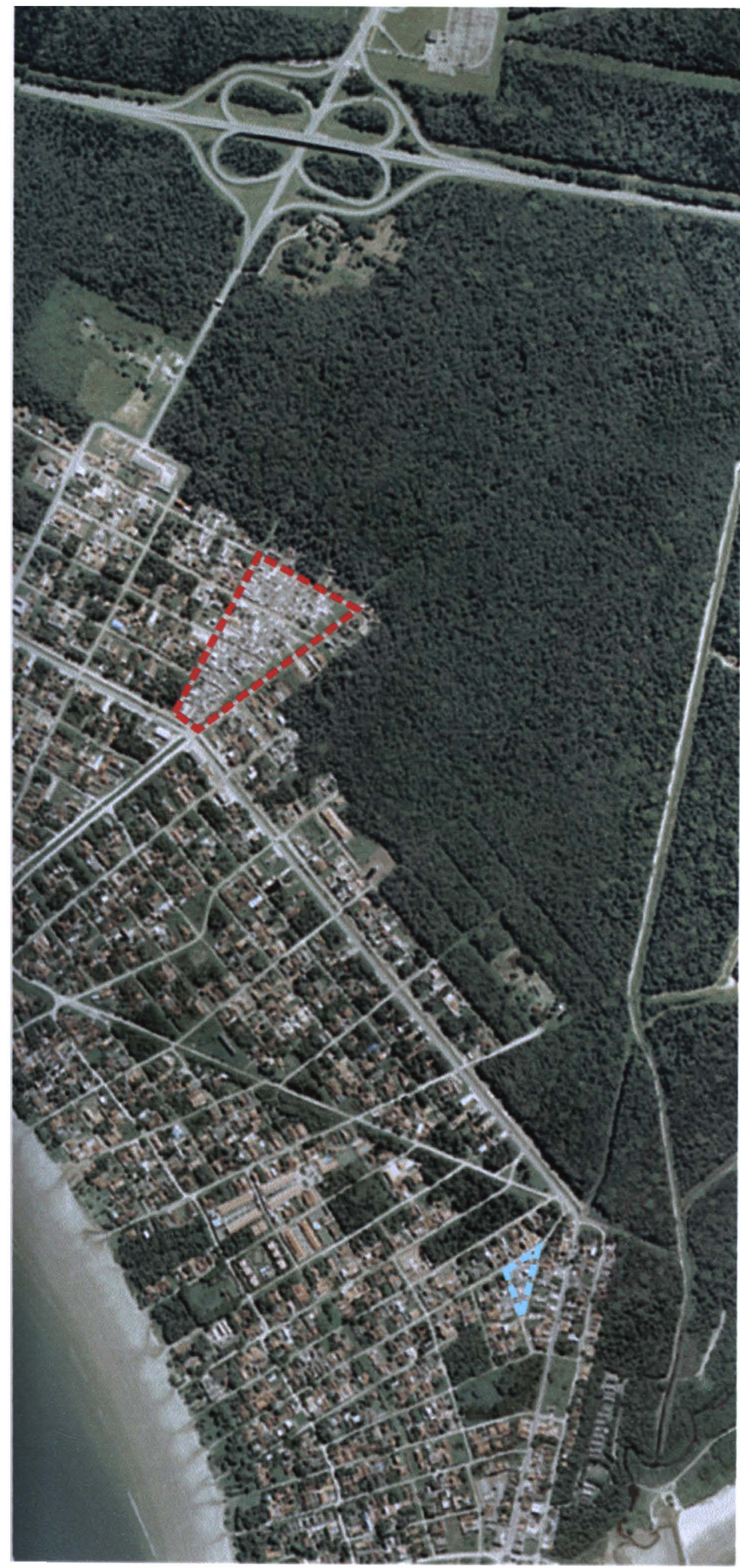

\section{AEROFOTO 4 \\ FAVELA INDAIÁ E \\ FAVELA \\ INDAIAZINHO}

\section{Legenda:}

- Favela Indaiá

Favela

Indaiazinho

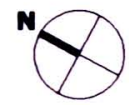

S/ ESCALA

Fonte: AGEM - 2002 


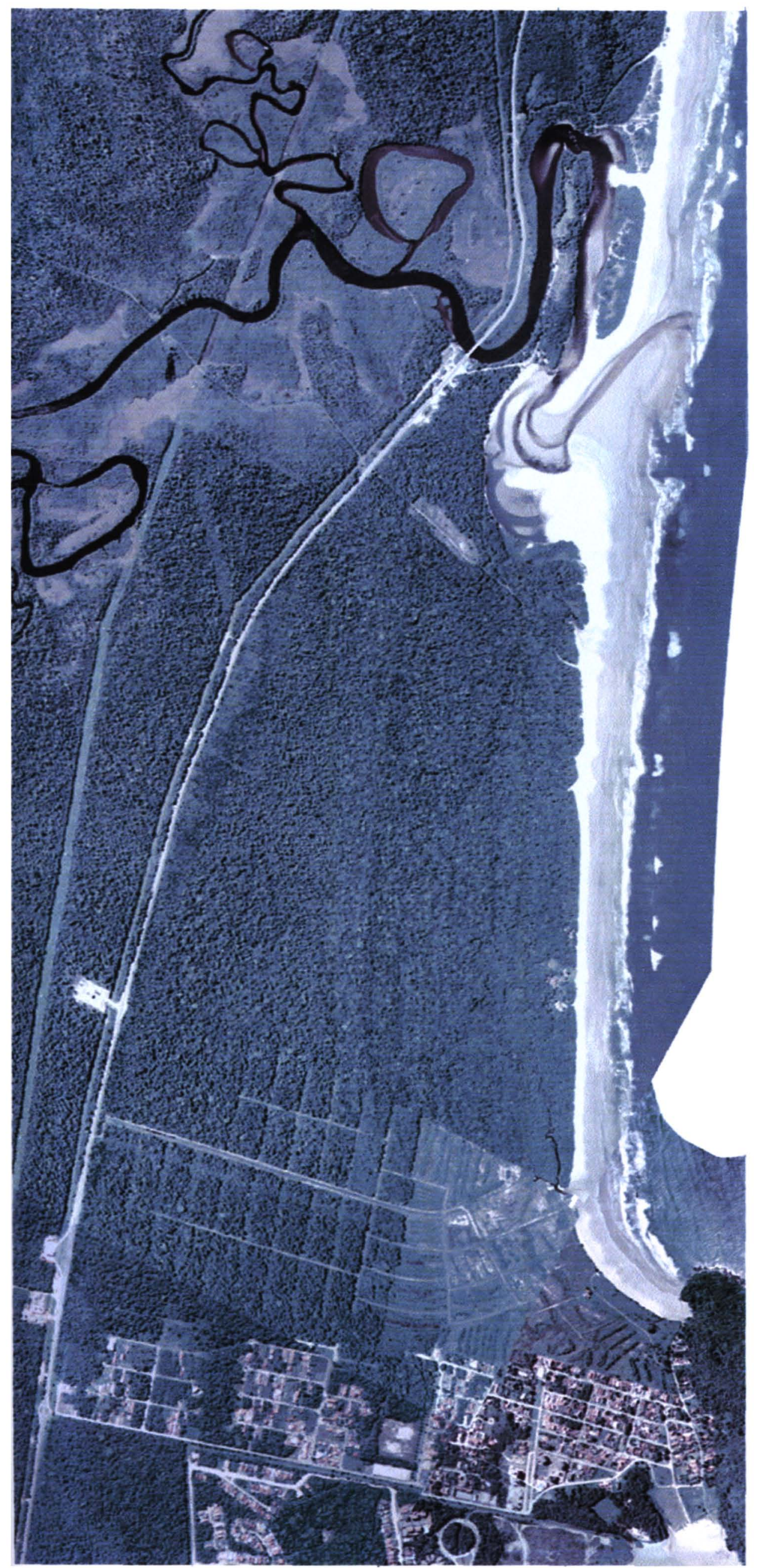

AEROFOTO 5

praia de

ITAGUARÉ

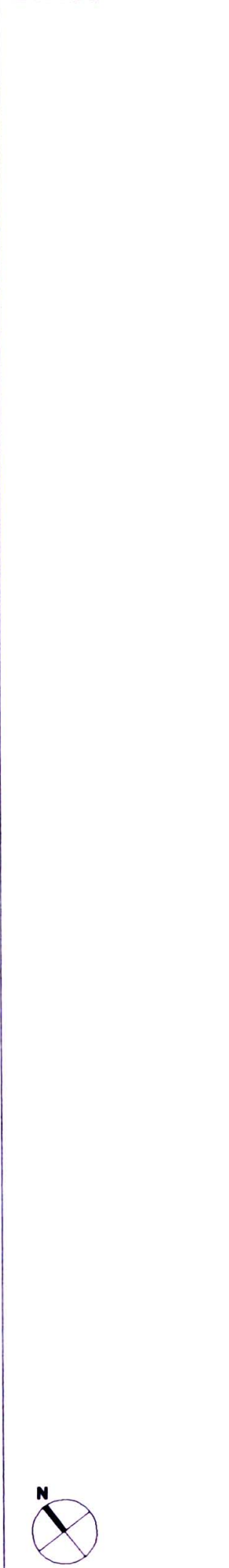

S/ ESCALA

Fonte: AGEM - 2002 


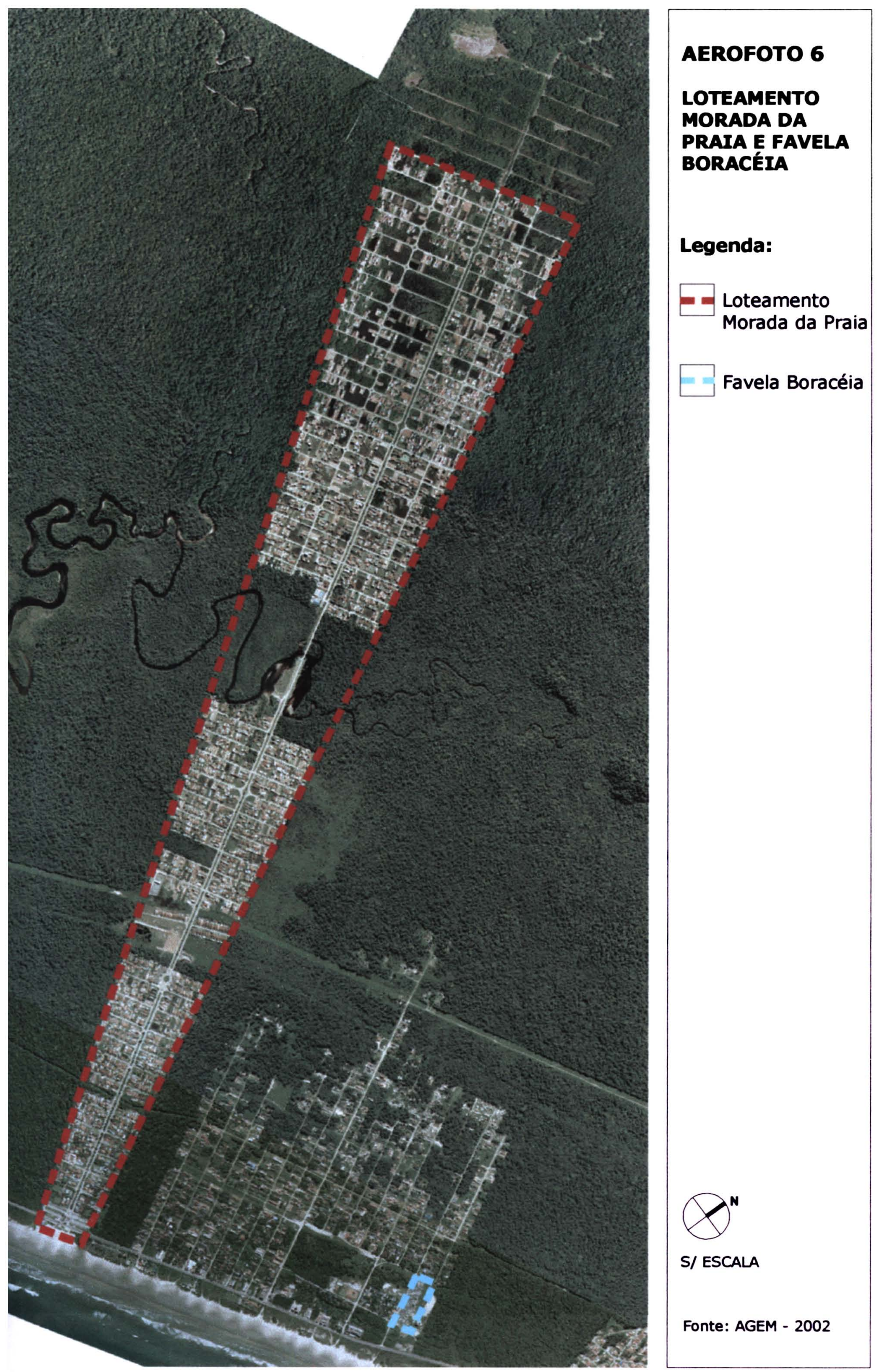




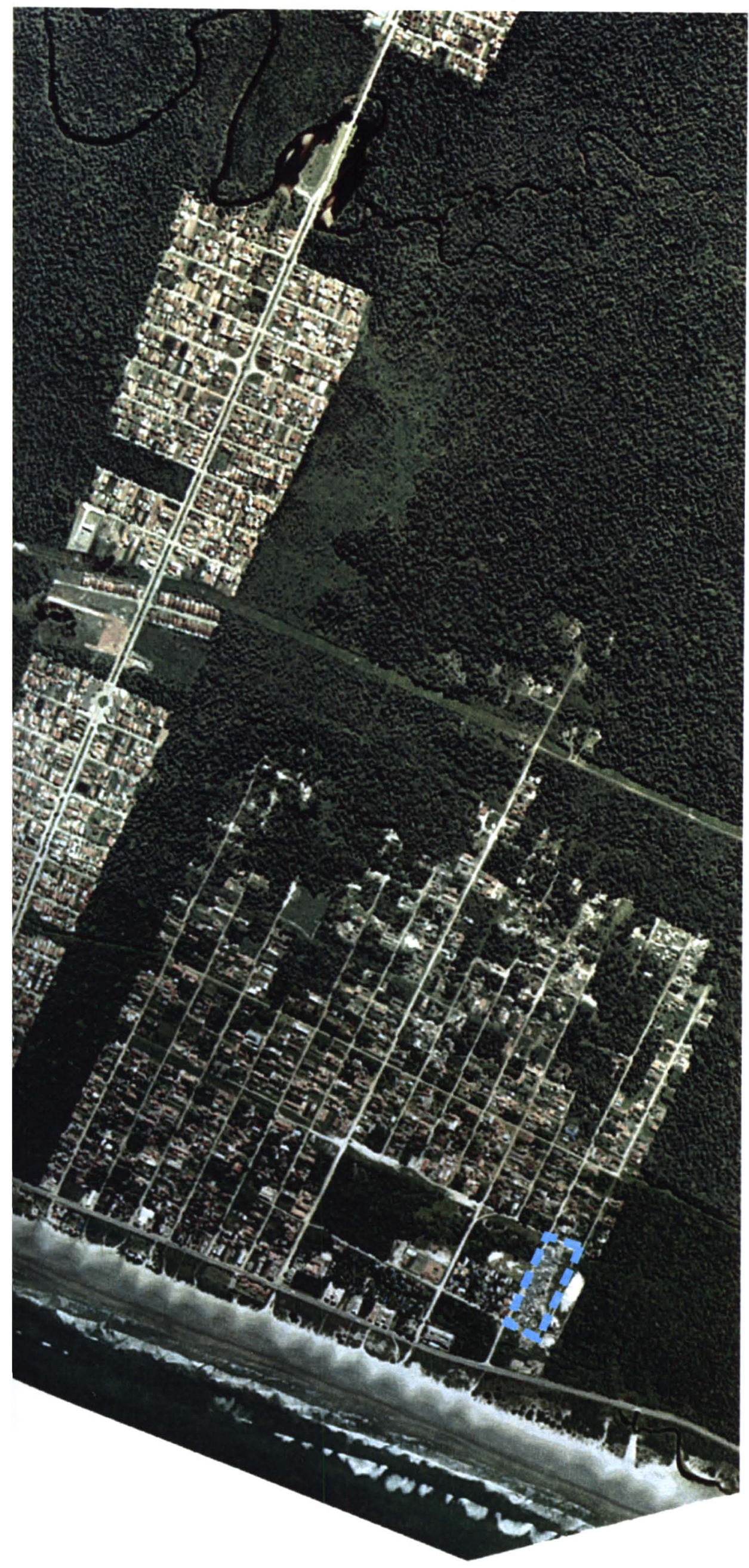

\section{AEROFOTO 7}

FAVELA

BORACÉIA

\section{Legenda:}

- Favela Boracéia

\section{E Favela Boracéla}

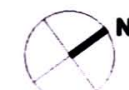

S/ ESCALA

Fonte: AGEM - 2002 


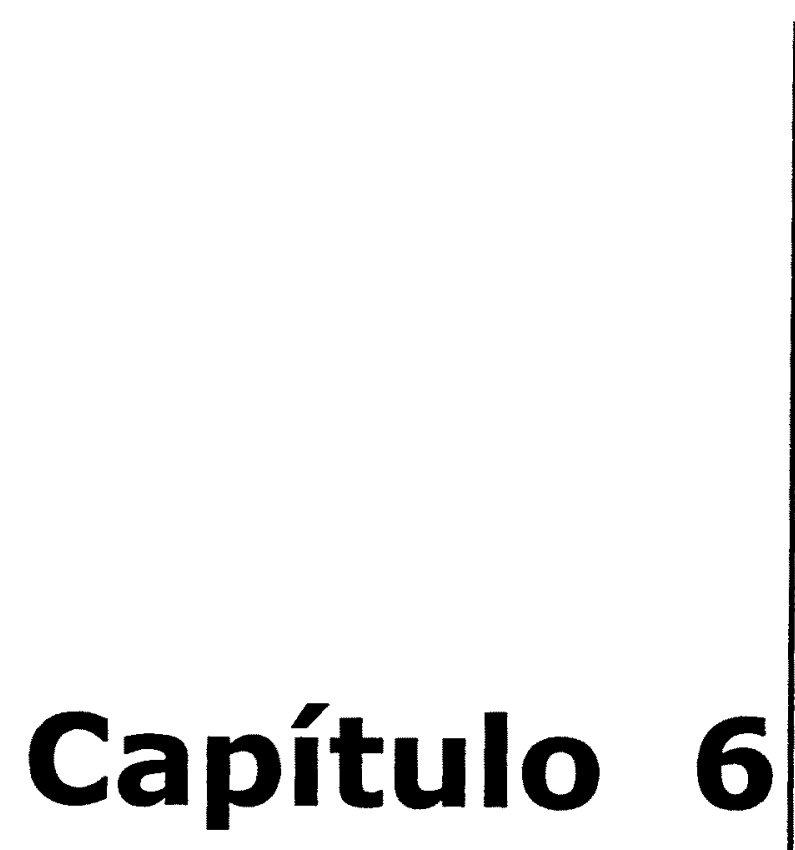

O Projeto Bertioga Município Saudável e a percepção dos moradores sobre os problemas urbanos 
Este capítulo tem por objetivo mostrar como a população e os diversos atores sociais de Bertioga percebem os problemas do município. Realiza-se uma descrição sucinta do Projeto de Pesquisa e Extensão Universitária Bertioga Município Saudável (PBMS) que permite contextualizar o quadro, principalmente do ponto de vista dos atores locais.

Procura-se realizar uma discussão sobre a percepção dos moradores, dos problemas e das estratégias para possiveis soluções, particularmente por parte dos que, em algum momento, participaram das atividades do PBMS.

Esta análise de cunho qualitativo baseia-se em dados obtidos pelo método da pesquisa-ação participante, e objetiva mostrar que desde os primeiros encontros com moradores, lideranças e atores políticos locais, os problemas urbanos estão colocados entre os que são sentidos como mais graves e emergenciais. A trajetória do trabalho participante e interativo desenvolvido no campo denuncia uma opção de priorização, por parte dos participantes do projeto na cidade, no sentido de dirigir as ações e recursos para intervir ou, ao menos, influir nas leis urbanísticas e nas políticas públicas urbanas, como estratégia central para a produção social da saúde.

Pretendemos demonstrar, por meio da análise da percepção e dos conteúdos dos discursos, que os participantes do PBMS nas diversas atividades desenvolvidas, elencaram os problemas urbanos (moradia, saneamento ambiental, transportes e mobilidade) entre os mais graves e prioritários. Como ver-se-á adiante, apesar das diferenças de valores, e de posicionamentos ideológicos, os atores que participaram e interagiram no âmbito do PBMS, ao priorizarem os problemas urbanos e defenderem a atuação do Projeto Município Saudável na esfera das políticas urbanas, evidenciavam também compreender a múltipla determinação do processo saúde/doença (Westphal, 1997).

A partir desta percepção, e a certo ponto do desenvolvimento do projeto, em que o governo municipal, após mudanças eleitorais se afastava do PBMS, os atores locais, co-responsáveis pelos rumos do trabalho de pesquisa e extensão, buscaram formas de interferir ou influenciar nas políticas públicas na perspectiva da produção social da saúde. O campo principal de preocupação e atuação por parte da população foi o das políticas urbanas. 
Assim, pretendemos demonstrar também, por meio da pesquisa ação participante, que o eixo estruturante de ações intersetoriais por políticas públicas saudáveis, priorizadas pelos integrantes do Projeto Bertioga Municipio Saudável, gravitou, ao longo do desenvolvimento do trabalho no município, em torno das políticas urbanas.

É importante notar que a análise da percepção dos moradores sobre os problemas da cidade reforça em diversos aspectos o diagnóstico sócio espacial e a análise das condições objetivas de vida. Ou seja, os problemas que 0 município apresenta, a partir da leitura e análise dos dados secundários e quantitativos são também percebidos pelos moradores e priorizados em diversos momentos do projeto. Entretanto, nota-se que aqui, alguns outros problemas revelados, ganham cores mais fortes nas falas dos que convivem cotidianamente com os conflitos e contradições do município litorâneo.

\subsection{Antecedentes e primeiras atividades}

Os primeiros contatos sobre a possibilidade de um trabalho de cooperação técnico-científica e de extensão universitária entre a Prefeitura de Bertioga e a FSPUSP - Faculdade de Saúde Pública da Universidade de São Paulo, deram-se em meados de 1999, quando o então Secretário Municipal da Saúde procurou a FSPUSP visando obter assessoria técnica na reorientação dos serviços de saúde.

Na ocasião, a FSPUSP contava com a Oficina Permanente de Estudos e Programas sobre Municipios Saudáveis e estava interessada em experimentar na prática as possibilidades de desenvolver um projeto que considerasse a saúde de uma forma mais abrangente, isto é a produção social da saúde, por meio da ação junto a organizações governamentais e não governamentais, visando a construção do compromisso com políticas públicas e iniciativas saudáveis (Arai, 2002, Westphal et al. 2000, Caricari et al. 2000).

Após alguns encontros, os representantes da FSPUSP propuseram que se realizasse um projeto mais abrangente na perspectiva da proposta de Municípios Saudáveis da OMS, que pudesse fortalecer os poderes locais para 
atuar sobre as condições ambientais, sociais, econômicas e culturais determinantes do processo saúde/doença (Mendes, 2000).

Em outubro daquele ano a OPAS - Organização Pan-Americana de Saúde/Região Brasil apoiou a iniciativa oferecendo então, um auxilio técnicofinanceiro para viabilizar a assessoria da FSPUSP à prefeitura municipal, e portanto, o início da experiência.

A FSPUSP liderou um conjunto de iniciativas visando a viabilização de atividades de pesquisa e extensão universitária, que incluiu a elaboração de projetos diversos, entre os quais um Projeto Temático de Pesquisa (Westphal et al, 2000) que contou com a participação de alguns professores de diversas unidades da USP além da FSP (Instituto Oceanográfico, Escola de Comunicações e Artes, Instituto de Geociências, Faculdade de Arquitetura e Urbanismo, Faculdade de Educação, Incubadora Tecnológica de Cooperativas Populares, Museu de Arqueologia e Etnologia) e de professores da PUCCAMP - Pontificia Universidade Católica de Campinas e Faculdade de Medicina do $A B C$.

Apesar do Projeto Temático de Pesquisa não ter recebido apoio da Fapesp Fundação de Amparo à Pesquisa do Estado de São Paulo, o trabalho continuou com apoio financeiro em 2001 e 2002 da Organização PanAmericana de Saúde (OPAS) e de julho de 2002 até dezembro de 2003 do Ministério da Saúde no âmbito do Projeto de Ampliação do Movimento de Municípios Saudáveis no Estado de São Paulo.

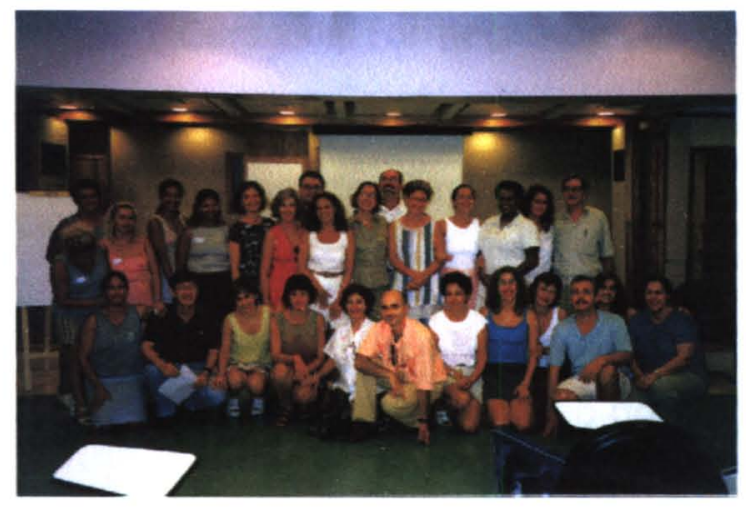

Fotografia 13 - PARTICIPANTES DA PRIMEIRA Oficina do Projeto Bertioga Municipio SAudAvel, no SESC Bertioga (2000) 
Uma equipe mais especifica da FSPUSP foi instituida com o fim de estudar e desenvolver tema de interesse relevante: Metodologias de Avaliação para Municipios Saudáveis. A equipe contou com um financiamento da Fapesp no âmbito do Programa de Financiamentos para Projetos de Pesquisa em Políticas Públicas ${ }^{1}$ (Akerman et al, 2002).

O Projeto iniciou oficialmente suas atividades em março de 2000, por ocasião da assinatura do Protocolo de Intenções entre as duas instituições parceiras.

As atividades realizadas em nome do Projeto Bertioga Município Saudável foram inúmeras nestes três anos e meio de percurso do trabalho. Pode-se dizer que ocorreram atividades de duas naturezas distintas: estruturantes ou estratégicas que estavam articuladas aos objetivos e finalidades maiores do projeto em função do Ideário Município Saudável, e outras mais pontuais que visavam atender demandas emergenciais e problemas localizados, em função da conjuntura e necessidades locais não previstas.

Entre as atividades estruturantes ou estratégicas podemos citar:

a) I Oficina de Sensibilização: Iniciando o Projeto Bertioga Município Saudável (2000);

b) Pesquisa exploratória: levantamento preliminar do tecido social do Município de Bertioga (2000);

c) Oficinas Regionais de Sensibilização (2000);

d) Oficinas do Futuro (2000);

e) Seminário Municipal e Formação da Comissão Intersetorial (2001);

f) I Curso de Formação de Agentes Multiplicadores para Assentamentos Humanos Saudáveis (2001);

g) Oficinas de Capacitação para Revisão do Plano Diretor Municipal (2002);

h) Seminário Municipal: contribuição do Projeto Bertioga Município Saudável para a revisão do Plano Diretor (2002);

i) Preparo e Participação nas Audiências Públicas do Plano Diretor (2002/03).

\footnotetext{
${ }^{1}$ Houve também para esta iniciativa de pesquisa apoio da Fundação Kellogg.
} 


\section{Métodos participativos na pesquisa-ação}

Do ponto de vista da metodologia, o trabalho desenvolvido pelos pesquisadores, professores e alunos de pós-graduação da universidade no município foi influenciado pelo referencial teórico da Promoção da Saúde e experiências práticas que os profissionais envolvidos, na maioria alunos de pós-graduação, traziam de suas experiências pessoais anteriores como educadores e facilitadores de projetos sociais.

Referências sempre presentes, na perspectiva da Promoção da Saúde, foram os princípios e estratégias da proposta por Municípios Saudáveis, já sistematizados e brevemente discutidos nos itens anteriores. A equipe da FSPUSP orientou-se inicialmente pelas recomendações da Organização Mundial da Saúde - OMS e da Organização Pan-Americana de Saúde (OPAS) para implementação de projetos. Neste sentido, existem diversas publicações das agências internacionais de saúde que sugerem um conjunto de passos para a implementação do projeto em uma cidade (WHO, 1995; PAHO, 1997; OPAS, 2002).

Por tratar-se de um trabalho de pesquisa e extensão universitária, o desenvolvimento do mesmo foi norteado também, do ponto de vista do referencial teórico, pela metodologia da pesquisa-ação como já descrito (Thiollent, 2000).

A equipe de trabalho tinha a interdisciplinaridade como uma das características centrais, em função do próprio conceito de saúde que orientou o trabalho, que se reporta à ampla determinação do processo saúde/doença e da qualidade de vida em decorrência disso.

A equipe era constituída por profissionais das seguintes áreas técnicas: sociologia, pedagogia, biologia, engenharia agronômica, medicina, enfermagem, nutrição, engenharia civil, engenharia química, farmácia, economia e administração. Com a ampliação do projeto para mais cinco municípios no Estado de São Paulo a partir de 2002, agregaram-se ainda profissionais de outras áreas: arquitetura e urbanismo, engenharia florestal, administração em turismo.

Do ponto de vista das técnicas de trabalho, utilizou-se de estratégias para mobilização social, mediação e facilitação em oficinas de trabalho. Procurou- 
se, de maneira geral, priorizar as ações em formatos de oficinas com caráter pedagógico, que utilizaram como estratégia, além de animação e recursos audiovisuais, dinâmicas de grupo - para aquecimento, sensibilização, entrosamento, reflexão, aprofundamento e avaliação (Arai, 2000; Gonçalves, 2002).

Assim, as atividades tiveram como objetivos, a identificação de potencialidades e problemas da cidade e sua causalidade, a partir da problematização do conhecimento empírico da população sobre suas condições de vida. Este processo possibilitou, gradativamente, uma compreensão mais crítica da realidade e por conseguinte a conscientização.

Todo o processo contou com a participação conjunta da população e técnicos, favorecendo o empoderamento dos primeiros e a reflexão e revisão dos conhecimentos científicos pelos técnicos.

A transposição da realidade da cidade para o local onde se realizaram as reuniōes, foi realizada, diversas vezes, por uma construção ou representação artística, iniciando um processo que culminava sempre na discussão das condições objetivas de vida e a realidade da cidade. Assim, a forma de representação dos problemas, potencialidades, desejos, projetos ou propostas (quer fossem desenho, objetos exteriores, pintura ou modelagem em argila) não passava de um meio que permitia a cada participante trazer a sua realidade para dentro da oficina e aprofundar mais a reflexão sobre o aspecto concreto e objetivo que era tema do encontro.

Para tal, tiveram influência também algumas abordagens recentes do movimento ambientalista por meio de ferramentas e técnicas utilizadas pela Educação Ambiental' (Ecoar, 1999 e Sorrentino 2001) e adequadas ao contexto do Projeto Município Saudável.

É fundamental frisar que a maior parte das origens e raizes dessas abordagens pedagógicas participativas com grupos, tem as referências primeiras na obra do educador e autor brasileiro Paulo Freire para o quem ensinar, não é transferir conhecimento, mas criar as possibilidades para a sua construção (Freire 1996,).

\footnotetext{
2 Foi importante a influência da metodologia e das experiências desenvolvidas pelo Instituto Ecoar para a Cidadania, aplicadas no âmbito de diversos programas de Educação Ambiental na cidade de São Paulo (PROCAV), em Itapecerica da Serra - SP, entre outros.
} 


\subsection{A Oficina: Iniciando o Projeto Bertioga Município Saudável}

Partindo do princípio que a sensibilidade e a racionalidade são essenciais em um processo de conscientização, a primeira oficina do PBMS abordou aspectos conceituais da promoção da saúde e de Municípios Saudáveis depois de ter utilizado várias estratégias de sensibilização.

O encontro visou também identificar a relação entre promoção da saúde e o Movimento por Municípios Saudáveis, possibilitar discussões sobre descentralização, intersetorialidade, interinstitucionalidade, participação social, avaliação, sustentabilidade e definir uma agenda de atividades.

Um grupo local eleito pelos pares, representando a prefeitura, a sociedade civil e com uma representação da universidade teria o papel de decidir sobre encaminhamentos do processo de construção do projeto. A $1^{a}$ Oficina contou com a participação de técnicos da prefeitura, políticos locais e diversos representantes de entidades e membros da sociedade civil (Caricari et al. 2000).

A Oficina foi desenvolvida em três partes. Na primeira parte foi realizada uma apresentação dos participantes, e em seguida, foi feito um levantamento de expectativas com relação ao encontro e com relação ao projeto que estava se iniciando. Foram discutidos os conceitos de promoção da saúde e de cidades saudáveis.

Na segunda parte foram divididos diversos grupos que discutiram e procuraram responder algumas questões: como é a minha cidade? Como eu gostaria que ela fosse? Na terceira parte foi proposta a formação de cinco grupos. Os grupos deveriam trabalhar com cinco relatos de moradores de Bertioga obtidos através de entrevistas. Cada grupo escolheu um relato e um problema a ser discutido. A tarefa do grupo foi levantar as causas do problema e elaborar propostas de encaminhamentos para soluções, com enfoque na intersetorialidade e na participação.

Desde esta primeira oficina a questão da habitação apareceu com grande força. Foram apontadas diferentes causas para o aumento de favelas e assentamentos precários: 
a) Causas sócio-econômicas identificadas: "desemprego no local de origem (dos que migram para Bertioga), baixa escolaridade, desemprego ou subemprego em Bertioga".

b) Causas político-administrativas identificadas pelo grupo: "falta de vigilância nas áreas públicas, falta de políticas habitacionais, sobrecarga de todos os serviços públicos (saúde e educação), o desemprego que causa violência, a degradação do meio ambiente, insalubridade, economia informal, marginalidade tributária."

Desde este momento já começaram a ser esboçadas soluções para os problemas. Estas porém, ainda no âmbito da "culpabilização da vitima", de caráter mais fiscalizadoras, demonstrando uma consciência pouco crítica ou superficial dos problemas.

Como propostas de soluções, foram elencadas:

"cadastramento (da população moradora dos assentamentos irregulares), congelamento das ocupações irregulares, vigilância rigorosa (com relação às invasões), política habitacional envolvendo os moradores (para eles serem fiscais), urbanização das áreas, integração desta população (inclusão), empreendimentos imobiliários, responsabilidade das empresas sobre os seus funcionários (quanto à solução de moradia)."

A referência ao tema da habitação também apareceu quando grupos trabalharam com outras temáticas. O grupo que trabalhou a questão da "falta de emprego principalmente na baixa estação" identificou entre as causas do problema o "aumento desordenado da população, a mão de obra desqualificada" (em geral). Entre as soluções propostas, foram citadas:

"geração de emprego através da dinamização do turismo, emprego na construção civil, no setor de serviços, entre outros."

É interessante notar que logo no primeiro encontro com representantes no município, em março de 2000, a moradia já era considerada um problema relevante. Vale notar também que o grupo relacionava como causas do problema da habitação, as más condições de vida das cidades de origem dos 
que migram para Bertioga. Foram relacionados também como causas, a baixa escolaridade e o desemprego ou o sub-emprego.

Naquele momento já havia a percepção clara da ausência de uma política pública consistente $e$, por conseguinte, a necessidade de se viabilizar a fiscalização, e ao mesmo de tempo, uma política de habitação. Como proposta de soluções, surgiram da discussão, as que passam pelo controle (cadastramento, congelamento e fiscalização), a política habitacional com urbanização e inclusão (envolvendo os moradores também como fiscais para evitar novas invasões), e a contra-partida dos empregadores e empresários, como responsáveis ou co-responsáveis pela solução de moradia dos funcionários (principalmente as empresas construtoras que a cada nova obra, traz novos operários para Bertioga).

\subsection{Pesquisa exploratória: levantamento preliminar do tecido social do Município de Bertioga}

A pesquisa exploratória, realizada nos meses de março e abril de 2000 teve como objetivos identificar os atores sociais chaves, movimentos sociais, entidades, organizações, grupos de interesse e outros atores locais; formar um banco de dados com os nomes e contatos para possiveis trabalhos conjuntos e colaboração; levantar a percepção das afinidades e conflitos entre lideranças e grupos sociais; levantar a opinião sobre problemas, aspectos positivos e sonhos para a cidade; iniciar o conhecimento sobre possiveis locais para a realização das oficinas regionais e do futuro e obter um conhecimento inicial do território.

A metodologia qualitativa de tipo exploratório foi a selecionada para o estudo. Os dados foram coletados por meio de entrevista seguindo as recomendações de Barros (1998) e Feuerstein (1986) a partir de um roteiro e da técnica popularmente conhecida por "bola de neve".

A amostragem foi intencional, pelo fato de a pesquisa objetivar a identificação de atores locais como lideranças comunitárias, representantes de grupos e entidades. A escolha foi baseada na indicação, obtida de "informantes chave" do próprio local, sendo a seleção também intencional. $O$ tamanho da amostra não foi determinado de antemão e dependeu das 
circunstâncias e das indicações recebidas a cada dia, do entrevistador e dos atores da área entrevistada (Arai, 2002). A pesquisa foi realizada durante 6 dias e foram entrevistados 86 homens e 48 mulheres, perfazendo um total de 134 pessoas. Foi solicitado, entre diversas questões, que o entrevistado respondesse:

- O que mais te incomoda no bairro/local? Cite três problemas.

- Quais são os três aspectos mais positivos de Bertioga?

- Qual é o seu sonho para Bertioga?

Objetivou-se abranger todo o território do município por meio da cobertura dos loteamentos mais centrais aos mais periféricos: Vicente de Carvalho II, Sitio São João, Jardim Lido, Chácaras Caiubura, Guarabira, Albatroz I, Albatroz II, Jd. Paulista, Jd. Itapanhaú, Vila Tamoios, Jd. Albatroz, Vila Tupi, Jd. Vista Linda, Maitinga, Center Vile, Vila Agaó, Jd. Rio da Praia, Uritinga, Mangue Seco, Jd. Rio da Granja, Rio Raso, Jardim Ana Paula, Jardim das Canções, Jardim Vista Alegre, Jardim Rafael, Chácara Vista Linda, Indaiá, Jardim do Sol, Praia do Indaiá, Jd. Caiçara, Jardim Indaiá, Vista Alegre, Boracéia, Vila Tiburcia, Guaratuba, Costa do Sol, Parque Jabaquara, Vila Clementina, Jardim São Lourenço, Loteamento Costa do Sol, Riviera de São Lourenço, Jardim São Lourenço, Mogiano e Morada da Praia.

\subsubsection{Percepção dos participantes da pesquisa exploratória}

A partir da análise efetuada, nota-se que apesar da diversidade de opiniões e percepções acerca da realidade do município, os problemas e necessidades apontados pelas lideranças locais coincidem (e no caso reforçam), em muitos pontos, com os diversos aspectos e características apresentados pelo diagnóstico sócio-espacial.

O problema mais citado "a falta de saneamento básico na cidade" coincide com os resultados do diagnóstico sócio-espacial apresentado no capítulo 5 do trabalho, uma vez que é o serviço público básico que tem a menor cobertura municipal. Além disso é um serviço público fundamental para a saúde da população. 
É interessante notar que se consideramos os problemas relacionados ao saneamento, temos 60 citações (13,5\% do total), manutenção de ruas e valas com 38 citações (8,5\% - relaciona-se à ausência de pavimentação e sistema de drenagem urbana), falta de iluminação pública com 18 citações (4\%), falta de infra-estrutura com 19 citações $(4,3 \%)$, enchentes com 8 citações $(1,8 \%)$, falta de uma política de habitação adequada com 8 citações $(1,8 \%)$, e abandono dos bairros pelos órgãos públicos com 16 citações $(3,6 \%)$ chegamos a cerca de 167 citações, equivalente à $37,59 \%$ do total das citações dos problemas da cidade (Tabela 33).

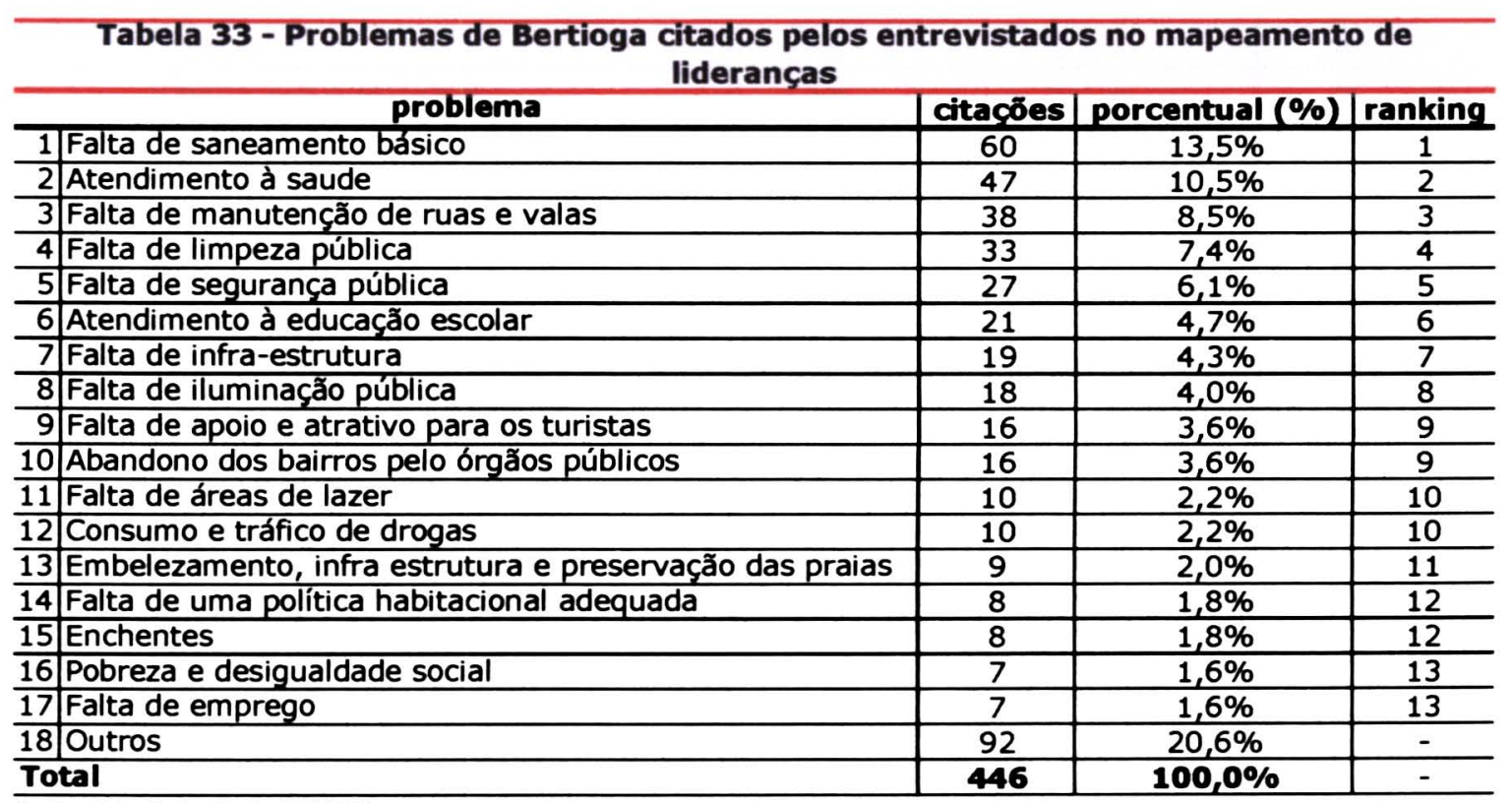

fonte: Adaptada de Arai (2002)

Esses problemas estão fortemente relacionados à necessidade das políticas urbanas no município e de provisão de infra-estrutura, aspectos fundamentais para melhorar a saúde, as condições de vida da população e para o município tornar-se mais saudável.

Entre os aspectos positivos citados pelos entrevistados, como se pode ver no quadro a seguir, destacam-se as praias com $11,21 \%$ das ocorrências de citações, as belezas naturais com $9,61 \%$ das citações, o potencial turístico $(5,87 \%)$ e o sossego $(5,34 \%)$. Nota-se que a maior parte dos itens declarados pelas lideranças ou atores locais relacionam-se às características do ambiente natural e da sua potencialidade do ponto de vista do seu 
aproveitamento para o desenvolvimento econômico (turismo, empregos e renda) qualidade de vida, tranqüilidade, contemplação (Tabela 34).

Se somarmos os percentuais de todos os aspectos positivos relacionados aos recursos naturais de Bertioga como praias, belezas naturais, Mata Atlântica e clima, chega-se a $38,5 \%$ do total de citações (Tabela 34 ).

\begin{tabular}{|c|c|c|c|c|}
\hline \multicolumn{2}{|r|}{ aspectos positivos citados } & citações & porcentual (\%) & ranking \\
\hline 1 & As praias & 42 & $11,2 \%$ & 1 \\
\hline 2 & Belezas naturais & 36 & $9,6 \%$ & 2 \\
\hline$\overline{3}$ & Potencial turistico & 22 & $5,9 \%$ & 3 \\
\hline 4 & Sossego & 20 & $5,3 \%$ & 4 \\
\hline 5 & Segurança publica & 19 & $5,1 \%$ & 5 \\
\hline$\frac{2}{6}$ & Mata Atlantica & 16 & $4,3 \%$ & 6 \\
\hline 7 & Patrimonio historico & 15 & $4,0 \%$ & 7 \\
\hline 8 & Caracteristicas positivas do povd & 14 & $3,7 \%$ & 8 \\
\hline 9 & 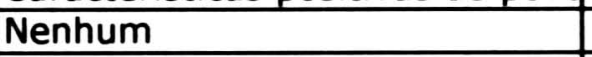 & 14 & $3,7 \%$ & 8 \\
\hline 10 & Qualidade de vida & 12 & $3,2 \%$ & 9 \\
\hline 11 & Atendimento na area da saúde & 10 & $2,7 \%$ & 10 \\
\hline$\overline{12}$ & Area de preservação ambiental & 8 & $2,1 \%$ & 11 \\
\hline 13 & Serviço publico de educação & 8 & $2,1 \%$ & 11 \\
\hline 14 & Proximidade dos grandes centro & 7 & $1,9 \%$ & 12 \\
\hline 15 & Transporte público & 7 & $1,9 \%$ & 12 \\
\hline 16 & Mar & 7 & $1,9 \%$ & 12 \\
\hline 17 & Clima & 7 & $1,9 \%$ & 12 \\
\hline 18 & Outros & 110 & $29,4 \%$ & - \\
\hline \multicolumn{2}{|c|}{ Total } & 374 & $100,0 \%$ & - \\
\hline
\end{tabular}

fonte: Adaptado de Arai (2000)

É interessante notar também que em alguns casos, o tema que aparece como um problema citado por muitos entrevistados, aparece como aspecto positivo citado por outros. É o caso do atendimento da área de saúde que aparece como ponto positivo em $2,67 \%$ das citações e como problema em $10,5 \%$ das citações. Neste caso, a maior parte dos que se referiram à saúde consideraram a falta de acesso e a qualidade dos serviços oferecidos, um problema no município (Tabelas 33 e 34 ).

O mesmo acontece com serviço público de educação que é visto como aspecto positivo em $2,1 \%$ das citações, ao mesmo tempo em que foi considerado problemático em $4,7 \%$ citações. Aqui, também a proporção dos 
que consideram um aspecto como problema, supera a dos que consideram o mesmo aspecto como positivo.

Outros aspectos positivos interessantes para ressaltar são o patrimônio histórico e as características positivas do povo, que ocupam a oitava e a nona posição com os percentuais de $4,0 \%$ e 3,7\%, respectivamente.

Com relação aos sonhos citados pelos entrevistados nota-se que muitos se relacionam de alguma forma com a superação dos problemas levantados (Tabela 35).

É o caso, por exemplo, da geração de emprego e renda, com 18 citações $(7,1 \%$ do total) do atendimento à saúde $(6,7 \%)$, do desenvolvimento da cidade $(6,3 \%)$, do ensino $(6,3 \%)$, da habitação $(6,3 \%)$, da melhoria da infra-estrutura nos bairros $(4,3 \%)$, do planejamento urbano $(3,9)$, do saneamento básico $(3,1 \%)$ entre outros (Tabela 35 ).

Houve destaque para os sonhos relativos à melhoria da administração pública. Como a entrevista focava os problemas, os sonhos, os aspectos positivos do município, na perspectiva de um Projeto Município Saudável, interpretamos que boa parte dos entrevistados se referiam à administração pública municipal, sugerindo que os governantes pudessem ser mais comprometidos com a melhoria das condições de vida na cidade.

Nota-se também, que é relevante o número de pessoas que vêem o turismo como uma grande saída para o município, declarando o desenvolvimento desta atividade como um sonho de futuro.

Aqui, a habitação volta a aparecer em lugar de destaque nas referências, com 16 citações. Se somarmos os aspectos relativos às políticas urbanas e infra-estrutura: habitação, infra-estrutura e preservação das praias, melhoria e conservação da infra-estrutura dos bairros, planejamento urbano da cidade, saneamento básico, chegamos à cerca de $28 \%$ das citações (Tabela 35). 
Políticas de habitação e desenvolvimento urbano em municípios saudáveis: o caso de Bertioga

Capitulo 6- O projeto Bertioga Município Saudável e a percepção dos moradores

sobre os problemas urbanos

Tabela 35 - Sonhos para Bertioga, mencionados pelos entrevistados no mapeamento de lideranças

\begin{tabular}{|c|c|c|c|}
\hline sonhos com relação à Bertioga & citações & percentual (\%) & ranking \\
\hline 1 Relacionados à administraçào pública & 28 & $11,0 \%$ & 1 \\
\hline 2 Relacionados ao turismo & 28 & $11,0 \%$ & 1 \\
\hline 3 Relacionados à geração de emprego e renda & 18 & $7,1 \%$ & 2 \\
\hline 4 Relacionados ao atendimento à saúde pública & 17 & $6,7 \%$ & 3 \\
\hline $5 \mid$ Relacionados à habitação & 16 & $6,3 \%$ & 4 \\
\hline 6 Relacionados ao desenvolvimento da cidade & 16 & $6,3 \%$ & 4 \\
\hline 7 Relacionados ao ensino público ou privado & 16 & $6,3 \%$ & 4 \\
\hline 8 Relacionados à melhoria de infra-estrutura e preservação das praias & 12 & $4,7 \%$ & 4 \\
\hline 9 Relacionados à preservção do meio ambiente & 11 & $4,3 \%$ & 5 \\
\hline \begin{tabular}{l|l}
10 & Relacionados à melhoria e conservação da infra-estrutura nos bairros
\end{tabular} & 10 & $3,9 \%$ & 6 \\
\hline 11 Relacionados ao planejamento urbano da cidade & 10 & $3,9 \%$ & 7 \\
\hline 12 Relacionados ao crescimento economico & 8 & $3,1 \%$ & 7 \\
\hline 13 Relacionados ao saneamento básico & 7 & $2,8 \%$ & 8 \\
\hline 14 Relacionados à melhoria da qualidade de vida & 7 & $2,8 \%$ & 9 \\
\hline 15 Relaciondos às condições sócio-econômicas da população & 7 & $2,8 \%$ & 9 \\
\hline 16 Relacionados à segurança pública & 6 & $2,4 \%$ & 10 \\
\hline 17 Pessoais & 5 & $2,0 \%$ & 11 \\
\hline 18 Relacionados ao problema do lixo & 5 & $2,0 \%$ & 11 \\
\hline 19 Realacionados à valores humanos & 4 & $1,6 \%$ & 12 \\
\hline 20|Relacionados ao incentivo cultural & 4 & $1,6 \%$ & 12 \\
\hline \begin{tabular}{|l|l|}
21 & Relaciondados aos aspectos religiosos \\
\end{tabular} & 3 & $1,2 \%$ & 13 \\
\hline 22 Relaciondos ao lazer & 3 & $1,2 \%$ & 13 \\
\hline 23 Relacionados à formação de lideranças e à capacitação profissional & 2 & $0,8 \%$ & 14 \\
\hline 24 Relacionados ao abastecimento & 2 & $0,8 \%$ & 14 \\
\hline \begin{tabular}{l|l}
25 & Relaciondados à cidadania \\
\end{tabular} & 2 & $0,8 \%$ & 14 \\
\hline \begin{tabular}{l|l}
26 & Relacionados à um ideal de cidade saudavel \\
\end{tabular} & 2 & $0,8 \%$ & 14 \\
\hline \begin{tabular}{l|l|}
27 & Relacionados ao estabelecimento de parcerias \\
\end{tabular} & 1 & $0,4 \%$ & 15 \\
\hline 28 Relacionados ao transporte público & 1 & $0,4 \%$ & 15 \\
\hline 29|Relacionados aos idosos & 1 & $0,4 \%$ & 15 \\
\hline 30 Sem sonhos & 1 & $0,4 \%$ & 15 \\
\hline 31 Que fosse uma cidade que os filhos pudessem ficar & 1 & $0,4 \%$ & 15 \\
\hline Total & 254 & $100,0 \%$ & - \\
\hline
\end{tabular}

fonte: Adaptado de Aral (2000)

Também se destacam, do nosso ponto de vista, a preocupação de parte dos entrevistados com a formação das lideranças e capacitação profissional, com a cidadania e com um ideal de cidade saudável ${ }^{3}$.

\footnotetext{
${ }^{3}$ Vale lembrar que os entrevistadores eram agentes comunitários de saúde e pesquisadores e estudantes de pós-graduação da USP que foram capacitados para tal. No início da entrevista o entrevistador ao apresentar-se, explicava que se tratava de uma atividade no âmbito do projeto em fase inicial de implementação do Projeto Bertioga Município Saudável.
} 


\subsection{Oficinas Regionais de Sensibilização, Oficinas do Futuro,} Seminário Municipal e Formação da Comissão Intersetorial

A análise detalhada das Oficinas Regionais e das Oficinas Futuro foi realizada por Arai (2002) em sua dissertação apresentada à Faculdade de Saúde Pública da USP: Análise de um processo participativo na experiência de implantação de um Projeto Município Saudável. Sendo assim, vamos nos referir aqui, de forma mais objetiva aos aspectos que foram levantados durante estas atividades relacionados principalmente à moradia, saneamento, transportes e infra-estrutura urbana.

As oficinas regionais de sensibilização com duração de 3 (três) horas, ocorreram em 10 (dez) localidades diferentes do município - visando permitir a participação de um maior número de pessoas - no mês de agosto de 2000. Tiveram como objetivo geral a sensibilização de diferentes segmentos de atores sociais das diversas regiões para participação no Projeto Bertioga Município Saudável e como objetivos específicos iniciar a formação de núcleos regionais de apoio ao Projeto, além de capacitarem agentes locais para atuarem como fomentadores do Projeto. Foram realizadas 10 (dez) oficinas regionais de sensibilização, com a participação de 141 pessoas (Arai, 2000).

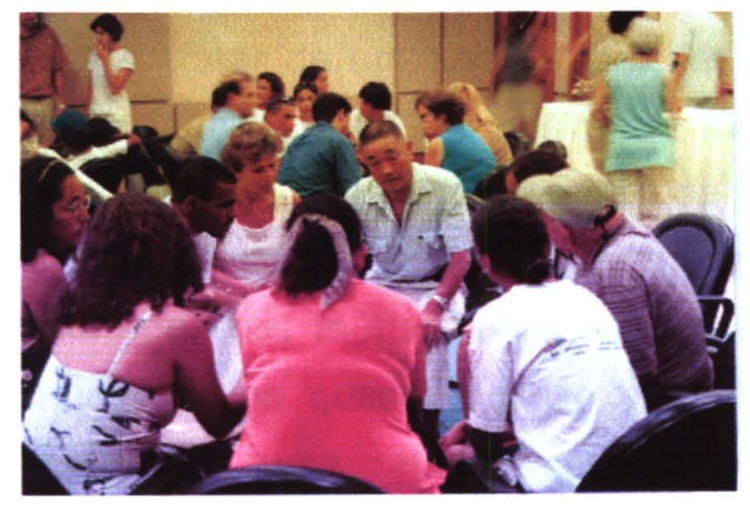

FotografiA 14 - GRUPO DE DISCUSSÃo durante Seminario Municipal no SESC BERTIOGA

Segundo Arai (2002) as Oficinas do Futuro, por sua vez, constituíram-se de 4 (quatro) encontros de cerca de 3 (três) horas cada, intercaladas de 1 (uma) semana cada e ocorreram no mês de outubro de 2000 . Ao final foram 
realizados encontros durante 16 dias com participação de 193 pessoas durante todo o processo.

As Oficinas Futuro constituem uma abordagem simplificada do Planejamento Estratégico Situacional Participativo. Neste sentido objetivaram "construir agendas de planejamento participativas para o municipio, baseadas no futuro que os moradores desejam para Bertioga. Visavam também estimular o diálogo entre os diversos segmentos da população e do poder público em torno de ações para a melhoria da qualidade de vida e implantação do Projeto Bertioga Município Saudável" (Arai, 2002).

Tinham como objetivos específicos contribuir para despertar e/ou fortalecer os sentimentos de pertencimento e compromisso em relação a todo o ambiente natural e construído; proporcionar a construção de técnicas de planejamento participativo e pesquisa participante que facilitassem a compreensão ampla e crítica das condições sócio-ambientais locais; contribuir para o levantamento e sistematização das demandas e propostas de parte da população da cidade, gerando subsídios para a definição de políticas públicas saudáveis; capacitar lideranças locais para o desenvolvimento de atividades que promovessem a melhoria da qualidade ambiental e de vida na região; formar grupos, representando os diversos segmentos da população; estabelecer redes de apoio ao Projeto, interligadas entre si (Arai 2002).

Por se tratar de um ano de eleições municipais, a equipe da Faculdade de Saúde Pública da USP considerou fundamental que todos os candidatos à prefeito tomassem conhecimento da proposta do Projeto Bertioga Município Saudável, de suas perspectivas de médio prazo e que se firmassem compromissos mútuos para sua continuidade, independente das eventuais mudanças no quadro político administrativo local. Em setembro de 2000 realizou-se uma reunião com participação de cerca de 47 pessoas de diversos partidos políticos. Estavam presentes, participantes filiados ao PSB, PRP, PPB, PV, PSDB, PL, PT e PPS. Participaram, o prefeito em exercício (PSDB) os candidatos a prefeito pelo PT, o ex-prefeito e candidato pelo PSB, e o candidato pelo PL que viria a ser o futuro prefeito da cidade (Arai 2000).

"Naquela ocasião, todos os candidatos se comprometeram a assumir a continuidade do projeto caso vencessem as eleições. Esta manifestação 
garantiu certa tranqüilidade quanto à continuidade e sustentabilidade do Projeto" (Arai, 2000).

No início de outubro, com a confirmação da vitória do candidato de oposição, do PL, a equipe da FSPUSP procurou viabilizar contatos para garantir a sua participação no Seminário Municipal, que seria realizado após as Oficinas do Futuro e estabelecer um novo plano de trabalho conjunto e uma relação positiva com os novos membros da administração municipal, o que graças aos esforços de relacionamento diplomático entre os integrantes da universidade junto aos governantes, resistiu até o primeiro semestre de 2003, quando o Projeto Bertioga Município Saudável retirou oficialmente seu escritório de trabalho do Paço Municipal, após inúmeras tentativas frustradas de negociar trabalho conjunto. Contando com apoio de muitos setores representativos da sociedade civil, o Projeto Bertioga Município Saudável continua com suporte político e econômico de entidades civis locais, nacionais e internacionais e tem sua sede em uma sala nas dependências da ACIPEB - Associação Comercial, Industrial e Pesqueira de Bertioga.

O I Seminário Municipal do Projeto Bertioga Município Saudável realizado em dezembro de 2000 objetivou apresentar as agendas de prioridades locais construídas pelos diversos grupos de Bertioga, durante as Oficinas do Futuro. Outros objetivos do Seminário foram: discutir como implementar as agendas no município; trocar experiências entre os grupos de diferentes bairros e realizar o intercâmbio das agendas; contribuir para o levantamento e sistematização das demandas e propostas de parte da população de Bertioga, gerando subsídios para a definição de políticas públicas saudáveis; iniciar 0 processo de constituição da Comissão Intersetorial e Interinstitucional do Projeto de caráter mais permanente em renovação à provisória eleita na primeira oficina. 


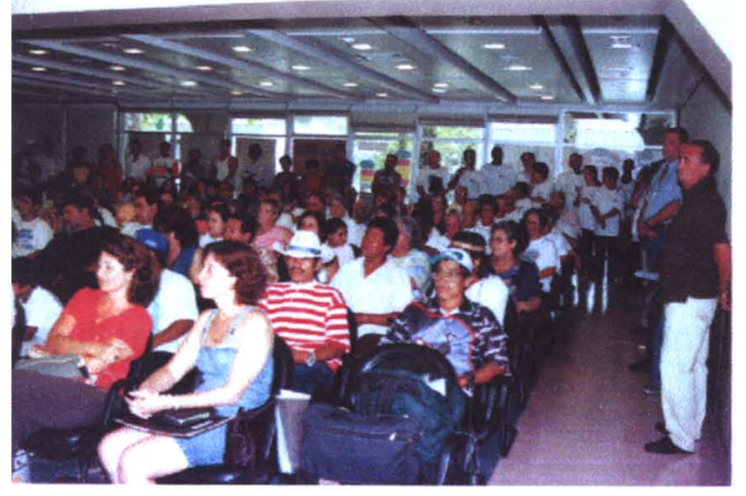

Fotografia 15 - Vista do Seminario Municipal no AUdTTÓRIo do SESC BERTIOGa

Até então, conforme nos relata Arai (2000) houve 574 participantes durante as principais atividades desenvolvidas. Este total equivalia à cerca de $1,9 \%$ da população total do município na época (30.619 habitantes pelo IGBE 2000).

Passaremos a seguir à descrição e discussão da percepção dos moradores e atores locais participantes das Oficinas do Futuro nas duas categorias de análise citadas.

\subsubsection{Percepção dos participantes das Oficinas do Futuro}

Neste item continuaremos com a análise qualitativa do estudo de caso utilizando os documentos produzidos e a transcrição de gravações, considerando a percepção dos atores locais sobre os problemas relativos aos componentes do campo das políticas urbanas (moradia; saneamento ambiental: abastecimento de água, esgotos sanitários, resíduos sólidos e drenagem; transportes e mobilidade: integração e fragmentação);

\section{Percepção dos atores locais sobre os problemas no campo das políticas urbanas}

Durante as Oficinas do Futuro constatou-se que boa parte dos problemas que mais incomodam a população, referem-se ao campo das políticas urbanas. Como observamos, é um problema sentido pelos moradores e que afeta a saúde e as condições de vida no cotidiano. 
Passaremos a mostrar, de que maneira a população se referencia aos problemas, relacionando-os uns com os outros, numa demonstração de que percebe e sente no dia a dia a ampla determinação do processo saúde/doença.

Esta abordagem é útil aqui, como já mencionado, na medida em que permite ampliar e aprofundar nossa compreensão dos fenômenos estudados, fortalecendo e complementando os dados quantitativos, além de permitir referendar e legitimar o diagnóstico de caráter técnico obtido com dados secundários oficiais de órgãos públicos. Além disso podem surgir elementos novos, levantados pela população, que não aparecem nos dados secundários de origem institucional ou oficial.

Para facilitar a discussão, procuramos, na análise das percepções dos moradores e atores locais, agrupar temas próprios e inter-relacionados pelos próprios participantes do processo.

\section{Políticas urbanas e os diversos problemas}

Durante as Oficinas do Futuro foram levantados diversos problemas, de modo que, por meio de exercícios de discussão em grupos, se buscasse interrelacioná-los e efetuar uma priorização para o grupo focar como prioridade de atuação. Os problemas urbanos aparecem em todos os grupos das 5 regiões da cidade onde foram realizadas oficinas (Arai, 2000).

Nesta passagem, um mediador de uma oficina lê no quadro as produções dos participantes locais, fruto da discussão:

"(...) então olha só, muro das dificuldades: favelas, favela e drogas, cachorro abandonado, participação da comunidade nesses problemas, saúde, escola mais perto, mais união, as drogas, buracos nas ruas, lixo nas ruas, individualidade dos moradores, falta de incentivo cultural e educativo, drogas e a juventude ociosa, ruas esburacadas, falta de atividade para as crianças, integração da comunidade, falta de comércio, falta de saneamento básico, segurança, limpeza nas ruas, falta de união, saneamento nas favelas, esgoto, barulho de cachorro, as drogas, saúde, má administração financeira, atendimento médico, ruas esburacadas, associação de bairro, má administração da verba pública, saúde e corrupção, isso foi o muro que 
vocês construiram aqui, (...) agora a gente vai entrar na problematização (...)." (mediador de uma Oficina em um bairro de Bertioga, outubro de 2000).

Em outra oficina, no início do trabalho, o muro das dificuldades produzido pelos participantes apresentou os seguintes problemas com os respectivos números de citações:

"(...) esgoto (2), rede coletora de esgotos (1), restos de poda (1) saneamento básico (3), lixo na rua (3), falta de emprego (1), pavimentação (1), valas abertas (4), falta de segurança (1), falta de um hospital (1), esgoto aberto (2), cachorro na cidade (1), segurança (1), cachorro na rua (4), ruas sujas e com buracos, desenho do Marcos - valas abertas (1), limpeza (1), balneabilidade da praia (1), calçamento (1), droga (1), ratos (1), limpeza de valas (1), ruas sem asfaltar (1), iluminação, falta de emprego (1), quadra poliesportiva (1), calçamento (1) (...)" (Muro das dificuldades / problemas levantados pelos participantes de uma Oficina do Futuro, outubro de 2000).

Nota-se que se considerarmos os problemas relacionados às políticas urbanas, tem-se 26 citações de um total de 34, ou seja, o equivalente a $76,47 \%$ das citações naquela oficina daquele bairro.

Um aspecto importante ocorrido nas atividades refere-se a separação e agrupamento de problemas diferentes ou de diferentes áreas. Trata-se de um exercício que envolve percepção da causalidade dos fenômenos, bem como da intersetorialidade necessária para a ação organizada ou institucional.

Neste sentido, essas passagens retratam um pouco, os diversos aspectos destas tentativas de sistematização dos grupos:

"Mediador: E naquela outra nuvem do problema da saúde, do lixo, da falta de saneamento, que título que a gente daria para essa nuvem?

Participante: Eu acho que falta de saúde.

Mediador: Falta de saúde?

Participante: Isso ai seria falta de saúde e de saneamento básico.

Mediador Falta de saúde, saúde precária. Qual, o que a gente pode colocar? Participante: Saúde precária. 
Qutro Participante: Falta de estrutura."

Com relação ao mesmo processo, em outra oficina foi registrado o seguinte argumento:

"(...) minha sugestão é de que deveria separar saneamento básico de lixo, pois são dois problemas muito graves, e já estamos colocando tudo junto...uma coisa é o lixo, é o lixão que nós temos aqui, é a degradação do meio ambiente, a falta de coleta. E outra é o saneamento básico, são dois problemas graves. Se colocar junto não daremos a devida atenção a um e outro (...)" (participante de oficina do futuro, outubro de 2000).

Nesta última passagem nota-se a preocupação em visualizar os problemas separadamente, com vistas a fortalecer a abordagem de cada problema, considerado importante.

(...) Olha como ficou aqui, o agrupamento nosso! União, participação, falta de participação e falta de comunicação. Aqui com relação aos serviços: falta de asfalto, falta de iluminação, falta de esgoto, falta de médicos, falta de escola, transporte sem qualidade, e falta de transporte. Trabalho, falta de trabalho. Aqui, descumprimento de leis e regulamentos, falta de fiscalização, falta de comprometimento do poder público. E aqui, as dificuldades, modificar as pessoas, falta de auto estima, sociabilidade, agora nós vamos tentar dar nomes para essas coisas (Mediador).

Em outra passagem procura-se também agrupar os problemas.

Mediador Saneamento, escola, saúde, asfalto, iluminação, vocês puseram tudo no mesmo bloco.

Participante: Tem que separar aí, falta de educação e falta de saneamento. Saneamento é uma coisa e educação é outra.

Outro participante: Falta de infra-estrutura (...)" (Oficina do Futuro, outubro, 2000).

Em outras situações os participantes relacionam com boa clareza temas como saúde e saneamento, por exemplo.

"(...) O saneamento básico tem muito a ver com a saúde. Crianças que ficam (brincando) nas valas, de esgoto, de córregos, elas vão muito mais vezes ao pronto socorro, do que se elas (as valas) não tivessem na frente da casa dela (...)" (participante de oficina do futuro, outubro de 2000). 
Em todos os estes passos do processo, as políticas urbanas emergem como necessidade sentida da população residente em todas as áreas do território de Bertioga.

\section{Moradia e favelas}

"Nossos assentamentos são de péssima qualidade e estamos destruindo nosso meio ambiente Se continuar nesse ritmo seremos a pior cidade em qualidade de vida"

(Avaliação de participante no final do Curso de Formação de Agentes Multiplicadores)

Dentre os problemas urbanos levantados, o problema da moradia está entre os mais mencionados e discutidos. Os moradores e atores locais o relacionam a diversos outros problemas e possuem também opiniões diferentes sobre o encaminhamento de soluções. Nota-se a posição de centralidade que 0 problema da habitação ocupa na percepção dos participantes.

Na seqüência, um morador apresenta o resultado da discussão de seu grupo aos demais grupos e aos organizadores da oficina:

"(...) Vou apresentar o primeiro problema: a favela. Quais são as causas: a falta de moradia, a falta de emprego, a falta de infra-estrutura, crescimento demográfico desorganizado, migração, criminalidade e desorientação. Desorientação significa aquele que vem para cá não sabe onde vai morar, e acaba indo para a favela".

Atividades $e$ as ações propostas: mapear e levantar dados sobre os moradores, a conscientização, a escolha de lideres para uni-los, reivindicar para melhores condições dentro da sociedade, Sociedades Amigos de Bairros, é para isso que elas existem, tem que ser a porta voz dos anseios da sociedade organizada, da comunidade. Nem sempre, mas espera-se.

Atores envolvidos: Prefeitura, Estado, Governo Federal e comunidade,

A data (para execucão): em tempo indeterminado, não dá para fixar uma data, que é um problema um pouco grande, bem grande, para se eliminar, então por isso que o tempo é indeterminado. (...)" (morador e participante da oficina do futuro em outubro de 2000). 
As favelas são também consideradas por alguns moradores, como relacionadas às drogas e ao lixo. Depoimentos como esses, mostraram a diversidade profunda de leituras e percepções da realidade. Todavia, a questão dos estigmas e preconceitos, procurou ser abordada indiretamente em diferentes momentos pela equipe da FSPUSP.

"(...) Mediador: Quem é que escreveu aqui: favela?"

Participante: Eu.

Mediador: Porque a favela é um problema?

Participante: Por que, a favela faz com que, o progresso indo embora e a favela chegando cada vez mais, antes era uma, agora são três favelas, quer dizer, ela está crescendo mais que o progresso.

Mediador: É, mas porque a favela é um problema?

Participante: Por que, problema assim, por que junta muito lixo, as pessoas vivem em condições precárias, existe sim da favela um grupo, um movimento que está liderando vários tipos de drogas, então vai incentivando as crianças a usarem droga, então eu sou contra a favela sim.

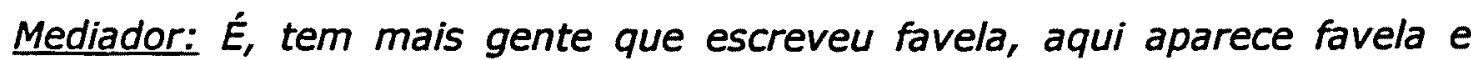
drogas, quem é que escreveu favela e drogas?

Qutro participante: Eu.

Mediador: Porque você acha, é o mesmo problema que a (...) está apontando, ou você acha que é uma situação diferente, que você quer colocar?

Outro participante: Não, é a mesma coisa. (...)

Mediador: Então a gente pode colocar junto, né, esses dois problemas (favela e drogas)? (...)" (diálogo em oficina do futuro, outubro de 2000).

É curioso notar como o participante relaciona a "chegada da favela" com o "progresso indo embora", além da precariedade, do lixo, com incentivo ao uso de drogas.

Há ainda, os que acreditam que, eventuais melhorias promovidas nas favelas, constituem-se incentivo ao surgimento e profusão de outras favelas na cidade. 
"(...) Eu peço discurso porque eu tenho pensamento radical, eu acho que se nós dermos condições para a favela, se a gente coloca luz na favela, se a gente coloca saneamento na favela, a gente acaba incentivando a favela, por isso que eu estou colocando esse pensamento radical que eu tenho, mas é esse meu pensamento (...)" (participante em oficina do futuro, outubro de 2000).

Alguns moradores percebem e relacionam também, a divisão das diferentes classes sociais no âmbito do local de moradia, com criminalidade e violência. "(...) quem chama a polícia em Guaratuba, são os que têm mais dinheiro, incomodados com essa situação das favelas. Agora, a gente acaba sabendo casos de estupro, que não são noticiados, de roubos a mão armada, tráfico de armas, tráfico de entorpecentes. Até no mês passado, peguei um traficante lá, bem ali próximo da quadra $A$, estava há muito tempo lá, quer dizer, a população sabe e não denuncia. Não disca 190 (...)" (participante de oficina do futuro, outubro de 2000).

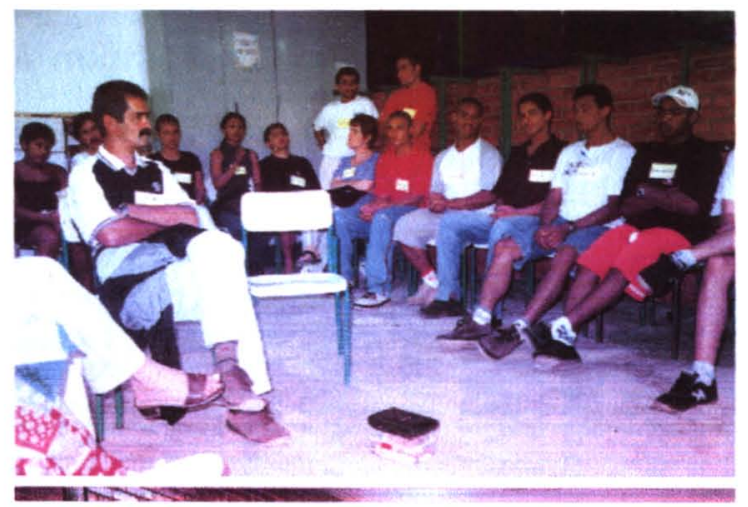

Fotografia 16 - Participantes de Oficina do Futuro em Escola Municipal de Bertioga

Provavelmente a migração é uma dos fenômenos mais percebidos pelos moradores relativamente ao surgimento das favelas na cidade. $E$ as migrações são relacionadas também por eles à construção civil, ao desemprego, entre outros. Veja-se a fala deste morador:

"(...) Só lembrando o seguinte, que muitas vezes as causas, as pessoas que vêm morar aqui, elas não tem culpa disso, porque aqui tem uma política de construção civil que atrai as pessoas para cá, então por isso se a gente for 
ver as raizes da origem das favelas, a gente pode até pegar na construção civil que chamam as pessoas para cá. $\dot{E}$, oferta de trabalhos (...)".(participante de oficina do futuro, outubro de 2000).

Outro participante diagnostica, durante a discussão na oficina, o fenômeno da migração, da origem dos migrantes e das raizes que eles deixam nos locais de onde saíram. Aqui a síntese das causas parece ser o desemprego:

"(...) A gente até sabe por alto, porque na verdade, a gente sabe que tem pessoas que tem casa na Bahia que veio para cá, que não tinha emprego lá, e estão na favela, tem casinha lá, mas não tem aqui. Bom a gente sabe porque o povo comenta com a gente (...). No Maranhão tem bastante produção de arroz (...). A maioria das favelas são com esse problema, entendeu. Eles têm casinha lá. (...) A Oferta de emprego aqui é melhor.(...). Vem em busca de emprego mesmo (...)".

(participante de oficina do futuro, outubro de 2000).

Outro morador chegou a dizer:

"(...) quando estiver falando da moradia, vai estar falando da migração (...)"

A migração é fortemente relacionada com a necessidade do trabalho e com as atividades de serviços de temporada de verão, na percepção dos moradores e atores locais.

"(...) O trabalho para o pessoal de fora, embora até sejam desqualificados, mas vêm de fora, o pessoal daqui, os caiçaras, ou quem mora aqui é pouco solicitado para alguma coisa, para algum tipo de trabalho, a equipe toda, 0 pessoal, normalmente vem de fora para cá (...). Eu, no meu caso, como eu trabalho na praia, trabalho no verão, no inverno eu passo fome, por que eu vou morrer de fome, por que se eu só depender da praia, ninguém vai (...) sendo que eu tenho possibilidade para fazer, posso fazer em Bertioga, mas ninguém dá, tenho que sair para fora (...)". (participante de oficina do futuro, outubro de 2000).

Neste sentido, a constante substituição da força de trabalho dos moradores atuais por novos migrantes que chegam ou são trazidos à cidade, parece revelar uma espécie de ciclo contínuo e permanente com o qual não se vislumbra formas de romper. Os atores centrais deste processo são os mais 
pobres, que migram para buscar alternativas de sobrevivência, e os que habitam das formas mais precárias. Assim, a moradia, parece ocupar posição de destaque na relação com a própria dinâmica populacional.

Outra questão levantada nas oficinas, que se relaciona intrinsecamente com uma moradia saudável e segura diz respeito à regularidade da posse e propriedade. A insegurança causada pela ausência de documentação e registros formais, ocasiona inclusive, timidez e dificuldade para abordar o assunto que, no caso de Bertioga, atinge parcela significativa da população. É o que mostra um diálogo em que se discutiam os problemas.

"(...) Mediador Teve uma pessoa que colocou legalização, o que significa ?

Participante: É porque eu moro...numa casinha...

Mediador: E por que isso é um problema?

Participante: É um problema para nois todos, essa rua inteira mora assim, nois queria que fizesse alguma coisa pela gente.

Mediador: Então essa legalização é de moradia, é isso? As casas não são legalizadas?

Participante: Não! (...)" (diálogo em oficina do futuro, outubro de 2000)

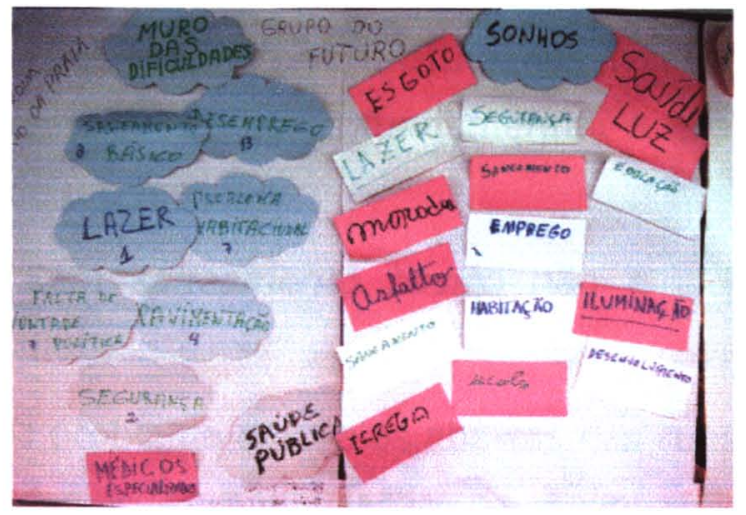

Fotografia 17 - MURO dAS Dificuldades E DOS SONHOS EM OFICINA do FUTURO

Outro fator relevante percebido pelos participantes das oficinas refere-se ao custo para obtenção ou produção da moradia. Como já mencionado no capítulo anterior, os custos dos terrenos urbanizados e dos materiais de 
construção são obstáculos centrais para o acesso à moradia adequada. Um morador menciona este aspecto nesta passagem:

"(...) Ali em frente ao depósito tem casos de uns anos para cá. Agora o que mais tem ali, esses onze lotes, que foram dados para pessoas carentes e as pessoas estão pagando seus impostos, parcelaram, e enquanto eles não acabarem de pagar eles não tem condições de construir. Porque são mulheres com filhos, é o caso, não é Célia. Então, são onze lotes, eu acho que tem cinco ou seis barracos, mas não são pessoas que invadiram. Os lotes foram doados. Eles estão pagando sua luz, sua água para poder construir suas casinhas, não questão que seja favela por invasão (...)" (participante de oficina do futuro, outubro de 2000 ).

\section{Saneamento ambiental}

"Meu sonho para Bertioga é que seja uma cidade limpa" (morador).

O saneamento aparece, do ponto de vista dos moradores e atores locais, em lugar de destaque. Quando mencionam os problemas de saneamento, muitos se referem aos esgotos lançados nas valas, nas ruas, nos rios ou no mar. A leitura local que se faz é que o saneamento está intrinsecamente ligado ao problema das valas, drenagem urbana e da pavimentação das vias públicas. Outros moradores relacionam o saneamento ao problema do lixo que muitas vezes também se mistura nas valas, nas ruas, está presente nas praias. 0 tema é tido como fundamental. A sua importância é tratada, como no dizer de um morador:

"Sem saneamento básico não é cidade". (oficina do futuro, outubro de 2000).

O problema das valas abertas nas ruas, por onde escoam as águas da chuva, mas que tem ligação de esgotos de muitas residências é mencionado diversas vezes, seja pela visibilidade do problema (está na rua), pelo cheiro, pela relação com a circulação e transportes, com os buracos, com a falta de pavimento e principalmente guias, sarjetas e sistemas coletores de águas.

"(...) Mas eu já me contento que na porta das casas, tem que (..) pelo menos tampem as valas, que é fedentina demais aquilo ali, já que nós não 
temos saneamento básico, pelo menos na frente das casas deles...que tampem tudo...tem muitas casas (...). Tem uma vala na frente de todas as casas que é pra fazer a drenagem do lençol. E é pra essa vala que são encaminhadas a água servida do esgoto (...)" (participante de oficina do futuro, outubro de 2000).

Apesar de se tratar de um município litorâneo, em que a maior parte dos moradores sobrevivem dos serviços e comércio ligados ao turismo, o mar e as praias foram pouco mencionados. Em uma das passagens, um participante cita:

"(...) Saneamento básico, não é...vai a água suja para o mar...isso gira em torno do saneamento (...)"

"(...) quem mora nas favelas, vive dentro dos esgotos, afeta muito a saúde (...)" (Morador de Rio da Praia em oficina do futuro, outubro de 2000).

"(...) até nos bairros mais nobres o esgoto cai no mar" (participante de oficina do futuro, outubro de 2000).

Em uma dinâmica de aquecimento, em que os participantes aludiam ao desejo de futuro para a cidade, um morador referiu-se:

"(...) Meu nome é Pedro e o Carlos quer uma cidade limpa, com saneamento básico. Meu sonho também é esse: uma cidade limpa, bonita, ajardinada e sem cachorro $(. . .)^{\prime \prime}$ (participante de oficina do futuro, outubro de 2000).

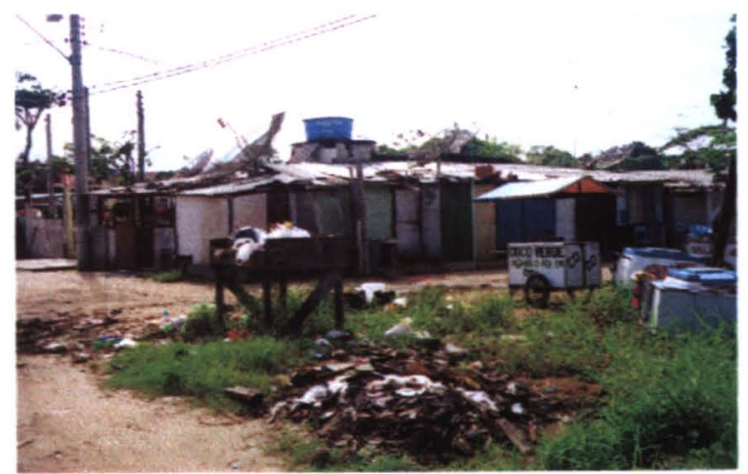

Fotografia 18 - VISTA DA FAVELA DO INDAIAZINHO. PROBLEMAS HABITACIONAIS, AMBIENTAIS E SANITARIOS

Nota-se em diversas passagens que os cachorros nas ruas e nas praias constituem um problema sentido pelos moradores. Por outro lado, a situação 
da precariedade de infra-estrutura urbana foi discutida na maior parte das ocasiões como um problema complexo e que exige solução integrada. Neste sentido a Comissão Intersetorial do PBMS discutiu diversas vezes a necessidade de implanta um Centro de Zoonoses na cidade, que até então não havia sido viabilizado.

"(...) acontece o seguinte, na minha opinião, se a gente colocar esgoto, as valas vão continuar abertas, com depressões. Só colocar rede de esgoto não vai resolver...acho que não é a prioridade não! (...)" (participante de oficina do futuro, outubro de 2000).

Apesar de não figurar como problema grave, do ponto de vista dos dados secundários levantados no capitulo 5 , a questão da coleta dos resíduos sólidos é considerada pelos moradores um problema que afeta diretamente a população.

A isto se relacionam, a manutenção dos sistemas públicos e os serviços de zeladoria urbana, como poda de árvores e varrição. Entretanto, a pavimentação (mesmo que permeável) parece ser também indispensável.

"(...) Lixo. Restos de poda. Porque eu sabia que a maioria daqui ia colocar esgoto e lixo... é uma das dificuldades que eu vejo no meu bairro...quando tem muito morador e tem muito mais veranistas...e é praxe todo mundo cortar o seu capim e cortar as árvores e jogar na rua. Isso no centro e lá na vila é até pior porque simplesmente atravessam e jogam no jardim da orla...correto...o resto de poda, palha de coqueiro, galhos... está sujo quem passa deixa mais um saquinho, mais um sacão (...)" (participante de oficina do futuro, outubro de 2000).

"(...) Balneabilidade entra nos dois lugares aí...tanto no lixo quanto nas valas abertas, na falta de rede coletora... ela entra nos dois. (...) Geral...geral...o lixo também colabora que cai nas valas.. nas valas abertas...nas valas de entulho (...)".(participante de oficina do futuro, outubro de 2000).

É importante esclarecer que os dados secundários referem-se à informação disponibilizada pelos órgãos públicos, no caso, sobre o indicador quantitativo de coleta do lixo, e as informações da população se referem aos hábitos, costumes e fatos cotidianos vivenciados e observados. Os dois aspectos exigem soluções diferenciadas (por meio das políticas públicas e da ação da 
comunidade). Têm sido comum, as prefeituras e órgãos governamentais preocuparem-se mais com a melhoria do indicador (porcentagem de lixo coletado e tratado, por exemplo) do que com a forma e a qualidade com que o serviço é prestado.

Nesta passagem o morador relaciona o problema do lixo com o da população de cachorros.

"(...) O problema do lixo aqui...o maior que nós temos é na coleta tá.. mas acontece que o coletor vai pegando o saco de lixo em cima do abrigo (...) pôr no meio da rua e ai vem a cachorrada esparrama tudo...e na hora de pegar o lixo e aí cai tudo esparramado no meio da rua o lixeiro devia pegar o lixo em cima das lixeiras (...) não pega, amontoado no meio da rua (...) depois de duas três horas que eles passam catando o lixo...e ai os cachorros, já bagunçou tudo no meio da rua... e o lixo ficou na porta...a reclamação mais do lixo na rua é mais por causa disso (...) . (participante de oficina do futuro, outubro de 2000).

Além das dificuldades impostas pela sobrecarga na infra-estrutura (que 0 município não dispõe nem mesmo para os moradores permanentes), a população flutuante, usuária de residências secundárias, pelo fato de ter objetivos diferentes dos moradores permanentes, defende outros valores e disputa poder político local.

Isso é o que se pode constatar de alguns relatos dos participantes das oficinas do futuro. Assim, muitos moradores aparentam vivenciar a contradição de defender o turismo e os turistas como prioridade em aspectos decisórios, como alternativa de sobrevivência, mas ao mesmo tempo, defender sua posição de morador e, portanto de requerer para si a prioridade nos beneficios e decisões de investimentos locais. Isso se passa no tema dos serviços e da infra-estrutura urbana.

"(..) Eu coloco assim, diferença de proprietários e moradores, interesses diferentes por que?, Pelo menos, lá em Guaratuba, proprietários que só vêm de fim de semana, interessa que faça sol e que tenha água, eles vêm, passa o final de semana ou as férias deles e vai embora. Então, diferente do interesse das pessoas da cidade, que moram no bairro e que realmente querem que tenha (coleta de) lixo, que tenha saúde, que tenha educação, 
que tenha saneamento, esse qu: :u chamo proprietário, aqueles de veraneio, eles vêm, precisa ter o sol, eles só querem para lazer (...)". (participante de oficina do futuro, outubro de 2000).

E continua argumentando sobre o conflito de interesse, de visões e sobre a disputa, e decisões na cidade.

"(...) O proprietário. Ele não quer a rua asfaltada por que ele quer vir de São Paulo, ele quer andar a pé, quer o menos movimento possivel. Já o morador não, ele quer que asfalte a rua, ele quer que tenha uma escola, e o proprietário não quer nada disso, ele quer vir, quer sossego. Sossego depende do local onde ele passa o final de semana para vir ver. Quer dizer ele tem o interesse dele naquele municipio onde ele reside. Ele quer sair do stress de lá para vir para cá. São interesses diferentes. Trazer o stress de lá para cá (...)". (participante de oficina do futuro, outubro de 2000).

E conclui o raciocínio:

"(...) então, nem a pessoa que mora aqui se prepara, nem o turista que vem, está integrado com os problemas (...)".(participante de oficina do futuro, outubro de 2000).

Analisando os relatos dos participantes das oficinas nota-se mais claramente, quanto os problemas estão intrinsecamente conectados, apesar da importância de identificá-los um a um, na perspectiva da compreensão. Assim, a ausência de pavimentação, na maior parte das ruas, afeta o transporte dos moradores do município de forma decisiva.

"(...) Buracos de ruas assim, eu gostaria de apresentar um (problema) que é prioritário aqui para nós de Boracéia. Eu acho que é o lugar onde, que nós descemos dos ônibus, que é o acostamento, que quem usa ônibus sabe a dificuldade de descer do ônibus aqui no acostamento. Não existe acostamento, tem poções, o ônibus tem que (...), é verdade, dia de chuva, é um problema geral. Quem pega o ônibus, sabe como é que é a dificuldade de subir no ônibus que, as vezes, ele pára numa pista em cima, e você fica aqui em baixo. (...) Quando você vai descer também, não tem lugar para a descida. A gente tentou entrar em contato, a gente não sabe com quem, com o DER, ou é a Prefeitura, ou é o Estado, a gente não sabe para quem 
perguntar, para fazer alguma coisa para isso aí (...)". (participante de oficina do futuro, outubro de 2000).

Em outra oficina no loteamento do Indaiá um participante reclama:

"(...) Quando chove muito, não passa mais carro, fica cheio de buraco (...). No Indaiá, aqui no bairro, o problema é o mesmo, é os buracos e os ônibus não podem passar (...)" (participante de oficina do futuro, outubro de 2000).

A questão da mobilidade e da situação das vias públicas contribui para agravar a situação de intensa fragmentação do território da cidade, resultado de um espraiamento de loteamentos em localidades distintas, conectados principalmente pelo sistema rodoviário regional, no caso, a Rodovia RioSantos.

\section{transportes, mobilidade e fragmentação territorial}

Mediador: Bom, quem colocou asfalto aqui?

Participante: Presente!

Mediador: Asfalto como é?

Participante: Falta...

(dialogo em oficina do futuro)

A questão da fragmentação urbana é possivelmente, um dos problemas que mais salta aos olhos, do ponto de vista do urbanismo no município de Bertioga (Foto Aérea 1 - Município de Bertioga). A população, obviamente, percebe o fenômeno enquanto divisão entre os bairros, dificuldade de chegar nos lugares, enquanto cidade de rodovias e de muros, "os lados de lá, e os lados de cá".

Todavia, a conseqüência mais sentida da falta de integração entre os loteamentos é a precariedade na mobilidade, a dificuldade para se transportar e a dificuldade de estabelecer comunicação, tanto enquanto fluxo de informações, quanto de notícias. Muitos depoimentos nas oficinas, sobretudo nos bairros mais distantes do centro, mostram as diferentes facetas desta realidade, sob o ponto de vista dos habitantes. 
"(...) Deixa-me fazer uma correção, não é municipio, nesse primeiro que eu mostrei foi o seguinte, quando as pessoas faziam um exercício de Bertioga, chegava em Riviera e depois acabava. Mas nem Boracéia nem Guaratuba. E outros dias, quando representam Bertioga também acabava no Riviera. A administração municipal, ela vem para Guaratuba e Boracéia e nem coloca escola, mal paga salário para os professores, e muito mal (...)".

Esta realidade se expressa também e sobretudo com a identificação da fragmentação promovida, principalmente pelos grandes condomínios e loteamentos fechados, como o Riviera de São Lourenço (em São Lourenço), - Costa do Sol e o Guaratuba (em Guaratuba) e Morada da Praia em Boracéia. Apesar de defesa de alguns moradores dos beneficios e importância desses empreendimentos, nas oficinas, a maioria dos depoimentos trazia algum descontentamento, quando não, traços de ressentimentos, sugerindo novamente a disputa de espaço e de poder no município.

"(...) É uma questão a nível nacional, mas tratando mais, por exemplo de Bertioga, nós temos situações bem distintas em Bertioga. Nós temos hoje uma Riviera de São Lourenço, onde o padrão de vida é altíssimo, onde tem rede de esgoto, tem segurança, tem tudo que apresenta de bom, enquanto nós temos do nosso lado de cá, uma situação onde falta segurança, onde 0 saneamento básico é precário, onde falta iluminação nas ruas, então isso em virtude de que, uma má distribuição de renda, onde as pessoas lá tem apartamento, às vezes utilizam o apartamento uma vez por ano. Não é que essas pessoas não tem direito. Fizeram, devem ter merecido ter esses apartamentos, mas cadê o outro lado daqui, nosso outro lado, onde falta habitação, onde a gente não tem moradia. Nós temos a Morada da Praia também, e esses dois lados nas últimas eleições para vocês terem uma idéia, eles praticamente definiram algumas coisas nas eleições, alguns cargos. No sentido de que essas pessoas moram em São Paulo, transferiram os títulos para cá, votaram e decidiram praticamente a eleição no nosso nome, e onde nós permanecemos aqui os quatro anos igualmente. Essas pessoas simplesmente desceram, votaram e foram embora de novo para São Paulo. Então em virtude disso, para que ela possa produzir uma geração de emprego, no sentido de que ninguém quer esmola, todo mundo quer um 
emprego decente, para que ele possa comprar sua casa, para que ele possa dar condições de vida para sua família, é nesse sentido que eu quero dizer (...)" (participante de oficina do futuro, outubro de 2000).

Esses discursos parecem sugerir a existência de várias cidades de Bertioga. Bertioga do centro, Bertioga das periferias, Bertioga das favelas, Bertioga dos condomínios e loteamentos fechados. De um lado, a cidade onde a vida e as pessoas comuns acontecem e do outro lado, a cidade do cenário, perfeita, ideal, limpa, ordenada e segura para os turistas, veranistas e classe média e alta. Analisando as percepções dos moradores torna-se mais clara a dualidade dos assentamentos na cidade. Dualidade entre os loteamentos comuns/bairros periféricos/favelas e os loteamentos fechados/condomínios: cidade aberta $x$ cidade fechada, cidade real $x$ cidade virtual.

Em outros casos, quando se menciona a falta de equipamentos públicos urbanos, de educação ou saúde, além da demanda por descentralização desses serviços, nota-se uma carência do sistema de transportes e mobilidade.

"(...) Eu coloquei falta de escola, porque Bertioga é muito extensa. Não se encontra escolas pela extensão do município. Eu mesmo venho lá da Vila Agaó para estudar aqui à noite! Ou você vem pela Anchieta ou você passa pelas trilhas aqui. É perigoso, não tem ônibus da Vila Agaó para cá...uma condução da Vila prá cá...então eu venho à pé! No meu caso, meu marido me traz, venho de carro, tudo bem, e quem não pode? Tem gente que vêm de Boracéia, tem gente que vêm do Indaiá, tudo prá cá, que é onde que tem, principalmente no ensino médio (...)".(participante de oficina do futuro, outubro de 2000)

Os moradores durante os relatos associavam esses problemas à outros de natureza próxima: a falta de comunicação institucional e oficial e falta de união entre as pessoas. Alguns grupos escolheram para trabalhar, prioritariamente com o tema da falta de união entre as pessoas, como veremos adiante.

"(...) É falta de união, falta de, acho que uma amizade, comunicação entre o ser humano, entre nós aqui. É por que aqui em Bertioga, é considerado do centro até o SESC. Do SESC em diante, são Bertioguinhas. Então, por 
exemplo, Indaiá dentro da cidade chega a alguma comunicação mais fácil, mas até Boracéia. Tá um show lá no centro Bertioga, e Boracéia não está sabendo. A cidade é muito comprida, e não tem um jornal, o jornal é semanal, eu na semana passada cheguei na banca e pedi um jornal, entregaram na sexta-feira até reservar. E não tinha mais jornal. Uma coisa que acontece numa igrejinha aqui em Indaiá, nós aqui não estamos sabendo, entendeu, do lado de lá, todo mundo sabe. Aqui não tem união e nem comunicação, em ponto nenhum (...)" (participante de oficina do futuro, outubro de 2000).

Desta forma, a inter-relação entre a fragmentação da cidade, os transportes públicos e a qualidade dos serviços prestados aparecem proeminentes na percepção dos participantes locais.

"(...) Transporte (...) é uma dificuldade tremenda. É uma aventura. Chega até Bertioga você passa mal. Começa com os motoristas que são grossos, na verdade $(\ldots)^{\prime \prime}$.

Outro morador comenta na seqüência.

"É ruim, a gente fica duas três horas no ponto e o ônibus não aparece, debaixo de chuva. Não tem abrigo, não tem nada. É verdade, para voltar à noite da escola. E quem cobra passagem é o motorista, motorista quem dá o troco. E mal humorado ainda. Então a qualidade do transporte é ruim, e agora, falta de transporte também ou não? Horário, espaço de horário e o ônibus faz um tour. Conheço toda a cidade".(participante de oficina do futuro, outubro de 2000).

Nota-se que as condições a partir das quais o municipio se desenvolveu, do ponto de vista urbano, parecem contrariar grande parte dos pressupostos de um projeto município saudável.

O sistema viário, como discutido anteriormente é inadequado para harmonizar a demanda de fluxos internos e dos fluxos de passagem. Desta forma, a presença dos condomínios e loteamentos que bloqueiam o sistema viário em muitos pontos agrava a situação. Como já mostrado, o município convive com incidência elevada de acidentes de toda a ordem, particularmente de tráfego. Este elemento, obviamente, também se relaciona com o serviço de saúde. 
"Bertioga precisa de um hospital porque acontece muito acidente. E só o Pronto Socorro de Bertioga atende desde lá o litoral norte até o Caruara. E vêm tudo pro pronto socorro".

As situações de emergências para atendimento no município são motivos de preocupação pelos atores locais, especialmente nos períodos de alta temporada em que a rodovia possui tráfego muito mais dificil. Um participante questiona um dos Secretários Municipais sobre isso em uma Oficina em São Lourenço.

"(...) Vai uma ambulância vai para lá. O que eu acho é que deveria ser colocado (...) supondo que alguém que eu conheça, alguém que eu conheça tenha um problema de urgência, como o senhor hoje, como o senhor atuaria? Nós estamos no dia 29 ou 30 de outubro, como agiria com o problema, se isso fosse no dia 18 de janeiro, que a estrada é intransitável, eu gostaria que o senhor me desse uma resposta? (...)" (participante de oficina do futuro questionando membro do governo em outubro de 2000).

Ficou claro, nas Oficinas do Futuro, a fragmentação do território e as dificuldades de transporte e mobilidade entre diferentes áreas/bairros do municipio, mantidas por questões de poder entre representação política dos bairros. É o interesse individual se sobrepondo ao coletivo, ou, o da menoria sobre o da maioria.

\section{Iluminação e Segurança}

Segundo a percepção dos participantes das oficinas do futuro, a iluminação pública está intimamente relacionada à sensação de segurança. Os moradores relacionam a iluminação também com as drogas. Alguns comentários mostram isso.

"(...) várias ruas aí e está tudo escuro... e isso. Risco de assalto, gera as drogas (...)" (participante de oficina do futuro, outubro de 2000).

"(...) olhe porque na rua onde eu moro não tem iluminação, inclusive quando ela chega onze e meia...tudo escuro...pode esconder algum assalto não é...algum cara pegar ela. Ali na Vila Agaó tem algumas ruas que não tem luz (...)". A droga está associada com tudo! (...)" (participante de oficina do futuro, outubro de 2000). 
Aqui novamente a complexidade para abordagem dos problemas parece voltar a sugerir a necessidade de abordagens integradas e intersetoriais.

"Nós não temos segurança na rua, nós não temos iluminação, tem roubo, não tem um poliesportivo para tirar as crianças das drogas...é uma nuvem de insegurança que está pairando sobre nós" (participante de oficina do futuro, outubro de 2000).

\section{Manutenção, fiscalização, governos e outros atores}

"Não tem nem esgoto, vai ter prédio..."

(morador, na Oficina do Futuro)

A manutenção e a fiscalização são apontadas por diversos participantes como um dos problemas presentes do município. Os moradores também relacionam esses itens com as políticas urbanas.

Como parte da metodologia das Oficinas do Futuro, após o levantamento dos problemas, com discussão e priorização dos mesmos realizou-se um levantamento dos atores envolvidos com os problemas, como associações de bairro, associações de moradores e entidades comunitárias. Em boa parte das ocasiões os moradores locais referiramse à administração pública, aos governos, particularmente no âmbito municipal. Além disso, durante o levantamento dos problemas, um dos mais apontados foi a falta de compromisso do poder público.

Passamos a apresentar algumas percepções sobre a responsabilidade e atuação desses atores nos problemas citados.

"(...) a má administração que causa a falta de esclarecimento. $E$ a administração, por exemplo, tem que esclarecer o proprietário que ele vai receber uma multa, vai executar o serviço (...)" (participante de oficina do futuro, outubro de 2000).

"eu tenho uma coisa pra falar também: é relacionado com uma fiscalização numa obra nova. Existe já fiscalização, eu já presenciei várias vezes. Existe uma regra pro consumidor. Só que essa mesma regra, não é utilizada pra outros, por problemas sociais, então, usa-se o famoso problema social pra 
fechar os olhos!!! Nas construções legalizadas e boas, isso existe. Nas outras obras, não!" (participante de oficina do futuro, outubro de 2000).

"Não! Esse é um problema sério. A lei vale para uns, não vale para outros, é relativizada. A pessoa não faz o que precisa fazer, o esgoto fica a céu aberto, então é uma coisa muito complicada. Existem leis que muitas vezes não são cumpridas por falta de rigor" (integrante do governo municipal participando da oficina, outubro de 2000).

$\mathrm{Na}$ maior parte das vezes os participantes das oficinas referiram-se aos integrantes do governo, incluindo o legislativo, sugerindo ou mesmo denunciando a falta de seriedade, de compromisso e a corrupção. Outras vezes as referências voltam-se para os aspectos da falta de um trabalho pedagógico ou educativo, de fiscalização mais séria e de serviços de manutenção.

"(...) eu acredito que a prefeitura deve informar ao cidadão sobre a necessidade de como faz a limpeza, porque, por exemplo, ela não vai dar conta de todas as valas, e existem muitas valas, aqui no SESC, é uma coisa dolorosa. E você vê que residências boas...por que? Aquilo é o excedente que tem da água das chuvas. Então, o grande problema é os esgoto das valas. Então, o que acontece? Se tivesse em cada esgoto, uma vistoria, como na SABESP, porque apesar de ter esgoto, não tem ligação. Falta educação e fiscalização (...)" (participante de oficina do futuro, outubro de 2000).

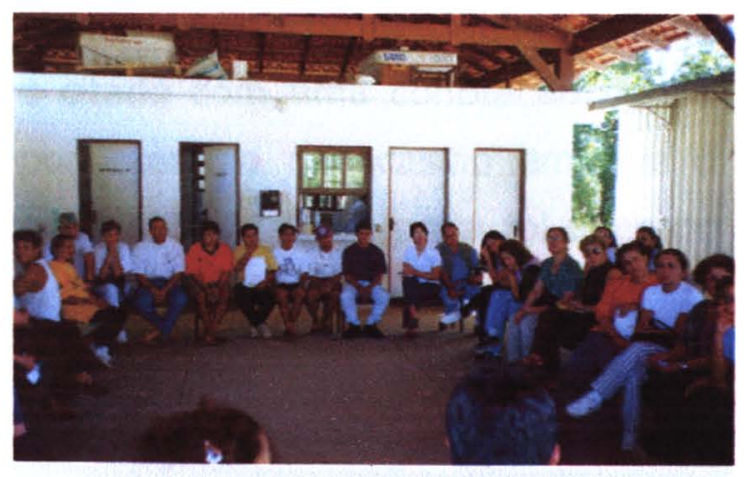

Fotografia 19 - Oficina em Boracéta com os PARTICIPANTES DA ALDEIA DO RIO SilveirAS 
A fiscalização aparece assim como algo muito importante aos olhos dos moradores, como uma das raízes ou causas dos problemas da cidade. Principalmente nos aspectos relativos às valas, ao lançamento de esgotos nas ruas, rios, etc. A fiscalização aparece com importância também com relação à execução de obras e desmatamentos.

"acho que uma boa parte das valas seria resolvida se houvesse fiscalização, aí não haveria nem a falta de pessoal, nem a falta de recursos". (participante de oficina do futuro, outubro de 2000).

"acho que não há um trabalho de limpeza de valas constante, e não é porque não tem recursos. Eu acho que tem a ver (com) um mau gerenciamento, né?! Por exemplo, se a fiscalização tivesse um treinamento, se os caras fossem lá vistoriar...tudo bem que tem gente que não tem rede de esgoto, mas a rede de esgoto será ampliada. Tem lugar que constróem e não tem rede de esgoto, então esse prédio, o fiscal deveria ir lá, fiscalizar" (participante de oficina do futuro, outubro de 2000).

Entretanto há um reconhecimento de que o papel do cidadão e da comunidade organizada são também essenciais. Este reconhecimento é um dos primeiros passos para as pessoas começarem seu processo de empoderamento individual e comunitário.

"porque as valas não é problema só da prefeitura, né?! É problema também do cidadão. Porque se eles fazem a vala e cobre, tá sanado o problema. A limpeza da vala...o problema é quando a vala tá aberta e abandonada!" (participante de oficina do futuro, outubro de 2000).

Apesar de pouco mencionado durante as oficinas, o mercado imobiliário local é citado com uma conotação negativa em algumas ocasiões. Isto ocorreu, por exemplo na ocasião em que o gabarito máximo para construção de edifícios na orla da praia foi alterado na lei de uso e ocupação do solo pelos vereadores na Câmara Municipal.

Desta forma, os atores ligados ao mercado imobiliário atuam por meio de articulações com diversos outros atores locais como políticos, corretores, proprietários de imobiliárias, vereadores (alguns são também proprietários de imobiliárias) e externos a Bertioga como construtoras, empreendedores, proprietários de terra, investidores. 
"(...) Eu pensei, em termos gerais, há um tempo atrás, a gente ainda comprometia-se com a cidade até não querer mais, comprometido com a cidade. (...) De vinte e quatro anos para trás. No começo foi tudo bem, depois, há uma semana atrás aí, nós vimos ai em público, o pessoal ao invés de montar e (...) lá na Câmara, em vez de puxar alguma coisa que melhore a cidade, votam em alguma coisa, e no final acaba por acabar com a estrutura da cidade, (...) o plano diretor não permite. Em relação àqueles prédios na beira da praia, não tem que pôr que isso (...) a Câmara não permite aquela altura. Não tem nem esgoto, vai ter prédio (...)" (participante de oficina do futuro, outubro de 2000 ).

A alteração na mudança de gabarito aprovada pelos vereadores em 2000, que permitiu a partir de então, a construção de edificios de até dez pavimentos na orla da praia foi bastante criticada por vários moradores.

Também com relação à moradia, os participantes referiram-se à responsabilidade governamental. A ausência de uma política habitacional, de uma produção que atenda a demanda e a existência das favelas da cidade, que na maior parte ainda não foram urbanizadas, são motivos dos questionamentos.

"(..) o outro problema atacado pelo grupo foram as favelas. 0 importante que se diga é o seguinte, o grupo não é contra a favela. O grupo é contra o porque que chega nesse estado de favela? Porque há uma omissão do poder público. O poder público não tem uma política de habitação, a política ao porte de habitação, a política ao porte de assistência social, a política ao porte de atendimento a crianças e adolescentes em situações de risco. Então essa omissão do poder público faz com que também não há uma política forte na questão do meio ambiente, questões ambientais. Quando se fazem favelas você está degradando o meio ambiente, então não há uma fiscalização do poder público nesse sentido. Existem muitas áreas institucionais em Bertioga que deveriam ser preparadas para colocar esse povo daquele local, até porque O BID, ele tem um programa nesse sentido. Falou muito no BID, no BID e nada aconteceu. Os atores são as autoridades competentes. Por que competentes? Porque são as autoridades específicas que podem atuar nesse sentido. Não adianta ser só solidário, tem que ser competente no assunto. As atividades, mesma coisa, conscientização da 
comunidade local. Tem que provocar o poder público através de abaixo assinado, reuniões, passeatas, videos, e etc. Mais uma vez eu falo, essa manifestação pública não é contra aquela comunidade que está em favela, mas sim para melhorar a qualidade de vida daquelas pessoas que estão nas favelas (...)".

As Oficinas do Futuro, concluindo, foram espaços onde se obtiveram diagnósticos sócio-comunitários e onde foram discutidas agendas de trabalhos comuns para o futuro, considerando também, as potencialidades locais. Nesta ocasião foi possivel resgatar aquilo que era valorizado como potencialidade e aprofundar o conhecimento das causas dos problemas, dentro de dinâmicas sócio-políticas e de poder dentro do município.

O conhecimento desses problemas e potencialidades gerou dois tipos de programas organizados pela FSPUSP, por meio de seus alunos de pósgraduação e professores do eixo temático de Promoção da Saúde e pesquisadores do Centro de Estudos, Pesquisa e Documentação - Cidades Saudáveis, constituído para substituir a Oficina Permanente de Estudos e Pesquisas sobre Cidades/Municípios Saudáveis: o Curso de Formação de Agentes Multiplicadores para Assentamentos Humanos Saudáveis (em 2001) e as Oficinas de preparação para a Revisão do Plano Diretor de Bertioga (em 2002).

Como a pesquisa ação participante, tanto gera conhecimentos, como estabelece um processo educativo permanente entre os que participam, foram constatados os resultados esperados: o empoderamento da população para a ação política pela produção social da saúde, que conforme vem sendo mostrado esteve em boa parte do tempo, voltada para as questões relativas às políticas urbanas e habitacionais.

No próximo capítulo estaremos analisando o empoderamento, como resultado de um processo sócio-educativo e de pesquisa - a pesquisa ação participante - eixo condutor do Projeto Bertioga Município Saudável. 


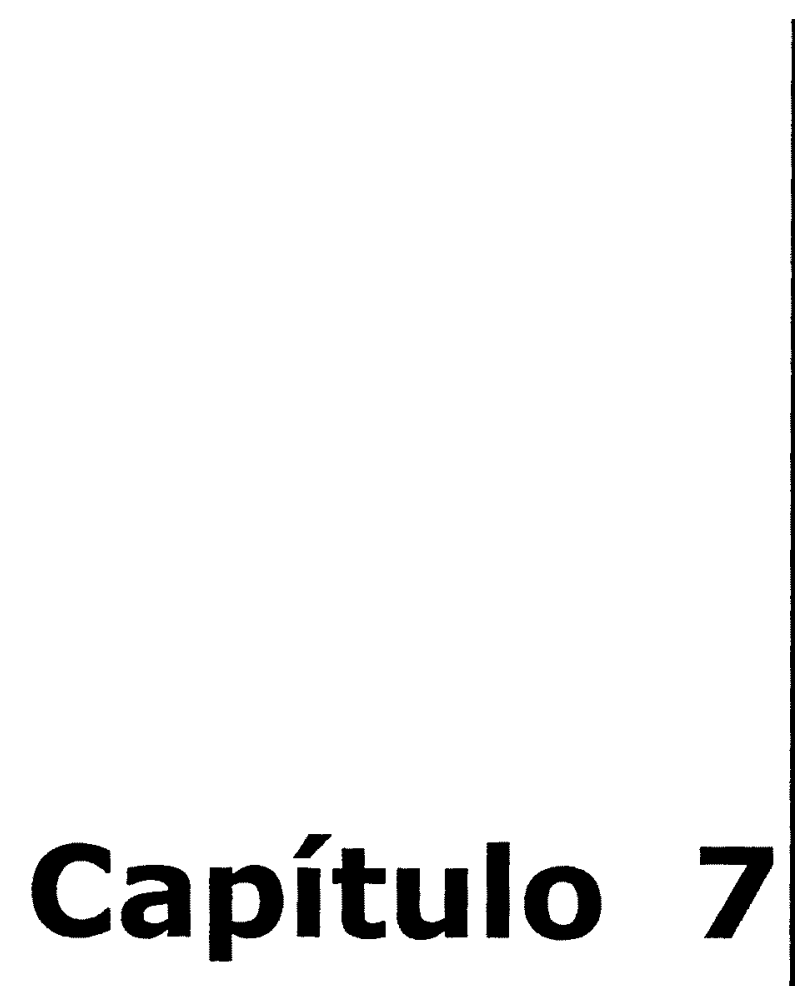

Empoderamento da população e advocacia por políticas urbanas saudáveis 
"ah eu moro na favelinha (...)".

Você é um cidadão brasileiro. Você ocupa um barraco numa favela? Você tem todo direito como eu tenho. Então você tem que lutar por você mesmo. Se não houvesse esse desejo, as pessoas não iam fazer isso não. A USP é que mexeu num vespeiro. Sabe então, as abelhas vão agora incendiar, picar todo mundol O negócio vai pegar fogo, não é?"

(Liderança popular, antigo morador, migrante nordestino e participante do PBMS, em Oficina do Futuro, 2000)

Pretendemos, neste capítulo sistematizar elementos relativos ao processo de participação já descritos que evidenciam um empoderamento de setores da população, que engajaram-se nos debates, audiências e espaços de participação formais e informais relativos à habitação, ao planejamento e gestão urbana, realizando advocacia por políticas urbanas saudáveis (Wallerstein, 1992; Dallari, 1996).

Neste sentido cabe esclarecer que em nenhum momento da pesquisa acreditamos que a população e os atores locais de Bertioga não possuíam formas próprias de organização e mobilização. Pelo contrário, durante e após - processo de emancipação, em que houve uma mobilização intensa, diversas associações de bairro e entidades foram criadas no seio da sociedade civil nas últimas duas décadas.

Entretanto, nossa discussão se assenta na forma e no caráter da participação no âmbito do PBMS e considerando os pressupostos do ideário Municipios Saudáveis: participação social, equidade, intersetorialidade, sustentabilidade. É importante que se diga, que é esperado que um Projeto Municipio Saudável, que tem estas características, ao longo do tempo, contribua para o desenvolvimento de um processo de empoderamento da população. Contudo consideramos útil esta sistematização como contribuição complementar à discussão e análise que nos propomos realizar.

Se utilizarmos os conceitos desenvolvidos por Labonte (1994) sobre as etapas do processo de empoderamento, a expectativa será de que os participantes do processo, aos poucos se preparem para o exercício da ação política.

Este resultado do processo é muito importante para o impulsionamento de transformações das políticas habitacionais, do planejamento e gestão 
urbanos e de saúde. A população estará gradativamente aumentando o seu espaço de controle sobre os investimentos, de modo que estes sejam saudáveis, e portanto; sobre os determinantes do processo saúde/doença.

Neste sentido, Labonte (1994) sugere um esquema de análise do empoderamento enquanto um objetivo meio e fim, na prática da Promoção da Saúde. $O$ autor propõe examinar o empoderamento na perspectiva de um processo de mudança ou transformação social de grupos comunitários, profissionais e instituições visando produzir situações de vida saudáveis (Labonte, 1994).

Embora sua proposta tenha sido elaborada no contexto de países desenvolvidos na perspectiva da promoção da saúde, acreditamos que os elementos do seu esquema de análise podem ser úteis aqui.

Sua proposta é fruto de idéias desenvolvidas após 6 anos de treinamento profissional e realização de oficinas de trabalho entre 1986 e 1992 envolvendo mais de 2.500 pessoas no Canadá, Nova Zelândia e Austrália. Na sua abordagem é sugerido um esquema, no qual o trabalho para o processo de empoderamento pode se dar por meio da passagem gradual por diferentes níveis de arranjos e articulações de relacionamentos (Figura 5):

\section{FIGURA 5 - ESQUEMA DE ETAPAS DO EMPODERAMENTO}

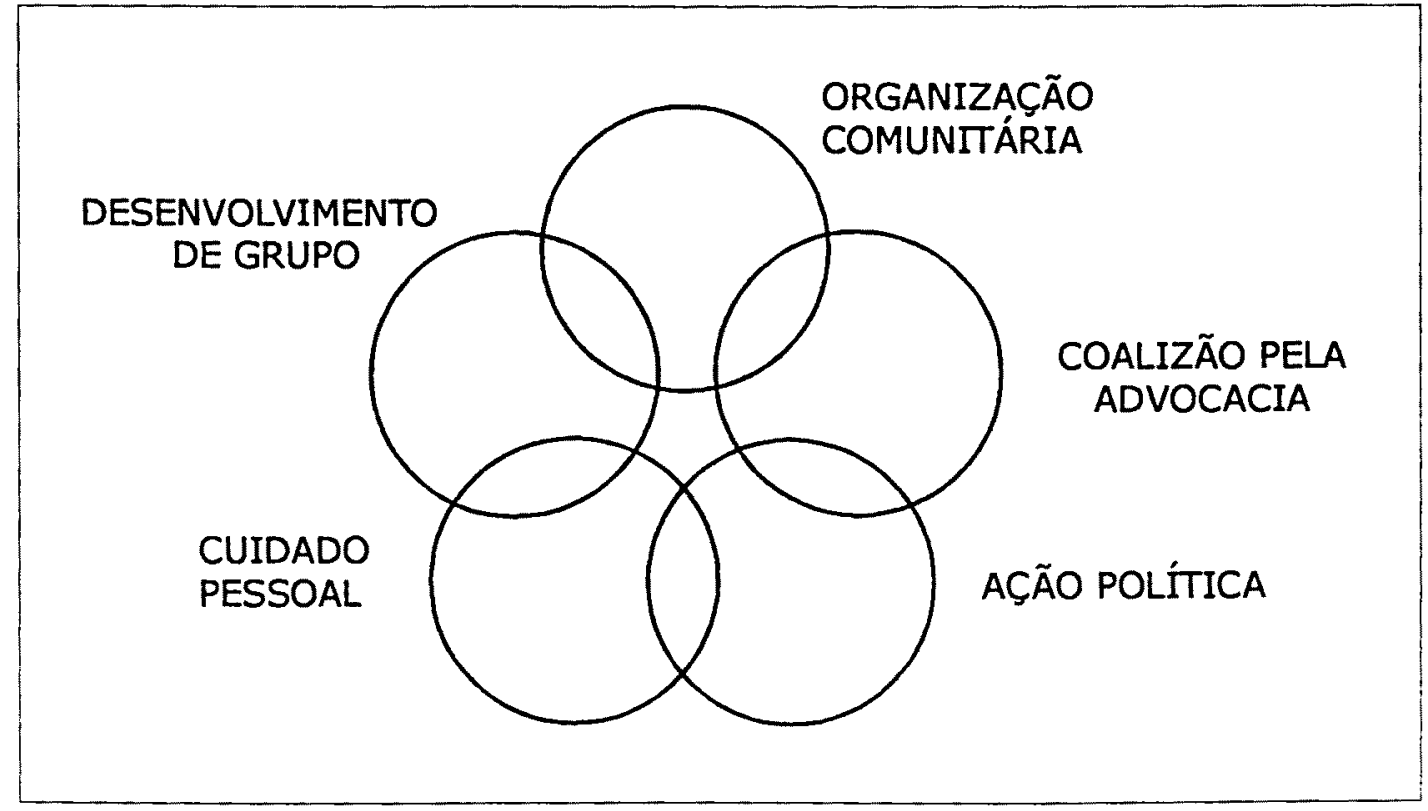

Fonte: Labonte (1994)1 
Cada esfera representa um estágio e uma estratégia de trabalho de promoção da saúde a ser desenvolvida no nível comunitário. Assim, o primeiro estágio, do nivel dos Cuidados Pessoais é aquele em que os individuos se encontram com maior impotência para controlar os determinantes do processo saúde/doença, logo com maior risco de enfermidades (Labonte, 1994, Wallerstein, 1992).

O segundo estágio, do Desenvolvimento de Grupo, é tido como, no dizer de Labonte (1994), um "motor da promoção da saúde, um veículo do empoderamento". O pequeno grupo é assim considerado o próprio "locus" da transformação. Segundo essa análise somente a interação com os outros (em um grupo) faz a pessoa conquistar algumas etapas de desenvolvimento, essenciais para o empoderamento: controle, capacidade, coerência, conectividade, pensamento crítico e conscientização. (Labonte, 1994).

O terceiro estágio, da Organização Comunitária, refere-se ao processo de organização das pessoas ao redor dos problemas ou desafios, e não mais ações individuais (Labonte, 1994).

O quarto, da Construção da Coalizão pela Advocacia, refere-se à superação das limitações da organização comunitária. Coalização significa aqui, grupos com objetivos compartilhados no espírito "unidos levantamo-nos, divididos caímos". Advocacia significa para o autor, o processo de tomar um posicionamento e iniciar ações em deliberada tentativa de influenciar escolhas de políticas públicas e privadas. Os dois conceitos aparecem juntos na holosfera, em função de que na prática, a advocacia geralmente acarreta coalizões, segundo o autor (Labonte, 1994).

O último, Ação Política, representa uma intensificação de ações iniciadas sob a rubrica da coalizão e da advocacia. Aqui, cada ação pode ser partidária ou não partidária, em nível local ou nacional, participativa ou representativa, na forma democrática, legal ou dar-se enquanto desobediência civil.

Segundo o autor, não se distingue perfeitamente a fronteira entre Coalizão pela Advocacia e a Ação Política (Labonte, 1994).

No caso de Bertioga, verificou-se ao longo da pesquisa ação, que grande parte dos participantes do PBMS foram, pouco a pouco, passando por estas fases, como será descrito. Tentaremos relacionar este elemento do processo, 
com a atuação dos integrantes da "Comissão do Plano Diretor" e da "Comissão Intersetorial" do PBMS no processo de tomada de decisão sobre as diretrizes e posicionamentos a serem adotados no processo de revisão do Plano Diretor do município.

O segundo trabalho que utilizaremos para referenciar essa discussão de autoria de Oakley e Clayton (2003): "Monitoramento e avaliação do empoderamento", refere-se a uma sistematização realizada por integrantes de organizações não governamentais (ONG's) internacionais que apóiam ONG's que trabalham diretamente com comunidades na perspectiva do desenvolvimento e do empoderamento. Esta referência oferece, para a avaliação e monitoramento do empoderamento, um instrumental, a partir de experiências realizadas em diversos países em desenvolvimento, como mencionado.

Utilizamos também os conceitos de Wallerstein (1992) sobre o processo de empoderamento na Promoção da Saúde.

\subsection{Percepções dos participantes nas primeiras atividades do Projeto}

O processo no qual se desenvolveu o PBMS junto à realidade local, do ponto de vista do envolvimento, participação, mobilização e empoderamento sugere algumas hipóteses que ora procuramos sistematizar sinteticamente. A primeira hipótese é que o processo desenvolvido junto aos moradores e atores locais contribuiu objetivamente para o empoderamento desses atores ao longo do trabalho, obedecendo, em certa medida, o esquema proposto por Labonte (1994).

A segunda hipótese é que esse processo de empoderamento foi norteado, nos últimos anos do trabalho, prioritariamente para o eixo em torno do qual orbitam as questões urbanas - eleitas como centrais para a melhoria da saúde e condições de vida da população.

A comprovação dessas hipóteses com o rigor que a fundamentação científica demanda, do nosso ponto de vista, trabalhos de investigação adicionais e mais aprofundados (que recomendamos que possam ser realizados nesta e em outras realidades). No entanto, nosso intuito aqui é mostrar, por meio desta oportunidade de sistematização, evidências de que o processo 
desenvolvido no âmbito do Projeto Município Saudável contribuiu para o empoderamento dos participantes locais na luta e advocacia por políticas urbanas mais democráticas, transparentes e inclusivas como forma de tornar a cidade mais saudável.

\subsubsection{O discurso e o empoderamento}

No primeiro ano de implementação do trabalho, notam-se alguns depoimentos dos participantes que ajudam a identificar elementos iniciais relacionados ao empoderamento dos grupos e dos participantes. Este processo contribuiu de forma particular para a formação e Desenvolvimento Inicial de Grupos nos bairros.

No caso das oficinas, o mediador ou facilitador teve um papel fundamental de conduzir o trabalho, administrando a distribuição da palavra e depoimento dos participantes no tempo acordado, visando os objetivos gerais e específicos em cada momento na oficina.

A passagem abaixo exemplifica o papel do mediador nas oficinas do futuro orientando sobre a importância do envolvimento das pessoas e instituições e sobre a amplitude das ações para atingir objetivos desejados:

"(...) o trabalho pessoal e individual é muito importante porque sem isso nada funciona, mas o trabalho das instituições é importante, por que uma instituição as vezes tem trinta sócios atrás dela. Então se a instituição consegue, é que nem a Prefeitura. Se a Prefeitura funcionar... Quantos funcionários tem a Prefeitura aqui?, Mil e pouco. Mais ou menos novecentos funcionários, então se uma Prefeitura funciona bem, são novecentos funcionários trabalhando para uma coisa, para alguma coisa funcionar. Então uma entidade também é desse jeito, se tem uma entidade forte em que trabalhem trinta sócios, ela puxa os trinta sócios para fazer um trabalho, se ela é bem organizada. É por isso que é importante esse trabalho que vocês estão pensando, por exemplo, aqui em Boracéia ou em Guaratuba, de fortalecer as organizações de vocês. Então esse era o produto que a gente estava pensando e a próxima reunião nossa é para trabalhar isso aqui. $A$ gente vai trabalhar agora uma agenda (...) (mediador durante oficina do futuro, outubro 2000). 
No princípio do trabalho, em 2000, nas Oficinas do Futuro, são recorrentes as passagens em que os participantes expressam a fragilidade do processo inicial de formação de grupos, de participação e mobilização coletivas. Notase uma preocupação constante neste sentido. Primeiramente criticando a falta de compromisso dos que não participam; argumentado sobre a importância da participação, e posteriormente, admitindo a possibilidade nos envolvimento dos grupos, em um nivel de compromisso maior assumido diante dos demais.

"(...) De uma maneira que nós estávamos naquele dia, tivemos vontade de sair correndo. Igual a primeira reunião. Quem veio na primeira reunião, da escola mesmo só estava eu e a Márcia (...)" (participante em oficina do futuro, outubro de 2000).

"(..) A comunidade não participa. Esse é o maior problema. O maior problema de Bertioga. Tudo em Bertioga é assim (...)".

Os participantes relacionaram questões diversas no âmbito da falta de união, como o desconhecimento, medo, falta de confiança e até falta de amor.

"Comodismo, e isso tudo como causa do desconhecimento. Falta de amor e vaidade. Talvez, medo de se expor. Falta de confiança". (participante em oficina do futuro, outubro de 2000).

Este diálogo expressa, naquele momento do processo, a percepção da falta de um compromisso coletivo mais consistente e de participação de mais pessoas.

Mediador: Então nessa atividade de hoje, antes da gente ir embora, o Victor já colocou lá para a gente não esquecer do nosso acordo de convivência, que todo dia a gente lê. Todo final de reunião a gente lê. Bom, o primeiro acordo: que todos participem.

Participante: Já está furado.

Mediador: Porque dona Maria?

Participante: Porque tem muita gente faltando (...). (diálogo em oficina do futuro, outubro de 2000). 
Alguns participantes expressam a importância da responsabilidade e do compromisso dos cidadãos em participar, como requisito essencial para ajudar a solucionar os problemas.

"(...) eu não moro aqui, mas eu estou mais aqui, e eu acho que as pessoas têm que se preocupar com Bertioga. Bertioga é uma cidade linda e acho que ela merece o comprometimento de vocês para tentar resolver os problemas que ela tem. Bertioga cresceu muito. Eu acho que a palavra é comprometimento; vamos juntos tentar resolver. Não é só colocar a culpa no poder público. Uma parcela da culpa é nossa, e se nós cruzarmos os braços ele não faz; é preciso nos comprometer e ajudá-los também". (participante em oficina do futuro em outubro de 2000 ).

Outro participante questiona o comodismo e a falta de união, remetendo ao conceito de impotência para controlar os processos que atuam na saúde ou na doença mencionado por Wallerstein (1992).

"(...) eu acho que essas três últimas: a falta de cidadania, o próprio comodismo das pessoas; tem gente que espera as coisas cairem do céu. E a falta de união" (participante em oficina do futuro em outubro de 2000).

"(...) Então assim, existem pessoas participando, mas é um pouco do que vocês estão apontando aqui. A participação ainda não é grande, não é efetiva (...)". (participante em oficina do futuro em outubro de 2000).

"O mais importante (...), eu acho que não tem como, sem a união. É o alicerce da coisa. É a união". (participante em oficina do futuro em outubro de 2000).

Nesta passagem ocorrida durante a avaliação no encerramento de uma oficina, um participante desabafa sobre o desinteresse dos moradores da cidade.

"(...) o que irrita não é o grupo em si, mas é o desinteresse do pessoal, porque a gente quer batalhar. Tem vários problemas sociais para a Escola aqui. Por exemplo, no Ginásio, e os caras (...). Aí isso irrita, (...) que é o esforço verdadeiro, a conscientização do pessoal, (...) não agem, não pensam (...)".(participante em oficina do futuro em outubro de 2000 ). 
Entretanto, outros depoimentos ao longo do processo dos quatro encontros das oficinas do futuro permitem reconhecer alguns traços de necessidade de organização coletiva de desenvolvimento de grupo e de organização comunitária (Labonte, 1994). Note-se também nestas passagens, a existência da mobilização e de iniciativas individuais importantes como referência, como experiência de luta.

"(...) Olha, eu faço parte do Conselho Municipal da Criança. Se vocês soubessem a dificuldade que é para conseguir alguma coisa que a Lei determina... (...)". (participante em oficina do futuro em outubro de 2000).

"(...) Eu acho que no dia em que a população acordar: cidadania e participação. Talvez melhore a sociedade. (...) $O$ que é cidadania... A sociedade não sabe, não sabe participar, cidadania existe com participação (...)".(participante em oficina do futuro em outubro de 2000).

"(...) Surpreso, porque eu estou vendo que tem gente interessada aqui. Você ver o pessoal de costas, você fica até desanimado e agora eu fiquei surpreso com esse grupo (...)"(participante em oficina do futuro em outubro de 2000).

Outra participante demonstra sua satisfação por perceber o embrião do grupo, a união das pessoas. E demonstra fortalecimento, ainda que no nível individual, nesta passagem de avaliação de encerramento de uma oficina.

"Eu escolhi que estou feliz, feliz com as duas coisas. Pela união nossa, por ver gente que tem os mesmos problemas que a gente e que juntos, nós vamos tentar resolvê-los e por saber que vocês da faculdade estão engajados aqui conosco para ajudar a resolver os problemas da nossa cidade. Então, isso me deixou muito feliz e me fortaleceu mais ainda, na minha luta de querer ajudar as pessoas e fortaleceu a mim mesma. Eu acho que é por aí, por essa união de nós todos Você junto com um pouquinho do grupo da Prefeitura, que tem uns pouquinhos, que estão engajados e nós aqui da nossa comunidade lutando por uma coisa justa. Fiquei feliz" (participante em oficina do futuro em outubro de 2000).

A ambigüidade da sensação de fortalecimento, e ao mesmo tempo a preocupação com o futuro do projeto em função das mudanças no quadro político-administrativo local, aparece no discurso desta moradora na oficina. 
"Meu nome é (...), sou moradora daqui, sou comerciante também, e gostaria que esse projeto não ficasse, não morresse, aquela coisa (...) que esse incentivo não ficasse só entre nós. Se espalhasse, saisse, e que desse continuidade. Que acontecesse, não ficasse somente no papel, que nem falaram. Por que aqui, tem que ter muitas mudanças (...). Eu gostaria de estar sempre na reunião e ver, sentir, e o que eu puder passar. Podemos passar para as pessoas o que se passa aqui. E que não pare por aqui, que continue, por que não adianta vivenciar um projeto e daqui há um tempo, esquecer, parar, deixar todo mundo desanimando. Aí, o que vai acontecer, vai ficar no esquecimento. Então que não aconteça isso, que fortaleça $e$ fortaleça o outro que está do seu lado" (participante em oficina do futuro em outubro de 2000).

Neste sentido, a percepção positiva de início de trabalho de grupo participativo na cidade se mistura com as incertezas de sustentabilidade do PBMS em função das mudanças ocorridas nas eleições municipais naquele período no ano de 2000.

"Bom, eu estou satisfeita, mas estou preocupada. Eu não sei se a gente vai conseguir resolver os problemas, se a gente vai poder ajudar. Não sei se amanhã ou segunda, vai acabar. Tudo o que a gente faz depende de política, depende de algum órgão público e no fim a gente pára". (participante em oficina do futuro em outubro de 2000).

"Não depende só da gente. Se dependesse só da gente (...), eu acho que o que depender da gente vai ser feito, agora o resto, se depender de outras pessoas (...)" (participante em oficina do futuro em outubro de 2000).

"(...) estou feliz porque os nossos problemas (...), parece que vamos tentar resolver. E preocupada por que a gente não sabe qual vai ser o rumo de todas as reuniões, dos nossos problemas. A gente não sabe ainda, se nós vamos conseguir resolver, entende. Então fica essa preocupação: estamos iniciando, estamos engatinhando ainda, então fica essa preocupação" (participante em oficina do futuro em outubro de 2000).

A percepção sobre os desafios concretos dos grupos para lutar pela solução dos problemas locais, surge em diversas passagens das oficinas, enquanto atitudes, sonhos, objetivos e ações individuais concretas. 
"(..) Meu sonho é elevar o nível político cultural da população". (participante em oficina do futuro em outubro de 2000 ).

"(...) Meu sonho é que existam políticos mais observadores no trato da coisa pública." (participante em oficina do futuro em outubro de 2000).

"(...) eu tive conhecimento do projeto, primeiro pelo rádio, ai depois pelos jornais, depois pelo Baltazar. Aí eu comecei a vir na reunião. Sou uma das classificadoras, convidei onze pessoas no mínimo, agora onze,......, o pessoal diz que vem, não sei, eu não entendo. Porque a gente vê muita reclamação, mas na hora de tomar qualquer atitude aqui, não vem. Além de não ter iniciativa (...). Tudo bem de não ter iniciativa, mas não dar apoio, não cooperar... Então eu acho que as coisas estão um pouco dificeis, você só reclama de barriga cheia, e está tudo ótimo, não é verdade (...)" (participante em oficina do futuro em outubro de 2000).

A dificuldade de modificar a forma de pensar das pessoas apareceu como uma questão importante a ser trabalhada.

"A dificuldade é modificar o jeito de pensar". (participante em oficina do futuro em outubro de 2000).

Um participante chegou a expressar, sobre a dificuldade de explicar para as pessoas, na perspectiva do entendimento dos problemas, sugerindo a necessidade de abordagens didáticas e pedagógicas.

"Não é nesse sentido. A dificuldade é muito grande para explicar para as pessoas. É entender a situação". (participante em oficina do futuro em outubro de 2000).

Nas oficinas, procurou-se efetuar a passagem da responsabilização e atuação dos membros da sociedade civil, do nivel individual para o nível coletivo. Para isso, questionou-se sobre o interesse e disposição de formar um grupo. A percepção sobre a importância da formação de grupos e atuação coletiva é presente.

"Bom, eu acho assim, lógico que nas conversas que a gente vai ter aqui, algumas vezes, uma pessoa não vai gostar do que a outra está falando. Eu acho que tem que ser um compromisso, tem que se abdicar, tentando um 
bem para obras saudáveis, não numa saúde pessoal só, o que é bom para mim (...)". (participante em oficina do futuro em outubro de 2000).

"Esperança de que a gente consiga colocar isso numa sociedade" (participante em oficina do futuro em outubro de 2000).

"A reunião foi boa, sai com esperança (...), sendo mais os vizinhos, por que a gente se cruza menos. (...) Adoro Bertioga, e com esse trabalho que a gente construa um bairro melhor" (participante em oficina do futuro em outubro de 2000).

"Eu espero que, com essa reunião, a gente consiga uma identidade, por que Bertioga não tem identidade. Então, a gente tem que procurar nossa identidade" (participante em oficina do futuro em outubro de 2000).

"A gente se sente na obrigação de se mexer e bastante" (participante em oficina do futuro em outubro de 2000).

"Agora você falando ai, acabamos achando ai o nosso maior problema: a falta de união. Só que nós já estamos unindo a Vila, Guaratuba e Boracéia, já é um começo" (participante em oficina do futuro em outubro de 2000).

Em algumas passagens, a percepção da falta de união e de integração entre as pessoas parece relacionar-se com a fragmentação física do território do município como já discutido.

"(...) Guaratuba, Boracéia e Bertioga e Indaiá. Tem que haver uma integração entre as comunidades.(...) Aumenta a força" (participante em oficina do futuro em outubro de 2000).

$\mathrm{Na}$ última das quatro oficinas que precedia a apresentação da Agenda daquele grupo no Seminário Municipal, onde compareceria, entre outros, o prefeito eleito, o mediador questionava se havia, por parte dos participantes, interesse em constituir um grupo do PBMS no bairro.

Este momento tinha uma importância particular, na medida em que colocava em questão, se após o trabalho desenvolvido nos quatro encontros haveria disposição para uma continuidade, remetendo a cada um, a opção de assumir ou não um posicionamento diante dos demais.

"Mediador: Então, a primeira pergunta que eu gostaria de colocar para vocês é se vocês gostariam de formar um grupo também. Aquelas meninas que 
sairam disseram que queriam continuar. Elas disseram que vão estar vindo na próxima reunião também. Vocês querem formar um grupo?".

Participante: Eu gostaria!

Sequndo participante: Gostaríamos!

Terceiro participante: Acho muito melhor!

Mediador: Gostariam? É por que aí, o que nós estamos considerando como grupo: são vocês. Então vocês gostariam de continuar, formar um grupo?

Outro participante: Com certeza!".

(diálogo na ultima oficina do futuro em um bairro, outubro de 2000)

Durante a avaliação da última oficina do futuro no loteamento do Jardim Rio da Praia, uma liderança antiga da cidade desenvolveu o seguinte discurso sobre o processo desenvolvido e sobre o futuro do PBMS.

"A iniciativa (...) não perdi uma reunião até hoje. Como iniciativa no início foi muito (...), ninguém colocava credibilidade para isso. Quando eu convidava todos. (me) chamavam "seu bobão". O negócio é começar do novo. O início que está acontecendo aqui, vai acontecer milhares de vezes com os outros lá fora. Se for pra nós sairmos daqui para a comunidade toda e chegar diante de nossos homens eleitos - nós elegemos! E quem nos ensinou isso? Quem trouxe foi a USP, que trouxe o problema político do mal. Mal que pegou. E desejos e os critérios pra isso, e os critérios que tem por meio de Bertioga. (...) Então, nosso agradecimento. Então vamos ver agora o projeto. Nós chegamos, era uma hora na escola (...) Estava só o pessoal do bom princípio lá daquelas favelinhas. O Natalício: "ah eu moro na favelinha". Você é um cidadão brasileiro. Você ocupa um barraco numa favela? Você tem todo direito como eu tenho, então você tem que lutar por você mesmo. Se não houvesse esse desejo, as pessoas não iam fazer isso não. A USP é que mexeu num vespeiro, sabe então, as abelhas vão agora incendiar, picar todo mundo! O negócio vai pegar fogo, não é?" 


\subsection{Nova estratégia para capacitação local: Curso de Agentes}

\section{Multiplicadores para Assentamentos Humanos Saudáveis}

Durante o ano de 2001, a conjuntura do primeiro período da gestão do novo prefeito eleito em Bertioga, levou os coordenadores e participantes do trabalho de extensão universitária a sentirem a necessidade de articular novas estratégias que contribuíssem para ampliar e consolidar a proposta, de promoção da saúde na cidade, uma vez que não houve nenhum espaço concreto de participação (formalmente aceito) na administração municipal, para o trabalho conjunto.

Várias atividades já haviam sido realizadas, visando comprometer o governo municipal, bem como grupos da população residentes em todo território municipal, com a proposta de promoção da saúde. Uma Comissão Intersetorial do PBMS já havia sido formada para planejar e monitorar o andamento dos subprojetos em nivel municipal, conforme já relatado com representação do governo local e de sociedade civil.

Entretanto, a relação com a nova gestão da prefeitura era delicada. 0 prefeito, apesar de ter se comprometido antes das eleições com a continuidade e apoio ao projeto, externava, na relação com a universidade, uma possibilidade de um interesse central bastante restrito: ampliar as receitas municipais e conseguir mais verbas para a sua gestão e seus projetos. Além disso, o prefeito sempre foi distante de atividades do projeto, evitando e impedindo seus secretários de participar.

O projeto, muito possivelmente, uma vez apoiado pelo novo prefeito, poderia fortalecer a imagem do seu rival (antecessor) e enfraquecer a sua, se ele se envolvesse ou apoiasse politicamente. Esta é, aliás, uma prática corrente na nossa jovem democracia brasileira, quando ocorrem as mudanças de partidos e/ou de governantes. O prefeito assume uma posição contraditora, respeitando a presença da USP (nos meses iniciais), mas não participando do processo.

Neste sentido, Mendes (2000) dedica um item de sua pesquisa sobre os Projetos Cidades Saudáveis no Brasil para discutir a questão da interrupção das experiências. Entre elas constam os municípios de São Paulo, Santos e Campinas no Estado de São Paulo, além de Palmeira no Paraná e Iraquara 
na Bahia. Das 20 (vinte) cidades estudadas pela autora, cinco havia interrompido suas experiências. A pesquisadora notou que em todas essas interrupções, caracterizava-se 0 quadro das mudanças administrativas envolvendo a figura do prefeito (Mendes, 2000).

A autora lembra também, que são inúmeros os fatores que dificultam a continuidade das experiências iniciadas em uma gestão anterior, como "instabilidade política, prevalência da política setorial, falta de apoio técnico aos projetos, dificuldades de ampliar parcerias fora do setor governamental, falta de mecanismos de informação e comunicação que garantam democratização das informações para a sociedade em geral, dificuldade em criar mecanismos de monitoramento e avaliação dos projetos". Vários desses fatores foram mencionados pelos técnicos das referidas cidades que acompanharam o processo de implantação das experiências (Mendes, 2000).

Voltando ao contexto das mudanças em Bertioga, outro aspecto importante diz respeito à forma de gestão municipal. O prefeito jamais demonstrou em momento algum, afinidades e interesse com os processos de gestão mais participativos e intersetoriais. Ao contrário, em inúmeras ocasiões sua marca foi a centralização do poder e das decisões. Isto feria frontalmente os princípios do Projeto Município Saudável, principalmente o da participação social, um dos ingredientes que viabiliza o empoderamento.

Alguns dos seus secretários municipais, ensaiaram uma aproximação com o projeto, porém apenas em momentos muito específicos, os seus representantes, realizaram de fato algo em conjunto com integrantes do PBMS.

Possivelmente o único momento em que isso ocorreu foi durante uma campanha que visava evitar uma epidemia de tuberculose, em plena iminência no município. Naquela ocasião, seis agentes de campo que realizaram seis mil entrevistas em 22 núcleos de favelas para a detecção de casos de tuberculose foram treinados pela Faculdade de Saúde Pública da USP em conjunto com a Secretaria de Estado da Saúde. De 10 de julho a 30 de agosto de 2002 haviam sido identificados 30 casos da doença no município. 
Qualquer atividade de cooperação ou de trabalho conjunto com o governo era sempre permeada de muitas dificuldades. Entretanto, considerando os esforços já realizados e em curso, apesar da importância do projeto poder influenciar diretamente as políticas públicas governamentais para tornaremse o mais saudáveis possíveis, optou-se por continuar o trabalho de extensão universitária, gerenciando, dentro do possível, a relação com o governo municipal e buscando no trabalho junto com os diversos setores da sociedade civil, entidades, associações; lideranças, a consolidação e o enraizamento necessário para a continuidade e sustentação da proposta.

Durante o primeiro semestre de 2001 após as Oficinas do Futuro, no Seminário Municipal, os grupos formados nos bairros instituíram uma "Comissão Intersetorial" de caráter mais permanente. Este grupo continuou reunindo-se mesmo sem a participação do governo municipal, com o fim de detalhar estratégias de luta para implementação das Agendas construídas em cada bairro. Entretanto, o acompanhamento da equipe da FSPUSP não chegou a ser sistemático nos bairros por limitações de apoio financeiro. Alguns grupos de bairros mais distantes demonstraram dificuldades de articularem-se autonomamente. Outros grupos continuaram realizando reuniões sistemáticas. Além disso, a Comissão Intersetorial formada por integrantes da sociedade, alguns técnicos da prefeitura e com participação da equipe da FSPUSP se reunia sistematicamente desde que foi formada, mantendo o PBMS vivo na cidade.

No ano de 2001 o amadurecimento da idéia de realizar um curso de formação foi influenciado por diversos fatores. O principal, tratava-se do fato de a coordenação do Projeto estar ligada à uma universidade pública, a maior do país. Além disso, diversos pesquisadores e estudantes de pósgraduação ligados ao Projeto já traziam experiências de trabalhos sócioeducativos junto à comunidades e experiências de docência para diferentes públicos.

Assim, os pesquisadores-alunos e professores, traziam experiências de outros cursos de extensão universitária na própria USP e também por meio de outras universidades, organizações não governamentais, sindicatos e assessorias técnicas sem fins lucrativos. 
Entre as diversas experiências já desenvolvidas no Brasil para formação de lideranças visando a ação no meio urbano citamos uma que influenciou, pelo menos enquanto inspiração, durante o processo de formulação e discussões que antecederam o Curso, que foi o "Curso de planejamento urbano e pesquisa popular". Esta experiência foi desenvolvida em Fortaleza pelo Cearah Periferia (organização não governamental) com entidades comunitárias locais e apoio da Oxfam (uma entidade financiadora de projetos francesa) e premiada no contexto da II Conferencia das Nações Unidas para os Assentamentos Humanos - Habitat II em Istambul em 1996 (Cavalcanti 1996).

Outra referência revista, na formatação da estrutura do trabalho foi o Curso de Formação em Mutirão, um projeto que foi desenvolvido na Escola Politécnica da USP em parceria com o Politecnico di Torino (Itália), e que contou com financiamento da União Européia. Constou de um curso de especialização para profissionais recém-formados (arquitetos, engenheiros, cientistas sociais e sociólogos) para atuação em programas de produção de empreendimentos de mutirões habitacionais autogeridos ou co-geridos.

Assim, o I Curso de Formação de Agentes Multiplicadores para Assentamentos Humanos Saudáveis foi formulado, tendo em vista os seguintes aspectos:

- necessidade de ampliar o alcance do trabalho do Projeto Bertioga Município Saudável para melhoria da qualidade de vida nos bairros e na cidade;

- oportunidade de fomentar propostas e projetos de desenvolvimento, organização e participação comunitária;

- necessidade de capacitar lideranças ampliando seus conhecimentos e desenvolvendo suas habilidades para mediação das relações entre sociedade civil e poder público - empoderamento para o exercício da cidadania;

- oportunidade para disseminar conhecimentos e tecnologias disponíveis na Universidade;

- possibilidade de intercâmbio de experiências com outras cidades do Brasil e do exterior; 
- uma proposta de capacitação de parte dos recursos humanos de Bertioga (sociedade civil e quadros técnicos da prefeitura),

O Curso foi aprovado oficialmente como "Curso de Difusão Cultural", oferecido pela Faculdade de Saúde Pública da USP. Como a prefeitura não se comprometeu a contribuir na sua viabilização econômica, e a coordenação do projeto ligada à FSPUSP considerava que era fundamental que fosse oferecido (aos interessados e aprovados em um processo de seleção) independentemente da capacidade de pagamento de taxas e mensalidades, buscou-se um apoio junto à Opas - Organização Pan-Americana de Saúde/Brasil. Ao mesmo tempo procurou-se uma série de apoios e patrocínios dos mais diferenciados, junto à empresas e entidades do município de Bertioga, que das mais diversas formas apoiavam, participavam ou eram simpatizantes do Projeto Municipio Saudável.

O curso pretendeu iniciar um processo de formação de técnicos municipais e de representantes da população que moravam nos bairros, de modo que pudessem desenvolver ou apoiar o andamento das atividades planejadas pela Comissão Intersetorial.

Na sua primeira versão o Curso oferecia cerca de 28 vagas para capacitar os quadros técnicos da prefeitura e 40 para integrantes da sociedade civil. Entretanto como alguns Secretários não indicaram nomes de técnicos ou funcionários e outros não os liberaram para a participação durante o horário de expediente, o curso contou com a participação de poucos integrantes do funcionalismo municipal - somente aqueles que estavam já diretamente ligados ao projeto. Estes tiveram, contudo, dificuldades junto às suas chefias diretas e só alguns poucos que, com muita perseverança e até na informalidade, compareceram às atividades. Assim, a proposta foi reformulada, visando atender muito mais às lideranças e membros de entidades civis, do que os quadros técnicos, apesar do comparecimento de alguns $^{1}$.

O Curso teve como objetivo geral capacitar moradores como agentes locais aptos a contribuir como multiplicadores no fortalecimento da

\footnotetext{
${ }^{1}$ Ver no Anexo I o quadro com a lista dos participantes nas diversas atividades do PBMS
} 
organização comunitária, a fím de que pudessem atuar a favor da qualificação, construção e desenvolvimento de assentamentos humanos saudáveis, sustentáveis e valorização e preservação do meio ambiente.

Teve como objetivos específicos: desenvolver um processo que contribuísse para a formação de uma visão crítica e compreensiva das realidades local e regional relativas ao meio ambiente e aos assentamentos humanos; a criação de oportunidades para a elaboração de caminhos e estratégias alternativos para enfrentar problemas e desafios dos assentamentos humanos e meio ambiente de forma integrada à implantação de programas de urbanização, regularização e melhorias habitacionais em curso ou em projeto; a formação e capacitação de lideranças, agentes comunitários e multiplicadores ambientais para contribuir na conservação e defesa do meio ambiente; o estímulo à cultura para apropriação e conservação de benefícios urbanos implantados; o estimulo à formas de organização que promovam a confiança interpessoal, da solidariedade, educação e atualização ambiental; a contribuição para iniciar um processo de elaboração de projetos para atividades produtivas, geração de trabalho e renda, qualificação profissional e a identificação de oportunidades de desenvolvimento econômico e social sustentado.

A metodologia do curso foi baseada também nos princípios da pedagogia de Paulo Freire (Freire 1970, 1982, 1992, 1996) e na pesquisa-ação participante (Thiollent 2000; Minayo, 1998; Haguete, 1987) que consistem em facilitar situações que contribuam para gerar na comunidade afetada um processo de autodiagnóstico ou autoconhecimento, a fim de que os seus membros (os participantes do curso), não só fiquem conscientes dos problemas que os afetam, mas que conheçam suas causas e procurem implementar ações de "resolução". Esse autodiagnóstico foi feito através de "lições de casa" relacionadas ao direcionamento do olhar dos participantes para os problemas, aspectos positivos, e iniciativas já existentes em suas próprias comunidades.

As técnicas adotadas nas diversas atividades durante o curso, visavam a troca de experiências, a construção de um saber coletivo, o desenvolvimento de habilidades de negociação e resolução de conflitos. Essas técnicas tinham - caráter de despertar a dimensão subjetiva de seus participantes e 
funcionarem como processos que contribuíssem para o desenvolvimento da autonomia dos indivíduos.

Foram adaptadas de fontes como a Pedagogia Social, a Educação Global, a Metodologia CEFE (GTZ - governo da Alemanha), o Método da Roda ou Paidéia para apoio à co-gestão de coletivos organizados (Campos 2000).

No início de cada oficina, sempre foram realizadas atividades de integração grupal e durante todo o curso, foram feitos trabalhos de grupo através de diálogos sistematizados com propósitos claros para favorecer a troca de experiências e a busca de consensos possíveis visando um ambiente favorável à aprendizagem e ao estabelecimento de vínculos de amizade.

A busca de consensos possíveis e a aceitação dos impossíveis e do conflito, como parte da essência da democracia institucional (Chaui, 2000) permite a identificação de metas e objetivos comuns e favorecem o desenvolvimento de habilidades como o "ouvir", o "argumentar", o "negociar" e o "aceitar o diferente".

No início do curso foi estabelecido um acordo de convivência ou "construção de contrato" para a co-gestão do trabalho sob a orientação de um apoiador (ou facilitador) conforme sugere Campos (2000), com normas referentes aos horários de início e término de cada oficina ou seminário, ao comportamento durante as falas dos participantes e à participação durante o curso. Esse acordo permaneceu durante todo o curso e no geral foi respeitado.

Houve também um controle de tempo, através de um cronometrista, que permitiu que as atividades fossem realizadas de acordo com o planejamento falhando com raras exceções. Houve com isto, uma democratização das oportunidades de intervenção nos trabalhos.

Os procedimentos metodológicos foram semanalmente revistos para ajustarse às demandas dos participantes e aos objetivos do Curso. O Curso foi composto de um conjunto de seminários, oficinas (módulo básico) e oficinas (módulo específico) que abordaram conteúdos teóricos e capacitação prática:

a) Seminários elaborados a partir de temas gerais (ex.: população, gestão, legislação, desenvolvimento econômico e social, políticas públicas, indicadores de saúde e condições de vida) que abordam e informam 
sobre a dimensão regional e o município de Bertioga e desenvolverem a habilidade de formular e fazer perguntas aos governantes;

b) Oficinas de trabalho/módulo básico: para sensibilização, formação geral e desenvolvimento de habilidades, mediação de processos e conflitos em grupos, planejamento intersetorial e participativo, elaborado a partir de temas relativos ao desenvolvimento, organização e sustentabilidade nas comunidades e bairros;

c) Oficinas de trabalho/módulo especifico: para informação, desenvolvimento de habilidades, estímulo e fomento à elaboração de projetos específicos de acordo com as demandas locais expressadas nas comunidades e bairros (comunicação, habitação, residuos sólidos, mobilização e trabalho com grupos).

Os Seminários foram organizados, de modo a contar sempre com a participação de pelo menos um professor da USP, um técnico da prefeitura, um representante de entidade ou instituição local que atua na área em questão. Tiveram como temas: Município de Bertioga: evolução urbana, assentamentos humanos e legislação; Desenvolvimento social e econômico e indicadores de saúde e qualidade de vida; Habitação e saneamento ambiental; Meio Ambiente e Turismo: experiências e potencialidades; Meio ambiente e Educação; Políticas públicas, participação e representatividade da sociedade civil; Avaliação Final.

Ao todo, foram realizados 7 (sete) seminários, 4 (quatro) oficinas do módulo básico e 4 (quatro) oficinas do módulo específico para duas turmas em dois bairros do município.

Como trabalho final, os participantes deveriam, em grupos, planejar, organizar e realizar uma intervenção ou uma iniciativa saudável no município, considerando os pressupostos do ideário Municípios Saudáveis (participação social, intersetorialidade, equidade e sustentabilidade) em qualquer campo abordado: ambiente construído, meio ambiente natural, promoção social, etc.

Este trabalho final visava facilitar aos participantes, o exercicio de enfrentar o desafio de concretizar propostas. Tinha também a intenção de fomentar a constituição de grupos ou núcleos de apoio ao PBMS nos bairros, 
contribuindo para a organização e articulação em ações coletivas de interesse público ou das comunidades.

Foram realizadas diversas intervenções na cidade, envolvendo diferentes entidades da sociedade civil local como por exemplo: "Entre nessa Onda" (mutirão de limpeza do Canal de Bertioga), "Mutirão de Limpeza da Pedra Selada" (Indaiá) que contou com participação de dezenas de crianças da Escola Municipal local, "Doação de Sangue para o Hospital da Cidade", entre outras ${ }^{2}$.

\subsubsection{Percepções do participantes}

Durante o curso uma série de atividades diferentes tiveram lugar e contaram com a participação de dezenas de alunos, professores, palestrantes do governo municipal, universidades e entidades da sociedade civil local.

Ao final de cada seminário e oficina, tanto do módulo básico como do módulo especifico, era realizada uma avaliação por escrito. Ao término do curso foi proposta uma avaliação mais abrangente também, que envolvia aspectos como: avaliação sobre a participação de cada um dos diferentes atores nas atividades do curso, o desenvolvimento de habilidades, conhecimento e informações adquiridas, eventuais mudanças de atitude, sugestões para o futuro, possibilidades de contribuição dos participantes enquanto agentes na cidade, visão sobre Bertioga, propostas para enfrentar os desafios dos assentamentos humanos e meio ambiente.

A avaliação final foi realizada através de um questionário de 14 itens abrangendo diversos aspectos do curso. Na Tabela 33 é apresentado o número de avaliações escritas por atividade do curso.

Passaremos a citar alguns elementos da percepção dos participantes sobre o curso, que orientam análises sobre o processo de envolvimento da população com os problemas do município e sobre o empoderamento da mesma.

${ }^{2}$ Exemplo de Material sobre as iniciativas no Anexo III. 
Tabela 36 - Número de Avaliações recebidas no Curso de Formação de Agentes Multiplicadores para Asentamentos Humanos Saudaveis

\begin{tabular}{l|c}
\hline \multicolumn{1}{c|}{ atividade } & $\begin{array}{c}\text { número de } \\
\text { avaliações } \\
\text { recolhidas }\end{array}$ \\
\hline Oficina II - Módulo básico & 30 \\
\hline Oficina III - Módulo básico & 28 \\
\hline Oficinas do Módulo básico & 19 \\
\hline $\begin{array}{l}\text { Seminário de Desenvolvimento Social e } \\
\text { Econômico e Indicadores de Saúde e Qualidade } \\
\text { de Vida }\end{array}$ & 23 \\
\hline Seminário de Educação e Meio Ambiente & 22 \\
\hline Seminário de Habitação e Saneamento & 16 \\
\hline Oficina de Mobilização Social & 19 \\
\hline Oficina de Introdução à Minimização de Resíduos & 10 \\
\hline Oficina de Habitação & 33 \\
\hline Avaliação final do curso & 15 \\
\hline Total & 215 \\
\hline fonte: Cepedoc/FSPUSP (Relatório Interno, 2002)
\end{tabular}

fonte: Cepedoc/FSPUSP (Relatório Interno, 2002)

Alguns participantes destacaram sobre a importância de ouvir o outro como um aspecto relevante, enquanto percepção do processo do curso.

"Ouvir, respeitar e com isso descobrir que as pessoas tem grandes idéias";

"Todos ouvem as idéias dos outros, na maioria das vezes, todos tem idéias diferentes, mas conversando todos entram em consenso";

"O que mudou foi aprender a ouvir mais o outro";

"Através de conversas e opiniões eu estou aprendendo a participar de grupos e conseguir com isto, uma bagagem maior para poder trabalhar com a comunidade e também a ouvir as opiniões dos outros e saber acatar, e se não estiver de acordo, tentar aprender o que é melhor para todos";

A solidariedade, bem como a vontade de realizar coisas pela cidade foram elencadas como elementos também importantes, que chamam a atenção nos depoimentos.

"A vontade de ser solidário que existe dentro do ser humano";

"A vontade que temos de fazer alguma coisa pelo nosso bairro, pela nossa cidade"; 
"A vontade de ser solidário que existe dentro do ser humano";

"A vontade que temos de fazer alguma coisa pelo nosso bairro, pela nossa cidade";

"Amor e solidariedade"

"E que não estamos sozinhos, existem grupos que podem nos apoiar";

A percepção de compartilhar objetivos comuns e a importância da união das pessoas de diferentes bairros para lutarem pela solução dos problemas também foram mencionados como aspectos importantes por alguns participantes ao final do curso.

"Outro fato marcante é que não registrei grandes discordâncias entre os participantes, logo grupo heterogêneo - idéias homogêneas";

"A união de um grupo heterogêneo que almeja a melhoria da qualidade de vida para a população do município, sendo que cada membro tem uma forma de agir com um fim comum";

"(...) o curso, além de propiciar o contato com vários temas e passar informações, possibilitou o encontro de pessoas, que mesmo sem saber, muitas vezes, tinha em comum a busca de uma melhor qualidade de vida (...)";

"Com o círculo que fizemos na última oficina, onde um sentou no colo do outro e ninguém sentiu peso nenhum. Para podermos trabalhar sem pesar para ninguém, teremos de estar unidos";

Nota-se que alguns participantes, refletindo sobre as atividades do curso, referem-se à dimensão do trabalho conjunto como um elemento importante para a atuação a favor de um município mais saudável. Esse aspecto se destaca na percepção dos participantes numa perspectiva do aprendizado, para o grupo ganhar força e para enfrentar os problemas locais.

"Pessoas de todas as idades e todas as classes sociais, todas trabalhando juntas e trocando informações";

"A oportunidade de conhecer e trabalhar com pessoas diferentes $e$ representativas de todos os segmentos sociais e bairros de Bertioga"; 
"As dinâmicas, os trabalhos em grupo e os depoimentos";

Alguns demonstraram admiração e surpresa por descobrir o interesse das outras pessoas em conhecer, discutir e atuar para melhorar a cidade.

"O interesse dos jovens por assuntos financeiros e políticos";

Outro aspecto valorizado refere-se ao acesso à informações, ao conhecimento de aspectos da realidade do município e da região e o aprendizado resultante.

"Eu achei muito interessante o levantamento dos problemas e das qualidades de cada bairro, assim todos ficaram a par do que acontece nos outros bairros";

"(...) conhecimento dos problemas de cada bairro (...)";

Um dos participantes mencionou um dos pressupostos 0 ideário de Municípios Saudáveis.

"sobre uma comunidade sustentável"

Outros destacaram a importância da ampliação do trabalho no município visando envolver mais pessoas e também o aprofundamento para superação das dificuldades e a melhoria das condições de vida.

"Deveria ter mais dias da semana";

"Expandir para que mais pessoas tenham a oportunidade de fazer o curso";

"Aumento de uma hora de carga horária".

"Eu só gostaria que a Profa. Patrícia voltasse e falasse mais sobre "o seu meio" já que ela é oceanógrafa";

"Assunto interessante, mas os palestrantes são demais para tempo tão curto. As questões relativas ao município são mais palpitantes";

"Faltou municiar dados da cidade quanto à educação, saúde preventiva e curativa e segurança";

Nesta perspectiva, também a obtenção de mais informações e conhecimento, parece constituir uma necessidade sentida por diversos participantes do trabalho. 
"Mais oficinas práticas sobre como entrevistar responsáveis pelas iniciativas comunitárias na cidade";

"Gostaria de ter uma sintese das oficinas por escrito, pois não consegui fazer registros em virtude da agilidade das atividades";

"Gostaria de ter conhecimento de iniciativas implantadas e bem sucedidas em outras localidades, que possam ser aplicáveis ao nosso município, dentro da nossa realidade";

"Apresentar dados do municipio, quanto a barracos, invasões, controles, fiscalização";

Além disso, a apropriação de conhecimento aparece, de maneira muito próxima ao expressado no item anterior

"Muito importante na parte dos indices de nossa cidade";

"Foi bem informatizado, deu para a gente ter mais noção dos problemas e como resolvê-los";

"Dr. Marco muito objetivo, didático, muito bom".

Quando perguntados se havia ocorrido a obtenção de informações ou conhecimentos novos ocorreram diversas manifestações.

"Muitas informações sobre trabalhos realizados nas cidades que não conhecia";

"Sobre o projeto Agenda 21";

"Coleta de lixo seletiva "Sobloco" "Quirino" ótima";

"Existência de uma ONG voltada para o meio ambiente";

"Discussão sobre o lixo descartável, a educação ambiental";

"O preço do tratamento do lixo na Riviera de São Lourenço é por volta de $R \$ 11.000,00 "$;

"Como é importante conhecer a nossa cidade e o próprio bairro e sabendo que nós mesmos podemos ajudar para ter Bertioga, o município saudável";

"Incubadora de cooperativas da USP";

"Sobre o Projeto Temático da FAPESP"; 
"Que as escolas estão abertas para a comunidade";

"O custo da reciclagem, o emprego do valor do lixo reciclado, a educação e a admiração das pessoas que aceitam, que colaboram para a boa limpeza enfim Riviera pode ser o espelho que Bertioga, a nivel de como educar os bertioguenses na coleta de lixo";

"Com relação aos serviços fornecidos pela SABESP e Caixa Econômica Federal";

"A exportação do lixo de Bertioga, os vários tipos de baratas, a nocividade dos ratos, a reprodução das moscas no lixo, tipos de doenças";

"Como participar e comprovar renda para obter o Programa de Habitação";

"O lixo que não devemos enterrar";

"Sobre o aterro que é feito ao ar livre; sobre as informações que o Márcio disse sobre a rede de esgotos pronta até 2001";

"Nunca imaginei que fosse dessa forma que chegaria água potável em nossa residência";

"4.000 moradias irregulares";

"ZEIS" (zona especial de interesse social).

Muitos aspectos foram levantados relativos às políticas urbanas além dos já mencionados acima, particularmente nas oficinas de módulo específico de habitação e de resíduos sólidos. As menções sobre o tema da habitação foram diversas e expressam a percepção diante das informações novas.

"Agora estou ciente que muitos projetos não são realizados, devido às diretrizes do plano diretor, que muitas vezes prejudicam a sociedade";

"Hoje acho urgentíssimo que providências sejam tomadas para frear a degradação do meio ambiente e promover um trabalho sério na questão da habitação";

"Me senti meio impotente e muito preocupada com a regularização de área pública ocupada";

"Saneamento básico de um bairro";

"Crescimento populacional"; 
"Habitação subumana nas áreas de risco e sem saneamento básico";

"Habitações subumanas e que o déficit é de 5.000 moradias";

"Reciclagem do material degradável ao meio ambiente";

"A respeito do lixo, desde quando sai das nossas casas, enfim todo o trajeto";

"Muito proveitosa, principalmente em saber que a maioria das pessoas está preocupada com construções dignas de um ser humano";

"Na prática, penso que continuará beneficiando aos políticos, corretores e imobiliárias, até que a comunidade se conscientize das causas e efeitos";

"Conhecimento sobre muitas construções habitacionais";

"Estatuto da cidade; os projetos apresentados pelo professor Roberto";

"Conhecimentos gerais a respeito de projetos "baratos" da construção civil";

"Descobri que, às vezes, as pessoas envolvidas nos projetos de habitação se preocupam com as pessoas";

"Nova lei de assentamentos humanos federal";

"Mutirões sobre habitações populares a preços muito baixos (cerca de $R \$ 5.000,00)$ ";

"Descobri que, tecnicamente, e legalmente Bertioga está muito bem amparada e pode melhorar ainda mais com a aprovação para criação das ZEIS, porém, nossa realidade é outra, com invasões em vários pontos da cidade. Como equalizar o que deveria ser, com a realidade?"

"Muito poder na mão de poucos";

"Projetos de urbanização popular";

"Capacitação de profissionais da construção civil";

"Sistema de coleta de lixo reciclado";

"Acredito que poderá mudar, quando os agentes conseguirem mobilizar a sociedade, e juntos reivindicarem a execução urgente de ações para assentamentos humanos, urbanização, saneamento básico $e$ desfavelamento. Quanto ao meio ambiente, com muita tristeza tenho 
dúvidas, depois de testemunhar, na limpeza da Praia do Indaiá, que "moradores" jogam seus detritos por cima de seus muros em direção da praia (pasmem!)"

"Conscientizando os moradores a fazerem fossas sépticas";

"O tópico de reciclagem (do qual não pude participar da oficina). É empolgante, interdisciplinar e arregimenta muita atenção. Dele, parte-se para o lixo, daí para a saúde, a educação, etc."

O desenvolvimento de habilidades foi uma das questões expressadas no questionário de avaliação final. Os participantes, em boa parte, sugeriram que este foi um elemento importante do processo desenvolvido no curso. Note-se que o desenvolvimento de habilidades é uma das recomendações da Carta de Otawa da $1^{a}$. Conferencia Mundial de Promoção da Saúde (Otawa, 1986). Relaciona-se também com o processo de empoderamento como já mencionado no capitulo 3 (Oakey e Clayton, 2003). Note-se que neste item sobre o desenvolvimento de habilidades, também o aspecto da comunicação está presente em diversas passagens, como uma dimensão muito valorizada do ponto de vista dos participantes. Alguns depoimentos sugerem mudança ou revisão de atitudes e posturas individuais.

"Olhar para uma pessoa e ver um ser humano";

"Em minhas mãos foram colocadas ferramentas e conhecimentos para afinar o instrumento do viver, procurando sempre desafinar o menos possível. As habilidades apresentadas nas atividades são notas importantíssimas na melodia";

"Comunicação, agir, e o mais importante, perseverança, espirito de grupo e liderança";

"A partir do momento em que comecei a aplicar as habilidades adquiridas aqui, representantes de iniciativas começaram a me procurar, solicitando possiveis soluções para problemas existentes e com propostas de gerar processos participativos";

"Com este curso aprendi a sentir as pessoas; me sinto em condição de elaborar e implantar uma série de projetos voltados para a comunidade"; 
"Não querer levar nada muito pronto, fechado; as propostas de ação devem surgir das pessoas conjuntamente, para que haja envolvimento real $e$ produtivo";

"Como se comunicar com as pessoas de maneira inteligente para conquistála para a mesma idéia";

"Técnica de trabalho em grupo, método de avaliação continuada, comunicação";

"Organização de um projeto";

"Aprendi agora que, com uma comunicação constante, poderemos participar, ao invés de apenas uma ação. Temos a oportunidade de colaborar com amigos de outras iniciativas, outros bairros, enfim estar pronto para a luta!"

"Estou aprendendo a me comunicar melhor com as pessoas";

"Novamente a comunicação. Antes do curso não havia participado de ações fora do bairro; graças ao curso já tenho participado de ações fora do meu bairro; a comunicação entre alunos do curso me propiciou estas oportunidades para colaborar";

"Sinceramente, não me sinto seguro para aplicar as técnicas mostradas durante o curso; me esforço bastante para falar em público, tenho sérias dificuldades; o que me atraiu mais foram as técnicas de grupo, gosto da dinâmica da evolução do grupo. Na prática, no dia a dia de nossas comunidades, a ferramenta mais importante é a comunicação; precisamos nos comunicar, dar valor às iniciativas que surgirem entre as pessoas";

"Aprendi a trabalhar em grupo, aprendi a ter paciência com algumas pessoas que são contrárias".

Um outro aspecto muito recorrente na maior parte das atividades, refere-se à percepção que os participantes têm do relacionamento do governo municipal com a sociedade civil. Também aparecem as manifestações de cobrança, de descrédito e crítica com relação ao poder público, particularmente a prefeitura.

"As informações fornecidas pelo representante da SABESP e prof. Wanda atenderam as minhas expectativas. Com relação à prefeitura, o corpo técnico, não conseguiram ser convincentes"; 
"Até o final do curso, o representante da Câmara poderia vir?"

Insatisfação com o modelo administrativo total;

"Não gostei das respostas da Sra. (...) (Secretária Municipal de Educação) não acrescentou nada";

"Seria ótimo se, em um desses seminários, o nosso prefeito pudesse nos fazer uma visita";

Falta de comunicação que existe entre os administradores municipais e a população;

"(...) porém sem ressonâncias, quando você esbarra nas responsabilidades do poder público, que não são cumpridas";

"Cobrar aquilo que compete aos órgãos públicos";

"Pude ver que a sociedade quer participar mais ativamente da administração, mas esta é irresponsável";

Esta postura crítica em relação ao governo se repetiu quando se tratava dos seus representantes que compareceram às atividades do Curso. Quando indagados sobre a avaliação da participação destes profissionais, os participantes realizaram diversas observações neste sentido.

"Os profissionais da prefeitura se mostraram com duas caras; quando fizeram a palestra deram a entender que estariam abertos ao diálogo; quando posteriormente procurados se tornaram dificeis";

"Foi bom; já pensou se eles não participassem!";

"Alguns participantes trouxeram informações preciosas, outros foram escorregadios, e outros ainda, parece que caíram de pára-quedas nos seminários";

"De média a baixa (avaliação), alguns pela falta de tempo, outros por não serem claros e com nenhum envolvimento com o projeto";

Sobre a participação de outros atores locais, como membros de entidades, organizações não governamentais, de conselhos municipais foram feitas algumas observações também. 
"As entidades têm um grande interesse, participaram ativamente, porém acredito que o que falta é um princípio norteador, para se alcançar realmente a participação";

"falta de contato mais freqüente, uma melhor comunicação";

"Gostei muito. Deu a oportunidade de conhecer cada conselho municipal e alguns participantes; ver qual atuação e sentir até onde eles podem ir; e 0 que eu senti é que todos eles são barrados sem conseguir seus objetivos".

Os participantes declararam também a importância de colocar em prática os conhecimento e habilidades adquiridas ou desenvolvidas durante 0 processo de trabalho dos grupos. Estas manifestações surgiram principalmente quando indagados sobre o futuro do projeto e dos trabalhos na cidade.

"Mais trabalho de campo, intervenções"

"Mais oficinas práticas, como o de entrevistar responsáveis pelas iniciativas" Gostaria de praticar para sentir o que ainda falta;

"(...) já tento, juntamente com outras pessoas do bairro, desenvolver um trabalho que vise uma melhora na qualidade de vida das pessoas, ainda que com falhas e dificuldades";

"(...) Sim, principalmente depois do trabalho de intervenção, quando saí a campo para falar com as pessoas, explicando a elas o que se passava; neste grupo existem agentes de verdade".

No final das atividades do curso, diversos participantes, quando indagados sobre conteúdos que teriam interesse, em uma outra eventual oportunidade, colocaram uma necessidade particular: aprendizado mais aprofundado sobre direitos, legislação e funcionamento do sistemas das instituições públicas e dos poderes, como pode-se notar por meio destas menções.

"Cidadania, política (regimes), democracia, psicologia nos grupos, comunicação e expressão pessoal";

"Informações mais técnicas sobre a função dos poderes públicos (obrigações, áreas de atuação), direitos e deveres dos conselhos municipais" 
"Maiores detalhes do "sistema", com relação aos trabalhos que o Legis/ativo e executivo atuam dentro do município";

"Gostaria de aprender uma maneira de fazer com que os profissionais da prefeitura de Bertioga participassem mais ativamente do "Projeto Bertioga Municipio Saudável";

"O que eu sinto muita dificuldade, principalmente nos seminários, é a falta de conhecimento na área legislativa".

Algumas passagens mostram as diferentes visões sobre politização e despolitização das pessoas e o compromisso com os problemas locais

Como o povo de Bertioga é receptivo, porém não é politizado, é uma pena. Não existe na cidade um "grupo forte" que possa contestar alguns absurdos cometidos pela administração municipal;

"Me tocou saber que têm pessoas com vontade de fazer algo para modificar este município. Mas elas são barradas por interesses políticos. Também me tocou que eu vi que Bertioga, quando se chega, esta cidade é horrível, de um aspecto deplorável, os turistas se assustam. O que salva é quando se chega na praia. Toma-se o seu banho, sua cerveja e vai embora; esta é a visão do turista".

Para completar, nas aspirações finais do curso, diversos participantes expressaram a importância e a intenção de influenciar nos rumos das políticas públicas, por meio de maior proximidade entre governo e sociedade civil, que permitisse atuação conjunta, apesar do reconhecimento das dificuldades existentes, como pode-se ver.

"Relação da integração entre sociedade e poder público, podem resolver os problemas, para uma qualidade de vida melhor";

"O documento a ser entregue ao prefeito, deveria estar sendo elaborado desde o início do curso";

"Dez cabeças pensam melhor que uma. As pessoas que estão participando possuem muitas idéias e projetos bons, além de possuírem também boa vontade para estar atuando. Possamos no final do curso fazer um projeto com diretrizes e sugestões para ser encaminhado a administração pública, 
para que possamos juntos (sociedade civil e administração pública) tentar sanar os problemas";

"Formação de grupos para atuar na comunidade, baseados em um programa traçado junto à prefeitura";

"Integração da comunidade e poder público";

"Pelo número de iniciativas em andamento na cidade, creio que a sociedade civil está ciente da necessidade de sua participação junto ao governo municipal, na busca de soluções para os problemas que afligem a nossa cidade";

"Descobri que o municipio não sabe o que quer realmente, que não adianta brigar por algo que não se sabe. Na minha visão temos que nos reunir tanto governantes, como civis e ver que rumo tomar, se somos uma cidade turística ou não, pois estamos afundando. Nossos assentamentos são de péssima qualidade e estamos destruindo nosso meio ambiente. Se continuar nesse ritmo seremos a pior cidade em qualidade de vida";

Por fim, os moradores expressaram sugestões para o futuro após o término do curso. Muitos demonstraram preocupação com a manutenção das atividades dos grupos, com a importância de reuniões periódicas e com os rumos do PBMS. As questões centrais da união, da atuação prática e da continuidade, sobressaem.

"Estabelecer reuniões mensais com o grupo para troca de experiências e "recarga de baterias"

"Planejarmos estrategicamente qual o objetivo claro a ser alcançado no final do curso";

"Em vez de fazermos grupos separados, devemos ser um grupo só para todas as iniciativas. Assim trabalharemos melhor em cada meta que fizermos. Unidos, não em bairros, mas sim em toda Bertioga, todos alunos juntos";

"Maior divulgação para melhorar a participação de todos os segmentos da sociedade de Bertioga";

"Conquistar um lugar fixo para o curso para não haver divisão de grupos, pois isso deu uma certa indiferença, como se divide centro e bairro, pois é 
importante sentir a visão de cada um. Gosto de observar o que cada um fala, etc.";

"Divisão melhor do tempo do curso. Uma vez por semana ficou muito distante, faz com que se esfrie algumas idéias, pensamentos, etc".

"Através do fortalecimento das entidades civis constituidas e assim partindo na busca de objetivos especificos e que vão provocar as mudanças necessárias rumo a uma cidade saudável";

"Esse grupo pode se tornar uma entidade. Continuar se reunindo, discutindo os problemas e também dando solução e levar isto até um órgão público para o desenvolvimento das ações";

"Formação de comissões participativas em todas as iniciativas existentes".

\section{Sobre a proposta de Municipios Saudáveis}

Em algumas avaliações, surgiram idéias e comentários sobre alguns pressupostos e conceitos relativos ao ideário Municípios Saudáveis. Mostram que, apesar da amplitude de temas de interesse local, estudados e discutidos, os participantes se apropriaram destes referenciais.

"(..) mas tenho certeza que em breve poderei agir como agente multiplicador para assentamentos humanos saudáveis, na medida em que eu participar em campanhas e movimentos para esses assentamentos humanos saudáveis, cujos resultados tragam beneficios para os que mais necessitam"; "(...) porque posso arregimentar pessoas para tornar iniciativas saudáveis factiveis e conquistá-las para um objetivo social e difuso, onde o ganho não é pessoal e sim coletivo";

"(...) ferramentas foram colocadas à disposição para todos que pretendem um município saudável; para assentamentos humanos a maior parte da responsabilidade cabe aos governos federais, estaduais e municipais. Porém a sociedade pode e deve participar, colaborando com os poderes constituidos";

"Creio que entendi bem o conceito de saúde no projeto Município Saudável".

"Aprendi que temos que ter amor ao que fazemos"; 


\subsection{Evidências de empoderamento e o processo de revisão do plano diretor municipal}

Após o término do Curso de Agentes Multiplicadores para Assentamentos Humanos Saudáveis, no final de 2001, os participantes da Comissão Intersetorial do PBMS e de grupos nos bairros, continuavam a inserir na pauta de discussão, entre outros, os problemas relativos à moradia, ao saneamento, ao planejamento e gestão urbana.

Nessa conjuntura, o Plano Diretor (PD) em vigor, aprovado em 1998 elaborado com participação intensa da Associação de Engenheiros e Arquitetos de Bertioga previa que sua revisão deveria ocorrer num prazo de 4 anos, ou seja em 2002.

Com a aprovação da Lei Federal 10.257, de 10 de julho de 2001 - o Estatuto da Cidade, reforçava-se a necessidade, sentida fora e dentro do governo municipal, de viabilizar a revisão da Lei do Plano Diretor de Bertioga.

Ainda no ano de 2001, antes da realização do Curso, os integrantes do Projeto Bertioga Município Saudável propuseram ao governo municipal a realização de uma atividade de extensão universitária denominada "Clínica de Urbanismo"3. A idéia é que a atividade objetivasse desenvolver diretrizes para aplicação dos instrumentos do Estatuto da Cidade no município, por meio de levantamentos, discussão e sistematização com participação dos representantes de governos, de setores locais, professores e estudantes de Arquitetura e Urbanismo.

A proposta foi aceita inicialmente por um dos Secretários Municipais e em seguida barrada por decisão do prefeito, constituindo-se mais uma demonstração da dificuldade do governo local de relacionar-se harmonicamente com as propostas do PBMS e de articular atividades mais participativas na cidade.

3 Sobre as Clinicas de Urbanismo e Laboratórios de Projeto Ver: Laboratório de Projeto Integrado e Participativo para o Prédio da Rua do Ouvidor, 63: extensão, ensino e produção do saber em movimento (Comarú et al., 2003). 
Durante o primeiro semestre de 2002 foi ficando cada vez mais claro a necessidade concreta de discutir com diversos segmentos interessados na cidade a revisão do Plano Diretor municipal, considerando o contexto da nova lei do Estatuto da Cidade.

Também, por parte do governo municipal, equipes técnicas iniciavam os trabalhos tendo em vista a elaboração da proposta de Projeto de Lei do Poder Executivo para o Poder Legislativo.

A equipe da FSPUSP propôs para a Comissão Intersetorial do PBMS, a organização de um conjunto de oficinas com lideranças e setores da população que visasse abrir um espaço de discussão do Plano Diretor atual e dos instrumentos do Estatuto da Cidade.

Para tal, seria necessário obviamente, uma abordagem de capacitação dos participantes do PBMS e outros moradores interessados, tendo em vista a especificidade do assunto e o seu caráter técnico e jurídico. Na interpretação da equipe da FSPUSP esta capacitação mínima era fundamental que ocorresse, considerando que a sociedade civil seria convidada a participar das audiências públicas.

E para que sua participação pudesse agregar qualidade e conteúdo, na perspectiva de uma contribuição concreta para melhoria das condições de vida na cidade em médio prazo, a compreensão do assunto era requisito essencial.

Além da equipe da FSPUSP que coordenou o trabalho, participaram cerca de 45 representantes de setores e segmentos da sociedade civil, tendo sido realizadas basicamente as seguintes atividades (Cepedoc, 2002):

- Conjunto de cinco oficinas, cada uma de 3 horas de duração;

- Seminário Municipal para apresentação dos resultados, com 5 horas de duração;

- Produção de Relatório, contendo as propostas da sociedade civil para a Revisão do Plano Diretor e considerações técnicas da equipe da Faculdade de Saúde Pública da USP, entregue oficialmente à Prefeitura Municipal de Bertioga; 
- Diversas reuniões de trabalho para detalhar uma proposta de diretrizes, para a revisão do Plano Diretor por participantes do PBMS.

A proposta de trabalho procurou contribuir para viabilizar uma efetiva participação, tendo em vista o cumprimento do Capítulo IV do Estatuto da Cidade, "Da Gestão Democrática da Cidade", segundo o qual:

"Para garantir a gestão democrática da cidade, deverão ser utilizados, entre outros, os seguintes instrumentos:

I - órgãos colegiados de política urbana, nos niveis nacional, estadual e municipal;

II - debates, audiências e consultas públicas;

III - conferências sobre assuntos de interesse urbano, nos niveis nacional, estadual e municipal;

IV - iniciativa popular de projeto de lei e de planos, programas e projetos de desenvolvimento urbano; ${ }^{\prime 4}$

Como mencionamos, a viabilidade da efetivação legítima e com qualidade da participação dos diversos setores e segmentos da sociedade civil, no caso de Bertioga, esbarrava principalmente em duas dificuldades.

A primeira refere-se ao fato já citado (Villaça, 1999 e Maricato 2001) de que, constantemente, os planos e as leis possuem linguagem hermética, prolongando-se em jargões tecnicistas, legalistas e detalhistas, muito dificeis de serem compreendidos, interpretados, difundidos e respeitados pela grande maioria da população.

Portanto, para que a participação da sociedade civil fosse efetivada, era necessário um mínimo de familiaridade com a linguagem técnica - jurídica e urbanística - de modo a sentir-se mais apta a contribuir com a formulação ou revisão das Leis que determinam o desenvolvimento de sua cidade (Plano Diretor, Lei de Uso e Ocupação do Solo, Código de Obras, entre outras Leis Municipais, além de Leis Estaduais e Federais).

\footnotetext{
${ }^{4}$ Lei Federal N 10.257/2001, Capitulo IV- Da Gestão Democrática da Cidade, Artigo $43^{\circ}$.
} 
A outra dificuldade centrava-se no esforço adicional a ser realizado no âmbito do PBMS para que os instrumentos de democratização da gestão urbana e outros, como o princípio da função social da propriedade e da cidade, garantidos pelo Estatuto da Cidade, fossem devidamente utilizados pela população e pelos gestores no atendimento do interesse público (Estatuto da Cidade, 2001; Cepedoc 2002).

Ou seja, que o debate, as proposições e reivindicações não se limitassem ao favorecimento de interesses específicos de grupos ou classes dominantes na cidade, em detrimento dos interesses coletivos e difusos. Para isso, era necessário que a população tivesse um melhor conhecimento da realidade da cidade, bem como compreensão básica das relações entre os diversos atores que contribuem para a produção do espaço urbano e da cidade (Santos, 1988), possibilitando a luta para que as leis municipais realmente possam garantir o desenvolvimento do território municipal de forma mais equilibrada, democrática e justa (Cepedoc, 2002).

Neste sentido, foi proposto que o trabalho se desenvolvesse por meio da realização de cinco oficinas temáticas, cuja metodologia é explicada a seguir.

Para atingir os objetivos propostos, foi necessária a articulação de métodos e técnicas diferenciadas que contribuíssem para a compreensão das linguagens técnica, jurídica e urbanística por todos os participantes, de forma a compensar (dentro do possivel) as diferenças de formação profissional e nivel de instrução. Procurou-se integrar um conjunto mínimo e consecutivo de temas que pudessem levar à população participante, condições de compreender e conhecer com alguma profundidade a realidade da cidade, 0 Plano Diretor atual, suas leis complementares e os instrumentos do Estatuto da Cidade que poderiam eventualmente ser aplicados em Bertioga. As oficinas tiveram como temas:

- Oficina 1 - Bio-Mapeamento das características e temas da cidade;

- Oficina 2 - Bertioga: dados secundários e aspectos da cidade real;

- Oficina 3 - Plano Diretor atual e o desenvolvimento urbano de Bertioga;

- Oficina 4 - Estatuto da Cidade e as possibilidades para Bertioga; 
- Oficina 5 - Bertioga e o futuro: a cidade desejada.

Para atingir comunidades de localidades distintas, o mesmo conjunto de oficinas foi oferecido em dois bairros e, em horários diferentes: no Centro $e$ no bairro do Indaiá (à tarde e à noite).

As metodologias e técnicas utilizadas eram semelhantes às daquelas utilizadas nas Oficinas do Futuro e do Curso de Formação. Entretanto para o trabalho com os mapas foram utilizadas outras referências também. Entre elas destacam-se a metodologia dos Biomapas Comunitários (Macnaughton, 2002 e UBC 2001) e alguns elementos do Kit das Cidades (Instituto Polis, 2002).

A metodologia dos Biomapas, que foi desenvolvida e divulgada no Brasil por professores da Universidade da Columbia Britânica - Canadá, já havia sido aplicada na Vila de Paranapiacaba, no município de Santo André no ano de 2002. O objetivo da oficina de Biomapas é introduzir aos participantes das comunidades e aos planejadores locais a técnica de elaboração de mapas comunitários. A idéia é que a população construa mapas temáticos de seu interesse a partir de pesquisas de campo na cidade.

Segundo Macnaughton, (2002) os mapas uma vez produzidos "devem mostrar claramente o conhecimento que a comunidade tem de seu meio ambiente, urbano, social e econômico e, ao mesmo tempo, aumentar o empoderamento de seus membros através da inserção do conhecimento local nos processos de planejamento, implementação e monitoramento".

O processo de elaboração participativo dos Biomapas Comunitários, segundo os idealizadores "deve também melhorar a eficiência e efetividade do planejamento a nível local, possibilitando que sejam desenvolvidas soluções para problemas locais, que sejam implementadas e monitoradas através das quais, assuntos de maior abrangência ou escopo possam ser identificados e soluções possiveis ou potenciais possam ser vislumbrados. Além disso, os canais de comunicação entre a comunidade e os planejadores podem ser aprofundados, e pode ser mais fácil identificar soluções para os problemas 


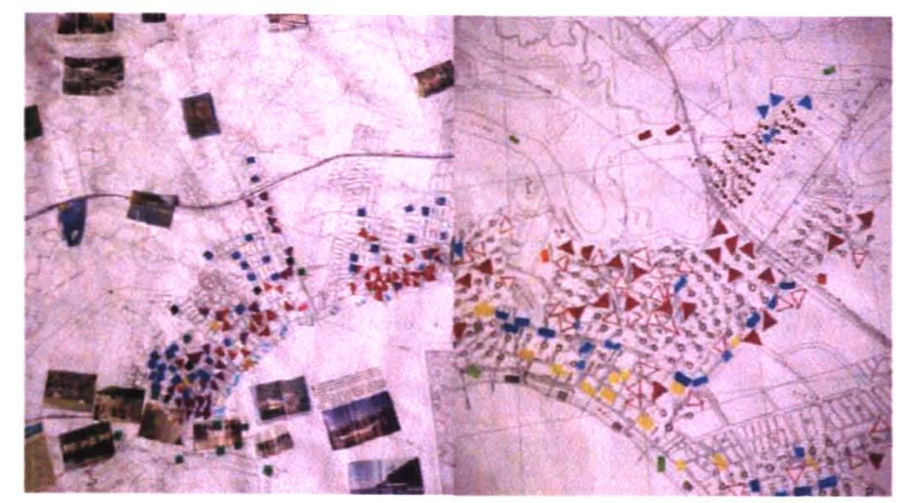

Fotografia 20 - EXEMPLOS DE BIOMAPAS PRODUZIDOS PELOS MORADORES DE BERTIOGA

Após a experiência bem sucedida em Bertioga, a metodologia dos Biomapas Comunitários foi utilizada em outros municípios que participam do Projeto de Ampliação de Municípios Saudáveis no Estado de São Paulo, contribuindo para à discussão dos planos diretores (sua formulação ou revisão): Itaoca, Ribeira, Motuca (formulação) e Lins (revisão) (Cepedoc, 2003).

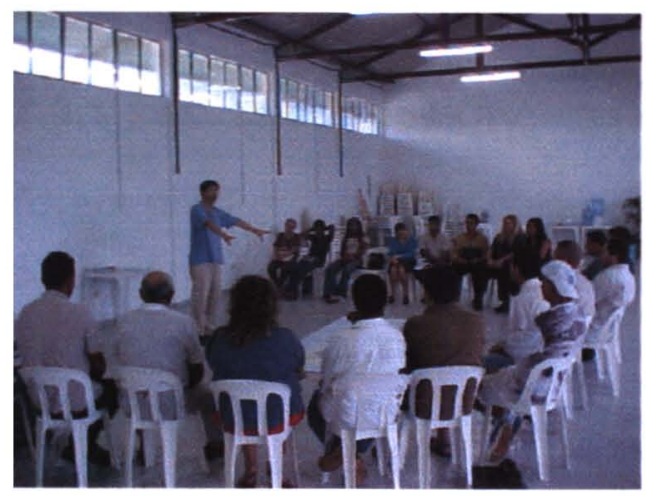

FOtOGRAFIA 21 - UM DOS FACILTADORES da FSPUSP trabalha em Oficina do Plano DiRETOR (2002)

O mesmo método de trabalho participativo dos Biomapas foi utilizado pela equipe do LabHab/FAUUSP nos distritos do Jardim Ângela e São Luis (Sub Prefeitura do $M^{\prime}$ Boi Mirim) no Município de São Paulo, em apoio ao processo de elaboração do Plano de Ação Habitacional e Urbano para a Secretaria de Habitação e Desenvolvimento Urbano da PMSP (LabHab, 2003).

O "Jogo do Estatuto da Cidade", pertencente ao "Kit das Cidades" foi o outro instrumento utilizado, a partir da adaptação de um trabalho do Instituto Polis (2001). A proposta é que os participantes formem grupos, cada um representando um importante ator social: prefeitura, setor imobiliário, 
de elaboração do Plano de Ação Habitacional e Urbano para a Secretaria de Habitação e Desenvolvimento Urbano da PMSP (LabHab, 2003).

O "Jogo do Estatuto da Cidade", pertencente ao "Kit das Cidades" foi o outro instrumento utilizado, a partir da adaptação de um trabalho do Instituto Polis (2001). A proposta é que os participantes formem grupos, cada um representando um importante ator social: prefeitura, setor imobiliário, movimento por moradia, ONG ambientalista, associação dos engenheiros e arquitetos, etc. Sua tarefa é discutir uma situação ou tema de desenvolvimento urbano da cidade, a partir da ótica da classe que representa. Deve-se então selecionar instrumentos urbanísticos do Estatuto da Cidade que melhor atendam a seus interesses, preparando-se para defendê-los publicamente. $O$ exercício permite ensaiar os eventuais interesses particulares em jogo na produção da cidade, bem como, permite um treino nas possibilidades de aplicação dos instrumentos do Estatuto da Cidade.

\subsubsection{Resultados das Oficinas do Plano Diretor}

Foram produzidos pelos participantes cinco Biomapas de diferentes temas pelos grupos formados nas oficinas: meio ambiente e ecoturismo, saneamento ambiental, comércio e serviços com ênfase ao turismo, uso residencial e equipamentos urbanos de interesse social (educação e saúde).

Em apoio ao trabalho dos moradores, foram produzidos pela equipe técnica da FSPUSP, mapas para complementar o diagnóstico e as análises, a partir de dados secundários do IBGE de 2000: população residente por setores censitários, domicilios ocupados permanentemente e domicílios vagos, desocupados ou ociosos por setores censitários. Foram produzidos também, pela equipe técnica, um mapa de uso do solo (predominante) e um mapa de densidade urbana (ver Mapa 2; Cepedoc, 2002).

Este conjunto de mapas mostrou-se importante na medida em que permitiu - conhecimento maior da realidade por todos os participantes, uma oportunidade de familiaridade e exercício com a linguagem cartográfica dos 
mapas e a possibilidade do registro de uma parte importante do diagnóstico (Cepedoc, 2002).

As propostas produzidas nas oficinas foram apresentadas no Seminário Municipal, aberto à população, que contou com a participação de vereadores e técnicos do Poder Executivo Municipal.

Elas representaram, o resultado das pesquisas, discussões e necessidades levantadas pelos grupos participantes. Algumas estão mais relacionadas ao conteúdo de que deve tratar um plano diretor. Outras estão mais relacionadas a políticas setoriais. Para facilitar as discussões $e$ implementação foram formados 4 (quatro) grupos temáticos para a formulação e desenvolvimento de propostas e recomendações: Terra Urbana e Moradia; Serviços, Infra-Estrutura e Acessibilidade para os Moradores; Serviços, Infra-Estrutura e Acessibilidade para os Turistas; Meio Ambiente e Saneamento (Cepedoc, 2002).

\subsubsection{Discussão dos resultados e propostas}

O processo desenvolvido mostrou que, ao longo das oficinas, diversos participantes foram transformando seu modo de leitura da cidade, a partir do entendimento de como esta foi sendo, ao longo do tempo, "planejada" e produzida, por meio da atuação do governo municipal, dos vereadores, dos empreendedores de loteamentos e condomínios, dos turistas e veranistas, da população de baixa renda e dos outros atores.

No encerramento do trabalho, os participantes concluíram pela necessidade do uso de diversos instrumentos do Estatuto da Cidade, visando a Gestão Democrática da Cidade e a função social da propriedade urbana e da cidade. Como se pode notar, as propostas produzidas pelos participantes dizem respeito não apenas ao Plano Diretor, mas também se relacionam com a gestão urbana, sendo que algumas poderiam ser incluídas em previsão orçamentária, outras discutidas nos conselhos municipais. 


\section{Terra urbana e moradia}

O grupo identificou e discutiu, durante e após o processo de elaboração dos Biomapas Comunitários, uma série de problemas e aspectos relacionados ao uso do solo, especialmente no tocante ao acesso à terra urbanizada e a moradia. Foi discutido como e quais instrumentos do Estatuto da Cidade poderiam ser implementados para superar os graves problemas diagnosticados.

O grupo debateu e elaborou sugestões no sentido de compensar os desequilibrios identificados, resultantes do processo de desenvolvimento excludente e fragmentado. As soluções propostas, passaram resumidamente pelos seguintes itens (Cepedoc, 2002):

- "Implantação e viabilização de utilização efetiva das Zonas Especiais de Interesse Social (ZEIS) objetivando a urbanização e regularização fundiária de assentamentos precários como favelas e áreas para a produção de Habitação de Interesse Social (HIS)",

- "Utilização do Parcelamento, Edificação ou utilização compulsória, IPTU Progressivo e desapropriação com títulos da dívida pública, objetivando aproveitar as áreas melhor servidas por infra-estrutura $e$ pouco adensadas (Centro da cidade e centros de bairro, como Indaiá)";

- "Implementação do Estudo de Impacto de Vizinhança para empreendimentos na cidade, visando disciplinar atividades e usos principalmente nos períodos de alta temporada. Articular a esse instrumento a formas de responsabilizar os empreendedores de loteamentos e condomínios por impactos sociais e urbanos causados pelas obras e serviços decorrentes dos empreendimentos (por exemplo com relação aos trabalhadores da construção civil $e$ prestadores de serviços nos loteamentos e condomínios)";

- "Implementação garantida da Assistência Técnica e Jurídica para os grupos menos favorecidos, tendo em vista a grande proporção de moradores de baixa e baixíssima renda, que não dispõe de qualquer orientação técnica para construir e realizar melhorias nas moradias"; 
- Implementação da Gestão Orçamentária Participativa (Orçamento Participativo), a exemplo de inúmeras cidades do pais, com convocatória por meio dos meios de comunicação de massa, permitindo um maior controle social nos gastos e investimentos públicos realizados";

- "Desenvolvimento e implementação de uma Política de Habitação e Desenvolvimento Urbano com participação popular, condizente com as reais necessidades e carências do municipio, evitando um maior comprometimento das condições de vida da população de baixa renda e degradação e impacto no meio natural".

É interessante notar, que no grupo havia participantes moradores de assentamentos precários e moradores de áreas regulares no centro ou em loteamentos de nível médio da cidade. No desenvolver do trabalho notou-se um amadurecimento dos posicionamentos diante da oportunidade de uma discussão mais aprofundada do problema das favelas, das invasões, da ausência de uma política habitacional, dos loteamentos fechados, da fragmentação da cidade. $\mathrm{E}$ a possibilidade de refletir conjuntamente, sobre como outros grupos da cidade têm se posicionado, e o que o Plano Diretor Municipal tem a ver com tudo isso.

\section{Serviços, infra-estrutura e acessibilidade prioritariamente aos moradores}

Foi relevante perceber a necessidade sentida pelos participantes de tratar separadamente (para melhor diagnosticar e analisar) as demandas específicas de infra-estrutura e serviços para os que residem no município, das demandas específicas para a atividade turística. Esta forma de abordagem permitiu notar também, quais os tipos de serviços e infraestrutura que são demandados pelos dois grupos.

Os moradores, apesar de defenderem a importância da atividade turística (da normatização, participação na elaboração e gestão de uma política para o setor), ao discutirem o plano diretor da cidade, demonstravam, o quanto suas necessidades básicas de cidadãos bertioguenses eram insatisfeitas. Realizaram uma série de propostas e recomendações neste sentido. 
- "Desenvolver uma Política Municipal de Transportes Públicos Urbanos, com a participação popular e que garanta a construção de ciclovias na área urbana, ao longo das vias principais e soluções de travessia de pedestres - passarelas - sobre as Rodovias (em parceria com 0 $D E R)^{\prime \prime} ;$

- "Reserva e destinação de áreas urbanas para lazer da população moradora";

- "Destinação de meios (fundos) para a capacitação de moradores para o desenvolvimento do turismo de forma sustentável";

- "Desenvolver estudos visando legislação específica de proteção ao trabalhador da construção civil já residente em Bertioga, de modo a des-incentivar a chegada permanente de novos operários em cada novo empreendimento na cidade. Articular com isso, o cadastramento, capacitação e envolvimento das empresas do setor";

- "Promoção da descentralização dos serviços de atenção à saúde nos bairros". Atualmente o serviço é centralizado e não existe o PSF Programa de Saúde da Familia, nem Agentes Comunitários de Saúde (foi desativada a iniciativa da gestão municipal anterior - de agentes comunitários de saúde);

- "Descentralização do sistema de segurança pública, articulando atuação nos bairros mais densamente povoados";

- "Adoção de um sistema de sinalização padronizada com nomes dos logradouros públicos e indicação do zoneamento correspondente, para a informação em lugares públicos como bairros e praias".

As formulações aparecem no sentido de procurar incluir no Plano Diretor, mecanismos e propostas, que visem minimizar os problemas sentidos mais relacionados às dificuldades de transporte e mobilidade (com destaque para os pedestres e ciclistas), a fragmentação do território (tema abordado no capítulo 5) e sistemas de informação e sinalização para os moradores (que serve também para os turistas).

Além disso, o grupo expressou preocupação com os serviços de saúde prestados na cidade e discutiu formas de atendimento para os moradores 
dos bairros, de forma mais descentralizada. Esta abordagem está sintonizada com as recomendações das Cartas de Promoção da Saúde que pregam a reorganização dos serviços de saúde e das diretrizes do SUS - Sistema Único de Saúde (Carta de Otawa, 1986; Ministério da Saúde, 1996).

\section{Serviços, infra-estrutura e acessibilidade prioritariamente para o turismo}

Diversos moradores se interessaram em participar deste grupo. A necessidade de participar no diagnóstico e formulação de propostas para o turismo foi sentida em diversos momentos. Isto ocorreu em uma conjuntura de dificuldades de participação neste sentido, por parte do poder executivo municipal.

Este grupo elaborou propostas visando principalmente a formulação e implementação de uma política ou plano de turismo sustentável com participação social.

- "Elaboração participativa de um Plano Municipal de Turismo Sustentável articulados com as outras políticas municipais e ao Plano Diretor de Turismo da Baixada Santista (elaborado pela AGEM)";

- "Destinação de Zonas específicas para eventos, festas e lazer ligados ao turismo, de modo a disciplinar o uso e descentralizar essas atividades, que tem priorizado a região central da cidade";

- "Regulamentar, destinar e disciplinar locais para a instalação de sanitários públicos nas praias, viabilizando para tal, a participação da comunidade, local dos projetos, construção e gestão dos espaços";

- "Descentralizar os serviços de resgate e salvamento (Corpo de Bombeiros) visando o atendimento de todos os bairros da cidade (tanto para casos de incêndios, como de afogamentos)".

A discussão sobre a proposta de elaboração de um Plano Diretor de Turismo Sustentável e participativo é observada desde as primeiras atividades do PBMS. Durante o Curso de Formação de Agentes Multiplicadores para Assentamentos Humanos Saudáveis, no Seminário coordenado pela profa. Miriam Rejowski do Departamento de Turismo da ECAUSP, diversos 
moradores demonstraram grande interesse em participar das atividades de planejamento deste setor no município. O tema, não tem sido tratado de forma integrada pelos diversos órgãos que elaboram propostas para a cidade e a para a região, como a Prefeitura de Bertioga, a AGEM, o Sebrae, as associações de comércio, serviços, turismo, monitores de ecoturismo e ambientalistas locais. (Rejowski, 2000; São Paulo, 2002).

Outro aspecto importante do ponto de vista do uso dos espaços na cidade, refere-se à reivindicação dos moradores para a descentralização dos eventos realizados no município. Há uma tradição de realizar na cidade eventos que se repetem anualmente, como festas e festivais (Festa do Índio, Festa da Tainha, Festa do Camarão na Moranga, etc.). 0 grupo discutiu a necessidade de rever a estratégia de investimento (apenas) nestas festas populares (algumas que atraem público de massa, como a Festa do Índio) e ao mesmo tempo realizá-las também nos bairros e praias mais distantes do centro, onde são tradicionalmente promovidas (como Indaiá e Boracéia). Foi discutida também a necessidade de infra-estrutura especial para esses eventos.

Por fim, expressou-se uma preocupação especifica com os serviços de emergência e salvamento relativos a incêndios e salva-vidas nas praias. Apesar destes serviços estarem a cargo do Corpo de Bombeiros da Policia Militar do Estado de São Paulo, o grupo decidiu por incluir como proposta/recomendação para a revisão no Plano Diretor no sentido de debater com setores locais, a necessidade de alguma atuação dos atores governamentais $E$ não governamentais locais, neste sentido. Não há nenhuma de sede de Batalhão de Corpo de Bombeiros no município. Nos casos de emergência, o atendimento é acionado via municípios de Guarujá ou Santos e se torna mais demorado o atendimento.

\section{Meio ambiente e saneamento}

Este grupo, que contava entre seus participantes, de representantes de setores ligados aos ambientalistas e monitores de ecoturismo, demonstrou a preocupação em incluir temas como a regulamentação e gestão das atividades desenvolvidas nas áreas de proteção ambiental na discussão do 
Plano Diretor e das políticas urbanas. Isto ocorreu, pelo entendimento do grupo, de que as atividades e usos urbanos, (moradia, transporte) estão relacionadas com as atividades e uso (potencial) de geração de emprego e renda representadas pelas áreas protegidas, trilhas na mata atlântica, cachoeiras, rios, etc. As propostas resumidamente constaram de:

- Mapeamento e cadastramento atualizado das trilhas de ecoturismo e regularização da atividade de monitoramento ambiental";

- "Desenvolvimento de uma Política Municipal Integrada de Saneamento Ambiental com participação e controle social, inclusive sobre as empresas contratadas prestadoras de serviços públicos (Abastecimento de água, esgotos sanitários, resíduos sólidos e drenagem)";

- "Instituição de um Sistema de Planejamento e Gestão Ambiental (incluindo Zoneamento - Áreas de Relevante Interesse Ecológico ARIE, Reservas Particulares de Patrimônio Natural - RPPN e Zoneamento Ecológico Econômico - ZEE) e Gestão Ambiental prevendo atividades de geração de renda, turismo ecológico, manejo sustentável e fiscalização";

- "Fiscalização para coibir o lançamento clandestino de esgotos sanitários";

- "Fiscalização para pavimentação de calçamento para pedestres";

- "Instituição de Educação Ambiental nos diversos niveis do sistema de ensino e também junto a moradores e turistas";

- "Estabelecimento de monitoramento constante das Bacias Hidrográficas da região, incluindo os Rios Itapanhaú, Itaguaré, Guaratuba, mantendo um banco de dados sobre volume e qualidade de água e mata ciliar";

- "Aprimoramento do sistema de preservação dos mananciais, flora e fauna aquática e terrestre, com participação de ONG's e órgãos Estaduais como a Secretaria de Estado da Saúde e Comitê de Bacias da Baixada Santista"; 
- "Criação de Portos de Recreio, compreendendo as ZSN - Zona de Suporte Náutico, como empreendimentos náuticos que possibilitem organizar a atividade náutica no município, enquadrando-se no sistema da Capitania dos Portos e no Plano de Gerenciamento Costeiro Estadual".

Os participantes relataram nesta e em outras ocasiões, como as trilhas de ecoturismo não têm sido utilizadas de forma adequada. As reclamações vão deste a falta de um levantamento, caracterização e planos de uso, regulamentação e reconhecimento da atividade de monitoria ambiental, fiscalização das atividades, bem como o manejo e manutenção das trilhas.

O grupo sugere um enfoque de uso sustentável e em benefício dos moradores locais, como os monitores de ecoturismo, ambientalistas e os pequenos comerciantes e prestadores de serviços. O grupo condenou uma espécie de monopólio exercido pela única agência de turismo da cidade, o fluxo de excursionistas que, em grande número entram nas trilhas deixando rastros de sujeira e depredação, e o governo municipal que não se empenha intervir, na medida em que tem o turismo de eventos e festas (além do turismo náutico) como prioritários.

Além dessas sugestões, os participantes demonstraram preocupação constante com a democratização e participação social nos sistemas de planejamento e gestão, na perspectiva da visibilidade e divulgação das informações e das leis.

Uma das propostas neste sentido feita por um participante, refere-se à instituição de um sistema de sinalização de praças e logradouros, que contemple a informação sobre qual Zona Urbana que se trata, em cada bairro, por meio de codificação, com uso de faixas e/ou cores. Isto poderia se dar, por exemplo, nos postes, nas guias ou junto às placas com os nomes das ruas.

Outras sugestões referem-se a uma proposta de fixar em todos os bares, padarias e quiosques de praia, cópias do mapa contendo a Lei de Uso e Ocupação do Solo, com indicação de legenda para que o cidadão comum e o 
turista, mesmo de passagem, possam visualizar a informação, de forma a torná-la mais acessivel.

Esta última, nos pareceu uma idéia inovadora que poderia contribuir para a democratização e acesso a elementos básicos das leis urbanísticas, por parte do cidadão, que muitas vezes só toma contato ou ouve falar delas em tempos de eleição, no momento de realizar um projeto na cidade, ou quando é autuado por algum fiscal. Neste sentido poderia se constituir numa abordagem mais pedagógica e informativa.

\subsubsection{A Advocacia por políticas públicas saudáveis e evidências do empoderamento: Audiências Públicas do Plano Diretor}

Após o Seminário Municipal do Plano Diretor no final de 2002, foi constituído um grupo de trabalho com um número menor de pessoas que ficou responsável, em nome do PBMS, por aprofundar os estudos realizados até então. $O$ trabalho visava detalhar mais a proposta para ser discutida pelos demais participantes das oficinas, outros integrantes e simpatizantes do projeto na cidade, para outros setores da sociedade civil e para o governo municipal (executivo e legislativo).

Este grupo, cujo número de participantes variou de 6 a 10 (seis a dez) pessoas, reuniu-se inúmeras vezes para debater e trabalhar conjuntamente. Parte das reuniões contaram com a participação de membros da equipe da FSPUSP. Em diversas outras reuniões, o grupo se reuniu sem a presença de membros da equipe da FSPUSP, dando mostras de evolução em termos de autonomia.

O grupo, que em 2003 participava ativamente das reuniões da Comissão Intersetorial, ficou conhecido como o "Grupo do Plano Diretor do Projeto Município Saudável". Este realizou algumas apresentações das propostas na cidade, no centro e em alguns bairros, visando mobilizar a população para a importância de participar do processo junto aos órgãos do governo local.

Até a redação do presente trabalho, o Poder Público Municipal havia realizado duas Audiências Públicas para debater a sua proposta de Projeto de 
Lei: a primeira delas no segundo semestre de 2002 e a segunda em setembro de 2003.

Pode-se dizer, de uma forma geral, que havia 3 grupos explicitamente preocupados envolvidos com a discussão do Plano Diretor. Cada um desses grupos tem externado na cidade, seus valores, projetos e propostas de futuro. O primeiro grupo é formado pelos responsáveis da proposta do Projeto de Lei no governo municipal. Após diversas dificuldades com os técnicos locais, a prefeitura contratou um grupo de arquitetos e advogados (não moradores de Bertioga, logo não envolvidos com a história da produção da primeira versão do Plano Diretor) que assumiu a tarefa de elaborar uma proposta. O grupo têm dado mostras de perceber as várias contradições e desafios presentes na cidade, e têm procurado atender, tantos aspectos emergenciais, quanto formular um plano. Compreendem, em boa medida, a importância e a pertinência da aplicação de alguns instrumentos do Estatuto da Cidade em Bertioga. Entretanto dependem sempre da palavra final do prefeito, em função de suas diretrizes políticas, alianças e governabilidade. Este grupo demonstra também sentir as pressões, tanto do grupo ligado à Associação de Engenheiros, Arquitetos e Agrônomos e atores ligados aos interesses de desenvolvimento dos loteamentos e condomínios como 0 Riviera de São Lourenço, quanto dos participantes e integrantes do PBMS Projeto Bertioga Município Saudável.

O segundo grupo é constituido, em boa parte, dos membros da Associação dos Engenheiros, Arquitetos e Agrônomos de Bertioga e contava também com integrantes da Sobloco (Empresa privada ligada à construção e administração do Riviera de São Lourenço). Este grupo esteve entre os principais responsáveis pela elaboração da proposta do Plano Diretor em vigor, aprovada em 1998. Em linhas gerais, este grupo tem defendido explicitamente que a aprovação de novos empreendimentos, como o Riviera de São Lourenço é uma saída para a crise de trabalho e empregos na cidade. Defendem também um incentivo maior ao setor de construção civil. Têm uma visão de que o Estatuto da Cidade é bom, porém pode ser perigosa a sua aplicação na cidade. Defendem a discussão técnica sobre os índices e parâmetros urbanísticos como uma das questões centrais de um bom zoneamento para a cidade. Montaram um grupo de discussão sobre a revisão 
do Plano Diretor, porém defendem apenas pequenas readequações, e não uma revisão mais completa da lei. Alguns de seus integrantes se aproximaram em alguns momentos do PBMS, mas sem um aprofundamento na participação no projeto. Criticam muito a prefeitura municipal, principalmente seus técnicos, em função da demora na elaboração do Projeto de Lei e pelo fato de sua sugestões não serem incorporadas plenamente. Possuem afinidades ideológicas e influência junto a diversos vereadores da cidade, corretores e o setor imobiliário.

O grupo formado pelos integrantes do PBMS tem origem nas diversas atividades de mobilização e capacitação desenvolvidas em nome do projeto na cidade. Têm, nos últimos três anos e meio, como diretrizes de atuação os pressupostos do ideário de Municípios Saudáveis e contam com a participação, algumas vezes em forma de assessoria (no mínimo 1 vez por mês em 2003) dos integrantes da equipe da FSPUSP, seja nas reuniões da Comissão Intersetorial, seja nas reuniões do Grupo do Plano Diretor. É considerado o grupo com as propostas mais arrojadas, principalmente no âmbito da participação, democratização e da implementação de instrumentos do Estatuto da Cidade. Ultimamente tem aumentado o respeito e a consideração dos demais grupos, reconhecendo o PBMS como um núcleo dinâmico que não representa apenas um segmento ou interesses corporativos ou político-partidários Tem uma face mais universal na cidade, em função da própria presença de membros da universidade e do Referencial da Promoção ampla da Saúde. Apesar disso há sempre as críticas de alguns que acham que no PBMS as pessoas, apesar de boas e bem intencionadas, discutem muito e concretizam pouco (coisas fisicas e mais visíveis para a cidade). Há pelo menos dois vereadores (que não participam da bancada de apoio direta do prefeito) que se aproximam, participam e apóiam diversas atividades ligadas ao PBMS, entre elas, as propostas de Revisão do Plano Diretor, pelo menos em parte. $O$ grupo é formado por moradores de diferentes perfis: comerciantes, aposentados, estudantes, ambientalistas, monitores ambientais, comerciantes ambulantes, pequenos empresários do setor de serviços, moradores de assentamentos precários, de loteamentos regulares no centro, artesãos, alguns advogados e engenheiros. 
A proposta apresentada pelo Executivo Municipal continha alguns avanços importantes (embora tímidos) em comparação com a lei em vigor, como um número menor de zonas para a cidade e a demarcação de novas áreas para ZEIS.

Muitos instrumentos importantes do Estatuto da Cidade foram citados de forma genérica na proposta, no entanto, sua implementação, no mais das vezes, era remetida para a aprovação em leis complementares a serem incorporadas e aplicadas futuramente. Um dos instrumentos citados no Projeto de Lei do Plano Diretor é o IPTU progressivo. Para situar o grau de diferenças ideológicas e visões de cidade, presentes nas audiências, apresentamos um pequeno trecho de um depoimento de um representante da Associação de Engenheiros, Arquitetos e Agrônomos de Bertioga que alegava possuir propostas para serem incorporadas na lei (A referida Associação que foi uma das entidades responsáveis pela elaboração da Lei do Plano Diretor em vigor desde 1998).

"(...) nós temos uma proposta que não tem nada haver com a proposta de vocês (Projeto de Lei do Executivo). Então pra não ser uma coisa incompativel, nos estamos revendo (...) e tentando adaptar pelo menos aquilo que a gente acha muito importante, da nossa proposta no trabalho de vocês, pra não descaracterizar completamente, um trabalho que foi feito pela administração. (...). A alteração maior que fez surgir mais dúvidas aqui é com relação ao Estatuto da Cidade. Aplicação do Estatuto da Cidade. Nos nossos municípios nós entendemos que o Estatuto da Cidade é um instrumento que é muito importante pra certas cidades já com muitos problemas. Cidades que já cresceram demais, e não tem mais forma de solucionar seus problemas. Têm que, através de uma legislação especial, mais moderna mais arrojada,tentar consertar todos os erros passados, e que no caso é o Estatuto da Cidade. Entendemos que o nosso município, não necessita da aplicação do Estatuto da Cidade para todas as situações. Existem situações que, por exemplo, no Estatuto da Cidade, que podem vir a ser extremamente interessante em serem aplicados aqui no município, outras entendemos que seja extremamente perigosas, além de não serem necessárias. E nós temos, pra que uma legis/ação especifica pra poder construir mais, seja na altura,(...), ou seja na ocupação, que esse edificio vai 
ter dentro de um terreno, se nós ainda estamos longe dos limites que a legislação de zoneamento (...), então mudasse a lei de zoneamento, (...) que possa vir a ter um lucro, uma compensação e aquele empreendedor também vai ter o seu lucro, sua compensação, pelo que ele está fazendo. Entendemos que é um instrumento muito perigoso, ainda pro municipio que ainda não está maduro pra isso, e acima de tudo um município que ainda não necessita desse tipo de instrumento. (...) Sendo assim, nós excluímos desse documento aquelas coisas mais polêmicas. Algumas que já foram levantadas aqui nessa reunião, e que com certeza, preocupam de uma forma assim, maior a todos, que gera uma grande insegurança, do que vai acontecer no futuro aqui, dentro do nosso município. Nós vamos ter imposto progressivo? O que nós vamos ter afinal aqu? E o que vai acontecer, a partir da hora da promulgação dessa Lel? Então essa insegurança está fora desses trabalhos. Tirando isso, que seria grande mudança (...) muito obrigado. (Representante da Associação dos Engenheiros, Arquitetos e Agrônomos de Bertioga durante audiência pública de revisão do Plano Diretor, 01 de setembro de 2003).

Pode-se notar que o conteúdo da intervenção do representante da Associação dos Engenheiros, Arquitetos e Agrônomos de Bertioga expressa a preocupação com a aplicação do Estatuto da Cidade, argumentando que o município não está maduro para isso. Na sua opinião o Estatuto deve ser aplicado em cidades onde a situação é mais problemática e que cresceram demais. Pode-se notar também que, no seu parecer há uma tendência à contrariedade e temor relativamente à aplicação do IPTU progressivo.

Com relação a este tema do IPTU, a proposta do Instituto Cidadania para a Moradia no Brasil considera justamente o oposto, reconhecendo as grandes resistências para uso do IPTU, como instrumento da política fiscal e da política urbana. Segundo essa proposta, os governos municipais enfrentam muitas resistências para agir mais resolutamente e aumentar a arrecadação (por meio do IPTU) por mais que os critérios sejam justificáveis. O IPTU é (ou deveria ser) "a principal fonte de recursos e instrumento da política urbana em todo o país. O IPTU seria mais eficaz e socialmente justo na forma de IPTU progressivo no tempo e no espaço. O que se observa entretanto que é que nem mesmo a aplicação do IPTU de forma simples é 
observada nos municípios brasileiros de acordo com dados do IBGE" (Instituto Cidadania, 2002).

Passaremos a apresentar algumas passagens da Audiência de 2003 em que pode-se notar evidências do processo de empoderamento dos participantes do PBMS, particularmente nas oficinas de capacitação para o Plano Diretor, tendo em vista a advocacia por políticas urbanas saudáveis, realizada pelo menos nas audiências públicas promovidas pelo Poder Executivo Municipal.

Na audiência pública havia cerca de 40 participantes, entre os quais, secretários e representantes de secretarias municipais (Gabinete do Prefeito, Meio Ambiente, Habitação, Desenvolvimento Urbano e Planejamento), dois vereadores (não ligados à bancada de apoio ao governo), lideranças comunitárias de diversos bairros (Vista Linda, Jardim Paulista, Centro, Guaratuba, etc.) e representantes de entidades da sociedade civil (Associação dos Engenheiros, Arquitetos e Agrônomos de Bertioga, Acipeb Associação Comercial, Industrial e Pesqueira de Bertioga, CDL - Central dos Dirigentes Logistas de Bertioga, Associação dos Monitores Ambientais, Sobloco - ligada à Riviera de São Lourenço, entre diversas outras). Dentre os presentes havia cerca de 15 pessoas que eram membros ativos do PBMS, e que haviam participado das Oficinas do Plano Diretor.

Um aspecto relevante levantado na audiência por um integrante do PBMS, dizia respeito à importância dos responsáveis pela organização das Audiências, de viabilizar a participação ampla de pessoas dos mais diversos segmentos e setores da cidade. Como Bertioga apresenta dificuldades para o transporte e mobilidade sugeriu que as audiências ocorressem em outros bairros mais distantes, como forma de democratizar e dar mais legitimidade ao processo. Assim se manifestou um participante do PBMS.

"Aproveitando o pedido da Associação (dos Engenheiros e Arquitetos de Bertioga) que estão pedindo uma audiência especifica para cada uma das leis, eu aumentaria um pouquinho o gancho pra dizer o seguinte, como Bertioga, que é um municipio tremendamente comprido, seria possível, fazer uma audiência com as três leis consolidadas na Boracéia, com as três leis consolidadas na (Praia de)Guaratuba, e aqui na sede (Centro). Fazemos ela aberta porque fica bastante desagradável bastante ruim, o (Poder) executivo só vai a (Praia de) Boracéia na verdade, quando quer alguma coisa 
entendeu. Não dá muita oportunidade para o povo (...). Eu não estou em Boracéia não, estou no meio. (...) Porque pra gente, a gente vai lá na palestra do plano diretor. Agora uma pessoa pega um carro e em meia hora esta aqui. Agora quem pega um ônibus, pra vim aqui (...). Exclui as pessoas humildes de Boracéia, exclui as pessoas mais simples de Guaratuba, principalmente da parte da serra. Então seria possivel estudar, uma consolidada (uma audiência) em Boracéia, uma consolidada (uma audiência) em Guaratuba? Obrigado. (empresário aposentado e participante das Oficinas do Plano Diretor do PBMS em Audiência Pública em setembro de 2003).

Outra participante, durante a audiência, questiona o fato de a proposta em discussão do Projeto de Lei (PL) do Plano Diretor do Executivo, referir-se a "estimular a participação", sem entretanto esclarecer como isso se dará, em termos de mecanismos legais que garantam essa participação. A participante demonstra claramente defender a democratização da gestão urbana no município.

"(...) e outra coisa, sobre gestão democrática, no artigo 28, 29 e 30, eu acho que em relação a gestão democrática, na verdade é a contrapartida. Porque assim, eu acho que o Estatuto da Cidade prevê a utilização de vários instrumentos da implantação da política urbana, pela administração. Ele dá uma contra-partida que é a participação e eu acho que nesse tocante é muito tímida a proposta de vocês em participação. Porque aqui a gente vê no artigo 30 do PL - Projeto de Lei do Plano Diretor fala-se: "deve-se estimular a formação dos fóruns locais em que a comunidade possa discutir questões relevantes para as condições de vida". Eu acho que, na verdade, "estimular não garante" (...). Eu acho que deveria ter um artigo pra garantir as discussões de fóruns locais (...)" (participante das Oficinas do Plano Diretor do PBMS em Audiência Pública em setembro de 2003).

Ao que, o representante do governo municipal procura responder.

"(...) Nós acabamos não enriquecendo esse tópico que fala da gestão democrática até porque em primeiro momento nós, da comissão entendemos que já tenha as várias coisas no capítulo especial de gestão democrática do próprio estatuto como o Estatuto da Cidade é uma lei federal e é maior, 
então eu, nós achamos que feito dessa forma o plano diretor, já estaria sendo subsidiado também com a lei federal. Então foi por estes motivos, que nós pusemos no capitulo, que vocês tenham achado um tanto curto, mas porque a gente tem uma outra fundamentação a nível federal, da própria constituição pra estar fundamentando a gestão democrática (...)" (representante do Executivo Municipal em audiência pública do Plano Diretor, setembro de 2003).

Ao que a cidadã, não satisfeita, ainda insiste no questionamento.

"(...) É que eu acho que a lei (federal) na verdade, ela garante a participação popular, na verdade, até as audiências, até a formulação da Lei (do PD) e a partir daí fica por conta da municipalidade. Isso, acredito que no Plano Diretor deva constar também um mecanismo pra garantir, não só estimular, de repente, é garantir mesmo.. (...)" (participante das Oficinas do Plano Diretor do PBMS em Audiência Pública em setembro de 2003).

Devido às divergências entre a Prefeitura Municipal e Governo do Estado na área ambiental, particularmente no tocante aos processos de licenciamento ambiental, a prefeitura tem tomado para si decisões que são questionadas do ponto de vista de sua competência legal. Nesta passagem uma participante, após identificar isso no Projeto de Lei do Plano Diretor, levanta essa questão.

"(...) só uma observação, é que eu (...) o município de Bertioga (...) em relação a alguns assuntos tem a tendência de legislar, achando que têm a disciplina de competência constitucional de falar tudo sobre todos os assuntos. Quando a gente fala de uso de ocupação de solo, por exemplo, dá para entender. Quando a gente verifica que os documentos, são só os exigidos pela prefeitura, e a gente tem que entrar num sistema, por exemplo metropolitano. A gente tem que verificar a legislação ambiental, que não é competência ampla do município. Então essa observação eu gosto de deixar colocado, que a gente tem que verificar a nossa posição como o município, dentro do espaço federativo. Tem umas competências constitucionais inseridas no (âmbito do Governo do) Estado. Eu só queria comentar. É uma coisa muito fechada pra o poder público municipal, que é a autonomia municipal. Nós estamos encarando essa autonomia e em relação, a parte do meio ambiente.(...) se o municipio larga a mão dessa autonomia, então é 
fácil agente estar brigando, principalmente, com o Estado de São Paulo, que é um Estado rígido em sua constituição estadual, em relação ao meio ambiente (...)" (participante das Oficinas do Plano Diretor do PBMS em Audiência Pública em setembro de 2003).

Outra questão relevante levantada por outros participantes do PBMS diz respeito à necessidade de integração do sistema viário do território por meio do prolongamento da Avenida Anchieta, paralelamente à Rodovia RioSantos, passando por dentro do Riviera de São Lourenço do Jardim São Lourenço, da Praia de Itaguaré e de Guaratuba. A Avenida Anchieta deveria originalmente fazer esse trajeto, porém os "lobbies" do Loteamento Riviera de São Lourenço nunca permitiram que o loteamento fosse aberto por uma avenida de passagem. A conseqüência disso, é que leva à necessidade dos veículos que realizam percursos intra-urbanos, terem que utiliza a Rodovia Rio-Santos, provocando aumento do risco de acidentes em função do conflito: fluxo local x fluxo regional, como já comentado no capítulo 5 . 0 morador questiona.

Sou (...) do Bertioga Município Saudável. Aproveitando o que todos falaram aqui, de certo modo toca meio ambiente, toca moradia, vem falando da qualidade de vida. Eu gostaria de saber sobre os sistemas de áreas do municipio. Eu gostaria de saber, o seu Martins, o seu Carlos Sergio, o Marcelo, o seu Marcelo, e o que a Sueli também falou, que tem uma observação interessante. As pessoas que moram no extremo norte do município, que estão após a Riviera de São Lourenço, isso em alta temporada, final de semana ou feriado prolongado, são obrigadas a pegar (...) a Rio-Santos, pra poder chegar até o centro da cidade. A minha observação é em relação a avenida Anchieta. Eu gostaria de saber se a Avenida Anchieta vai continuar, até o extremo norte do municipio. Se em Itaguaré terá um problema muito sério, em impacto ambiental eu gostaria de saber se, nesse plano diretor, o que vocês pretendem fazer ou desenvolver nessa área e se realmente há um projeto de passar a avenida Anchieta pelo condomínio, na seqüência, depois do Indaiá, e atingir até o norte do município para que a população, que esteja no norte do município, tenha acesso ao centro da cidade. Todo o serviço público, também que tem aqui no Centro, sempre tem que se pegar a rodovia Rio-Santos. E assim, 
com certeza, nós sabemos dos problemas de vida. Que tem atropelamentos, e é muito complicado o tempo que você leva de Boracéia até chegar ao centro. Você pega a Rio-Santos. Gostaria de saber se a avenida Anchieta vai continuar até o extremo norte do município? (participante das Oficinas do Plano Diretor do PBMS em Audiência Pública em setembro de 2003).

Diante do que, o representante do governo municipal responde, argumentando que o problema não se trata da passagem por dentro do Riviera de São Lourenço, mas da dificuldade e complexidade para transpor o morro de Guaratuba para depois ter que voltar para a Rodovia, novamente em Boracéia. Ao que o mesmo participante do PBMS insiste.

"(...) se nós estamos falando do desenvolvimento do município, nós não podemos excluir nenhuma área, é essa a problemática. Sobre isso, eu acho que a sociedade tem que discutir sim. Porque não iremos ficar usando a $\mathrm{Av}$. Anchieta? Sabemos que o municipio está crescendo. O litoral norte vem crescendo e não temos que deixar pra mais tarde, problemas que nós já temos hoje no município. Em relação a Itaguaré e Guaratuba, existe projeto que é possivel. A Secretaria do Meio Ambiente está (...). Tem que ir lá. Se não tiver (força política) nós podemos participar juntos com a comissão técnica (da PMB) e buscar solução em relação ao meio ambiente nessa região e desenvolver um projeto pra que o município seja interligado como um todo e não fique dividido em duas partes. Porque a sensação que dá é que nós vamos ficar com uma região, e lá vai ficar uma outra região do municipio. Então eu acho que o município tem que ser interligado, como um todo. E se falem por isso nessa cidade. Não podemos ter essa problemática como um obstáculo. Eu acho que nós temos que discutir todo esse problema que vai existir, e está existindo agora e principalmente poupar a vida que existe daquele lado, que pra ter acesso ao Centro da cidade, elas são obrigadas a pegar a Rio- Santos. Isso eu falo porque eu tenho problemas. Eu já tive problemas com parentes e amigos que moram lá e infelizmente (...) que hoje não fazem mais parte desse (...), mas se existe e o momento é pra ser discutido, temos que discutir como um todo o município de Bertioga, é isso. Obrigado" (participante das Oficinas do Plano Diretor do PBMS em Audiência Pública em setembro de 2003). 
Note-se que a intervenção do participante chama a atenção para a integração do território, dos que vivem "do lado de lá" poderem acessar o Centro nos períodos de temporada. Outro aspecto importante diz respeito à defesa do espaço político e de discussão representado pela ocasião da Audiência. Aqui, a discussão é valorizada como algo extremamente importante, principalmente por se tratar do risco à saúde e vidas das pessoas.

Depois desta intervenção, o representante do Poder Executivo solicitou que se encaminhasse uma proposta por escrito para a Comissão de Revisão do Plano Diretor. Outro participante do PBMS retoma o tema e defende que a solução de travessia para o morro de Guaratuba é perfeitamente possível hoje em dia, tanto em termos de técnicas de engenharia, quanto de recursos, que o país dispõe. $E$ argumenta que inúmeras soluções como essas já foram realizadas em diversas cidades, portanto é factível. No caso da indisponibilidade de recursos municipais para investir nesta obra no curto prazo o participante defende que, pelo menos, seja previsto no Plano Diretor para que se lute política e economicamente pela sua viabilização em médio prazo.

"(...) mas pode constar no plano diretor, das marginais, que passe num túnel no morro de Guaratuba, à longo prazo. E isso é possivel porque tem na Av. Paulista, tem no Rio de Janeiro, em vários pontos em outras cidades aqui perto também que tem vários túneis, em Santos tem (...)".(participante das Oficinas do Plano Diretor do PBMS em Audiência Pública em setembro de 2003).

Outro aspecto muito importante desta discussão é que remete ao questionamento do processo de "fechamento", que os loteamentos e condomínios promovem no município, por meio da interrupção do sistema viário, de ruas, avenidas, bloqueando e agravando o problema da fragmentação e a dificuldade de mobilidade no território.

O debate sobre a continuidade da Avenida Anchieta pode representar assim, um passo importante para também discutir (mesmo que a principio indiretamente) a re-democratização do espaço público da cidade, que foi semi-privatizado ou privatizado pelos loteamentos e condomínios em nome 
do turismo, do conforto, da valorização imobiliária, e da segurança (de alguns).

Neste sentido, o debate e as alterações vão depender das correlações de força atual e futura na cidade. Como afirma o Instituto Cidadania: "mais que instrumentos, leis e planos, é necessária uma correlação de forças positiva para fazer valer o interesse público sobre 0 interesse dos proprietários privados e lobistas de corporações ou setores empresariais" (Instituto Cidadania, 2002).

\section{Discussão sobre as evidências de empoderamento}

Retomando o modelo teórico discutido e proposto por Labonte (1994) apresentado no início do capítulo 7, e das conceituações de Wallerstein (1992) e Oakley e Clayton (2003) discutidas no capítulo 3, algumas considerações merecem ser feitas para o caso de Bertioga.

Considerando a evolução das atividades e do conteúdo dos depoimentos dos participantes do PBMS nota-se que, apesar de não apresentarem um respeito exato à ordem proposta por Labonte (1994), há evidências da passagem dos grupos e pessoas participantes do PBMS por algumas etapas do esquema de empoderamento proposto.

Nas primeiras atividades relativas ao Seminário de Sensibilização, Pesquisa Exploratória e Oficinas do Futuro, observa-se uma tendência dos participantes, preocupações mais focadas no nível individual, que configuram queixas e reclamações mais ou menos generalizadas.

As oficinas do futuro, por sua vez, constituíram-se na primeira atividade consistente e aprofundada, voltada para o incentivo à formação de grupos. Apesar de não ter-se logrado o desenvolvimento de grupos nos bairros (com autonomia em relação a FSPUSP) foi formada uma Comissão Intersetorial atuante, que se constituiu num espaço político aberto à participação na cidade, num momento de refluxo dos espaços de participação institucionais locais (como conselhos e fundos municipais) em função da mudança de prefeito na virada de 2000/2001. 
A formação da Comissão Intersetorial recomendada pela OMS na implantação de um Projeto Município Saudável foi fundamental, tanto para a manutenção do projeto nos momentos mais críticos, quanto para a sua ampliação nos momentos de maior vigor e dinâmica. Assim, a Comissão Intersetorial constituida por integrantes da sociedade civil (sem o governo municipal a partir de 2001) foi o primeiro grupo a se desenvolver no âmbito do PBMS (WHO, 1995).

O Curso de Formação de Agentes Multiplicadores para Assentamentos Humanos Saudáveis constituiu-se numa estratégia para superar o momento de "crise" vivenciado pelo projeto com o afastamento constante da prefeitura. A partir dele, ampliou-se o acesso a participação no projeto e permitiu-se a capacitação de diversas pessoas que já haviam participado das atividades anteriores, além de membros da Comissão Intersetorial. Buscouse, por meio dele, entre outros, o desenvolvimento de grupos (autônomos) nos bairros e a organização e mobilização comunitária.

Além da Comissão Intersetorial, que se reuniu sempre no centro da cidade, vislumbrou-se naquele contexto a formação de um grupo do PBMS no bairro do Indaiá. Havia também um grupo no Jardim Rio da Praia que já tinha tradição de organização própria (no sentido de realizar reuniões periódicas e de representarem-se mutuamente, compreendendo $o$ significado de representatividade).

No final do Curso, em 2001 a proposta de realização de intervenções ou iniciativas saudáveis pelas equipes dos moradores na cidade, poderia fomentar a constituição de grupos nos bairros. Os moradores do Indaiá sempre estiveram próximos de consolidar grupos, entretanto alguns conflitos internos e as dificuldades naturais das pessoas representaram barreiras para um desenvolvimento mais autônomo. Os participantes do Jd. Rio da Praia, por sua vez, sempre demonstraram entendimento mais maduro do processo de participação e representação. Estes continuavam ativamente presentes nas reuniões da Comissão Intersetorial (que também contou com a participação de moradores do Indaiá). Mais correto seria considerar que até - final de 2001, apenas a Comissão Intersetorial constituía um grupo desenvolvido e atuante de fato - o núcleo do PBMS. 
Entretanto em 2002 com o clima de revisão do Plano Diretor, surgiu um novo cenário de atuação mais concreta dos integrantes do PBMS: o conjunto de leis urbanísticas e de uso do solo da cidade.

As atividades relativas às Oficinas para a Revisão do Plano Diretor, bem como aquelas relativas ao Grupo de Revisão do Plano Diretor e a participação nas Audiências Públicas revelam, uma articulação e mobilização de interesse político e público, com vistas a influir no arcabouço legal municipal (e com possibilidades reais disto).

Os participantes do PBMS viram neste contexto, uma oportunidade (garantida por lei) de lutar para influir nos destinos da cidade via debate, advocacia e alianças ou articulações. Este movimento é realizado por meio das oficinas, seminários, inúmeras reuniões de trabalho e apresentações e discussões de propostas nos bairros da cidade. Constituiu-se num movimento inicial de coalizão e ação política, tendo em vista advogar para influir na correlação de forças locais, na perspectiva das políticas urbanas saudáveis.

É possivel realizar um paralelo entre este processo e o esquema sugerido por Labonte (1994), respeitando-se as peculiaridades de um contexto muito particular de cidade periférica do litoral brasileiro.

Por outro lado, a questão da luta coletiva por influir na lei do Plano Diretor constitui-se numa tentativa, no sentido de aumentar ou melhorar o controle sobre o próprio destino, um dos elementos centrais adotados por Wallerstein (1992) na sua análise do empoderamento na Promoção da Saúde.

Oakey e Clayton (2003), por sua vez enfatizaram a importância do conhecimento como fonte do poder. Neste sentido, a nosso ver, as metodologias utilizadas nas Oficinas do Plano Diretor, com destaque para a construção dos Biomapas Comunitários, foram essenciais. Por meio delas, os participantes se aproximaram mais de uma apropriação e conhecimento real do território de Bertioga (fragmentado, confuso, dificil de ser apreendido até pelos técnicos). O esforço para a compreensão das leis locais e do Estatuto da Cidade levou a mais conhecimento agregado pelo grupo, que demonstrou evidências de empoderar-se também neste sentido. 
Por fim, alguns elementos de coesão interna do grupo, de sentido de solidariedade, de habilidades para discutir e analisar criticamente, além do desenvolvimento de atividades coletivas pelos grupos, e a habilidade de relacionar-se com os outros, foram trabalhados e incorporados em maior ou menor grau pelas pessoas e grupos, ao longo das atividades do PBMS, inclusive no contexto do Plano Diretor (Oakley e Clayton, 2003).

O Projeto Moradia elaborado pelo Instituto Cidadania (2002), após citar inúmeras provas fatídicas e jurídicas que justificariam a transformação da moradia numa prioridade nacional, se refere à importância de uma "correlação de forças políticas positiva" que permita a concretização disso.

Esta correlação de forças, em Bertioga, é produto de um processo de médio prazo, capaz de mobilizar pessoas e grupos, transformar valores, informar, desenvolver conhecimentos e habilidades, e sobretudo, despertar o compromisso do amor a uma cidade mais justa e democrática. 


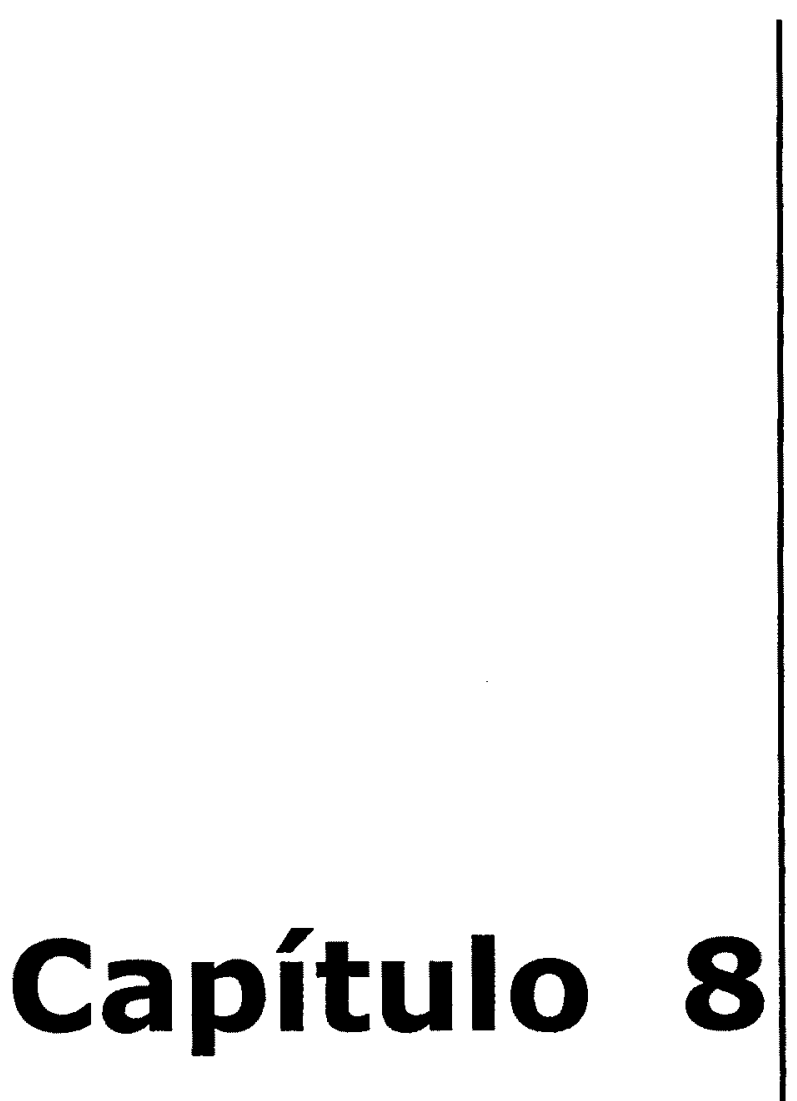

Discussão: condições objetivas de vida, pesquisa ação participante e referencial

teórico 
Resgatando o debate a respeito das primeiras intervenções urbanas sob a ideologia do sanitarismo, consideramos importante lembrar que no final do século XIX e início do século XX, a despeito do autoritarismo da ordem vigente e da moralidade higiênica, a saúde pública teve com o sanitarismo intervencionista naquele contexto, um caráter de ação ambiental e no espaço urbano. Dadas às circunstâncias, a prática dos sanitaristas da época, como o Eng. Saturnino de Brito, baseou-se na teoria dos meios, que se contrapunha às teorias microbiana, pasteuriana, às quarentenas, e às terapias focadas nos corpos físicos dos cidadãos.

Ao contrário dos defensores da linha de atuação microbiana, os sanitaristas (principalmente engenheiros e médicos) viam a ação no ambiente urbano como a solução para as doenças, as pestes, as epidemias que tantos prejuízos humanos, sociais e econômicos ocasionavam. Analisada sob este prisma, e respeitados os contextos histórico e social, pode-se dizer que constituía para a época, uma ação muito mais próxima da prevenção e da promoção da saúde do que a visão hospitalocêntrica, curativista e individual, que tornou-se hegemônica na prática sanitária no século $X X$, principalmente após 1930.

Com relação às abordagens do problema habitacional, a prática consistia na demolição de casas consideradas insalubres e o conseqüente desalojamento dos moradores mais pobres, muitos recém-chegados às cidades que apresentavam intenso crescimento populacional, devido às correntes de imigrantes europeus, a abolição da escravatura e ao processo de industrialização e urbanização crescente em cidades como São Paulo, Rio de Janeiro, Vitória, Porto Alegre, Recife, entre outras.

Após a análise dos dados secundários e dos depoimentos dos moradores e atores de Bertioga, torna-se quase natural procurar esboçar algum paralelo sobre o histórico e secular controle repressivo e policial realizado nas formas de moradia dos pobres. Naquele tempo as ações sanitaristas desalojaram muitas famílias inteiras em nome das doenças epidêmicas. Em Bertioga, atualmente, faz-se isso, principalmente em nome das leis de preservação e da causa ambiental.

Mais de um século depois, os problemas e as ações guardam muita semelhança. Trata-se de um desafio histórico para a reflexão mais 
aprofundada dos arquitetos, urbanistas, engenheiros, sanitaristas e para os educadores em saúde, educadores ambientais e os que trabalham sob a rubrica da higiene.

O referencial teórico sistematizado e a discussão realizada sugerem assim, que a saúde pública contemporânea, em uma perspectiva renovada, pode instituir-se, a partir do ideário da Promoção da Saúde, como um referencial que detone os valores de Reforma Sanitária Brasileira, na medida em que exercite e pratique a intersetorialidade e o empoderamento dos setores sociais, especialmente dos mais excluídos. A população que ocupa um território, e se conscientiza dos seus direitos e deveres, poderá, por meio da advocacia, criar espaços e políticas públicas mais saudáveis. Defendendo a saúde como uma produção social, pode lutar para utilizar a mídia para suas comunicações, construindo espaços democráticos, lutar pelo acesso à cultura, à inclusão social e ao exercício dos direitos econômicos, políticos, sociais, urbanos, culturais e ambientais. Um grande desafio.

O resgate teórico e o estudo empírico desenvolvido, permitem concluir que a proposta de promoção da saúde, por meio da estratégia Municípios Saudáveis pode prestar contribuição importante para fortalecer o movimento em defesa da Reforma Urbana, da implementação dos instrumentos do Estatuto da Cidade e ampliar e qualificar a participação dos setores da sociedade civil nos processos de planejamento e gestão urbana, engajando também técnicos do setor sanitário e ambientalistas (Carta de Otawa, 1986; FNRU, 2003).

Verificou-se que, no caso de Bertioga, as estratégias de participação de um projeto Município Saudável desenvolvido com setores e segmentos da sociedade civil, contribuíram para inserir na agenda de discussão local, a necessidade das políticas urbanas, como prioritárias e pré-requisitos essenciais para a melhoria das condições de vida e saúde da população da cidade.

Entende-se por políticas urbanas, pelo menos, às referentes aos setores da moradia, do saneamento, e do transporte e mobilidade, em uma perspectiva do desenvolvimento urbano e das atividades de planejamento e gestão urbana - incluem-se aí os aspectos ligados à legislação urbanística e edilícia. 
No caso de Bertioga e de demais cidades litorâneas da região paulista, dadas as características geográficas, topográficas, pluviais, fisiográficas, e de pluviosidade, constata-se que o equacionamento dos problemas da micro e da macro-drenagem são também fundamentais para a melhoria das condições de vida urbana e salubridade no meio local. Este aspecto deve ser mais atentamente estudado e solucionado.

Apesar do trabalho não ter efetuado análises de eficiência e eficácia de investimentos econômico-financeiros, o material estudado permite deduzir que as políticas urbanas, particularmente, políticas de habitação e desenvolvimento urbano - objeto aqui estudado - devem, em muitos municípios, ser consideradas prioritárias enquanto investimento (Instituto Cidadania, 2002). Mesmo que isso aconteça, essas políticas não se efetivarão se não estiverem articuladas às prioridades de outros setores como saúde, meio ambiente e educação. A intersetorialidade que articula as políticas urbanas aos setores sociais e econômicos é a chave a ser trabalhada dentro e fora das instituições governamentais, para prevenir doenças e promover saúde e qualidade de vida, com mais eficiência e custos sociais e econômicos mais reduzidos.

Constata-se também, que as politicas urbanas podem ganhar um novo sentido, na medida em que se aproveita o ensejo dos processos de participação para a gestão e planejamento da cidade, para envolver, conscientizar e empoderar os diversos segmentos da sociedade civil, particularmente aqueles tradicionalmente mais excluídos dos processos de produção e usufruto dos bens e serviços da cidade.

A pesquisa de campo confirma que há uma grande potencialidade a ser explorada, em termos de exercício da cidadania, durante os processos de implementação de um Projeto Município Saudável, que vão desde o planejamento comunitário participativo, formação de agentes multiplicadores e comunitários, à participação atuante na discussão do plano diretor, planos urbanísticos, projetos habitacionais e gestão urbana. Para isto, entretanto, é necessária a participação de técnicos dos setores habitacionais e urbanos, além dos sanitaristas.

Outro aspecto importante, refere-se à inclusão, nas discussões sobre moradia, saneamento, transporte, desenvolvimento, planejamento e gestão 
urbana do princípio da produção social da saúde, como critério norteador para a tomada das decisões sobre políticas e programas que afetam a coletividade.

O trabalho de pesquisa procurou contextualizar a discussão dos pressupostos do ideário Cidades Saudáveis, quer sejam:

a) participação social, enquanto concepção de democratização e controle social das decisões que afetam as esferas públicas ou coletivas, concepção de locução e estratégia central para o "empoderamento" dos representantes dos diversos setores, especialmente os segmentos mais excluídos;

b) intersetorialidade, como exercício do trabalho conjunto e complementar dos diversos setores públicos (intersecretarias), privados, movimentos, entidades e organizações não governamentais;

c) sustentabilidade, como conceito que visa a continuidade dos processos para além de uma gestão, ou período políticoadministrativo de um governo, além do enfoque ambiental e do equilíbrio ecológico que leva em conta a sobrevivência das espécies e das gerações humanas presentes e futuras;

d) equidade que traz no seu bojo, uma finalidade maior, de superação das iniqüidades - desigualdades evitáveis - e a necessidade de tratar de forma diferente os que têm condições desiguais, por meio das políticas públicas que devem ser, necessariamente subsidiadas.

Além destes, considera-se, como já expressado, o principio da produção social da saúde - ou da doença - um conceito importante na discussão das decisões que envolvem os outros setores, além da saúde, na estratégia de Municípios Saudáveis.

No caso brasileiro, esse potencial se soma à possibilidade de articular essas estratégias no contexto de revisão dos planos diretores de inúmeras cidades, por ocasião da nova lei federal do Estatuto da Cidade e das Conferências da Cidade em fase de realização em todo o país, promovidas pelo Ministério das Cidades. 
Além disso, as potencialidades para participação social, garantida em lei pelo Estatuto da Cidade, controlada e garantida, em diversos casos concretos pelo Ministério Público, e a possibilidade de integração e intersetorialidade nas políticas publicas, a exemplo da criação e do Ministério das Cidades, são boas e novas conquistas que referenciam o campo de atuação dos sanitaristas, urbanistas, educadores, cidadãos e atores políticos para viabilizar a produção social da saúde nas cidades.

O trabalho mostrou a importância de abordagens não convencionais em saúde, educação popular e planejamento urbano, por meio da atuação (debates, diagnósticos, reflexões, proposições, planejamentos) de processo educativo (fora da sala de aula e da escola), sobre a saúde (fora do hospital e dos postos de saúde), embora tendo o processo pedagógico e a promoção e a produção social da saúde como referências.

A proposta desenvolvida no município permite verificar empiricamente, evidências de mudanças em alguns parâmetros da realidade local recomendados no relatório elaborado pelo LabHab em pesquisa sobre parâmetros para urbanização de favelas realizada em cinco cidades brasileiras: fortalecimento da organização social da comunidade, mudanças na relação Estado-sociedade no tocante às políticas públicas, mudanças nas relações sociais $e$ de poder entre os moradores e organizações da comunidade, mudança na percepção ambiental dos moradores em relação ao seu habitat, avanços na matriz de demandas/reivindicações da comunidade (LabHab, 1999).

A intervenção habitacional em programas que atendem a população por meio dos diferentes projetos devem estar sempre embasadas em políticas públicas de acesso à cidade, ou seja, devem estar vinculadas às políticas de desenvolvimento urbano, política fundiária, políticas de meio ambiente, do planejamento urbano e as políticas sociais de saúde e educação.

Do ponto de vista da intersetorialidade um dos resultados inesperados que o estudo empírico ofereceu foi demonstrar a importância da participação e engajamento dos profissionais e ativistas da saúde pública nos assuntos tradicionalmente afetos aos outros setores, no caso, o setor habitacional e urbano. A vivência da pesquisa ação participante, como estratégia, permitiu um entendimento mais abrangente de sensibilização dos outros profissionais 
sobre a importância da ação do seu setor e vice-versa - como contribuição para promover a saúde das pessoas nas cidades (Marks, 2001).

Um outro aspecto relevante mostrado pelo trabalho foi a (re) descoberta e revisão de novas ferramentas participativas e pedagógicas do urbanismo e da saúde pública. $O$ que pode ser traduzido como um novo urbanismo pedagógico e participativo, à maneira da nova saúde pública. Ações urbanas mais partilhadas, mais abertas, democráticas, em que o planejador urbanista/sanitarista se torne um ouvinte, mediador e nesta medida, educador urbano, ambiental e sanitário, são paradigmas emergentes e desafiadores no novo contexto brasileiro. Tudo isso deve ser exercitado, sem que, nem o urbanista, nem o sanitarista, se sintam como que se furtando das responsabilidades inerentes às suas profissões. Ao contrário, devem acrescentar-lhe mais esta: a de tomar decisões ouvindo, ponderando, discutindo, mediando processos e procurando exercer a justiça e equidade.

Assim, em nossos dias, emerge a necessária retomada do processo de reconstrução e (re) apropriação da cidade, à maneira do estabelecido pelo Estatuto da Cidade (2001): "aproveitando melhor as áreas mais centrais e dotadas de infra-estrutura, implantando infra-estrutura urbana e serviços públicos nas periferias e viabilizando a gestão democrática da cidade". 


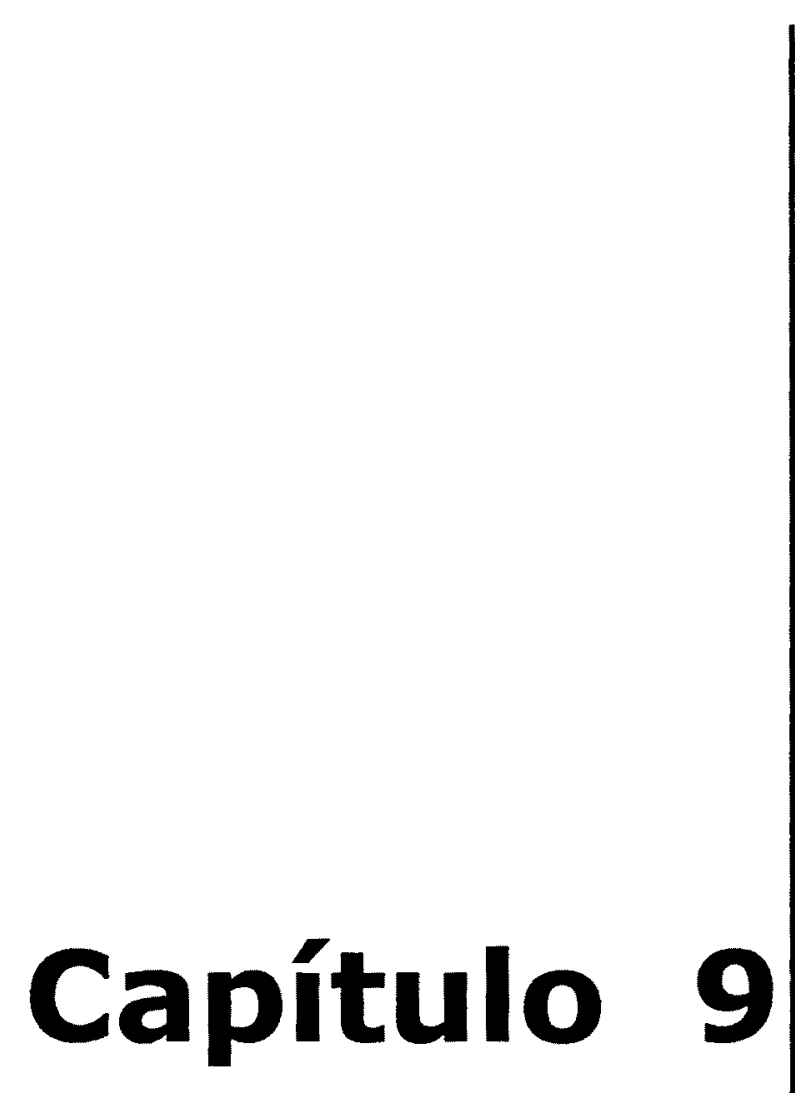

Conclusões e Recomendações 


\subsection{Conclusões}

O diagnóstico sócio espacial e a sistematização e análise das condições objetivas de vida dos moradores de Bertioga permitiram concluir que, tanto para prevenir doenças e mortes que afetam a população, quanto para promover a saúde e melhorar as condições de vida, são fundamentais a formulação e implementação de políticas de habitação e desenvolvimento urbano integradas às demais políticas urbanas, igualmente necessárias.

Assim, ressaltamos que a tese central aqui demonstrada é a de que as políticas de habitação e desenvolvimento urbano (a partir do estudo de uma realidade do litoral paulista) são fundamentais, para um município que pretende tornar-se saudável. Ou seja, sem políticas urbanas e habitacionais não há município saudável.

Neste sentido, a informação de que no Brasil, a cada $R \$ 4,00$ investidos em saneamento, economiza-se $\mathrm{R} \$ 10,00$ em internações hospitalares, deveria ser suficiente para reorientar as políticas e investimentos nas áreas da saúde e das políticas urbanas (Geo Brasil, 2002).

As condições inadequadas de moradia de parcela significativa da população de Bertioga, do ponto de vista de habitabilidade e salubridade: materiais de construção inadequados, adensamento populacional, ausência ou insuficiência de infra-estrutura e serviços de coleta e tratamento de esgotos, drenagem urbana, pavimentação e abastecimento de água potável, bem como risco de inundação e alagamento, influenciam muito negativamente as condições de saúde e de vida.

Além disso, verificou-se problemas e dificuldades nos sistemas de transportes e na mobilidade da população, seja pela fragmentação do território urbano e deficiências no sistema viário, seja pela ausência de uma política integrada de transportes públicos urbanos. Neste sentido, a situação agravou-se em função da existência dos loteamentos e condomínios fechados que bloqueiam as vias internas, e da ausência de plano e gestão urbanos integrados que disciplinem e racionalizem o uso, a expansão e a ocupação do solo. 
A partir da análise da percepção dos moradores e atores locais, participantes das atividades do Projeto Bertioga Município Saudável, o trabalho demonstra que os problemas urbanos são sentidos entre aqueles mais graves de Bertioga. Além dos problemas de habitação, saneamento ambiental (incluindo coleta de resíduos sólidos), transportes e mobilidade urbana, os moradores citaram os problemas de iluminação pública, manutenção e zeladoria urbana (limpeza de ruas e logradouros, de calçadas, dos sistemas de drenagem existente - quer sejam valas, canaletas, sarjetas ou bueiros e tubulações).

A análise dos dados qualitativos por meio da percepção dos moradores, permitiu conhecer com maior profundidade as questões problemáticas e revelou aspectos a partir de outro ponto de vista, que não tinham aparecido com tanta força, caso considerássemos apenas os dados secundários quantitativos. Exemplos ilustrativos disso, referem-se à coleta dos resíduos sólidos e, conseqüentemente, o lixo espalhado nas ruas e calçadas, o problema do excesso de cachorros nas ruas e os problemas relativos à manutenção e zeladoria urbana, todos citados pelos moradores. Além disso os problemas relativos aos transportes apareceram com uma nova ênfase na voz dos moradores.

As discussões realizadas nos capítulos 6 e 7 permitem verificar que, ao logo do processo, as questões ligadas às políticas urbanas tornaram-se um dos focos centrais de atuação dos participantes. Estes, ao engajarem-se nas audiências públicas para a revisão do Plano Diretor Municipal, defendendo as políticas urbanas saudáveis, mostraram na prática, compreender a ampla determinação do processo saúde/doença, conceito central na Promoção da Saúde.

Assim, constatou-se evidências de um processo de empoderamento da população participante do PBMS, ao longo do processo de quatro anos, do início do ano de 2000 até o final do ano de 2003. Verificou-se também, uma mobilização constante dos participantes, visando aumentar o controle sobre os determinantes do processo saúde/doença, e a advocacia pelas políticas urbanas saudáveis, que foi viabilizada, entre outros, pelo aumento de conhecimento sobre os problemas e suas causalidades e sobre as formas possiveis de atuação bem como as ferramentas e instrumentos disponiveis 
(que vão desde técnicas e habilidades para trabalhos de grupos até os instrumentos do Estatuto da Cidade).

Entre os conhecimentos e habilidades relevantes, levantados pela população no término do Curso de Formação de Agentes Multiplicadores para Assentamentos Humanos Saudáveis, destacam-se: a importância de mudar a própria forma de pensar, a importância de explicar novos conceitos para outras pessoas, o trabalho em grupo, a importância de aprender a "ouvir" as pessoas, a importância da união entre as pessoas e do amor que se deve ter pelas coisas que se faz na cidade e pela cidade. Os moradores demonstraram também, valorizar os conhecimentos e técnicas relativas à comunicação intra e intercomunidades. As declarações dos participantes permitem verificar evidências de que 0 processo pode contribuir para 0 aumento da auto-estima e da autonomia.

Notou-se que o trabalho desenvolvido permitiu também um treinamento e 0 desenvolvimento da habilidade de dialogar com os representantes do poder público em diferentes situações, quer fossem obter informações, discutir problemas ou questionar sobre as políticas e ações governamentais.

Entre os interesses dos participantes da sociedade civil, destaca-se, a necessidade sentida de aprofundar conhecimentos sobre direitos, legislação e o funcionamento dos sistemas e instituições públicas.

\subsection{Recomendações}

Do ponto de vista de recomendações sobre diretrizes para políticas de habitação e desenvolvimento urbano em Municípios Saudáveis, considerando a realidade estudada - litoral paulista - destacamos alguns instrumentos do Estatuto da Cidade que podem se mostrar adequados.

Devido às caracteristicas extremamente desfavoráveis ao racional desenvolvimento das funções urbanas, como: aumento populacional intenso e fluxos migratórios constantes; fragmentação e segregação social e territorial; especulação imobiliária; alto custo dos terrenos; baixos índices de cobertura por infra-estrutura urbana e serviços essenciais (principalmente esgotos, drenagem e pavimentação); barreiras econômicas, imobiliárias, geográficas e topográficas ao sistema viário; população flutuante em 
quantidade muito significativa; solo inadequado (lençol freático alto), recomenda-se o uso intensivo dos instrumentos que visem:

a) combater a especulação imobiliária e a retenção de terra urbana para fins de valorização privada;

b) combater a fragmentação e segregação do território urbano;

c) compensar a ausência de terras urbanizadas para fins de moradia social, bem como ampliar o banco de terras municipal;

d) enfrentar o déficit habitacional quantitativo e qualitativo com produção de unidades novas e urbanização de assentamentos precários;

e) enfrentar as constantes invasões ilegais de terra por parte de todos os segmentos populacionais, prevenindo agressões ao meio ambiente;

f) ampliar e qualificar a participação dos moradores e atores locais no planejamento, gestão e na elaboração, implementação, monitoramento e avaliação de políticas urbanas, favorecendo o empoderamento.

Neste sentido, recomenda-se o uso dos seguintes instrumentos visando um maior controle e melhor gestão municipal do solo urbano, no enfrentamento dos problemas citados: Parcelamento, edificação ou utilização compulsórios, IPTU Progressivo no Tempo e no Espaço; Desapropriação com Pagamento em Títulos da Dívida Pública; ZEIS - Zonas Especiais de Interesse Social, Direito de Preempção, Regularização Fundiária, Usucapião Especial de Imóvel Urbano; Estudo Prévio de Impacto Ambiental (EIA) e Estudo Prévio de Impacto de Vizinhança (EIV). Recomenda-se realizar também, estudos sobre a viabilidade de utilizar o instrumento Direito de Superfície.

Aproveitamos para chamar a atenção da importância particular que assume, o desenvolvimento e definição de critérios de Impacto de Vizinhança, no caso de cidades que vivem com intenso fluxo turístico em períodos de alta temporada.

O trabalho sugere que se efetuem estudos mais apropriados e especificos sobre os efeitos dos grandes loteamentos e condomínios, na integração/fragmentação nas cidades litorâneas. No caso de Bertioga, notou- 
se que os grandes empreendimentos desta natureza estão intimamente relacionados a prejuízos sociais e incômodos urbanos, principalmente do ponto de vista de moradia, transporte, mobilidade e integração urbana. Inclui-se nesta avaliação, inclusive o Loteamento Riviera de São Lourenço, a despeito da sua renomada qualidade ambiental. Neste sentido, seria recomendável, que se evitassem os grandes loteamentos desta natureza, ou no caso de sua adoção, recomenda-se estipular critérios e exigências especiais para minimizar os efeitos negativos já discutidos no trabalho.

Além disso, recomenda-se também, o uso extensivo dos mecanismos de participação, acompanhamento e controle social previstos no Capítulo IV do Estatuto da Cidade sobre a Gestão Democrática da Cidade, particularmente: audiências, debates e consultas públicas, conferências sobre assuntos de interesses diversos, especialmente gestão orçamentária participativa ou orçamento participativo.

É desejável também, incorporar estes aspectos afetos às políticas urbanas, nos Conselhos Municipais, não apenas os de Habitação e de Meio Ambiente, mas inclusive no Conselho Municipal de Saúde. Neste particular, dos canais de participação e controle social, o SUS - Sistema Único de Saúde trouxe à realidade brasileira uma perspectiva histórica e importante que deve ser também aproveitada e desenvolvida plenamente. No caso de Bertioga foi sugerida por nós, durante as audiências públicas e para os participantes do PBMS, a criação de um Conselho Municipal de Política Urbana, que poderia viabilizar um acompanhamento mais efetivo para a gestão e implementação do Plano Diretor.

Recomenda-se que sejam efetuados estudos sobre o fenômeno da migração, que subsidie políticas nacionais e regionais, de modo que abordem $o$ problema, não apenas do ponto de vista do município do destino migratório - como é o caso de Bertioga e de diversos outros no litoral e no interior do Estado - mas também os municípios de origem dos fluxos. Foram detectadas pela equipe da FSPUSP alusões da população e atores locais sobre diversos casos de troca de passagens de ônibus e outros favores para famílias carentes do interior do Brasil, por votos em determinados candidatos e políticos no litoral. 
Do ponto de vista do empoderamento, a experiência do trabalho em outros municípios, como Motuca e Lins, no Estado de São Paulo, permitiu verificar que o resgate popular de aspectos da história da cidade por meio de técnicas como construção de "linhas do tempo", pesquisa popular e exposição de objetos e fotografias antigas que ajudem a contar a história, têm-se mostrado ferramentas valiosas para o empoderamento dos moradores, além da apropriação do território por meio da técnica dos Biomapas, de importância e eficácia pedagógica comprovada também em Bertioga.

Para viabilizar essa experiência do Capedoc/FSPUSP na implementação dos cinco Projetos Municípios Saudáveis no Estado e São Paulo (que inclui além de Bertioga, Itaoca, Ribeira, Motuca e Lins) nos últimos anos, foi absolutamente fundamental que os técnicos, alunos de pós-graduação e graduação, pesquisadores e professores desenvolvessem e exercitassem a capacidade de "ouvir" a população, os trabalhadores e atores locais. Os pressupostos de Municípios Saudáveis, a metodologia da pesquisa ação participante e os princípios da pedagogia de Paulo Freire e da educação popular impuseram esta condição, para qual a maioria dos profissionais ainda não é preparada. Isto sugere uma revisão profunda da relação saber popular/empírico $\times$ saber científico/técnico. Sugere, conseqüentemente, uma mudança de abordagem e de paradigma nos cursos que formam os profissionais, e ao mesmo tempo, uma mudança de atitude por parte dos que se habituaram a deter e exercitar o discurso da competência (Chauí, 2000), em nome da técnica e da ciência, sem ouvir, antes de propor ou decidir para a coletividade.

Assim, para finalizar, sugerimos a realização de estudos mais específicos e aprofundados sobre o empoderamento da população nos processos de participação social em programas da área das políticas de saúde pública e de políticas urbanas. Também neste particular, sugere-se um trabalho conjunto ou articulado, em que os educadores em saúde, educadores ambientais, educadores e profissionais do setor habitacional e urbano, sistematizem métodos e desenvolvam indicadores de monitoramento e avaliação do empoderamento da população, articulando-se a estes, medidas sobre as melhorias e conquistas urbanas e sanitárias. 
A experiência prática e as referências teóricas têm mostrado que a construção coletiva do conhecimento da própria história, aliada à pesquisa para mapeamento e domínio do território, pode ser pontos de partida importantes no processo de empoderamento da população para atuação nas cidades. 


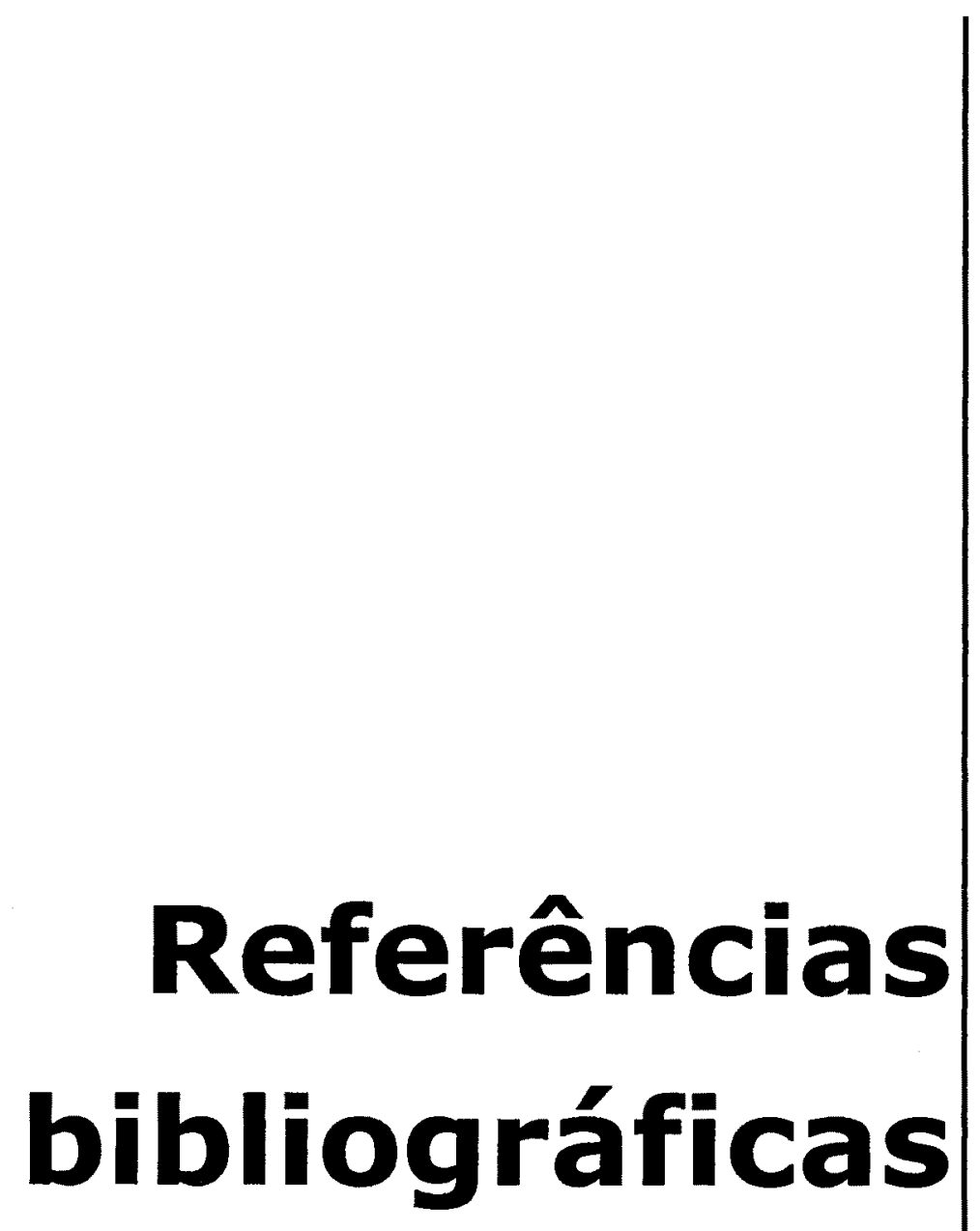


Abrasco, Ciência e Saúde Coletiva - Qualidade de vida e saúde, 2000.

Acioly, C.; Davidson, F. Densidade urbana: um instrumento de planejamento e gestão. (Trad. Cláudio Acioly) - Rio de Janeiro: Mauad, 1998.

Agenda Habitat - Conferência das Nações Unidas sobre os Assentamentos Humanos - Habitat II, Istanbul, 1996.

Akerman, M. Mendes, R. et al. Avaliação em promoção da saúde: foco no município saudável. In Revista de Saúde Pública, 2002;36(5):638-46.

Akerman, M. Metodologia de construção de indicadores compostos: um exercício de negociação intersetorial. In: Seminário Latino Americano sobre condições de vida e situação de saúde. ABRASCO, Associação Brasileira de Pós Graduação em Saúde Coletiva, São Paulo, 1995.

Almeida, C. Saúde e equidade nas reformas contemporâneas. Saúde em debate, 2000; 24(54):6-21.

Almeida, E. S. Contribuição à implantação do SUS: estudo do processo com a Estratégia Norma Operacional Básica 01/93. São Paulo, 1995. Tese de Livre Docência, Faculdade de Saúde Pública, Universidade de São Paulo.

Almeida, E.S.; CHIORO, A. ZIONI, F. Políticas públicas do sistema saúde: antecedentes, reforma sanitária e o SUS. São Paulo, 1997. Apostila do Curso de Capacitação de Gestores Municipais de Saúde - Faculdade de Saúde Pública da USP.

Andrade, C. R. M. A peste e o Plano. O urbanismo sanitarista do engenheiro Saturnino de Brito. Dissertação de Mestrado. Faculdade de Arquitetura e Urbanismo. Universidade de São Paulo, 1992.

Andrade, C.R.M. A cidade como um corpo são e belo: o pensamento do engenheiro Saturnino de Brito. In: Cidade e História - Modernização das Cidades Brasileiras nos Séculos XIX e XX. Seminário de História Urbana, 1. Salvador: UFBA / Faculdade de Arquitetura. Mestrado em Arquitetura em Urbanismo; ANPUR, 1992.

Andrade, L. O. M. e Barreto, I. C. H. Promoção da saúde e cidades/municípios saudáveis: propostas de articulação entre saúde e ambiente. In: Minayo,M.C.S. et al (org.) Saúde e ambiente sustentável: estreitando nós. Rio de Janeiro: Ed. Fiocruz, 2002.

Arantes; P.F. Arquitetura nova - Sergio Ferro, Flávio Império e Rodrigo Lefrève, de Artigas aos mutirões. São Paulo. Ed. 34, 2002.

Arai, V.R.; Caricari, A .M. Levantamento preliminar do tecido social no município de Bertioga. Prefeitura Municipal de Bertioga, Faculdade de Saúde Publica da USP, mimeo, 2000.

Arai, V.J. Análise de um processo participativo na experiência de implantação de um projeto Município Saudável. Dissertação de Mestrado. Faculdade de Saúde Pública da Universidade de São Paulo, 2002.

Arretche, Marta (1993) Os Descaminhos da Descentralização na Política Habitacional, in Cadernos da Cidade n⿳01, V.1. 
Ashton. Healthy Cities. Open University Press, Bristol, 1991.

Barros, F. C.; Victoria, C. G. Epidemiologia da saúde infantil. Um manual para diagnósticos comunitários. São Paulo, Hucitec, 1998.

Belém (Município). I Congresso Geral da Cidade de Belém. Documento Base do Congresso da Cidade. Prefeitura Municipal de Belém, 2001. (mimeo)

Bertioga (Município). Herjack - Engenharia S/C Ltda. Diagnóstico para assentamentos subnormais do Município de Bertioga. Bertioga, 2002.

Bertioga; Prefeitura Municipal. Diagnóstico de saúde do município de Bertioga. (xerocopiado). Bertioga, 1999.

Bonduki, N. Habitação e autogestão: construindo territórios de utopia. Rio de Janeiro, FASE, 1992.

Bonduki, N.G. (1996a) (ORG.) Habitat - As práticas bem-sucedidas em habitação, meio ambiente e gestão urbana nas cidades brasileiras, São Paulo, Studio Nobel, 267p.

Bonduki, N.G. Origens da Habitação Social no Brasil. Arquitetura moderna, lei do inquilinato e difusão da casa própria. Ed. Estação Liberdade, São Paulo, 1998.

Bonduki, N.G.; Rosseto, R. et al. Arquitetura e habitação social em São Paulo - 1989 - 1992. São Paulo, $2^{a}$. Bienal Internacional da Arquitetura de São Paulo. São Paulo, 1993.

Bonduki. N.G.(org.). Habitat. As práticas bem sucedidas em habitação, meio ambiente e gestão urbana nas cidades brasileiras. São Paulo: Studio Nobel, 1996.

Brasil, Constituição da República Federativa do Brasil: Promulgada em 5 de outubro de 1988. 27ª . ed. - São Paulo: Saraiva, 2001.

Brasil. Ministério da Saúde. Norma Operacional Básica - SUS n. 1/96. Diário Oficial da União, Brasília, 1996.

Brasil. Ministério do Meio Ambiente. GEO Brasil 2002 - Perspectivas do Meio Ambiente no Brasil. Santos, T.C.C. e Câmara, J.B.D.C. (orgs) - Brasília: Edições IBAMA, 2002.

Bueno, L.M.M. Projeto e Favela: metodologia para projetos de urbanização. Tese de Doutorado. Faculdade de Arquitetura e Urbánismo da USP. São Paulo, 2000.

Campos, G.W.S. Um método para analise e co-gestão de coletivos: a constituição do sujeito, a produção de valor de uso e a democracia em instituições: o método da roda. São Paulo: Hucitec, 2000. Saúde em Debate, 131.

Cardoso, M.R. A Indoor environmental risk factors for lower respiratory diseases in Young children in São Paulo, Brazil. Londres, 1997. Tese de Doutorado, University of London. 
Caricari, A M. Arai, V. et. al. Primeira Oficina de trabalho do Projeto Bertioga Município Saudável. Relatório. Prefeitura Municipal de Bertioga - Faculdade de Saúde Publica da USP, 2000.

Caricari, A. As condições de vida e de saúde dos trabalhadores da construção civil de Bertioga. Trabalho de qualificação para Dissertação de Mestrado. Faculdade de Saúde Publica da Universidade de São Paulo. (mimeo). São Paulo, 2002.

Carta de Adelaide. Declaração adotada na Segunda Conferencia Internacional sobre Promoção da Saúde (1988). In: Ministério da Saúde. Revista Promoção da Saúde. Experiências Saudáveis. Ano 1. no. 2. nov/dez, 1999.

Carta de Bogotá. Declaração da Conferencia Internacional de Promoção da Saúde (1992). In: Ministério da Saúde. Revista Promoção da Saúde. Experiências Saudáveis. Ano 1. no. 1. ago/out, 1999.

Carta de Jacarta. Declaração adotada na Conferencia Internacional sobre Promoção da Saúde (1997). In: Ministério da Saúde. Revista Promoção da Saúde. Experiências Saudáveis. Ano 1. no. 1. ago/out, 1999.

Carta de Otawa para promocion de la salud, Una Conferencia Internacional sobre Promocion de la Salud: Hacia un nuevo concepto de la salud publica, OMS, Canadá, Associacion Canadense de Salud Publica, 1986.

Carta de Otawa. Declaração adotada na Primeira Conferencia Internacional sobre Promoção da Saúde (1986). In: Ministério da Saúde. Revista Promoção da Saúde. Experiências Saudáveis. Ano 1. no. 1. ago/out, 1999.

Castro, M.C. A explosão do autofinanciamento na produção da moradia em São Paulo nos anos 90. São Paulo: FAUUSP, 1999. Tese (Doutorado).

Castro, M.C.; Silva, H.M.B. Legislação e mercado residencial em São Paulo. São Paulo: LABHAB/FAUUSP, 1997.

Cavalcanti. D. Curso de planejamento urbano e pesquisa popular. In: Bonduki. N.G.(org.). Habitat. As práticas bem sucedidas em habitação, meio ambiente e gestão urbana nas cidades brasileiras. São Paulo: Studio Nobel, 1996.

Centro Gaspar Garcia de Direitos Humanos, et. al. Relatório de atividades de implementação do Programa de Reabilitação Integrada do Habitat PRIH - Luz. Secretaria de Habitação da Prefeitura de São Paulo. São Paulo, 2003.

Cepam - Fundação Prefeito Faria Lima; Prefeitura do Município de Bertioga. Diagnostico sobre a capacidade institucional dos municípios no setor urbano/habitacional para o atendimento das populações de baixa renda. Relatório encaminhado a SEDU - Secretaria de Estado do Desenvolvimento Urbano da Presidência da Republica - Programa de Desenvolvimento Institucional dos Municípios para a Gestão Urbana. Bertioga, 2001.

Cepam -Fundação Prefeito Faria Lima; Bertioga (Município). Diagnóstico sobre a Capacidade Institucional do município no setor urbano/habitacional para 
atendimento das populações de baixa renda. Relatório (mimeo). Apresentado à Sedu - Secretaria de Estado do Desenvolvimento Urbano da Presidência da Republica. 2002.

Cepedoc, Centro de Estudos, pesquisa e documentação sobre cidades saudáveis da FSPUSP. Subsídios para revisão do Plano Diretor de Bertioga à luz do Estatuto da Cidade: contribuição dos membros da sociedade civil por meio do Projeto Bertioga Município Saudável. Relatório (mimeo). São Paulo, 2002.

Cepedoc. Projeto de Apoio ao Movimento de Municípios Saudáveis no Estado de São Paulo. Relatório de Avaliação, 2003 (mimeo).

Chalhoub, S. Cidade Febril: cortiços e epidemias na Corte Imperial. São Paulo, Companhia das Letras, 1996.

Chauí, M.S. Cultura e Democracia: o discurso competente e outras falas. 8. ed - São Paulo: Cortez, 2000.

Chiesa, A. M. A equidade como princípio norteador da identificação de necessidades relativas ao controle dos agravos respiratórios na infância. Tese de Doutorado. Faculdade de Saúde Pública da Universidade de São Paulo, 1999.

Cidades Saudáveis. Saúde e Sociedade, 1997, n.6 (2).

Comarú, F. A . Uemura, M.M. Estudos de caso em São Paulo. In: LabHab, FAUUSP, Relatório final de pesquisa Parâmetros para urbanização de favelas, 1999.

Comaru, F. A . Vitale, L. O Laboratório de Projeto Integrado e Participativo para o Prédio da Rua do Ouvidor, 63: extensão, ensino e produção do saber em movimento. Revista de Pós Graduação da Faculdade de Arquitetura e Urbanismo da Universidade de São Paulo. FAUUSP, Julho, 2003

Comarú, F.A .Intervenção habitacional em cortiços da cidade de São Paulo: o mutirão Celso Garcia. Dissertação de Mestrado. Escola Politécnica da USP, São Paulo, 1998.

Conh, A. Estado, políticas públicas e saúde. In: Canesqui A M., (org). Ciências sociais e saúde. São Paulo, Hucitec/Abrasco, 1997. P.157-172.

Costa; N. R. Estado, educação e saúde: a higiene da vida cotidiana. In: Cadernos do Cedes - Centro de estudos de educação e sociedade Educação e Saúde no. 4. Ed. Cortez. São Paulo, 1987

Crespo, P. G. Sistema de esgotos. Belo Horizonte, Ed. UFMG. Departamento de Engenharia Sanitária e Ambiental da Escola de Engenharia, 1997.

Czeresnia, Dina (org.) Promoção da saúde: conceitos, reflexões e tendências. Rio de Janeiro: Ed. Fiocruz, 2003.

Dallari, D. A . Elementos da Teoria Geral do Estado. São Paulo: Saraiva, 1991.

Dallari, S. G. et. at. Advocacia em saúde no Brasil contemporâneo. In: Revista de Saúde Pública, 30 (6), 1996. 
Demo, P. Participação e avaliação: projetos de intervenção e ação. In: Sorrentino, $M$, (coord.). Ambientalismo e participação na contemporaneidade. São Paulo: Educ/Fapesp, 2001, 229p.

Denaldi, R. Políticas de urbanização de favelas: evolução e impasses. Tese de Doutorado. Faculdade de Arquitetura e Urbanismo da USP. São Paulo, 2003.

Engels. F. A Situação da classe trabalhadora na Inglaterra. Lisboa. Editorial Presença, 1974.

Escorel, S. Vidas ao léu: trajetórias de exclusão social. Rio de Janeiro: Editora Fiocruz, 1999.

Escorel. Reviravolta na saúde: origem e articulação do movimento sanitário, Rio de Janeiro, Ed. Fundação Oswaldo Cruz, 1999.

Farah, M.F.S. Parceria, novos arranjos institucionais e políticas locais. In: Fundação Prefeito Faria Lima - Cepam. O município no Século XXI: cenários e perspectivas. ed. esp. São Paulo: Cepam/Correios: 1999.325-42.

Felipe, J. P. Mutirão e autogestão no Jardim São Francisco (1989-1992): movimento de moradia o lugar do arquiteto. São Carlos. Dissertação de Mestrado. EESC - USP, São Carlos, 1997.

Fernandes, A.; GOMES, M. A . F. (org.) Cidade e História - Modernização das Cidades Brasileiras nos Séculos XIX e XX. Seminário de História Urbana, 1. Salvador: UFBA / Faculdade de Arquitetura. Mestrado em Arquitetura em Urbanismo; ANPUR, 1992.

Fernandes, F. Capitalismo dependente e classes sociais na América Latina. Rio de Janeiro: Zahar, 1975.

Ferraz, S.T. A pertinência da adoção da filosofia de cidades saudáveis no Brasil, Saúde em Debate, n. 41 dez, 1993.

Ferraz, S.T. Cidades Saudáveis - uma urbanidade para 2000. Brasília, Ed. Paralelo 15, 102 p., 1999.

Ferreira, J.S.W. São Paulo: o mito da cidade-global. Tese de Doutorado apresentada à Faculdade de Arquitetura e Urbanismo da Universidade de São Paulo. São Paulo, 2003.

Feuerstein, Marie-Therèse. Partners in evaluation. Evaluating development and community programs with participants. Macmillan Publishers / TALC Teaching aids at low cost. London, 1986.

Fix, M. Parceiros da Exclusão: duas histórias da construção de uma 'nova cidade' em São Paulo: Faria Lima e Água Espraiada. São Paulo: Boitempo, 2001.

FNRU - Fórum Nacional da Reforma Urbana. Resoluções do Encontro Nacional. Rumo à Conferencia Nacional das Cidades: uma outra cidade é possível. 2003. 
Freire, P. Educação como pratica da liberdade. Rio de Janeiro: Paz e Terra, 1982.

Freire, P. Pedagogia da esperança: um reencontro com a pedagogia do oprimido. Rio de Janeiro: Paz e Terra, 1992.

Freire, Pedagogia do oprimido. São Paulo: Paz e Terra, 1970.

Freyre, G. Sobrados e mocambos: decadência do patriarcado rural e desenvolvimento urbano. Rio de Janeiro: José Olympio, 1985

Fundação João Pinheiro (1995) Déficit Habitacional Brasileiro - Relatónio Final (Versão Preliminar), Belo Horizonte, mimeo.

Fundação Seade - Fundação Sistema Estadual de Análise de Dados. Condições de vida e acesso a serviços de saúde em municípios saudáveis no Brasil. Termos de Referência, 1999.

Furtado, C. Formação Econômica do Brasil. São Paulo. Cia. Editora Nacional, 1995.

Gianotten, V.; With T. Pesquisa participante em contexto de economia camponesa. In: C.R. Brandão, Repensando a pesquisa participante. $2^{a}$. ed. São Paulo, Ed. Brasiliense, 1985, p. 158-188.

Gonçalves, A.M. Dinâmica de grupos na formação de lideranças. Rio de Janeiro: DP\&A editora, 2002. $8^{\mathrm{a}}$. edição152p.

Goumans, M. Innovations in a fuzzy domain. Healthy Cities and (health) policy development in the Netherlands and the United Kingdom. Phd Tesis. University of Maastricht - Faculty of Health Sciencies. Maastricht, 1997.

Guimarães, G. Uma cidade para todos: o Plano Diretor do Município de Angra dos Reis. Rio de Janeiro: Forense, 1997.

Haguette, T.M.F. Metodologias qualitativas na sociologia. Ed. Vozes, Petrópolis, 1987.

Harvey, D. A condição pós moderna: uma pesquisa sobre as origens da mudança cultural. $3^{\mathrm{a}}$ ed. São Paulo. Loyola, 1989.

Herrero, L.M.J. Desarollo Sustenible y Economia Ecológica. P. 30-171, 1993.

Hochman, G. A Era do Saneamento: as bases da política de Saúde Pública no Brasil. Ed. Hucitec, Anpocs, São Paulo, 1998.

Holanda, S. B. Raízes do Brasil. Rio de Janeiro: José Olympio, 1971

IBGE - Instituto Brasileiro de Geografia e Estatística. Censo Demográfico 1991.

IBGE - Instituto Brasileiro de Geografia e Estatística. Censo Demográfico 2000 .

Instituto Cidadania. Projeto Moradia. $2^{a}$. edição. São Paulo: Instituto Cidadania e Fundação Djalma Guimarães, 2002. 
Instituto ECOAR para a Cidadania. Desafio das águas: Agenda 21 do Pedaço. São Paulo.

Instituto Polis. Kit das Cidades. São Paulo, 2001.

Jacobi, P. Cidade e meio ambiente: percepções e práticas em São Paulo. Annablume, São Paulo, 1999. Anablume, São Paulo, 1999.

Jornal Costa Norte. Edição especial. Bertioga, 11 anos. Maio de 2002

Jornal da Baixada. Setembro de 2001.

Jung, C.G. Prefácio. I Ching. O livro das mutações. São Paulo: Ed. Pensamento.

Junqueira, R.G.P. A intersetorialidade do ponto de vista da educação ambiental: um estudo de caso, Revista de Administração Pública, 32, 1998.

Knitzer, J. E. Child advocacy: a perspective. Am.J. Orthopsyquiatry, 46: 20016, 1976.

Kowarick, L. Ant, C. Cem anos de promiscuidade: o cortiço da cidade de São Paulo. In: Kowarick, L. (org.) As lutas sociais e a cidade: São Paulo, passado e presente. $2^{a}$. ed. Ver. E atual. - Rio de Janeiro: Paz e Terra, 1994.

$\angle A B H A B$ - Laboratório de Habitação e Assentamentos Humanos da Faculdade de Arquitetura e Urbanismo da Universidade de São Paulo. Parâmetros para urbanização de favelas, São Paulo. FINEP/CEF, 1999 (relatório de pesquisa).

LABHAB, Laboratório de Habitação e Assentamentos Humanos da FAUUSP. Programa Bairro Legal. Programa Bairro Legal - Coordenação da Metodologia dos Planos de Ação Habitacional e Urbano para áreas em situação de risco pela exclusão sócio-econômica e violência. Relatório P4. São Paulo, 2003.

Labonte, M.A.R. Health Promotion and Empowerment: Reflections on Professional Practice. Health Education Quarterly, Vol. 21 (2): 253-268 (Summer 1994). SOPHE. Published by John Wiley \& Sons, Inc.

Lacombe \& Poirier. The Quebec Network villes et villages en santé. Paper prepared for the annual meeting of Healthy Cities National Networks Coordinators, Eindhoven, 1992.

Lefèvre, F.; Cavalcanti, A. M.; Teixeira, J.J.V. (orgs) O discurso do sujeito coletivo: uma nova abordagem metodológica em pesquisa qualitativa

Lemos, A C. Os primeiros cortiços paulistanos (1998). In: Sampaio, M.R. (org) Habitação e cidade. Fapesp, Faculdade de Arquitetura e Urbanismo da Universidade de São Paulo, São Paulo.

Lichti, F.M. Poliantéia de Bertioga. Instituto Histórico e Geográfico de São Vicente, Prefeitura do Município de Bertioga. Ed. Vice-Rei. $1^{\text {a }}$. ed. 2002.

Macnaughton; Alison. Processo de elaboração passo-a-passo de Biomapas Comunitários.(mimeo) Projeto GEPAM. UBC - Universidade de Colômbia Britânica e Prefeitura de Santo André, 2002. 
Malik, A .M. Cidades Saudáveis. Estratégia em aberto. In: Saúde e sociedade. São Paulo, 1997; 6(2):19-30

Maricato, E.T. Enfrentando desafios: a política desenvolvida pela Secretaria de Habitação e Desenvolvimento Urbano da Prefeitura de São Paulo 1989/1992. São Paulo. Tese de Livre Docência. Faculdade de Arquitetura e Urbanismo da USP, 1997.

Maricato, E.T. Metrópole na periferia do capitalismo: ilegalidade, desigualdade e violência. São Paulo, Hucitec, 1996.

Maricato, E.T.M. Apresentação - Democratização na gestão das cidades. In: Gumarães, G. Uma cidade para todos: o Plano Diretor do Município de Angra dos Reis. Rio de Janeiro: Forense, 1997

Maricato, E.T.M. Brasil, cidades: alternativas para a crise urbana. Ed. Vozes. Petrópolis, RJ, 2001.

Maricato, E.T.M. et al. A cidade do pensamento único: desmanchando consensos. Ed. Vozes, São Paulo, 2000.

Marks, J.S. Foreword. In: Policy and environmental change: new directions for public health. ASTDHPPHE and U.S. Center for Disease Control and Prevention - CDC. Santa Cruz, 2001.

Martins, M. L.R. Movimentos populares urbanos face à desregulamentação no tocante à cidade. Revista Proposta: FASE, n.6, dez, 1995.

Martins, M. L. R. Os desafios da Gestão Municipal Democrática - Santos, São Paulo: Polis, 1998, 48p.

Martins, M.L.R. Os desafios da Gestão Municipal democrática - Belém 1997-2000: desenhando a cidade do terceiro milênio. São Paulo: Polis, 2000. 112p.

Martins, M.L.R. São Paulo: além do Plano Diretor. In: Estudos Avançados (Revista). Instituto de Estudos Avançados da USP. Vol. 17, no. 47. jan/abr 2003. São Paulo.

Mendes, R. Cidades Saudáveis no Brasil e os processos participativos: os casos de Jundiaí e Maceió. Faculdade de Saúde Pública da USP. Tese de Doutorado, 2000.

Minayo, M.C.S. O desafio do conhecimento. Pesquisa qualitativa em saúde. Hucitec-Abrasco: São Paulo-Rio de Janeiro, $5^{a}$. ed., 1998.

Minayo, M. C. S. Enfoque ecossistêmico de saúde e qualidade de vida. . In: Minayo,M.C.S. et al (org.) Saúde e ambiente sustentável: estreitando nós. Rio de Janeiro: Ed. Fiocruz, 2002.

Ministério das Cidades. Brasil. Conferência das Cidades. Cidade para todos: Construindo uma política democrática e integrada para as cidades. Texto Base. 2003. (mimeo). 
Ministério do Bem Estar Social. Brasil (1993) Programas Habitar-Brasil e MorarMunicipio. Manual de Orientação para os Programas Integrados das Áreas de Habitação, Saneamento Básico e Promoção Humana. Brasília, mimeo.

Ministério da Saúde. Brasil. Norma Operacional Básica 01/91. NOBSUS 01/91, 1991.

Ministério da Saúde. Brasil. Norma Operacional Básica 01/96. NOBSUS 01/96, 1996.

Morse, S. Formação histórica de São Paulo. São Paulo, difel, 1970.

Najar, A . L.; MARQUES, E.C. (org.) Saúde e espaço: estudos metodológicos e técnicas de análise, Ed. FIOCRUZ, Rio de Janeiro, 1998.

Oakley, P.; Clayton, A. Monitoramento e avaliação do empoderamento ("empowerment"). Trad Araschiro, Z. e Sameshima, R. São Paulo, Instituto Polis, 2003. 96p.

Oliveira, F. A economia brasileira: crítica à razão dualista. Cadernos CEBRAP, n.2, São Paulo: 1972.

OMS, Organização Mundial da Saúde. Repartição de Saúde Ambiental Global e Integrada. OMS, Genebra, 1998. mimeo.

OPAS - Organização Pan-Americana de Saúde. Municípios e comunidades saudáveis. Guia dos prefeitos para promover qualidade de vida. Versão em português. Washington, 2002.

OPAS, Organización Panamericana de la Salud/Organización Panamericana de la Salud. Programa Especial de Salud materno-infantil y Población. Control de las Infecciones Respiratorias Agudas: Bases Técnicas para las Recomendaciones de la OPS/OMS. Equador-Quito: OPAS/OMS, 1993.

OPS - Organización Panamericana de la Salud. El movimiento de municipios saludables en America. Washington, 1995.

PAHO - Pan American Health Organization. The healthy municipalities movement: a strategy for health promotion in Latin America. Washington, 1997.

PAHO - Pan American Health Organization. The healthy municipalities movement. A setting approach and strategy for health promotion in Latin Amerca and the Caribben. (Draft). Washington, 1999.

PAHO, Pan- American Health Organization. Promoting health in the Americas. Annual Report of the Director. Washington, 2001

Parllet, M.; HAMILTON, D. Avaliação iluminativa: uma nova abordagem no estudo de programas inovadores. In: Goldberg, M.A .A . et Souza, C.P., org. Avaliação de programas educacionais: vicissitudes, controvérsias e desafios - pag. 38-45, São Paulo, E.P.U., 1992.

Piccini, A . Cortiços e reestruturação do centro urbano de São Paulo: habitação e instrumentos urbanísticos. São Paulo, 1996, 203p. Tese de Doutorado. Escola Politécnica da USP. 
Pinheiro, M.C. Equidade em saúde e as Conferencias Nacionais de Saúde pos constituição Federal de 1988. Dissertação (Mestrado). Faculdade de Saúde Publica, Universidade de São Paulo. São Paulo, 2003.

PNUD, Programa das Nações Unidas para o Desenvolvimento. Relatório de Desenvolvimento Humano, 1999.

Prado Jr., C. História Econômica do Brasil. São Paulo: Brasiliense, 1990.

Rejovski, M. Sub Projeto Turismo.In: Westphal, M.F; et. al. (coord.). A proposta de municípios saudáveis (OMS) em Bertioga: contribuição dos conhecimentos técnicos, científicos, interdisciplinares e das representações sociais. Projeto Temático de pesquisa encaminhado à Fapesp. São Paulo, 2000.

Ribeiro, R.T. et. al. Diagnóstico Situacional do Município de Bertioga. (mimeo). Bertioga, 2002.

Rodrigues, A . M. A Produção e o consumo do especo para o turismo e a problemática ambiental. In: Yázigi, E.; Carlos, A F. A; Cruz, R.C.; Turismo: espaço, paisagem e cultura. São Paulo: Hucitec, 1999.

Ronconi, R. Habitações construídas com gerenciamento pelos usuários, com organização da força de trabalho em regime de mutirão (O Programa Funaps Comunitário). Dissertação de Mestrado.EESC-USP, São Carlos, 1995.

Rosa, F.S; Fierz, M.S.M. A Paisagem x Evolução do uso e ocupação do solo em Bertioga, litoral paulista. In: Revista do Departamento de Geografia n. 13, 1999. FFLCH USP. São Paulo.

Rosen, G. Uma História da Saúde Pública. São Paulo: Ed. Unesp, Ucitec, Abrasco, 1994.

Royer, L. O . Política Habitacional no Estado de São Paulo: estudo sobre a Companhia de Desenvolvimento Habitacional e Urbano do Estado de São Paulo. Dissertação de Mestrado: FAUUSP. 2002.

Prado Jr. C. História Econômica do Brasil. São Paulo: Brasiliense, 1990.

Santos C.; Ultramari, C. Dutra, C. Artigo base sobre o meio ambiente urbano. In: Meio ambiente Brasil: avanços e obstáculos pós-Rio 92. Capobianco, J., Oliveira, J. (orgs). São Paulo: Estação Liberdade: Instituto Sócio-Ambiental, Rio de Janeiro: Fundação Getúlio Vargas, 2002

Santos J.L.; Westphal, M. F. Práticas emergentes de um novo paradigma de saúde: o papel da universidade. In: Estudos Avançados. Universidade de São Paulo. Instituto de Estudos Avançados, São Paulo, 1999.

Santos, C. N. F. A cidade como um jogo de cartas. São Paulo. Projeto: 1988. Santos, M. A urbanização brasileira. $3^{a}$ ed. São Paulo, Hucitec, 1995.

São Paulo (Estado). Agencia Metropolitana da Baixada Santista - Agem. Fundo Estadual de Recursos Hídricos - Fehidro Programa Regional de Identificação e Monitoramento de Áreas Criticas de Inundações, Erosões e Deslizamentos - 
PRIMAC da Região Metropolitana da Baixada Santista. Relatório Final. Novembro, 2002.

São Paulo (Estado). Agencia Metropolitana da Baixada Santista - Agem. Plano Diretor de Turismo da Baixada Santista. Julho, 2002.

São Paulo (Estado). Secretaria do Meio Ambiente. Informações básicas para - planejamento ambiental. Secretaria de Estado do Meio Ambiente, Coordenadoria de Planejamento Ambiental. São Paulo, SMA, 2002.

São Paulo (Estado). Secretaria do Meio Ambiente. Macrozoneamento do litoral norte. Plano de Gerenciamento Costeiro. Secretaria de Estado do Meio Ambiente, Coordenadoria de Planejamento Ambiental. São Paulo, SMA, 1996.

São Paulo (Estado). Secretaria dos Transportes Metropolitanos; Empresa Paulista de Planejamento Metropolitano - Emplasa; Agencia Metroplitana da Baixada Santista - Agem. Plano Metropolitano de Desenvolvimento Integrado - PMDI. Agosto, 2002.

Saule Jr. N. (org.) Direito à cidade: trilhas legais para o direito às cidades sustentáveis. POLIS - Instituto de Formação e Estudos em Políticas Sociais, Max Limonad, São Paulo, 1999.

Schwarz, R. As idéias fora do lugar. Estudos Cebrap 3. São Paulo, 1973.

Schwarz, R. Um mestre na periferia do capitalismo: Machado de Assis. São Paulo: Duas Cidades, 1990.

Seroa da Motta, T. Et al. Health and economic values for mortality and morbidity cases associated with air pollution in Brazil. Expert workshop on Assessing the Ancillary Benefits and Costs of GHG Mitigation Satrategies, IPEA/Rio de Janeiro, 2000. Mimeo.

Silva, H.M.B. Terra e moradia: que papel para o município? São Paulo: FAUUSP. Tese de Doutorado, 1998.

Singer, Paul, "Economia Política Da Urbanização", São Paulo, Brasiliense, 1981.

Siqueira, M. E. S. A. A proposta e a prática da questão ambiental: uma análise da coerência em relação ao turismo em Bertioga. Dissertação (Mestrado).

Departamento de Geografia da Faculdade de Filosofia, Letras e Ciências Humanas da Universidade de São Paulo. São Paulo, 2002.

Smolka, M.; Furtado, F. Argumentos para a reabilitação di IPTU e o THBI como instrumentos de intervenção urbana (progressista). Revista Espaço e Debates, ano XVI, no. 39, 1996.

(orgs.) Recuperación de plusvalias em América Latina, Santiago: Eurelibros, 2001.

Sorrentino, M, (coord.). Ambientalismo e participação na contemporaneidade. São Paulo: Educ/Fapesp, 2001, 229p. 
Sposati A . Movimentos utópicos da contemporaneidade. In: Sorrentino, M, (coord.). Ambientalismo e participação na contemporaneidade. São Paulo: Educ/Fapesp, 2001, 229p.

Suarez, M. Gestão Local e desigualdade de gênero. Brasília: Agende, 2002. v.2.p.120. Cadernos Agende, v.2.

Swarbrooke, J. Turismo sustentável: conceitos e impacto ambiental, vol 1. São Paulo: Aleph, 2000.

Taschner, S.P. Favelas e cortiços no Brasil: 20 anos de pesquisas e políticas. São Paulo, FAUUSP, 1993.

Taschner, S.P. Moradia da pobreza: habitação sem saúde. Tese de Doutorado. Faculdade de Saúde Pública da Universidade de São Paulo, 1982.

Taschner, S.P. Cadernos de pesquisa do LAP. Favelas e cortiços no Brasil: 20 anos de pesquisas e políticas. LAP: FAUUSP, Março-Abril de 1997.

Thiollent, M. (1985). Metodologia da pesquisa ação. Cortez, São Paulo.

Tommasi, L.R. Considerações ecológicas sobre o sistema Estuarino de Santos (SP) - I CETESB, 1982. 79 p. + anexos.

UBC, University of British Columbia. Centre for Human Settlements. Mananciais sustentáveis. Desenho da paisagem urbana para assentamentos de baixa renda. Charrette do Projeto Vizinhança Pintassilgo. FAUUSP. Santo André, 2001.

UN - Habitat, United Nations Human Settlements Program. Habitat's new Global Report on Human Settlements. The Challenge of slums. 2003.

Universidade de São Paulo; Desenvolvimento local e sustentabilidade em Bertioga - metodologias para um município saudável. Projeto de pesquisa temático encaminhado a Fapesp - mimeo. São Paulo, 2001

Vargas, N. Tendências da modernização da construção civil no Brasil. Proceedings. México: Batlett International Summer School, 1987

Villaça, F. Espaço intra-urbano no Brasil. São Paulo: Nobel, 1998.

Villaça. F. Uma contribuição para a história do planejamento urbano no Brasil. In: Deák, C. e Schiffer, S.R. (orgs) O processo de urbanização no Brasil. São Paulo: Edusp/Fupam, 1999.

Villela, A . Favelização no litoral norte: o modelo de turismo e seu impacto na estrutura urbana. Trabalho final de graduação. Faculdade de Arquitetura e Urbanismo da Universidade de São Paulo. São Paulo, Agosto 2003.

Waldman, E. A . A transição epidemiológica: tendências e diferenciais dos padrões de morbimortalidade em diferentes regiões do mundo. In: $\mathbf{O}$ mundo da saúde. Ano 24 v. 24 n. 1 jan/fev 2000.

Werna, E. Harpham, T. et al. Heathy city projects in developing countries: an international approach to local problems. Earthscan Publications, London, UK, 1998. 
Werna, E; Harpham, T.. The evaluation of healthy city projects in developing countries. In: Habitat International n. 3, 1995.

Wesphal, M.F. Municípios Saudáveis: aspectos conceituais. In: Saúde e Sociedade. Faculdade de Saúde Pública da Universidade de São Paulo e Associação Paulista de Saúde Pública. v.6, n.2 (jan/jul, 1997), São Paulo, 1997.

Westphal, M.F. Arroyo, J.M.E. Castro-Albarrán. Public health policies and advocacy in Latin America: chances and environments to support these initiatives. In: International Journal of Health Promotion and Education, Vol. VII, 2000/4.

Westphal, M.F. Participação da mãe no cuidado da criança com asma brônquica. São Paulo, 1982. Tese de Doutorado. Faculdade de Saúde Pública da USP.

Westphal, M.F. Participação popular e políticas municipais de saúde: 0 caso de cotia e vargem grande paulista. Tese (Livre docência). Facuoldade de Saude Pública. Universidade de São Paulo, 1992.

Westphal, M.F; et. al. (coord.). A proposta de municípios saudáveis (OMS) em Bertioga: contribuição dos conhecimentos técnicos, científicos, interdisciplinares $\mathbf{e}$ das representações sociais. Projeto Temático de pesquisa encaminhado à Fapesp. São Paulo, 2000.

WHO - World Health Organization. Regional Office for Europe. Twenty steps for developing a Healthy Cities project. $2^{\text {nd }}$. Edition, 1995

WHO - World Health Organization, Promoting Health in the urban context. WHO Regional Office for Europe. Copenhagen, Denmark, 1988.

WHO - World Health Organization. Social Determinants of Health. The solid facts. European Regional Office, 1998.

Wise, $M$. The role of advocacy in promoting health. In: International Journal of Health Promotion and Education, Vol. VIII, 2001/2.

Witehead, M. The concepts and principles of equity and health. Copenhagen: World Heath Organization Regional Office for Europe, 1990.

World Bank, Entering the $21^{\text {st }}$ Century. World Development Report 1999/2000. Oxford University Press, 1999.

Ziglio, E. et al. Priciples, metodology and practices of investment for health. Promotion \& Education, 2000; 2(2): 4-15.

Ziglio, E. Promoção em saúde: políticas públicas e investimentos. Apostila de curso. Faculdade de Saúde Pública da USP, São Paulo, 2000. 


\section{LEIS}

Brasil (1988). Constituição da República Federativa do Brasil: promulgada em 5 de outubro de 1988. $27^{a}$.edição: São Paulo: Ed. Saraiva, 2001.

Brasil, Estatuto da cidade (2001). Estatuto da cidade: Lei no. 10.257, de 10 de julho de 2001, que estabelece diretrizes gerais da política urbana Brasília: Câmara dos Deputados, Coordenação de Publicações, 2001, 273p.

Bertioga (Município). Lei 315-98 que institui o Plano Diretor de Desenvolvimento Sustentado. Bertioga, 1998.

Bertioga (Município). Lei 316-98 que institui o Código de Edificações do Município de Bertioga. Bertioga, 1998.

Bertioga (Município). Lei 317-98 que institui a Lei de Uso e Ocupação do solo do Município de Bertioga. Bertioga, 1998.

\section{SITIOS INTERNET}

DATASUS. Governo Federal, Ministério da Saúde. Datasus. Disponível em: http://www.datasus.gov.br (2002).

Emplasa. Empresa Paulista de Planejamento Metropolitano. www.emplasa.sp.gov.br.

Fundação Seade. Fundação Sistema Estadual de análise de dados. Disponível em www.seade.sp.gpv.br, 2003.

IBGE - Instituto Brasileiro de Geografia e Estatística.

www.ibge.gov.br/cidades (27/06/01)

\section{IMAGENS AÉREAS}

AGEM, Agencia Metropolitana da Baixada Santista. Sistema Cartográfico Metropolitano da Baixada Santista: Mapeamento Digital. Ortofotos do Município de Bertioga. Santos, 2003. 


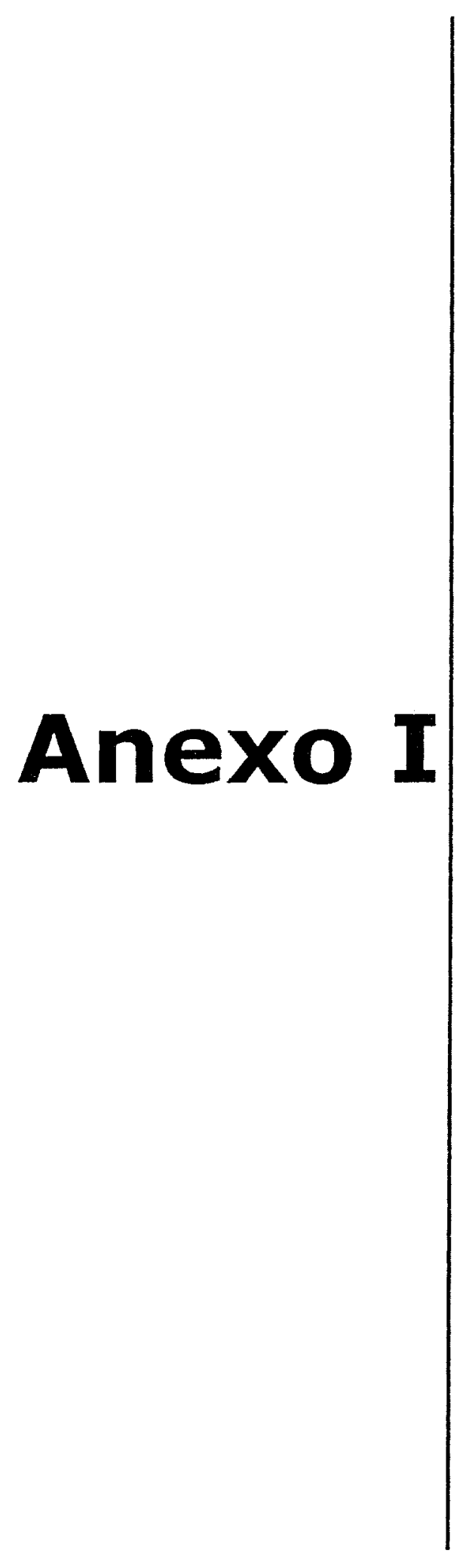


ANEXO I - QUADRO COM PARTICIPANTES AO LONGO DAS PRINCIPAIS ATIVIDADES DO PBMS (2000/2003)

\begin{tabular}{|c|c|c|c|c|c|c|c|c|}
\hline \multicolumn{9}{|c|}{$\begin{array}{l}\text { Atividade / ano } \\
\end{array}$} \\
\hline & \multirow[t]{2}{*}{ Participante } & of sensib & pesq. expl. & of. region & of. futuro & sem mun. & curso ag. & of. p.dir. \\
\hline & & & & & & & & \\
\hline 1 & Adaltivo Gonçalves da Silva & & & & & & & \\
\hline 2 & Ademilson Soares da Silva & & & & & & & \\
\hline 3 & Adiel Pereira & & & & & & & \\
\hline 4 & Adriana Arajs Marques & & & & & & & \\
\hline 5 & Adriana Ferreira de Santana & & & & & & & \\
\hline 6 & Adriana do Carmo Barbosa & & & & & & 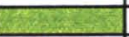 & \\
\hline 7 & Adriana Mara da Silva & & & & & & & \\
\hline 8 & Adriano Correia de Freitas & & & & & & & \\
\hline 9 & Aguinaldo de Oliveira Dixon & & & & & a & & \\
\hline 10 & Alailde Viana de Souza & & & & & & & \\
\hline 11 & Alayde Muniz Bernardo & & & & & & & \\
\hline 12 & Alcir Scariot (Tiko) & & & & & & & \\
\hline 13 & Aldo Ennos de Moraes & & & & & & & \\
\hline 14 & Alessandra Aparecida Ferreira de San & ina & & & & & & \\
\hline 15 & Alessandro Gomes Garcia & & & & & & & \\
\hline 16 & Alex de Souza & & & & & & & \\
\hline 17 & Alexandra da Conceição & & & & & & $x$ & \\
\hline 18 & Alexandre Horvath & & & & & & & \\
\hline 19 & Alexandre Martins Lopes & & & & & & & \\
\hline 20 & AL ANTOKNIO ABRAO, & & & & & & & \\
\hline 21 & Aline do Amparo Santos & & & & & & & \\
\hline 22 & Aline Nunes de Oliveira & & & & & & & \\
\hline 23 & Aluísio Bichir & & & & & & & \\
\hline 24 & Álvaro André & & & & & & & \\
\hline 25 & Amanda Arass Marques & & & & & & & \\
\hline 26 & Amauri F. Tavares & & & & & & & \\
\hline 27 & Ana Angélica S. Santos & & & & & & & \\
\hline 28 & Ana Beatriz de Meireles Reis & & & & & & & \\
\hline 29 & Ana Carolina Arlindo do Rosário & & & & & & & \\
\hline 30 & Ana Leonor Castelo Branco Ferreira & & & & & & & \\
\hline 31 & Ana Lúcia Casagrande de Oliveira & & & & & & & \\
\hline 32 & Ana Maria Bitelli & & & & & & & \\
\hline 33 & Ana Maria Borges de Santana & & & & & & & \\
\hline 34 & Ana Maria S. de Andrade Lima & & & & & +2 & & \\
\hline 35 & Ana Maria Siqueira Antunes André & & & & & & & \\
\hline 36 & Andréla Janzioni Faria & & & & & & & \\
\hline 37 & Andreza Aparecida Nunes & & & & & & 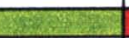 & \\
\hline 38 & Andrezza Monteiro dos Santos & & & & & 3 & & \\
\hline 39 & Antenor Francisco Matias & & & & & & & \\
\hline 40 & Antônia Aparecida de Paula Oliveira & & & & & & एक & \\
\hline 41 & Antônia Aparecida dos Santos & & & & & & & \\
\hline 42 & Antonia Gomes dos Santos & & & & & & & \\
\hline 43 & Antônio Carlos Cordeiro Costa & & & & & & & \\
\hline 44 & Antônio Carlos Magalhães Santos & & & & & & & \\
\hline 45 & Antonio Gentilio ...... & & & & & & & \\
\hline 46 & Antônio José Peixoto Fernandes & & & & & & & \\
\hline 47 & Antônio Lombardi Junior & & & & & & & \\
\hline 48 & Antônio Luiz de Souza(Toninho Guara & ba) & & & & & & \\
\hline 49 & Antônio Rodrigues Filho & & & & & & & \\
\hline 50 & Aparecida Maria Brasil & & & & & & & \\
\hline 51 & Aparecido Soares de Mello & & & & & & & \\
\hline 52 & Aquilles C. Sessa & & & & & & & \\
\hline 53 & Artur Guilherme Richter & & & & & & & \\
\hline 54 & Assunta Ferracioli & & & & & & & \\
\hline 55 & Atila Aparecido de Miranda & & & & & & & \\
\hline 56 & Benedita Aparecida André & & & & & & & \\
\hline 57 & Benedita Silva Cunha & & & & & & & \\
\hline 58 & Benedito S. Teles dos Santos & & & & & & & \\
\hline 59 & Boaventura Francisco Vitório & & & & & & & \\
\hline 60 & Bolivar Barbanti Junior & & & & & & & \\
\hline 61 & Bruno José Ribeiro & & & & & & & \\
\hline 62 & Caio Rodrigues Carvalhal & & & & & & & \\
\hline 63 & Canivaldo Rodrigues Silva & & & & & & & \\
\hline 64 & Carla Regina Riesco & & & & & & & \\
\hline 65 & Carlos Eduardo dos Santos Jr. & & & & & & & \\
\hline 66 & Catiane 0 . Pinto Pereira & & & & & & & \\
\hline 67 & Catlane de Oliveira Pinto Pereira & & & & & & & \\
\hline 68 & Célia Regina Migues Rodrigues & & & & & & & \\
\hline 69 & Célla Regina Pereira & & & & & & & \\
\hline 70 & Célia Regina Vieira Pereira & & & & & & - & \\
\hline 71 & Celso da Silva Martinez & & 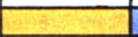 & & & & & \\
\hline 72 & Cícero da Silva Feitosa & & & & & & & \\
\hline 73 & Cícero Galdino da Silva & & & & & & & \\
\hline 74 & Ciro Rors & & & & & & & \\
\hline 75 & Clarissa Fernanda Zanirato & & & & & & & \\
\hline 76 & Claudenir Vieira da Silva & & & & & & & \\
\hline 77 & Cláudio Cardoso dos Santos & & & & & & & \\
\hline
\end{tabular}




\begin{tabular}{|c|c|c|c|c|c|c|c|}
\hline 78 & Cláudio Isola & & & 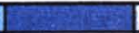 & 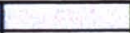 & & \\
\hline 79 & Cledemilson Sampaio Silva (Sampaio) & & & & & & \\
\hline 80 & Cleide Guerreira de Souza & & & & & & \\
\hline 81 & Clerison Betons Pereira da Silva & & & & & & \\
\hline 82 & Cristina Zanella C. de Araújo & & & & & & \\
\hline 83 & Dagmar Corrêa Silva & & & & & & \\
\hline 84 & Dalva Pereira & & & & & & \\
\hline 85 & Dalvanete dos Santos Costa & & & & & & \\
\hline 86 & Damares Mesquita Bezerra & & & & & & \\
\hline 87 & DAMIANA CAMELO RODRIGUES, & & & & & & \\
\hline 88 & Damião Querino dos Santos & & & & & & \\
\hline 89 & Damiấo Quirino dos Santos & & & & & & \\
\hline 90 & DANIEL LIBERATO DA SILVA, & & & & & & \\
\hline 91 & DANIEL ORLANDINI PASSOS & & & & & & \\
\hline 92 & Daniel Ribeiro Novais & & & & & & \\
\hline 93 & Daniele do Carmo Barbosa & & & & & & \\
\hline 94 & Dany Hereng Felisbino Pereira & & & & & & \\
\hline 95 & Dayse Oliveira Silva Fernandes Almeida & & & & & & \\
\hline 96 & \begin{tabular}{|l|l|} 
Deise da Silva \\
\end{tabular} & & & & & & \\
\hline 97 & Delcilene Maria de Souza & & & & & & \\
\hline 98 & Delvani Dutra de Almeida Santos & & & & & & \\
\hline 99 & Denis Eduardo Hartung Vallongo & & & & & & \\
\hline 100 & Denise Dalseno & & & & & & \\
\hline 101 & Diamantino de Sousa Batista & & & & & & \\
\hline 102 & Diney Lyra & & & & & & \\
\hline 103 & Dirceu dos Santos & & & & & & \\
\hline 104 & Ditmar Schmidt & & & & & & \\
\hline 105 & Donizete Aparecido da Silva & & & & & & \\
\hline 106 & Douglas Castro Gonçalves de Freitas & & & & & & \\
\hline 107 & Douglas Dias de Freitas & & & & & & \\
\hline 108 & Edenilton Eloi dos Santos & & & & & & \\
\hline 109 & Edgard Lucas Lourenço & & & & & & \\
\hline 110 & Edimaura Nogueira Viura & & & & & & \\
\hline 111 & Edith Maria Medeiros da Silva & & & & & & \\
\hline 112 & Edson Sllva Cardoso & & & & & & \\
\hline 113 & Edson dos Santos Lardosa & & & & & & \\
\hline 114 & Edson Passos de Oliveira & & & & & & \\
\hline 115 & Edson Siqueira Sina & & & & & & \\
\hline 116 & Eduardo Pereira de Abreu & & & & & & \\
\hline 117 & Elaine Maria de S. Paiăo & & & & & & \\
\hline 118 & Elba Ramalho Silva & & & & & & \\
\hline 119 & Elessandro Torres Pereira & & & & & & \\
\hline 120 & Eliana Avelino dos Santos & & & & & & \\
\hline 121 & Eliana de Oliveira & & & & & & \\
\hline 122 & Eliana Paulino Cunha Fernandes & & & & & & \\
\hline 123 & ELIANE BARBIRATO, & & & & & & \\
\hline 124 & Elisabete de Castro Alves & & & & & & \\
\hline 125 & Elisabeth F. de L. Bruno & & & & & & \\
\hline 126 & Elizabeth de Fátima Correia & & & & & & \\
\hline 127 & Ellzangela da Silva Bernardino & & & & & & \\
\hline 128 & Elka Dias da Rosa & & & & & & \\
\hline 129 & Elton Nazaré de Oliveira & & & & & & \\
\hline 130 & Eraldo José R. dos Santos & & & & & & \\
\hline 131 & Erica C. Fernandes & & & & & & \\
\hline 132 & Erica Daniela de Oliveira & & & & & & \\
\hline 133 & Erica Pereira de Carvalho & & & & & & \\
\hline 134 & Erida Vieira de Souza & & & & & & \\
\hline 135 & Eroldo Trindate de Jesus & & & & & & \\
\hline 136 & EUNICE O LOBATO, & & & & & & \\
\hline 137 & Ezeuda Alves Martins & & & & & & \\
\hline 138 & Fabiana Almeida do Nascimento & & & & & & \\
\hline 139 & Fabiano Pereira de Sousa & & & & & & \\
\hline 140 & Fábio Mazzoni & & & & & & \\
\hline 141 & Fabrício Tavares de Souza & & & & & & \\
\hline 142 & Fátima Aparecida Dias Barretto & & & & & & \\
\hline 143 & Fátima de L. Ramos da S. Vleira & & & & & & \\
\hline 144 & Fáuzia Neves & & & & & & \\
\hline 145 & Felipe de Souza Bichir & & & & & & \\
\hline 146 & Fernanda de Castro Batista & & & & & & \\
\hline 147 & Fernando ........... de Oliveira & & & & & & \\
\hline 148 & Fernando da Silva Lepique & & & & & & \\
\hline 149 & Fernando Herrero & & & & & & \\
\hline 150 & Fernando Rossoni Junior & & & & & & \\
\hline 151 & Filomena Mendes Pacheco & & & & & & \\
\hline 152 & Fisao Tanabe & & & & & & \\
\hline 153 & FRANCINI OLIVEIRA SANTOS, & & & & & & \\
\hline 154 & Francisca Amélia Arrais Alves e Silva & & & & & & \\
\hline 155 & Francisco Alves Lourenço da Silva (Ray) & & & & & & \\
\hline 156 & Francisco de Souza Silva & & & & & & \\
\hline 157 & Francisco Evangelista de Sousa & & & & & & \\
\hline 158 & Francisco Matias & & & & & & \\
\hline 159 & Francisco Mendes de Castro & & & & & & \\
\hline
\end{tabular}




\begin{tabular}{|c|c|c|c|c|c|c|c|c|}
\hline 160 & Francisco Pedro dos Santos & & & & & & & \\
\hline 161 & Francisco Serralvo Moreno & & & & & & & \\
\hline 162 & Fred George Cano & & & & & & & \\
\hline 163 & Galditino José de Souza & & & & & & & \\
\hline 164 & Gastão Sandoval Marcondes & & & & & & & \\
\hline 165 & Geane dos Santos Souza & & & & & & & \\
\hline 166 & GEISA RIBEIRO DE SOUZA, & & & & & & & \\
\hline 167 & Genilson Mota Souza & & & & & & & \\
\hline 168 & Geraldo Fernandes da Silva & & & & & & & \\
\hline 169 & Geusivam Alves da Cruz & & & & & & & \\
\hline 170 & Gildásio Jesus Lima & & & & & & & \\
\hline 171 & Glvaldo Ferreira da Silva & & & & & & & \\
\hline 172 & GLEIDSON GOUVEA, & & & & & & & \\
\hline 173 & Guilhermina Vieira Dantas da Sllva & & & & & & & \\
\hline 174 & Hamilton Teixeira Martinez & & & & & & & \\
\hline 175 & Héllo da Silva Marques & & & & & & & \\
\hline 176 & Hélio Shornik Vita & & & & & & & \\
\hline 177 & Heloísa Helena Araújo Duarte Ribeiro & & & & & & & \\
\hline 178 & Herbert Mendes Dutzmann & & & & & & & \\
\hline 179 & Hercilio Arcanjo Luz & & & & & & & \\
\hline 180 & Hermógenes Fiaschi Dores & & & & & & & \\
\hline 181 & Hirao Sakamoto & & & & & & & \\
\hline 182 & Hozana Pereira dos Santos & & & & & & & \\
\hline 183 & Humberto G. B. Almeida & & & & & & & \\
\hline 184 & Hylce Rangel Marcondes & & & & & & & \\
\hline$\frac{207}{185}$ & Icledimilson Sampaio Silva & & & & & & & \\
\hline 186 & Igor Pereira do Nascimento & & & & & & & \\
\hline$\frac{100}{187}$ & Ircari Helena Pereira & & & & & & & \\
\hline 188 & Irene de Oliveira & & & & & & & \\
\hline 189 & Irene Vaz Pinto Lyra & & & (4) & & & & \\
\hline 190 & Isidoro Toito de Paula & & & & & & & \\
\hline 191 & Ivana Silva dos Santos & & & & & & & \\
\hline 192 & Ivani Aparecida Correia & & & & & $\sqrt{3}$ & & \\
\hline 193 & Ivone de Castro Batista & & & & & & & \\
\hline 194 & Ivone Peres da Rocha & & & & & & & \\
\hline 195 & Ivone Pires de Almeida Guerreiro & & & & & & & \\
\hline 196 & Ivonete da Silva Honorato & & & & & & & \\
\hline 197 & Ivonete Pinto da Conceição & & & & & & & \\
\hline 198 & Jacobi Pereira & & & & & & & \\
\hline 199 & JAIR OLIVEIRA SIMÁO, & & & & & & & \\
\hline 200 & Jair Rosário Braz & & & & & & & \\
\hline 201 & Jamile Bichir Canoilas & & & & & & & \\
\hline 202 & Januário José dos Santos Neto & & & & & & & \\
\hline 203 & Jaqueline Cordeiro dos Santos & & & & 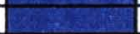 & & & \\
\hline 204 & Jefferson Ricardo Espírito Santo & & & & & 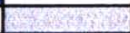 & & \\
\hline 205 & Jerlaine de Jesus Santos & & & & & & & \\
\hline 206 & Jéssica Aparecida do Amaral Carvalho & & & & & & & \\
\hline 207 & Joana Galdino Duarte & & & & 5 & & & \\
\hline 208 & Joăo Alberto............ & & & & & & & \\
\hline 209 & João Alexandre Vieira & & & & & क्ये & & \\
\hline 210 & João Aparecido M Gouveia & & & & & & 4 & \\
\hline 211 & João Aparecido Marmé Gouvela & & & & & & & \\
\hline$\frac{212}{212}$ & João Carlos Rlesco & & & & & & & \\
\hline 213 & João Hipólito Neto & & & & & & & \\
\hline 214 & João José V. dos Santos & & & & & & & \\
\hline 215 & João Martins Ortiz Filho & & & & & & & \\
\hline 216 & Joaquim de Oliveira Miranda & & & & & & & \\
\hline 217 & Jocella da Silva Santos & & & & & & & \\
\hline 218 & Jocilda Crisando dos Santos & & & & & & & \\
\hline 219 & Joel dos Santos & & & & & & & \\
\hline 220 & Joel Ferreira & & & & & & 5 & \\
\hline 221 & John Julius Balthazar & & & & & & & \\
\hline 222 & Jorge Attillo Pascucci & & & & & & & \\
\hline$\frac{223}{223}$ & Jorge Ellas Mahtuk & & & & & & & \\
\hline$\frac{224}{224}$ & Jorge Lulz Cruz da Costa & & & & & & & \\
\hline 225 & José A. de Figueiredo Irmão & & & & & & & \\
\hline 226 & José Adelton Cordeiro da Silva & & & & & & & \\
\hline 227 & José Aldo Ricciardi Favaretto & & & & & & & \\
\hline 228 & José Almeida de Melo & & & 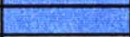 & & & & \\
\hline 229 & José Antonio Rufino ........... & & & & & & & \\
\hline 230 & José Araújo Varjăo & & & & & & & \\
\hline 231 & José Benedito de Lima & & & & & & & \\
\hline 232 & José Cardoso da Silva & & & & & & & \\
\hline 233 & José Carios de Barros & & & & & & & \\
\hline 234 & JOSE CARLOS FRANCISCO DA SILVA, & & & & & & & \\
\hline$\frac{237}{235}$ & José Carlos Rodrigues (Zezinho) & & & & & & & \\
\hline 236 & José Cláudio de Abreu & & & +8 & & & & \\
\hline 237 & José Cordeiro Costa & & & & & & & \\
\hline 238 & José Deodato da Silva & & & & & & & \\
\hline 239 & José Dias Lbório & & & & & & & \\
\hline 240 & José E. Lima Vieira & & & & & & & \\
\hline 241 & José Evangelista dos Santos & & & 50 & & & & \\
\hline
\end{tabular}




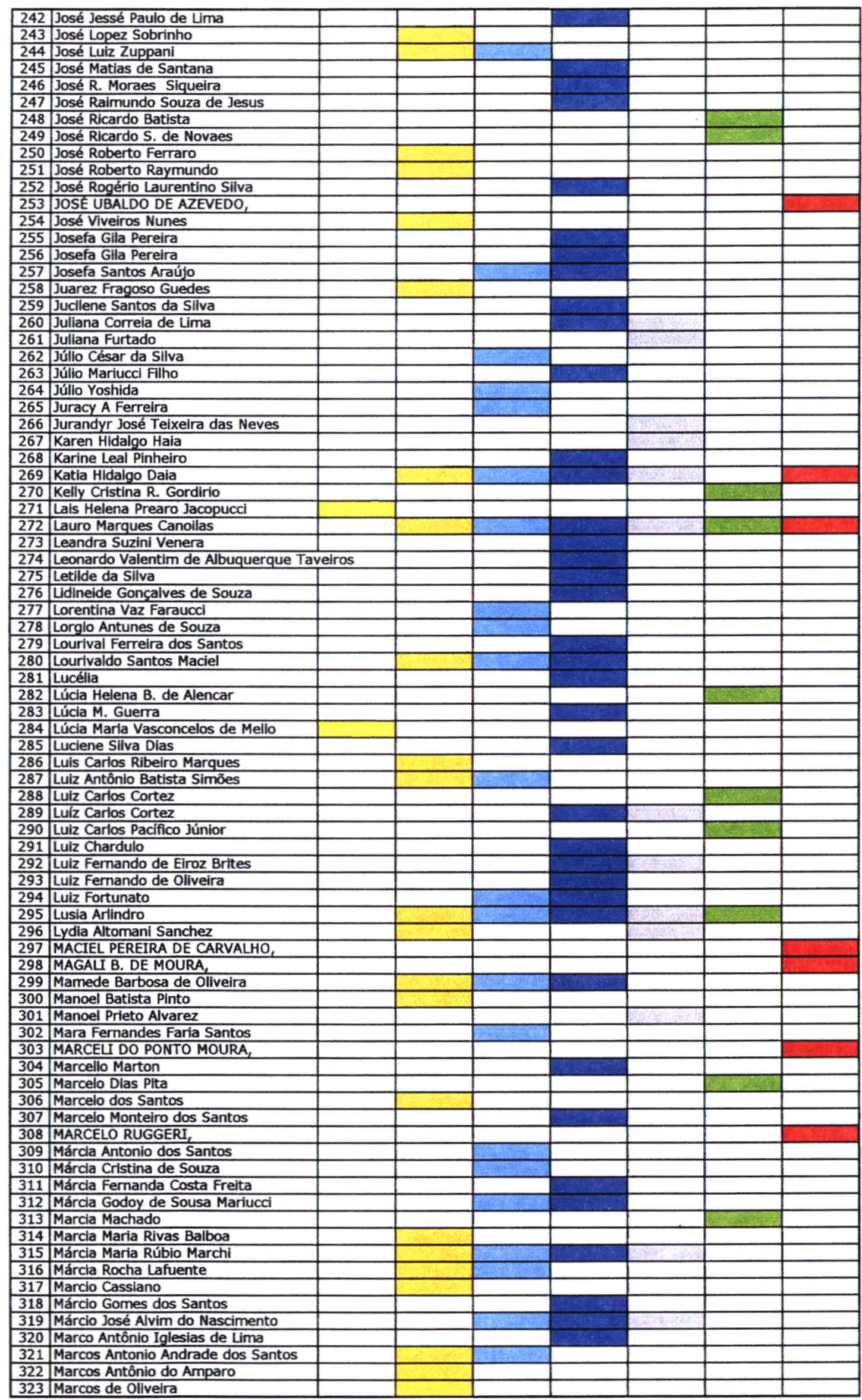




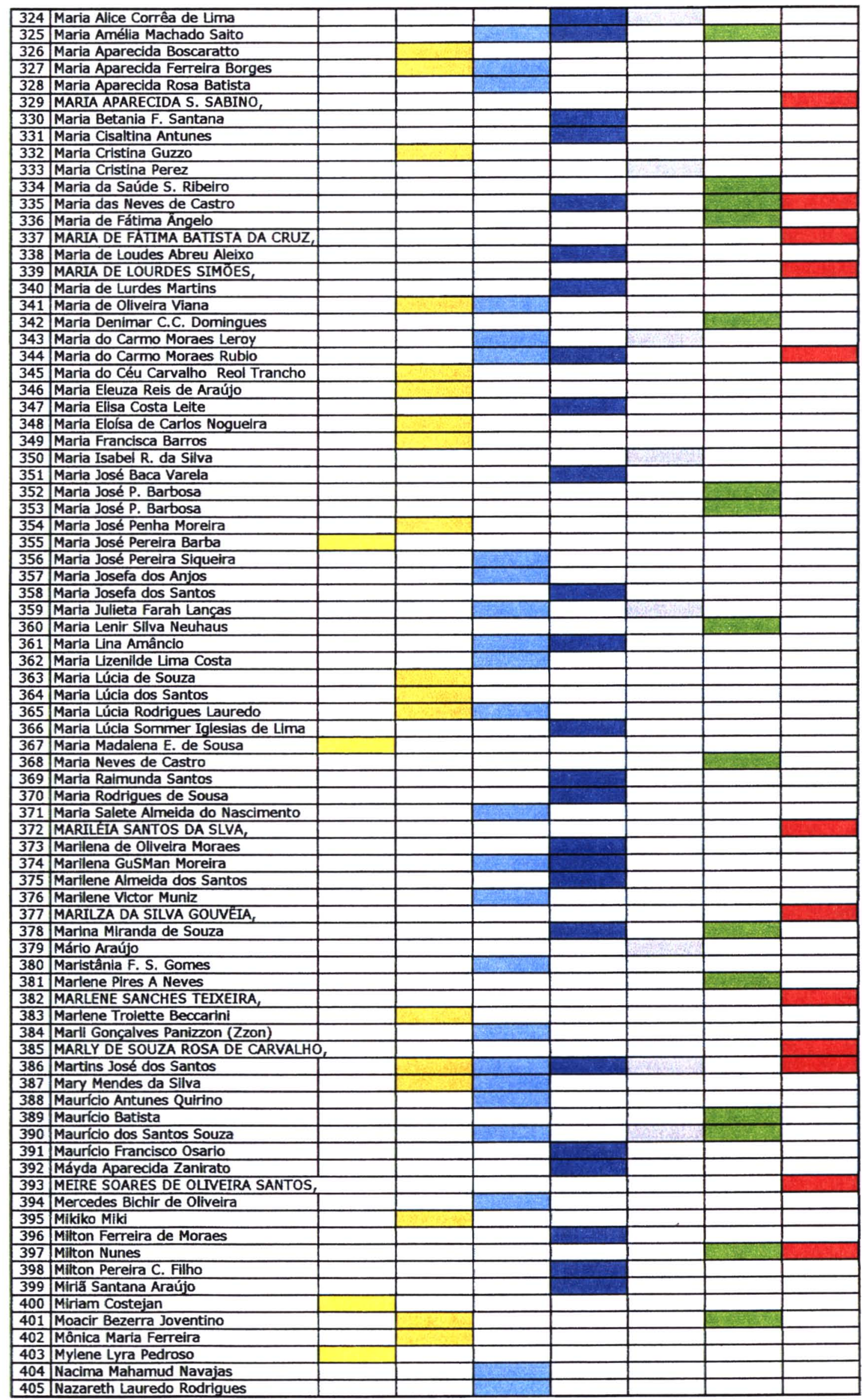




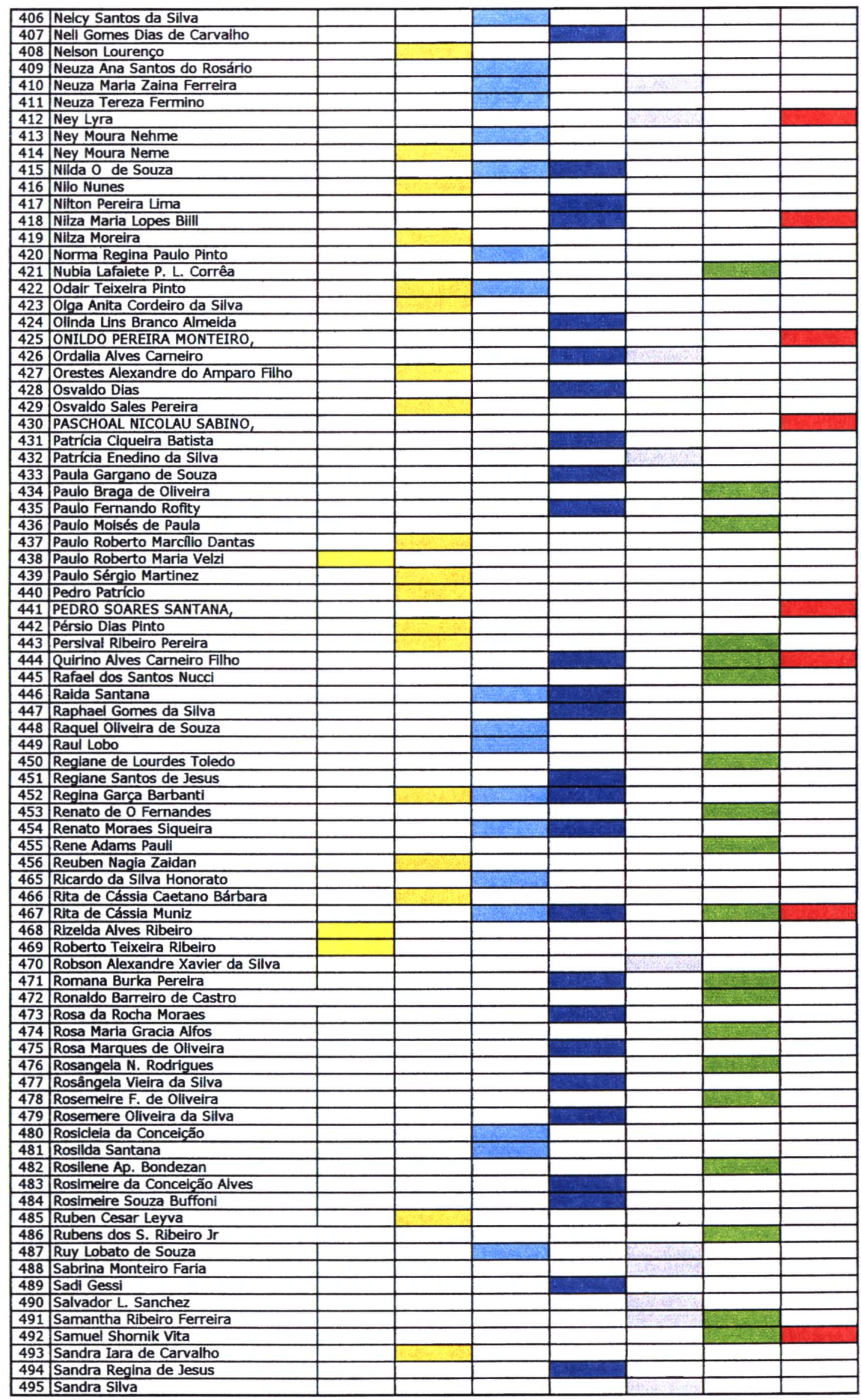




\begin{tabular}{|c|c|c|c|c|c|c|c|c|}
\hline 496 & Saulo Juvêncio da Cruz (Gaúcho) & & & & & & & \\
\hline 497 & Sebastiana de Lima & & & & & & & \\
\hline 498 & Sebastião Lourenço dos Santos & & & & & & & \\
\hline 499 & Selho Iha & & & & & & & \\
\hline 500 & Selma Bispo Santiago & & & & & & & \\
\hline 501 & SERGIO FONSECA JUNNIOR, & & & & & & & \\
\hline 502 & SERGIO FONSECA, & & & & & & & \\
\hline 503 & Sérgio Zenbinatti & & & & & & 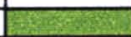 & \\
\hline 504 & Shirley Aparecida Alvarenga Souza & & & & & & & \\
\hline 505 & Sidinéya F. de Jesus Paula & & & & & & - & \\
\hline 506 & Silvana Steinwacher Cunha & & & & & & & \\
\hline 507 & Silvia Maria de Abreu Fortunato & & & & & & & \\
\hline 508 & Ślvio José Magalhães & & & & & & & \\
\hline 509 & Simar Antônio & & & & & & & \\
\hline 510 & Simião Ribeira KJerme & & & & & & & \\
\hline 511 & Simone Costa de Oliveira & & & & & & & \\
\hline 512 & Simone Cristina Barrol & & & & & & & \\
\hline 513 & Sival Melo Silva & & & & & & & \\
\hline 514 & Solange Maria Fontes Togliosca & & & & & & & \\
\hline 515 & Sonia dos Santos Reis & & & & & & & \\
\hline 516 & Sônia Maria Gonçalves Chaves & & & & & & & \\
\hline 517 & Sônia Regina Gutiez & & & & & & & \\
\hline 518 & Stefânia Suzini Venera & & & & & & & \\
\hline 519 & Stella Maris Veloso Lioi & & & & & & & \\
\hline 520 & Suell Aparecida Garcia de Freitas & & & & & & & \\
\hline 521 & SUEL AZEVEDO DO NASCIMENTO. & & & & & & & \\
\hline 522 & Suell Lins Albuquerque G. Silva & & & & & & & \\
\hline 523 & Suell Martins da Costa & & & & & & & \\
\hline 524 & SUELY HATSUKO TAKATA KURIHARA, & & & & & & & \\
\hline 525 & Suzete Ribeiro da Silva & & & & & & 6 & \\
\hline 526 & Tairine Alves Carneiro & & & & & & & \\
\hline 527 & Tâmara Oganesouna Chernow & & & & & & & \\
\hline 528 & Tamires Voca Vorella & & & & & & & \\
\hline 529 & Tayara Alves Carneiro & & & & & & & \\
\hline 530 & Tayná Alencar Neves & & & & & & & \\
\hline 531 & Tereza Cristina Pinho Favaretto & & & & & & & \\
\hline 532 & Terezinha Sousa Rodrigues de Matos & & & & & & & \\
\hline 533 & Thaís Vanessa Gouveira de Amorim & & & & & & & \\
\hline 534 & Tibúrcia Maria de Jesus & & & & & & & \\
\hline 535 & Ublrajara Gonçalves de Lima & & & & & & & \\
\hline 536 & Valdecir Lima & & & & & & & \\
\hline 537 & Valdelice Siqueira dos Santos & & & & & & & \\
\hline 538 & Valdemar da Silva (Valdir) & & & & & & & \\
\hline 539 & Valdemir de Carvalho Barbosa & & & & & & & \\
\hline 540 & Valdenice Rodrigues Oliveira Maia & & & & & & & \\
\hline 541 & Valdete Nilza da Silva & & & 78 & & & & \\
\hline 542 & Valdir Ribeiro Junior & & & & & & & \\
\hline 543 & Valéria Andrade Barbosa & & & & & & & \\
\hline 544 & Vanessa Auxilladora Bueno & & & & & & & \\
\hline 545 & Vanilda Rodrigues da Silva & & & & & & & \\
\hline 546 & Varnei F. dos Santos & & & & & & & \\
\hline 547 & Violeta Ortega Gonzalez Ferreira & & & & & & & \\
\hline 548 & Wagner Lamônica Lopes Fernandes & & & & & & & \\
\hline 549 & Walter dos Reis & & & & & & & \\
\hline 550 & Walter Fernandes Ferraz & & & & & & & \\
\hline 551 & Washington Luiz Araújo Ferreira & & & & & & & \\
\hline 552 & Welington Bitencourt & & & & & & & \\
\hline 553 & WTL KRUISE, & & & & & & & \\
\hline 554 & Willian Gilberto de V. Oliveira & & & & & & & \\
\hline 555 & Wilma de Melo Cavalcanti & & & & & & & \\
\hline 556 & Wilson Aparecido Morais & & & & & & & \\
\hline 557 & Wilson das Neves & & & & & & & \\
\hline 558 & Wilson Rodrigues & & & & & & & \\
\hline 559 & Wladimir E.R.S. Grudzinslel & & & & & & & \\
\hline 560 & Zaine Bichir Cassis & & & & & & & \\
\hline 561 & Zenilde Braz Brandão & & & & & & & \\
\hline
\end{tabular}




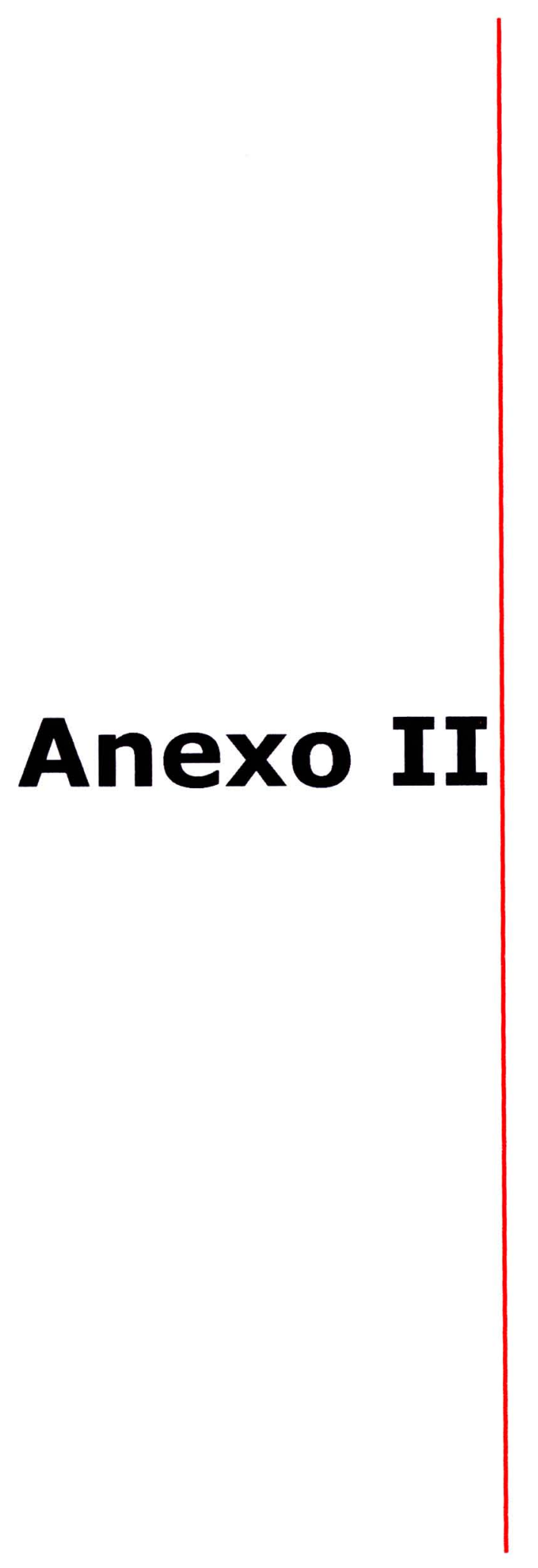




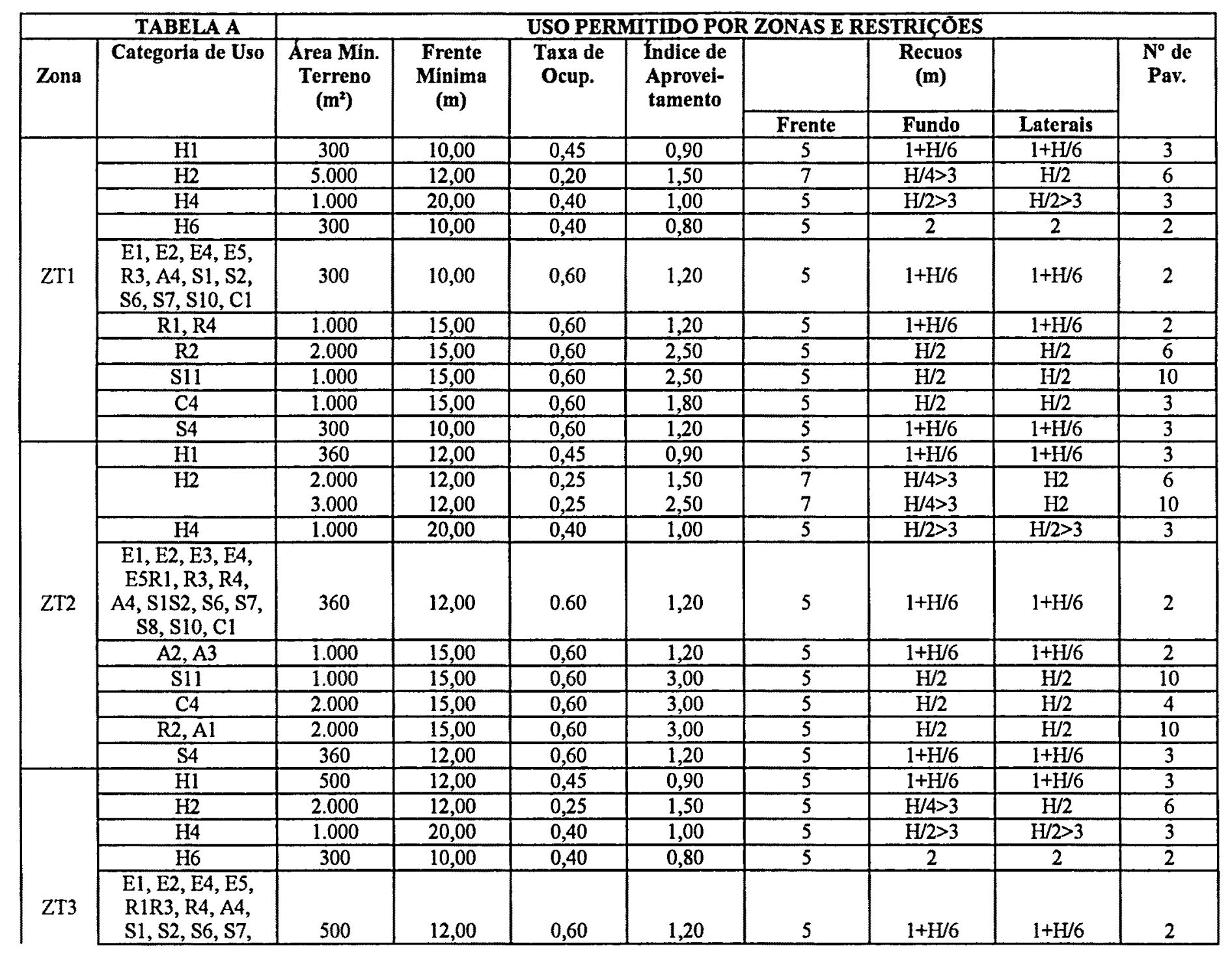

Políticas de habitação e desenvolvimento urbano em municípios saudáveis: o caso de Bertioga Anexo II - Tabela com os parámetros e coeficientes da atual legislação municipal 


\begin{tabular}{|c|c|c|c|c|c|c|c|c|c|}
\hline & $\mathrm{S} 10, \mathrm{Cl}$ & & & & & & & & \\
\hline & $\mathrm{C4}$ & 1.000 & 12,00 & 0,60 & 1,20 & 5 & $\mathrm{H} / 2$ & $\mathrm{H} / 2$ & 4 \\
\hline & S11 & 1.000 & 12,00 & 0,60 & 2,70 & 5 & $1+\mathrm{H} / 4$ & $\mathrm{H} / 2$ & 10 \\
\hline & $\mathrm{S} 4$ & 500 & 12,00 & 0,60 & 1,20 & 5 & $1+\mathrm{H} / 6$ & $1+\mathrm{H} / 6$ & 3 \\
\hline & $\mathrm{R} 2$ & 2.000 & 20,00 & 0,60 & 2,50 & 5 & $\mathrm{H} / 2$ & $\mathrm{H} / 2$ & 6 \\
\hline \multirow{6}{*}{$\begin{array}{l}\text { ZT4 } \\
\text { Mod. } \\
1 \text { A } 9\end{array}$} & $\mathrm{H1}$ & 360 & 12,00 & 0,40 & 1,50 & 5 ou 7 & $2+\mathrm{H} / 10$ & $1,5+\mathrm{H} / 10$ & 3 \\
\hline & $\mathrm{H} 2$ & $\begin{array}{l}2.100 \\
2.100 \\
\end{array}$ & $\begin{array}{l}20,00 \\
20,00 \\
\end{array}$ & $\begin{array}{l}0,40 \\
0,20 \\
\end{array}$ & $\begin{array}{l}1,50 \\
1,50 \\
\end{array}$ & $\begin{array}{c}5 \text { ou } 7 \\
7\end{array}$ & $\begin{array}{l}2+\mathrm{H} / 10 \\
2+\mathrm{H} / 10\end{array}$ & $\begin{array}{l}\mathrm{H} / 2 \\
\mathrm{H} / 2 \\
\end{array}$ & $\begin{array}{c}5 \\
10 \\
\end{array}$ \\
\hline & $\mathrm{H} 4$ & 2.100 & 20,00 & 0,40 & 1,50 & 5 & $2+\mathrm{H} / 10$ & $1,5+\mathrm{H} / 10$ & 3 \\
\hline & $\begin{array}{l}\text { E1, E2, E4, R1, } \\
\text { R2, I3, C1, S1, } \\
\text { S4, S8S10, S11 }\end{array}$ & 360 & 12,00 & 0,40 & 1,50 & 5 ou 7 & $2+\mathrm{H} / 10$ & $1,5+\mathrm{H} / 10$ & 2 \\
\hline & $\mathrm{C} 3, \mathrm{C} 4, \mathrm{~S} 5$ & 1.000 & 15,00 & & & 5 ou 7 & $1,5+\mathrm{H} / 10$ & $1,5+\mathrm{H} / 10$ & 2 \\
\hline & $\mathrm{R} 2$ & 2.000 & 15,00 & 0,60 & 2,50 & 5 ou 7 & $\mathrm{H} / 2$ & $\mathrm{H} / 2$ & 6 \\
\hline
\end{tabular}




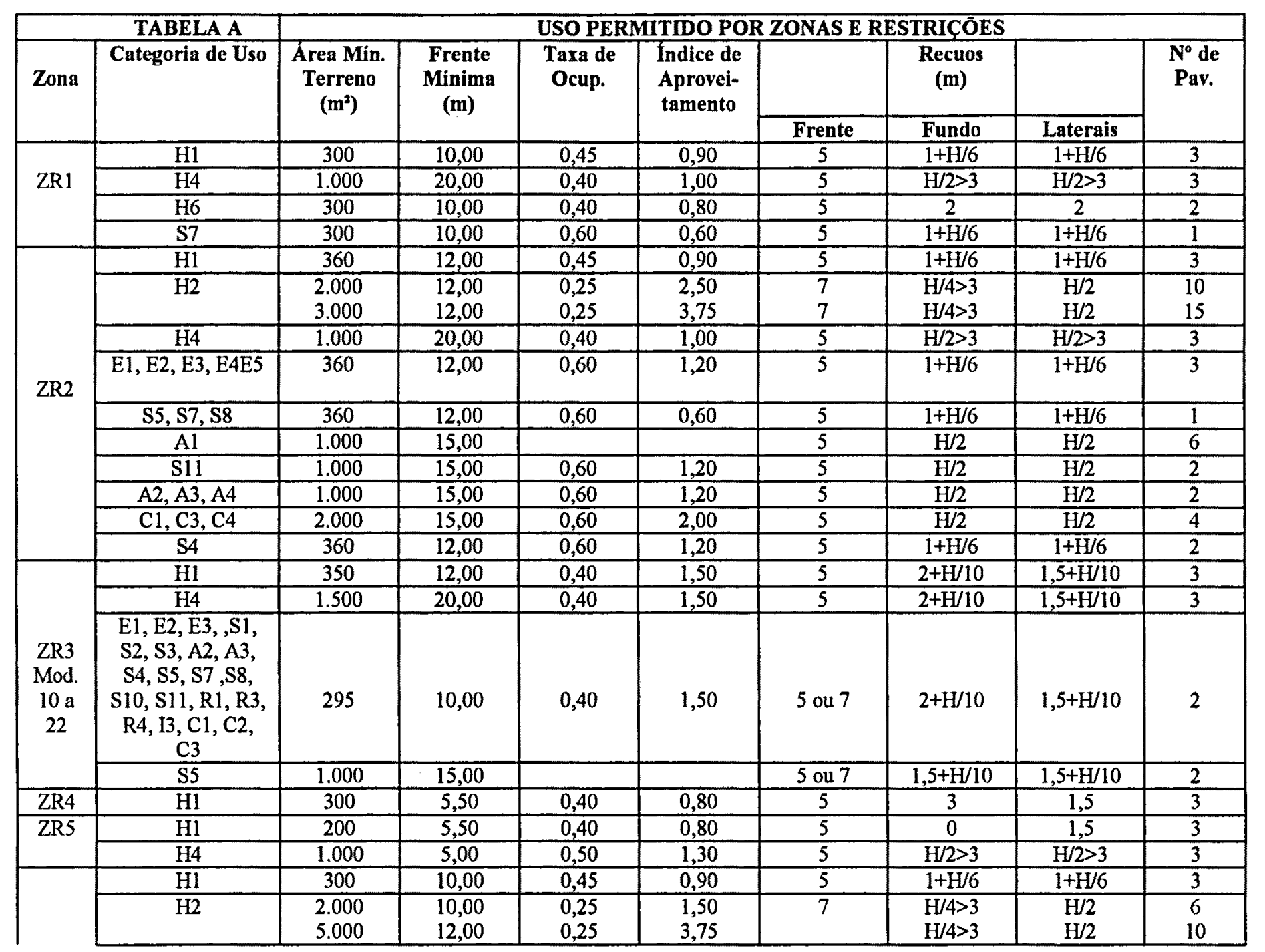

Políticas de habitação e desenvolvimento urbano em municiplos saudáveis: o caso de Bertioga Anexo II - Tabela com os parâmetros e coeficientes da atual legislação municipal 


\begin{tabular}{|c|c|c|c|c|c|c|c|c|c|}
\hline \multirow{6}{*}{ ZM1 } & $\mathrm{H} 4$ & 1.000 & 10,00 & 0,50 & 1,30 & 5 & $\mathrm{H} / 2>3$ & $\mathrm{H} / 2>3$ & 3 \\
\hline & $\mathrm{H} 6$ & 300 & 10,00 & 0,40 & 0,80 & 5 & 2 & 2 & 2 \\
\hline & $\begin{array}{l}\text { E1, E2, E3, E4, } \\
\text { E5, A4, S1, S2, } \\
\text { A2, A3, S6, S7, } \\
\text { S8, S4, S10, 13, } \\
\text { R1, R3, R4, C1 }\end{array}$ & 300 & 10,00 & 0,60 & 1,20 & 5 & $1+\mathrm{H} / 6$ & $1+\mathrm{H} / 6$ & 2 \\
\hline & $\mathrm{R} 2$ & 2.000 & 15,00 & 0,60 & 2,50 & 5 & $\mathrm{H} / 2$ & $\mathrm{H} / 2$ & 6 \\
\hline & Al & 1.000 & 15,00 & 0,45 & 3,00 & 5 & $\mathrm{H} / 2$ & $\mathrm{H} / 2$ & 6 \\
\hline & S11 & 1.000 & 10,00 & 0,45 & 2,70 & 5 & $\mathrm{H} / 2$ & $\mathrm{H} / 2$ & 6 \\
\hline \multirow{6}{*}{$\begin{array}{l}\text { ZM2 } \\
\text { Mod. } \\
23 \text { a } \\
33\end{array}$} & $\mathrm{H1}$ & 300 & 10,00 & 0,50 & 1,50 & 5 & $2+\mathrm{H} / 10$ & $1,5+\mathrm{H} / 10$ & $\overline{3}$ \\
\hline & $\mathrm{H} 4$ & 1.200 & 20,00 & 0,40 & 1,50 & 5 & $2+\mathrm{H} / 10$ & $1,5+\mathrm{H} / 10$ & 3 \\
\hline & $\begin{array}{c}\text { E1, E2, E3, E4, } \\
\text { E5, S1, S2, S3, } \\
\text { S4, S7, S8, S10, } \\
\text { C1, C2, R1, R3, } \\
\text { R4, A2, A3, I2, } \\
\text { I3, I4 }\end{array}$ & 250 & 10,00 & 0,75 & 1,50 & 5 ou 7 & $2+\mathrm{H} / 10$ & $1,5+\mathrm{H} / 10$ & 4 \\
\hline & $\mathrm{C} 3, \mathrm{C} 4$ & 1.000 & 15,00 & & & 5 ou 7 & $\mathrm{H} / 2$ & $\mathrm{H} / 2$ & 2 \\
\hline & $\mathrm{R} 2$ & 2.000 & 15,00 & 0,60 & 2,50 & 5 ou 7 & $\mathrm{H} / 2$ & $\mathrm{H} / 2$ & 6 \\
\hline & $\mathrm{S} 5$ & 1.000 & 15,00 & & & 5 ou 7 & $1,5+\mathrm{H} / 10$ & $1,5+\mathrm{H} / 10$ & 2 \\
\hline \multirow{3}{*}{ Zona } & TABELA A & \multicolumn{8}{|c|}{ USO PERMITIDO POR ZONAS E RESTRIÇŌES } \\
\hline & Categoria de Uso & $\begin{array}{c}\text { Area Mín. } \\
\text { Terreno } \\
\left(\mathbf{m}^{2}\right)\end{array}$ & $\begin{array}{l}\text { Frente } \\
\text { Mínima } \\
\text { (m) }\end{array}$ & $\begin{array}{l}\text { Taxa de } \\
\text { Ocup. }\end{array}$ & $\begin{array}{l}\text { Indice de } \\
\text { Aprovel- } \\
\text { tamento }\end{array}$ & & $\begin{array}{c}\text { Recuos } \\
\text { (m) }\end{array}$ & & $\begin{array}{l}\mathbf{N}^{\circ} \mathrm{de} \\
\text { Pav. }\end{array}$ \\
\hline & & & & & & Frente & Fundo & Laterais & \\
\hline \multirow{3}{*}{$\mathrm{ZHC}$} & $\mathrm{Hl}$ & 300 & 10,00 & 0,50 & 1,00 & 5,00 & 1,5 & 1,5 & 3 \\
\hline & $\begin{array}{c}\mathrm{E} 2, \mathrm{E} 4, \mathrm{C} 1, \mathrm{~S} 6, \\
\mathrm{~S} 7, \mathrm{R} 1, \mathrm{R} 3, \mathrm{~S} 4, \\
\text { S10 }\end{array}$ & 300 & 10,00 & - & - & 0 & $1+\mathrm{H} / 6$ & 0 & 2 \\
\hline & $\mathrm{S} 11$ & 1.000 & 10,00 & - & - & 0 & $1+\mathrm{H} / 6$ & 0 & 2 \\
\hline \multirow[b]{4}{*}{$\mathrm{CC}$} & H1 & 300 & 10,00 & 0,45 & 0,90 & 5 & $1+\mathrm{H} / 6$ & $1+\mathrm{H} / 6$ & 3 \\
\hline & $\mathrm{H} 2$ & 1.000 & 12,00 & - & - & 5 & $1+\mathrm{H} / 4$ & $1+\mathrm{H} / 6$ & 4 \\
\hline & $\mathrm{H} 4$ & 1.000 & 20,00 & 0,50 & 1,30 & 5 & $\mathrm{H} / 2>3$ & $\mathrm{H} / 2>3$ & 3 \\
\hline & $\begin{array}{l}\text { E4, E5, R3, R4, } \\
\text { R1, A3, A4, S1, } \\
\text { S2, S3, S4, S7, } \\
\text { S8, S10, C1, } 13\end{array}$ & 300 & 10,00 & - & - & 5 & $\mathrm{H} / 2$ & $1+\mathrm{H} / 6$ & 2 \\
\hline
\end{tabular}

Politicas de habitação e desenvolvimento urbano em municípios saudáveis: o caso de Bertioga Anexo II - Tabela com os parâmetros e coeficientes da atual legislação municipal 


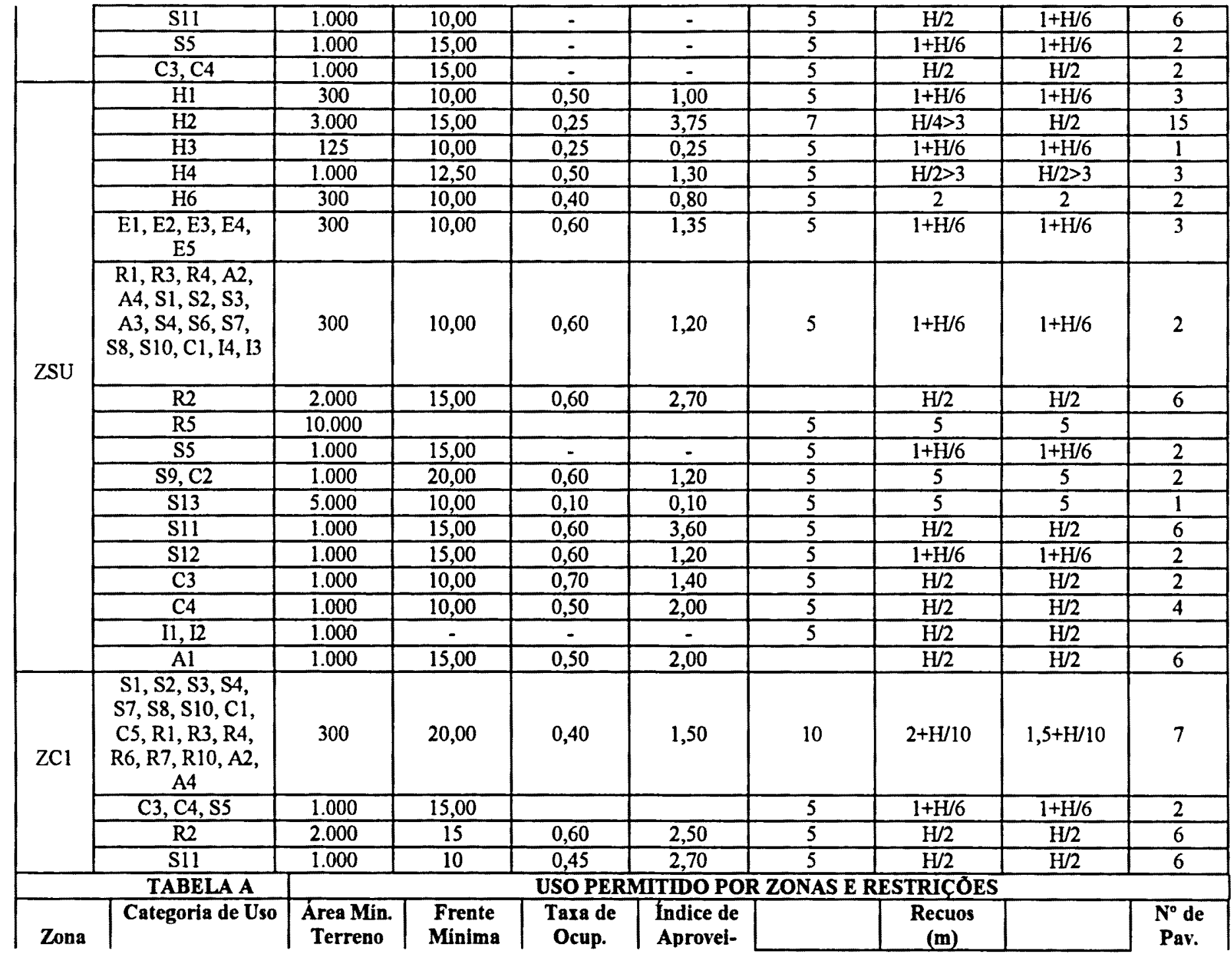

Politicas de habitação e desenvolvimento urbano em municíplos saudáveis: o caso de Bertioga Anexo II - Tabela com os parâmetros e coeficientes da atual legislação municipal 


\begin{tabular}{|c|c|c|c|c|c|c|c|c|c|}
\hline & & $\left(m^{2}\right)$ & (m) & & tamento & & & & \\
\hline & & & & & & Frente & Fundo & Laterais & \\
\hline \multirow{9}{*}{$\mathrm{ZC2}$} & $\mathrm{Hl}$ & 300 & 5,50 & 0,40 & 0,80 & 5 & & 1,5 & 3 \\
\hline & $\mathrm{H} 2$ & 1000 & 12,00 & & & 5 & $\mathrm{H} / 4>3$ & 3 & 6 \\
\hline & $\mathrm{H} 4$ & 1000 & 5,00 & 0,50 & 1,30 & 5 & $\mathrm{H} / 2>3$ & $\mathrm{H} / 2>3$ & 3 \\
\hline & $\begin{array}{c}\mathrm{E} 4, \mathrm{E} 5, \mathrm{A3}, \mathrm{S} 1, \\
\mathrm{~S} 2, \mathrm{~S} 3, \mathrm{~S} 4, \mathrm{~S} 10 \\
\mathrm{~S} 13, \mathrm{I}\end{array}$ & 300 & 10,00 & & & & $\mathrm{H} / 2$ & 2 & 2 \\
\hline & $\mathrm{R} 1, \mathrm{R} 3$ & 500 & 10,00 & & & & $\mathrm{H} / 2$ & & 2 \\
\hline & S11 & 1000 & 10,00 & 0,45 & 2,70 & 5 & $\mathrm{H} / 2$ & $\mathrm{H} / 2$ & 6 \\
\hline & S5 & 1000 & 15,00 & & & 5 & $1+\mathrm{H} / 6$ & $1+\mathrm{H} / 6$ & 2 \\
\hline & $\mathrm{C2}$ & 1000 & 15,00 & & & 5 & $\mathrm{H} / 2$ & & 2 \\
\hline & $\mathrm{Cl}$ & 1000 & 15,00 & & & 5 & $\mathrm{H} / 2$ & & 2 \\
\hline \multirow[t]{7}{*}{$\begin{array}{l}\mathrm{ZC3} \\
\mathrm{ZC4}\end{array}$} & $\begin{array}{c}\text { E1, E2, E3, E4, } \\
\text { E5, R1, R3, R4, } \\
\text { A3, S1, S2, } \\
\text { S3, S4, S7, S8, } \\
\text { S10, H1, I3, I4 }\end{array}$ & 200 & 5,5 & 0,40 & 0,80 & 5 & & 2 & 4 \\
\hline & $\mathrm{C} 3, \mathrm{C} 4$ & 1000 & 15 & & & 5 & $1+\mathrm{H} / 6$ & $1+\mathrm{H} / 6$ & 2 \\
\hline & S5 & 1000 & 15 & & & 5 & $1+\mathrm{H} / 6$ & $1+\mathrm{H} / 6$ & 2 \\
\hline & $\mathrm{R} 2$ & 2000 & 15 & 0,60 & 2,50 & 5 & $\mathrm{H} / 2$ & $\mathrm{H} / 2$ & 6 \\
\hline & $\mathrm{H} 2, \mathrm{~S} 11$ & 3000 & 10 & 0,25 & 2,50 & 5 & & $\mathrm{H} / 2$ & 6 \\
\hline & $\mathrm{H} 1$ & 360 & 12 & 0,45 & 0,90 & 5 & $1+\mathrm{H} / 6$ & $1+\mathrm{H} / 6$ & 3 \\
\hline & $\mathrm{H} 2$ & 2000 & 12 & 0,25 & 2,50 & 5 & $H / 4>3$ & $\mathrm{H} / 2$ & 10 \\
\hline \multirow{5}{*}{ ZSN } & $\mathrm{H4}$ & 1000 & 12 & $\overline{0,40}$ & 1,00 & 5 & $H / 2>3$ & $\mathrm{H} / 2>3$ & 3 \\
\hline & $\mathrm{H} 6$ & 300 & 10 & 0,40 & 0,80 & 5 & 2 & 2 & 2 \\
\hline & $\begin{array}{c}\text { E2, E5, R1, R2, } \\
\text { R3, R4, A3, A4, } \\
\text { S1, S4, S5, S6, } \\
\text { S7, S8, S10, } \\
\text { S11, C1, C3 }\end{array}$ & 360 & 12 & 0,60 & 1,20 & 5 & $1+\mathrm{H} / 6$ & $1+\mathrm{H} / 6$ & 2 \\
\hline & $\mathrm{C} 4$ & 1000 & 12 & 0,60 & 1,20 & 5 & $\mathrm{H} / 2$ & $\mathrm{H} / 2$ & 2 \\
\hline & 11,14 & 1000 & & & & 5 & $\mathrm{H} / 2$ & $\mathrm{H} / 2$ & \\
\hline \multirow{3}{*}{ ZSA } & $\mathrm{Hl}$ & 2000 & 25 & 0,10 & 0,20 & 5 & 5 & 5 & 3 \\
\hline & $\mathrm{H3}$ & 2000 & 25 & 0,03 & 0,03 & 5 & 5 & 5 & 1 \\
\hline & $\mathrm{S13}$ & 5000 & 25 & 0,10 & 0,10 & 5 & 5 & 5 & 1 \\
\hline ZBDI & $\mathrm{Hl}, \mathrm{El}, \mathrm{E} 2, \mathrm{E} 3$, & 1000 & 20 & 0,20 & 0,40 & 7 & $1+\mathrm{H} / 4$ & $\mathrm{H} / 2$ & 2 \\
\hline
\end{tabular}

Politicas de habltação e desenvolvimento urbano em municiplos saudáveis: o caso de Bertioga Anexo II - Tabela com os parâmetros e coeficientes da atual legislação municipal 


\begin{tabular}{|c|c|c|c|c|c|c|c|c|c|}
\hline & $\mathrm{S} 4, \mathrm{~S} 11, \mathrm{~S} 13$ & & & & & & & & \\
\hline \multirow{9}{*}{$\begin{array}{c}\text { ZBD2 } \\
\text { (máx. } \\
30 \% \\
\text { da } \\
\text { área } \\
\text { total) }\end{array}$} & $\mathrm{HI}$ & 2000 & 15,00 & 0,45 & 2,50 & 7 & $\mathrm{H} / 2$ & $\mathrm{H} / 2$ & 10 \\
\hline & $\mathrm{H} 2$ & 3000 & 20,00 & 0,60 & 6,00 & 7 & $1+\mathrm{H} / 4$ & $\mathrm{H} / 2$ & 15 \\
\hline & $\mathrm{H} 4$ & 1000 & 20,00 & 0,40 & 1,00 & 5 & $\mathrm{H} / 2>3$ & $\mathrm{H} / 2>3$ & 3 \\
\hline & $\begin{array}{l}\text { E1, E2, E3, E4, } \\
\text { E5, R1, R3, R4, } \\
\text { A4, S1, S2, S6, } \\
\text { S7, S8, S10, C1 }\end{array}$ & 360 & 12,00 & 0,60 & 1,20 & 5 & $1+\mathrm{H} / 6$ & $1+\mathrm{H} / 6$ & 2 \\
\hline & $\mathrm{A} 2, \mathrm{~A} 3$ & 1000 & 15,00 & 0,60 & 1,20 & 5 & $1+\mathrm{H} / 6$ & $1+\mathrm{H} / 6$ & 2 \\
\hline & S11 & 1000 & 20,00 & 0,60 & 6,00 & 7 & $\mathrm{H} / 2$ & $\mathrm{H} / 2$ & 15 \\
\hline & $\mathrm{C} 4$ & 2000 & 15,00 & 0,60 & 3,00 & 5 & $\mathrm{H} / 2$ & $\mathrm{H} / 2$ & 4 \\
\hline & $\mathrm{R} 2, \mathrm{Al}$ & 2000 & 15,00 & 0,60 & 3,00 & 5 & $\mathrm{H} / 2$ & $\mathrm{H} / 2$ & 10 \\
\hline & $\mathrm{S4}$ & 360 & 12,00 & 0,60 & 1,20 & 5 & $1+\mathrm{H} / 6$ & $1+\mathrm{H} / 6$ & 3 \\
\hline
\end{tabular}

Políticas de habitação e desenvolvimento urbano em municípios saudáveis: o caso de Bertioga Anexo II - Tabela com os parâmetros e coeficientes da atual legislação municipal 


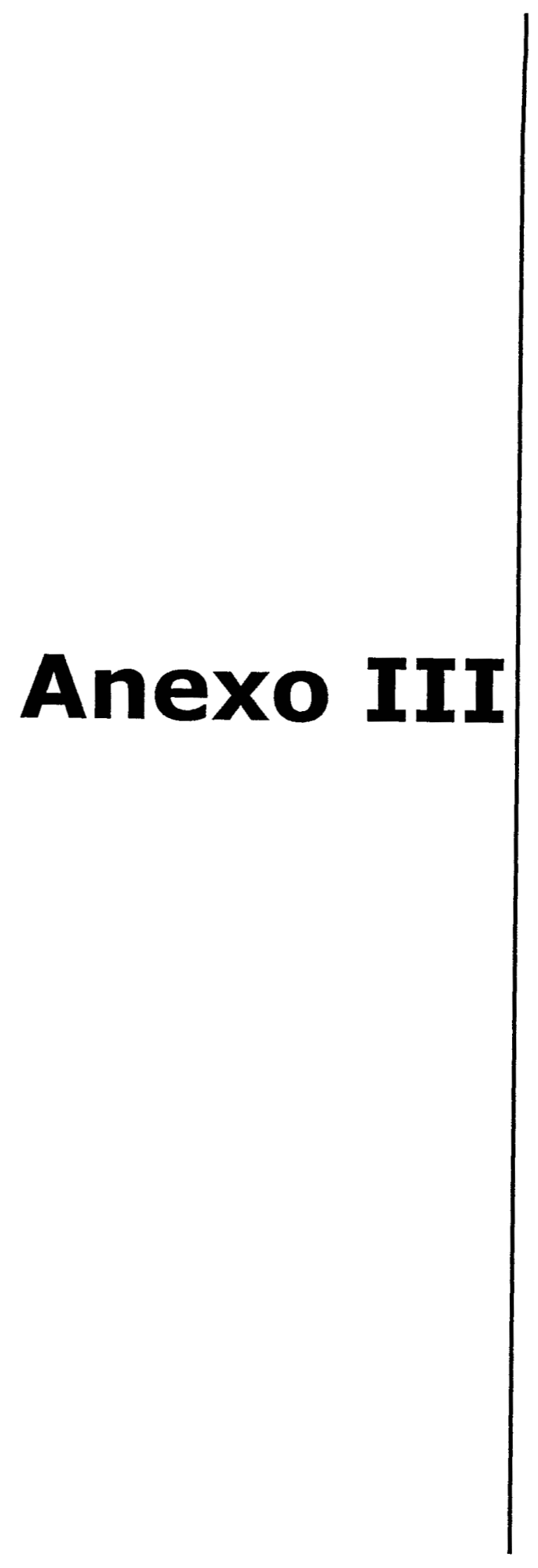




\section{POLUIÇÃO DO RIO ITAPANHAU}
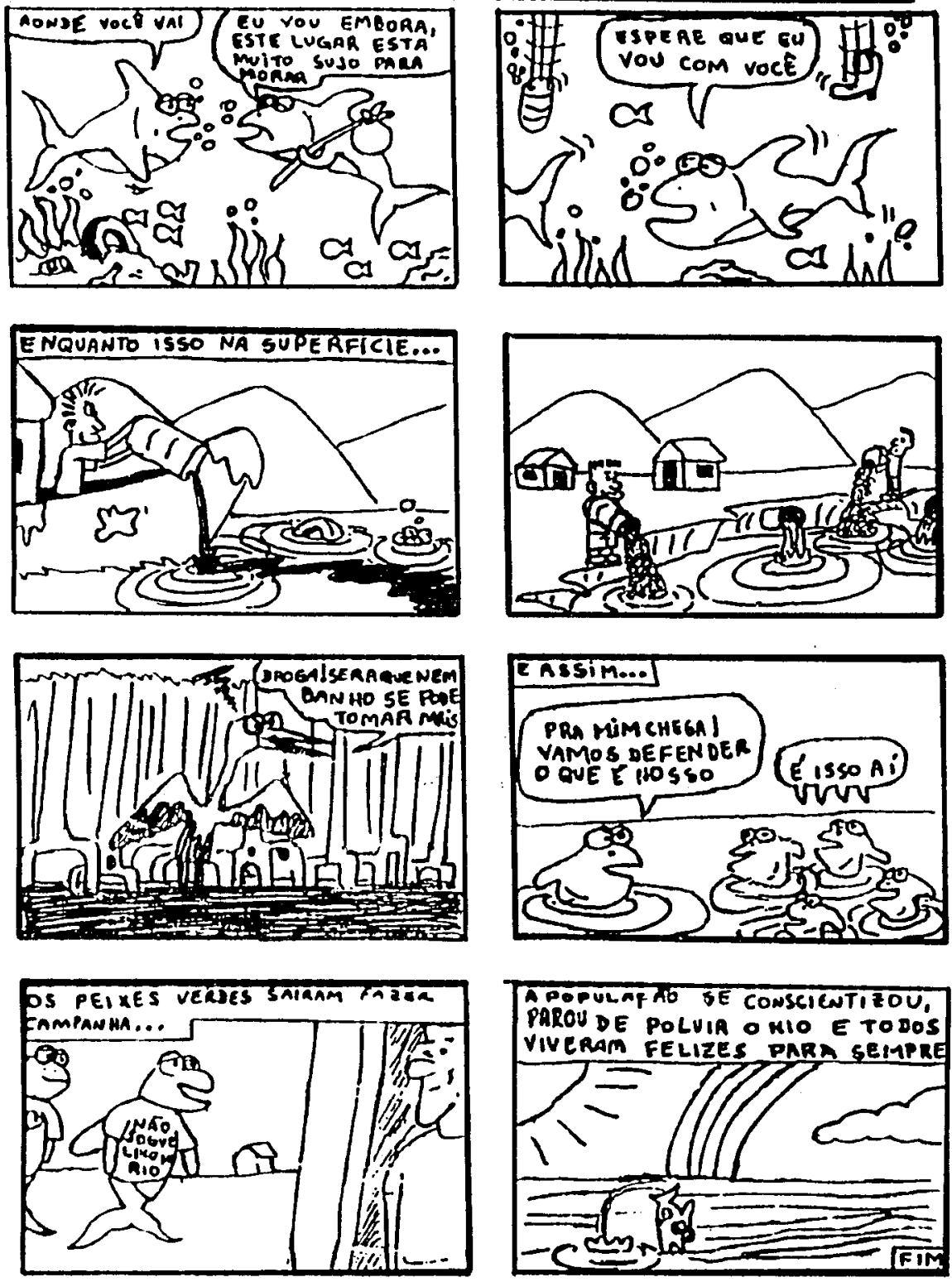

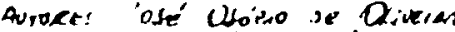
ovaen Oeman Di gat

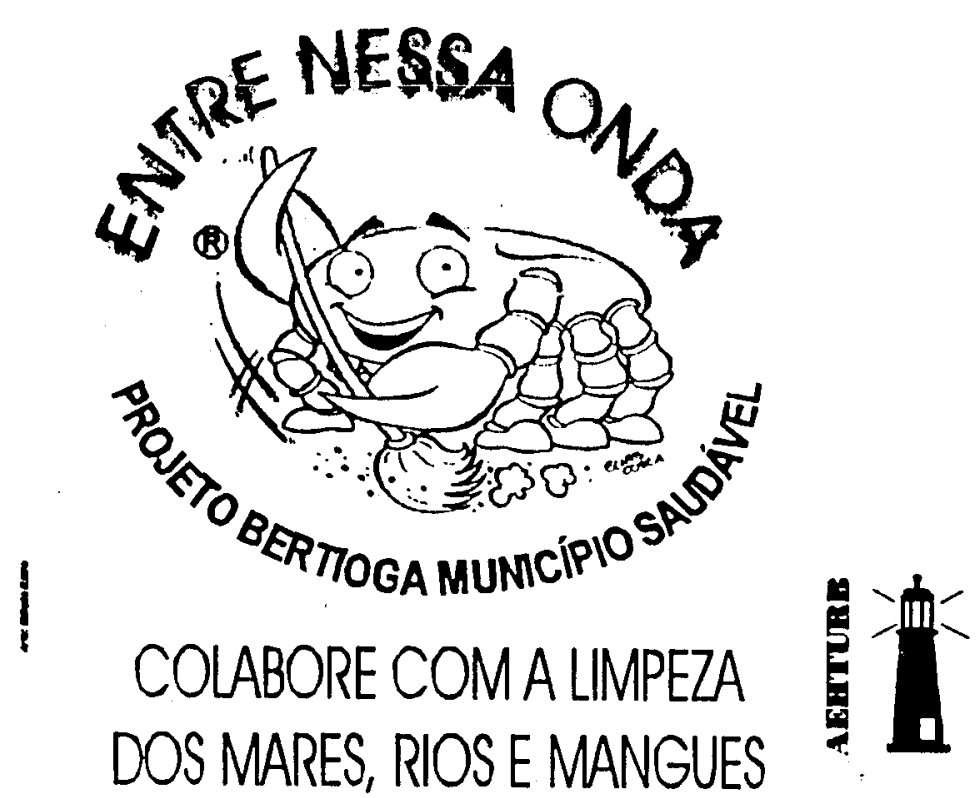
DOS MARES, RIOSE MANGUES

EDITORIAL

A campanha - ENTRE NESTA ONDA -

colabore com a limpeza dos Mares, Rios elMangues,

é parte integrante do projeto "BERTIOGA MUNICÍPIO SAUDÁVEL",

que tem como um dos objetivos, a formação de Agentes Multiplicadores em açōes comunitárias. O objetivo desta campanha é o de conscientizar a população e os turistas que freqüentam Bertioga, sobre a problemática da poluiçāo dos mares, rios e mangues, sendo os responsáveis por esta campanha, os integrantes do $1^{\circ}$ Curso de formaçäo de Agentes Multiplicadores para Assentamentos Humanos Saudáveis, os Sis.. Lauro Marques Canoilas, Rosa Maria Gracia Alfos, Maria Valéria Gago, Rosângela Najarro Rodrigues, Maria Denimar C. C. Domingues, Ana Angélica Santana Santos. Lúcia Helena Borges de Alencar, Luiz Carlos Pacílico Júnior, William Gilberto de V. Oliveira, Antônia Aparecida Paula de Oliveira. José Ricardo Batista, Delcilene de Souza Thommy e Tayna Alencar Neves. Contamos com a colaboração da Prefeitura Municipal de Bertioga, Supermercado Albatroz, Marina Acqua Azul, Associaçăo Parcel CEA - Aquário e Museu Marinho Didático Itinerante, Nautmar, Bertigraph, AMAVI, Colônia de Pescadores Z-23, Jornal Cosła Norte, Jornal da Baixada, Jornal Extra, Jornal Palavra da Restauraçăo, Rádio Alternativa, Rádio Costa Norte, Armazém Geral, LAGAdviser - Assessoria e Consultoria, Lauro Sucos, Padaria Monte de Trigo, Viga Mestra Materiais de ConstruçãoPizzaria Veleiros e Marina Porto deBertioga. A Campanha será realizada no período de 15 a 17 de Novembro, no Centro de Bertioga, entre o Forte São João e a Marina Polygon. Após este período, a mesma campanha deverá ser realizada sob outros enfoques (limpeza de trilhas na mata e bairros) em todas as Cormunidades de Bertioga. A semente está lançada! Participe . 


\section{LIXO NOS MARES, RIOS E MANGUES}

Lixo nos mares, rios e mangues nada é mais do que restos de embalagens e objetos que foram usados por alguém $\theta$ descartados em lugar errado. Tudo que as pessoas jogam nos rios, nas praias, nas cachoeiras $\theta$ nos mangues, ou até nas ruas, é levado pelás chuvas a ventos até o mar, causando problemas para os animais, plantas e homens que vivem e dependem desse amblente táo importante para a saúde do planeta. O lugar certo para jogar restos de comida e materiais que de fato nāo podem ser aproveitados, é na LATA DE LIXO bem tampada. Assim evita-se que os restos ali depositados não caiam para fora evitando a proliferação de insetos e roedores que causam e transmitem doenças. O lixo e a poluiçăo comprometem a balneabilidade das praias e podem transmitir doenças através de animais e dejetos, portanto residuos líquidos, como por exemplo, esgotos domésticos $\theta$ industriais devem ser lançados na rede coletora de esgoto ou em fossa séptica.

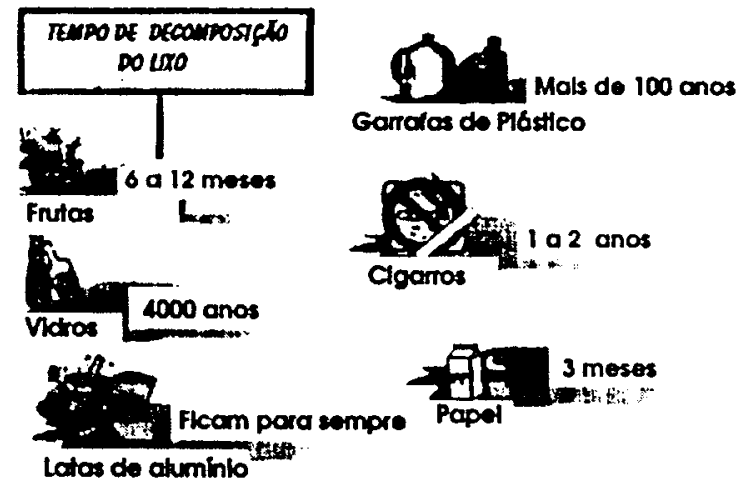

\begin{tabular}{|l|} 
CONSEQŪÊACIAS DO LIXO NO MEIO \\
AMBIENTE AQUÁTICO \\
Devido ao lixo lançado por barcos de pesca ou \\
de passeio, como por exemplo, garratas \\
plásticas, restos de redes e outros, aprisionam \\
e ferem animais aquáticos, levando-os a morte \\
pela fome e stress. O homem freqüentando \\
ambientes poluidos e contaminados pode-se \\
cortar e contrair doenças $\theta$ micoses, sem \\
contar que o ambiente poluido, prejudica o \\
turismo e a economia local.
\end{tabular}

Existem duas questōes importantes em relação ao LIXO no meio ambiente aquático, a flutuaçāo $\theta$ a degradação dos materiais lançados nele.

\section{FLUTUACÃO}

Muitos dos objetos jogados no mar são feitos de materiais leves e impermeáveis que ficam flutuando na superficie da água, poluindo a paisagem - prejudicando o lazer e a pesca ou mesmo os próprios animais marinhos que sobem até a superfície para respirar. Plásticos, alguns tipos de borracha $\theta$ madeira estāo entre os materiais encontrados boiando na superficie do mar $\theta$ dos rios.

\section{DEGRADAÇÃO}

Degradação é a capacidade que possui toda a matéria de se desfazer, de se desmanchar, de partir-se em pedaços cada vez menores, pela açāo da temperatura, da umidade e de microrganismos, como as bactérias e os fungos. Os materiais mais persistentes, que demoram mais tempo para se desmanchar são os tecidos sintéticos, o metal, o vidro, os plásticos e a borracha sintética, ambos podem levar até 250 anos ou mais para se desfazer na natureza, enquanto que o papel, a madeira e os tecidos naturais levam menos tempo. Mesmo assim descarte-os na lata de lixo.

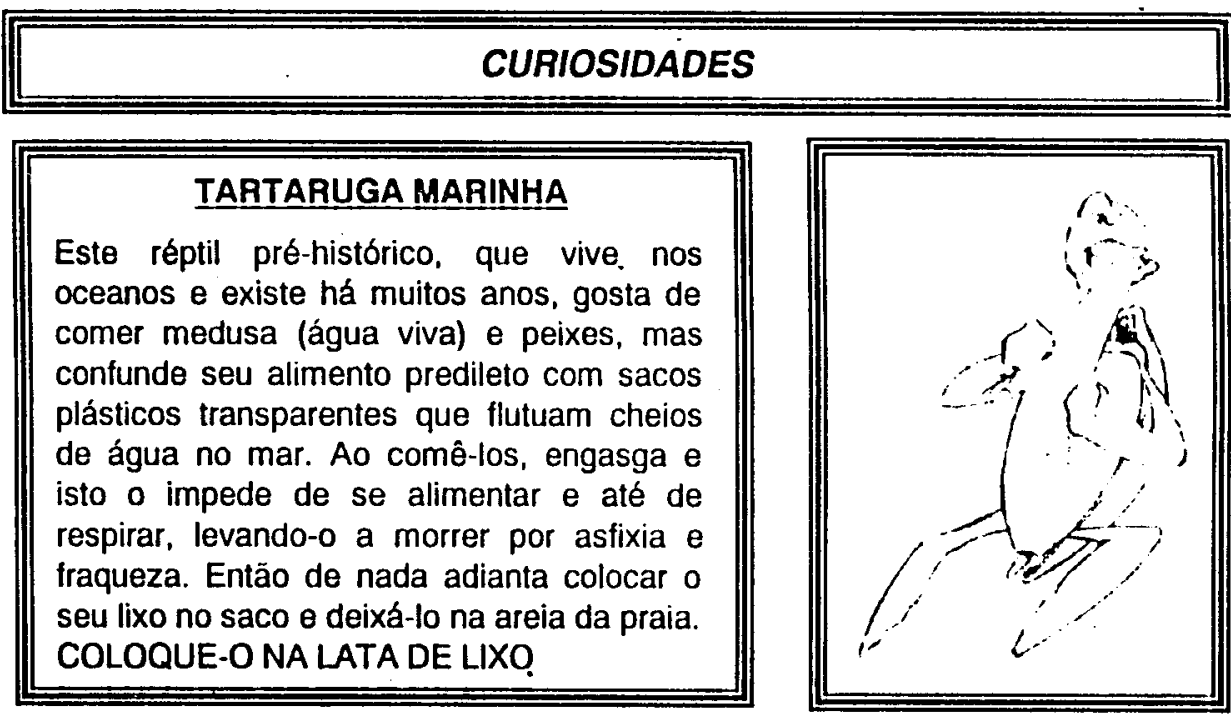

Os textos a llustraçōes sāo partes integrantes do materlal didátlco intitulado "OS DEFENSORES DOS OCEANOS", cedidos pela Assoclaçāo Parcel Centro de Educağ̉o Ambiental Aquário e Museu Marinho. 


\section{APOIOS:}

AGRADECEMOSOAPOIO DAS EMPRESAS

EENTIDADESABAIXO, SEM O QUE Nito

PROJETO BERTIOGA MUNICÍPIO SAUDÁVEL

PODERIAMOSTORNAR VIA VEL ESTE PROJETO.

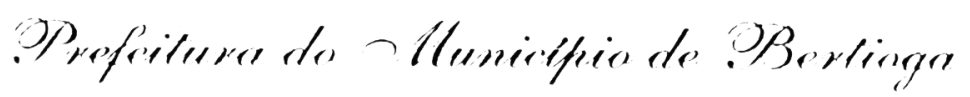

BERTIGRAPIICOORRETORA DE SE GUROS E G R A F ICA

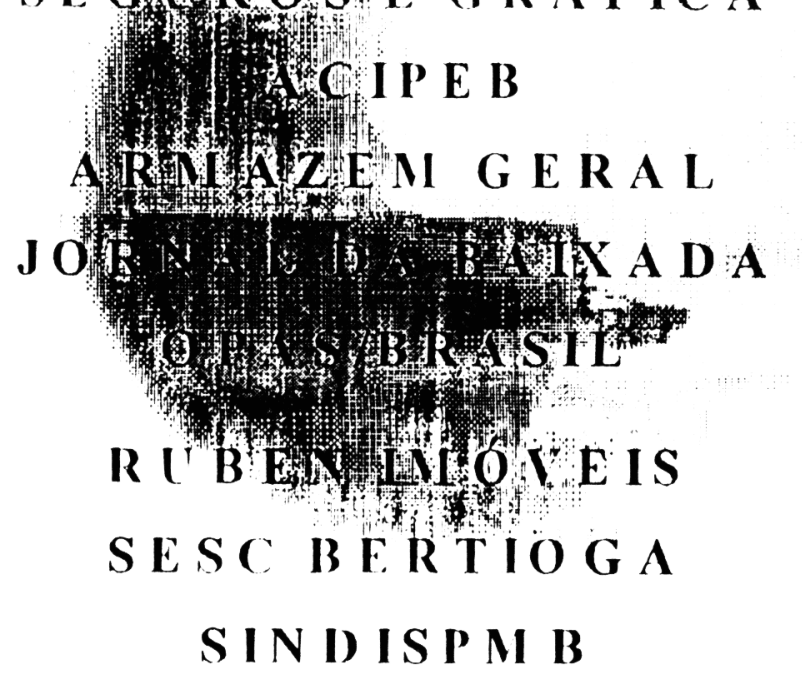

OR GANIZACÃO:

FACUI,DADEDESAÚDE PÚBLICA DA II S P

I Curso de Formação de Agentes para Assentamentos Humanos Saudáveis

BERTIOGA 2001 


\section{PERIODO DO C CURSO}

De 20 de Agosto a 19 de novembro de 2001

\section{NÚMERO DE VAGAS}

Serão 40 vagas para moradores de Bertioga

\section{CARGA IIORÁRII}

O Curso tera uma carga horária total de 60 horas

\section{IIORÁRIOS}

$2^{4}$ s ou $3^{4}$ s feirastdas 13 às 17 horas

\section{INSCRICÕES}

De 6 a 10 de agosto, das 9 às 15 horas, ’a rua Luis Pereira de Campos. no puédio da Prefeitura Municipal

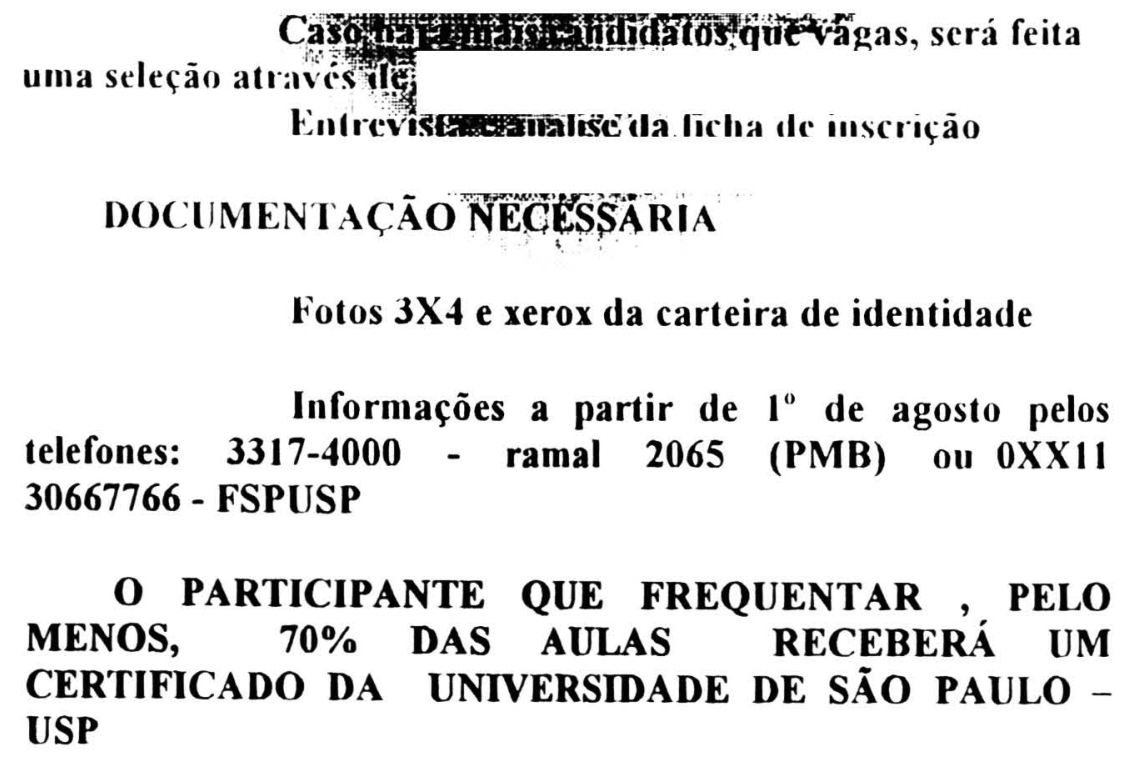

Fotos $3 \times 4$ e xerox da carteira de identidade

Informações a partir de $1^{\circ}$ de agosto pelos telefones: 3317-4000 - ramal 2065 (PMB) ou 0XX11 30667766 - FSPUSP

O PARTICIPANTE QUE FREQUENTAR, PELO MENOS, 70\% DAS AULAS RECEBERÁ UM CERTIFICADO dA UNIVERSIDAdE DE SÃO PAULO USP

O PROJETO BERTIOG I MIINICIPIO SAIIDÁVEI, é UMa iniciativa da qual participam representantes da Sociedade Civil de Bertioga, da Prefeitura Municipal e da Universidade de São Paulo-

USP, com o intuito de utilizar inciativas locais para melhorar a qualidade de vida no municipio.

Seus princípios baseiam-se na participação social, na equidade, no trabalho conjunto, no respeito às diferenças, na resolução de conflitos e em uma política pública saudável.

Para apoiar esta iniciativa foi formada uma Comissão Intersetorial da qual fazem parte representantes da Sociedade Civil, da Prefeitura e da USP.

A Comissão se reúne em todas as primeiras quintas leiras de cada mês. Às 17 horas, naysala destinada pela própria Prefeitura ao Projeto, localizadazdentro do prédio da própria prefeitura

\section{DBJETIVOS DO CURSO}

- CAPAOUIXRYIDADÃOS PARA PARTICIPAREM DA INICA II)

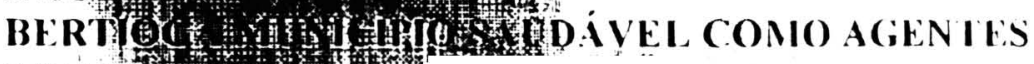

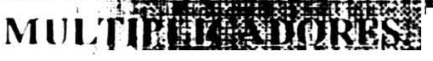

- ENSINARTLETISAS PARI FICIIITIRO DESEMPENITODIFURABAIIIOS ( OMUNITÁRIOS

- REFLETIR SÔBRE AS IORNAS POSSIVEIS PARA MELHORAR A QUALIDADE DE VIDA DOS MORADORES DE: BERTIOGA.

\section{CONDICÕES PARA PARTICIPAR DO CURSO}

Ser morador de Bertioga e ter mais de 16 anos

Pertencer a algum grupo, entidade ou ter experiência emı trabalhos comunitários 


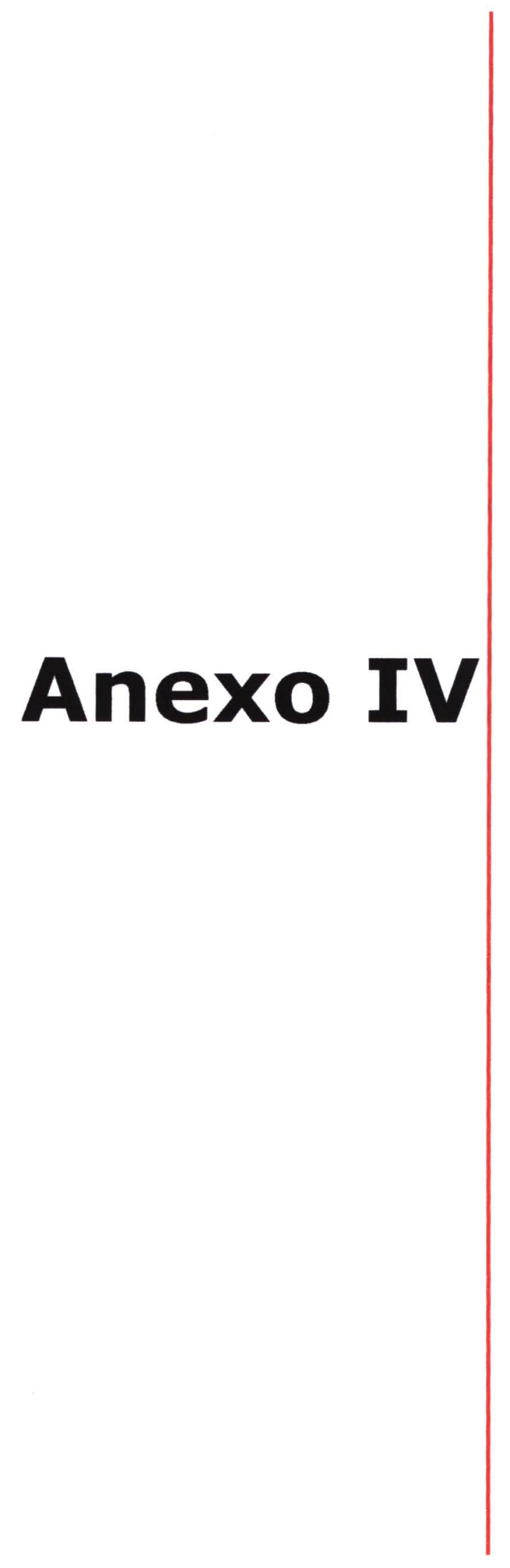




\section{UNIVERSIDADE DE SÃO PAULO \\ FACULDADE DE SAÚDE PÚBLICA}

AV. DR. ARNALDO, 715 - 01246-904 - SÃO PAULO - SP - TEL (011) 853-2329 - FAX (011) 3066-7709

São Paulo, 05 de novembro de 2001

Prezados Senhores,

Vimos por meio desta, convida-lo a participar do Seminário: Habitação e Saneamento Ambiental em Bertioga: programas e projetos, a realizarse das 13:00 às 17:00h do dia 12 de novembro de 2001 no Centro de Vivência ( $3^{\mathrm{a}}$ Idade) junto ao Setor de Promoção Social da Prefeitura do Município de Bertioga, a Rua Walter Pereira Prado, 77, Bertioga - SP.

Este seminário é parte das atividades desenvolvidas no âmbito do I CURSO DE FORMAÇÃO DE AGENTES MULTIPLICADORES PARA ASSENTAMENTOS hUMANOS SAUDÁVEIS, no escopo do Projeto Bertioga Município Saudável.

Lembramos que a sua participação é muito importante para o desenvolvimento e a qualidade de vida em Bertioga.

PROGRAMA:

Coordenação: Profa. Dra. Wanda Gunther - Faculdade de Saúde Publica da USP

\section{Expositores:}

Representante da Diretoria de Habitação da Prefeitura do Município de Bertioga Representante da caixa Econômica Federal - Bertioga

Representante da Sabesp - Companhia de Saneamento Básico do Estado de S.P.

Profa. Dra. Wanda Gunther - Faculdade de Saúde Publica da USP

Café'

Levantamento de duvidas

Debate

Encerramento

Coordenação do Projeto Bertioga Município Saudável Comissão Intersetorial do Projeto Bertioga Município Saudável 


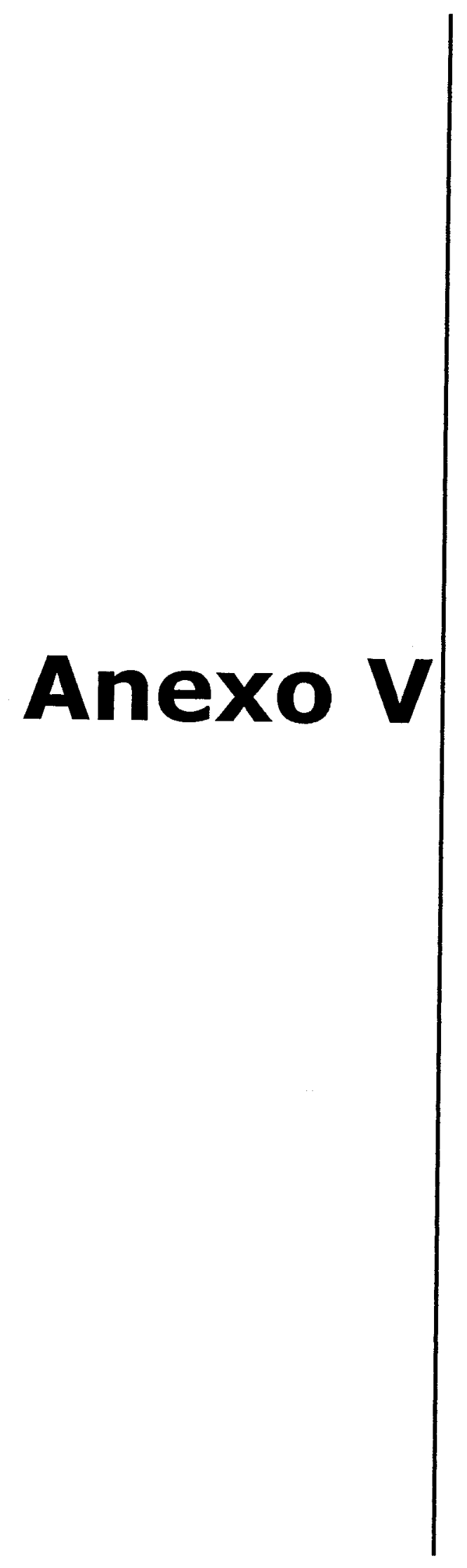




\section{Projeto Bertioga Municipio Saudável}

\section{Curso de Agentes Multiplicadores para Assentamentos Humanos Saudáveis}

Oficinas do Modulo Especifico: Habitaçāo Social, Participaçāo e Co-gestāo

Estagiảrio Iniciação Científica: Samuel Shomik, Endyra Russo

Professores: Roberto Pomperia, Maria Albertina Fehr e Francisco Comaru

Coordenação Geral: Marcia Faria Westphal

\section{Avaliação da oficina 23/10/01}

A. Qual a sua avaliação sobre as atividades da oficina de hoje?

B. Você obteve alguma informação ou conhecimento novo? Qual?

C. Você acredita que os participantes do Curso no Projeto Bertioga Município Saudável podem contribuir de alguma forma para melhorar a qualidade dos assentamentos humanos em Bertioga? Como?

Nome: 


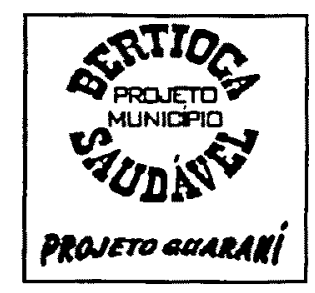

\section{CENTRO DE ESTUDOS, PESQUISAS E DOCUMENTAÇÃO EM CIDADES/MUNICIPIOS SAUDÁVEIS - CEPEDOC}

\section{CONVOCAÇÃO}

REUNIÃO DA COMISSÃO INTERSETORIAL DO PROJETO BERTIOGA MUNICÍPIO SAUDÁVEL

LOCAL: LANCHONETE LELAMI (EM FRENTE AO MERCADO DE PEIXE) HORÁRIO: $19 \mathrm{H} 30$

DATA: $13 / 11 / 2003$

PAUTA:

* proposta de ReVisão do plano diretor de bertioga (PRÓXIMAS AÇÕES, AUDIÊNCIA PÚBLICA E DIVULGAÇÃO );

* estudar a possibilidade de um novo espaço para o PROJETO BERTIOGA MUNICÍPIO SAUDÁVEL;

* O INVENTÁRIO dOS MATERIAIS (EQUIPAMENTOS, DOCUMENTOS, MATERIAL DE ESCRITÓRIO, MAPAS, ETC) DO PROJETO BERTIOGA MUNICÍPIO SAUDÁVEL PARA BERTIOGA;

* boletim eletrônico do cepedoc para divulgação dos PROJETOS CIDADES SAUDÁVEIS E BOLETIM INFORMATIVO IMPRESSO;

* estudo de caso sobre o projeto bertioga município SAUDÁVEL ENVIADO PARA OPAS PARA EDIÇÃO DE UM LIVRO

INFORMES

* apResentação do projeto em um congresso nos eUa e na AUSTRÁLIA E TAMBÉM INFORMATIVO NA REVISTA DA ONG CARE;

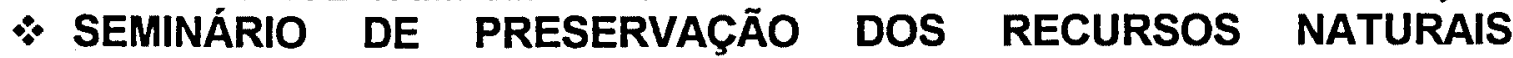
REALIZADO NA ESCOLA WILLIAM AURELLI;

* participação na terceira audiéncia pública do plano DIRETOR DE BERTIOGA;

* O ANDAMENTO DA CRIAÇÃO DA OSCIP MUNICÍPIO SAUDÁVEL;

* FINANCIAMENTO DA PETROBRAS EM PROJETOS AMBIENTAIS PARA APRESENTAÇÃO DE PROJETOS ATÉ JANEIRO DE 2004 


\section{MANIFESTO POPULAR}

Dentre os inúmeros trabalhos realizados pelo PROJETO BERTIOGA MUNICIPIO SAUDÁVEL e a COMISSÃO INTERSETORIAL, há que se destacar a realização das oficinas que tiveram como tema o Plano Diretor à luz do Estatuto da Cidade.

Com muito orgulho e com a ajuda de grande parte da comunidade, conseguimos sistematizar os anseios da população em um documento concreto, que tem como características a sua isenção de interferências setoriais ou corporativas, o caráter futurista e dirigente, objetivando apenas a melhora da qualidade de vida da população e um desenvolvimento sustentável.

Foi discutida a questão da democratização das informações, a necessidade de maior transparência nos atos administrativos, a necessidade de uma gestão mais democrática e simplificação das zonas urbanas.

Foi demonstrado por formulas, equações, dados, fundamentos jurídicos, que, existe a possibilidade de sonharmos com uma vida melhor se houver a disposição política.

Achamos oportuno registrar, neste documento, as assinaturas das pessoas que entendem da mesma forma.

\begin{tabular}{|l|l|l|}
\hline NOME & RG & ASSINATURA \\
\hline & & \\
\hline & & \\
\hline & & \\
\hline & & \\
\hline & & \\
\hline & & \\
\hline & & \\
\hline & & \\
\hline & & \\
\hline & & \\
\hline & & \\
\hline & & \\
\hline & & \\
\hline & & \\
\hline & & \\
\hline
\end{tabular}

